\title{
TÁJHASZNÁLATI SZEMPONTOK A VIDÉKI TÉRSÉGEK VERSENYKÉPESSÉGÉNEK ÉRTELMEZÉSÉHEZ
}

Filepné Kovács Krisztina

Budapest, 2013 
A doktori iskola

\author{
megnevezése: Budapesti Corvinus Egyetem \\ Tájépítészeti és Tájökológiai Doktori Iskola \\ tudományága: Agrármüszaki tudományok \\ vezetője: $\quad$ Csemez Attila, DSc \\ egyetemi tanár \\ Budapesti Corvinus Egyetem \\ Tájtervezési és Területfejlesztési Tanszék
}

Témavezető: $\quad$ Csemez Attila, DSc

egyetemi tanár

Budapesti Corvinus Egyetem

Tájtervezési és Területfejlesztési Tanszék

A jelölt a Budapesti Corvinus Egyetem Doktori Szabályzatában elöírt valamenynyi feltételnek eleget tett, az értekezés mühelyvitájában elhangzott észrevételeket és javaslatokat az értekezés átdolgozásakor figyelembe vette, ezért az értekezés védési eljárásra bocsátható. 
A Budapesti Corvinus Egyetem Élettudományi Területi Doktori Tanács 2013. június 4-i 113/2013. számú határozatában a nyilvános vita lefolytatására az alábbi bíráló Bizottságot jelölte ki:

\title{
BÍRÁLÓ BIZOTTSÁG:
}

\author{
Elnöke \\ Jámbor Imre CSc
}

\author{
Tagjai \\ Illyés Zsuzsanna, CSc \\ Kabai Róbert, PhD \\ Balogh Ákos, CSc \\ Kollányi László, CSc
}

Opponensek

Szlávik János, DSc

Dömötör Tamás, PhD

Titkár

Kabai Róbert, PhD 


\section{$\begin{array}{llllllllllllllll}\mathbf{T} & \mathbf{A} & \mathbf{R} & \mathbf{T} & \mathbf{A} & \mathbf{L} & \mathbf{O} & \mathbf{M} & \mathbf{J} & \mathbf{E} & \mathbf{G} & \mathbf{Y} & \mathbf{Z} & \mathbf{E} & \mathbf{K}\end{array}$}

BEVEZETÉS

1. IRODALMI ÁTTEKINTÉS

1.1. A versenyképesség, élhetőség, fenntarthatóság fogalomrendszere 11

1.1.1. Élhetőség 12

1.1.2. Környezeti fenntarthatóság 16

1.1.3. Versenyképesség 20

1.2. A tájhasználati rendszer, mint a fenntarthatóság, az élhetőség és a versenyképesség alapja

2. ANYAG ÉS MÓDSZER

\section{ESETTANULMÁNY: CSORNAI-KISTÉRSÉG}

\subsection{Tájhasználati változások tendenciái}

2.1.1. I. periódus: túlélés, alkalmazkodás

2.1.2. II. periódus: alkalmazkodás, lokális tájalakítás 49

2.1.3. III. periódus: nagyléptékü tájalakítás 56

2.1.4. IV. periódus: intenzív tájhasználat megszilárdulása 63

2.1.5. V. periódus: védelem, helyreállítás $\quad 69$

2.2. A tájhasználat változásának értékelése $\quad 72$

2.2.1. Területhasználati változások $\quad 73$

2.2.2. Tájökológiai változások

2.2.3. Tájképi változások

2.2.4. Társadalmi változások $\quad 78$

2.2.5. Térszerkezeti változások $\quad 83$

2.3. A tájhasználati rendszer/ tájhasználati funkciók a versenyképesség, az élhetőség és a fenntarthatóság tükrében $\quad 86$

2.3.1. Termesztési érték $\quad 89$

2.3.2. Gazdasági érték 95

2.3.3. Elérhetőség érték 98

2.3.4. Környezeti integritás érték 100

2.3.5. Élőhelyi érték 101

2.3.6. Tájesztétikai érték 103

2.3.7. Rekreációs és kulturális érték 107 
2.4. Élhetőségi szempontrendszer a mintatérségben

2.4.1. Humángazdaság/demográfiai jellemzők

2.4.2. Társadalmi értékrend, civilszféra értékelése

2.5. Környezeti fenntarthatóság és versenyképesség

2.5.1. Környezetgazdálkodási kompenzáció

2.5.2. Szabályozási keretrendszer müködése a mintatérségben

2.6. Versenyképességi értékelés

2.6.1. Nagytérségi kapcsolatrendszer értékelése

2.6.2. Mintatérség településeinek összesített versenyképességi értékelése

2.6.3. Fejlesztéspolitika hatékonysága

2.7. Scenáriók az élhetőség, a fenntarthatóság és a versenyképesség súlyponti eltolódásának függvényében

\section{EREDMÉNYEK}

3.1. A tájfunkciók változásának történeti értékelése, versenyképesség változásának tükrében

3.2. A tájfunkció-elemzés eredményei

3.3. A versenyképességi értékelés eredményei

3.4. A tájfunkció elemzés és a versenyképességi elemzés összevetése

3.5. Térségi jövőkép

A szerző témához kapcsolódó publikációi

Irodalomjegyzék

Ábrák és táblázatok jegyzéke

Felhasznált térképek jegyzéke

Jegyzetek

Tájépítészeti követelmények teljesülése a Csornai kistérségben

\section{Mellékletek}




\section{BEVEZETÉS}

Ma már szinte divatszónak számít a közéletben a versenyképesség fogalma. Korábban leginkább termékekkel, vállalatokkal, iparágakkal kapcsolatban használták, ma már azonban egyre gyakrabban hallunk nemzeti illetve regionális versenyképességről is. Termékekkel kapcsolatos versenyképességi értelmezés viszonylag egyszerü, alapvetően a közgazdaságtan, a hatékonyság által meghatározott. Sokkal komplexebb a térségi szintű értelmezés, hiszen a jövedelemtermelés mellett a jóléti, az életminőségi szempontok is meghatározóak. Önmagában tehát a közgazdaságtan fogalom-rendszerével, eszközeivel a térségi versenyképesség nem értelmezhető, szükség van a fogalom kiterjesztésére. A hagyományos versenyképességi értelmezésekben jobbára a gazdasági szempontok dominálnak, a társadalmi szempontok közül is elsősorban a közvetlenül a gazdasághoz kötődők jelennek meg (a munkaerő képzettsége, alkalmazkodóképessége). Az újabb, a már a fenntartható fejlődés szempontrendszerét is figyelembe vevő versenyképességi értelmezésekben megjelennek ugyan a környezet minőségét értékelö kritériumok, de a környezeti szempontok integrálása inkább a környezeti fenntarthatóság korlátainak vizsgálata miatt történik.

A versenyképességi és területfejlesztési elemzések középpontjában a gazdasági és a társadalmi fejlődés hajtóerejeként megjelenő ipar, a szolgáltatások és az ezeket kiszolgáló infrastruktúra szerepel. A térgazdaság így egy adott térségen belül a városok és az azokat összekötő infrastruktúra hálózatát jelenti a legtöbb esetben és a tér nagy részét kitevő agrártérség alárendelt szerepet kap, háttérbe szorul. Magas-szintü ipar, szolgáltatások nem települhetnek minden településre. Az életminőséget egyéb tényezők is meghatározzák, mint a közszolgáltatások minősége, elérhetősége, a civilszféra erőssége, aktivitása, a helyi identitás amelyek az élhetőségi szempontokat ölelik fel. Együtt, azonban különböző hangsúllyal kell kezelni a környezeti fenntarthatóság, az élhetőség és a versenyképességi szempontok rendszerét. Egy adott térség nem maradhat vonzó lakóhely, ha a (gazdasági hatékonyság) versenyképesség előtérbe kerül a fenntarthatóság, az élhetőség kritériumrendszere nélkül.

Az erőteljesen gazdasági szempontú értelmezések helyett más megvilágításból szeretném a versenyképesség problémakörét megközelíteni, amely nem értelmezhető térségi szinten a fenntarthatóság, az élhetőség egymásra ható, egymást kiegészítő feltételrendszere nélkül. A környezeti, a társadalmi és a gazdasági rendszerek egymástól elválaszthatatlanok. Ha a fejlesztéspolitika nem veszi figyelembe ezt az integritást, az beláthatatlan következményekkel járhat.

Alapvető célom a választott kistérség versenyképességi helyzetének javítása, amelynek eszköze a versenyképességi és ehhez kapcsolódóan a fenntarthatósági, az élhetőségi feltételrendszer érvényesülésének elemzése és egy komplex fejlesztési stratégia alapelemeinek kidolgozása. E hár- 
mas kritériumrendszer által állított korlátok és lehetőségek leképeződnek/nyomot hagynak a térség tájhasználati rendszerében. A tanulmányban különösen a tájhasználat vidéki térségek versenyképességét erősítő szerepére szeretném felhívni a figyelmet. Komplex, sokoldalú vidékfejlesztési elemzés készítése a célom, amelynek egy alapvető eszköze gazdasági értékeléssel kiegészített tájfunkció elemzés, amely arra keresi a választ, hogy a környezeti, a gazdasági, a társadalmi szempontok azonos hangsúlya mellett a táji adottságokat, a tájpotenciált a vidéki versenyképességének javítása érdekében hogyan lehet optimálisan hasznosítani. Részletesen foglalkozom a tájhasználat szerepével, szabályozásával a vidéki térségek versenyképességével összefüggésben. A gazdasági (versenyképességi), a társadalmi (élhetőségi) és a környezeti (környezeti fenntarthatóság) feltételek, elvárások meghatározzák a térség tájhasználati rendszerét.

Az alábbi célokat tüztem ki a tanulmányban (1. ábra):

1. Célom a vidéki térségek sikerességének /versenyképességének terület- és tájhasználati feltételeinek, kritériumainak megállapítása (a környezeti fenntarthatóság és az élhetőség szempontrendszerének együttes értelmezésével). Célom a mintatérség helyzetének (elsősorban a versenyképességi, de az élhetőségi és fenntarthatósági feltételekkel párhuzamosan) javítása.

2. Célom a táji adottságok hasznosításának, a tájalakításnak a mintatérség népességmegtartó képességének változásában játszott szerepének, továbbá az egyes történeti korszakokban a gazdaság és a társadalom fejlődésének mozgató rugóinak feltárása a versenyképesség, az élhetőség és a fenntarthatóság, mint meghatározó értékrendi szempontok változása mentén.

3. Célom olyan módszer és indikátorkészlet kidolgozása, amely alkalmas a tájhasználati rendszer komplex (versenyképességi, élhetőségi és fenntarthatósági) szempontú értékelésére, amely hozzájárulhat a vidékfejlesztési stratégiák megalapozottabb kidolgozásához.

4. Célom összefüggések keresése a mintatérség sikeres és kevésbé sikeres településeinek tájhasználatában, továbbá annak feltárása, hogy a tájhasználat módja jelenthet-e korlátokat egy térség versenyképességét, népességmegtartó képességét illetően.

5. Célom a terület- és vidékfejlesztés eszköz- és intézményrendszerének értékelése a mintatérségben, annak érdekében, hogy feltárjam a fejlődés tájhasználati feltételeit, korlátait. 


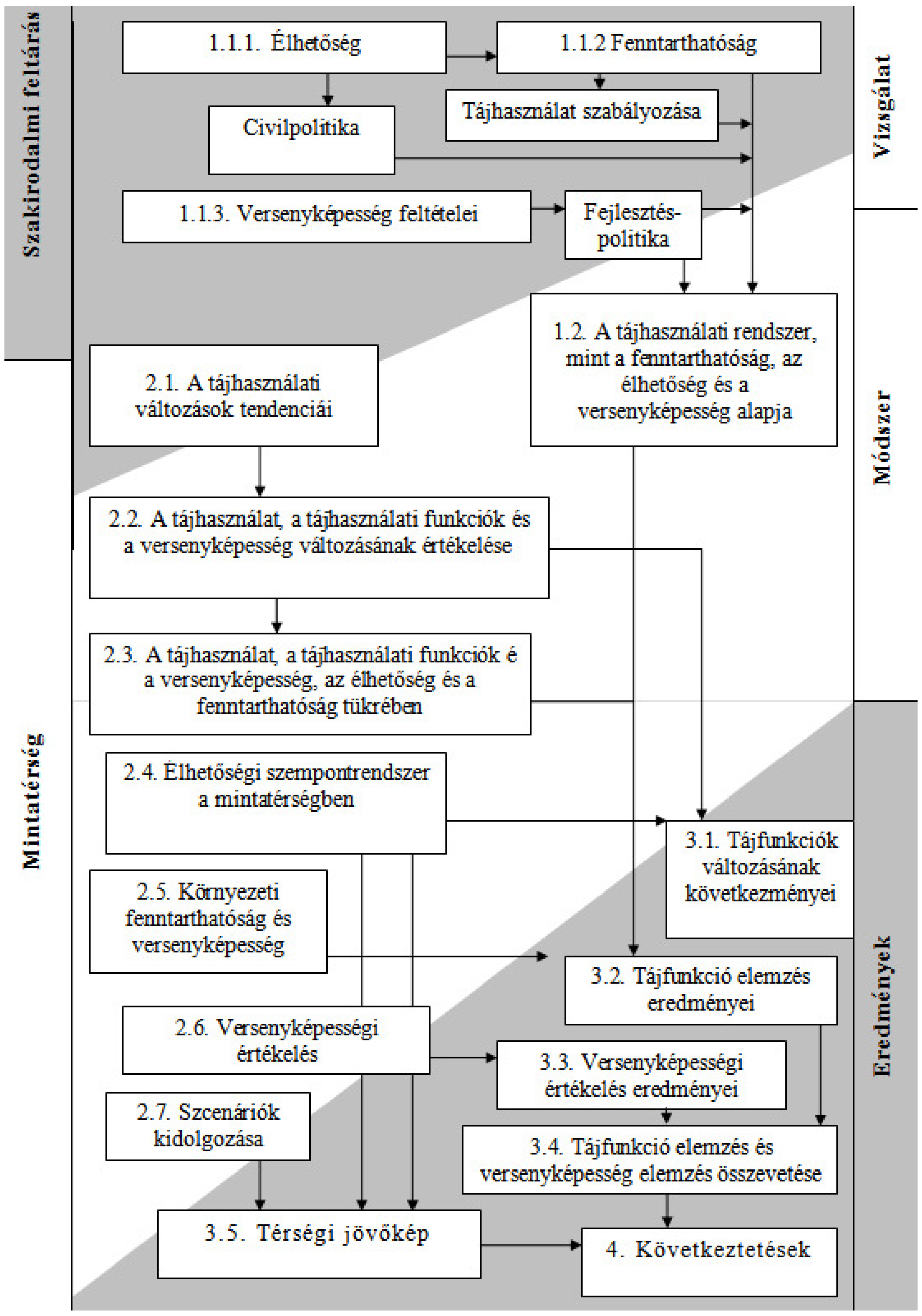

1. ábra: A tanulmány felépítése (saját szerkesztés) 


\section{IRODALMI ÁTTEKINTÉS}

\subsection{A versenyképesség, az élhetőség, a környezeti fenntarthatóság fogalomrendszere}

A fenntarthatóság, az élhetőség és a versenyképesség különböző léptékben értelmezhető, de egymáshoz szorosan kapcsolódó fogalmak. A környezeti fenntarthatóság értékrendszerét a természet diktálja, korlátainak betartása egyetemes érdek. A terület- és településrendezési tervek szabályozási munkarésze szolgálja a táj- és környezetvédelmet biztosító területhasználat kereteinek meghatározását. A fenntarthatóság korlátainak felismerése magával vonta a környezetgazdálkodás előtérbe kerülését. Az élhetőség helyi szinten megjelenő, a helyi lakosság életminőségét meghatározó tényezők összessége, ahol a civil társadalom önszerveződő, együttműködő, alkalmazkodó, és megújuló képességének (humángazdaság) meghatározó szerepe van. Nem elhanyagolható a közszolgáltatások elérhetőségét, az oktatáspolitikát, a civil-szerveződések életképességét, a civilrészvétel mértékét a kormányzásban, a demokratikus menedzsmentet meghatározó civilpolitika sem. A versenyképesség inkább nagytérségi szinten értelmezhető (2. ábra), fontos alkotóeleme, hogy a térségi feladatmegosztásban a vizsgált terület milyen szerepet tölt be. Meghatározója az egyes gazdasági ágazatok hatékonysága, versenyképessége (macrogazdaság), ide kapcsolódik a gazdaság állapota által meghatározott jövedelemszint és a társadalom aktív gazdaságformáló tevékenysége, a fejlesztéspolitika. Alapvető szempont a helyi társadalom alkalmazkodóképessége a külső kihívásokra, az újításra való hajlama/képessége stb. (az egyszerüsítés érdekében ezt a szempontot, az alapvetően társadalmi jellegü élhetőség alrendszerbe soroltam). A helyi társadalmaknak a természet nyújtotta belső korlátok és a globalizáció által támasztott hasonlóan kemény kihívások között kell boldogulnia.

\begin{tabular}{|c|c|c|c|}
\hline & \multicolumn{3}{|c|}{ Fenntartható fejlödés } \\
\hline 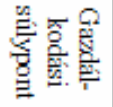 & Fenntarthatóság & Élhetôség & Versenyképesség \\
\hline 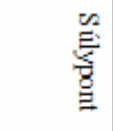 & & & \\
\hline 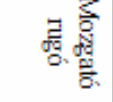 & Egyetemes természet & Lokalitás & Globalizáció \\
\hline 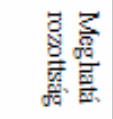 & $\begin{array}{l}\text { Környezet-, } \\
\text { tájvédelem }\end{array}$ & $\begin{array}{l}\text { Társadalmi } \\
\text { igények }\end{array}$ & $\begin{array}{l}\text { Nagytérség, } \\
\text { gazdaság }\end{array}$ \\
\hline 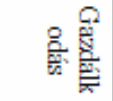 & $\begin{array}{l}\text { Környezet- } \\
\text { gazdálkodás }\end{array}$ & Humángazdaság & $\begin{array}{l}\text { Település- és } \\
\text { térgazdaság }\end{array}$ \\
\hline
\end{tabular}

2. ábra: A fenntarthatóság, az élhetőség a versenyképesség fogalomrendszere, értelmezési szintjei (Forrás: Balogh, 2009) 
A különböző kihívások, elvárások, adottságok, értékrendek meghatározzák egy-egy térség belső értékgazdálkodását, amely számomra, tájépítészként a tájhasználatban képeződik le, változatos, kiegyensúlyozott tájhasználati rendszert feltételezve (3. ábra). A három különböző szempont összhangja (versenyképesség - a gazdasági, élhetőség - a társadalmi, a környezeti fenntarthatóság - a környezeti), harmóniája képezi a fenntartható fejlődés komplex feltételrendszerét, kisebb nagyobb súlyponti eltolódással.

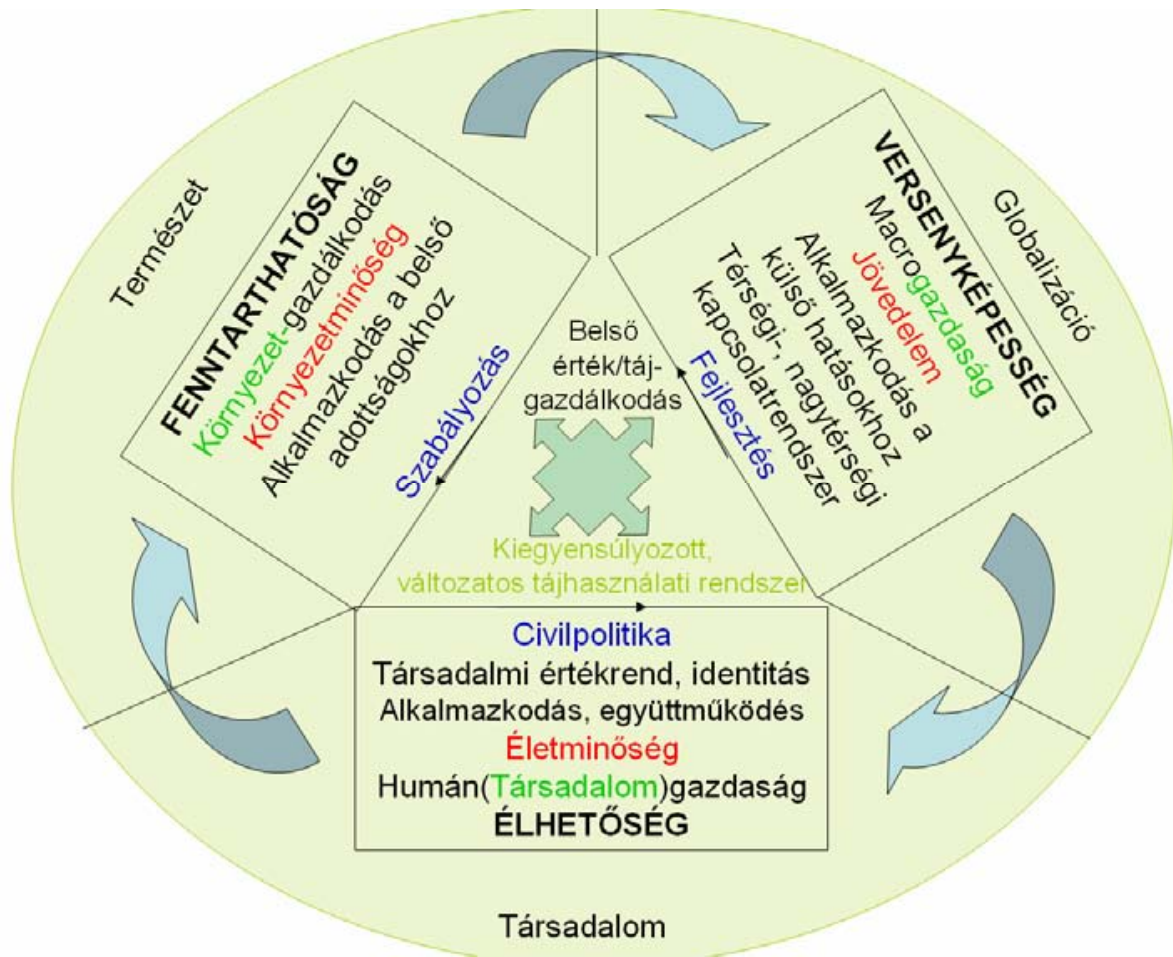

\section{3. ábra: A fenntarthatóság, az élhetőség, a versenyképesség kritériumrendszere}

(saját szerkesztés)

Az élhetőséget, a fenntarthatóságot és a versenyképességet meghatározó tényezők rendkívül összetett, egymásra ható rendszereket alkotnak. A terjedelmi korlátok miatt az egyes feltételrendszerek, elsősorban a versenyképességben is meghatározó, szakterületi szempontból releváns szempontjait emelem ki, az egyes pillérek részletes elemzése további kutatások tárgya lehet.

\subsection{1. Élhetőség}

Az élhetőség mára egyre gyakoribb fogalommá vált a településfejlesztésben. Az élhetőség, mint fogalmi keret, a fenntarthatóság és a versenyképesség komplex rendszerében a helyi társadalom által leginkább meghatározott, befolyásolt, az életminőséghez kapcsolódó tényezőket foglalja magába. A helyi társadalom értékítélete, aktivitása, együttmüködési kultúrája meghatározza a gazdasági-, társadalmi folyamatokat. Ebbe a fogalomkörbe tartozik a társadalom megújuló képességével, a demográfiai folyamatokkal jellemezhető humángazdaság. ${ }^{1}$

\footnotetext{
1 „A korai, valamint napjaink vezető közgazdászai által megalkotott, de eddig egymással összefüggésbe nem hozott, integrálatlan felismeréseiböl ... egy olyan gazdasági tartomány sejlik fel, amelyben nem anyagi és pénzjavakat termel-
} 
A legtöbb elmélet, amely a vidéki térségek sikerességével foglalkozik, nagy hangsúlyt fektet a társadalmi jellemzőkre, amelyek a lakosság képzettségét, foglalkoztatási aktivitását, elöregedését, de egyéb statisztikai adatokkal nem leírható jellemzőit is magába foglalja. Egy térség, kistelepülés sikeressége, a földrajzi, a gazdasági tényezők mellett jelentős mértékben múlik a helyi társadalom aktivitásán, önszerveződő képességén. Több irodalmi hivatkozás (Bugovics, Jackson, Szörényiné...) emeli ki a helyi/térségi identitást, mint fejlesztéspolitikai mozgatórugót. Az életminőség mára egyre gyakoribban használt fogalommá, a területfejlesztési célkitűzések alapjává vált. Pontos meghatározására, leírására nehéz vállalkozni, hiszen kulturális, környezeti, gazdasági vonatkozásai egyaránt vannak. Az életminőséget az élhetőség fogalomrendszerébe soroltam, mert legmeghatározóbbnak a kulturális jelleget, a helyi társdalom szerepét tekintem az életminőség befolyásolásában (természetesen nem elválasztható a jövedelemszint, sem a környezetminőség, ezek egymásra ható rendszerek).

A helyi társadalom szerepe

A szakirodalomban a társadalmi oldal valamennyi versenyképességi elemzésben említésre került. De valóban van jelentősége egy térség helyzetében a társadalmi szempontoknak? Leglátványosabban két kistelepülés példája szemlélteti, hogy ténylegesen nem hanyagolhatók el az emberi tényezők. Miért lehetséges az, hogy teljesen hasonló táji adottságok mellett egymástól alig több mint 30 kilométerre is lehet egy település sikeres és hátrányos helyzetü? A HVG folyóirat 2008-ban összeállítást készített a települések „rangsoráról” az egy före jutó éves személyijövedelemadó-befizetések alapján, amely érdekes jelenségekre hívta fel a figyelmet. Zala megyében, periférikus helyzetben található két apró falu, Iborfia és Gosztola. Hasonlóan az elvándorlás problémái érintették mindkét falut. Gosztolán azonban egy helyi vállalkozó tíz évvel ezelőtt elhatározta, előnyt kovácsol az elnéptelenedő falu érintetlenségéből, és a település azóta egy sokkal gondozottabb, ápoltabb arcot mutat a világnak: „ma már parkosított telkeken nönek ki a földböl a frissen festett, modern házak. Iborfián viszont a kopottas épületek egyhangúságát mindössze a tyúkólak törik meg” (HVG, 2008). A benyomást a statisztikai adatok is visszaigazolják: Gosztola a több mint háromezer magyarországi település közül a harmadik az egy főre jutó éves személyijövedelemadó-befizetésben, Iborfia viszont hátulról a hetedik a jövedelemtermelő képességben.

nek és forgalmaznak, hanem a szubjektumot, az embert. A beruházás az emberi tőkébe, a mesterségesen előállított szociális karakterek, indítékaik és azonosságaik; embertermelés; s az e mesterségesen előállított karakterek diktált fogyasztása képezik az eddig megnevezett részeit ennek a sajátos gazdasági tartománynak, a humángazdaságnak.” (http://www.magyarszemle.hu/cikk/humangazdasag) 
A vidéki térségek fejlődésében meghatározóak az alábbi szereplök:

Civil szervezetek

— A helyi civil szervezetek aktivitásukkal hozzájárulnak a kistelepülések kulturális életének színesítéséhez illetve tevékenységi területüktől függően nagy szerepük lehet a hagyományőrzésben, a helyi érték-védelemben, a tájvédelemben. Civil szervezeteknek jellemzően egyre inkább nő a lobbi erejük, érdekérvényesítő képességük. Meghatározó a civil szervezetek száma, tevékenységi köre, támogatottsága, együttműködési képessége (Márkus, 2000).

Önkormányzati szereplők

— Különösen kistelepülések esetében a térség fejlődését befolyásolhatja, hogy vannak-e elhivatott, lokálpatrióta, kezdeményezőkészséggel rendelkező hivatali dolgozók, polgármester, akik szívügyüknek tekintik településük, térségük boldogulását. Meghatározó az önkormányzati szereplők kezdeményező, problémamegoldó és együttmüködési képessége. A térség versenyképességét lobbi erejükkel, infrastruktúra-fejlesztéssel valamint az oktatás, rekreáció és a szociális ellátás területén végrehajtott és kezdeményezett fejlesztésekkel javíthatják. A települési környezet alakításában a település képviselőtestületének a helyi szabályozások elfogadásával döntő szerepe van (Konkoly-Gyúró, 2000).

Egyéb kulturális és szakmai elit csoportok

- A helyi kezdeményezések elindításában fontos szerepe a helyi intézmények vezetőinek, akik képzettségük és elhivatottságuk alapján alkalmasak lehetnek, kedvező változások elindításában, vagy újítóképességük folytán a kedvező folyamatok fenntartásában...

Gazdasági szervezetek

- A gazdasági szervezetek munkaerő-piaci hatásaikon keresztül hatnak a helyi társadalmakra, szolgálják a munkahely-teremtést, munkakultúra megváltoztatását, a megfelelő színvonalú munkaerő iránti igény megteremtését, a szakképzés közvetlen és közvetett formálását stb. Nagy jelentőségü lehet szponzorációs tevékenységük is elsősorban a sport, a kultúra és az oktatás területén. Egy-egy vállalkozó pozitívan járulhat hozzá az utcakép, településkép szépítéséhez.

- A gazdálkodóknak különösen nagy szerepük van a települések külterületének formálásában: környezetkímélő gazdálkodással, mezővédő cserje- és erdősávok telepítésével a biodiverzitás megőrzéséhez járulnak hozzá és oldhatják az intenzív agrártérségek tájképének monotonitását. A környező piacokon versenyképes termékek előállításával magasabb jövedelem megtermelésével járulhatnak hozzá településük helyzetének javításához.

Térségi identitás

A vidékfejlesztés elméletében és gyakorlatában egyre nagyobb hangsúly kerül a térségi identitás fejlesztésére. A területi identitást meghatározó tényezők különböznek a városi és falusi környezetben 
élők között (1. táblázat), de a gazdaság állapota, a munkalehetőségek mindenütt alapvetőek. A tájhoz való vonzódás elsősorban a falvak lakói számára meghatározó (Bugovics, 2007). Az identitás amiatt különösen fontos, hogy a helyi értékek ne vesszenek el ebben a globalizációs folyamatok által oly mértékben befolyásolt világban. Erős helyi identitás esetén meghatározó maradhat a helyi fogyasztói kultúra, a helyi termékek előnyben részesítése (Jackson, 2004). Az identitás alapvető fontosságú, hogy a gazdaságot élénkítő és a helyi társadalmat aktivizáló, tényleges fellendülést hozó fejlesztések legyenek megvalósíthatóak és a fejlődést akadályozó szomszédsági rivalizálás kiküszöbölhető legyen (Bugovics, 2007).

1. táblázat: Identitás-faktorok városokban és falvakban (Bugovics, 2007)

\begin{tabular}{|l|c|c|}
\hline Identitást meghatározó tényező & $\begin{array}{c}\text { Tényezö értékelése } \\
\text { városokban (1-5) }\end{array}$ & $\begin{array}{c}\text { Tényezö értékelése } \\
\text { falvakban (1-5) }\end{array}$ \\
\hline Lakóterület szeretete & 3 & 5 \\
\hline Táj vonzása & 3 & 5 \\
\hline Gazdaság állapota & 5 & 4 \\
\hline Infrastruktúra fejlettsége & 4 & 4 \\
\hline Kulturális viszonyok & 4 & 4 \\
\hline Müvelödési-szellemi környezet & 5 & 4 \\
\hline Emberi tényezők & 4,5 & 5 \\
\hline Munkalehetőség & 5 & 4,5 \\
\hline Erkölcs-értékrend helyi jellege & 3 & 3 \\
\hline Etnikai-területi specifikum & 3 & 3 \\
\hline Földrajzi identitás & 2 & 2 \\
\hline Fogyasztási környezet & 4 & 4 \\
\hline
\end{tabular}

\section{Civilpolitika}

Civilpolitika alatt összefoglaló értelemben értem elsősorban a közigazgatás, a területi kormányzás demokratikus, decentralizált jellegét, a helyi kormányzásban a civil részvételt, a kormányzás nyitottságát a párbeszédre, együttmüködési hajlandóságát a civil szférával másrészt a civil társadalom szervezettségét, aktivitását stb. Ide tartoznak mindazok az alapelvek, amelyeket a ,jó kormányzás” elve alatt összegez a Norvég Civil Alap, tehát a: „(1) részvételre és bevonásra építés, (2) elszámoltathatóság, (3) átláthatóság, (4) felelősség, (5) hatékonyság és (6) jogrend- követés" (www.norvegcivilalap.hu). A terjedelmi korlátok és a tanulmány fókusza miatt a civil politika néhány szempontját emelem csak ki. A központi és a helyi igazgatásnak az alábbi célok megvalósítására kell törekednie:

- „Tudásra alapozott rurális társadalom kialakulása

- Emberi erőforrások - egyéni és kollektív jellegü adottságok, kapcsolatok fejlesztése,

- Térségi identitás erösítése - a helyi identitás megléte, illetve az értékek közvetitése,

- A kormányzás demokratikus jellegének erösítése (a demokratikus menedzsment minden formáját jelenti, a civil részvétel erösítése is) - elsősorban az együttmüködés elösegitésének képessége és 
a public-private kapcsolatok támogatása, de fontos elem az individualizáció illetve a kollektív cselekvés viszonya is,

- Know-how és képességek, új funkciók elfogadásának és megtelepedésének segitése, ösztönzése legfontosabb a felhalmozott tudás továbbfejlesztésének képessége; tartalmazza az új követelmények felismerésének képességét, illetve a helyi adaptációs hajlamot is." (Leader, 2001; Szörényiné Kukorelli, 2009. Rechnitzer, 2009).

Változó hozzáállás, közösségfejlesztés, a civilszféra megerősítése azért is fontos, mert a civil szervezetek a vidékfejlesztés hazánkban még ki nem használt bázisát képezhetik (Kovács et al, 2005), valamint a vidékfejlesztési források alacsony hatékonyságát a gyakran a helyi közösségek alacsony szervezettségi foka, a helyi kormányzás és a helyi civil szféra nem megfelelő együttmüködése, kommunikációja okozza.

\subsubsection{Környezeti fenntarthatóság}

A fejlődésnek, de elsősorban a növekedésnek környezeti korlátai vannak. Már az 1970-es években megjelentek az első elméletek, amelyek felhívták a figyelmet a határtalan, pazarló gazdasági működés kedvezőtlen környezeti hatásaira és a Föld erőforrásainak végességére. Az ezekhez az elméletekhez kapcsolódó ökológiai-közgazdaságtannak, környezet-gazdaságtannak ma már széleskörü irodalma van. Az alapfilozófiát rögzítő ábrán (3. ábra) környezetgazdálkodás fogalom alatt utaltam mindazokra a gazdálkodási módokra, amelyek alapvető célja a környezeti, táji elemek védelme, az ökológiai rendszer fenntartása, megőrzése, gazdagítása. Ilyen optimális helyzet azonban ma nagyon ritkán, általában nem fordul elő, egyre nagyobb hangsúly kerül azonban a gazdálkodás fenntartható, a környezeti elemek védelmét, megújulását lehetővé tévő formáira. A fenntartható fejlődés elmélete éppen emiatt a környezeti, a társadalmi és a gazdasági igények harmonikus egyensúlyát emeli ki, hangsúlyozza. A környezeti fenntarthatóság alapvető érdekeit szolgálja a természet- és tájvédelem kiépült országos intézmény-, és eszközrendszerén kívül a település- és a területrendezés szabályozási eszközrendszere. A terjedelmi korlátok miatt e feltételrendszer egy alapkövére, a terület- és a településrendezés szabályozási tartalmára helyezem a hangsúlyt.

A 1996. évi XXI. törvény határozza meg hazánkban a területi tervezés eszköz és intézményrendszerét. A vonatkozó jogszabályok alapján a területi tervek lehetnek területfejlesztési koncepciók és programok, valamint területrendezési tervek. A szabályozásnak és egyben a több évtizedes hagyományoknak köszönhetően nálunk különválik a fejlesztési (gazdasági, társadalmi) és a rendezési (müszaki, ökológiai) típusú tervezés. A területrendezés az adottságok feltárásával és az ezekre alapozott térségi terület-felhasználási és övezeti szabályokkal, valamint a térségi jelentőségű műszaki infrastrukturális rendszerek térbeli rendjének meghatározásával befolyásolja a tájhasználatot. A rendezési tervek feladata lenne a tájpotenciál és a tájterhelhetőség feltárása, de a szabályozási jelleg do- 
minanciája miatt alapvetően korlátok felállítására koncentrálnak. A két tervtípus közötti eligazodást segíti, hogy a fejlesztési koncepciók a Mit és a Mikor kérdésre adnak választ, a rendezési tervek a Hol és Hogyan kérdésre, azaz a fejlesztési koncepció meghatározza, hogy egy térség milyen fejlesztést, beruházást (mit) mikor (pénzügyi lehetőségei, szándékai alapján) kíván megvalósítani, a rendezési terv megjelöli, hogy a beruházás hol és hogyan valósulhat meg. A fejlesztési koncepció egy gazdasági, politikai dokumentum, tükrözi a település, az adott térség céljait, motivációit, pénzügyi lehetőségeit.

\section{Szabályozási eszközök}

A hazai tervezési rendszer egyik sokat említett gyengesége éppen a rendezési és fejlesztési tervek/tervezés túlzott szétválasztása. Gyakran teljesen eltérő tervezőcsapatok készítették a terveket Extrém eset, hogy megyei szinten különböző testületek készíttették és fogadták el a területfejlesztési koncepciót (megyei területfejlesztési tanács) és a területrendezési tervet (megyei önkormányzat). A következmény nem kellően összehangolt, a területi sajátságokat nem kellően kiemelő és hasznosító tervek születése volt, amelyek nem vagy csak részlegesen tükrözték a helyi közösség preferenciáit. A fejlesztési intézményrendszer átalakulása, a megyei szint szerepének erősítése kapcsán a megyei szinten a két tervtípus kidolgozása egy kézbe kerül².

A területrendezés célkitüzései:

- a térség folyamatainak kontrollálása,

- a táji értékek védelme,

— kedvezőtlen irányú területhasználatok visszaszorítása,

— kedvező irányú folyamatok támogatása,

— térségi jelentőségű folyamatok támogatása, előnyben részesítése

— a táj terhelhetőségének megfelelő tájhasználat biztosítása (Schuchmann, 2008; 1996, XXI. évitv.).

A területfejlesztési koncepciók és programok kidolgozására országos, regionális, megyei és kistérségi szinten kerül sor, míg területrendezés terv készül országos és megyei illetve kiemelt térségi (Balaton és Budapesti agglomeráció) szinten. A területrendezési tervezési hierarchia csúcsán a területfejlesztéshez hasonlóan az országos szintü terv áll. Az Országos Területrendezési Terv 2003-ban fogadta el az országgyülés, majd 2008-ban módosításra került. Az 5 éves felülvizsgálati kötelezettség alapján 2013-ban kell a felülvizsgált törvénytervezetet az Országgyülés elé terjeszteni. A 2012-ben elkészült javaslat célja átjárhatóbb kapcsolat a terület- és településrendezési eszközök között, hatékonyabb integráció kialakítása a területi- és ágazati tervezés között valamint közös kapcsolódási pontok kialakítása a területrendezési és területfejlesztési tervezés elméleti háttere és gyakorlata kö-

\footnotetext{
21996 évi XXI. tv. - a területfejlesztésről és területrendezésről módosítása: 2011. évi CXCVIII. törvény 10. §. Hatályos: 2012. I. 1-töl
} 
zött. Alapvetően a terv szerkezete nem módosult, az övezetrendszer egyszerüsödött. Az Országos Területrendezési Terv jelentősége nem csak abban áll, hogy meghatározza az ország egészére vonatkozó térszerkezeti rendet és szabályokat, hanem abban is, hogy meghatározza a kiemelt térségek és megyék területrendezési terveinek készítésénél alkalmazható térségi terület-felhasználási kategóriák és övezetek fajtáit és a hozzájuk rendelhető szabályokat.

Az európai szintű, nemzeti és térségi de egyben a települési szintü tervezésben egyre hangsúlyosabbá váló együttmüködés (itt a térségek közötti, határon átnyúló együttmüködésekre gondolok) sem jelenik meg a rendezési tervezésben. Sem az OTrT, sem a megyei tervek nem foglalkoznak a közigazgatási határon túli területekkel (Balogh, 2010). Az Európai Unió részeként követnünk kellene az iránymutató dokumentumokat, mint Európai Unió Területi Agendája (Agenda 2011), amely kiemelt prioritásként kezeli többek között a várostérségek európai szintű együttműködését, ökológiai és kulturális hálózatok közös fejlesztését, fenntartását (a hazai fejlesztéspolitikában van ilyen irányú elmozdulás). A közigazgatási határokon belüli tervezés nem segíti a táji adottságok jobb hasznosítását vagy a fenntartható tájkezelést. (Az európai programozáshoz kapcsolódó pályázati rendszerben előrelépést jelentett például a három régió, öt megye területén elhelyezkedő Balaton térségi pályázatok egységben történő meghirdetése.)

Az országos és a megyei tervek szabályozásai a településrendezési terveken keresztül valósulhatnak meg. Az országos tervek léptékéből adódóan, a megyei terveknek csekély mozgásterük miatt néhány kivételtől eltekintve nem jelentős a korlátozó erejük a településekre. A településrendezési tervekben kötelező készíteni tájrendezési és környezetalakítási munkarészeket, sajnos részletes módszertan nem készült e fejezetek tartalmi követelményeire, ezért tervezői csoporttól, a településtől rendkívül erősen függ ezek színvonala.

A tájtervezés, tájfejlesztés eszközrendszerét a településrendezési tervek Országos Településrendezési és Építési Követelmények által meghatározott kategória rendszere csak részlegesen tartalmazza. A vidéki térségek versenyképességét javító tájkezelés, tájfejlesztés megvalósítására szükség van további tervezésre, a szükséges beavatkozások megtervezésére.

Az Európai Unió agrárpolitikájában ma már evidensnek számító multifunkcionalitás elve nem épül be a településrendezés gyakorlatába. Az OTÉK a mezőgazdasági területeken erősen korlátozza az elhelyezhető épületek körét (csak a termékfeldolgozás és tárolás épületeit engedi elhelyezni) ezzel a szabályozás ellentmond a Földtörvény mezőgazdasági tevékenységek definíciójának, amely valóban megfelel az EU agrárpolitikájában is megjelenő multifunkcionális gazdálkodásnak. A 1994. évi LV., a termőföldről szóló törvény definíciója szerint: 
„3.§ (k) Mezögazdasági tevékenység: növénytermesztés, kertészet, állattenyésztés, halászat, haltenyésztés, szaporító anyag-termesztés, vadgazdálkodás, erdögazdálkodás, vegyes gazdálkodás;...

...(l) Kiegészitő tevékenység: falusi és agroturizmus, kézmüvesipari tevékenység, fürészárufeldolgozás, elsödleges élelmiszer-feldolgozás, a mezögazdasági tevékenység során keletkezett melléktermékek, növényi és állati eredetü hulladék hasznositása, nem élelmiszer célú feldolgozása, valamint az ezekböl a termékekböl keletkezett termékek közvetlen termelöi értékesítése, mezögazdasági szolgáltatás..."

A törvény szerint széles az a tevékenységi kör, amellyel a gazdálkodók kiegészítő jövedelemre tehetnek szert, amelyet korlátoz a településrendezés. A településrendezésről szóló rendelet ${ }^{3}$ „mezőgazdasági területen a növénytermesztés, az állattartás és állattenyésztés és a halászat, továbbá az ezekkel kapcsolatos, a saját termék feldolgozására, tárolására és árusítására szolgáló építmények" elhelyezését engedi meg. A 2013-tól hatályos OTÉK csak egy lépéssel halad elöre: birtokközponthoz kapcsolódóan teszi lehetővé mezőgazdasági tevékenységhez kötődő szállás jellegü épület, vendéglátó épület létrehozását.

A fejlesztési tervek és rendezési/szabályozási tervek szemlélete rendkívül eltér, az egyes ágazatok tervezés, fejlesztési tevékenysége nem kapcsolódik össze, mindezek nagymértékben gátolják a település-, és területfejlesztés sok szempontú, a területhasználati tervezést, a tájfejlesztést is magába foglaló, ennek a tématerületnek a társadalmi oldalát is kezelni tudó megvalósulását ${ }^{4}$. A 314/2012. (XI. 8.) Korm. rendelet a korábbinál szorosabbra füzi a településrendezés-, és a fejlesztés kohézióját, kiemelve a koncepció és a településszerkezeti terv tartalmi összhangját, amit erősít a közös megalapozó vizsgálat készítésének a lehetősége.

A rendezési tervezésből hiányzik a kistérségi és mikro-térségi tervezés néhány kezdeményezéstől eltekintve. A kistérségi (járási) szint (illetve aprófalvas térségek esetében inkább a mikro-térségi tervezés, 6-12 településből álló térségre) lenne legalkalmasabb a tájhasználat szabályozására, a tájszerkezet védelmére, a települések együttműködésén alapuló táji erőforrás hasznosítás ösztönzésére. Az építésügyi törvény (1997. évi LXXVIII. törvény az épített környezet alakításáról és védelméről) lehetővé teszi az önkormányzatok számára közös településrendezési eszköz készítését. A társulásban készült településszerkezeti terv, illetve (314/2012. (XI. 8.) Korm. rendelet) építési szabályzat saját közigazgatási területére eső részét minden önkormányzat külön dokumentumként fogadja el. Apró-

\footnotetext{
${ }^{3}$ 253/1997. (XII.20.) Korm. Rendelet az országos településrendezési és építési követelményekröl és módosítása a 90/2012. (IV. 26.) Korm. rendelet 21. §. Hatályos: 2013. I. 1-töl.

${ }^{4}$ A fejlesztés és rendezés egymásra épülésének hiánya érhető tetten az országos szintű tervek kapcsolatának hiányában is: az országos területrendezési terv elöírásai, övezetei nem épülnek az országos fejlesztési koncepció (OTK) illetve a megújított Országos Fejlesztési és Területfejlesztési Koncepció (OFTK) célrendszerére. Annak ellenére, hogy az OFTK-ban erőteljesen megjelenik a táji szemlélet (külön foglalkozik egyes, országos jelentőségü tájegységekkel, táji értékekre alapozott növekedés térségeivel, foglalkozik fenntartható területhasználati elvekkel stb.), a különböző területi szintü rendezési tervek érdemben nem tudnak az eltérő táji adottságok közepette eltérő kezelést igénylő fenntartási, fejlesztési problémákkal hatékonyan foglalkozni, inkább csak ajánlás szinten.
} 
falvas térségekben kimondottan fontos lenne közös tervek készítése, ösztönzőket kellene kidolgozni, hogy a települések éljenek a jogszabályok nyújtotta lehetőséggel.

\subsubsection{Versenyképesség}

A versenyképességet alapvetően a gazdasági ágazatok hatékonysága, jövedelem-termelő képessége, a makrogazdasági viszonyok és mindezek alapján létrejövő jövedelemviszonyok határozzák meg. A továbbiakban feltárom, hogy a versenyképesség, a térségi versenyképesség valamint a vidéki térségek, mint sajátos funkcionális terek gazdasági teljesítményét hogyan értékeli a hazai és nemzetközi szakirodalom. A szakirodalmi kutatás és a fenntarthatóság, az élhetőség és a versenyképesség összefüggő feltételrendszere alapján saját definíciót fogalmaztam meg a vidéki térségek versenyképességére.

Mi köze a tájépítészetnek a korábban szigorúan gazdasági szempontú versenyképesség értelmezéséhez? Egy Japánban rendezett tájépítészeti világkonferencián hangzott el a következő gondolat: „A jövö század gazdasági, kulturális versenyét a világ azon régiójának népe fogja megnyerni, amelynek környezetét, életterét, hozzáértö tájépítészek olyanná alakítják, hogy az kreativitásra késztessen" (idézte: Csemez, 1996).

\section{Versenyképesség hagyományos értelmezése}

A versenyképességet korábban elsősorban vállalkozásokkal kapcsolatosan emlegették, majd megjelentek a területi alapú (nemzetközi, regionális, helyi szintü) versenyképességi értelmezések (Németh, 2005). A különböző szinteknek megfelelően különböző szempontok kerülnek túlsúlyba, de alapvetően a kereslet és a kínálat viszonyáról van szó. A versenyképesség általában lehetőség arra vonatkozóan, hogy az adott térség (vállalat stb.) mennyire, milyen szinten tud a külső környezet kihívásaira válaszolni, reagálni, de alapvetően nem foglalja magában a versenyben való „,győzelmet”. Az OECD több dokumentuma, az EU hatodik regionális (1999-es) és második kohéziós (2001-es) jelentése alapján a versenyképesség fogalma: a vállalatok, az iparágak, a régiók, a nemzetek és a nemzetek feletti régiók képessége relatíve magas jövedelem és relatíve magas foglalkoztatottsági szint tartós létrehozására, miközben a nemzetközi (globális) versenynek ki vannak téve. Több nemzetközi szervezet rangsorolja évről évre az országokat versenyképességi szempontból. Az IMD rangsora mintegy 323 kritérium alapján rangsorol 55 országot. A kritériumoknak a többsége konkrét adatokon és mindössze a harmada véleménykutatáson alapul. A versenyképességi szempontok között megjelennek a fenntarthatósághoz kötődő környezeti szempontok is, sajnos ezek köre és hangsúlya nem igazán mérhető a gazdasági szempontokhoz (Jegyzetek: 1.). A környezetet elemző kritériumok között megtalálható az ökológiai lábnyom, a $\mathrm{CO}_{2}$ kibocsátás, a megújuló energiák aránya, az életminőség. 
Az országokhoz kapcsolódó versenyképességi értelmezés több szempontból is különbözik a vállalati szinttől. A vállalatok versenyétől eltérően a sikertelen országokat nem lehet bezárni, megszüntetni. Az országok közötti kereskedelem nem lehet zéró-összegü, tehát míg a sikeres vállalatok versenytársai tönkremehetnek, sikeres országok szomszédai is prosperálhatnak a fellendülésből. Egy más megközelítés szerint országok között nem versenyről, hanem rivalizálásról lehet beszélni, rivalizálásról a tőkéért, a befektetőkért (Lengyel, 2003).

A Hatodik Periodikus Jelentés definíciója alapján Lengyel Imre megfogalmazásában a „területi egységek akkor versenyképesek, ha gazdaságuk nyitott és az egy lakosra jutó jövedelmük tartósan magas és növekvő, valamint magas szintü és nem csökkenö a foglalkoztatottsági ráta, azaz ebböl a jövedelemböl a lakosság széles rétegei is várhatóan részesülnek” (Lengyel, 2003).

Egy régióban a jólétet a termelékenység határozza meg, azaz ahogyan a tőke és a termelési tényezők hasznosulnak, a cél tehát a magas termelékenységi szint elérése. Azt a régiót tekintik tehát versenyképesnek, amelynek meghatározó iparágai és vállalatai versenyképesek ${ }^{5}$. A fejlett országokból kiszorultak az olyan kevésbé innováció-igényes iparágak, mint a textilipar, szénbányászat. Mi a helyzet a mezőgazdasággal, értelmezhetőek-e itt klasszikus formában a versenyképesség kritériumai? Igaz, ma már nem tekinthető oly mértékben stratégiai ágazatnak az agrárium, mint évtizedekkel ezelőtt, de az élelmiszer és ipari-nyersanyag termelésen kívül rendkívül fontos nem-piaci funkciókat is ellát, mint természetvédelem, tájfenntartás, hagyományok védelme stb. Bármennyire válságba is kerül a mezőgazdaság, nem szünhet meg, nem lehet bezárni, legfeljebb termelői funkciói gyengülnek (Horváth, 2006). Enyedi György széles körü tényezőcsoportot (Jegyzetek 2.) vett figyelembe a városok sikerességének értékelésében (Enyedi, 1998).

Lengyel Imre egy piramismodellben összegezte a régiók versenyképességét meghatározó tényezőket (4. ábra). A modell talapzatát a hosszú távú sikerességhez elengedhetetlen társadalmi és gazdasági faktorok alkotják, itt jelennek meg a környezeti szempontok is. A piramis középső részén szerepelnek az alaptényezők, amelyek döntő fontossággal bírnak. A régiók versenyképességét a régióban élők életminősége határozza meg. Lengyel Imre a jólétet alapvetően a térség jövedelmére és foglalkoztatottsági szintjére vezeti vissza. ${ }^{6}$

\footnotetext{
${ }^{5}$ A regionális versenyképesség meghatározására korábban döntően a következő tényezőket vizsgálták:

- a regionális GDP egy lakosra jutó nagyságát,

- a régióban a munkatermelékenységet,

- a régióban a foglalkoztatottsági rátát,

— a régió gazdaságának nyitottságát (Lengyel, 2003).

${ }^{6}$ Legalapvetőbb feltételként a közgazdaságtani tényezők jelennek meg, viszonylag hangsúlyos elemként megjelennek a humángazdaság alapjai mint a társadalmi kohézió, a társadalmi szerkezet, intézményi- és társadalmi tőke. Sokkal kevésbé hangsúlyos elem a környezeti fenntarthatóság kérdése, inkább ez is az életminőség kritériuma Lengyel értelmezésben.
} 


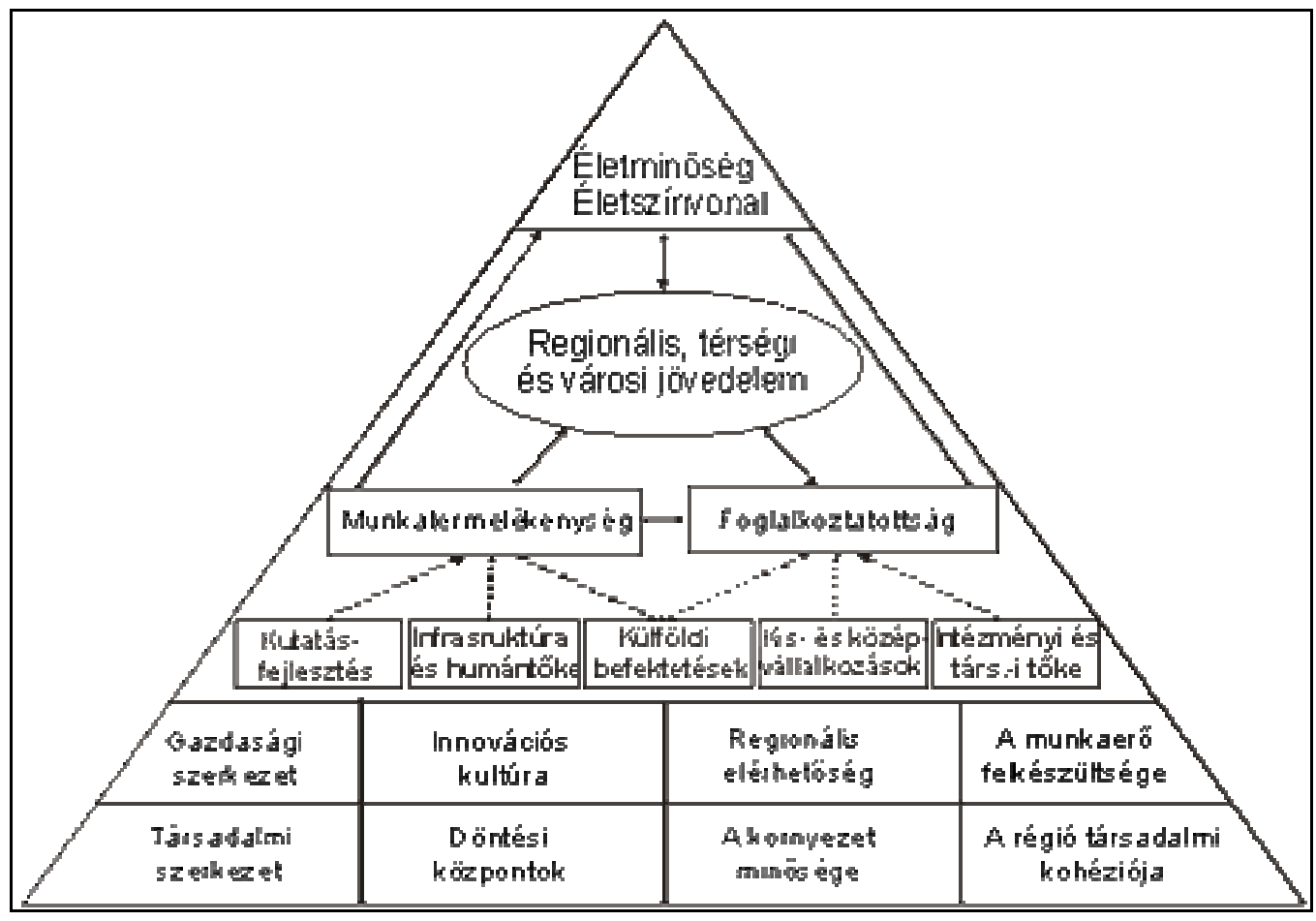

4. ábra: Régiók versenyképességének piramis-modellje

(Forrás: Lengyel Imre, 2000)

Koltai Zoltán értelmezésében már sokrétủ kritériumrendszert fogalmazott meg a régiók versenyképességét illetően, magába foglalva a gazdasági szerkezettől, innovációs kultúra, elérhetőség munkaerő felkészültségét, környezetminőséget, döntési központok, problémakezelő képességet egyaránt (Jegyzetek: 3.). Koltai Zoltán kritériumai elsősorban a régiók központjaira alkalmazhatók, az alkalmazott kritériumok kistérségi szinten nehezen értelmezhetők, illetve alapvetően az urbánus térségekre teljesülnek ${ }^{7}$.

\section{Vidéki térségek versenyképességének értelmezése}

Az Európai Bizottság 2004-ben elfogadta az OECD definícióját a rurális térségekről, amely alapján vidéki térségeknek tekinthetjük mindazokat a térségeket, amelyekre teljesül az alábbi állítások valamelyike:

— Települési szinten: 150 fö/ $/ \mathrm{km}^{2}$ alatti népsürüség

— Térségi szinten: három térségtípus

○ Dominánsan rurális régiók, melyekben a lakosság több mint 50\%-a él „rurális településeken".

○ Szignifikánsan rurális régiók, ahol a lakosság 15-50\%-a él „rurális településeken”.

○ Dominánsan urbánus régiók, ahol a lakosságnak kevesebb, mint 15\%-a él „rurális településeken".

\footnotetext{
${ }^{7}$ E kritériumrendszer alapján csak a nagyvárosi kistérségek számítanának versenyképesnek (innovációs kultúra, döntési központok stb.).
} 
Az ország területe az európai átlagnál jóval nagyobb arányban vidéki (rurális) jellegü. A korábbi tapasztalatok alapján a vidéki térségek lehatárolásának szabályait továbbfejlesztették így 2007-2013 között a 120 fö/ $\mathrm{km}^{2}$ népsürüséget meg nem haladó, vagy 10.000 főnél kevesebb lakosú településeket tekintik vidéki térségnek, kivéve a budapesti agglomeráció településeit, de beleértve azokat a nem vidékinek számító településeknek a külterületeit, amelyekben a teljes népesség több mint 2\%-a él a külterületeken. Ez az ország településeinek 95\%-át, területének 87\%-át és a népesség 45\%-át fedi le. A vidéki térségek azt a sajátos térségtípust képviselik, ahol alacsonyabb a népsürüség, ahol a megélhetést jellemzően a föld biztosítja, valamint általános a nem városi jellegủ (falusi, kisvárosi, egyes régiókban pedig a tanyákra jellemző) településszerkezet (Új Magyarország Vidékfejlesztési Program, 2007-2013).

Vidéki térségeinket sajátos - sok esetben egyre értékesebbnek tekintett - adottságok (alacsony fokú urbanizáltság, kis népsűrüség, természeti területek magas aránya) és jellegzetes társadalmi-gazdasági problémák jellemzik. Átlag alatti jövedelemszint a városokhoz képest, alacsonyabb a befektetési, a vállalkozói aktivitás, az urbánus térségekhez képest rosszabb az infrastrukturális ellátottság, nagyon sok vidéki kistérségben átlag feletti a munkanélküliség, magas az elvándorlás, különösen az aprófalvakat fenyegeti az elöregedés, magas az agráriumban foglalkoztatottak aránya és még sorolhatnánk a negatív jellemzőket. Azonban mégsem állhat/áll le az élet a városok határában, vidéki térségek is rendelkezhetnek jelentős népességmegtartó erővel. Sajnos a versenyképességi elemzések döntően a gazdaság hajtómotorjaként megjelenő ipart és szolgáltatásokat vizsgálják.

Az alábbiakban áttekintem, hogyan értelmezik a szakirodalomban a vidéki térségek gazdasági teljesítményét, versenyképességét. A vidéki Európa képe egyre inkább összekapcsolódik az elvándorlás, az elöregedés képével, a technológiai fejlődés is inkább csak a foglalkoztatottság csökkenését okozza a mezőgazdasági szektorban. Az 1990-es években végzett összehasonlító elemzések mutatják, hogy Európában a vidéki térségekben a mezőgazdaság súlyának csökkenése együtt járt az ipari és a szolgáltatási szektorok bővülésével. Azonban a mai napig a vidéki térségekben a szolgáltatások súlya a gazdaságban 10\%-kal alacsonyabb, mint a városias térségekben. Bár több vidéki térségben a nem-mezőgazdasági munkahelyek növekedése nem tudta kompenzálni az elveszített mezőgazdasági munkahelyeket, vannak példák, ahol a foglalkoztatás bővülése meghaladta a városi térségekét. Az, hogy a leginkább rurális jellegü térségekben sem haladja meg a mezőgazdaságban foglalkoztatottak aránya a 15\%-ot az EU 15-ök esetében, mutatja, hogy ma már vidéki térségek gazdaságának nem kizárólagosan a mezőgazdaság lehet a gerince (Terluin, 2003). A vidéki térségek képe az Európai Unióban igen változatos, vannak köztük nyertesek és vesztesek egyaránt. Ez a mozaikosság felveti a kérdést, milyen mozgatórugók, erők állnak e jelenség mögött. Mi okozza a vidéki térségek eltérő 
gazdasági teljesítményét? A térségek eltérő gazdasági teljesítménye mögött lokális és globális tényezők kölcsönhatása áll. A kérdés összetettségét a következő szempontok is megvilágítják:

- Hazánkban, hasonlóan Európa többi vidéki térségéhez az utóbbi évtizedben egyre intenzívebb a rurális térségekből történő elvándorlás. A megélhetési lehetőségek hiányában a legtöbben feltehetően a munkavállalás és a jobb megélhetés reményében távoznak. Ebből a szempontból pozitív változás csak a közép-magyarországi, valamint a közép- és nyugat-dunántúli régiókban történt; az észak-magyarországi és az észak-alföldi régióban azonban kedvezötlenebb a vándorlási egyenleg. A jelenlegi tendenciák változatlansága esetén Magyarországon valamennyi régióban a népesség elöregedésére, az inaktív népesség arányának növekedésére kell számítani (Új Magyarország Vidékfejlesztési Program, 2007-2013).

- Különösen az utóbbi másfél évtizedben, hazánkban is erőteljesen jelentkező szuburbanizációs folyamatok következtében vannak térségek (kistelepülések), ahol a vándorlási mérleg pozitív, ami szintén konfliktusok elé állíthatja a helyi közösségeket. A bevándorlók csoportja nagyon változatos: gazdaságilag aktív emberek, nyugdíjasok, és visszatérők. A beköltözők vágyai és elvárásai - amelyek leggyakrabban a vidéki idillhez, a környezet minőségéhez, az alacsonyabb megélhetési költségekhez kapcsolódnak - példátlan kihívás elé állítják az ottani kultúrát, közösséget. Ebben az összefüggésben a vidéki térségek fejlődése komplex gazdasági, társadalmi és politikai folyamat, amelynek eredménye a szereplők közötti erőviszonyoktól függ.

- A vidéki térségekre hatnak a gazdasági, a társadalmi és a környezeti változásokat egyaránt okozó globalizációs folyamatok, mint a tőke növekvő mobilitása, a termelési folyamat különböző fázisainak szétválása, amely a vállalatok szervezeti felépítését befolyásolja. A kommunikációs technológia fejlődésének következtében csökkennek a távolságok és változásokat hoznak a különböző geopolitikai események, mint a hidegháború vége, az Európai Unió kibővülése, kereskedelem liberalizációs tárgyalások (Terluin, 2003).

A vidéki térségek fejlődése a globális hatótényezők és a helyi válaszok kölcsönhatásának eredménye. A helyi válaszok a gazdasági tevékenységek változatosságán, a helyi adottságoknak a mindenkori igényeknek és feltételeknek megfelelő hasznosításán és a lokális szereplőknek a megváltozott feltételekhez való alkalmazkodásán múlnak. A válaszok nagyban függnek a helyi közösség strukturális és intézményi felépítésén, a hagyományokon, a helyi vezetésen. Nemcsak a helyi, regionális társadalmi-gazdasági folyamatoknak, de a nemzeti szintnek is nagy jelentősége van a vidéki térségek fejlődésében, hiszen a központi kormányok a felelősek az erőforrások elosztásáért az infrastruktúra, a szociális biztonság, az oktatás, vidék- és mezőgazdasági fejlesztések stb. területén. Még az eddig áttekintett tényezők sem adnak egzakt választ a vidéki térségek fejlődéséről, a továbbiakban áttekintem a legfontosabb elméleteket a vidéki térségek fejlődésének hajtóerőiről. 
A gazdasági fejlődést szűkebb értelemben általában, ahogy ezt a versenyképességhez kapcsolódóan is láthattuk, az egy före jutó GDP növekedéshez szokták kapcsolni. A gazdasági fejlődés tágabb értelmezésében és főleg a vidéki térségekhez kapcsolódóan már társadalmi-kulturális és politikai dimenziót is figyelembe vesznek a gazdasági szempontok mellett. A társadalmi-kulturális dimenzió magába foglalja a kulturális igényeket, a közösségi identitást, a politikai dimenzió pedig utal arra, hogy az egyének csoportjai milyen mértékben vesznek részt a döntési folyamatokban.

Számos elmélet foglalkozik a regionális fejlődéssel, amelyek azonban egy pontban közösek: elsősorban a régióban megtermelt javakra koncentrálnak, ami azonban kimondottan a régió iparának versenyképességéhez köthető. Az első közgazdaságtani elméletek általában az exportra termelő ágazatok forrásnövelő szerepét (hagyományos modellek), a fejlődő ipari térségek növekvő előnyét (agglomerációs modellek) emelik ki, majd az egyre inkább előtérbe kerülő elméletek a helyi sajátosságokra (helyi miliő modellek), kezdeményező készségre, innovációra való képességre (területi innovációs modellek) helyezik a hangsúlyt (Jegyzetek 4.).

A fenti elméleteken túl vita alakult ki a vidéki térségek gazdasági fejlődéséről is, központban azzal a kérdéssel, hogy a vidékfejlesztés miképpen serkentheti a gazdasági növekedést a rurális térségekben. Három különböző szemlélet különíthető el:

1. Exogén fejlődési megközelítés

2. Endogén fejlődési megközelítés

3. Az exogén és endogén fejlődés megközelítés elegye

Ezek a megközelítési módok többé-kevésbé a vidékfejlesztés elméletének kronologikus fejlődését is mutatják. Számos párhuzam figyelhető meg az agglomerációs, a helyi miliő és a területi innovációs modellekkel.

Az exogén fejlődési elméletek legfontosabb jellemzői, hogy a kívülről meghatározott vidékfejlesztést meghatározott régiókra alkalmazzák és a fejlődés hasznát kivonják a régióból és elnyomják a helyi értékeket. Az exogén modellek azon a nézeten alapulnak, hogy a modernizáció a gazdasági tevékenységek városi és vidéki területek közötti megosztásának eredménye: a városi térségek az ipari tevékenységeknek és a szolgáltatásoknak a fő színtereivé válnak a vidéki területek pedig a mezőgazdaságé, erősen függve a városoktól. A szemlélet alapvetően határozta meg az EU agrárpolitikáját az 1980-es évekig. A nyolcvanas években jelentkező problémák - mint a mezőgazdaság foglalkoztatási szerepének csökkenése, a növekvő társadalmi és szociális költségek vagy a környezetszennyezés miatt ipari vállalatokat telepítettek vidékre, hogy munkahelyeket teremtsenek a vidéki népesség számára. Ezek az elméletek az 1970-es évek végére népszerűségüket vesztették, miután 
nem hoztak fenntartható gazdasági fejlődést a vidéki térségek számára és magukkal vonták a CAP reformját is. ${ }^{8}$

Az endogén fejlődés alatt helyi kezdeményezés alapján indult, helyi erőforrásokon alapuló fejlesztést/fejlődést értünk. Az exogén fejlődéssel ellentétben a fejlődés haszna a helyi gazdaságban marad és a helyi értékeket tiszteletben tartják. A vidékfejlesztésen belül a hangsúly eltolódott a vidéki gazdaság diverzifikációja felé, az alulról építkezés elve került előtérbe, a helyi vállalkozások támogatása, a helyi kezdeményezések bátorítása, gondoskodás a megfelelő képzésről.

Két jellegzetesen rurális elméletet lehet kiemelni: a közösség vezette vidékfejlesztési elmélet és Bryden elmélete, mint a vidéki térségek számára kompetitív előnyök létrehozása, a mozdíthatatlan erőforrások kiaknázása révén.

A közösség vezette vidékfejlesztési elmélet központi eleme a helyi szereplők „,̈nsegítő” - önszervező képességének erősítése, amit a helyi gazdaság fejlődésének elindításában és fenntartásában alapfeltételnek tartanak. A partnerség-építés és az intézményi hálózat fejlesztése tekinthető a fő eszközöknek. A szakirodalomban a közösség vezette vidékfejlesztés mellett közösségfejlesztés (community development), alulról építkező partnerség (bottom-up partnership approach) fogalmak mind erre a megközelítésre utalnak. ${ }^{9}$

A közösség vezette vidékfejlesztés kiinduló pontja az a megfigyelés, hogy sok vidéki térség és közösség szinte leküzdhetetlen nehézségekbe ütközik gazdasági fejlődés generálásában, annak következtében, hogy a gazdasági problémák megoldására elégtelenek a képességek, nem megfelelő az intézményi környezet, nincs politikai döntési kompetencia. A problémák kezelésére a megoldás a közösség „önsegítő” képességének erősítése. A végső cél, hogy megváltozzon a helyi szereplők hozzáállása, az apátiát, beletörődést lelkesedés és önmagára-támaszkodás váltsa fel. Az intézményi hálózat fejlesztése különösen a helyi, regionális és nemzeti hatóságok közötti kapcsolatrendszer szempontjából fontos, hiszen a közösség vezette fejlesztés olyan intézményi struktúrát igényel, amely bátorítja az alulról jövő kezdeményezéseket.

Bryden szerint a globalizációs folyamatok közepette, amikor rendkívül magas a tőke-, az információ-, a kvalifikált munkaerő és egyéb javak áramlásának, mozgásának szabadsága, ezek az erőforrások már nem nyújtanak stabil alapot a vidéki térségek fejlesztésére. Ezek a „,mozdítható” erőforrások szükösek, a vidéki térségeknek versenyezni kell egymással ezen erőforrások megszerzéséért

\footnotetext{
${ }^{8}$ Ezen elméletek és a gyakorlat sikertelenségének alapvető indoka a fenntarthatóság és az élhetőség szempontrendszerének figyelmen kívül hagyása. Az elmélet és gyakorlat bukása igazolja, hogy komplex megközelítésre van szükség.

${ }^{9}$ Az elmélet leghangsúlyosabb eleme az élhetőséghez, a humángazdasághoz kapcsolódó szempontrendszer. A versenyképesség elérését a társadalom fejlesztésén keresztül képzeli el, hiszen a gazdasági folyamatok, a sikeresség is a „fejekben döl el". A környezeti, fenntarthatósági szempont azonban hiányzik a megközelítésböl. Az elmélet azonban a vidékfejlesztés egy nagyon hangsúlyos elemére hívja fel a figyelmet. A hazai Leader alacsony hatékonyságának a közössségfejlesztési gyakorlat hiánya az egyik oka.
} 
másrészt pedig a siker egymás kárára érhető el. Így Bryden tézise kimondja, hogy a vidéki térségek kompetitív előnye a „mozdíthatatlan” erőforrásokon alapuljon, amelyek azonban nem versenyezhetnek. A „mozdíthatatlan” erőforrások adott térséghez kötődnek, és nem mozdíthatók el egyik helyszínről a másikra. Egyesek megfoghatók, mint az ingatlanok, a fizikai infrastruktúra és a természeti erőforrások, de vannak megfoghatatlan, eszmei javak, mint tudás, kultúra stb. Bryden a mozdíthatatlan erőforrások négy csoportját különbözteti meg: társadalmi, kulturális, környezeti, helyi tudás tőke. A mozdíthatatlan erőforrások meghatározzák a helyi fejlődés lehetőségeit és korlátait és tükrözik a helyi és a regionális intézményrendszer hatékonyságát e lehetőségek és korlátok kezelésében (Bryden, 2000, 2003).

Bryden szerint a mozdíthatatlan erőforrások csoportjai:

- Társadalmi tőke: magába foglalja a társadalom olyan sajátosságait, mint a másokba vetett bizalom, a közösségi normák, hálózatok, amelyek a társadalom hatékonyságát növelik.

- Kulturális tőke: magába foglalja a történelmet, szokásokat, nyelvet, zenét, müvészeteket, amelyek területhez köthetők.

— Környezeti tóke: ami egy térség aktuális fizikai adottságaira utal. Magába foglalja mind a természeti környezeti tőkét (táj, éghajlat stb.) mind az épített környezeti tőkét (történelmi jelentőségü építmények, szerkezetek, fizikai és turisztikai infrastruktúra).

- Helyi tudás tỏke: ez egy térség képessége formális és informális tudás és információ-tömeg generálására, fenntartására és felhasználására (Bryden, 2000). ${ }^{10}$

Az endogén fejlődési megközelítés minden régióban helyi fejlődési potenciál meglétét feltételezi, ami kiaknázásra vár. Slee (1993) értelmezésében az endogén fejlődés nem egy fogalom kidolgozott elméleti gyökerekkel, hanem inkább a vidékfejlesztés egy perspektívája, értelmezése. Tagadja endogén fejlődési modell létezését, ehelyett úgy tekint rá, mint exogén modellre, ahol a fejlődés meghatározói külső erők, de a folyamatot endogén erők is befolyásolják. Az endogén fejlődési modellben a ,fiók üzemek” létrehozására irányuló stratégia helyett a helyi vállalkozások támogatására, a hagyományos bürokratikus támogatástól hálózati funkciókkal rendelkező kezdeményezők létrehozására került a hangsúly, de a fejlődési folyamata alapvetően nem változott (Slee, 1993).

Az exogén és endogén fejlődés megközelítés elegyeként megnevezett elmélet elveti az exogén és endogén modellek végletes megközelítési módját, ehelyett hangsúlyozza a fejlődési folyamat során a helyi és a külső erők kölcsönhatásait. Ez az elmélet a vidékfejlesztést a globalizációs folyamatokhoz kapcsolja a kommunikációs és az információs technológiák gyors fejlődése következtében. A válto-

\footnotetext{
${ }^{10}$ Az eddigi értelmezésekhez képest legteljesebben tartalmazza a környezeti és a társadalmi szempontrendszert. A környezeti szempontokat azonban nem a fenntarthatósági korlátok oldaláról, hanem a hasznosítható tőke/érték oldalról közelíti. A gazdasági vonatkozásokat mindezen tőke hasznosításának folyományaként szemléli.
} 
zó globális környezetben a vidéki térségek mind helyi mind regionális hálózatok résztvevői, de a hálózatok mérete, irányultsága, és sürüsége régiónként különböző. Ezek a hálózatok lefednek vállalaton belüli kapcsolatokat, vállalatok közötti kapcsolatokat, vállalatok és helyi illetve nem helyi intézmények közötti kapcsolatokat. A vidékfejlesztés a hálózatok szövevényének tekinthető, amelyekben mobilizálják az erőforrásokat, és amelyekben a kontrollt a helyi és a külső erők összjátéka adja. ${ }^{11}$

A helyi erőforrások mobilizálásán, a helyi közösség cselekvő közremüködésén alapulnak a például Ausztriában mindennapi gyakorlatnak minősülő Local Agenda 21 programok, amelyek a természeti környezet fejlesztése mellett felölelik az épített környezet, közlekedés, energiaellátás, agrárium fejlesztését (Füle, Szlávik, Turchany, 2002) egyaránt, tehát valamennyi olyan ágazatot, tématerületet, amelyek egy város, falu életét, jövőjét meghatározzák.

Az OECD 2001-es kiadványában fogalmazzák meg a területi tőke fogalmát, hiszen már régóta nyilvánvalóvá vált, hogy a vidéki térségek nem kategorizálhatók az addigi versenyképességi szempontok szerint. Egy térség területi tőkéje „különbözik minden más térségétől, sokféle tényezö határozza meg, amelyek között megtalálható a földrajzi helyzet, méret, termelési tényezöellátottság, éghajlat, hagyományok, természeti adottságok, életminöség vagy a városok által nyújtott agglomerációs hatások... Egyéb faktorok mint hagyományok, íratlan szabályok, amelyek lehetövé teszik, hogy a gazdasági szereplök együttmüködjenek akár bizonytalan körülmények között is vagy a szolidaritás vagy együttmüködés valamely ötlet kifejlesztésében, megvalósításában azonos gazdasági ágban müködö kis és közepes vállalkozások által (szociális tőke). Végül ott van egy megfoghatatlan faktor: „valami a levegöben”, a „környezet”, amely az intézmények, szabályok, gyakorlatok, termelök, kutatók, politikusok együttesének eredménye, amely bizonyos kreativitást, innovációt tesz lehetővé. A „területi töke” a beruházások nagyobb arányú megtérülését teszi lehetővé, hiszen a térséghez jobban alkalmazkodtak, hatékonyabban hasznosítják értékeit és adottságait." (OECD Territorial Outlook, Territorial Economy, 2001; Terluin, 2001) ${ }^{12}$

Nagyon érdekes a Leader program versenyképességi értelmezése (Leader, 2001), amelyben a környezeti és a táji vonatkozások sokkal nagyobb jelentőséget kapnak és ahol a fenntarthatóság alappilléreihez hasonlóan azonos súllyal jelenik meg a gazdaság, a társadalom és a környezet szempontrendszere. A Jelentés a Vidéki térségek globális versenyképességéről a területi versenyképesség négy dimenzióját fogalmazza meg:

\footnotetext{
${ }^{11}$ A modell elsőként magába foglalja a versenyképesség egy alapvető elemét, a nagytérségi összefüggéseket, kapcsolatrendszert.

${ }^{12}$ A fogalom nagyon jól szemlélteti a „probléma” komplexitását, bonyolultságát, az egyedi megközelítés szükségességét, viszont strukturálatlansága miatt alkalmazhatósága korlátozott. Önmagában nem lehet az elemzés alapja.
} 
— „társadalmi versenyképesség” - a bevont szereplök képessége arra, hogy hatékonyan együttmüködjenek közös elvek alapján különböző intézményi szintek támogatásával;

— „környezeti versenyképesség” - a bevont szereplők képessége arra, hogy környezetükből a lehető legtöbbet hozzák ki, térségük különleges elemévé téve azt, miközben biztosítják a természeti erőforrások és örökség megőrzését és revitalizációját;

— ,gazdasági versenyképesség” - a szereplők képessége arra, hogy a térségben maximális hozzáadott értéket hozzanak létre és tartsanak fenn a különböző szektorok közötti kapcsolat erősítésével és egyesített erőforrásaik révén a helyi termékek és szolgáltatások értékének és különlegességének fokozásával;

— ,globális versenyképesség” - a szereplők képessége arra, hogy meghatározzák térségük szerepét más területekhez képest és általában a külső világ viszonylatában, oly módon hogy területi tervük megformálásával biztosítsák életképességét a globális kontextusban ${ }^{13}$ (Leader, 2001).

A vidékfejlesztés komplex szempontrendszerét tükrözi, a vidéki térségek fejlettségének/versenyképességének méréséhez is segítséget nyújt a PAIS projekt, amelynek keretében egy komplex szempont és indikátorrendszert (életminőség/társadalmi jólét, gazdasági teljesítmény, demográfiai jellemzők) állított össze a projekt keretében együttmüködő szakértőgárda (Jegyzetek 5).

A szakirodalom feldolgozása valamint az élhetőség, fenntarthatóság és a versenyképesség összesített szempontrendszere alapján azokat a vidéki térségeket tekintem versenyképesnek/sikeresnek, amelyek képesek a népesség hosszú távú megtartására, megfelelő szintü jövedelmet és életminőséget biztosítva a lakosság számára, miközben fenntartható módon gazdálkodnak természeti és kulturális értékeikkel, javaikkal. A fentiek elérésének alapvető eszköze a helyi szereplők együttmüködési képessége, az újításra, az innovációra való készsége. A térségi szintű versenyképesség nélkülözhetetlen feltétele a helyi adottságokhoz idomuló alkalmazkodás a külső környezet kihívásaihoz.

\section{Táji szempontok az Európai Unióban fejlesztéspolitikájában}

A fejlesztéspolitika formai keretrendszerét a települési szinttől az európai fejlesztési stratégiák egymásra épülő rendszere határozza meg. A tanulmány készítése során elemeztem az Európai Unió legfontosabb fejlesztési stratégiáit, területi jellegü dokumentumait, annak feltárása érdekében, hogyan érvényesülnek a fejlesztési stratégiákban és támogatáspolitikájában a táji értékek, erőforrások (2. táblázat).

\footnotetext{
${ }^{13}$ A Leader elméletében jelenik meg legjobban az élhetőség, a fenntarthatóság és a versenyképesség feltételrendszere. A Leader program hazai sikertelenségét a sematikus elemekből felépülő, a helyi adottságokat, a helyi társadalom képességeit ill. külső környezetet kevésbé figyelembevevő stratégiák illetve a közösségfejlesztési megközelítés hiánya okozza. A sikerességet gátolja, hogy kistérségi szinten a területi tervezés eszközei, feltételrendszere hiányosak, a fejlesztési társulások eszközrendszere elégtelen, kistérségi fejlesztési koncepció készül ugyan területrendezési terv azonban nem. A fejlesztési források kistérségi szinten hiányoznak még a pályázati önrész biztosításához is.
} 
2. táblázat: A táj „megjelenése” az európai stratégiákban (saját szerkesztés)

\begin{tabular}{|c|c|c|c|c|}
\hline $\begin{array}{l}\text { Dokumentum a területi } \\
\text { fejlödésről }\end{array}$ & $\begin{array}{c}\text { Kibocsátó szervezet, } \\
\text { dátum }\end{array}$ & Hangsúlyos elem & $\begin{array}{l}\text { Hangsúlyozott versenyké- } \\
\text { pesség szempontok }\end{array}$ & Környezet/ a táj „szerepe” \\
\hline $\begin{array}{l}\text { White Paper on Growth, } \\
\text { Competitiveness and } \\
\text { Employment/ } \\
\text { Fehér könyv a Növekedés- } \\
\text { röl, a Versenyképességröl } \\
\text { és Foglalkoztatásról }\end{array}$ & Európai Bizottság & Az Európai Unió versenyképessége & $\begin{array}{l}\text { Gazdasági és társadalmi } \\
\text { tényezök }\end{array}$ & $\begin{array}{l}\text { Jobbára a környezetvédelmi } \\
\text { projektek, aggodalmak a } \\
\text { környezeti erőforrások } \\
\text { „úlhasználatáról' mint jóléti } \\
\text { veszteségről }\end{array}$ \\
\hline $\begin{array}{l}\text { European Spatial } \\
\text { Development Perspective } \\
\text { (ESDP)/ } \\
\text { Európai Területfejlesztési } \\
\text { Perspektíva (ETP) }\end{array}$ & $\begin{array}{l}\text { Területi tervezésért } \\
\text { felelös miniszterek } \\
\text { informális tanácsa, } \\
1999\end{array}$ & $\begin{array}{l}\text { Az EU területének kiegyensúlyozott fejlődé- } \\
\text { se, versenyképesség }\end{array}$ & $\begin{array}{l}\text { A gazdasági, a társadalmi és } \\
\text { a környezeti szempontok } \\
\text { azonos hangsúllyal szere- } \\
\text { pelnek, az "európai szociális } \\
\text { modellt" kiterjeszti a térben } \\
\text { is. }\end{array}$ & $\begin{array}{l}\text { A táj gazdasági tényezőként } \\
\text { jelenik meg, } \\
\text { Természetvédelem és gazdál- } \\
\text { kodás harmóniáját célzó } \\
\text { Natura } 2000 \text { hálózat meghir- } \\
\text { detése }\end{array}$ \\
\hline $\begin{array}{l}\text { Territorial Agenda of the } \\
\text { European Union/ } \\
\text { Az Európai Unió Területi } \\
\text { Agendája }\end{array}$ & $\begin{array}{l}\text { Területi tervezésért } \\
\text { felelös miniszterek } \\
\text { informális tanácsa, } \\
2007\end{array}$ & Területi kohézió & $\begin{array}{l}\text { Gazdasági és társadalmi } \\
\text { szempontok, } \\
\text { Policentrikus városhálózat, } \\
\text { hozzáférés az infrastruktúrá- } \\
\text { hoz és a tudáshoz, kocká- } \\
\text { zatkezelés, fenntartható } \\
\text { fejlődés }\end{array}$ & $\begin{array}{l}\text { Az ökológiai hálózat és kultu- } \\
\text { rális értékek védelme, mint a } \\
\text { fejlödés számára hozzáadott } \\
\text { érték. } \\
\text { A táj nem jelenik meg önálló } \\
\text { szempontként. }\end{array}$ \\
\hline $\begin{array}{l}\text { Community Strategic } \\
\text { Guidelines/ } \\
\text { Közösségi Stratégiai } \\
\text { Iránymutat }\end{array}$ & $\begin{array}{l}\text { Európai Bizottság, } \\
2005\end{array}$ & Az Európai Unió versenyképessége & $\begin{array}{l}\text { Gazdasági és társadalmi } \\
\text { szempontok (foglalkoztatás } \\
\text { és termelékenység) }\end{array}$ & $\begin{array}{l}\text { Környezetvédelem mint } \\
\text { szempont a régiók vonzerejé- } \\
\text { nek növeléséhez }\end{array}$ \\
\hline $\begin{array}{l}\text { Guiding Principles for } \\
\text { Sustainable Spatial } \\
\text { Development of the } \\
\text { European Continent } \\
\text { Irányelvek az Európai } \\
\text { Kontinens Fenntartható } \\
\text { Területi Fejlődéséhez } \\
\end{array}$ & Európa Tanács, 2000 & $\begin{array}{l}\text { Területi kohézió, } \\
\text { Fenntartható fejlödés }\end{array}$ & $\begin{array}{l}\text { Harmónia a gazdasági, a } \\
\text { társadalmi és az ökológiai } \\
\text { szempontok között }\end{array}$ & $\begin{array}{l}\text { A táj fontos szerepet kap a } \\
\text { fejlesztési szempontokban, } \\
\text { irányelvek különböző tájtípu- } \\
\text { sokra }\end{array}$ \\
\hline $\begin{array}{l}\text { European Landscape } \\
\text { Convention/Európai Táj- } \\
\text { egyezmény }\end{array}$ & Európa Tanács, 2000 & $\begin{array}{l}\text { Tájvédelem, tájgazdálkodás, és tájtervezés } \\
\text { ösztönzése, } \\
\text { Európai együttmüködés a tájjal kapcsolatos } \\
\text { témákban }\end{array}$ & $\begin{array}{l}\text { kulturális, ökológiai és } \\
\text { társadalmi területen a táj } \\
\text { mint kiemelkedő közérdek }\end{array}$ & $\begin{array}{l}\text { A tájnak kiemelkedő jelentő- } \\
\text { sége van minden tervezési } \\
\text { tevékenységben, folyamatban }\end{array}$ \\
\hline Európa 2020 & $\begin{array}{l}\text { Európai Bizottság, } \\
\text { Európai Tanács, } 2010\end{array}$ & $\begin{array}{l}\text {-Intelligens növekedés: tudáson és } \\
\text { innováción alapuló gazdaság kialakitása. } \\
\text {-Fenntartható növekedés: eröforrás- } \\
\text { hatékonyabb, környezetbarátabb és ver- } \\
\text { seny-képesebb gazdaság. } \\
\text { - Inkluzív növekedés: magas foglalkozta- } \\
\text { tás, valamint szociális és területi kohézió } \\
\text { jellemezte gazdaság kialakitásának ösz- } \\
\text { tönzése }\end{array}$ & $\begin{array}{l}\text { K+F, digitális társadalom, } \\
\text { oktatás, foglalkoztatás } \\
\text { javitása, társadalmi felzár- } \\
\text { kóztatás; } \\
\text { Termelékenység javítása, } \\
\text { környezetbarát technológiák } \\
\text { elterjesztése }\end{array}$ & $\begin{array}{l}\text { Területi vonatkozásai nincse- } \\
\text { nek, táj nem jelenik meg, } \\
\text { inkább a környezetvéde- } \\
\text { lem/kibocsátás csökkentés, } \\
\text { területi kohézió, és a termé- } \\
\text { szeti erőforrások jobb haszno- } \\
\text { sítása ,jelszavakon" keresztül } \\
\text { kerül említésre }\end{array}$ \\
\hline Duna Stratégia & $\begin{array}{l}\text { Európai Bizottság, } \\
2011\end{array}$ & $\begin{array}{l}\text { Közlekedésfejlesztés, turizmus környezet- } \\
\text { védelem, gazdaságfejlesztés, intézményfej- } \\
\text { lesztés }\end{array}$ & $\begin{array}{l}\text { A Dunához mint természeti } \\
\text { erőforráshoz köthető fejlesz- } \\
\text { tési lehetöségek mint fenn- } \\
\text { tartható közlekedésfejlesz- } \\
\text { tés, energiagazdálkodás, } \\
\text { turizmus stb. }\end{array}$ & $\begin{array}{l}\text { Hangsúlyosak a környezetvé- } \\
\text { delmi és táji szempontok, } \\
\text { kulturális és természeti örök- } \\
\text { ség }\end{array}$ \\
\hline $\begin{array}{l}\text { Territorial Agenda of the } \\
\text { European Union/ } 2020 \\
\text { Az Európai Unió Területi } \\
\text { Agendája } 2020\end{array}$ & $\begin{array}{l}\text { Területi tervezésért } \\
\text { felelös miniszterek } \\
\text { informális tanácsa, } \\
\text { 2011, Gödölllö }\end{array}$ & Területi kohézió & $\begin{array}{l}\text { Régiók erős helyi gazdasá- } \\
\text { gon nyugvó globális ver- } \\
\text { senyképessége }\end{array}$ & $\begin{array}{l}\text { Az ökológiai, a táji és a kultu- } \\
\text { rális értékek védelme a } \\
\text { fenntartható fejlödés feltétele }\end{array}$ \\
\hline $\begin{array}{l}\text { A vidékfejlesztésre vonatko- } \\
\text { zó közösségi stratégiai } \\
\text { iránymutatások }\end{array}$ & $\begin{array}{l}\text { Európai Tanács } \\
2006 \\
\text { 2006/144/EK }\end{array}$ & $\begin{array}{l}\text { Versenyképes mezőgazdaság, } \\
\text { Vidék környezeti minőségének megörzése } \\
\text { Vidéki élet minőségének javitása }\end{array}$ & $\begin{array}{l}\text { Versenyképes mezőgazda- } \\
\text { ság } \\
\text { Tudás, innováció, együttmü- } \\
\text { ködés a versenyképesség } \\
\text { alapja a vidéki társadalmak- } \\
\text { ban }\end{array}$ & $\begin{array}{l}\text { Fontos gazdasági, belső } \\
\text { erőforrás }\end{array}$ \\
\hline
\end{tabular}


A dokumentumok közül néhányat kiragadva jól látható a versenyképesség kérdéskörének megkerülhetetlen szerepe a gazdasági és a társadalmi kohézióban, a gazdasági növekedésben és a foglalkoztatottságban, vagyis az egységes belső piac eredményes müködtetésében.

A regionális politika célrendszerét meghatározta a Lisszaboni stratégia, megfogalmazva az unió legfontosabb politikai törekvését, hogy az Európai Uniót a „világ legversenyképesebb és legdinamikusabb tudás alapú gazdaságává kell tenni, mely képes a fenntartható gazdasági fejlödésre több és jobb munkahelyet és szorosabb társadalmi összetartást biztosítva”. A Göteborgi Csúcson 2001-ben a stratégiát kiegészítették a fenntartható fejlödés kritériumával.

A Lisszaboni stratégia területi vetületeként fogalmazták meg a regionális politikáról és területi kohézióról rendezett informális miniszteri találkozón az európai városok és régiók területi tőkéjének (territorial capital) erősítését, amely magában foglalja a térségek belső erőforrásainak hasznosítását, a területi integrációt és a területi kormányzást (a horizontális és vertikális politikai együttműködés erősítése).

A Területi tervezésért felelős miniszterek informális tanácskozásán 1999. május 10-11-én Potsdamban elfogadták az Európai Területfejlesztési Perspektívát (ETP) ${ }^{14}$, amely az európai, a nemzeti és a regionális fejlesztési politikák számára a következő célokat fogalmazza meg:

- Gazdasági és társadalmi kohézió,

- Természeti erőforrások és kulturális örökség megörzése,

- Az európai régiók kiegyensúlyozottabb fejlődése.

Ezek a célok megfelelnek a területfejlesztés hagyományos célkitüzéseinek, a gazdasági és szociális kohézió az esélyegyenlőségnek, a kiegyensúlyozott fejlődés a hatékonyságnak, a természeti erőforrások és kulturális örökség megőrzése a fenntartható fejlődésnek. A régiók és a városok versenye nem vezethet társadalmi kirekesztéshez és nem utasíthatja el a környezetvédelmi felelősséget, az „európai szociális modell” gyakorlatilag kiterjeszti a szolidaritást a térben is. (Lengyel, 2003). Az ETP felhívja a figyelmet arra, hogy a természeti és a kulturális örökség egyben gazdasági tényező is, amely egyre fontosabb szerepet kap a területfejlesztésben. Az életminőség a településeken, városokban, a környező táj, a vidéki térségek ma már egyre jelentősebb szerepet játszanak a vállalatok telephelyválasztásában, a kulturális és természeti értékek pedig alapvetően meghatározzák a turizmus fejlődését. Az ETP felhívja a figyelmet az európai tájak egy közös sajátosságára, amely a folyamatos fejlődés, ami sajnos sok esetben uniformizálódáshoz a biodiverzitás csökkenéséhez vezet. Az ETP több irányelve szól a tájvédelemről és felhívja a figyelmet a táji értékekre, mint a területi fejlődés fontos forrásaira. Az ETP hirdeti meg először a természet- és tájvédelem újszempontú megközelítését jelentő Natura 2000 hálózat bevezetését, amely a gazdálkodva, hasznosítva védeni elvet tükrözi.

\footnotetext{
${ }^{14}$ Az ETP a fenntartható fejlődést biztosító gazdasági (versenyképesség), társadalmi (élhetőség) és környezeti (k. fenntarthatóság) feltételrendszer harmonikus egyensúlyát tüzi ki célul.
} 
Itt kell megemlíteni az Európai Unió Területi Agendáját (Agenda), amelyet az ETP folytatásaként fogadtak el 2007 májusában. Az Agenda egy rövid politikai üzenet, amelynek célja az európai régiók és városok erőforrásainak mobilizálása a fenntartható gazdasági fejlődés és a több munkahely létesítése érdekében. Az Agenda az ESPON program (European Spatial Planning Observation Network) legfrissebb tudományos eredményeire támaszkodik és kapcsolódik a Lipcsei Kartához az integrált településfejlesztésről valamint az Európa Tanács által elfogadott Irányelvek az Európai Kontinens Fenntartható Fejlödéséhez (Guiding Principles for Sustainable Spatial Development of the European Continent). Az Agenda a kihívásokra a regionális identitás erősítését, és a területi különbségek hatékonyabb kihasználását tekinti megfelelő válasznak. Az Agenda kijelöli az EU fejlődésének új területi prioritásait:

- A policentrikus fejlődés erősítése a különböző méretü régiók és városok együttműködése révén.

- A partnerség új formáinak és a területi kormányzás a városi és vidéki területek között.

- Határon átnyúló, versenyképes és innovatív regionális klaszterek támogatása.

- A Transz-Európai Hálózatok megerősítése és kiterjesztése.

- Transz-Európai kockázatkezelés támogatása (ideértve a klímaváltozás hatásait).

— Ökológiai hálózatok és kulturális és természeti erőforrások védelme.

A célok megfogalmazásában az Agenda nagyrészt visszatér az ETP irányelveihez kiegészítve a kockázatkezeléssel. Jellemzően komplex megközelítés helyett néhány kiragadott elvet hangsúlyoz. Új elemként jelenik meg a tájvédelemhez és a tájvédelemhez és -fejlesztéshez kapcsolódóan, hogy a dokumentum támogatja a kulturális és a természeti értékeket egybefogó útvonalak és hálózatok nemzetközi összefogással történő fejlesztését és fenntartását. Az Agendát megalapozó háttérdokumentumban sajnos a tájelemek két különböző fejezetben jelennek meg (természeti örökség illetve kulturális örökség), ami nem segíti a táji érdekek hatékony védelmét. A dokumentum nem foglalkozik a tájjal önállóan, ami visszalépést jelent a korábbi irányelvekhez képest. Az Agenda háttérdokumentációjának első munka-anyagában még külön fejezetben foglalkoztak az egyedülálló tájak, mint folyóvölgyek, tengerpartok, hegyvidékek sajátos problémáival, ami sajnos kimaradt a végső változatból.

Az Európai Bizottság által kiadott Közösségi Stratégiai Iránymutatásokban 2007-2013, a jelen programozási időszak kohéziós politikájának irányelveit fogalmazza meg. A dokumentum fő célja a Lisszaboni és a Göteborgi stratégia elveinek beépítése az unió kohéziós politikájába és a közösségi prioritások jobb integrálása a nemzeti és a regionális fejlesztési programokba. A stratégiai iránymutatás a következő irányelveket fogalmazza meg:

— ,,a tagállamok, a régiók és a városok vonzerejének növelése az elérhetőség javításával, a szolgáltatások megfelelő minőségének és szintjének biztosításával, valamint környezet megőrzésével, 
— az innováció és a vállalkozói szellem, továbbá a tudásalapú gazdaság növekedésének a kutatási és innovációs képességekkel - ideértve az új információs és kommunikációs technológiákat történő ösztönzése, valamint

— több és jobb munkahely oly módon történő megteremtése, hogy több embert vonzanak a foglalkoztatás vagy a vállalkozói tevékenység körébe, valamint fejlesztik a munkavállalók és a vállalkozások alkalmazkodóképességét, és növelik a humánerőforrásba történő.” (COM(2005) 0299, 2005). ${ }^{15}$

A stratégiai dokumentum szerint az Európai Unió versenyképességének növelésére a kulcsmegoldás a gazdasági és szociális feltételek javítása. Elsősorban az első irányelvben jelenik meg a környezetvédelem prioritásként (infrastruktúra, kockázat-megelőzés, Kyotoi protocol kötelezettségei, energiahatékonyság, megújuló erőforrások és alternatív technológiák). A stratégiai iránymutatások a kohéziós politika területi hatásait hangsúlyozzák és elsősorban ebben az összefüggésben bukkannak fel a táji szempontok. A dokumentum hangsúlyozza, hogy a fejlesztési stratégiákban a táji adottságok figyelembevétele javítja a területi kohéziót és a régión belüli illetve régiók közötti együttmüködést. A vidéki térségek esetében a táji értékek a versenyképesség alapját jelentik, a belső erőforrások, a kulturális és a természeti értékek nyújtanak lehetőséget a gazdasági diverzifikáció számára.

A Lisszaboni stratégia által előtérbe helyezett versenyképesség megjelenik az Európai Unió agrár- és vidékfejlesztési politikájában is. A miniszteri tanács által elfogadott szabályozás ${ }^{16}$ négy prioritási tengelyt határoz meg:

— mezőgazdaság és erdészet versenyképességének javítása,

— a környezet és a vidéki térségek minőségének javítása a tájgazdálkodás támogatásával

— vidéki térségekben élők életminőségének javítása és a gazdasági tevékenységek diverzifikációjának elősegítése,

— Leader, alulról induló kezdeményezések támogatása.

A vidékpolitika alapelveiben a vidéki térségek fejlesztésének komplex feltételrendszerét fogalmazza meg. Alapvetően a mezőgazdaságot erdőgazdálkodás versenyképességére teszi a hangsúlyt a gazdasági ágazatok között, hangsúlyozza az élhetőség és a környezeti fenntarthatóság elveit is.

A Területi Tervezésért felelős Miniszterek Európai Konferenciája (Európa Tanács) 2000 szeptemberében fogadta el az „Irányelvek az Európai Kontinens Fenntartható Fejlódéséhez” című dokumentumot (Guiding Principles for Sustainable Spatial Development of the European Continent), amely egy politikai ajánlás a területfejlesztési intézkedések és kezdeményezések és nemzetközi együttmüködések számára. A dokumentum célja, hogy összehangolja gazdasági és szociális követelményeket

\footnotetext{
${ }^{15}$ Alapvetően a versenyképességi és az élhetőségi elveken van a hangsúly.

${ }^{16}$ COUNCIL REGULATION (EC) No 1698/2005 of 20 September 2005 on support for rural development by the European Agricultural Fund for Rural Development (EAFRD)
} 
az adott térség ökológiai és szociális funkcióival, ezáltal hozzájárulva a hosszú távú, kiegyenlített területi fejlödéshez ${ }^{17}$.

Az Európa Tanácsnak jelentős a szerepe a tájvédelemben. Számos nemzetközi jogi dokumentumnak van közvetlen vagy közvetett hatása a tájértékekre, bár specifikusan és átfogóan egy sem foglalkozott az európai tájakkal és védelmükkel. Az Európai Tájkonvenció töltötte be ezt az ürt. 2000 júliusában az Európa Tanács elfogadta és aláírásra megnyitotta a 41 tagállamnak az Európai Tájegyezményt. A tájfenntartás tájvédelem szempontjából a Tanács kezdeményezése kulcsfontosságú. Az egyezmény célja, hogy elősegítse a tájak védelmét, kezelését és tervezését valamint, hogy hozzájáruljon a tájak terén megvalósuló európai együttműködéshez. Az egyezmény hatálya a felek teljes területére kiterjed, érvényes mind a természeti, vidéki, városi és városkörnyéki térségekre. (Ide értendők a szárazföld, a belvizek és a tengeri területek is.) A definíció szerint a táj magába foglalja mind a kiemelkedő minőségű, mind az átlagos vagy leromlott állagú tájakat is. A tájegyezmény ajánlásokat fogalmaz meg minden európai tájtípusra ami Európában előfordul. Az egyezmény általános célja, hogy bátorítsa a hatóságokat, hogy olyan politikát folytassanak mind helyi mind regionális, nemzeti és nemzetközi szinten, amely fenntartja, illetve fejleszti a tájak minőségét és ráébreszti a szervezeteket és a helyi hatóságokat a tájak fontosságára és értékére (Jegyzetek 6).

A Lisszaboni stratégiát felülíró Európa 2020 stratégia a gazdasági válságból való kilábalás mellett sokkal nagyobb hangsúlyt kíván fektetni a kutatás-fejlesztés, innováció mellett a humánerőforrásfejlesztésre, a szegregáció leküzdésére. A Bizottság a lényegi különbségek között hangsúlyozza az erősebb kormányzást (európai uniós kontroll, monitoring, szankciók) és a gazdasági kormányzás (EU és nemzeti koordináció, finanszírozás, konvergencia és reform programok) jelentőségét.

A Lisszaboni stratégia kudarcából okulva a célok elérésének ellenőrzéséhez számon kérhető/mérhető, elvárt eredmények teljesülését írja elő a Bizottság (Jegyzetek 7). A stratégiának nincsenek területi vonatkozásai, nem említ speciális térség illetve tájtípusokat, az általa felvázolt problémák és konfliktusok egy jelentős része azonban erőteljesen sújtja a vidéki térségeket, mint például elöregedés, alulfoglalkoztatottság, szegregáció. Célkitüzésként megjelenik a területi kohézió, a természeti erőforrások jobb hasznosítása, az éghajlatváltozáshoz kötődő környezetvédelmi célokon keresztül villan csak fel a tájgazdálkodás. A jelenlegi mutatókat, folyamatokat látva, a célok eléréséhez sokkal átfogóbb, komplex szemléletü, a társadalom sokkal szélesebb rétegeit bevonó együttmüködésen alapuló tervezésre, térségfejlesztési stratégiákra lenne szükség hazánkban.

2011-ben Gödöllőn fogadták el az Európai Unió Területi Agendája 2020 című megállapodást. Nagyobb hangsúly került a város és vidék partnerségére, a különböző vidéki térségek szükségleteire és

\footnotetext{
${ }^{17}$ Ez az első olyan európai szintü területfejlesztési stratégia, amely különböző tájtípusok (kultúrtáj, városi térségek, vidéki területek, hegyvidékek, tengerpartok és szigetek, eukorridorok, árterek, felhagyott ipari és katonai területek, határvidékek) fenntartásához, fejlesztéséhez fogalmaz meg ajánlásokat. Az itt megfogalmazott irányelvek részletesebben az Európai Tájkonvencióban jelennek meg.
} 
lehetőségeire, arra a tényre, hogy lelassult a hátrányos helyzetü térségek felzárkózása, és felgyorsult a hátrányos helyzetü társadalmi csoportok leszakadása. A TA2007-hez képest kiemelten hangsúlyozza a vidék és a város integrált fejlesztésének szükségességét, valamint a széles körü partnerségen nyugvó hely-alapú stratégiák kidolgozását. A TA2020 ${ }^{18}$ céljai:

1. A policentrikus és kiegyensúlyozott területi fejlődés elősegítése

2. Az integrált fejlesztés ösztönzése a városokban, és a vidéki és sajátos adottságú régiókban

3. A határokon átnyúló és transznacionális funkcionális régiók területi integrációja

4. A régiók erős helyi gazdaságokon nyugvó globális versenyképességének biztosítása

5. A területi összeköttetés javítása az egyének, a közösségek és a vállalkozások érdekében

6. A régiók ökológiai, táji és kulturális értékeinek kezelése és összekapcsolása.

Az EU vidékpolitikájának prioritásai sokrétüen felölelik a vidéki térségek konfliktusait, de alapvetően gazdasági alapnak a mezőgazdaságot és az élelmiszeripart tekinti (Jegyzetek 9), bár nagy hangsúlyt fektet az innováció lehetőségeinek és az információs technológiák terjesztésére:

1. A mezőgazdasági és erdőgazdálkodási ágazat versenyképességének javítása

2. A környezet és a vidék minőségének javítása

3. A vidéki élet minőségének javítása és a vidéki gazdaság diverzifikálása

4. A helyi kapacitás (partnerség) kiépítése a foglalkoztatottság és a diverzifikáció érdekében (2006/144/EK).

Az Európai Unió regionális politikájában egyre nagyobb hangsúly kerül a térségi integrációra (placebased megközelítések). A 2014-2020 programozási időszakban bevezetésre kerülő két fontos új térségi integrációs eszköz (COM(2011) 615):

1. Integrated Territorial Investments (ITI) Integrált Területi Befektetések

2. Community-led Local Development (CLLD) Közösségvezérlet Helyi Fejlesztések ${ }^{19}$, amely tulajdonképpen a LEADER koncepció általánossá tételét jelenti a regionális politikában, amely kiindulási alapként kedvező feltételeket teremthet az endogén és közösségvezérelt vidékfejlesztési modellek megvalósulásának. A hazai felkészülés során felmerült lehetőségek azt erősítik, hogy a járási szint lehet a CLLD-k területi szintje. ${ }^{20}$ Kiküszöbölheti a LEADER-ben is jelen lévő prob-

\footnotetext{
${ }^{18}$ A TA2020 céljai között erőteljesebben jelen van a fenntartható fejlődés hármas kritériumrendszere illetve az élhetőség, fenntarthatóság és versenyképesség komplex feltételrendszere.

${ }^{19}$ KSK alapok közös rendeletterv 28. cikk

Közösségi szinten irányított helyi fejlesztés ..:

a) konkrét szubregionális területeket vesz célba;

b) irányítása az adott közösség szintjén történik, a helyi társadalmi-gazdasági érdekek köz- és magánszférabeli képviselőiből álló helyi akciócsoportok révén, ahol döntéshozatali szinten sem a közszféra, sem egyetlen más érdekcsoport nem rendelkezik a szavazati jogok 49\%-ot meghaladó hányadával;

c) integrált és több ágazati területen alapuló helyi fejlesztési stratégiák révén valósul meg;

d) célja a helyi szükségletek és lehetöségek figyelembe vétele és a helyi környezet innovatív jellemzőinek bevonása, hálózatépítés és adott esetben együttmüködés.

${ }^{20}$ A jelen tanulmány aktualitását és szükségességét erősíti.
} 
lémát az ágazatok elkülönült kezelését, hiszen a CLLD egyetlen olyan eszköz, ahol a fejlesztések valamennyi alapból finanszírozhatók.

Az elemzés során megállapítottam, hogy bár az Európai Unió legfontosabb célkitűzései között szerepel az életminőség javítása, a környezetvédelem, a területfejlesztési dokumentumokban nem jelennek meg kellő hangsúllyal a táji szempontok, hiszen a gazdasági versenyképesség javítása élvez elsődleges prioritást, itt kivételnek tekinthető a vidékfejlesztés. Az elhanyagoltság másik oka, hogy a területi tervezés nem tartozik a közösségi politikák közé. Talán ennek tudható be az is, hogy az Európa Tanács sokkal részletesebben foglalkozott a táji értékek fejlesztéspolitikában betöltött szerepével. Annak ellenére, hogy számos közösségi politika közvetlen vagy közvetett hatással van a tájra (például a közös agrárpolitika, a környezetvédelem, a kohéziós politika, a Transz-Európai Hálózatok), nem történt valódi elemzés arra vonatkozóan, hogy e politikák hogyan befolyásolják a táji adottságokat. Az Európai Unió felismerte, hogy a vidék a térségi munkamegosztás részeként nem tekinthető pusztán élelmiszertermelő térségnek (exogén fejlődési modell), és a harmonikus területi fejlődés érdekében a hagyományos agrártámogatások rendszerén kívül, kifejezetten a vidéki térségek sajátos problémáinak kezelésével közösségi szinten szükséges foglalkozni (fejlesztéspolitikát az endogén modell felé orientálni). A vidékfejlesztési politika több programozási időszakon keresztül fejlődve érte el mai formáját, de már ma is felfokozott vita zajlik a vidékfejlesztés jövőjéről.

Az EU vidékpolitikájának elvei teljes mértékben megfelelnek a modern, a belső erőforrások mozgósítására, a közösségformálásra épülő fejlesztési elveknek, amelyek magukba foglalják a táji erőforrások tiszteletét, fenntartható hasznosítását. Nyugat-Európában sikeresnek bizonyult a Leader megközelítés, amelynek lényege, hogy térségi/kistérségi szinten a helyi szereplők önszerveződő jelleggel, helyi akciócsoportokat hoznak létre, amelyek bonyolítják a stratégia-alkotást és a forráskezelést/pályáztatást: azaz a helyiek határozzák el, hogy közvetlen környezetükben milyen fejlesztésekre van szükség és milyen kisléptékü fejlesztések nyerjenek támogatást. A vidékfejlesztésben elért siker alapján a (CLLD) a Közösségvezérlet Helyi Fejlesztések révén az EU lehetőség kíván nyújtani a regionális politikában a hatékony, helyi együttműködésen alapuló fejlesztések megvalósítására. Nagyon sok múlik a helyi közösségeken, hazánk csak néhány éve tapasztalta meg, éli át a fejlesztéseknek ezt a módját és egy komoly tanulási, felkészülési időszakra van szükség, hogy a helyi erők ténylegesen képesek legyenek erőforrásaik jobb hasznosítására, a pályázati lehetőségek kihasználására (lásd esettanulmány).

Az egyes közösségi politikák hatásainak elemzésében jelentős előrelépés volt az ESPON program (European Spatial Planning Observatory Network) elindítása, de sajnálatos módon a táji szempontok leggyakrabban megosztva jelennek meg a természeti erőforrások és a kulturális örökség témákban. Szükséges lenne, hogy az ESPON program keretein belül önálló vizsgálatként indulna el a táji hatá- 
sok értékelése. Szükséges lenne a legjelentősebb hatással bíró politikák és intézkedések céljait öszszehangolni, mint például a Natura 2000 és a kohéziós politika.

\section{Táji szempontok a hazai területfejlesztési politikában}

Nemzeti Fejlesztés 2020/ Országos Fejlesztési és Területfejlesztési Koncepció (OFTK)

Jelenleg társadalmi egyeztetés alatt áll a Nemzeti Fejlesztés 2020 című dokumentum, amely az Országos Területfejlesztési Koncepció (97/2005 (XII.25.) OGY) felülvizsgálataként készült el, és meghatározza a hazai fejlesztéspolitika kereteit 2014 és 2020 között. Elsőként a dokumentum gazdasági, környezeti és társadalmi csoportosításban sorra veszi a hazai társadalmat érő kihívásokat, trendeket és megfogalmazza a fejlesztéspolitika válaszait, prioritásait (Jegyzetek 8). Térhasználati elveket fogalmaz meg, amelyek elsősorban a fejlesztésekhez kapcsolódó prioritásokat, szempontokat és a közlekedésfejlesztés elveit határozza meg. A fejlesztéspolitikai prioritások megfogalmazásában komoly hiányosságokat pótol, átvéve, alkalmazva az EU Területi Agendájának prioritásait, mint határon átnyúló ökológiai rendszerek, város-vidék kapcsolat stb. A vidékpolitikát a korábbi OTK hagyományaira alapozva továbbviszi, nevesíti is a leghátrányosabb helyzetű térségeket. A vidéki térségek fejlesztésére az agrár- és élelmiszeripari fejlesztését, a helyi gazdaság megerősítését nevezi meg prioritásként. Kijelöli, lehatárolja az egyedi táji adottságokkal bíró térségeket, amelyek a „táji értékekre alapozott növekedés térségei”-vé válhatnak. A területfejlesztés alapegységeivé a megyéket teszi. Rövid összefoglalókban pozícionálja a megyéket és jelöli ki a legfontosabb fejlesztési irányokat (Nemzeti Fejlesztés 2020, Országos Fejlesztési és Területfejlesztési Koncepció http://www.nth.gov.hu).

\subsection{A tájhasználati rendszer, mint a fenntarthatóság, az élhetőség és a versenyképesség alapja}

A belső értékgazdálkodás a tájhasználati rendszerben tükröződik térségi szinten. Fontosnak tartom a tájhasználat szempontrendszerének figyelembevételét a versenyképesség elemzésekhez kapcsolódóan, mert a táj a mindenkori társadalmi, gazdasági és természeti folyamatok eredménye, lenyomata. Jelen van benne az összes, az emberi életet meghatározó szempont. Balogh Ákos (1993) hasonló értelmezésben definiálta a tájat, amely ,dinamikus egyensúlyú társadalmasított természet, az emberi közösségek élettere. Tartalmában és formájában múltját őrzi, tükrözi a természeti adottságokat, a társadalmi-gazdasági-politikai viszonyokat." A városias térségekkel, az agglomerációkkal ellentétben a vidéki térségek esetében a táji értékek, a táji adottságok felértékelődnek, jelentősen növelhetik a versenyképességet, hiszen hozzájárulnak a gazdasági diverzifikációhoz, az életminőség javításához. Amint a versenyképességi értelmezésekből és fejlesztési stratégiákból kiderül, sok esetben számolnak a környezeti tényezőkkel, de a táji/tájhasználati szempontok ritkán vagy egyáltalán nem merülnek fel. 
A táj mai formáját a természeti és társadalmi erők szétválaszthatatlan hatásainak összességéböl nyerte el, egy rendkívül összetett, sokrétű rendszerről van szó, vizsgálatához is több tudományterület eredményeit kell segítségül hívni. A tájhasznosítás formái meghatározzák a vidéki térségekben élők életminőségét, a tájhasználat sokrétüsége jelentősen növelheti a rurális térségek sikerességét. Felhívom a figyelmet, hogy nem a táji adottságok értékelését tartom fontosnak, hiszen ahány táj, térség annyiféle adottságokkal rendelkezik, hanem elsősorban arra helyezem a hangsúlyt, hogy hogyan hasznosítjuk táji erőforrásainkat.

A tájhasználati rendszer értékeléséhez tájfunkció elemzést alkalmaztam. A tájfunkciók illetve az ökoszisztéma szolgáltatások fogalma az óta terjedt el, mióta egyre nyilvánvalóbbá vált, hogy az emberi jólét alapvetően az élő rendszerek állapotával függ össze. Azokat a javakat, funkciókat, spirituális és esztétikai értékeket nevezzük ökoszisztéma szolgáltatásoknak, amelyeket az emberiség közvetve vagy közvetlenül felhasznál (Costanza et al., 1997; de Groot et al,. 2002; MEA, 2005). A nemzetközi szakirodalomban az ökoszisztéma szolgáltatások többféle kategorizálásával találkozhatunk, de három főcsoport mégis egyértelműen kirajzolódik: ellátó- (pl. élelem, faanyag), szabályozó(pl. szén-dioxid megkötés) és információs funkciók (pl. rekreáció, oktatás, esztétikai érték).

A fogalomrendszer gyökerei az 1970-es évekre vezethetők vissza, arra helyezve a hangsúlyt, hogy az ökológiai rendszerek által nyújtott javak tulajdonképpen gazdasági szolgáltatásnak tekinthetők, ezért különösen fontos a biodiverzitás védelme. A hazai szakirodalomban az 1960-as évektől foglalkoztak az erdők (Keresztesi, 1968; Mészöly, 1981) és a települési zöldfelületi rendszerek (Radó 2001) sokrétű funkcióinak felismerésével. Ezt követte a multifunkcionális mezőgazdaság gondolatának megszületése (EEC, 1992, Ángyán et al., 1999), melynek alapeszméje, hogy a mezőgazdaság termelői funkció mellett elismeri a vidéki térségekben betöltött kulturális és természetvédelmi jelentőségét is. Extenzív hasznosítású, javarészt természetközeli felszínborítással rendelkező térségek esetében az ökoszisztéma szolgáltatások és a tájfunkciók közé egyenlőségjel tehető, hiszen alapvetően a természet nyújtotta javak és létfenntartó folyamatok állnak a középpontban (Konkoly-Gyuró, 2011). Általában azonban, hiszen ma már jórészt a társdalomnak éppolyan fontos szerepe van táji rendszerek formálásában mint a természetnek (ahogy a tájfogalom is utal erre) az említett három alapfunkció kiegészül az „eltartó” funkcióval (illetve az ellátó funkció szerepét átveszi az eltartó), amely a mező-erdőgazdálkodást, lakóhely, szállítás, ipari termelés feltételeinek biztosítását foglalja magában. A tájfunkció fogalmát általában a térségek, a tájak, a tájhasználati rendszerek által nyújtott javakhoz, szolgáltatásokhoz köti a nemzetközi szakirodalom, amikor a terület- és a tájhasználat müszaki, kulturális és gazdasági jellemzőit is kiemelik az abiotikus és biotikus komponensek mellett (Lamarque et al., 2011). Itt tulajdonképpen nemcsak tájfunkcióról, hanem tájhasználati funkcióról is beszélhetünk (5. ábra), hiszen ezek a javak egyértelmủen a társadalmi-gazdasági igényekhez köthetők és a társadalom tájalakító tevékenysége révén válnak elérhetővé. Sok esetben azonban nehezen 
szétválaszthatók a tájfunkciók és tájhasználati funkciók, hiszen a müvelt tájrészletek is szolgálhatnak esztétikai értékkel, vagy egy felhagyott bányató nyújt a társadalom számára rekreációs lehetőségeket. Norgaard (2010) figyelmezteti a kutatókat az ökoszisztéma kutatások egy jellemző hiányosságára, hogy azok gyakran túlzóan leegyszerüsítőek, a társadalmi hatások által kiváltott változásokkal nem számolnak. A kutató szerint fontos lenne az ökológiai és a társadalmi rendszer komplexebb, sokoldalúbb összekapcsolása és kiegészítő elemzésekre is szükség lehet ${ }^{21}$.

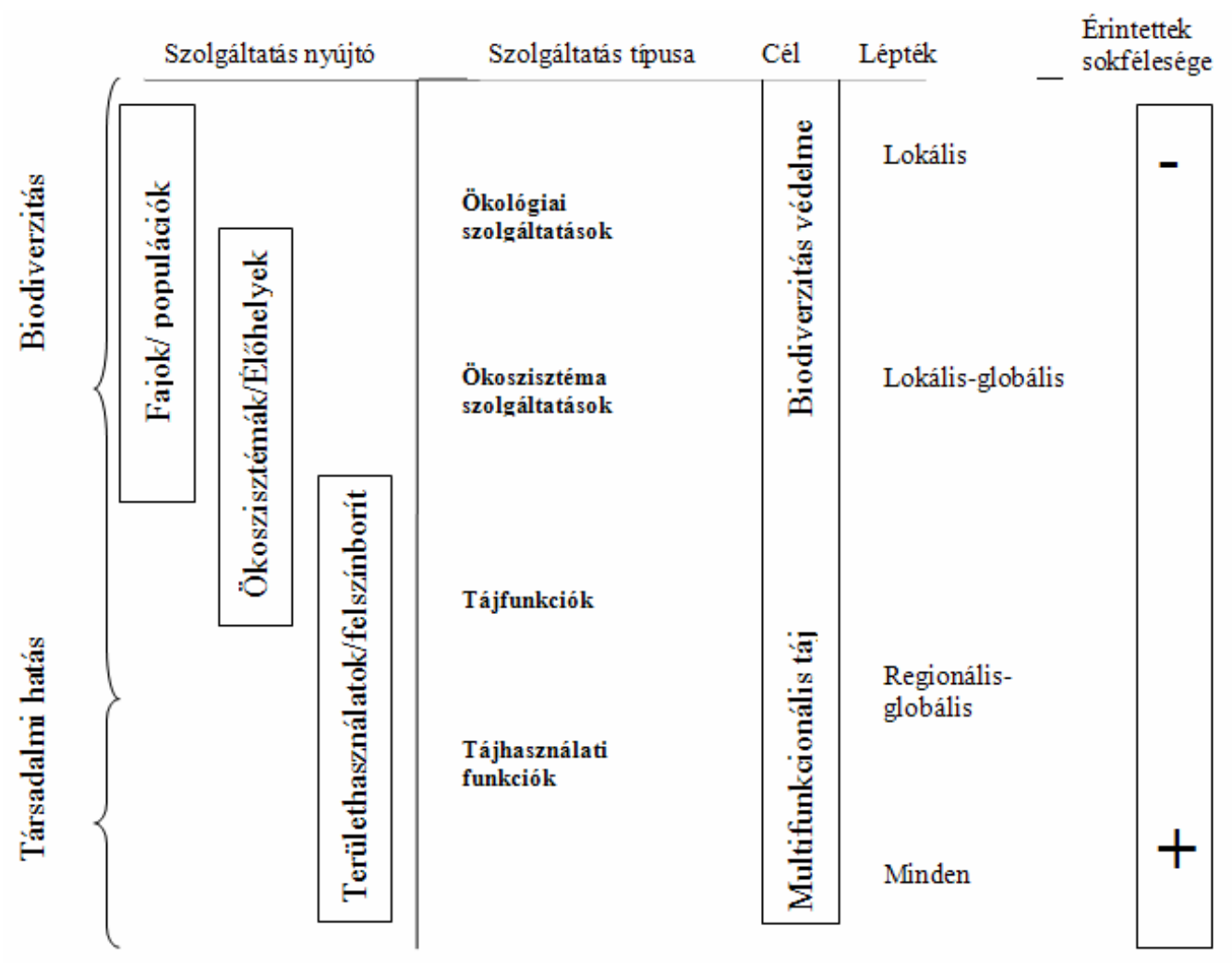

5. ábra: Fogalmak közti különbségek (Lamarque, 2011)

A hazai tájépítészeti terminológiában több szakkifejezés utal a táj fenntartható, erőforrás-megőrző hasznosítására: ilyen a tájgondozás, (de elsősorban) a tájgazdálkodás fogalma, amely Csemez Attila definíciója alapján (Csemez, 2009) a tájrehabilitálás, a természetvédelem, a tájvédelem, a környezetvédelem és a fenntartható területfejlesztés összhangjának megteremtése, beágyazása a megtartandó tájelemek rendszerébe. A fogalom-meghatározást azzal egészíteném ki, hogy a tájhasználatok olyan rendszerét érthetjük alatta egy adott térségben, amely segíti a táj harmonikus múködését, a tájfunkciók és a tájhasználati funkciók sokrétü, kielégítő szintü, hosszútávon fenntartható müködését és egyben törekszik a társadalom mindenkori igényeinek a kielégítésére.

A tájhasználat sokrétűségének elve nem új keletü, az Európai Unió mezőgazdasági politikájában jelentős hangsúly eltolódás következett be, amely szerint a mezőgazdaság feladata nem csak élelem

\footnotetext{
${ }^{21}$ Emiatt az ökoszisztéma szolgáltatásokból kifejlödött tájfunkció, tájhasználati funkció elemzés mellett döntöttem, hiszen itt nagyobb szerep jut a társadalmi hatásoknak, ami egyértelmüen fontos az alapvetően rurális jellegü mintatérségben. Az esettanulmányban a tájfunkció elemzés, egy alapelemzés, amelyet egyéb gazdasági, társadalmi elemzés egészít ki.
} 
előállítása, hanem egyéb fontos szolgáltatások biztosítása, mint táj- és tájképvédelem, természetvédelem, biodiverzitás fenntartása, rekreációs lehetőségek biztosítása, kulturális örökségvédelem stb. "Belletti et al (2002: p2). Egyre elterjedtebb a tájépítészeti nemzetközi szakirodalomban a multifunkcionalitás elve (Mander et al 2007). Barkmann et al. (2004), ami arra vonatkozik, hogy a táj egyidejüleg javak és szolgáltatások sokféleségét biztosítja, nyújtja a társadalom szükségleteinek és igényeinek kielégítésére. A tájfogalom önmagában is utal erre a multifunkcionalitásra. A táj teljesítőképességét több szempontból is csökkentheti, rombolhatja a nem megfelelő emberi használat (idézte Willemen et. al, 2010).

A nemzetközi és hazai szakirodalomban többféleképpen is nevesítik, csoportosítják a táji rendszerek által nyújtott javakat, értékeket: alapvetően három nagy csoport jelenik meg: termesztés/gazdasági, ökológiai/környezeti és egyéb társadalmi (kulturális, esztétikai stb.) javak és szolgáltatások. Hasonló megközelítést képvisel a tájpotenciál terminológia: a táj ökonómiai, ökológiai és tájképi teljesítőképessége. A tájfunkció-elemzés rendszerén belül is a tájak környezetvédelmi, ökológiai szerepével azonosíthatók a szabályozási és élőhely funkciók, a gazdasági szerepkörhöz az eltartó (emberi tevékenységekhez biztosítanak területet és alkalmas közeget) és ellátó funkciók (ma már kisebb jelentőségü az ember tájalakító tevékenysége miatt) és az egyéb társadalmi igényeket elégítik ki az információs/kulturális funkciók (rekreáció, esztétikai érték stb.), amelyek harmonikus megléte szintén nélkülözhetetlen a vidéki népesség életminőségének biztosításához.

Az ENSZ által életrehívott Millennium Ecosystem Assessment program keretében 2005-ben elkészült összefoglalóban vizsgálták a társadalmi jólét és az ökoszisztéma szolgáltatások kapcsolatrendszerét (6. ábra). A vidéki térségekben élők életszínvonala szempontjából alapvető fontosságúnak tartom, hogy a tájhasznosítás révén a táji rendszerek által szolgáltatott javak ne csorbuljanak, a tájfunkciók harmonikusan érvényesüljenek. Tájhasználati konfliktusok leggyakrabban olyankor fordulnak elő, ha valamely tájhasználati funkció zavarja/elnyomja valamely tájfunkció müködését leggyakrabban a szabályozó vagy élőhely funkciót vagy kulturális funkciót. 


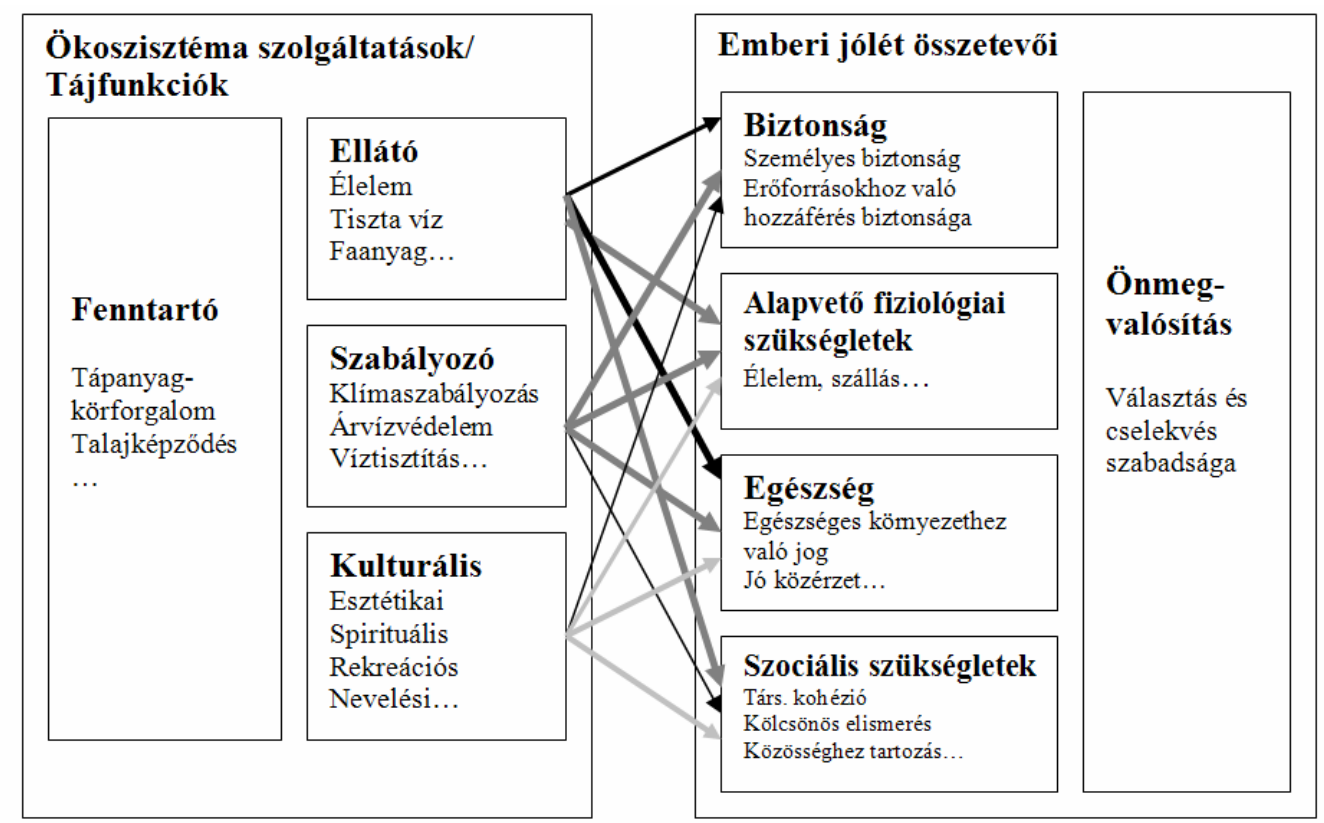

6. ábra: Ökoszisztéma szolgáltatások/tájfunkciók hatása az emberi jólétre (a nyilak vastagsága

fejezi ki a kapcsolat erősségét; a nyilak színe fejezi ki a helyettesíthetőségét lehetőségét/mértékét társadalmi vagy gazdasági tényezőkkel, minél sötétebb annál kevésbé)

(Forrás: Millennium Ecosystem Assessment)

Willemen és kutató csoportja egy holland vidéki térségben értékelte az adott tájegység által nyújtott javakat és szolgáltatásokat, vizsgálta az egyes tájhasználati funkciók (intenzív állattartás, szántóföldi termesztés, lakófunkció, turizmus, kulturális örökség, élőhely, rekreációs célú kerékpározás) egymásra hatását és arra a következtetésre jutottak, hogy azokban a térségekben, ahol többféle tájhasználati funkció van jelen, a táji rendszerek által nyújtott javak és szolgáltatások összesített értéke magasabb, mint a monofunkciós helyeken (7. ábra). Másrészt viszont az egyes tájfunkciók által nyújtott javak értéke kisebb a multifunkcionális tájegységekben, azzal a kitétellel, hogy a multifunkcionális ,forró pontokon” ez a sokféleség nem vezet az tájfunkciók által nyújtott javak elvárt szint alá csökkenéséhez (Willemen et al., 2010).
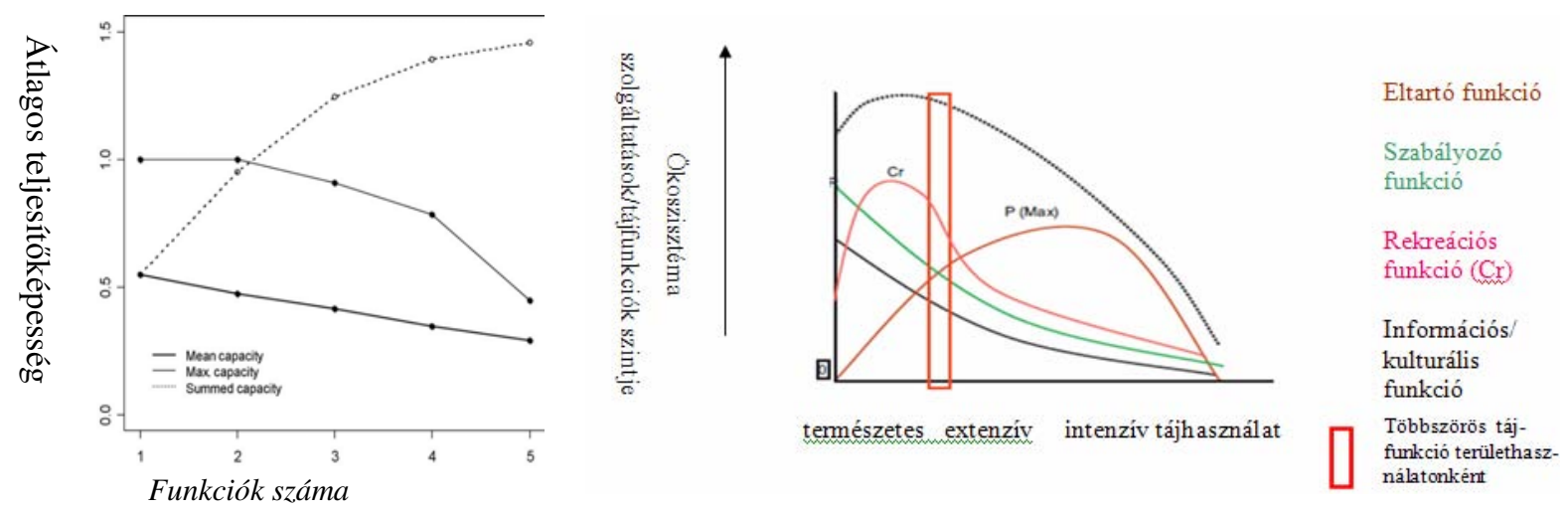

7. ábra: A tájfunkciók számának és az átlagos, maximális és összesített teljesítőképességének összefüggései (Willemen et al., 2010) valamint a területhasználat, biodiverzitás, tájfunkciók

(Braat, de Groot, 2012) 
A különböző tájhasználati módok között nagyon sokrétü kölcsönhatás fedezhető fel, különösen az eltartó funkciók és az egyéb tájfunkciók egymásra hatása erős. Braat és ten Brink szemléletesen ábrázolta, hogy az intenzív mezőgazdasági termesztés hatására milyen erőteljes csökkenés figyelhető meg az egyéb tájfunkciók müködésében (7. ábra). Rekreációs és turisztikai szempontból nagyon kedvező, ha a tájrészlet jól megközelíthető és az alapinfrastruktúra kiépített, az ökoszisztéma rendszer leromlása révén azonban jelentősen csökken a hely attraktivitása (Braat, de Groot, 2012).

Rekreációs szempontból a legkedvezőbb az extenzív hasznosítás. A mezőgazdasági termesztés maximuma intenzív agrártájban érhető el, de itt a tájfunkciók összesített értéke sokkal alacsonyabb. Kivételnek tekinthető a szintén intenzív hasznosításnak számító szőlőtermesztés, hiszen esztétikai értéke miatt sokak számára rekreációs értékkel is bír.

Egyre több kutatás irányul a mezőgazdasági termesztés egyéb tájfunkciókat rontó hatásainak csökkentésére és az agrár-térségek szabályozó és kulturális értékének növelésére. Legnagyobb kihívás a tájfunkciók, tájhasználatok optimális összhangjának megteremtése, olyan egyensúly kialakítása, amely az ökológiai rendszert nem rontja és egyben összességében a legnagyobb gazdasági hasznot hozza. A területhasználatok optimalizálása többféle szempontból is elvégezhető: közösségi szempontból, egyéni földbirtokos szempontjából stb. (EASAC, 2009). Egy másik vezérlő elv lehet az ökológiai rendszerek degradációjának minimalizálása, hiszen ebben az esetben valamennyi tájfunkció működése jelentősen leromlik. (Braat, de Groot, 2012 p. 7).

A tájfunkciók/tájhasználati funkciók elemzése tulajdonképpen arra a kérdésre keresi a választ, hogy az egyes tájhasználatok mennyire teszik lehetővé a tájpotenciál ${ }^{22}$ érvényesülését. Sem Európában, sem hazánkban nincs letisztázott állásfoglalás a tájfunkciók értékelésére, vannak, akik közgazdasági alapon pénzben fejezik ki a természet nyújtotta javakat (Marjainé Szerényi, 2011), míg mások ökológiai megközelítésen alapuló százalékos értékelést alkalmaznak, célom viszonylag egyszerü értékelés kidolgozása egy esettanulmány bemutatásával, amely komplex szemlélettel mutatja be az adott térségben a tájfunkciók szintjét (az egyes tájfunkciókat a tájfunkció értékek jellemzik, részletes bemutatás a 2.3. fejezetben). A nemzetközi szakirodalmi példák átvételét nehezíti, hogy általában hazánkban nem mindig egyszerü részletes, friss adatok elérése.

\footnotetext{
${ }^{22}$ A tájpotenciál „a táj teljesítőképessége, alkotói az adott tájegység egymással kölcsönhatásban álló ökológiai, ökonómiai és tájképi potenciáljai. Kifejezi a tájhasználat lehetséges mértékét, azt, hogy egy táj milyen mértékben alkalmas a társadalom sokrétü igényeinek kielégítésére." (MSZ-13-195-1990, Általános tájvédelem, Fogalom-meghatározások, 40.,46.)
} 


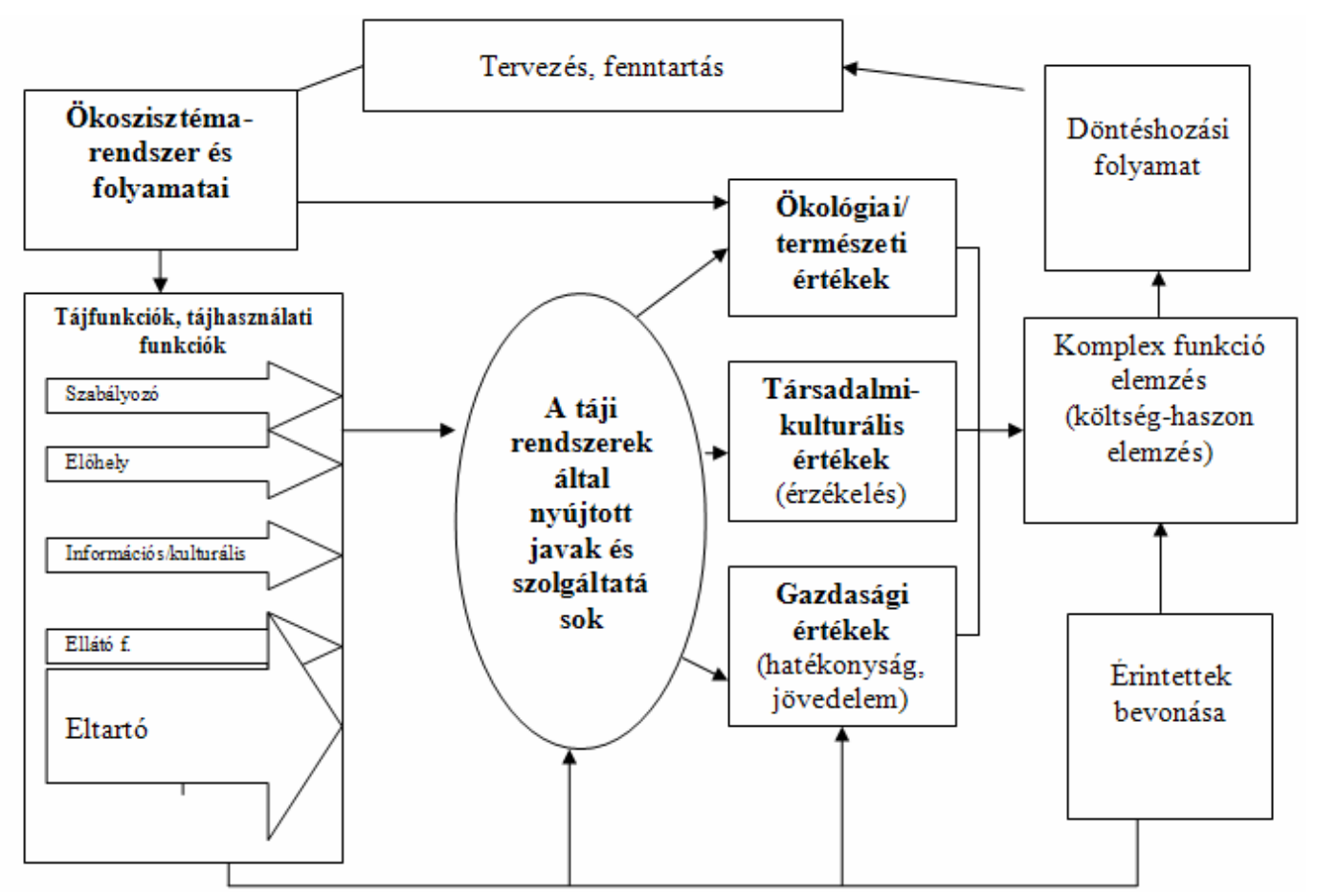

8. ábra: A környezettervezésben alkalmazható funkció-elemzés és értékelés szerepe (de Groot, 2006 nyomán)

Az értékelést bonyolítja, hogy a tájhasználati módok elemzését gazdasági szempontú értékeléssel ötvözöm, hiszen a versenyképesség valamint a vidékfejlesztés és szélesebb körben a területfejlesztés, területi tervezés célkitüzéseit szeretném összekapcsolni a tájrendezés, egy erőteljesebben környezetvédelmi és kulturális (környezeti fenntarthatóság és élhetőség) szempontú elemzés célkitűzéseivel. A környezeti és a gazdasági szempontú értékelés és tervezés összehangolása konfliktusokkal terhelt, alapvető, hogy a döntéshozatalban kompromisszumokra kell törekedni. Emiatt a tájhasználatok több szempontú értékelését tájhasználati célkitüzések, irányelvek megfogalmazásával egészítettem ki, és értékeltem az esettanulmányban a térségi megfelelést, amit, mivel nem közvetlenül kapcsolódik a tájfunkció értékeléshez, továbbá a terjedelmi korlátok miatt a mellékletben helyeztem el (általános elvek: jegyzetek 9.; elvek érvényesülése a mintatérségben külön melléklet).

A táji adottságok, illetve az általuk nyújtott funkciók értékelésére sokféle eszköz áll rendelkezésre (8. ábra). Egyre gyakrabban alkalmaznak mutatószámokat ún. tájindikátorokat, melyhez adatok elsősorban társadalmi és gazdasági - a legkülönfélébb adatbázisokból nyerhetők (Központi Statisztikai Hivatal, Országos Területfejlesztési és Területrendezési Információs Rendszer, TájÉrtékKAtaszter), jóval ritkábban az egyes tájegységek ökológiai állapotát jellemző adatbázisok (Természetvédelmi Információs Rendszer, Magyarország Élőhelyeinek Térképi Adatbázisa). Egyes funkciók, javak jellemzése, leírása viszonylag nehéz vagy nem lehetséges mutatószámok alkalmazásával. A mintatérségre sokrétủ adatsor felhasználásával részletes tájfunkció-elemzést készítettem. 


\section{ANYAG ÉS MÓDSZER}

\section{ESETTANULMÁNY: CSORNAI-KISTÉRSÉG}

Az elméleti összefüggéseket a tanulmány további részében egy olyan kistérség elemzésével szemléltetem, amely nem rendelkezik kiugró táji „attrakciókkal”, a fejlettebb központok (Sopron és Győr) illetve a turisztikai szempontból népszerü Fertő-tó és Szigetköz közötti „árnyéktérben” helyezkedik el, mindig is belső perifériának számítva. Szeretném felhívni a figyelmet, hogy a táji adottságok hatékonyabb kihasználása igenis hozzájárulhat még egy periférikus helyzetủ rurális kistérségben élők életszínvonalának javításához is. A választást a térség sajátos tájtörténete és a védett területek magas aránya is indokolta. Gyermekkori kötődésem és emlékeim is arra sarkalltak, hogy ezt a kistérséget válasszam.

A Rábaköz-Tóköz-Hanságmente Településeinek Regionális Fejlesztési Társulását 1995-ben hozta létre a gazdaság fellendítése, az együttműködés erősítése céljából 35 települési önkormányzat és a Győr-Moson-Sopron Megyei Önkormányzat társult tagként. A többcélú kistérségek létesítésének lehetővé válásakor az együttmüködés keretei megváltoztak, létrejött a korábbi társulást felváltó Csornai kistérség. 4 település átsorolására került sor, amelyek azonban továbbra is erősebben kötődnek a csornai vonzáskörzethez napi kapcsolataik révén. A területlehatárolással szemben kritikaként merülhet fel, hogy közigazgatási területegységet és nem önálló tájat illetve tájegységet választottam vizsgálatom tárgyául, mégis a többcélú kistérségi társulásra esett a választásom, amelynek korábban önként szerveződő elődje volt (tehát az együttmüködésnek már korábbi előzményei vannak), másrészt az adatok könnyebb elérhetősége indokolja a választást. A kistáji szint a Rábaköz, amely a Csornai- és a Kapuvári sík településeit foglalja magába nagyon nagy térséget jelent, a Hanságtól való lehatárolás problematikus kérdés volt, a Hanság maga önálló fejlesztési egységként sosem jelent meg, hiszen a természeti adottságokból adódóan a települések a Hanság szélén, peremén alakultak ki. A Rábaköz kistáj nagyvonalakban két kistérségi társulás (Csornai és Kapuvári többcélú társulás, ma járás, és összességében több mint 60 települést foglalnak magukba) területét fedi le, az északi rész már a Hansághoz tartozik (néhány település teljes egészében, de döntően a települések északi részeként). A járási rendszer alapvetően nem befolyásolta a területi lehatárolást, mindössze két tóközi települést soroltak a Győri járáshoz, a többcélú kistérségi társulás munkaszervezete megszünt ugyan, de a társulás megmaradt, hiszen komoly oktatási, szociális fejlesztéseket kell az együttmüködési szervezetnek fenntartani.

A kistérség nagytájaink közül a Kisalföldön, ezen belül a Győri-medencében, Győr-Moson-Sopron Megye két nagy központja között helyezkedik el, ez a centrumhiányos ,árnyékhelyzet” jelentősen rányomja bélyegét a térség életére. Annak ellenére, hogy hazánk egyik legfejlettebb régiójában, az 
osztrák határhoz közel található, mindig belső perifériának számított. A terület három mikrorégióból, a Rábaközből, a Hanságból és a Tóközből tevődik össze.

\subsection{A tájhasználati változások tendenciái}

A táji adottságok a múltban jelentősen meghatározták a társadalom életfeltételeit, lehetőségeit. Évszázadokkal korábban a technológiai fejlettség színvonala meghatározta a tájalakítás kereteit, léptékét. Kezdetekben az ember a természet erőforrásait sokrétüen hasznosítva, a tájat elsősorban csak a települések környezetében változtatta meg, alakította, vonta művelésbe. Sokáig a természet legyőzhetetlennek bizonyult számára (jelen esetben a Hanság mocsárvilága, a Rába és Rábca árvizei). A gazdaság, a társadalom fejlődése a tájalakítás kereteit kitágította, a tájhasználat, -hasznosítás formáit átalakította növelve a táj népességeltartó képességét. A tájalakítás, tájhasználat tendenciáinak áttekintése után feltártam a tájhasznosítás és a táj népességeltartó képességének összefüggéseit, a tájátalakítás következményeit. Arra a kérdésre kerestem elsősorban a választ, hogy a nagyléptékü tájátalakítás, ami a hansági településekre jellemző, mennyiben járult hozzá a térség népességmegtartó képességének erősödéséhez és a térség versenyképességi helyzetének javításához. A tájalakítás, a tájhasználat változásának elemzése mellett feltárom az élhetőség, a fenntarthatóság és a versenyképesség súlyponti változásait. A versenyképesség kiemelt feltétele az adott régió markáns megjelenése a nagytérségi kapcsolatrendszerben. A tájalakítás révén javuló népességeltartó képesség abban az esetben járul tehát hozzá a térség versenyképességének erősödéséhez, amennyiben ez a nagytérségi kapcsolatrendszerben egy kiemelten fontos ,szerephez/ feladathoz” kötődik, és a térség képes a belső adottságokhoz idomulva, a lehetőségeket maximálisan hasznosítva alkalmazkodni a nagytérségi (globalizációs) folyamatokhoz. A lehetőségekhez mért legjobb életminőség elérése mindig az emberiség legfontosabb törekvése volt, de a technikai fejlődés az ókori civilizációk megjelenésének korára tette lehetővé a túlélés alapvető szempontjainak minőségi megváltozását és az élhetőségi szempontok előtérbe kerülését. A versenyképesség megjelenése alapvetően a társadalmi gondolkodás megváltozásával a középkor végére tehető. A középkori gondolkodást alapvetően a kritikai gondolkodás hiánya jellemezte (Huizinga, 1996). A környezeti fenntarthatóság kényszere a nagy volumenű, intenzív tájalakítás lezárultával az intenzív tájhasználat meghonosodásával jelent meg.

Zólyomi Bálint 1936-ban írt művében három periódust különböztetett meg a Hanság tájalakulástörténetében, amelyet több szakasszal egészítettem ki, hiszen a XX. századra jellemző tájátalakítás és tájhasznosítás jellemzőiben eltér a XIX. századtól (3. táblázat). A hansági és rábaközi részek tájalakulás-történetét együtt tárgyalom, mivel éles határ nehezen húzható. Komoly különbséget jelent, hogy a Hanságtól távolodva fokozatosan nő a müvelt területek aránya már a kezdetektől, hiszen a földrajzi adottságok miatt ezek a területek voltak a legkönnyebben művelés alá vonhatók. Sajnos a 
pontos területhasználati adatokról csak a XIX. század végétől vannak adataink, történeti térképek viszonylag megbízható adatokkal a XVIII. századtól szolgálnak. Korábbi adatok már inkább becsléseken, leírásokon alapulnak. Úrbérrendezés, oklevelek, régészeti kutatások leírásait, eredményeit használtam fel a tájhasználat évszázadokkal ezelőtti tendenciáinak feltárására. Hasznos forrásnak bizonyult az 1865-ös összeírás, amely segített statisztikai adatokkal is bizonyítani, hogy a tájhasználat átalakulása döntően a XX. század elejére az ország más területeihez hasonlóan lezajlott és a lecsapolási munkák a későbbiekben a Hanság addig megőrzött belső területeire koncentrálódtak. Fontos szempontnak tartom, hogy megvizsgáljam, hogy egy adott térségben a tájhasználat milyen mértékben alakult át, hiszen a tájhasználat folytonossága, stabilitása kihat a jelen tájhasználati konfliktusaira. Statisztikai adatok és a történeti térképek alapján rekonstruálható területhasználatok alapján összehasonlítottam egyes tájfunkciók szintjét a különböző történeti korszakokban.

3. táblázat: A Csornai kistérség tájalakulás-történetének, tájhasználat változásainak jellegzetes szakaszai (saját szerkesztés)

\begin{tabular}{|c|c|c|c|c|}
\hline Periódus & Időtartam & $\begin{array}{l}\text { Tájalakítás, tájhasználat } \\
\text { jellegzetességei }\end{array}$ & $\begin{array}{l}\text { Területhasználati változások } \\
\text { jellemzői } \\
\text { Hanság, Tóköz települései }\end{array}$ & $\begin{array}{c}\text { Területhasználati válto- } \\
\text { zások jellemzői } \\
\text { Rábaköz keleti része } \\
\end{array}$ \\
\hline $\begin{array}{l}\text { l. periódus: } \\
\text { Túlélés, alkal- } \\
\text { mazkodás }\end{array}$ & $\begin{array}{l}\text { I.sz. I. száza- } \\
\text { dig }\end{array}$ & $\begin{array}{l}\text { A neolit kortól lakott a térség, } \\
\text { alkalmazkodás a természet- } \\
\text { hez, vadászó, halászó élet- } \\
\text { mód. }\end{array}$ & $\begin{array}{l}\text { Erősen korlátozott gazdálkodási } \\
\text { lehetőségek a peremterületeken }\end{array}$ & $\begin{array}{lr}\text { Korlátozott } & \text { gazdálkodási } \\
\text { lehetőségek } & \text { magasabb } \\
\text { felszíneken } & \end{array}$ \\
\hline $\begin{array}{l}\text { Il. periódus: } \\
\text { Alkalmazkodás, } \\
\text { lokális tájalakítás }\end{array}$ & $\begin{array}{l}\text { i.sz. I. század } \\
\text { - XVIII. század }\end{array}$ & $\begin{array}{l}\text { A Hanság lápvegetációja jelentö- } \\
\text { sen nem változik, a környezö } \\
\text { erdőségek aránya csökken az } \\
\text { erdőirtások révén, kisebb arányú } \\
\text { lecsapolások. Tóközi tógazdál- } \\
\text { kodás időszaka }\end{array}$ & $\begin{array}{l}\text { Magas a mocsaras területek, a } \\
\text { rétek-legelők aránya, alacsony, } \\
\text { lassan növekvő szántóterületi } \\
\text { arány }\end{array}$ & $\begin{array}{l}\text { A települések körül fokoza- } \\
\text { tosan növekvő szántóterü- } \\
\text { letek, magas rét-legelő } \\
\text { arány }\end{array}$ \\
\hline $\begin{array}{l}\text { III. periódus: } \\
\text { Nagyléptékü } \\
\text { tájalakítás }\end{array}$ & $\begin{array}{l}\text { XVIII. század } \\
\text { vége- I. vgh }\end{array}$ & $\begin{array}{l}\text { Intenzív lecsapolások, víz- } \\
\text { rendezés időszaka, a Hanság } \\
\text { lápvilága fokozatosan zsugo- } \\
\text { rodik, folyószabályozások. }\end{array}$ & $\begin{array}{l}\text { 1865: 40\%-os össz.szántóarány, 54\% } \\
\text { gyep; 1913: 68\% szántó, 27\% gyep }\end{array}$ & $\begin{array}{c}\text { Erőteljes növekedés a } \\
\text { szántók arányában a gyep- } \\
\text { területek terhére } \\
\text { Intenzív agrártáj kialakulá- } \\
\text { sa } \\
\text { 1865: } 62 \% \text { szántó, } 25 \% \text { gyep } \\
\text { 1913: } 77 \% \text { szántó, } 12 \% \text { gyep } \\
\end{array}$ \\
\hline $\begin{array}{l}\text { IV. periódus: } \\
\text { Intenzív tájhasz- } \\
\text { nálat megszilár- } \\
\text { dulása }\end{array}$ & $\begin{array}{l}\text { XX. század } \\
\text { eleje }-1980-a s \\
\text { évek eleje }\end{array}$ & $\begin{array}{l}\text { Lecsapolások folytatódása, a } \\
\text { Hanság belső lápvilágára is } \\
\text { kiterjedő átalakítás }\end{array}$ & $\begin{array}{c}\text { Szántók arányának kismértékü, } \\
\text { de folyamatos növekedése, } \\
\text { gyepterületek csökkenése, } \\
\text { erdők arányának növekedése } \\
\text { Nagyüzemi, intenzív müvelés } \\
\text { 1935: } 61 \% \text { szántó, } 23 \% \text { gyep } \\
\text { 1984: } 57 \% \text { szántó, } 21 \% \text { gyep } \\
\end{array}$ & $\begin{array}{c}\text { Szántók arányának kismér- } \\
\text { tékü csökkenése, gyepterü- } \\
\text { letek stagnálása, erdők } \\
\text { arányának növekedése } \\
\text { 1935: } 78 \% \text { szántó, } 11 \text { \% gyep } \\
\text { 1984: } 71 \% \text { szántó, } 11 \% \text { gyep }\end{array}$ \\
\hline $\begin{array}{l}\text { V. periódus: } \\
\text { Védelem, hely- } \\
\text { reállítás }\end{array}$ & $\begin{array}{l}\text { 1980-as évek } \\
\text { végétől }\end{array}$ & $\begin{array}{l}\text { Természetvédelmi szemlélet } \\
\text { erősödése, élöhely- } \\
\text { rekonstrukciós munkák a } \\
\text { Hanságban, Natura } 2000 \\
\text { hálózat a Hanságban és a } \\
\text { Rábaközben }\end{array}$ & $\begin{array}{c}\text { Szántók arányának folyamatos } \\
\text { növekedése, gyepterületek } \\
\text { csökkenése } \\
\text { Védett területek rendszerének } \\
\text { kialakítása } \\
\text { 2011: } 68 \% \text { szántó, } 16 \% \text { gyep }\end{array}$ & $\begin{array}{l}\text { Szántók arányának folya- } \\
\text { matos növekedése, gyepte- } \\
\text { rületek csökkenése }\end{array}$ \\
\hline
\end{tabular}

Forrás: saját szerkesztés Zólyomi, KSH adatok és a katonai térképek adatai nyomán 
Több korszakból figyelhetők meg a tájalakítás nyomai a google.maps térképén Győrsövényháza térségében (9. ábra).

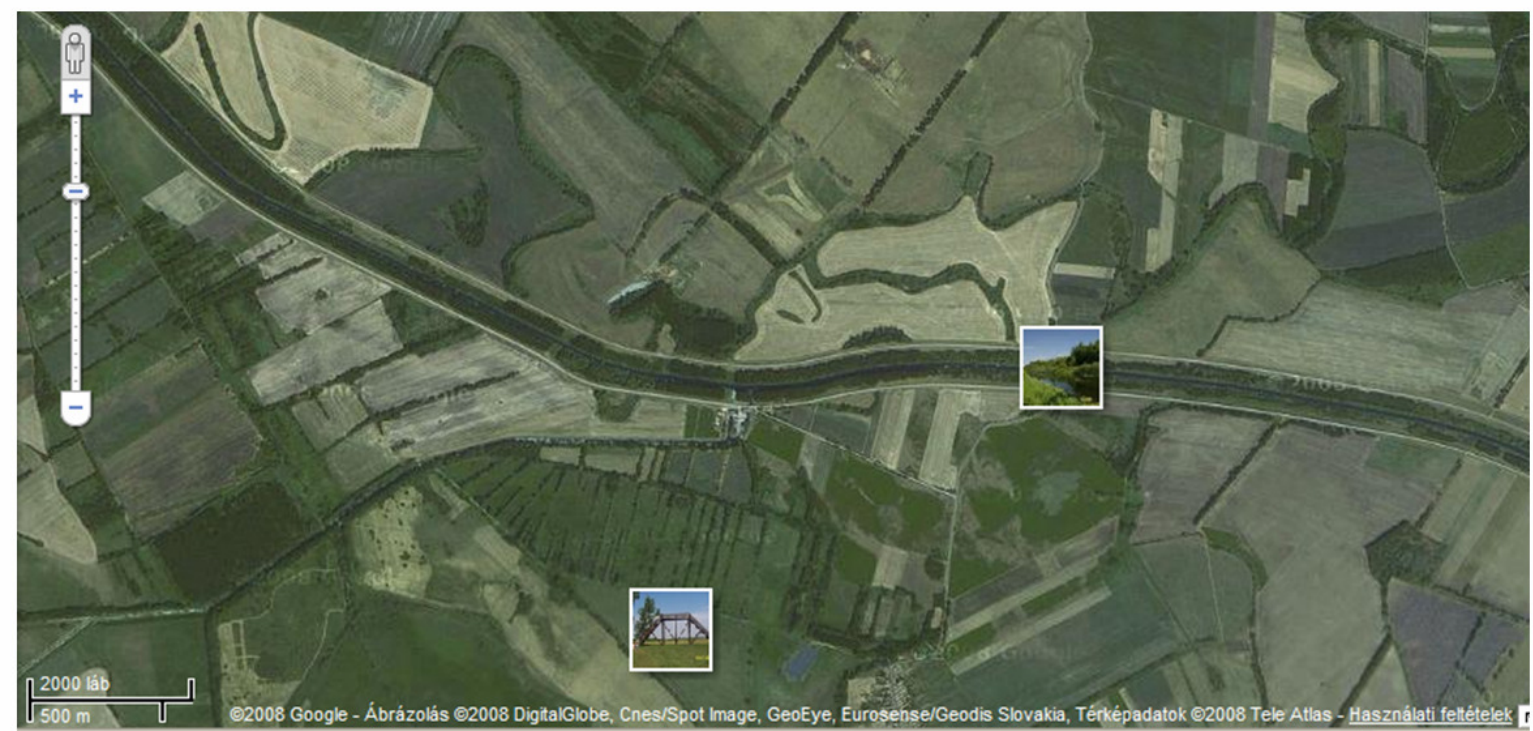

9. ábra: Fennmaradt Árpád-kori csatornarendszer (amelyet a sürü sövénysorok jeleznek), Rábca levágott kanyarulatai, Győrsövényház

(Forrás: maps.google.com [2010.])

\subsubsection{I. periódus: túlélés, alkalmazkodás}

Időszámításunk szerinti I. századig tartó időszakot tekintem az alkalmazkodás korszakának (4. táblázat). Nagyon sok régészeti lelet tanúskodik arról, hogy évezredek óta lakott a térség. Több településen bukkantak a régészek neolitkori és bronzkori kultúra nyomaira (Mihály, 1971).

4. táblázat: Az I. periódus jellemzői (saját szerkesztés)

\begin{tabular}{|c|c|c|c|c|c|}
\hline Kor & Tájátalakítás & Tájhasznosítás & Konfliktusok & $\begin{array}{c}\text { Népességeltartó } \\
\text { képesség }\end{array}$ & Értékrend \\
\hline $\begin{array}{l}\text { i.sz. I. } \\
\text { század }\end{array}$ & $\begin{array}{l}\text { Erősen korláto- } \\
\text { zott, alkalmazkodó } \\
\text { életmód }\end{array}$ & $\begin{array}{l}\text { A rábaközi térségre } \\
\text { korlátozódó hasznosí- } \\
\text { tás, vadászat, halászat }\end{array}$ & $\begin{array}{l}\text { Közlekedést, gaz- } \\
\text { dálkodást akadályo- } \\
\text { zó vízviszonyok }\end{array}$ & $\begin{array}{l}\text { A táji adottságok miatt } \\
\text { alacsony népességeltar- } \\
\text { tó képesség, Hanság } \\
\text { lakatlan mocsárvilága }\end{array}$ & $\begin{array}{l}\text { Az életminöség } \\
\text { javítása megha- } \\
\text { tározó, a ver- } \\
\text { senyképességet } \\
\text { meghatározó } \\
\text { értékrend még } \\
\text { nem jellemző. }\end{array}$ \\
\hline
\end{tabular}

A Hanság, de a hozzá szorosan kapcsolódó Rábaköz táji adottságait és ezáltal a tájhasznosítás kereteit évezredeken át a vizek határozták meg. A folyóhordalékból kialakult síkságot a Hanságba (Hanyba) futó patakok szabdalták, amelyekben nyáron alig volt víz, de ősszel és tavasszal elöntötték a síkságot és csak a Rábaköz magasabban fekvő része és a földszigetek maradtak szárazon. A települések ezeken a helyeken fejlődtek ki (Timaffy, 1989). 
A Hanság vizeinek legnagyobb részét délről a Rábából és a Répcéből nyerte (szabályozás előtti állapot). A Rába árvize itt vagy a Tóközön keresztül zúdult a Hanságra. De nemcsak a Rába, a Duna áradása is jelentős hatással volt a térségre. Zólyomi Bálint 1931-es leírása szerint a Duna áradása esetén a láp lefolyását képező Rábca vize visszatorlódott egészen a Fertőig, illetve közvetlenül tört be a Duna vize Mosonnál a lápmedence keleti részébe (Melléklet I.)

\section{Tájalakítás}

A kor emberei döntően cölöpkunyhókban éltek, halásztak, vadásztak, életmódjukra leginkább a természethez való alkalmazkodás volt a jellemző (Fajkusz, 2005).

\section{Tájhasználat}

A kistérség északi részét, amely a Hansághoz tartozik döntően összefüggő mocsár, lápvegetáció, a peremterületeket ligetes fás társulások, gyep, cserjés borította, a Rábaköz is az időszakosan elöntött területek közé tartozott.

Általában a Hanság vizeinek jellege pangó volt, aminek jelentős hatása volt a növénytakaróra, hiszen a láp jellegzetes égereseinek, füzeseinek elterjedése attól függött, hogy hol helyezkedtek el vízfolyások, vagy hol állt rendelkezésükre oxigénben dúsabb víz. Az eredeti erdőterületek így ligeterdőszerúen helyezkedtek el a láp déli vízjárta peremein. A láp északi, mosoni részein, amit vízfolyás nem táplált, általában hiányoztak az erdőtársulások. Az Északi-Hanságban nyírlápok is kialakultak (Rakonczay, 1996).

A települések a magasabban fekvő területeken alakultak ki, a szántóföldi művelés is a vízjárás által kevésbé befolyásolt területeken indult meg a Rábaközben és a Hanság peremén.

\subsubsection{II. periódus: alkalmazkodás, lokális tájalakítás}

A II. periódust, a lokális tájalakítás korszakát a rómaiak korától a technológiai változások lassan meginduló fejlődése miatt a XVIII századig számítottam (5. táblázat). A tájalakítási munkálatok a mocsaras vidékek peremterületein lévő erdőségek irtását legelővé majd szántóvá alakítását és árokrendszerek kialakítását foglalta magában elsősorban a Hanság peremterületén illetve a Rábaköz mélyen fekvő részein. A térség jelentősebb piaccal rendelkező mezővárosai: Csorna, Szil. 
5. táblázat: Az II. periódus jellemzöi (saját szerkesztés)

\begin{tabular}{|c|c|c|c|c|c|c|}
\hline Kor & Tájátalakitás & Tájhasznositás & Konfliktusok & Népességeltartó képesség & Értékrend & Versenyképesség \\
\hline $\begin{array}{l}\text { I.sz. I.- } \\
\text { XVIII. } \\
\text { század }\end{array}$ & $\begin{array}{l}\text { Lokális léptékü, } \\
\text { árkok építése, } \\
\text { nádasok felége- } \\
\text { tése, erdők irtá- } \\
\text { sa, gyepfeltörés }\end{array}$ & $\begin{array}{l}\text { A magasabb térszí- } \\
\text { nekrerárlátozódó } \\
\text { legeltetés, kezdetben } \\
\text { nomádrállattartás, } \\
\text { fokozatosan kialaku- } \\
\text { ló, teret hódító szán- } \\
\text { tóföldi gazdálkodás; } \\
\text { Sajátos tó- és halgaz- } \\
\text { dálkodás a Tóközben, } \\
\text { Helyi eröforrásokra } \\
\text { épülő háziipar kiala- } \\
\text { kulása }\end{array}$ & $\begin{array}{l}\text { Közlekedést, } \\
\text { gazdálkodást } \\
\text { akadályozó vízvi- } \\
\text { szonyok, háborús } \\
\text { pusztítások }\end{array}$ & $\begin{array}{l}\text { Alacsony, lassan növekvö népes- } \\
\text { ségeltartó képesség, a X. század- } \\
\text { ban 20-30 család minden köz- } \\
\text { ségben, növekvő népsürüség a jó } \\
\text { talajadottságú rábaközi falvak- } \\
\text { ban; alacsony népsürüség a han- } \\
\text { sági, tóközi falvakban. A tógaz- } \\
\text { dálkodás időszakában magasabb } \\
\text { népességeltartó képesség. } \\
\text { A táji adottságok korlátozó hatá- } \\
\text { sa egyértelmü }\end{array}$ & $\begin{array}{l}\text { Alkalmazkodás az } \\
\text { adottságokhoz, kislép- } \\
\text { tékü tájalakítás az } \\
\text { életminöség javitása } \\
\text { érdekében }\end{array}$ & $\begin{array}{l}\text { A tóközi tógazdálkodás idöszaka } \\
\text { sajátos versenyképes korszaknak } \\
\text { tekinthetö, hiszen a termesztési } \\
\text { feltételeknek nem kedvezö adottsá- } \\
\text { gokhoz kiválóan alkalmazkodtak, } \\
\text { amely magas település- és népsü- } \\
\text { rüség kialakulását tette lehetövé. A } \\
\text { tógazdálkodás megszünése a szü- } \\
\text { ken vett tóköz versenyképességi } \\
\text { helyzetének, népességeltartó képes- } \\
\text { ségének visszaesését hozta. } \\
\text { A Rábaközben a középkor végétöl } \\
\text { lassan javuló versenyképességi } \\
\text { helyzet. }\end{array}$ \\
\hline
\end{tabular}




\section{Tájalakítás}

A Fertő és a Hanság vízrajzilag összefüggő területeit a IV. század elején Galerius római császár vízszabályozási munkálatai érintették először (Zólyomi, 1931). A honfoglaló magyarok is megtelepedtek a térségben és elsősorban állattartásra hasznosították a természeti adottságokat. Oklevelek tanúsága szerint az Árpád korra benépesült minden község, húsz-harminc család élt a magasabb peremekre épült sövényfalu kunyhókban. A népesség gyarapodásban az egyik legjelentősebb állomás a besenyő székely határőrök betelepítése volt a gyepűk védelmére. Veszély esetén vízzel árasztották el az egész vidéket (Timaffy, 1988).

Egyértelműen évezredeken át a vizek uralták a vidéket. Az ember harcolt az áradások ellen, de legjobb tudása szerint hasznosította is a vizeket. A folyók, patakok partján töltést emeltek, ,eszterüt” építettek illetve lecsapoló munkaként árkokat ástak a folyó felé, így vezették el a vizet. Ha kiszáradt a nádas, a lápos területet felgyújtották és ezután szántották fel. Azonban a vizek egy részét megőrizték és hasznosították: a láposokon elgátolt tavakban halat tenyésztettek. Régészeti kutatások kiterjedt árokrendszert tártak fel a Tóköz településein, amelyeknek nyomai ma is láthatóak, de döntően a XVIII. századra elpusztultak (Takács, 2000). A régészeti kutatásokkal feltárt árokmaradványok és a XIII. századi oklevelek által említett tavak egy összetett, de elfeledett víz- és halgazdálkodási rendszerről tanúskodnak a Tóközben, amely leginkább a fokgazdálkodáshoz volt hasonlítható. A csatornákra alapvetően kettős vagy hármas szerkezet jellemző, tehát két vagy három meder futott párhuzamosan egymás mellett közöttük töltéssel. Néhol megfigyelhető a medrek oldalának lépcsőszerü kiképzése, valószínüleg a mederben dolgozó emberek munkájának megkönnyítésére. A csatornák szélessége 4-5 métertől 30-35 méterig terjedt mélységük 0,5 méter és 4 méter között változott. A csatornák tavak gazdag rendszerét kötötték össze (a csatorna és tórendszerhez kapcsolódó gazdálkodási mód részletes leírása a tájhasználat alfejezetben). Sajnos a csatorna- és tórendszer a XVIII. századra eltűnt, nem ábrázolták a katonai térképeken sem, csupán összefüggő vizes, mocsaras területet látunk a Tóközben a Rába felé húzódni.

A történelem folyamán a Hany és folyói szeszélyei miatt számos alkalommal árasztotta el a víz nemcsak a Hanságot keretező falvakat, hanem gyakran az egész Rábaközt is. Az első kísérlet a Hanság lecsapolására 1658-ban történt, amikor a Rábca medrét Bősárkány és Királytó között kiegyenesítették és mélyítették. A munka jól látható az 1796-os térképen (Melléklet II). Évszázadokon át leginkább az erdőirtások hoztak legjelentősebb változásokat a tájban, a Hanságot gyökeresen átalakító vízrendezési munkálatok első lépései a XVIII. század második felében kezdődtek (Zólyomi, 1931). Az ember folyamatosan jelentős erőfeszítéseket tett a mocsarak lecsapolására, a terméketlen területek termőre fordítására. Jelentős területeket hódítottak el a lápvilágtól és erdőktől. A I. katonai felmére alapján a Hanság peremén a magasabb fekvésü, kevésbé vízjárta területeken indult meg először a szántóföldi müvelés (Melléklet III.). 
Az erdőt a jó fekvésű, jó talajú területeken irtották, a kisarjadt területet legelőnek majd kaszálónak használták és csak ezután szántották fel. Réteket és cserjéseket is feltörtek, felszántottak. Igyekeztek a vizet lecsapolni, a folyók felé árkokat ástak így vezették le a vizet, a terület kiszáradása után a nádast felgyújtották és felszántották. Csorna környékén a lakosok 1690 és 1846 között 1500 kishold szántót (538 ha) nyertek irtásból (Horváth, 1964). Hosszú évtizedekig tartott, míg egy-egy területet lecsapoltak, a cserjéstől megtisztítottak és termővé tettek. Ezek a termékeny területek szigetként emelkedtek ki a környező vizenyős láptalajból (ezért is hívták őket szigeteknek). A lecsapolt területeket (termékeny szigeteket), azon családok után nevezték el, akik termővé tették azokat ${ }^{23}$.

\section{Tájhasználat}

Térképek jobbára a XVIII. századtól állnak rendelkezésre, legpontosabb képet (de még mindig inkább tájékoztató jellegüt) az I. katonai felmérés térképlapjai (1782-1784) adják a térség tájhasználatáról, arról tanúskodva, hogy a Hanság mocsárvilágán kívül komoly gazdálkodás folyt a Rábaközben (a tájhasználat és egyes tájfunkciók változásának nyomon követése érdekében digitalizáltam az I. katonai térképet -Melléklet IV. - a III. katonai térképet - VII. Melléklet- és az 1951-es topográfiai térképet- VIII. Melléklet).

Nagyon jelentős volt az állattenyésztés, a kapuvári uradalom minden helységében tenyésztettek lovat, ökröt és tehenet, néhány helyen bárányt, kecskét és sertést, de foglalkoztak méhészettel is. A folyókban, patakokban és „,hall tavacskák”-ban nevelkedett halak (ebédhal, csík, rák) szintén bevételi forrást jelentettek a lakosság számára (Mikó, 1992), a tájhasználat e formájára egyéb források is utalnak. A határban nem csapoltak le minden vizet, meghagytak kisebb tavakat, amelyekben haltenyésztéssel foglalkoztak. Ez különösen a Tóköz térségére igaz, ahol régészeti kutatások és XIII. századi határleírások bizonyítják, hogy a mély fekvésű, a Hansággal szoros kapcsolatban álló rábaközi térségben a természetes mélyedésekben tavak helyezkedtek el, amelyeket kiterjedt csatornarendszer kötött össze (10-11. ábra). A fennmaradt XIII. századi öt határleírás közül (idézte Takács 2000) a Kóny határát leíró tartalmaz a legtöbb lokalizálható tavat/halastavat. Összességében 16 halastóról tesznek az oklevelek említést, amelyek közül az ármentesítések előtti időszakra csak egy maradt fenn. A beazonosítható tavak mind természetes mélyedésben helyezkedtek el. Feltételezhetően más hasonló mélyedésekben is lehettek tavak, így akár több százra is tehető a középkorban a tóközi halastavak száma (Takács, 2000). Nemcsak az említett régészeti kutatások alapján, hanem több, a rábaközi halászatról szóló forrás alapján következtethetünk az évszázadokon át űzött, de elfeledett gazdálkodási formára. A Barbacsi tó nevével először 1390-ben találkozhatunk, amikor Zsigmond

\footnotetext{
${ }^{23}$ Például Acsalag határában ,a Mester- és a Jankó-szigetet 1753-ban, a Bónya-szigetet 1759-ben, a Jáger-szigetet 1773-ban kezdték lecsapolni, illetve kiirtani. 1850-ig az acsalagiak így kb. 350 hold földet tettek termékennyé a Csornához csatolt Mátyás-szigeten kívül." (Nagy, 1980)
} 
király a Kanizsaiaknak adományozza. A birtok a kapuvári uradalom része, vele együtt kerül a XVI. században a Nádasdyk majd a XVII. században az Eszterházy család kezére kerül (Jegyzetek 10.).

A török hódoltság alatt viszonylag nyugalmat élvezett a térség, de a portyázások alkalmával több település néptelenedett el ideiglenesen. Az árokrendszer fáradságos munkával volt fenntartható, valószínűleg a XVIII. századra nem érte meg fenntartani a rendszert, és hamarosan feledésbe merült a virágzó hal- és vízgazdálkodás (Bedy, 1938). A kuruc szabadságharc is harcok helyszínévé tette a térséget. Mindezek hozzájárulhattak a munkaigényes tógazdálkodás fenntartásának ellehetetlenüléséhez.
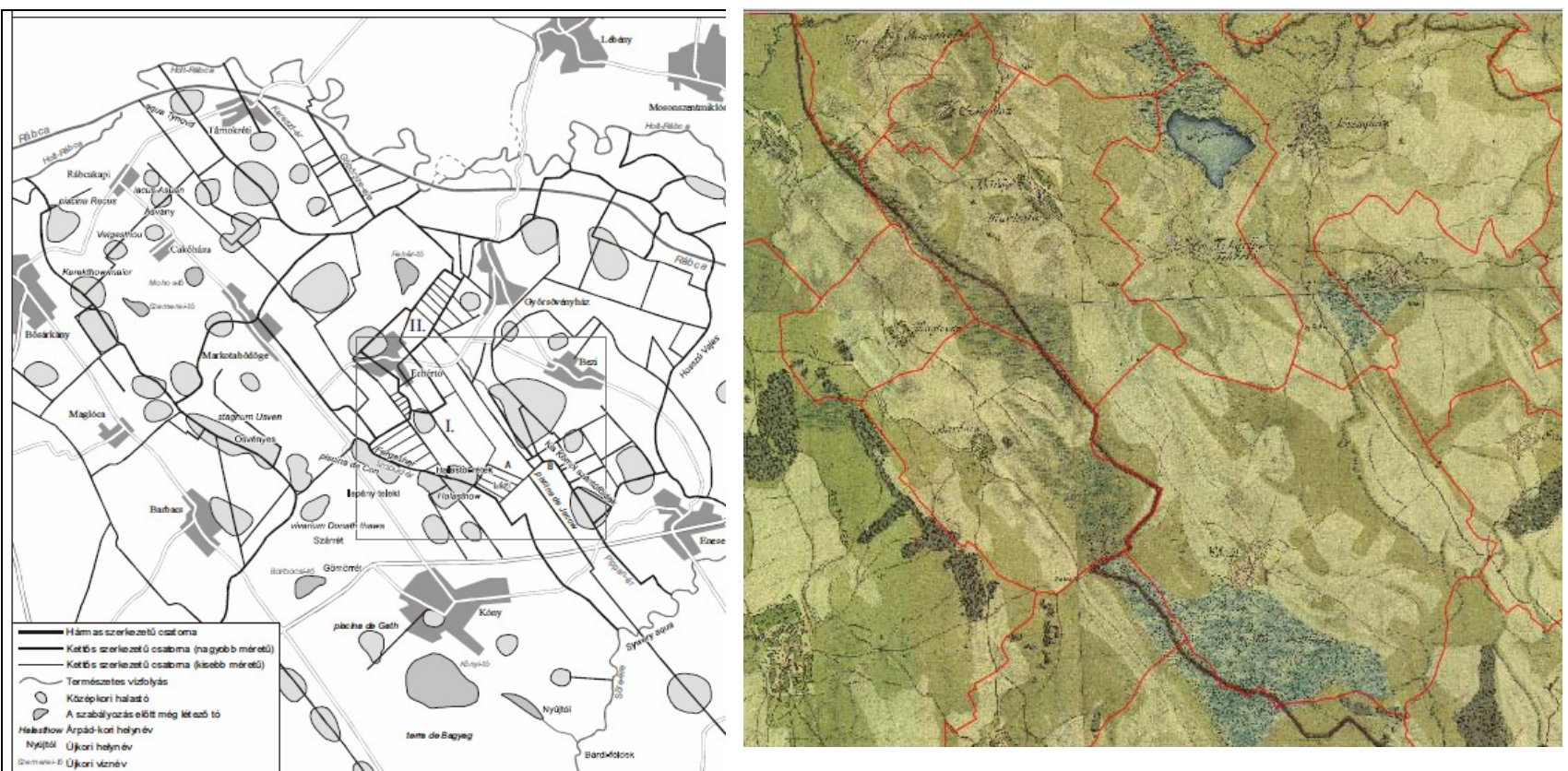

10. ábra: Régészeti kutatások és XIII. századi határleírások alapján feltételezhető csatorna- és halastavak rendszere (Takács, 2000) és a térség az I. katonai felmérésen (XVIII. századra mocsaras területek maradtak vissza a korábbi tórendszer helyén) (www.tajertektar.hu)

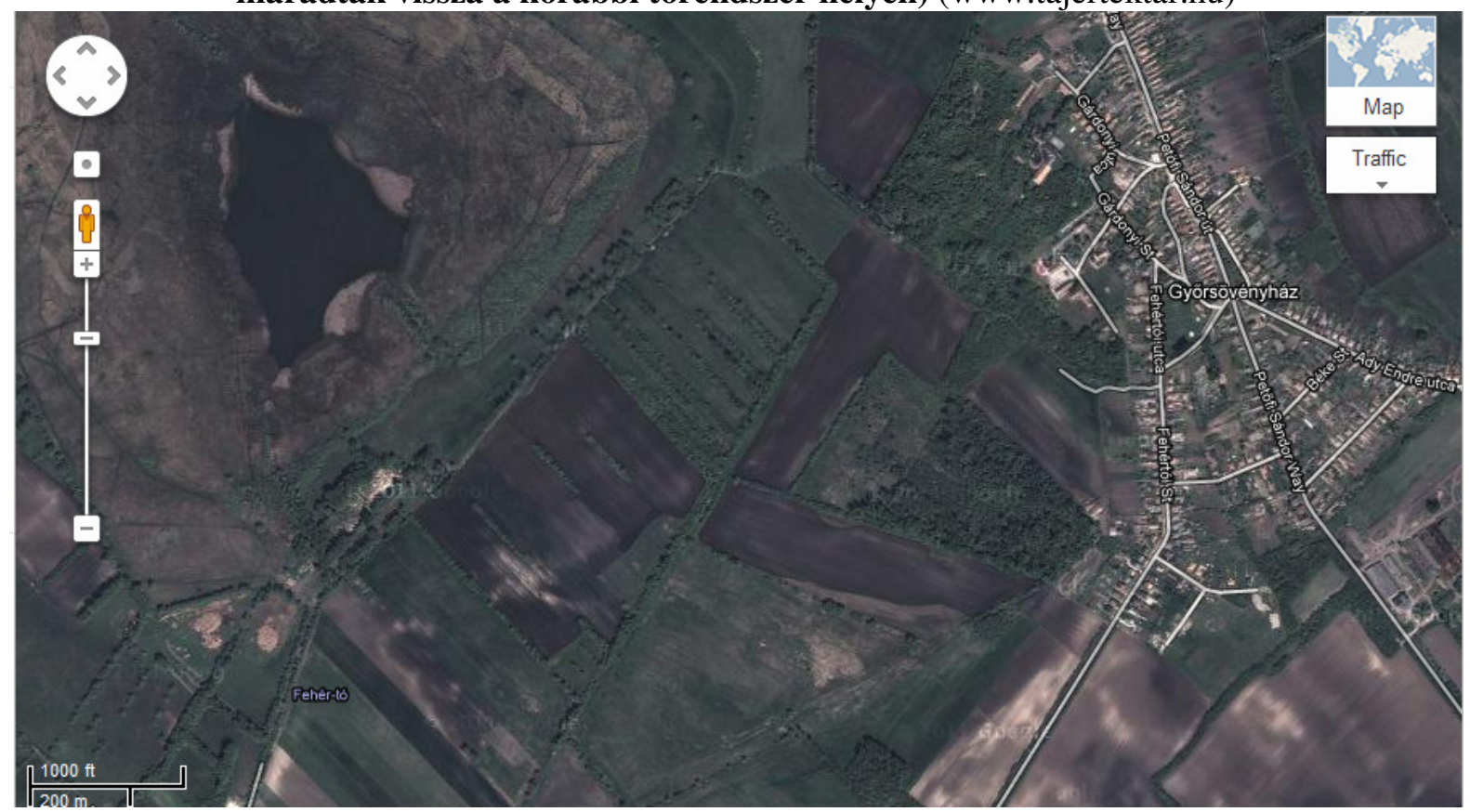

11. ábra: A középkori csatornarendszer nyomai Győrsövényház térségében (maps.google.com) 
A XIII-XIV. századra már nemzetségi birtokokon müvelték a földet a Rábaközben (Jegyzetek 11). Ki kell emelni az 1180 körül alapított csornai premontrei monostor birtokát és az 1206-ban alapított lébényi bencés monostor gazdaságát, amely átnyúlt a Rábaköz területére is. A gazdálkodás fejlődésében nagy jelentőségük volt, hiszen ők adták át a jobbágyok, a köznemesek számára az európai színvonalú gazdálkodási ismereteket (Timaffy, 1989). A kétnyomásos gazdálkodás volt általános a XVI-XVII. századig, bár a szerzetesek már háromnyomásos gazdálkodást folytattak.

Csornát 1529-ben dúlták fel először a Bécs ellen vonuló török hadak. A XVI. századra Győr vármegye a tóközi, csilizközi és szigetközi járásokra zsugorodott, a török uralom a Rába vonaláig terjeszkedett. De a portyázások pusztították Tóköz és Szigetköz falvait is. (Gecsényi, Arrabona 19-20). A pusztítások ellenére a török háborúk keresletet teremtettek, ami ösztönzőleg hatott a gabonatermelés és állattenyésztés fejlődésére. A földesurak saját kezelésükben lévő major (allódium) létrehozásába kezdtek, ahol a jobbágyok robotját használták a földek megművelésére. Csornán a XVI. század közepén az enyingi Török Bálint birtokán, s a prépostság birtokán is nagy kiterjedésủ major létesült. (Pájer, 1999). A majorgazdálkodás fejlődését megtörték a török hadjáratok. Az 1594. évi török betörés annyira elpusztította a Rábaközt, hogy egyes községek teljesen lakatlanokká váltak (Páli, Farád Rábasebes, Rábaszentadrás stb. ${ }^{24}$. A majorgazdaságok megszűnésével hatalmas legelők keletkeztek a Rábaközben (Felhő, 1970). A viszonylagos másfél évszázados nyugalmat a török sereg Bécs elleni hadjárata borította fel. Az 1680-as évek során több falu néptelenedett el újra. Az 1690-es évektől indult meg az elpusztult falvak benépesítése többek között Csanaké. A Rákóczi szabadságharc is sok pusztítást hozott. Az 1710-esévektől magyar visszatelepülők mellett német, horvát családok telepedtek meg több településen (1720-as összeírás). Győrsövényházát 1718-ban a Német Birodalomból érkezett 37 család népesítette be (Gecsényi, Arrabona 19-20) (Jegyzetek 12).

A XVIII.-XIX. században tértek át a háromnyomásos gazdálkodásra, lehetővé téve azt, hogy a termésmennyiség növelését ne csak új szántóterületek nyerésével érjék el. Legfőbb termények a búza, a rozs, a árpa, a zab, a borsó, a lencse, a bab volt, az irtáskertekben gyümölcsligeteket tartottak fenn az erdők helyén, a ház körül pedig zöldséget, gyümölcsöt és kendert termesztettek.

A rábaközi táj külön színfoltját jelentették a vízimalmok. A XII. századtól már említenek oklevelek vízzel hajtott malmokat. A XVIII. században a Rábán, a Kisrábán és a Répcén dolgoztak vizesmalmok. A malmok többsége parton álló vizesmalom volt, amelynek kerekét gátak közé szorított, összegyüjtött víz hajtotta (Kainrath terve több malmot említ, Melléklet V.). Sok helyen sövénygátakkal elterelték vagy felduzzasztották a vizet. Voltak ún. hajómalmok, amelyek két hajóból álltak: a mederben a völgyhajó, a part mentén a házhajó a malombódéval. A két hajó között hatalmas

\footnotetext{
${ }^{24}$ Ennek következtében Soós leírása szerint a Rábaköz az 1594-1604 közt eltelt tíz évben nem adózott s így az 1598. évi házösszeírást sem hajtották itt végre (Soós, 1937 közlése alapján: Országos Levéltár dicalis összeírások sopronmegyei kötete. Itt található az 1598. évi házösszeírás, valamint az 1599. évi taksás névsor is).
} 
lapátkerék volt kifeszítve (Timaffy, 1989). Fényes Elek ország-leírásában például Rábapatonánál, Sobor mellett említ vízimalmot a XIX. század első felében (Fényes, pp104-025; 244-293).

Évszázadokon át a Rábaköz legfontosabb megélhetési forrása az állattartás volt. A vizes területek között hatalmas legelők voltak, amelyeken még a XII. századig vándorolt az állatállomány. A későbbiekben a községek határterületén tartották őket. A XVIII. századra érte el csúcsát az extenzív állattartás: a hatalmas réteken, legelőkön nagy számban élt a gulya, a ménes, a juhnyáj, a tölgyerdőkben disznókondák makkoltak. Ennek az évszázadokon meghatározó tájhasználatnak állítanak ma is emléket a fennmaradt gémeskutak, amelyek már az I. katonai felmérésen is kivehetők a települések környezetében, ahogy a népdal is megörökíti: „...Szili kút Szanyi kút, Szentandrási, Sobri kút...".

\section{Társadalmi, népesedési viszonyok}

Sopron megyére jellemző az országos viszonylatban is magas nagybirtokok aránya. Két óriásbirtokos családhoz füződött a legújabb korig a megye története: a XIV-XV. században területének legnagyobb része az Osl nemzetségből kiemelkedett Kanizsaiak birtoka volt, majd az Ostffyak kerültek előtérbe (Felhő, 1970). A Mátyás király által visszaszerzett elzálogosított területeken, az általa kialakított adórendszer hatására az egytelkes nemesek elbocsátották jobbágyaikat, és földjeiket adómentes nemesi földnek nyilvánították. Így jöttek létre az ún. nemesi (kuriális) községek. Kanizsai családba beházasodva 1535-ben Nádasdy Tamás megszerezte a birtokaikat. Nádasdy volt, aki a majorgazdaságok létesítésével példát mutatott a középnemesség számára. A Nádasdy-birtok a Wesselényi-összeesküvés bukása után, Nádasdy Ferenc lefejezését követő széthullása az Esterházyak és a Széchenyiek felemelkedését hozta. Az egyházi birtokok közül a györi püspökség és a csornai premontrei prépostság jelentősebb (Rétvári, 1970).

A XVIII. század első felének népességi adatairól, gazdálkodásáról ad képet Acsády Ignác müve, a „Magyarország népessége a Pragmatica Sanctio korában, 1720-1721”. A felmérésben csak az adózás alanyait, a jobbágyokat, a zselléreket és az adózás céljára szolgáló földeket írták össze. A Győr vármegyéről szóló leírásban említik, hogy a „Tóközi járás... ...mód nélkül szenved a víztől s általában... ... a földmüvelés csak a magasabban fekvő helyeken ér valamit”. Sövényház több éven keresztül puszta volt, újra betelepülése 1715 táján indult meg. A leírás nem tesz azonban említést a tóközi halászatról. Kevés község tartozott a középbirtokosokhoz, a curialis községekben azonban tömegesen lakott a kis-nemesség”. Curialis község volt Dőr, Farád, Jobaháza, Vág, Zsebeháza. Nem ad sajnos átfogó képet a térség lakosságáról és területhasználatáról a felmérés, hiszen csak a jobbágyok, zsellérek által megművelt földterületet regisztrálták. Az adatoknak az 1865-ös területhasználati adatokkal történő összehasonlításából kitünik, hogy a települések többségében a későbbi teljes szántó és gyepterületek töredékét müvelték meg a XVIII. század elején jobbágyok (10-50\% közötti arány), 
egyrészt a még nem lecsapolt területek magasabb aránya miatt (Hanságmenti, tóközi települések), illetve a kisbirtokos réteg magas száma miatt (lásd curiális települések).

Ahogy az előző fejezetben részleteiben is láthattuk, a háborúk utáni békés időszakban, az 1700-as évektől egyre nagyobb arányban indul meg a szántóföldek kiterjesztése, amely azonban nem járult hozzá a parasztság gazdasági felemelkedéséhez. Werbőczi alaptörvényei csak a földesúri osztály számára tették lehetővé a föld birtoklását, ezért az irtásföldek mind földesúri tulajdonba kerültek, megindult az irtás- és egyéb jobbágyföldek majorságokba történő bekebelezése. Emiatt érintette legerőteljesebben a Kisalföldet az országban a föld birtoklásának polarizálódása, a zselléresedés folyamata. Míg 1720 és 1775 között a jobbágygazdaságok száma háromszorosára (telkek aprózódtak), a zsellérek száma 11-szeresére nőtt. Az 1770-es úrbérrendezés idejére jelenősen megnőtt, bár a kistérségen belül nagy különbségeket mutat az úrbéres területek aránya. Legmagasabb az úrbéres földek aránya a dél-rábaközi és a tóközi falvakban. Az alacsony arány egyrészt a táji adottságok miatt (a Hansági térségek), másrészt a curiális településeken fordul elö. Az úrbérrendezés nagy jelentőségü volt, hiszen az úrbéres földek felett a földesurak nem rendelkezhettek korlátlanul, belőlük nem csatolhattak sajátkezelésủ majorságaikhoz. Az 1848-as törvény az úrbéri viszonyok megszüntetéséről az úrbéres földeket adta feudális járadéktól mentes földként addigi müvelöi kezébe (Felhö, 1970). Az úrbérrendezés azért is fontos, hiszen a régóta zajló földesúri allodizációs folyamat részeként a jobbágytelkek jelentős része, valamint az irtásföldek mintegy 3/4-e a majorsági gazdálkodás keretei közé került. E korból eredeztethető az Eszterházyak, a Festetichek, a Széchenyiek és más nagybirtokosok gazdagsága (Melléklet VI.). Az Eszterházyak birtokuk több mint felét jobbágyoktól visszavett irtásföldekből nyerték (Rétvári, 1977).

\subsubsection{III. periódus: nagyléptékü tájalakítás}

A legnagyobb léptékü tájalakításokat magába foglaló időszakot tulajdonképpen a XIX. század öleli fel, amely korszak hozzájárult a Hanság szinte teljes átalakulásához, a Rábaköz intenzív mezőgazdasági tájjá változásához (6. táblázat). A térség mezővárosai: Csorna, Egyed, Szany, Szil (Kapuvár, Mihályi). 
6. táblázat: A III. periódus jellemzői (saját szerkesztés)

\begin{tabular}{|c|c|c|c|c|c|c|}
\hline Kor & Tájátalakítás & Tájhasznosítás & Konfliktusok & $\begin{array}{l}\text { Népességeltartó ké- } \\
\text { pesség }\end{array}$ & Értékrend & Versenyképesség \\
\hline $\begin{array}{l}\text { XVIII. } \\
\text { vége } \\
\text { XX. } \\
\text { század } \\
\text { eleje }\end{array}$ & $\begin{array}{l}\text { Nagyléptékü tájren- } \\
\text { dezések korszaka, a } \\
\text { Hanság lecsapolása } \\
\text { szervezetten megin- } \\
\text { dul, folyószabályo- } \\
\text { zások (Rába, Ráb- } \\
\text { ca), a Rábaköz ár- } \\
\text { mentesítetté válik, } \\
\text { kiépül a vasútháló- } \\
\text { zat }\end{array}$ & $\begin{array}{l}\text { Növekvö szántóföldi ter- } \\
\text { mesztés, fejlödö állattartás, } \\
\text { növekvö arányú majorsági } \\
\text { gazdálkodás, ipari növé- } \\
\text { nyek termesztése, helyi } \\
\text { eröforrásokra épülö házi- } \\
\text { ipar, helyi gabonatermesz- } \\
\text { tésen alapuló fejlett malom- } \\
\text { ipar } \\
\text { Sokrétü mellékhasználat: } \\
\text { nád-, szénatermelés, gyé- } \\
\text { kényhasznositás, méhészet } \\
\text { stb. }\end{array}$ & $\begin{array}{l}\text { Közlekedést, gazdálko- } \\
\text { dást nehezítö vízviszo- } \\
\text { nyok, tözegtüzek }\end{array}$ & $\begin{array}{l}\text { Növekvö népességeltartó } \\
\text { képesség részben a táji } \\
\text { adottságok korlátozó } \\
\text { hatásával; alacsony nép- } \\
\text { sürüség a tóközi és a } \\
\text { Hanság peremének falva- } \\
\text { iban a nagybirtokok ill. a } \\
\text { táji adottságok miatt; } \\
\text { magas népsürüségü dél- } \\
\text { rábaközi falvak }\end{array}$ & $\begin{array}{lll}\text { Alapvetö hajtóerö a } \\
\text { természet } & \text { átalakításá- } \\
\text { val a lehetö legnagyobb } \\
\text { terméseredmények } \\
\text { elérése a } & \text { nagybirtok- } \\
\text { okon. } & \text { Alkalmazkodás } \\
\text { helyett } & a & \text { természet } \\
\text { átalakitása } & \text { kerül } & \text { elö- } \\
\text { térbe. } & \end{array}$ & $\begin{array}{l}\text { A fejlett agrotechnika, a malomipar } \\
\text { fejlödése a vasútvonalak kiépülésével a } \\
\text { mintatérségben Csorna és közvetlen } \\
\text { környékének kedvezö helyzetét erösítet- } \\
\text { te. A térség északi része az Osztrák- } \\
\text { Magyar Monarchia részeként Bécs } \\
\text { ellátó körzetéhez tartozott. A földbir- } \\
\text { tokokon kialakult majorságok verseny- } \\
\text { képes mezögazdasági müvelést tettek } \\
\text { lehetövé. A tájalakítás ebben az idö- } \\
\text { szakban hozzájárult a térség versenyké- } \\
\text { pességének javulásához. A Rábaköz déli } \\
\text { része fejlettségben lemarad, elaprózódó } \\
\text { birtokszerkezetü túlnépesedett térséggé } \\
\text { válik. }\end{array}$ \\
\hline
\end{tabular}




\section{Tájalakítás}

A XVIII század végi nagy árvizek jelentősen hozzájárultak, hogy komolyan kezdtek foglalkozni a mocsárvilág lecsapolásával. Sopron, Moson és Győr vármegyék megbízták Hegedűs Antalt a mocsarak felmérésével és a szabályozás tervének elkészítésével. Kutatásaim során két tervre is bukkantam 1790 tájékáról (Jegyzetek 13, vízrendezési tervek Melléklet V.).

A tulajdonképpeni lecsapolási munkálatok Hegedüs Antal tervei alapján az 1795-99 között kiásott Bősárkány és a Király-tó közötti Rábca szakasszal kezdődtek, majd 1813-ra elkészült a Rábcacsatorna Királytótól a Nagy-Égererdőig terjedő szakasza is. 1800 és 1813 között szabályozták a Hanságba ömlő folyók alsó szakaszát. Az elkészült csatornák állapotának megőrzéséről azonban senki nem gondoskodott, így az 1820-as évekre nagyrészt használhatatlanokká váltak. Az 1810-es évektől több mint egy évszázadon át folytatott nagyarányú vízrendezéssel gyakorlatilag a Hanság jelentős úszólápjainak, mocsarainak lecsapolása is megtörtént.

A vízrendezési törekvések a XIX. század második felében kaptak újabb lendületet. A Rába és a Hanság vízrendezési munkálatainak irányítására létrehozták a Rábaszabályozó Társulatot. A szabályozási tervekben eredetileg Meiszner Ernő a Hanság déli részén futó külvízi csatornát tervezett, mely Kapuvár-Hugoth között 11 m eséssel hozta volna a vizeket a Rábába és Kapuvárnál felvette volna a Hövejtől odavezetett Répcét és Kisrábát. A magasvezetésű csatorna erőművi kihasználás mellett gravitációs öntözővízzel is ellátta volna a Hanság egy részét. Ezenkívül szerepelt a tervben a Hanság-csatorna kiásása egészen a Vulkáig. A költségek miatt azonban a Rábaszabályozó Testület átalakíttatta a terveket és törölték a külvízi csatornát és a Hanság-csatornát is csak Pomogyig hagyták meg, amelyet 1892-1895 között építettek meg. Úgy gondolták, hogy a Rábca mederbővítéséből kikerülő földanyag felhasználható és egyben fedezi az árvédelmi töltések földszükségletét. A külvízi csatorna elhagyásával pedig megtakarítás érhető el és a Rába medrét mélyebbre építik. Két csatorna helyett tehát csak egyet építettek. A későbbi problémák mind ide vezethetők, a külvizeket bevezették az ártérbe, ahonnan azokat zsilipeken kellett átereszteni, vagy szivattyúkkal a Rába töltésein átemelni (Ihrig, 1973). A Rábca kotrása 1886-ban indult. A pomogyi hídtól a Fertőbe nyúló szakaszt 1910ben építették csak meg.

A Hanság szabályozása mellett a térség lakosai számára meghatározó volt a Rába szabályozása. A Rábaköz lakosságának a Rába felől érkező árvizekkel is meg kellett küzdeniük. A Rába mintegy 250 km-es mederben kanyargott, vízjárása nagyon szeszélyes volt. Ennek ellenére a falvak határa nem állt állandóan víz alatt, a Rába mentén mocsaras területek, erek, száraz-homokos vidékek, erdők váltották egymást. Nicknél a Rába két ágra szakadt, a Kis-Rába észak felé haladva szintén több ágra szakadva a Hanságban ömlött a Rábczába (Jegyzetek 14.).

A Rába partjain már a középkorban gátak épültek (Dóka Klára anyaga a Rába szabályozás előtti képéről (Lipszky térkép és OL S 12 Térképtár, Helytartótanács, Div. XIII. No. 295/3 ). Már évszá- 
zadok óta védekezett a lakosság gátakkal az áradások ellen, ahogy ezt legkorábban, egy 1247-ben Csáky István nándor, soproni ispán által kiállított oklevél említi, aki tudósít a csornai premontreiek vízimalmáról és gátjairól a Rábán. Az ispán feladata volt, hogy elrendelje a Rábán és a Rábcán épített vízimalmok lebontását, amelyeket egyrészt felelőssé tettek az árvizekért (Pájer, 1990). A malmok tulajdonosai vagy bérlői az alacsony vízállás miatt gátakkal duzzasztották fel a vizet, „,felemelték a malomfejet”. A II katonai térképen több Rába-parti település körül látunk gátakat, csatornákat. A helyi lakosok a XIX. századig nagyon sokat tettek az árvíz elleni védekezés terén, de a végleges szabályozásra csak az 1880-as évek végén került sor utolsóként a Duna és a Tisza mellékfolyói között, hiszen nagyon komplex és költséges munkáról volt szó: nemcsak a Rába és mellékfolyóinak szabályozásáról volt szó, de idekapcsolódott a Hanság és Fertő ügye is (Dóka, 1977). A XVIII. század végén a Rába menti megyék (Győr, Sopron, Vas, Veszprém) közösen egy árvízvédelmi bizottságot alapítottak Szany mezővárosban, amely megállapította a malmok, hidak okozta problémákat (Jegyzetek 15.). Átfogó beavatkozásra ekkor még nem került sor, a bizottság csak ajánlásokat fogalmazott meg.

A XIX. században egyre inkább figyelem terelődött az áradások problémájára, sorra készültek a Rábát és a Rábaköz vizeit ábrázoló térképek. 1802-ben Szapáry József királyi biztos Hegedüs Jánost a Sopron megyei, Kenedits Józsefet a Vas megyei Rába szakasz felmérésével bízta meg. Szapáry egyik fő feladata volt a Rába malmainak szabályozása, amit térképek készíttetésével kezdett. Másik feladat volt a Hanság lecsapolási munkálatainak irányítása. Az elkészült térképek alapján kezdték meg a malmok felmérését. 1822-ben indult átfogó, szintezéssel készült felmérés a Rábáról, amelynek felülvizsgálatára és a szabályozási terv elkészítésére 1830-ban Keczkés Károly hajózási mérnököt kérte fel a Helytartótanács. A tervet ki kellett terjeszteni a Rábcára, a Fertőre és a Hanságra is (Dóka, 1977) (Jegyzetek 16).

A Rába-szabályozás első lépését Festetics Ignác gróf tette meg, aki sobri és egyedi birtokain a kanyarulatok átvágása céljából csatornát ásatott 1812-ben egy kanyarulat lerövidítése érdekében (Sár$k \ddot{o ̈ z i}, 1968)$.

Létrehozták (Jegyzetek 17) az Alsó-rábaközi Rábabizottságot, amelynek feladata elsősorban a védelem és a megrongált gátak helyre-állításának irányítása volt. A rábaközi községek közmunkában végezték a helyreállítást. A munkák általában a vízbeesett farönkök eltávolítását, a malmok környékének megtisztítását, a duzzasztott vízszintek csökkentését, a part menti töltések megerősítését foglalták magukban. Az árvízveszély megszüntetésére azonban nem voltak elegendőek ezek az erőfeszítések (Timaffy, 1991).

Keczkés terve után többen is végeztek felméréseket a Rábán és készítettek szabályozási tervet (1860ban Kleinrath József, Újházy János 1873-ban). Munkájukban felhasználták Keczkés mérési eredményeit. A végleges szabályozási terv készítője Meiszner Ernő volt, aki kiindulásként használta 
Keczkés munkáját. Keczkés terveinek elkészülte után eltelt 50 évben jelentősen megváltoztak a társadalmi gazdasági feltételek: a vízimalmok már nem jelentettek problémát, viszont új igények merültek fel az öntözéssel és a belvízlevezetéssel kapcsolatban. Szabályozási tervének legfontosabb elemei azonban megvalósításra kerültek (Dóka, 1977).

A végső árvízmentesítést a Rábaszabályozó Társulat 1873-as létrehozása, illetve az 1885. évi XV. törvénycikk a Rába és mellékfolyóinak szabályozásáról, hozta meg (Jegyzetek 18.). A Rábaszabályozó Társulat az ország egyik legnagyobb ármentesítő szervezete volt ebben a korban, hiszen müködési területe kiterjedt a Rába folyó vízgyüjtő területének alsó szakaszára (mintegy 15000 km² területre) valamint a Hanság vidékére. Az ármentesítési munkák vezetésével Radó Kálmánt bízták meg, akinek irányításával 10 év alatt a Rábát Sárvár és Győr között 87 átvágással „,kiegyenesítették", valamint a folyó mentén mindkét parton árvédelmi töltéseket építettek. A töltések hossza összesen 345 km lett. Az általában 4-6 m koronaszélességü töltések között 400-600 m széles hullámteret hagytak az árvizek levonulására. Sárvár és Győr között a folyó hossza 51 km-rel rövidült, összességében 300000 kat. holdat mentesítettek. A Rábaszabályozó Társulat irányításával hasonlóan a Rábához Bősárkánytól Győrig gátakat építettek a Rábca mentén, valamint csatornázták a Rábcát Pomogytól Rábcakapiig (Sárközy, 1968).

A Rábaszabályozó Társulat müködési területe kiterjedt a Hanságra is. Az akkor már évtizedek óta zajló lecsapolások eredményeként a Hanság talajvizének nagy részét már elvesztette. Naponta mintegy $25000 \mathrm{~m}^{3}$ víz áramlott ki a medencéből, aminek következtében a láprétek kiszáradtak. Belvízlevezető szivattyúkat építettek Lébénynél, Bősárkánynál és Győrsövényházánál. A hansági táj vízháztartását nemcsak a levezető csatornák változtatták meg, hanem a medencébe folyó vizek szabályozása, töltések építése, az árvízveszély megszüntetése (bár véglegesen az árvízveszély nem hárult el). Körülbelül ekkor, a XIX. század végén kezdődött a tőzegbányászat is. A kor nagyarányú tájalakító terveit jellemzi, hogy a Rábaszabályozó Társulat foglalkozott a Fertő-tó lecsapolásának lehetőségével is (Sárközy, 1968). A Rába-szabályozás utolsó nagy munkálata volt a Rábca-torkolat áthelyezése Győr térségében. A Rába szabályozásával egy időben zajlott az Öreg-Duna szabályozása is.

A tájszerkezet, településhálózat átalakulásához hozzájárult a XIX. század végén megépült vasúthálózat: 1876-ban adták át a Győr-Sopron vasútvonalat, majd ezt követően a Pozsony-Szombathely vonal (1891), legvégül a Csorna-Pápa vonal épült meg.

\section{Tájhasználat}

A katonai térképek viszonylag jól tájékoztatnak a tájhasználatról és a tájhasználat átalakulásáról. A II. katonai felmérés a térségben 1840-1847, a III. katonai felmérés 1872, 1880-ban készült a térségre. A XIX. század közepének tájhasználatát rögzíti a II. katonai térkép. Drasztikus változásokat még nem látunk a területhasználatokban (Jegyzetek 19.) bár, ahogy a tájalakításról szóló fejezetben említésre került a Rábca egyes szakaszait szabályozták, megépült a Hanság-főcsatorna őse (Új Metszés, 
Kis Metszés). A II katonai térképen jól kivehető a Sopron-Győr vasútvonal, amely ugyan csak 1876ban nyílt meg, majd ezt követően a Pozsony-Szombathely vonal (1891), legvégül a Csorna-Pápa vonal épült meg.

A II. katonai térképen a Hanság peremén ábrázolt erdők határvonalai nyílegyenesek tudatos erdőgazdálkodásra utalnak. A vízrendezés lehetővé tette a mezőgazdasági művelést, ebben a korban termelték le a Király-tó körül elhelyezkedő ligetes valószínüleg nyírből álló lápi erdőállományt (Ádám, 2005), amelyből csak a Király-erdő maradt meg. A Hanság déli peremének erdeit fokozatosan északra a lecsapolt területekre helyezték át, éger telepítésével.

Az egyre hatékonyabbá váló lecsapolási munkáknak és a technológiai fejlődésnek köszönhetően intenzívebbé válik a mezőgazdálkodás a térségben. 1811 és 1842 között az Eszterházy uradalom 4060 holdat, Csorna 9150 holdat mentesített. Duplájára nőtt a gabonatermesztés, elsősorban a búzáé, de az árpáé is nőtt, továbbá a kukorica termőterülete főleg a sertéstenyésztés térhódításának köszönhetően, majd a század végén a cukorrépa termesztése is megjelent (Timaffy, 1988). Egyre intenzívebbé vált a növénytermesztés. (Jegyzetek 20.) Gabonát a szántóterület 48\%-án termesztettek, kapásokat 28\%-án, takarmányokat 19\%-án (Timaffy, 1988). A korábban jellemző két- és háromnyomásos gazdálkodást felváltotta a forgórendszer, amely az uradalmak példáján elterjedt a paraszti gazdálkodásban is. A Rábaközben jellemzően a vegyes vetésforgót használták: első évben kapást vetettek, másodikban tavaszi gabonát, a harmadikban szálastakarmányt, a negyedikben pedig őszieket. Általában az országos átlagnál magasabb terméseredményeket értek el. A virágzó agráriumhoz fejlett malomipar kapcsolódott, amit bizonyít a rábaközi malmok viszonylag magas száma, hiszen míg a Rábaköz Sopron vármegyének mintegy negyedét ölelte fel, a szárazmalmok több mint felét, a szélmalmok kétötödével és a gőzmalmok harmadával rendelkezik, egyedül a vízimalmokat illetően alacsonyak az arányszámok (Jegyzetek 21.).

A korszerü földműveléshez fejlettebb állattenyésztés kapcsolódott. Növekedett az állatszám az egyre jobban ármentesített legelökön (Jegyzetek 22.). Az állatállomány a XIX. század végéig föleg régi tájfajtákból állt: elterjedt volt a magyar marha. Azonban a tejtermelés előtérbe kerülésével a tájfajtákat kiszorította a vöröstarka szarvasmarha és fokozatosan keresztezésükkel a mosoni tájfajta terjedt el. A XIX. században elterjedt magyar parlagi lovakat is kiszorították a keresztezett fajták döntően a katonaság igényeihez alkalmazkodva. A juhtartás fokozatosan visszaszorult, a sertéstenyésztés terjedt el (Timaffy, 1988).

A térségben a gazdálkodást nehezítő legfontosabb természeti csapásként a tavaszi áradásokat emeli ki Fényes Elek (Jegyzetek 23), ami szegénységet, éhezést okoz a különösen magas vízállású években (Fényes, 1870-1876).

A jobbágyfelszabadítás megváltoztatta a gazdálkodás üzemi rendszerét. A jobbágyok attól függően, hány ökörrel dolgoztak, annak megfelelő nagyságú földet kaptak 1848 után. A szegényebbek ún. 
tizennyolc-napos tagot kaptak (kb. 1800 négyszögöl), amiért 18 napot kellett dolgozni az uraságnak. A kiosztott földet általában a határ különböző részein kapták meg a gazdák, amelyek közül a gyengébb minőségüt tartották meg legelőnek. A termőterület mintegy 60\%-át a paraszti gazdaságok mellett a nagybirtokos uradalmak foglalták el, ahol a majorok üzemi formája alakult ki. A Rábaközben a Hansággal együtt számuk a 100-at is meghaladta (Timaffy, 1988). A majorok általában zárt területek voltak, központjukban az intézők laktak, a majorok szélén a cselédházak, gazdasági épületek, istállók, magtárak, műhelyek helyezkedtek el. Szigorú rend szerint működő társadalmuk alakult ki.

A technológiai fejlődés és a bécsi piac növekvő élelmiszer és egyéb nyersanyag szükségletei hozzájárultak a tágabb térség vetésszerkezetének átalakulásához: a korábban gabonatermelő térségben egyre inkább (a XIX század utolsó harmadától és a XX. század folyamán) ipari növények termesztésére és a tej és hús termelésére kezdtek berendezkedni. A nagybirtokokon fokozatosan növekedett a sörárpa és a cukorrépa termesztésének aránya. Bevezetésre került a belterjes, istállózó állattartás, magas tejhozamú fajtákat honosítottak meg (Rétvári, 1977).

A XIX. század végének tájhasználatát szemlélteti a III. katonai térkép (1870-80-as évek). Sajnos a térképet viszonylag nehéz értelmezni, mert egyszínü. A II. katonai térképhez képest feltünő változás a III. katonai térképen a majorok nagy száma. A vízrendezés hatásai szintén egyértelműen látszanak: elkészültek a legfontosabb csatornák (Einser Kanal, Kis-metszés, Új metszés), árkokat ástak. Szembetűnő a Hanság peremén, Rábaköz északi és déli részén a mozaik jellegủ területhasználat, árkok és az azokat kísérő fasorok szabdalják a tájat, rétek, szántók váltakoznak. Jelentősen csökkent a mocsarak és a lápok aránya a Hanság peremterületein és a Tóközben (Jegyzetek 24).

Míg az érintett megyékben a lassú és a fokozatos ipari fejlődés következtében az élelmiszeriparon, könnyüiparon túl fokozatosan megjelent a nehézipar is, a Rábaközben a gabonatermesztésen alapuló malomipar vált csak jelentőssé (Jegyzetek 25). A térségben korábban a vízimalmok telepedtek meg, de a Rába-szabályozás a vízimalmok jelentős részét megszűntette. A már említett vasútépítés a malomiparra pozitív hatással volt, sorra épültek malmok a vasutak mentén, továbbá a Csornán kereszteződő vasútvonalak megerősítették a mezőváros központi szerepét a térségben.

Az adóztatás megkönnyítése érdekében készítettek földadókatasztert (Jegyzetek 26), amelyből jól látszik, hogy a térség összehasonlítva a környező osztályozási vidékekkel viszonylag jó minőségü földekkel rendelkezik (az egyes minőségi fokozatokban szinte dupla jövedelemmel számolnak mint például a Győri becslőjárás első osztályozási vidékén). (Győr és Sopron megye adóközségeinek területe és kataszteri tisztajövedelme mívelési áganként és osztályonként, 1914, Budapest). A rét művelési ág a szántókkal vetekedő jövedelmet biztosított.

Az adatokat vizsgálva láthatjuk, hogy a szántó területek túlnyomó része a közepes minőségü osztályokba tartozik, viszonylag kisebb arányban esnek a legmagasabb és csupán néhány százalék esik a 
legrosszabb kategóriákba. A rétek arányához képest viszonylag alacsony a legelők aránya, döntően a legrosszabb minőségű területeket használták legelőként.

\section{Társadalmi, népesedési viszonyok}

Az ipari fejlődés hiánya miatt a népesség a megyében a XIX. század első felében az országos átlag alatti mértékben növekedett, elvesztette a népsürüségi rangsorban a vezető helyét. A század közepéig a jobbágytelkek tovább aprózódtak, a fejlettebb technológiával dolgozó majorságok nem szívták fel a föld nélküli parasztságot. A jobbágyfelszabadítás hatásai korlátozottabbak voltak itt, mint az Alföldön a jobbágyság kisebb aránya miatt. A kishatárú falvak többségében az egy före jutó földterület nem érte el az 1 hektárt, ami alapján agrár-túlnépesedésről beszélhetünk (Rétvári, 1977). A nagybirtokok területén a népsürüség alacsony maradt, hiszen a fejlettebb agrotechnika miatt kisebb munkaerő igénnyel dolgozhattak.

A XIX. század végétől egyre erőteljesebben érintette a Győr, Moson, Sopron megyét is a kivándorlás (Estók, 2003), amely az 1870-es évekre a Mosoni-síkság után átterjedt a Rábaköz magas népsűrüségü kistelepüléseire. Míg Sopron környékén a filoxéra vész, addig a Rábaközben a Rába és a Rábca szabályozása miatt megnövekedett közterhek járultak hozzá a lakosság helyzetének romlásához és az 1-2 holddal rendelkező földtulajdonosok (Jegyzetek 27), a mezőgazdasági cselédek és napszámosok mellett inkább külföldön kerestek boldogulást (Estók, 2003, Rétvári, 1977). Rétvári László kutatásai alapján az akkori Moson, Sopron, Győr megye természetes szaporodásának 20, 40, 60\%-át vitte el a kivándorlás.

\subsubsection{IV. periódus: intenzív tájhasználat megszilárdulása}

Tájalakítás, tájhasználat szempontjából érdemes a XX. századot külön tárgyalni, hiszen a nagyléptékü tájalakítási munkák a nagytérséget illetően döntően lezajlottak, de a Hanság belső területein folytatódtak (kiterjedt a láp meghódítása az eddig még érintetlen területekre is) (7. táblázat). Egyre erőteljesebben váltak érezhetővé a tájalakítások negatív hatásai. A mezőgazdasági termelés szerkezete jelentősen átalakult, a nagyüzemi növénytermesztés és állattenyésztés terjedt el. 
7. táblázat: A IV. periódus jellemzöi (saját szerkesztés)

\begin{tabular}{|c|c|c|c|c|c|c|}
\hline Kor & Tájátalakítás & Tájhasznositás & Konfliktusok & $\begin{array}{l}\text { Népességeltartó képes- } \\
\text { ség }\end{array}$ & Értékrend & Versenyképesség \\
\hline $\begin{array}{l}\text { XX. sz } \\
-1980- \\
90-e s \\
\text { évekig }\end{array}$ & $\begin{array}{l}\text { A Hanság belsö } \\
\text { területeit is átalakí- } \\
\text { tó vízrendezés }\end{array}$ & $\begin{array}{l}\text { Intenzív, belterjes növény- } \\
\text { termesztés és állattenyész- } \\
\text { tés, } \\
\text { A század elsö felében öntö- } \\
\text { zéses erdögazdálkodás } \\
\text { égerrel a Hanságban majd } \\
\text { az éger lecserélése nyárral } \\
\text { Fokozatosan visszaszoruló, } \\
\text { napjainkra eltünő mellék- } \\
\text { használatok: méhészkedés, } \\
\text { nád- szénatermelés, tözeg- } \\
\text { bányászat }\end{array}$ & $\begin{array}{l}\text { A lecsapolások } \\
\text { negatív hatásai } \\
\text { kiütköznek: tözeg- } \\
\text { tüzek, defláció, } \\
\text { aszály és belvíz. }\end{array}$ & $\begin{array}{l}\text { A népességeltartó képességet } \\
\text { a mezögazdaságban lezajló } \\
\text { téeszesités és az urbanizációs } \\
\text { folyamatok határozzák meg, } \\
\text { eröteljes népességvesztés a } \\
\text { rábaközi falvakban, kisebb } \\
\text { arányú népességvesztés a } \\
\text { Tóközben, Csorna népesség- } \\
\text { száma nö. }\end{array}$ & $\begin{array}{l}\text { A társadalom értékrendjét a } \\
\text { központosító szocialista politika } \\
\text { befolyásolja, a vidéki életmód } \\
\text { „renoméja megkopik”. Mester- } \\
\text { ségesen felgyorsított urbanizá- } \\
\text { ció. A tájhasználatot a raciona- } \\
\text { lizáció, az ipari méretü mezö- } \\
\text { gazdasági termesztés határozza } \\
\text { meg. Az élhetöség területén } \\
\text { elörelépést jelent a közszolgál- } \\
\text { tatások megszervezése. }\end{array}$ & $\begin{array}{l}\text { A térség versenyképességét jelen- } \\
\text { tösen rontja, hogy a Trianoni } \\
\text { határok miatt leszakad Bécs ellá- } \\
\text { tó körzetéröl, határ menti perifé- } \\
\text { rikus térséggé válik. A szocialista } \\
\text { fejlesztéspolitika minimális ipar- } \\
\text { fejlesztést tesz lehetövé, alapvetö- } \\
\text { en mezőgazdasági nyersanyag- } \\
\text { termesztés térségi szerepkörét } \\
\text { kínálja a kistérségnek/járásnak } \\
\text { (exogén fejlödési modell). A foly- } \\
\text { tatódó tájalakítás nem hoz továb- } \\
\text { bi gazdasági fejlödést, a verseny- } \\
\text { képesség javítását. }\end{array}$ \\
\hline
\end{tabular}




\section{Tájalakítás}

A XX. század első felében tovább folytak a lecsapolási munkálatok, ami elsősorban a meglévő belvízmentesítő, illetve öntöző csatornahálózat mélyítésében, karbantartásában, illetve újabb levezető árkok ásásában nyilvánult meg. A II. világháború okozta károkat helyreállítva, felújították a főmüveket, de a mezőgazdasági müvelésbe vonáshoz további lecsapoló-árkokra volt szükség. Már Sárközy is beszámol az 1960-as években a Hanságban és peremvidékén a termelést akadályozó kettős problémáról: a továbbra is előforduló „káros vízbőség”-et és a peremterületeket sújtó szárazságot. A mezőgazdasági hasznosítás fejlesztésére 1953-ban ún. „komplex Hanság-terv” végrehajtását indították el, amely kiterjedt mind az árvizek, az esőzések alkalmával fellépő belvizek levezetésére mind az árhullámok vizének öntözés céljára történő hasznosítására, az Ikva, a Kardos-ér, a Répcemedrének kibővítése valamint a kapuvár-bősárkányi csatorna rendezésére. A vízrendezési munkálatokat mezővédő erdősávok telepítésével tervezték kiegészíteni, amelyek a szél deflációs hatását csökkentették volna. A mezőgazdaság és a kapcsolódó iparágak fejlődését gazdasági vasút kiépítésével és a kiszélesített csatornákon kishajózással tervezték megalapozni. A komplex vízrendezési munkákkal 40000 kataszteri hold vízmentesítését és kb. 7000 hold öntözését tervezték, ami a szántóföldek 7000 holddal, az erdők területének 6000 kataszteri holddal történő növelését jelenthette (Sárközi, 1968). Ha a vízrendezési tervek nem is valósultak meg teljes egészében, a csatornarendszer kiépítése folytatódott. A Hanság sorsát az un. KISZ táborok (1958-1972) keretében végzett munkálatok pecsételték meg főleg az Észak-Hanság területén. Az Észak-Dunántúli Vízügyi Igazgatóság adatai szerint 1958 és 1972 között 19877 fiatal vett részt a táborozásban, közben megástak 128 km csatornát, kitermeltek 369000 köbméter földet. A korábban átláthatatlan mocsaras vidék lecsapolási munkáinak befejezését a határ szigorúbb ellenőrzésének igénye is motiválta. A Hanság jelenlegi természeti viszonyait és a gazdálkodási lehetőségeket egyaránt meghatározza a lecsapoló-rendszer (www.index.hu, Rólunk a Hanság énekel).

A szabályozások után a láp visszahúzódott és főleg a peremterületeken megkezdődött a rétek feltörése (lásd a 3. táblázatban a rét arányának további csökkenése 1935 és 1962 között), a tőzegbányák nyitása, a nagykiterjedésủ égerállományok kitermelése és a mélyebb fekvésủ területek erdősítése nemesnyár klónokkal.

A lecsapolások miatt a Király-tó is kiszáradt, de az intenzív tőzegbányászat következtében újjászületett. Kogutovicz Károly leírása szerint a lecsapolások következménye, hogy a tőzeg alól eltünt a víz, az úszólápok megfeneklettek, a hatalmas égererdőségekben a talaj 1-2 métert süllyedt és napvilágra kerültek az égerfák sátorszerü támasztópillérei (Kogutovicz, 1936). A Hanság vizeinek teljes elvezetése következtében a XX. század második felében további talajszint süllyedés következett be valamint többször is nagyarányú tőzegtüzek keletkeztek, a legjelentősebbek 1945-47-ben (5800 hektáron a talajszint 40-60 cm-t süllyedt) és 1976-ban volt, amikor 76 ha rét semmisült meg (Rakonczay, 
1996). A tőzegláprétek zsugorodásában nagy szerepe volt a meginduló oxidációs folyamatoknak (kotusodás), amit elősegített a mezőgazdasági müvelésben alkalmazott gőzekés rigolírozás és a tőzegréteg kiégetése.

A lecsapolások után a Hanság ma az ország legsürübb csatornahálózatával rendelkező vidéke. Az öntöző és levezető csatornák hálózatának kiépítése a '60-as évek végén befejeződött (több mint 1700 km hosszú, Jegyzetek 28). A csatornák ma kettős feladatot látnak el, magasabb vízállás esetén a belvizet vezetik el, máskor pedig a területek öntözésére szolgálnak (Rakonczay, 1996). A kisebb mocsaras területektől eltekintve ma már csak a Fehér-tó és a Barbacsi-tó rendelkezik nagyobb nyílt vízfelülettel, a tavakat a Keszeg-érből lehet szükség szerint táplálni.

\section{Tájhasználat}

A területhasználatok változásának nyomon követését már a statisztikai adatok is segítik. Ezen időszak változásait több térkép is szemlélteti: a III. felújított katonai térkép a XX. század első felének, a század közepének tájhasználatát az 1951-es topográfiai térkép alapján a korábban alkalmazott területhasználati kategóriák segítségével ábrázoltam (Melléklet VII-VIII.). Jelentősen nőtt a szántók aránya elsősorban a gyepek feltörése miatt, erre az időszakra a Hanság peremterületein már minden magasabban fekvő területet felszántottak. Mozaik jellegűen váltakoznak a gyepes és a szántó területek. Jelentős mértékben csökkent a gyepek aránya, annak ellenére, hogy a kiszáradt mocsaras területeken új gyepterületek keletkeztek (Takács, 2011) a Hanságban. A gyepeket a szélerózió miatt fasorokkal tagolták. Már a XIX. század végi térképen is nagyszámú major és egyéb telephely figyelhető meg, de a XX. század elejére tovább nőtt a számuk. Jelentősen nőtt a mai Csorna közigazgatási területére eső Csíkos-éger és a Tarcsai-éger kiterjedése (korábban itt nem is voltak erdők, illetve az erdőterületek áthelyeződtek). A fennmaradt régi üzemtervek (Ádám, 2005) tanúsítják, hogy a XX. század elejére az éger vált szinte egyeduralkodóvá a Hanságban, összefüggő, elegyetlen állományokat alkotott, hiszen a felújításokat, telepítéseket mézgás égerrel végezték (legnagyobb állományát 1940-ben érte el, Közép-Európában kuriózumnak számítva). A lecsapolások következtében a víz a Hanságban kelet felé áramlott, de folyamatosan pótlódott, ami friss, oxigénben dús vízellátást biztosított: kiváló körülményeket az éger számára. Ez az ún. „öntözéses erőgazdálkodás” egyedülálló volt az egész világon. Jelentősen változtak azonban az erdőgazdálkodás irányelvei 1945 után. Az 1954, 1956, 1964-es árvizek nyilvánvalóvá tették, hogy az éger nem viseli el tartósan a pangó vizet. A vízgazdálkodásban is változás következett be: a zsilipek kezelését a Vízügyi Igazgatóság vette át, csökkentek az öntözés lehetőségei. Az égererdők talaja kiszáradt, megszünt az egyenletes vízutánpótlás, ami nem kedvezett az éger növekedésének. Fokozatosan lecserélték tehát az égerállományt nyárra, az éger elegyaránya az 1950-es 90\%-ról 1972-re 20\%-ra csökkent. Az első nemes nyár fajtákat (Populus euramiricana $c v$. 'serotina') a XIX. század végén ültették. A különböző nemesnyár-fajták 
alkalmazása során a termesztés számára a legalkalmasabbnak az „I-214” klónok bizonyultak (Ádám, 2005).

A vízrendezési munkák folytatását a megye agrárgazdaságának fejlesztési szándéka indokolta (Jegyzetek 29). Győr-Moson-Sopron megyében hat állami gazdaság és 115 termelőszövetkezet jött létre. A Rábaközben kisebb méretü TSZ-ek létrehozása volt jellemező, átlagos üzemnagyságuk nem érte el a 2,1 ezer hektárt. (Rábamenti Állami Gazdaság, Lajta-Hanság ÁG.). Az 1970-es évek végén íródott jellemzés magas színvonalúnak értékeli a térség mezőgazdasági termelését, az országos átlagokhoz képest kedvező terméseredményekkel. Az üzemek többsége gazdaságosan termelt. Az értékelés kedvezőtlennek ítéli, hogy nem kellően használták ki a specializáció lehetőségét: visszaszorult az állattenyésztés és elsődlegesen a munkaerőhiány miatt visszaesett a zöldség- és gyümölcsellátó övezetek termelése. A Rábaköz csaknem minden mezőgazdasági üzemében öntöztek, a 100 ha mezőgazdasági területre jutó traktoregység (20-25) a megyei átlag felett volt (Rétvári, 1977). A szocializmus évtizedeiben a gyümölcsösök telepítése révén nőtt a járásban a gyümölcstermesztés. A Rábaköz északi részének zöldpaprika termesztése volt jelentős megyei viszonylatban. Fő termesztett növények: kukorica, búza, cukorrépa, őszi és tavaszi árpa.

A Rábaközben sohasem volt nagy jelentőségü az erdőgazdálkodás, a II. vgh. utáni birtokrendezés során az erdők kiosztásra kerültek magángazdák között és a nagybirtokok államosítása révén létrehozták az Államerdészetet. Az 1950-es évek végén 60-as évek elején létrejöttek az MGTSZ-ek, gyakorlatilag megszűnt az önálló gazdálkodás, csak háztájiban maradtak kisebb erdőterületek. A téeszek fő gazdálkodási területei a növény és állattenyésztés voltak, sokkal kisebb figyelem irányult az erdőgazdálkodásra. Az erdészeti termelést a gazdasági racionalizálás jellemezte, előtérbe kerültek a gyors növekedésü, kevesebb fenntartást igénylő fajok: a nemes nyárak és az akác (Ádám, 2005).

Az 1980-as évek végére iparszerü méreteket öltött a mezőgazdasági termesztés, egyes nehezebben megművelhető területeken a téeszek felhagytak a földműveléssel (legelők, árokpartok stb.) és erdőt telepítettek. A Rábaköz dél-keleti részén 150, ritkább esetben 250 hektáros egybefüggő szántóföldek is kialakultak, tóközi és a hanságmenti részeken a sűrü csatornahálózat miatt mozaikosabb a tájszerkezet.

A XX. században a hansági településeken a szántók aránya 1935-ben éri el csúcspontját, innen enyhe csökkenés illetve inkább stagnálás figyelhető meg, ellentmondásos tény, de a szántók a 2000-es években újra növekedésnek indultak (legerőteljesebb növekedés Csorna közigazgatási területén jellemző). A gyepek csökkenése viszont rohamléptekkel folytatódott, gyakorlatilag máig meg sem állt a kivett területek és az erdők lassú, de folyamatos növekedése mellett. 


\section{Társadalmi, népesedési viszonyok}

Az 1910-es évek viszonylagos fellendülést hoztak, hiszen megindult az I. világháborúra való felkészülés, az érintett megyék nagyvárosaiban (magyaróvári lőporgyár, győri ágyúgyár stb.) megtelepedő nehézipari üzemek fokozták a városok népességelszívó hatását. Az I. világháború idején az alacsony munkabérek, a magas infláció és a hadikölcsönök miatt tovább növekedtek a lakosság terhei. Ideiglenes fellendülés jellemezte az 1920-as éveket az 1929-1932-es válság kirobbanásáig. A gazdasági válság megsokszorozta a falusi népesség elvándorlását. 1930-1941 között Győr-Sopron megyében átlagosan 1/5-ére csökkent a falvakban lakók növekedési üteme, míg a jelentősebb ipari központtal nem rendelkező csornai és a kapuvári járás népessége abszolút értékben is csökkent (Rétvári, 1977).

Magasabb népsűrüségü falvak a városok közelében (Győr, Kapuvár, Csorna), jó közlekedés-földrajzi helyzetben (utak, vasutak mentén) és a jó talajadottságú, kedvezőbb birtokviszonyokkal rendelkező térségekben alakultak ki. A szocializmus első évtizedeiben, különösen az 1950-es években GyőrMoson-Sopron megye népessége dinamikusan növekedett. A megyén belül azonban jelentősek voltak az eltérések: a városokban az extenzív iparfejlesztés következtében erőteljesen nőtt a népesség, még a viszonylag jelentéktelenebb iparral rendelkező Csornán is, míg a város- és közlekedésárnyékban lévő kistelepülések népességcsökkenést szenvedtek el. A Rábaköz déli részén elhelyezkedő aprófalvas térség 10-20\%-ot is meghaladó mértékü népességcsökkenést szenvedett (KSH, 2002; Rétvári, 1977). Kisebb mértékű népességcsökkenést illetve népességnövekedést csupán a Győr-Sopron, Csorna-Szombathely vasútvonal menti települések és a Győr vonzáskörzetébe tartozó települések mutattak. A Csorna körüli kistelepülésekre is fogyás volt jellemző, vagyis az akkor még nagyközség közlekedési csomóponti, kulturális, szociális, kereskedelmi és egészségügyi központ szerepe ellenére sem tudott jelentős népességmegtartó szerepet betölteni tágabb környezetében.

Még az 1960-as években is döntő jelentősége volt a mezőgazdaságnak a Rábaköz gazdaságában: a Csornai járásban a mezőgazdaság 86\%-os részesedéssel járult hozzá a térség jövedelméhez (Rétvári, 1977). A térség meszezéssel javítható vályogtalajai kiváló lehetőséget biztosítottak az intenzív gazdálkodásnak, a nagyüzemi gazdálkodás egyre alacsonyabb munkaerőigénye azonban nagymértékben hozzájárult a korábban magas népsürüségű falvak népességvesztéséhez. A szocializmus utolsó évtizedeiben majd a rendszerváltozástól napjainkig folytatódik a népességfogyás.

Az 1950-es évek szocialista iparfejlesztései elkerülték a határvidéket, az 1960-as évek fejlesztései a korábbi ipari bázisokat létesítették előnyben: dinamikus fejlődésnek indult Győr mellett Mosonmagyaróvár (Timaffy, 1988).

A gazdasági fejlettséget az ipar jelenléte/hiánya határozta meg az 1960-as évekre: míg a győri és a mosonmagyaróvári járást a korrigált nemzeti jövedelem alapján fejlettnek, a soproni és kapuvári járást közepesen fejlettnek a csornai járást az elmaradott kategóriába sorolták (Rétvári, 1977). 
A szocializmus első évtizedeiben dinamikusan fejlődött a megye ipara, amelynek térbeli eloszlását nagymértékü koncentráció jellemezte, az iparban foglalkoztatottak 90\%-a az akkori városokban dolgozott (Győr, Mosonmagyaróvár, Sopron). A falusi térségekre kisebb fémtömegcikket, textilt előállító üzemek, de alapvetően az élelmiszeripar megtelepedése volt jellemező. Csornán malom-, hús-, tejipar volt jelen évtizedek óta, a Soproni Ruhagyár, a MOFÉM, a Richards Finomposztógyár, a Győri Mezőgépgyár és Szolgáltató Vállalat részlegei működtek.

A 60-as évek végén formálódó új településhálózat fejlesztési politika egyik célja a városhálózat bővítése volt, Kapuvár (1969) és Csorna (1971) városi rangot és fejlesztési lehetőségeket kapott. Csorna távlati népességszámát 15-16 000 före becsülték, a rábaközi aprófalvak egy részének a felszámolódásával számoltak (Rétvári 1977; Timaffy 1988). Az 1980-as évekig Csornának kisebb vonzáskörzete alakul ki.

\subsubsection{V. periódus: védelem, helyreállítás}

Az 1990-es években országos szinten is megfigyelhető a természetvédelmi szemlélet erősödése ( 8 . táblázat). Az első természetvédelmi akciók a Hanságban még a két világháború közötti időszakra tehetők. A Hanság jelentős része mára természetvédelmi kezelés alatt áll, védelme érdekében már 1931-ben is tettek kísérletet: Király Iván csornai tanár az Esterházy herceg anyagi segítségével madárvártát, azaz madár-megfigyelőállomást alapított (Győr-Moson-Sopron Megye kézikönyve). Sajnos a következő évtizedekben még továbbra sem a természet- és a tájvédelem szempontjai voltak előtérben, folytatódtak a lecsapolások. Újabb lépésre csak 1976-bankerült sor, amikor a Hanságot tájvédelmi körzetté minősítették 6242,5 ha területtel (www.ferto-hansag.hu). Az alapítás után többször bővített védett területet 1994-ben csatolták a Fertő-Hanság Nemzeti Parkhoz. A védett terület több részből áll: Dél-Hanság (4.643 ha), Észak-Hanság (4.059 ha), Tóköz (1.780 ha - Barbacsi-tó, Fehér-tó). 
8. táblázat: Az V. periódus jellemzői (saját szerkesztés)

\begin{tabular}{|c|c|c|c|c|c|c|}
\hline Kor & Tájátalakítás & Tájhasznosítás & Konfliktusok & $\begin{array}{l}\text { Népesség- } \\
\text { eltartó képes- } \\
\text { ség }\end{array}$ & Értékrend & Versenyképesség $^{25}$ \\
\hline $\begin{array}{l}-1980- \\
90-e s \\
\text { évektől }\end{array}$ & $\begin{array}{l}\text { Védett területeken } \\
\text { visszaárasztás; } \\
\text { Folytatódik a szántó- } \\
\text { területek növekedése }\end{array}$ & $\begin{array}{l}\text { Intenzív, belterjes nö- } \\
\text { vénytermesztés, leépüllö } \\
\text { állattenyésztés } \\
\text { A Hanságban az éger } \\
\text { elegyarányának fokoza- } \\
\text { tos növelése; } \\
\text { Természetvédelmi terüle- } \\
\text { tek kijelölése (TK, NP, } \\
\text { Natura 2000) }\end{array}$ & $\begin{array}{l}\text { A lecsapolások negatív hatá- } \\
\text { sai kiütköznek: defláció } \\
\text { aszály és belvizek, természet } \\
\text { közeli társulások kiszáradá- } \\
\text { sa, invazív, tájidegen növé- } \\
\text { nyek terjedése } \\
\text { Természetvédelem és gazdál- } \\
\text { kodás konfliktusa }\end{array}$ & Fogyó népesség & $\begin{array}{l}\text { A versenyképességi és a környezeti } \\
\text { fenntarthatósági értékrend konfliktu- } \\
\text { sa jelentős. Erős korlátozó jelleg } \\
\text { érvényesül az országos természetvé- } \\
\text { delemben, amely rontja a kedvezöt- } \\
\text { len elérhetőségü tóközi falvak gazda- } \\
\text { sági, társadalmi életképességét. A } \\
\text { társadalom értékrendje és a pénzügyi } \\
\text { korlátok viszont nem biztosítanak } \\
\text { kompenzációt a turizmus, egyedi } \\
\text { biotermékek vagy agrár- } \\
\text { környezetvédelmi kifizetések révén. }\end{array}$ & $\begin{array}{l}\text { A térség határ menti, kedvezö } \\
\text { elhelyezkedése ellenére a } \\
\text { kistérség központ és a fö } \\
\text { közlekedési folyosók menti } \\
\text { települések kivételével kedve- } \\
\text { zötlen gazdasági és társa- } \\
\text { dalmi mutatókkal rendelkezik. } \\
\text { A tóközi települések gazdasá- } \\
\text { gi lehetöségeit korlátozzák a } \\
\text { szigorú környezetvédelmi } \\
\text { szabályok. }\end{array}$ \\
\hline
\end{tabular}

\footnotetext{
${ }^{25}$ Napjaink társadalmi gazdasági helyzetének részletes elemzése a későbbi fejezetekben.
} 
A mocsártól elhódított területekre telepített nemesnyár hibridek nem töltötték be azt az ökológiai funkciót mint a hajdani égererdők, ahonnan a fajoknak mindössze 10\%-a telepedett meg ezekben az „ökológiai sivatagokban”. A Hanságban az egykori 8 ezer hektár csíkos égerből mára 80 hektár maradt mutatóba. Az erdészeti törvénynek köszönhetően területük növekszik, mert a kitermelt nyár helyébe őshonos égert kell telepíteni.

A természetvédelmi szempontok a térség vízgazdálkodásában is egyre fontosabb szerepet játszanak. 1990-től bevezették a vízrendszer medreinek ökológiai szempontú üzemeltetését, amely folyamatos üzemrendet, az un. ökológiai minimum vízhozam biztosítását (az öntözési időszakon kívül sem állnak szárazon a medrek) jelenti. A mintegy 2000 km nagyságú vízrendszer legfontosabb levezető medrei a Rábca és a Hanság főcsatorna, amelyek elsődlegesen a Fertő többletvíz-levezetését, az Ikva-patak, a Kőris patak árvizeinek és a térség belvizeinek levezetését szolgálja.

A térség vízpótlása délről a Kis-Rába rendszeren keresztuil, északról a Lébény-Hanyi vízpótló rendszeren keresztül lehetséges. A rendszer kettős müködtetésủ belvizek levezetésére és öntözésre egyaránt alkalmas. Fenntartása részben állami, részben víztársulati, önkormányzati és magánkézben van. Sajnos a fenntartás színvonala nem egységes a rendszerben, amely részleges hatékonyságot eredményez (Kovács, 2012).

\section{Tájalakítás}

A Dél-Hanság medencéjének legdélebbi részén, Nyirkai-Hanyban figyelemreméltó tájrehabilitációs programot hajtottak végre. A Nyirkai Hany-Keleti Mórrétek elárasztására 2001. március 15-e és október 20-a között került sor három ütemben. A területre azért esett a nemzeti park munkatársainak választása, mert lecsapolására viszonylag későn került sor és hasznosítására is csak extenzív gazdálkodás volt jellemző, mivel mély fekvése miatt az év nagy részében belvizes volt. Területét három jelentős vízfolyás szeli át: a Hanság-főcsatorna, a Rábca és a Kis-metszés csatorna, amelyek a befogadói a területen összegyülekező belvizeknek és ezek kínáltak lehetőséget a rekonstrukció vízigényének biztosítására (www.ferto-hansag.hu). Az elárasztások előtt itt jelentősebb botanikai vagy zoológiai érték nem maradt másrészt talaja kotusodott tőzeg, amely alatt vízzáró agyagréteg helyezkedik el gátolva a vertikális irányú szivárgást, ez volt a kiválasztás egyik indoka, mert ilyen módon a vízszint gyors emelésével elérhetővé vált a nyílt vízfelület reprodukciója és ez nem veszélyeztette védett fajok állományait (www.ferto-hansag.hu). Nagy László, a Fertő-Hanság Nemzeti Park nyugalmazott tájegységvezetője tájékoztatása alapján az elárasztás óta évente monitorozzák a területet. Számtalan madárfaj tért vissza, a betelepített 20 növényfajnak azonban csak a fele maradt meg, mert nem elég tiszta a Rábca vize, valószínűleg ez az oka annak is, hogy nem indult meg újra a tőzegképződés sem (www.index.hu, Rólunk a Hanság énekel). 
A hansági vizes élőhelyek rekonstrukciós programja keretében a Fertő-Hanság Nemzeti Park Igazgatóság további elárasztások megvalósítását tervezi az Osli-Hany 1322 ha-os területére. Az újraárasztás tervei elkészültek, a beruházás vízjogi engedélyt kapott, megvalósítása 2013 során várható (www.ferto-hansag.hu).

\section{Tájhasználat}

A lecsapolások révén eltüntek a hagyományos mesterségek és a mezőgazdasági hasznosítás vált kizárólagossá. Nagy jelentőségüvé vált a malomipar és a cukoripar a térségben, a sors fintora, hogy a cukorgyártás az Európai Uniós csatlakozást követően az utolsó cukorgyár bezárásával szinte megszünt Magyarországon. A téeszek, állami gazdaságok megszűnése nem hozta magával a müvelt területek felhagyását, a térség továbbra is intenzív agrártáj maradt. A mezőgazdaság nemzetgazdasági súlyának csökkenése ellenére a Hanságban és a Rábaközben is az egyik legfontosabb gazdasági ág maradt, még jelenleg is a foglalkoztatottak 13\%-át - bár folyamatosan csökkenő mértékben továbbra is a mezőgazdaság adja.

A térségben visszaszorult a zöldség és gyümölcstermesztés, bár az 1990-es években nagy mennyiségben termesztettek uborkát, amelyet a „Rábaköz aranyának” is hívtak, de a felvásárlás keletre húzódott, töredékére estek vissza a felvásárlási árak. Visszaszorult az állattenyésztés, ipari növények termesztése jellemző.

\subsection{A tájhasználat változásának értékelése}

Történeti térképek, statisztikai adatok, leírások segítségével értékeltem a területhasználati változások alapján az egyes tájhasználati funkciók változását és a térség gazdasági, társadalmi helyzetének változását az évszázadok során. A gazdasági, versenyképességi helyzetet a demográfiai folyamatok, elérhető statisztikai adatok (pl. földadó kataszter), történeti leírások (Fényes Elek), és korábbi térszerkezeti elemzések (Beluszky Pál, Győri Róbert) alapján becsültem.

Az ember évszázadok óta harcol a természettel, hogy kiszolgáltatottságát enyhítse, müvelésre alkalmas földeket nyerjen. A tájalakító tevékenység kezdetben csak lokális mértékű volt, majd a technika fejlődésével ez a hatás érintette a Hanság egész területét, gyökeres területhasználati és tájképi változásokat okozva. Zólyomi Bálint 1934-ben közölt vizsgálatai már arról számolnak be, hogy az úszó hínárnövényzet kisebb, mélyebb területekre szorult vissza, a magasabban fekvő lápi növénytársulások a vízszint csökkenésével a korábban mély vizű részekre húzódtak be (Zólyomi, 1931). A nagy nádasok a lecsapolásoknak köszönhetően fokozatosan eltüntek, a tőzeget gyors ütemben bányászták ki és kiszárított területeken megindult a mezőgazdasági művelés. Később, különösen a második világháborút követően nagy erdőtelepítések kezdődtek, kezdetben égerrel, majd elsősorban nemes nyár 
hibridekkel, nemesített füzekkel. A szántók aránya jelentősen nőtt, drasztikusan csökkent a rétek, legelők aránya, eltünt illetve nyomokban maradt meg a hajdani mocsárvilág.

A tájalakítással párhuzamosan változott a tájhasznosítás módja: a kezdeti vadászó, halászó, gyüjtögető életmódot felváltotta a növénytermesztésen és állattenyésztésen alapuló gazdálkodás bár évszázadokon keresztül a gazdálkodást a változó vízviszonyok erősen befolyásolták. Az emberek széleskörűen hasznosították a természet kincseit: nádat arattak, szénát gyüjtöttek, halásztak, méhészkedtek, gyüjtötték a gyékényt stb. A XX. század második felére a tájátalakítás szinte teljessé vált, visszaszorultak a „mellékhaszonvételek”, eltüntek a hagyományosan halászathoz és a meghonosodott rétgazdálkodáshoz kapcsolódó mesterségek. Mindezek a változások jelentősen érintették a térség társadalmi gazdasági viszonyait.

A társadalom gazdasági bázisát évszázadokon át a mezőgazdaság adta, így a népesség eltartó/megtartó képesség alapvetően a térség agrártermelésén múlott. A fejlődést sokáig alapvetően a termőterület növelése alapozta meg. A technológiai fejlődés a XIX. századra alapozta meg a nagyléptékü tájalakítást, illetve ekkorra a legmodernebb agrotechnikák alkalmazásával (amelyben a térség az országos tendenciák előtt járt) a termésmennyiség növelése nemcsak termőterület nyeréssel volt lehetséges. A mintatérség kedvező versenyképességi helyzetét a XIX. századra mindezek, de alapvetően Bécs közelsége alapozta meg, amely a térség termékeinek felvevőpiacát jelentette. A következő évszázadban azonban a nagytérségi kapcsolatrendszer megváltozott és a térség ezt a kedvező versenyképességi helyzetét máig nem tudta visszanyerni. Vizsgálataim célja elsősorban annak a feltárása volt, hogy ez a nagymértékü tájalakítás milyen tájökológiai, társadalmi és gazdasági hatásokkal járt és hozzá tudott-e járulni a térség népességmegtartó képességének és versenyképességének erősítéséhez.

\subsubsection{Területhasználati változások}

A területhasználati változásokról a tájhasználatról szóló fejezetrészekben esett szó, itt összességében tekintem át a területhasználati tendenciákat. A müvelésmódok változásának részletesebb vizsgálatához a KSH 1895-től rendelkezésre álló településsoros adatait valamint az 1865-ős összeírás adatait (nem teljes mértékben használhatók az adatok a községek területének módosulása miatt, de a legtöbb településen minimálisak voltak a változások, így a területhasználati arányok összehasonlíthatók) hívtam segítségül. A jobb áttekinthetőség kedvéért a \%-os értékekkel dolgoztam ${ }^{26}$. Az eltérő adottságok miatt a hanságmenti, tóközi településeket és a Dél-Kelet Rábaköz településeit külön vizsgáltam. A statisztikai adatok közigazgatási területre érhetők el, ezért Csorna adatsorát önmagában vizsgáltam, hiszen területe egyrészt a Hanság másrészt a Rábaköz része.

\footnotetext{
${ }^{26}$ Történeti adatsor csak közigazgatási területre érhető el, ami némileg befolyásolja az adatokat, de a változások, a tendenciák jól nyomon követhetők.
} 


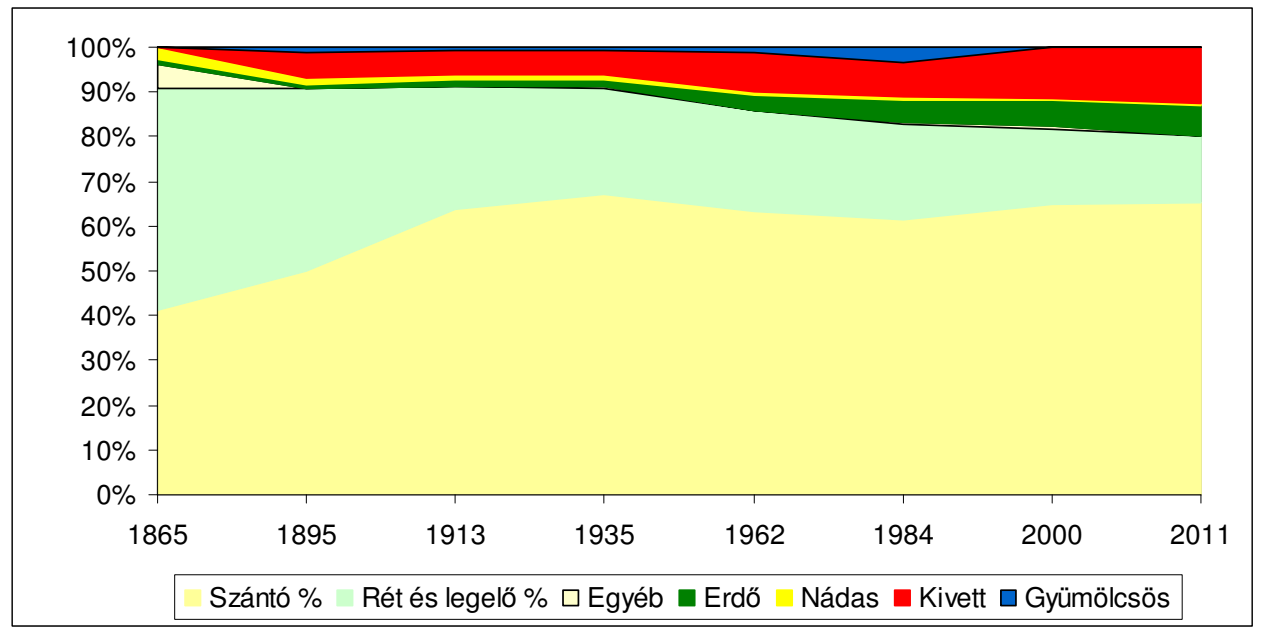

12. ábra: Területhasználat változások a Hanság, Tóköz településein a Csornai kistérségben (saját szerkesztés, adatok forrása: $\mathrm{KSH}$ )

A Tóköz, Hanság településein a szántók változását szemléltető diagram (12. ábra) alapján levonható a következtetés, hogy a legjelentősebb területhasználati változásoknak a XIX. század adott keretet és gyakorlatilag a XX. század elejéig a tájhasználat átalakulása nagyvonalakban lezajlott. Legszembetűnőbb változások a szántók arányának erőteljes növekedése és a rét-legelők arányának drasztikus csökkenése (13. ábra és Melléklet IX.). A XX. század folyamán a rét, legelő arány kisebb mértékben, de napjainkig nem szünően csökken. A szántók aránya az 1930-as években volt a legnagyobb, a II. világháborút követően kismértékben csökkent és a rendszerváltás után tovább nőtt. A szocializmus korában nőtt az erdők (ez klónozott nemes nyarasok telepítését jelentette elsősorban, hozzájárulva az ökológiai értékek pusztulásához). Száz év alatt a müvelés alól kivett terület aránya is megduplázódott és a gyümölcsösök aránya is nőtt. A rendszerváltás óta a gyümölcsösök aránya töredékére esett vissza.
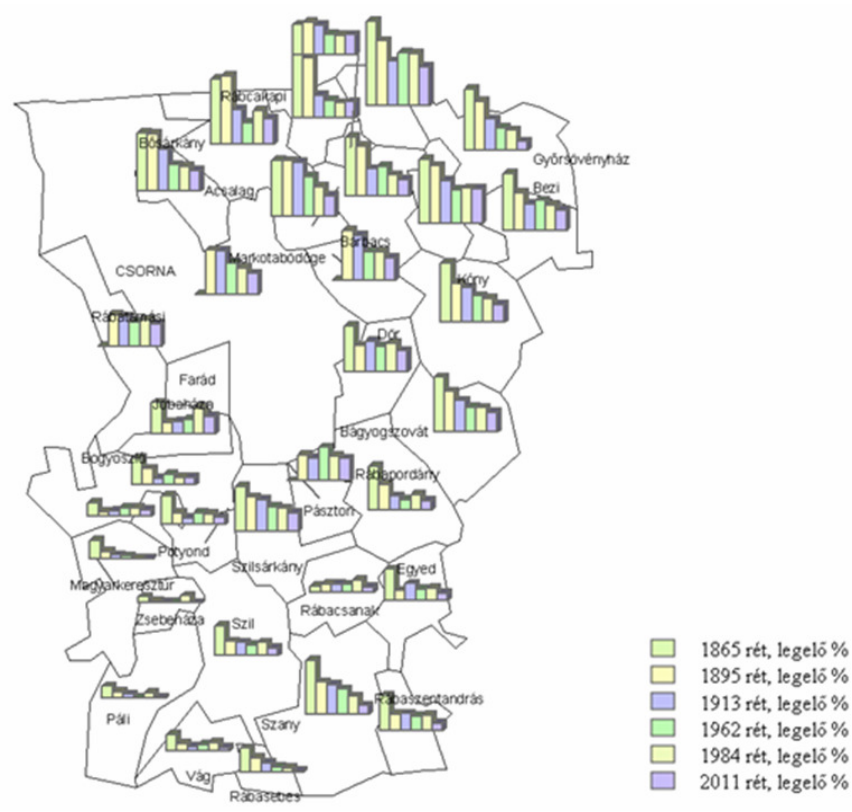

13. ábra: A rét, legelő arányának változása napjainkig (saját szerkesztés, adatok forrása: $\mathrm{KSH}$ ) 
A XIX. század közepén a rétek-legelők együttesen a települések területének 50\%-át tették ki, 1913ra ez az érték a felére csökkent, napjainkra 15\%-ra zsugorodott. A szántók aránya: 41\%-ról 65\%-ra nőtt. Az utóbbi években a szántók arányának stagnálása illetve néhány településen növekedése figyelhető meg.

A Rábaköz falvaiban a legjellemzőbb területhasználatok arányainak hasonló jellegü változását tapasztaljuk (14. ábra): a korábban évszázadokon át elterjedt hagyományos tájhasználat alapját képező rétek és legelők aránya drasztikusan csökkent a XIX. század folyamán.
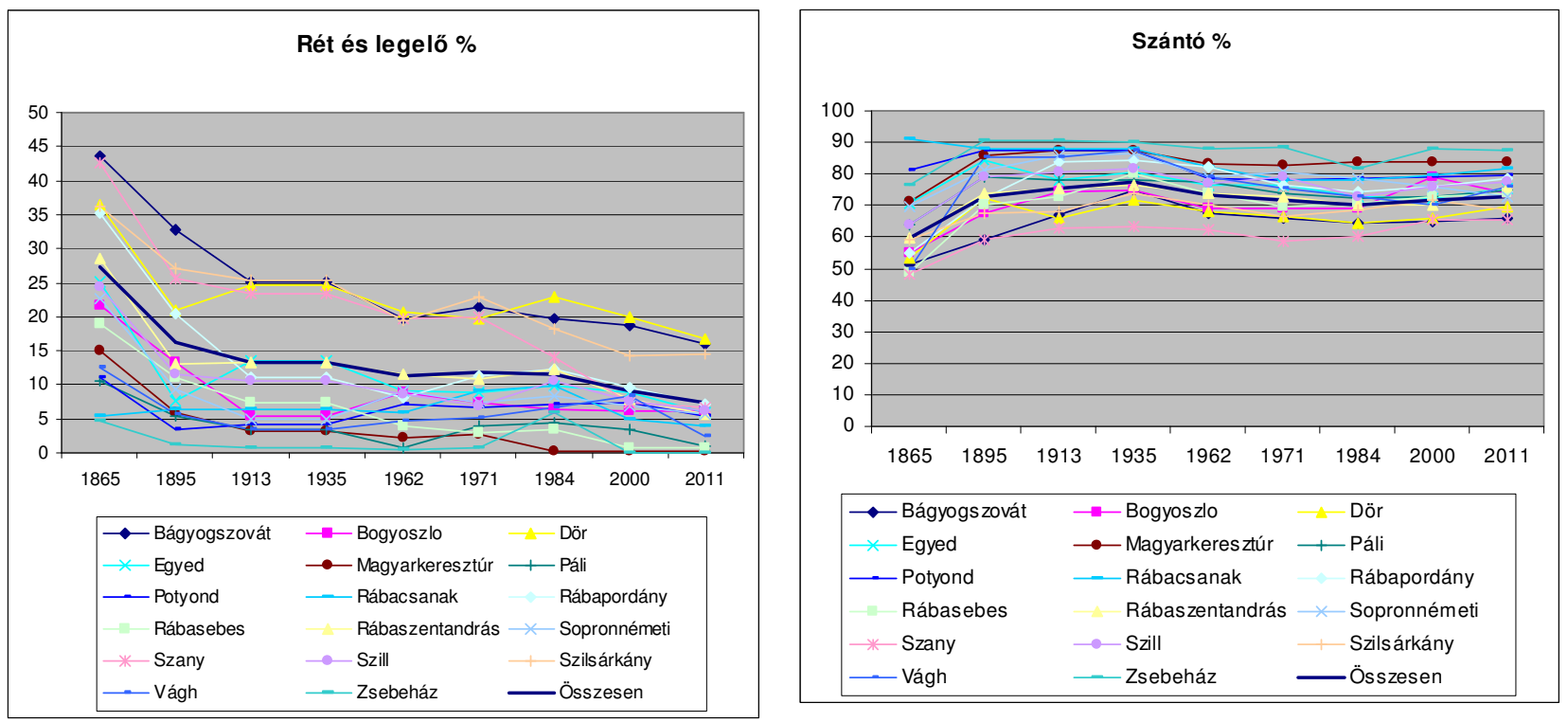

\section{4. ábra: A D-K Rábaköz falvaiban a rét, legelö valamint a szántók arányának változása}

(saját szerkesztés, adatok forrása: $\mathrm{KSH}$ )

A szántók aránya a csúcson a II. világháború előtt volt, a szocializmus nagyüzemi mezőgazdasága több helyen felhagyott a szántóföldi műveléssel és erdőket telepítettek. Nőtt a gyümölcsösök aránya is. A rendszerváltós óta azonban újra a szántók kismértékủ növekedését figyelhetjük meg. A szántóföldek aránya nagyon magas, meghaladja az országos átlagot: 73\%. Az évszázados hagyományok ellenére a rét és legelő arány mindössze 7\%. A rétek és legelők csökkenése azonban töretlenül folytatódott, és folytatódik napjainkban is.

Csorna közigazgatási területéhez tartozik a Király-tó is, tehát jócskán a Hanság része, viszont területének déli része tipikus rábaközi táj. Csornán a XIX. század közepén a szántóföldek 30\%-ot foglaltak el, mára ez az érték 58\%. Extrém csökkenést tapasztalunk a rétek legelők esetében: 61\%-ról 16\%-ra csökken a gyepterületek aránya. Karakteres változásként több mint négyszeresére nőtt az erdők aránya. Csornán erősebb tendenciaként figyelhető meg, hogy a szocializmus enyhe csökkenését követöen a rendszerváltás után tovább nőtt a szántók aránya.

\subsubsection{Tájökológiai változások}

A vízrendezések, a növekvő arányú szántóföldi termesztés egyértelműen a táj környezeti és ökológiai értékének csökkenését hozták. A tájalakítás, a tájhasználat jellegének, intenzitásának ismeretében 
(ahogy az extenzív területhasználatokat egyre inkább az intenzív veszi át) a környezeti integritás és az ökológiai-élőhelyi értékek mint tájfunkciók szintjének változása becsülhető.

A lecsapolás előtti Hanságban botanikai és zoológiai vizsgálatok nem folytak. A ránk maradt leírások szerint hatalmas nádasok, kiterjedt hínarasok voltak itt, úszó lápszigetekkel. A mélyebb részeken 3-4 m mélységü nyílt vízü tavak voltak, fás vegetáció csak kisebb égeres foltok formájában a láp peremén volt. Kornhuber András bécsi botanikus tanúsága szerint még a XIX. század végén is vadvízország volt ez a táj. Így ír erről: „A felmérhetetlen láperdőkön, az ingoványon csak csónakkal lehet nagy nehezen átvergődni, de a keskeny csatornák az evezők használatát nem teszik lehetővé, legbiztonságosabb csáklyázni a tőzeges iszapban. A vízben álló égerek sűrüjében úszóláp, másutt nyílt víztükör csillog, embertől nem háborgatott víziszárnyasok birodalma. Az áthatolhatatlan mocsárvilág süllyedő zsombékjai közt csak az égertuskókban lehet kapaszkodni. A gyökerek harasztok és kúszó növények lepik el, a növények sűrüségénél csak a szúnyogfelhők sűrübbek” (Idézte: Rakonczay, 1996). Zólyomi Bálint 1934-ben közölt vizsgálatai már arról számolnak be, hogy az úszó hínárnövényzet kisebb, mélyebb területekre szorult vissza, a magasabban fekvő lápi növénytársulások a vízszint csökkenésével a korábban mély vizủ részekre húzódtak be (Zólyomi, 1931). A nagy nádasok fokozatosan eltüntek, a tőzeget gyors ütemben bányászták ki és kiszárított területeken megindult a mezőgazdasági művelés. Később, különösen a második világháborút követően nagy erdőtelepítések kezdődtek, kezdetben égerrel, majd elsősorban nemes nyár hibridekkel, nemesített füzekkel.

A lecsapolások miatt a Király-tó is kiszáradt, de az intenzív tőzegbányászat következtében ujjászületett. Kogutovicz Károly leírása szerint a lecsapolások következménye, hogy a tőzeg alól eltünt a víz, az úszólápok megfeneklettek, a hatalmas égererdőségekben a talaj 1-2 métert süllyedt és napvilágra kerültek az égerfák (5. kép) sátorszerü támasztópillérei (Kogutovicz, 1936). A Hanság vizeinek teljes elvezetése következtében a XX. század második felében további talajszint süllyedés következett be valamint többször is nagyarányú tőzegtüzek keletkeztek, a legjelentősebbek 194547-ben (5800 hektáron a talajszint 40-60 cm-t süllyedt) és 1976-ban volt, amikor 76 ha rét semmisült meg (Rakonczay, 1996).

A mocsártól elhódított területekre telepített nemesnyár hibridek nem töltötték be azt az ökölógiai funkciót mint a hajdani égererdők, ahonnan a fajoknak mindössze 10\%-a telepedett meg ezekben az „ökológiai sivatagokban”. A Hanságban az egykori 8 ezer hektár csíkos égerből mára 80 hektár maradt mutatóba. Az erdészeti törvénynek köszönhetően területük növekszik, mert a kitermelt nyár helyébe őshonos égert kell telepíteni.

A flóra elszegényedését mutatja, hogy végérvényesen eltünt a területről a tőzegeper (Comarum palustre), a halványlila virágú mocsári hízóka (Pinguivula vulgaris) és a vidrafü (Menyanthes trifoliata) (Rakonczay, 1996) és több más ritka növény. A kiszáradás következményeivel a 
nemzetipark munkatársainak máig küzdeniük kell: az Észak-Hanság korábban több tízezer hektáros láprétjeiből megmaradt néhány száz hektárnyi területet a lecsapolások során kialakított rendszer ma is szárítja, a kiszáradás következtében az özönnövények terjedését kell megakadályozni: a legnagyobb problémát a selyemkóró és a magas aranyvessző okozza. A nemzeti park tervezi a lecsapoló rendszer átalakítását, egyes csatornák eltömését, más csatornák pedig a vízutánpótlást fogják segíteni. A kiszáradás sajnos a legtöbb értékes élőhelyet veszélyezteti: az Észak-Hanság, láprétjeit, láperdeit, a Dél-Hansági láperdőket, a Fehértó, Barbacsi-tó nagymértékben elnádasodott... (FHNP fejlesztési terv).

A mezőgazdasági területek nyerése mellett a lecsapolásoknak számos negatív hatása is volt: a térséget az aszály és a belvíz egyaránt sújtja, aminek az oka, hogy a hosszadalmas előzmények után megvalósult beavatkozások a betorkolló vízfolyásoknak a medence permén létesítendő, a vizeket közvetlenül a Duna felé elvezető övcsatorna létesítését elvetették, helyette a medence legalacsonyabban fekvő részén épült ki a vízelvezető rendszer. Mindez oda vezetett, hogy a mélyebben fekvő területek hasznosítása érdekében olyan alacsony szinten szabályoz, hogy a magasabban fekvő területeket nyár derekán gyakran aszály sújtja. A Dél-Hanság öntözése már a XIX. században megkezdődött. Először a Répce folyóból, majd a Nicki-duzzasztó megépítésével a Kis-Rábán keresztül táplálták be a vizet (Rakonczay, 1996).

Tulajdonképpen mielőtt a lecsapolások befejeződtek volna, a hansági emberek észrevették, hogy a „művelet” túlzottra sikerült: az addig jól termő földek és kaszálók a talaj kiszáradása miatt kisültek, a vízben szegény láptalaj a szél martalékává vált. Felvetődött az árasztás igénye. A gazdasági igények kielégítése érdekében duzzasztók épültek, hogy vízutánpótlást biztosítsanak a nemes nyár ültetvényeknek. A Hanság sajátos domborzati viszonyai miatt a lecsapolások következtében évente az az ellentmondásos helyzet okoz szinte orvosolhatatlan problémákat, hogy a mélyebb részek tavaszi víztelenítése következtében a magasabban fekvő területeken aszályos helyzet alakul ki a nyár derekára.

\subsubsection{Tájképi változások}

A tájkép jelentősen szegényedett az elmúlt évszázad lecsapolásainak köszönhetően, nőtt a szántóföldek aránya, és jelentősen csökkent a rétek, legelök aránya. A fás legelők, ligeterdők, rétek, mocsarak határozták meg a Hanság tájképét, mára azonban leginkább a szántók a meghatározóak és örül a szem, ha réteket, legelőket láthat. A harmadik felújított katonai térképen szembeötlő, hogy különösen a tóközi, Hanság peremi területeken milyen nagy a fás legelők aránya. A Hanság vidékének jellegzetes tájképi elemei a láprétek és a magas sásos társulások, amelyek szintén nagymértékben viszszahúzódtak az elmúlt évszázadban. Kiterjedtebb nádasok sajnos ma már csak a Fehér-tónál, Barbacsi-tónál és a Kónyi-tónál találhatók, de a vizesebb rétek mélyebb részein is több hektáros fol- 
tok fordulnak elő. Sőt előbukkannak a szántókon is, emlékeztetve a letünt világra. Eltűnt, illetve radikálisan csökkent a vízfelületek aránya. A történeti térképek tanúsága szerint a Rábaköz már évszázadokkal ezelőtt szántók és rétek, legelők uralta agrártérséggé alakult, a tájhasználat változást a

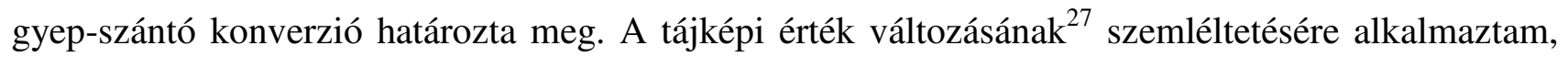
átalakítottam a Koschke, Fürst, Frank, Makeschin kutatók értékelési mátrixot (alapja az egyes területhasználatok 1-100 pontszámmal történő értékelése: az extenzívebb hasznosítás magasabb pontértéket kap, részletesen a pontszámok a X. Mellékletben). Példaként az alábbi ábrákon (15-16) csak a XVIII. század végi és az 1950-es állapot.).

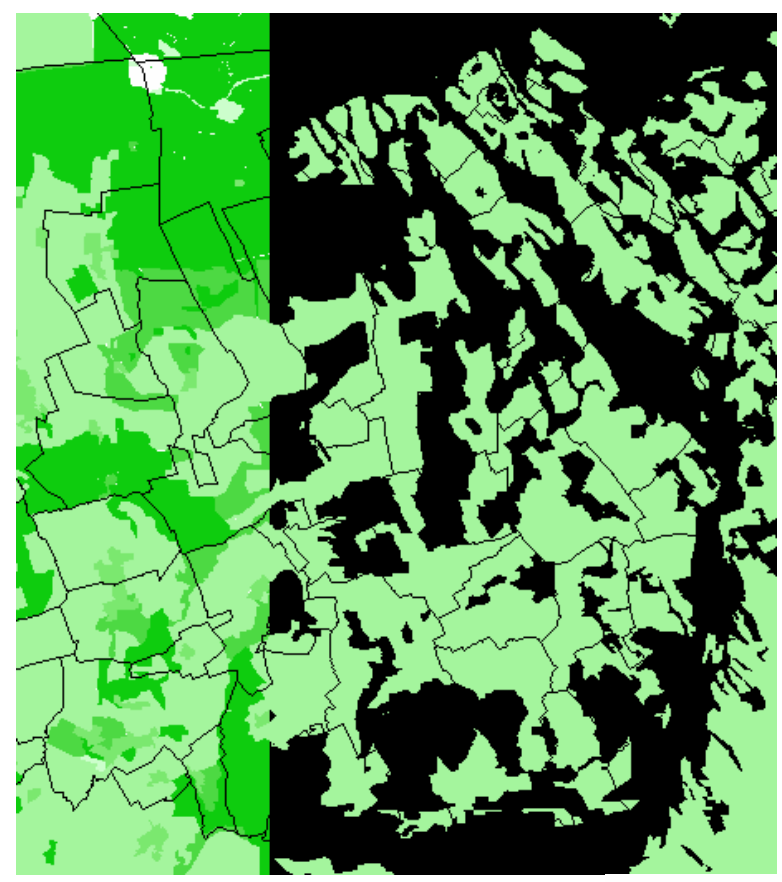

0

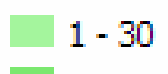

$31-37$

15. ábra: Tájesztétikai érték az első katonai térkép alapján (Koschke, Fürst, Frank, Makeschin értékelési mátrix átdolgozásával, saját szerkesztés)

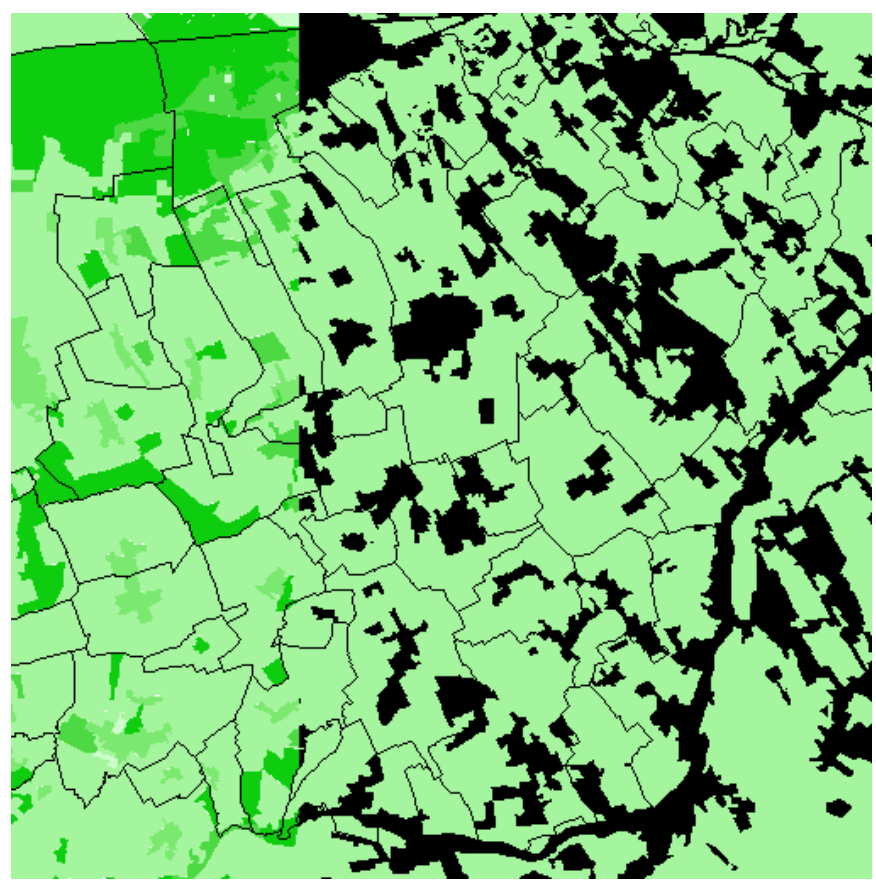

$38-68$

$69-95$

\section{6. ábra: Tájesztétikai érték az 1950-es topográfiai térkép alapján \\ (Koscke et.al. nyomán saját szerkesztés)}

\subsubsection{Társadalmi változások}

A demográfiai mutatók a térségre vonatkozóan általában a megyei és országos átlagnál kedvezőtlenebb helyzetet mutattak az évszázadok során. Összehasonlító vizsgálatokat végeztem a kistérség helyzetét nagyobb térség (megye, ország) helyzetéhez, illetve a térségen belül, a települések helyzetét egymáshoz viszonyítva.

\footnotetext{
${ }^{27}$ A tájfunkció elemzés térképes alapú módszerére példaként alkalmaztam történeti térképek alapján a tájesztétikai érték változásának bemutatását. A módszer részletes leírása a 2.3. fejezetben található, a Lars Koschke, Christine Fürst, Susanne Frank, Franz Makeschin által kidolgozott értékelő mátrixot adaptáltam (Melléklet XVI.) ahol minden területhasználathoz egy 1-100 közötti értéket rendeltek az ökoszisztéma szolgáltatások biztosításában játszott szerepük alapján, az eredeti mátrixot adaptáltam a hazai területhasználati rendszerhez és termesztési adottságokhoz (Koschke et. al. 2012).
} 
Összehasonlítottam a népességváltozás tendenciáit az országos, megyei átlaggal, és arra a következtetésre jutottam, hogy a lakosságszám változás iránya, mértéke mindig kedvezőtlenebb volt a megyei illetve az országos átlagnál (17. ábra).

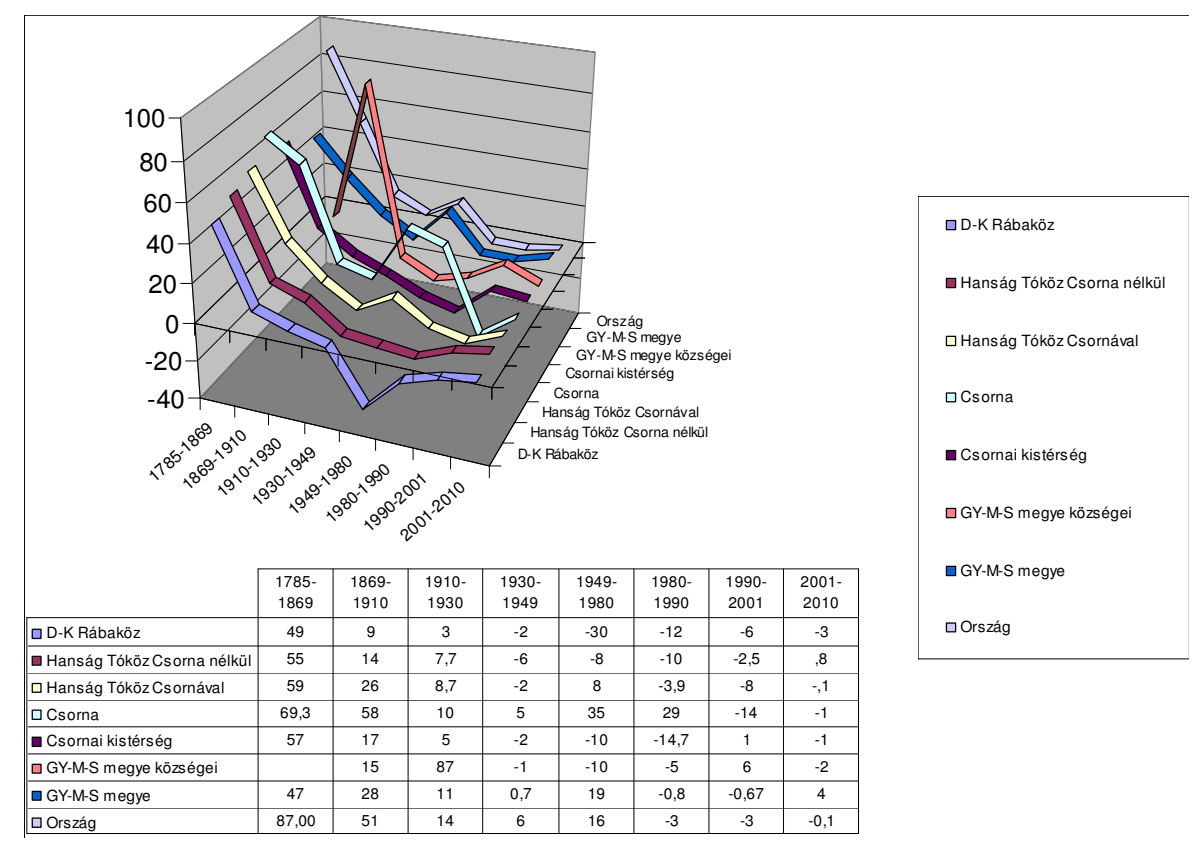

17. ábra: Népességnövekedés dinamikája, Népességváltozás százalékos értékekkel kifejezve (adatok forrása: Rétvári, 1977, KSH, 2002, TEIR)

Az első, viszonylag pontos felmérésnek II. József rendeletére végrehajtott népszámlálás tekinthető, amely alapján képet kaphatunk a térség népesedési viszonyairól, a táj népességeltartó képességére is következtethetünk, hiszen ekkor a népesedés alapja a termőföld volt. Bár a megyén és a vizsgált térségen belül is jelentős különbségek voltak, országos összehasonlításban Győr és Sopron megyék az ország legsürübben lakott térségének számítottak. Míg az ország átlagos népsürüsége 28 fö/km2 volt, az érintett megyékben 42,8fö/km² volt a népsürüség (Rétvári, 1977).

Az 1700-as évektől egyre nagyobb arányban indul meg a szántóföldek kiterjesztése, amely azonban nem járult hozzá a parasztság gazdasági felemelkedéséhez. Werbőczi alaptörvényei csak a földesúri osztály számára tették lehetővé a föld birtoklását, ezért az irtásföldek mind földesúri tulajdonba kerültek, megindult az irtás- és egyéb jobbágyföldek majorságokba történő bekebelezése (allodizációs folyamat).

Az úrbérrendezés nagy jelentőségü volt, hiszen az úrbéres földek felett a földesurak nem rendelkezhettek korlátlanul, belőlük nem csatolhattak sajátkezelésű majorságaikhoz. (Felhő, 1970). A kistérség településein az 1770-es évek úrbérrendezésekor rögzített úrbéres területek arányát és a jelentősebb birtokosokat térképen ábrázoltam (18. ábra). Jól látható, hogy magas az úrbéres földek aránya a 
déli rábaközi falvak és egyes tóközi falvak esetében, a térség észak-nyugati részében viszont alacsony.

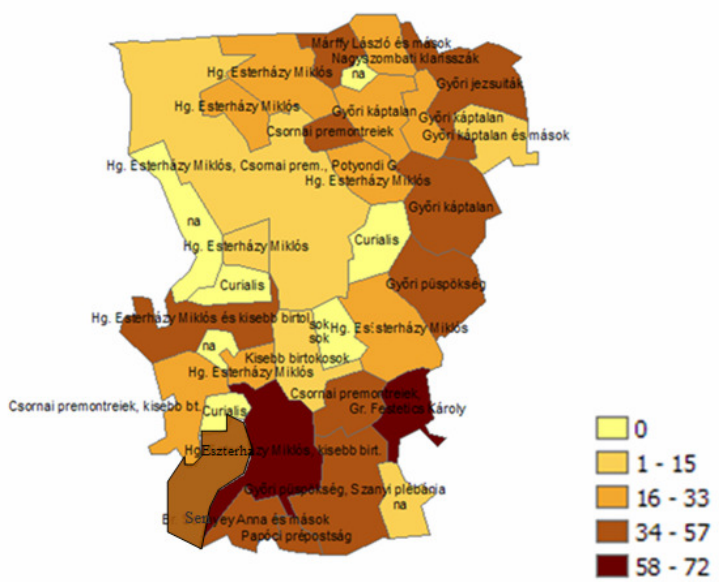

\section{8. ábra: Úrbéres földek aránya (\%) az 1865-ben megmüvelt földekhez (szántó, rét, legelö) képest, és a föbb birtokosok 1770-ben (saját szerkesztés, adatok forrása: Felhő, 1970)}

A népsürüség különbségeit a XVIII. század végén még elsősorban a táji adottságok és kisebb mértékben a földbirtokviszonyok (majorok nagyobb számban később kerülnek kialakításra) határozták meg. Alacsonyabb népsürüséget láthatunk a hanságmenti, tóközi településeken, (a nagy volumenü tájalakítás csak később indult meg) magasabbat a Rábaköz déli, nyugati részén elhelyezkedő jó talajminőségű, kishatárú, szabadparaszti falvakban. A kedvező talajadottságok a Győr és Sopron vármegyéket illetően a dél-rábaközi falvakban tették lehetővé magas (Győr és Sopron városokat és környezetüket követő legmagasabb) népsürüség kialakulását (Rétvári 1977).

A XIX. század közepéig a lakosságszám növekedése az 1774-76-os értékekhez képest országos viszonylatban 87\%-os volt, a vizsgált térség növekedése jóval alatta marad ennek az értéknek (57\%), ami azonban magasabb a megye növekedési üteménél (47\%). Nagyobb arányú volt a népességnövekedés a hanságmenti, tóközi falvakban és alacsonyabb a dél-kelet rábaközi településeken, hiszen ekkorra a mezőgazdaságnak kedvező adottságok miatt itt már korábban is magas népsürüség alakult ki.

Az 1869-es népesedési adatok alapján látható, hogy nőtt ugyan a népsürüség, de a Csorna és a környezetében elhelyezkedő települések közepes népsürüségünek számítanak, annak ellenére, hogy Csorna mezővárosi ranggal több évszázados piaci hagyományokkal rendelkezik (bár Ollram leírása alapján kisebb vonzáskörzetre következtethetünk). Magasabb népsűrüséggel csupán Szil (szintén mezőváros) és a körülötte elhelyezkedő, jó talajadottságú, nagybirtok által kevésbé befolyásolt falvak rendelkeznek. A Tóköz északi részének települései szintén alacsonyabb népsürüséggel rendelkeztek, ami egyrészt a táji adottságoknak (lápos, nem mủvelhető területek) és a birtokviszonyoknak köszönhetö, ezek a területek voltak többségében a nagybirtokosok kezében (19. ábra). A XIX. szá- 
zad során a majorok száma ugrásszerüen megnőtt: míg a II. katonai térképen összesen négy, a III. katonain (1869-1884) 32 db majort számoltam meg viszonylag egyenletes eloszlással a térségben. Csorna (lakossága az 1869-es 4853-ról 7679-re nőtt az 1910-es évekre (KSH, 2002)) és néhány közlekedés-földrajzi szempontból kedvező elhelyezkedésű település kivételével az 1910-es évekig hasonlóan kismértékü népességnövekedést regisztrálhatunk a kistelepülések többségében Az 1910-es évekig az országos és a megyei átlagot el nem érő növekedést tapasztalhatunk a kistérség falvaiban, a nagybirtokrendszer hatásainak a tóközi térségben illetve az agrár túlnépesedés hatásainak köszönhetően. A vasúthálózat kiépítése módosította a településhálózatot: a vasút mentén elhelyezkedő települések kedvezőbb helyzetbe kerültek: a malomipar megtelepedését és ezzel a foglalkoztatási lehetőségeket is jelentősen befolyásolta a vasútállomás léte.
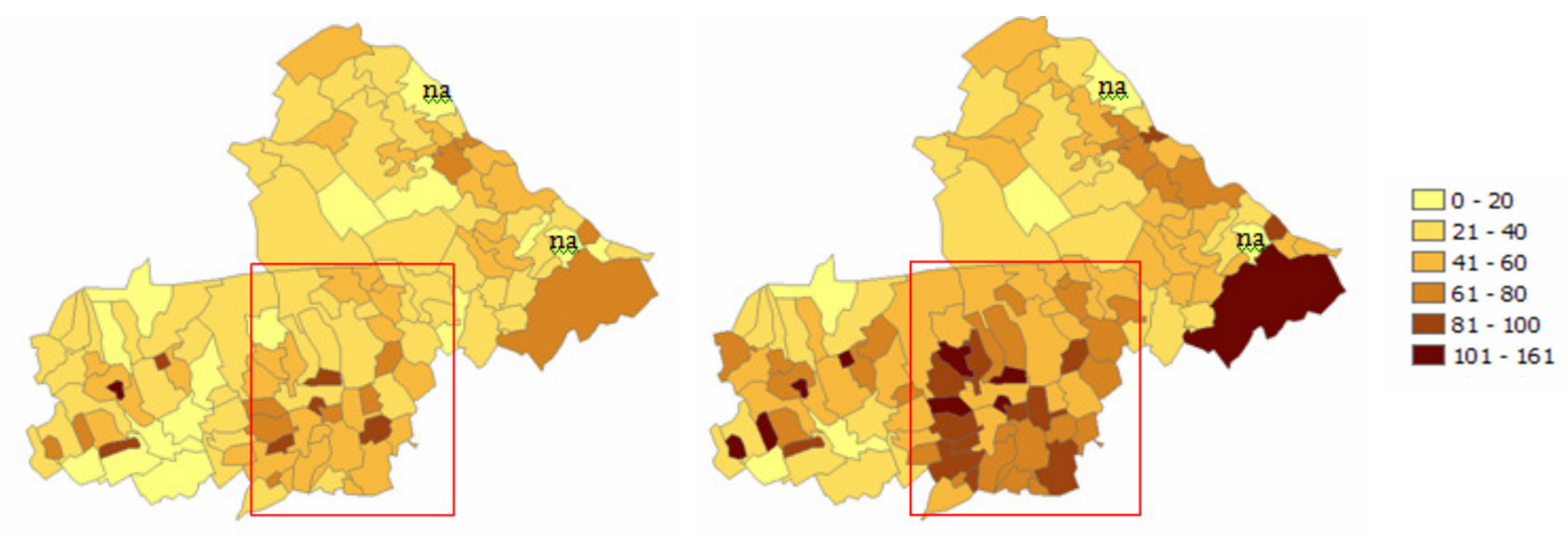

19. ábra: Népsürüség az 1785-ős és az 1860-as években (KSH, 2002; Rétvári, 1977)

(saját szerkesztés)

Összességében megállapítható, hogy a XIX. század folyamán rendkívül dinamikus, de az országos átlag alatt maradó népességnövekedést (D-K Rábaköz népességnövekedése XX. század 2. felében 9\%, Tóközben $14 \%$, országos $51 \%$ és a megyei $28 \%$ ) figyelhetünk meg a kistérségben, a növekedés üteme drasztikusan csökken a század második felére, annak ellenére, hogy ekkorra valósulnak meg a legnagyobb volumenü vízrendezési munkák. A tóközi, hansági települések népességszámának növekedése kismértékben meghaladja a rábaközi falvak népességnövekedését. Az eltérés annak fényében, hogy milyen óriási a szántóföldek növekedésének mértéke az első településcsoportban, jelentéktelennek tünik. Az ellentmondásra a birtokszerkezet jellegzetességei adnak magyarázatot: az irtásföldek jelentős része a nagybirtokosok vagyonát gazdagította, akik majorságok keretein belül szervezték a gazdálkodást, általában a kor átlagos technológiai szintjénél fejlettebb színvonalon, azaz kisebb munkaerőigénnyel, mint a kisparaszti gazdaságok. Következtetésként levonhatjuk, hogy a nagyarányú tájátalakítás nem hozta magával a táj népességmegtartó képességének hasonló szintü növekedését. A mezőgazdaságnak kedvező adottságok a nagybirtokok által kevésbé befolyásolt D-Ny rábaközi falvakban tette lehetővé magas népsürüség kialakulását a XVIII. századra. 


\section{A birtokszerkezet sajátságai miatt jórészt fennmaradnak a XX. század elejéig a térségben ki-}

alakult népsürüségi különbségek, a Rábaköz D-Nyi részén a kishatárú falvak néhány hold földdel rendelkező népessége intenzív állat-tenyésztést, és növénytermesztést folytatott. Dinamikus, bár a rábaközi falvakban kisebb mértékű növekedés figyelhető meg egyöntetüen a XX. század elejéig, a népességváltozás tendenciái azonban differenciáltabbá válnak. A XX. században egyre erōteljesebben érződnek az ipari fejlődés, a közlekedés-földrajzi hatások. Az ipari fejlődés hiánya, alacsonyabb foka miatt a rábaközi térségben nem indul meg oly mértékü népességkoncentráció, mint Győrben, Mosonmagyaróváron és Sopronban, a kistérségen belüli népsűrűségi különbségek kiegyenlítődnek, a vasútvonalak mentén elhelyezkedő települések népessége dinamikusabban nő.

A szocializmus jelentős változásokat hoz a népesedésben, legfontosabb hatótényezőkké az erőltetett téeszesítés, iparosítás, és a központi funkciókon alapuló településhálózati politika válik. GyőrMoson-Sopron megye községeinek az átlagát magasan meghaladó népességcsökkenés figyelhető meg a rábaközi aprófalvakban (a korábbi örökségként megmaradt magasabb népsürüség miatt népességük 30\%-át vesztik el 1949 és 1980 között), a tóközi települések népességvesztése kisebb mértékü (-8\% Csorna nélkül), de még így is a megye községi átlaga (-2\%) alatti (20. ábra).

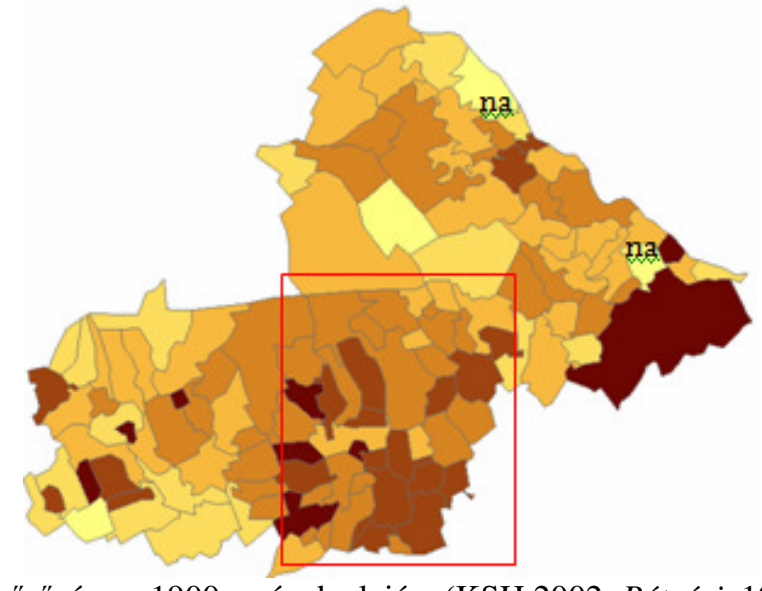

Népsürüség az 1900-as évek elején, (KSH 2002; Rétvári, 1977)

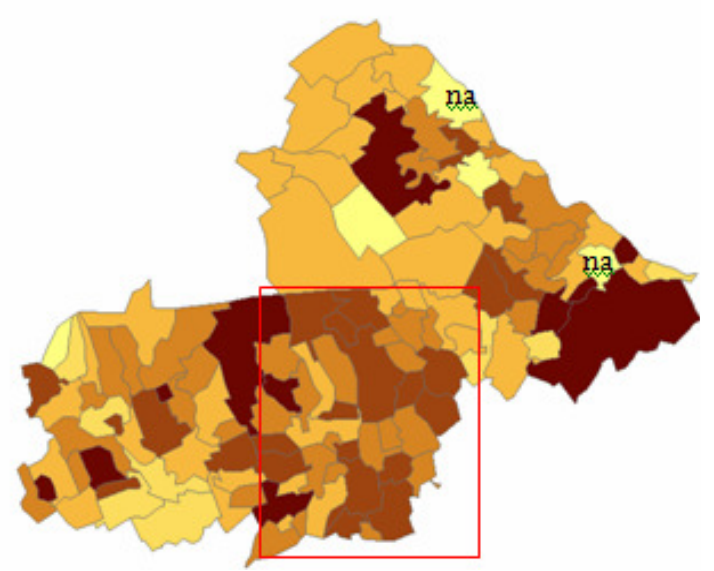

Népsürüség 1949-ben, (KSH, 2002)

20. ábra: Népsürüség változása a XX. század folyamán (KSH 2002; Rétvári, 1977)

Meghatározóvá váltak a mezőgazdasági lehetőségeket alakító természeti adottságok helyett a közlekedés-, és gazdaságföldrajzi tényezők. Jelentős népességcsökkenést szenvedtek el a közlekedés- és városárnyékos rábaközi (dél-nyugati aprófalvak és tóközi) aprófalvak, a Tóköz fejlődő településeivé váltak a kistérség közlekedési „ütőerei” mentén elhelyezkedő Bősárkány (86. sz.), Kóny (86. sz.) és a Hanság déli peremét képező Farád (85. sz. út). Kóny fejlődésére Győr vonzása is jelentős hatással volt. A negatív tendenciák a rendszerváltás óta sem sokat változtak, míg a megye községei összességében kismértékü növekedést éltek meg, a Rábaköz népességvesztése folytatódik, bár a népességcsökkenés kisebb arányú.

Csorna népességfejlődését vizsgálva karakteresen elkülöníthető periódusokat különítettem el: 1910ig a mezőváros népessége megháromszorozódik (a vasúthálózat kiépítése felerősíti közlekedés- 
földrajzi központ szerepét, ami lökést ad többek között a malomipar fejlődésének), a XX. század első felében kisebb dinamikával, majd a szocializmus évtizedeiben a rendszerváltásig ismét lendületesen növekedett. Az 1990-es évektől azonban egyértelműen és megállíthatatlanul fogyott a kisváros népessége.

A Dél-Rábaköz térségének a XIX. században dinamikusan fejlődő központi szerepkörrel is rendelkező települései közül Szil (Csorna mellett sokáig az egyetlen mezőváros a térségben, majd a XIX. századra Szany és Egyed is mezővárosi rangot kap) drasztikus népességcsökkenést szenved a változó gazdaság-, és közlekedés-földrajzi helyzetnek köszönhetően (a vasútállomás a település belterületétől távol helyezkedik el, közös megállója van Sopronnémetivel). Csökkenő népességszámot figyelhetünk meg Szany esetében is, de a megtelepedő ipari üzemeknek köszönhetően helyi foglalkoztatási központ szerepet őrzött/alakított ki környezetében (21. ábra).
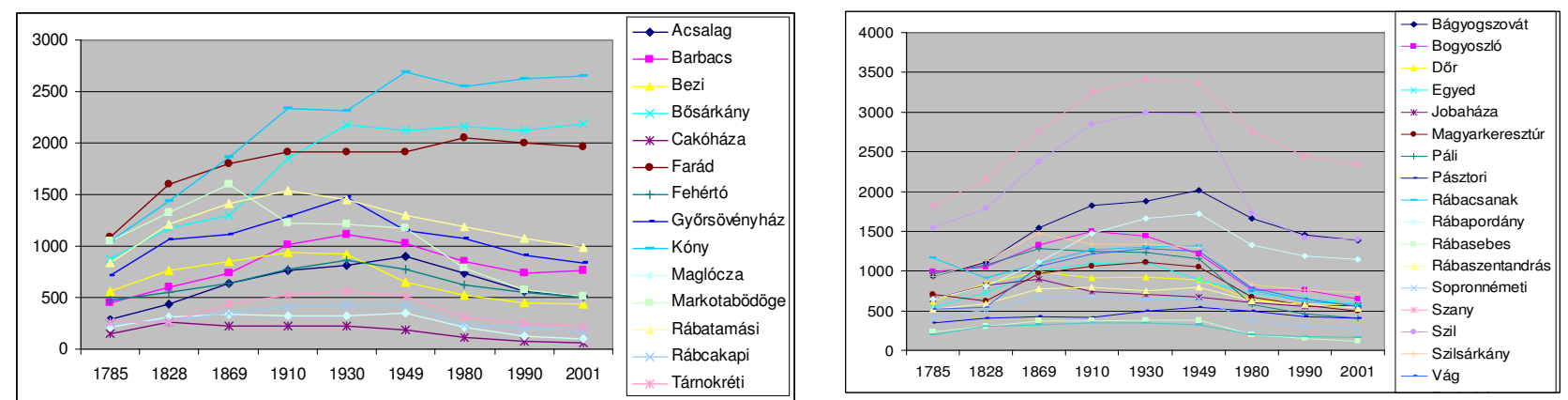

21. ábra: A Hanságmente, Tóközi falvak és a D-Ny Rábaközi falvak népességének növekedése (saját szerkesztés, adatok forrása: KSH)

\subsubsection{Térszerkezeti változások}

\section{A táji adottságok évezredeken át rányomták bélyegüket a település-, és a közlekedési-hálózat}

kialakulására. A Hanság átjárhatatlan lápvilága lehetetlenné tette az ember megtelepedését, a települések a mocsárvilág szélén jöttek létre. Farád neve állítólag onnan ered, hogy itt volt a termővidék vége, ,fara”, utána a mocsárvilág kezdődött (Timaffy, 1989). A Hanságot és a Rábaköz mélyen fekvő területeit együtt öntötte el az ár, csak a lápszigetek és földszigetek álltak ki belőle, ezeken települt le az ember, valószínüleg ezzel magyarázható, hogy a Kisalföldön itt jellemző egyedül az aprófalvas településhálózat.

Az úthálózat kialakítását is alapvetően befolyásolta a mocsárvilág a fő kelet-nyugati irányú kapcsolatot jelentő út és később a vasút a Hanságtól délre alakult ki. Lassan épültek meg a mocsárvilágot átszelő utak: Eszterháza és Pomogy között 1777-1780 táján épült fasoros töltésen vezetett át út (20 km hosszan), és Bősárkány mellett jött létre az észak-déli irányú összeköttetés.

A közigazgatási téregységek kialakítását is meghatározták a táji adottságok. Moson és Sopron megyék határát az áthatolhatatlan mocsárvilágon keresztül húzták meg, Sopron és Győr megyék határát a Hanságtól észak-déli irányban húzódó vizes, mocsaras sávban, a Tóköz vonalán és a délen 
a Rába mentén jelölték ki. A Tóköz térsége mióta térképek készültek a térségről periférikus helyzetü mocsárvilág által befolyásolt területnek számított a fennmaradt csatornarendszerek alapján elindult kutatások azonban sajátos középkori tógazdálkodás nyomait tárták fel. A tóközi tógazdálkodás időszaka sajátos versenyképes korszaknak tekinthető, hiszen a termesztési feltételeknek nem kedvező adottságokhoz kiválóan alkalmazkodtak, amely egy magas település- és népsűrüség kialakulását tette lehetővé. A tógazdálkodás megszünése a szüken vett Tóköz versenyképességi helyzetének, népességeltartó képességének visszaesését hozta.

A Rábaköz kiváló agráradottságú térségeit hamar müvelésbe vonták és jellemzően az ország átlagos színvonalánál magasabb színvonalon müvelték, amelyben nagy szerepük volt a csornai premontreieknek (alapítva 1180 körül), a lébényi bencés monostor (1206) Rábaközre is átnyúló gazdaságának és a győri káptalan birtokterületének a XV. századtól. A térség kevésbé szenvedte meg a török hódításokat, a háborúk a gabonatermesztés fellendülését hozták. Az uradalmak feljegyzései tanúskodnak az állattartás jelentőségéről a térségben a XVIII. században. A háromnyomásos gazdálkodásra ebben a térségben álltak át először a XVIII-XIX. század fordulóján. A XIX. században jelentős fellendülés volt érzékelhető a mezőgazdaságban, duplájára nőtt a gabonatermesztés, általánossá vált a kukorica termesztése, a fellendült sertéstenyésztés, új termékként megjelent a cukorrépa a század végén. A terméseredmények jobbak voltak az országos átlagnál. A vásárokat rendező települések rendelkeztek a legfontosabb térszervező erővel, a térségben megtermelt javakat Bécsbe, Pozsonyba, Győrbe szállították. A Rábaköz sürü mezővárosi hálózattal rendelkezett: Csorna, Szany, Szil, Egyed (Fényes Elek, Mo. leírása) voltak mezővárosi rangú települések. A Rábaköz térsége a birodalmi főváros Bécs ellátó körzetének peremterületéhez tartozott, az országos átlaghoz képest magasabb (elsősorban Csorna és közvetlen térsége) vagy átlagos fejlettséget képviselve (Győri, 1999), csupán a Tóköz térsége maradt a gazdálkodást nehezítő vízviszonyok miatt fejletlenebb. A tájalakítás ebben az időszakban hozzájárult a térség versenyképességének javulásához, hiszen a magas termelékenységü mezőgazdaság megtalálta felvevőpiacát.

A térszerkezet átalakulását hozta a vasúthálózat megépülése, korábban jelentős települések vesztettek térségi szerepkörükből, Csorna fejlődéséhez azonban nagymértékben járult hozzá, elsősorban a malomipar megtelepedését segítve. Csorna járási székhelykén a XIX. század folyamán egyre több adminisztratív feladatot látott el közvetlen térsége számára. Beluszky Pál 75 intézmény meglétének súlyozás nélküli számbavételével készített egy hierarchikus városrangsort 1900-ra. A Rábaköz kisvárosa Csorna viszonylag előkelő helyezéssel dicsekedhetett (Melléklet XI.).

A vízrendezési munkáknak köszönhetően átalakult a tájszerkezet, a mocsárvilág visszahúzódott, a szántók, gyepek a térség egyre nagyobb arányát foglalták el. Megváltoztak a társadalom, gazdaság mozgató erői: legfontosabb térszervező erővé a nagy forgalmú közlekedéshálózatok (közút, vasút) és az iparosodó városok váltak. 
A XIX. század végén majd sokkal erőteljesebben a XX. század folyamán a területi fejlődés legfontosabb alakítójává az iparosodás vált. Míg azonban Magyaróváron, Győrben, Sopronban a gyáripar széles skálája telepszik meg, Csornán csak az élelmiszeripar és könnyüipar. Az iparosítás hiánya mellett alapvetően rontotta a térség versenyképességét, hogy a Trianoni határok miatt leszakad Bécs ellátó körzetéről, határmenti periférikus térséggé válik. A szocialista fejlesztéspolitika alapvetően mezőgazdasági nyersanyag-termesztés térségi szerepkörét kínálja az akkori járásnak, ami tulajdonképpen exogén fejlesztési modell alkalmazásának tekinthető. A folytatódó tájalakítás nem hoz további gazdasági fejlődést, a versenyképesség javítását, hiszen a tájalakítás „haszonélvezője” a mezőgazdaság rohamosan veszít jelentőségéből a GDP-ben és a foglalkoztatásban. A szocializmusban a Rábaköz és a Hanság peremvidékének képét a nagyüzemi mezőgazdaság határozta meg, a Hanságban hatalmas nyárfaültetvényeket telepítettek. Az 1950-es években a határ menti fekvés miatt a szocialista ipar elkerülte a térséget. Az erőltetett iparosítás, amely a korábbi ipari központokat részesítette előnyben és a falvakat háttérbe szorító fejlesztéspolitika hátrányosan érintette a térséget, a kistelepülések jelentős népességvesztést szenvedtek el. Az 1970-es évekre fontos fejlesztéspolitikai céllá vált a városhálózat bővítése, ekkor kapott Csorna fejlődési lehetőséget és kialakult munkaerő vonzáskörzete. A napjainkra jellemző munkaerőpiaci vonzáskörzetek alapján látható (Melléklet XII), hogy a Rábaköz, Győr-Moson-Sopron megye nagycentrumai között, mintegy árnyékhelyzetben helyezkedik el, belső perifériaként jellemezték helyzetét (Rechnitzer, 1999).

A gazdálkodás módjainak változását részletesen áttekintettem a tájhasználat alfejezetekben, itt csak néhány gazdálkodási forma nagy jelentőségű változásaira hívom fel a figyelmet. A lecsapolások révén eltűntek a hagyományos mesterségek és a mezőgazdasági hasznosítás vált kizárólagossá. A mezőgazdasági művelésben meghatározóvá napjainkra a szántóföldi művelés, ezen belül az ipari növények termesztése vált: a gabonanövények, a napraforgó, a repce, (a cukorrépa az EU csatlakozás óta visszaszorult). A térség megélhetésének gazdasági alapja évezredeken át a mezőgazdaság volt ezen belül is elsősorban az állattartás (Fényes Elek is a Tóközi emberek megélhetésének alapjaként jellemezte).

A XIX. századig a vizek által még nagymértékben befolyásolt térségekben elsősorban az állattartás volt a legfontosabb megélhetési forma. Az egyre nagyobb lendületet kapó árvíz-mentesítési, lecsapolási munkák a földmüvelés térhódítását tették lehetővé. Fokozatosan átalakult, belterjessé vált az állattartás, egyes fajok tenyésztése visszaszorult. Pontos adataink az állatállományról csak a XIX. század végétől állnak rendelkezésre. Ezt megelőzően történeti leírásokból megállapítható, hogy elsősorban a szarvasmarha és a lótartás volt meghatározó a térségben, a sertéstenyésztés kisebb, majd fokozatosan növekvő jelentőségű volt. 1895-ben kistérség településein 22185 szarvasmarhát, 19723 sertést és 6854 lovat tartottak. A területhasználati arányok változásával is összefüggésben töredékére esett vissza napjainkig a lótenyésztés. Lassú emelkedés és stagnálás után a XIX. század végének 
volumene alá esett vissza a szarvasmarha-tartás, de majdnem megnégyszereződött a sertéstenyésztés volumene (Melléklet XIII.). Az állattartás, legeltetés aránya, mértéke azért is fontos, mert a természetvédelmi területek, a Natura 2000 területek döntően legelőterületek, amelyek fenntartásához nyújtott agrár-környezetvédelmi támogatások gyakran állatszámhoz kötöttek (gazdálkodás és természetvédelem konfliktusa, lásd a későbbi elemzéseket).

A későbbi elemzések miatt fontos áttekintenünk a szarvasmarha tartás változását (Melléklet XIV.). Ha összehasonlítjuk a két tájegység adatait, a XIX. század végi adatokhoz képest mindkettőben kb. 27\%-kal, a szocializmus állattartásához képest 34-38\%-kal csökkent mára az állatszám. A települések között azonban jelentős különbségek vannak. A Dél-Rábaköz falvaiban drasztikusabb változásokat tapasztalunk: egyes településeken nagyon jelentős mértékben csökkent illetve nőtt a tenyésztett állatok száma. A tóközi és hanságmenti falvakban kiegyenlítettebb folyamatok voltak jellemzőek: általában csökkent, de egyes településeken stagnált vagy kismértékben nőtt az állatszám. Nőtt az állatszám Bogyoszló, Egyed, Rábapordány, Szilsárkány, Szil és Farád és Bősárkány településeken. Az élelmiszeriparon belül a malomipar és a cukoripar vált jelentőssé a termesztési hagyományokra épülve a térségben, a sors fintora, hogy a cukorgyártás az Európai Uniós csatlakozást követően az utolsó cukorgyár bezárásával szinte megszünt Magyarországon. A mezőgazdaság nemzetgazdasági súlyának csökkenése ellenére a Hanságban és a Rábaközben is az egyik legfontosabb gazdasági ág maradt, még jelenleg is a foglalkoztatottak 20-30\%-át a falvak többségében (egyes falvakban 4050\%-ot, kistérségi átlag: 13\%) - bár folyamatosan csökkenő mértékben - de továbbra is a mezőgazdaság adja (Melléklet $X V$.).

\subsection{A tájhasználati rendszer a versenyképesség az élhetőség és a fenntarthatóság tükrében}

A vidéki térségek népességének életminőségét jelentősen meghatározza, hogy az adott térségben milyen tájhasználatok vannak jelen, mennyire egyoldalú a tájhasználat vagy esetleg a lehetséges funkciók széles skálája a megfelelő szinten érvényesül. Vidéki térségek sikerességének (versenyképességének) egy alapvető feltétele a táji rendszerek által biztosított ökológiai, gazdasági és egyéb oktatási, kulturális és esztétikai javak/szolgáltatások érvényre jutásának sokrétü, harmonikus teljesülése, a tájfunkciók diverzitása. Vidéki térségek esetében létfontosságú, hogy hogyan tudjuk a társadalom igényeit, sokrétü elvárásait kielégíteni, miközben fenntartjuk, megőrizzük a magas környezeti minőséget, mindehhez pedig a tájhasználat hogyan járul hozzá (22. ábra). Az emberi tevékenységek, a tájhasználat alapvetően befolyásolják a tájfunkciók működését. A tájhasználati rendszer értékelésére tájfunkció-elemzést alkalmaztam, amely kétféleképpen is elvégezhető: 
1. statisztikai és egyéb gyüjtött adatok, információk alapján, egyedi értékelési szempontrendszer kidolgozásával (kisebb területi egységekre alkalmazható, pontosabb probléma és tényfeltárást lehetővé tevő értékelés, 22. ábra, a tanulmányban erre a módszerre helyeztem a hangsúlyt ${ }^{28}$ ).

2. alapvetően a területhasználat jellemzőire alapozva, Corine térképi adatbázis alapján (sematikus elemzést lehetővé tevő, de nagyobb területi egységre könnyebben végrehajtható elemzés ${ }^{29}$ ).

1. A tájhasználat rendszerét a mintatérségben a tájfunkció elemzés alapján kidolgozott egyedi elemzési rendszert felhasználva értékeltem összehangolva a környezeti, társadalmi/kulturális és gazdasági szempontokat (22. ábra).

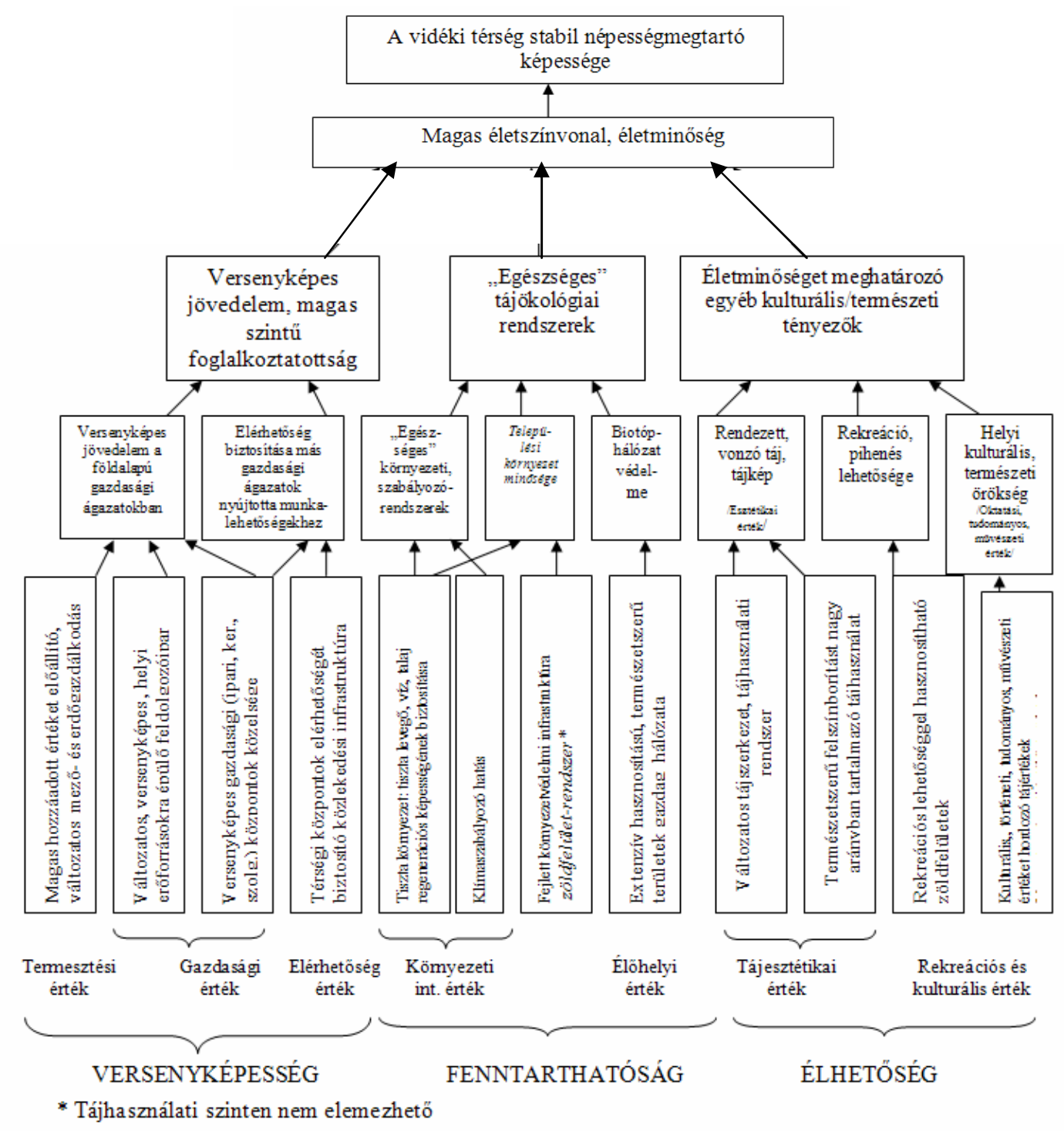

22. ábra: Tájhasználati szempontok vidéki térségek versenyképességéhez, az esettanulmányban

értékelt tájhasználati szempontok (termesztési érték, gazdasági érték, elérhetőség, környezeti integritás, élőhelyi, esztétikai, rekreációs, kulturális érték)

\footnotetext{
${ }^{28} \mathrm{Az}$ alábbi fejezetben ezt a módszert részletezem, az egyes tájfunkciók szintjére utalnak a statisztikai adatok súlyozásával nyert „értékek”, mint termesztési érték, élőhelyi érték stb.

${ }^{29}$ A környezeti integritás értéknél ezt az egy módszert alkalmaztam az adatok komplexitása és nehezen hozzáférhető jellege miatt - 29. ábra, valamint a módszer alkalmas történeti térképek alapján a tájfunkciók történeti elemzésére, példa a tájesztétikai érték változása a 14. ábrán.
} 
A tájhasználatok értékelését a társadalmi-gazdasági folyamatokat elsődlegesen meghatározó a jövedelemszintet befolyásoló tájhasználatok, tájhasználati funkciók értékelésével kezdem: mezőgazdasági termesztés, erdőgazdálkodás (termesztési érték), egyéb gazdasági ágazatok (gazdasági érték), elérhetőség (elérhetőség). Környezeti, ökológiai megközelítésű értékelést foglal magába a környezeti integritás és élőhely-védelmi funkciók elemzése. A kulturális/ társadalmi szempontú értékelés az esztétikai, tudományos-nevelési, művészeti, rekreációs értékét vizsgálja a táji rendszereknek, tájhasználatoknak (tájesztétikai érték, kulturális/rekreációs érték). A TEIR és egyéb adatbázisok alkalmazásával többféle adat súlyozásával nyertem az egyes településekre jellemző tájfunkció értékeket, amelyeket a települések illetve mikro-térségek komplex jellemzésére illetve a tájfunkciók térségi szintü müködésének különbségeinek elemzésére használtam fel (23. ábra).

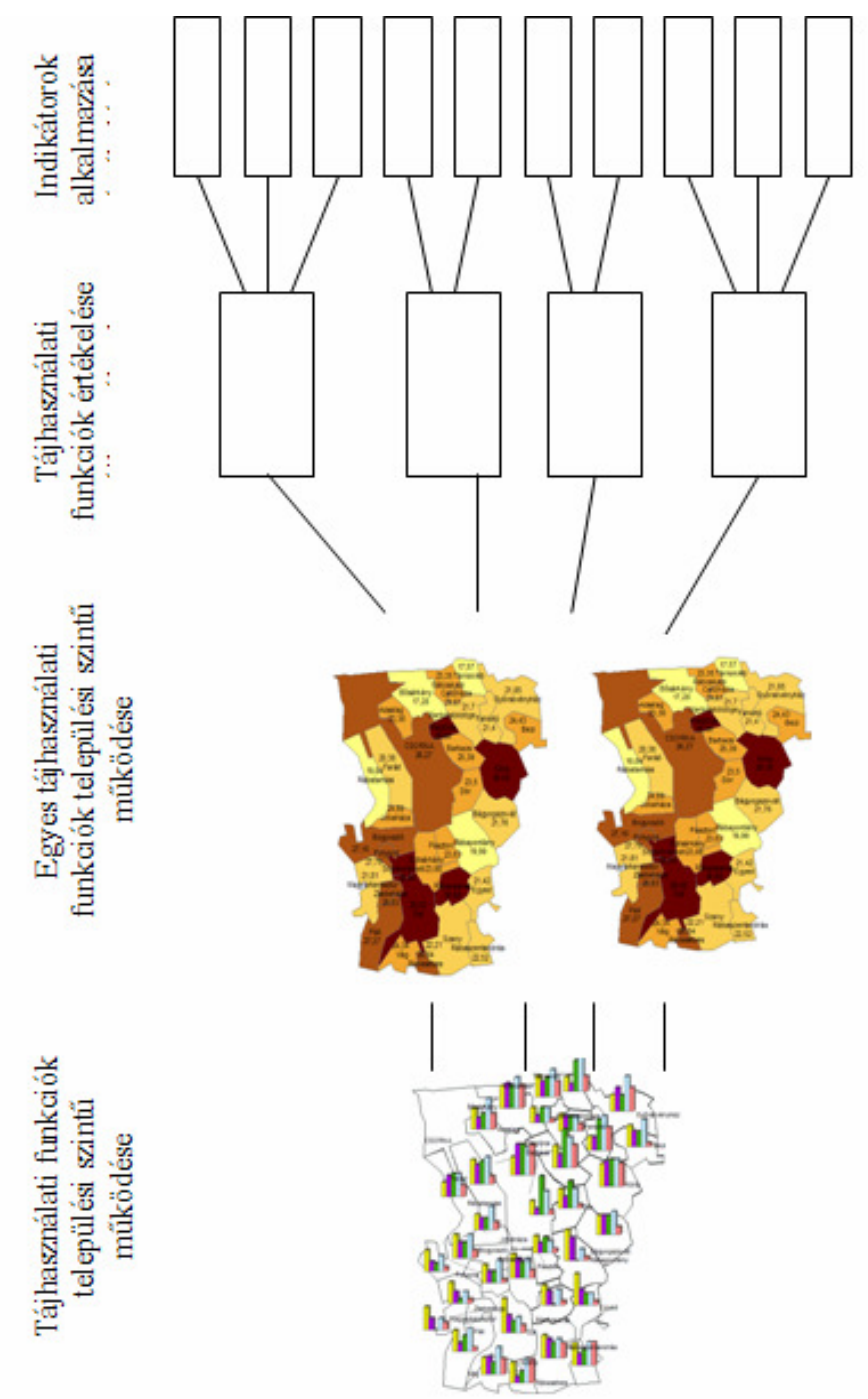

\section{3. ábra: Tájhasználatok, tájhasználati funkciók értékelésének folyamata}

2. A második módszer, az egyoldalúan térképi adatbázisra épülő értékeléshez a Lars Koschke, Christine Fürst, Susanne Frank, Franz Makeschin által kidolgozott értékelő mátrixot adaptáltam (Melléklet XVI.) a hazai területhasználati rendszerhez és termesztési adottságokhoz (Koschke et. al. 2012). Alapvető változtatásként módosítottam az egyes termesztési kultúrákhoz tartozó értékeket 
(gyümölcsös, öntözött szántó magasabb értékek, mint a nem öntözött szántó stb.). Az alkalmazás hátránya, hogy számos a jövedelmezőséget alapvetően befolyásoló szempont (termesztett kultúrák, állatszám stb.) nem vehető figyelembe, emiatt a tanulmányban részletesebben az első értékelési módszert dolgoztam ki, hiszen ez a területi szint lehetővé teszi egyedi adatbázisok alkalmazását (Melléklet XVII. az egyes funkciók szerinti térképlapok). A környezeti integritás funkciónál azonban a funkció rendkívül komplex jellege és részletes környezeti adatok elérhetőségének nehézsége miatt a Koschke féle értékelést alkalmaztam. A tájtörténeti feldolgozásban szereplő mátrixban annyi egyszerüsítést hajtottam végre, hogy a kevésbé részletes korai történeti térképek miatt nem a CLC50, hanem a CLC100 adatbázis részletességét, kategóriarendszerét vettem alapul.

A tájhasználati funkciók részletes értékelése után néhány kiválasztott tájfunkció harmonikus működését települési majd mikro-térségi szinten értékeltem, összehasonlítottam és következtetéseket vontam le a legfontosabb, a tájhasználati rendszert érintő fejlesztéseket illetően. A települési szintü adatgyüjtést, értékelést fontosnak tartom, mert így válik lehetővé a társadalmi, és a gazdasági adatok, mutatók alkalmazása. A tájhasználati rendszerek által elért haszon értékeléséhez többféle mutatót használtam fel. A területhasználati rendszer értékeléséhez alaptérképként, adatforrásként a Corine adatbázist használtam. Az értékelés során azonban nem minden esetben lehet csak és kizárólag a térképi adatbázisokra támaszkodni, hiszen egyes tájhasználati funkciók esetén, egyéb a térképi adatbázisban nem feltétlenül megjelenő információra is szükség lehet, mint például a rekreáció esetén, ahol az alapvető infrastruktúra jelentősen befolyásolhatja a használhatóságot. A tartalmi és terjedelmi keretek szükössége miatt az egyes tájhasználati funkciókhoz kapcsolódó, a tájépítészeti követelményeknek való megfelelés értékelése és a javaslatok a mellékletben szerepelnek.

A tájhasználatok gazdasági szempontú értékelése során kiemelten kezelem a mezőgazdasági termesztés, a gazdasági érték (gazdasági tevékenységek/aktivitás, ingázás, jövedelemszint) és az elérhetőség kérdését, az összesített tájfunkció és versenyképességi értékelésben ezek szerepelnek az eltartó funkciók csoportjából.

\subsubsection{Termesztési érték}

A történeti elemzés valamint a területhasználati és foglalkoztatási adatok (13\% a mezőgazdaságban foglalkoztatottak aránya) alapján is egyértelmű, hogy ma is fontos a mezőgazdaság a kistérség életében. A talajadottságok is kedveznek a mezőgazdasági termelésnek, különösen a dél-rábaközi falvakban magas a szántók aranykorona értéke (Melléklet XVIII.).

A szántóterületek aránya nagyon magas (Melléklet XIX.), az országos 48\%-hoz képest 66\%. A gyepterületek aránya annak ellenére átlagosnak tekinthető, hogy egy évszázaddal ezelőtt mintegy 37\% volt. A szántók aránya településenként széles amplitúdó között változik, de a legalacsonyabb is az 
országos átlagon van. Alacsonyabb a hanságmenti, tóközi településeken (Csorna: 48\%, Tárnokréti, Fehértó: 49\%), legmagasabb a dél-rábaközi falvakban (Rábacsanak 79\%, Magyarkeresztúr 86\%).

Döntően gabonaféléket, ipari növényeket termesztenek (a 2000. évi mezőgazdasági összeírás szerint a kistérség vetésterületének 38\%-át cukorrépa, 10\%-át kalászos gabona, 5\%-át kukorica, 15\%-át takarmánynövények, 12\%-át zöldségfélék, fél százalékán ipari növényeket termesztettek ezek az arányok az EU csatlakozás óta cukorrépa visszaszorulása, továbbá a gabonanövények és napraforgó termesztésének irányába tolódtak el.)

A zöldség- és a gyümölcskertek aránya $(0,24 \%)$ az 2\%-os országos átlag alatt van, bár a szocializmus alatt dinamikusan növekedett az ültetvények aránya. A Rábaközben és tágabb térségében jelentős hagyományi voltak a gyümölcstermesztésnek (Mihályi-Kisfalud, Beled-Kapuvár: alma; málna, Pannonhalma: meggy), a szocializmusban kialakult nagyüzemi gazdálkodás mellett a munkaigényes gyümölcs, és kis részben zöldség (málna, egyéb bogyósok, uborka) a kiskertekben, háztáji gazdaságokban folyt. Az osztályozást, a felvásárlást az ÁFÉSZ hálózata oldotta meg. A térségben közvetlenül ne, de a szükebb és tágabb környezetében számos konzervgyár ${ }^{30}$ müködött, amelyek közül csak néhány maradt meg. A minőségi termesztést, megújulást a Fertődi Gyümölcskutató segítette. A rendszerváltás után nagy mennyiségben, válogatott minőségben termeltek a Rábaközben uborkát, olyannyira, hogy a Rábaköz aranyának is hívták az itt termelt zöldséget. Nem alakult ki azonban karakteres helyi termék, feldolgozóipar sem kapcsolódott hozzá és mára töredékére esett vissza az uborkatermesztés. Az országos folyamatokhoz hasonlóan, a kistérségben is csökkent a zöldség- és gyümölcstermesztés volumene, amely több okra vezethető vissza:

— az uniós piac megnyílásával visszaesett az igény a konzervzöldségre és gyümölcsre;

— a térség feldolgozóipari kapacitása a töredékére esett vissza;

— a szocialista országok (elsősorban a Szovjetunió) piacainak összeomlása miatt a hazai nagyüzemi gyümölcstermesztés termékei az országon belül keresték piacaikat, (tehát Győr-Moson-Sopron megyében is a helyi almát kiszorította az olcsóbb Szabolcsi) visszaszorítva a kiskerti termesztést,

— „nyugatiasodás”/ rurbanizáció, a vidéki életmód megváltozása, illetve a növekvő elvárások a munkahelyeken (ahogy a térségben megjelent több jelentős munkaerőigénnyel rendelkező vállalkozás (Audi Győr, Interfa Szany), ahol adott esetben 8 óra helyett naponta 10 órát kellett dolgozni), visszaesett a mellékállásban termesztéssel foglalkozók száma, amely kevesebb termékmennyiség előállításához vezetett, hosszabb távon tovább szűkítve a felvevőpiacot.

A termelők számának csökkenése az elmúlt évtizedben is folytatódott (Csornán az 1990-es évek végén, 2000-es évek elején még mintegy 3000 őstermelői igazolást adtak ki a helyi falugazdászok, mára ez az érték 400 körül stabilizálódott), csak a hozzáértő, fejleszteni tudó, jelentősebb termesztő-

\footnotetext{
${ }^{30}$ (Koroncó, Mosonmagyaróvár, Fertőd, Győr, Győrszabadhegy, Zalaegerszeg, Székesfehérvár, Dunakiliti)
} 
felülettel rendelkező gazdálkodók tudtak talpon maradni. Csupán néhány településen találkozunk jelentősebb gyümölcs és zöldség ültetvénnyel, mint egy 60 hektáros gyümölcsös Sopronnémetiben vagy több kisebb ültetvénnyel Csornán. A mezőgazdaság jövedelmezőségét rontja, hogy a gabonaés a tejiparon kívül az itt termelt termények feldolgozására helyben nem alakult ki feldolgozóipar. A mezőgazdasági termelés jövedelmezőségét emelik a munkaigényes, magas hozzáadott értéket előállító ágazatok, mint az intenzív zöldség- és gyümölcstermesztés vagy bio- és ökológiai gazdálkodás. A 2000-es ÁMÖ felmérés szerint rendkívül kicsi a biogazdálkodást folytatók száma a térségben, Csornán néhány gazdálkodó és Rábcakapin egy kiemelkedően jó példa (100 hektáron ökológiai gazdálkodást alakítottak ki, nagyon jó értékesítési kapcsolatokkal pl. a hanságligeti Hipp Kft.) található. A mezőgazdasági termesztés biztonságát, jövedelmezőségét alapvetően meghatározza az öntözhető mezőgazdasági területek aránya. Nincsenek kihasználva a folyók és a csatornák nyújtotta öntözési lehetőségek. A településeken általában az országos átlagnak megfelelő az öntözhető területek aránya néhány magasabb értékkel rendelkező település kivételével (Melléklet XX.).

A térség rendszerváltás előtti nagymértékű állatállománya napjainkra jelentősen lecsökkent, és amennyiben nem történik jelentős változás, további csökkenés várható. Az állattenyésztés a mezőgazdaság egy „mostohagyermekének” tekinthető, rendkívül kiszolgáltatott a piaci változásoknak, kisebb arányban támogatott, mint a növénytermesztés, az alacsony felvásárlási árak miatt nem jövedelmező illetve nagyon magas a feketegazdaság aránya, amely a gazdasági szervezeteknek további versenyhátrányt jelent. Az állattartást még fel nem adó vállalkozásoknál gyakori, hogy a növénytermesztés hasznából finanszírozzák az állattenyésztés veszteségeit. A legfontosabb tenyésztett állatfajták a szarvasmarha, a sertés, a ló, a pulyka, a csirke, a lúd, a kacsa és a nyúl. A szarvasmarhatartás elsősorban Egyed, Szil, Bogyoszló, Rábapordány, Csorna, Bősárkány településeken jelentős, kisebb arányú a tóközi falvakban (Melléklet XXI.). A folyamatosan csökkenő állatszám komoly konfliktust okoz a döntően Natura 2000 státusú rétek, legelők fenntartásában, másrészt fogltalkoztaási szempontból is kedvezőbb, hiszen magasabb a munkaerőigénye a gabonatermesztéshez képest.

9. táblázat: Az összesített funkcionális értékelésben alkalmazott indikátorok a termesztési érték jellemzésére (saját szerkesztés)

\begin{tabular}{|c|c|c|}
\hline Tájfunkció & Szempontok & Indikátorok és adatforrás \\
\hline \multirow{4}{*}{$\begin{array}{l}\text { Termesztési } \\
\text { érték }\end{array}$} & $\begin{array}{l}\text { A mezőgazdaság hozzájárulása a } \\
\text { GDP-hez, a foglalkoztatáshoz }\end{array}$ & $\begin{array}{l}\text { Mezőgazdálkodásban foglalkoztatottak aránya (KSH) } \\
\text { Mezőgazdasági termékérték*(AMÖ, 2000) }\end{array}$ \\
\hline & $\begin{array}{l}\text { A mezőgazdasági termesztés inten- } \\
\text { zitása/jövedelmezősége }\end{array}$ & $\begin{array}{l}\text { Egyedi, tájtermékek megléte } \\
\text { Öntözött szántóföldek aránya (AMÖ, 2000, Corine) } \\
\text { Munka-intenzív zöldség/gyümölcs ültetvények aránya (Takarnet, Corine) } \\
\text { Bio/ökológiai gazdálkodás aránya (AMÖ, 2000) } \\
\text { Agrár-környezetvédelmi bevételek (NVH) }\end{array}$ \\
\hline & $\begin{array}{l}\text { A mezőgazdasági termesztés terü- } \\
\text { lethasználati aránya, extenzitása }\end{array}$ & $\begin{array}{l}\text { Szántóföldek aránya (Takarnet, Corine) } \\
\text { Állattartás volumene, számosállat-sűrüség (AMÖ, 2000, KSH) }\end{array}$ \\
\hline & $\begin{array}{l}\text { A mezőgazdasági termékszerkezet } \\
\text { változatossága }\end{array}$ & $\begin{array}{l}\text { Szántók, gyümölcsösök, rétek aránya } \\
\text { Kiegészítő tevékenységek/jövedelem aránya (AMÖ, 2000) }\end{array}$ \\
\hline
\end{tabular}

* országos szintü összehasonlítást tesz lehetővé, kistérségi szintü adat 
Az összesített számosállat sürüséget vizsgálva a dél-rábaközi falvakban látunk magasabb értékeket, amit elsősorban a sertéstartás népszerüsége befolyásol a szarvasmarhatartás mellett (Melléklet XXII.).

A termesztési értéket (9. táblázat) a számosállat sürűség, a szántóterületek aránya, az öntözhető szántóföldek, a gyümölcsösök aránya alapján súlyozással számoltam, amely a mezőgazdasági termesztés (Melléklet XXIII.) jövedelmezőségét/intenzitását (24. ábra) jellemzi. Az összesítésben kis súllyal, de jövedelemként számítottam az agrár-környezetvédelmi bevételeket is, hiszen a korlátozást, az extenzívebb termelés miatti jövedelem-kiesést kompenzálja. Az értékelés alapján látható, hogy legintenzívebb a mezőgazdasági termelés a dél-rábaközi és a Csornát körülvevő falvakban.
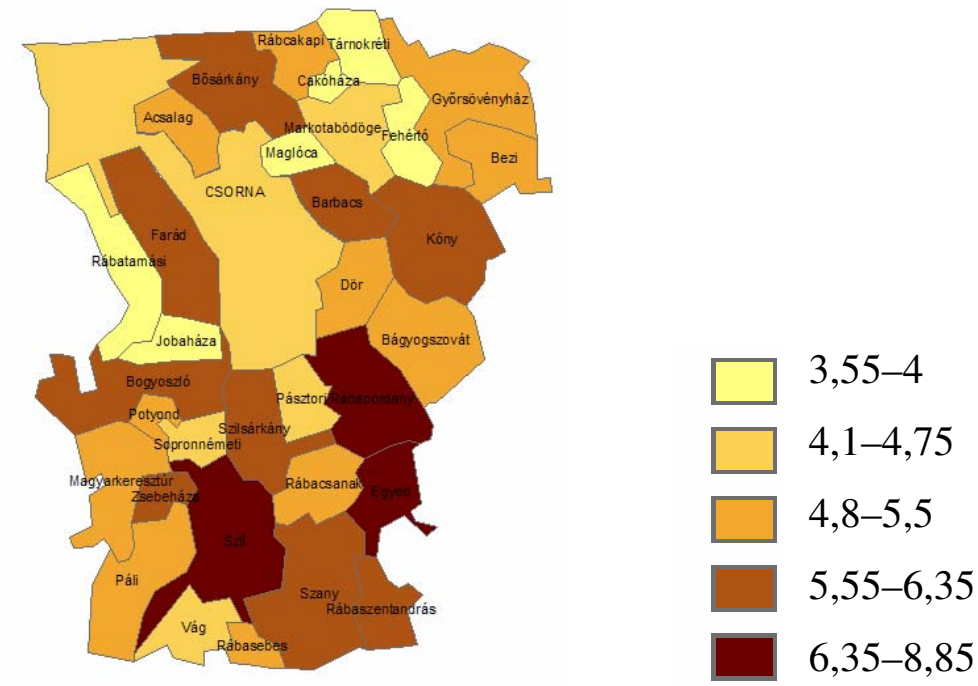

A mezőgazdasági termelés összesített intenzitása a számosállat sűrüség (súly: 0,4), szántóterületek aránya

(súly: 0,4)), öntözhető mezőgazdasági területek aránya (súly: 0,1), gyümölcsösök aránya (súly: 0,05), agrár-környezetvédelmi kifizetések aránya (súly: 0,05) alapján (1-10)

24. ábra: A mezőgazdasági termesztés intenzitása (1-10) (saját szerkesztés, adatok forrása: TEIR)

A kistérségben a mezőgazdaság mind a gazdaságban, a foglalkoztatásban, a tájhasználatban az országos átlagot meghaladó jelentőséggel bír. A mezőgazdasági termesztés jövedelmezőségének országos szintü összehasonlítását szolgálja az Általános Mezőgazdasági Összeírás adatbázisában elérhető, kistérségi szinten értelmezhető, egy gazdaságra jutó mezőgazdasági termék értéke adatsor (TEIR). Ha országos viszonylatban vizsgáljuk a mezőgazdaság jövedelmezőségét: az egy gazdaságra jutó mezőgazdasági termék értéke a növénytermesztő gazdaságokban (18 millió Ft) országos átlagnál (14 milli Ft) magasabb, de elmarad a jó agráradottságú kistérségek átlagától, továbbá alacsonyabb a hasonló adottságú szomszédos kapuvári kistérség (25 millió Ft) átlagánál (ÁMÖ, 2000). Ha az összes gazdaság statisztikáját nézzük a kistérség kedvezőbb helyzetben van (kistérségi érték 102 millió Ft, országos átlag 71 millió Ft). A Rábaközt szokták a nyugat-magyarországi térség éléskamrájának is nevezni, olyan gazdag a mezőgazdasági termékek skálája, azonban a magas minőségü, 
magas hozzáadott értéket jelentő termékek hiánya, a feldolgozás alacsony foka miatt csekély a mezőgazdasági termesztés jövedelemtermelő képessége.

A mezőgazdasági termesztés jövedelmezőségét alapvetően meghatározzák az ágazati szereplők közötti együttmüködések formája, hatékonysága. A hagyományosan elaprózott birtokszerkezet nem kedvez a gazdálkodók piaci helyzetének. A gazdálkodók piacra jutásának segítésére támogatták Termelői Értékesítő Szövetkezetek létrehozását. Több TÉSZ alakult a térségben, de alapjaiban nem tudták megváltoztatni a viszonyokat, egyre kevésbé tudtak újabb termelőket bekapcsolni. A felvásárlás, piacra jutás elsősorban a zöldség-, gyümölcs ágazatban nem megoldott. Az osztrák piac közelsége ellenére nehéz bejutni egy magyar termelőnek a szomszédos ország piacára, hiszen az osztrák piac rendkívül zárt, a hazai termékek előnyben részesítése rendkívül erős prioritás. A gyümölcs-, a zöldség-termesztés fejlesztési lehetőségeit alapvetően befolyásolja:

— a hütő-, tároló,- feldolgozóipari kapacitás hiánya,

— jelentős tőkeigény a fejlesztésekhez,

— elérhető támogatások, (amelyek az elmúlt évtizedben a többi ágazathoz képest kisebb arányban voltak elérhetők);

— szakértelem és technológia hiánya a magas minőségű termék folyamatos volumenben való előállítására;

— termelöi együttmüködések hiánya,

— termelési költség, öntözési lehetőségek,

— értékesítési lehetőségek.

Az ökológiai gazdálkodás nagyobb arányban történő elterjedése kimondottan kedvező lenne vidékfejlesztési szempontból, hiszen a konvencionális gazdálkodást akár két és félszeresen meghaladó a munkaerő igénye továbbá környezet- és tájvédelmi szempontból sokkal kedvezőbb. A kistérség területén több ökológiai gazdálkodás is működik, bár itt sajátos koncentráció figyelhető meg: a térségből Győrsövényházáról három, Kónyból egy gazdasági szervezet szerepel az osztrák ökológiai gazdálkodásról szóló tanúsítvánnyal rendelkező szervezetek adatbázisában (a Rábaköz többi településéről nincs más szervezet akkreditálva). Sajnos országos viszonylatban az 1990-es évek dinamikus növekedését követően csökkent illetve stagnált az ellenőrzött ökoterületek nagysága ${ }^{31}$. Az ökológiai gazdálkodás helyzetét jelentősen rontja, hogy Európában túltelített a piac, amely nyomott árakat okoz. A hazai piacon nincs komoly fizetőképes kereslet a biotermékekre, emiatt nem tud az ökológiai gazdálkodás nyereségesebb lenni a konvencionális gazdálkodásnál (a korlátozások miatti terméskiesést nem kompenzálja magasabb ár). Emiatt a térségben többen hagytak fel az ökológiai gazdálkodással, hiszen komoly szakértelmet és odafigyelést igényel.

\footnotetext{
${ }^{31}$ Országos kitetkintés: 1995-ben 8232 ha; 2003-ban 113816 ha és 2010-ben 115555 ha, bár a terv 600000 ha elérése volt (http://anubis.kee.hu/pdf/bscoko/bevezet122.pdf)
} 
Rendkívül erős birtokkoncentrációs folyamatok figyelhetők meg a térségben (25. ábra). A 2011-es AMÖ összeírás alapján falvak jelentős részében felére, negyedére csökkent a földhasználók száma. A bérletben megmüvelt földek aránya mintegy 50\%-os. A bérlet magas aránya kihatással van a mezőgazdasági termesztés versenyképességére, drágítja a termelést, rontja a beruházási, fejlesztési hajlandóságot. Nem a kiemelkedő nagyságú nagybirtokok, de 800-1000 hektáros földbirtokok előfordulnak a térdégben. A szocializmus időszakában létrehozott téeszek egy része átalakult, gazdasági szervezetként nagykiterjedésü földterületeket müvel. A gazdák átlagéletkora magas, várható tehát, hogy ha nem is ilyen intenzitással, de folytatódik a birtokkoncentráció. Elgondolkodtató, hogy előfordul a térségben, hogy egy község határainak jelentős részét ökológiai gazdálkodással műveli meg egy gazdálkodó szervezet (1100 ha bérelt területen gazdálkodik), míg jellemzően a konvencionális módon gazdálkodó szervezetek jellemzőek, és a birtokkoncentráció következtében egyre nagyobb összefüggő területeket müvelnek meg.

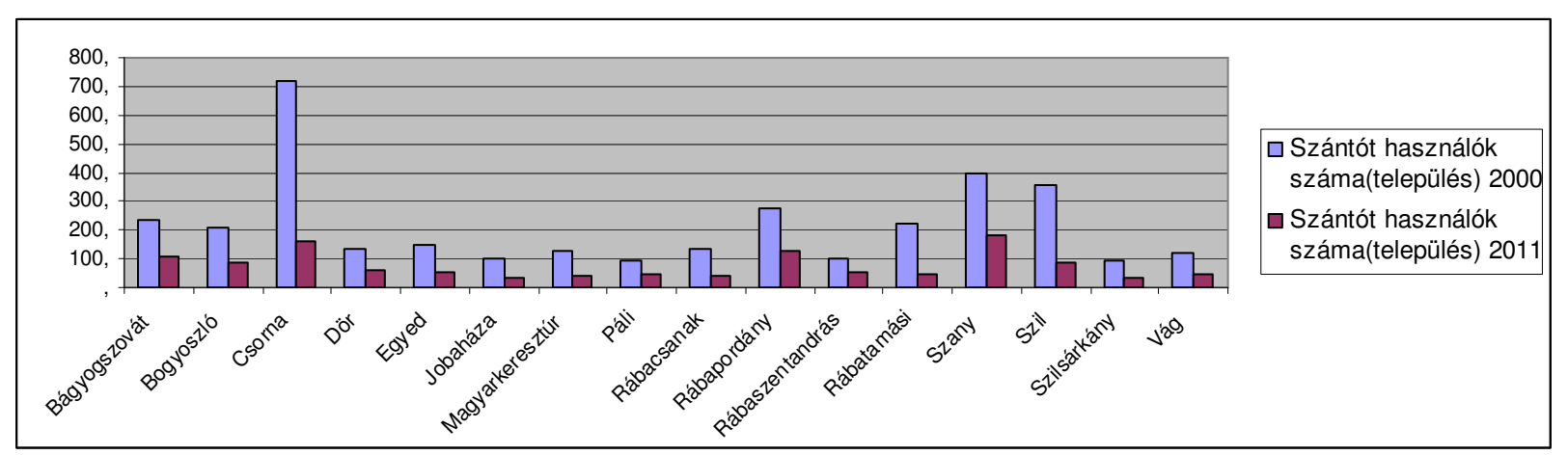

\section{5. ábra: Szántót használók számának változása néhány Rábaközi településen 2000-2011 kö-}

zött (saját szerkesztés Általános Mezőgazdasági Összeírások adatai alapján)

\section{Erdőgazdálkodás}

Országos összehasonlításban alacsonynak számít a térségben az erdősültség (Melléklet XXIV.): nem éri el a 10\%-ot. A Hanság lápvidéke kivételével évszázadok óta művelt területek találhatók a Rábaközben, ennek köszönhető, hogy a dél-rábaközi falvak némelyikében 3\%, illetve egyesekben $1 \%$ alatti az erdősültség. Magasabb erdő arányt elsősorban a Hanságban és a Tóközben találunk valamint a Rábaközben egy-egy jelentősebb erdőterület révén (Páli helyi védettségü gyertyános-tölgyes, bogyoszlói Tölös erdő). A kistérség erdőterületei három erdő-tervezési körzet területére esnek: Rábaközi-Iváni cser körzet, Dél-Hansági körzet és a Győri körzet. Az erdők több mint 30\%-a védelmi erdő, a Nemzeti Park területére eső védett erdők (a fokozottan védett csornai Csíkos-éger, Barbacsitó körüli erdő) és a Rába-menti partvédelmi erdők (Szany, Vág) magas aránya miatt. A védett erdőkön belül 3-4\%-ot tesznek ki a mezővédő erdősávok (arányuk településenként változó, a rábaközi falvakban magas arányt képviselnek). Az erdészeti területek részaránya meghaladja a 70\%-ot, amely területek kezelését a Kisalföld Erdőgazdaság Részvénytársaság Dél-hansági és Rábaközi erdészetei 
végzik. Egyéb állami tulajdonosok közül ki kell emelni az FHNP és az Észak-Dunántúli Vízügyi Igazgatóságot.

A térség természetes erdőtársulásai ma már csak nyomokban lelhetők fel, mint az éger ligetek, a nyírlápok, a kocsányos tölgyesek és a tölgy-kőris-szil ligeterdők. Helyettük az erdőkben magas a nemesnyárak (az 1-30 éves korosztályok zömét adják) és az akácok aránya. Fokozatosan növekvő arányt képvisel a kocsányos tölgy és a kőris az elmúlt 2-3 évtizedes szemléletváltásnak köszönhetően. Az éger aránya az idős (71-80 éves) korosztályokban és a fiatal (21-30) éves korosztályokban nagyobb. Várhatóan növekedni fog a hazai nyaras, a kocsányos tölgyes, a kőrises és elsősorban az égeres faállománytípusok aránya (Rábaközi-Iváni cser körzet, Dél-Hansági körzet és a Győri körzet erdőterve).

\section{Összegzés/termesztési érték}

Az értékelésben feltártam, hogy legintenzívebb a mezőgazdasági termelés a dél-rábaközi és a Csornát körülvevő falvakban. A néhány kiemelkedő példa ellenére az országos átlag alatti a zöldség,- a gyümölcskultúrák aránya, gyakorlatilag nem beszélhetünk egyedi és tájtermékekről, valamint rendkívül alacsony a kiegészítő tevékenységek köre, kiegészítő jövedelmek aránya. Az országos átlagot messze meghaladó szántó művelési arány ellenére/mellett azonban a magas minőségű, magas hozzáadott értéket jelentő termékek hiánya miatt viszonylag alacsony a mezőgazdasági termesztés jövedelemtermelö képessége.

\subsubsection{Gazdasági érték}

Az ipar, a kereskedelem volumene, térbeli szerkezete alapvetően meghatározza egy térség gazdaságának fejlettségét, az alábbiakban kiemelten foglalkozom a bányászat, a feldolgozóipar területi jellemzőivel. A gazdasági értékhez kapcsolódóan alapvetően három megközelítést vettem figyelembe (10. táblázat):

— a területhasználatok tájépítészeti célkitüzéseknek való megfelelését (bányászat, ipar) (Melléklet),

— a települések gazdaságában, foglalkoztatottságában mennyire meghatározó a mezőgazdaság,

— az összesített gazdasági értéket (a gazdasági aktivitást, a lakosság jövedelemszintje, iparüzési adó, adófizetők aránya alapján).

10. táblázat: A gazdasági értékelésben alkalmazott mutatók (saját szerkesztés)

\begin{tabular}{|l|l|l|}
\hline $\begin{array}{c}\text { Tájfunkciók } \\
\text { értékelése }\end{array}$ & \multicolumn{1}{|c|}{ Jellemző } & \multicolumn{1}{c|}{ Indikátorok (adatforrás) } \\
\hline \multirow{3}{*}{ Gazdasági érték } & Gazdasági aktivitás & $\begin{array}{l}\text { Jelentősebb foglalkoztatók, gazdasági szervezetek száma (KSH) } \\
\text { Adófizetők aránya (KSH) } \\
\text { Iparüzési adó (TÁKISZ) }\end{array}$ \\
\cline { 2 - 3 } & \multicolumn{1}{|c|}{ Lakosság jövedelmi szintje } & Összes belföldi jövedelem/lakos (KSH) \\
\hline Kiegészitő elemzés & $\begin{array}{l}\text { Mezőgazdaság jelentősége a GDP-ben } \\
\text { és a foglalkoztatásban }\end{array}$ & $\begin{array}{l}\text { Ingázók aránya (KSH) } \\
\text { Mezőgazdaságban foglalkoztatottak aránya (KSH) }\end{array}$ \\
\hline
\end{tabular}




\section{Bányászat}

A Rábaközben kb. 10-50 m homokos-kavicsos üledékrétegének köszönhetően több településen folytattak kavicsbányászatot, ma csak néhány településen található müködő bánya (Szany, Magyarkeresztúr, Páli). A müködő bányáknál jelentősebb a felhagyott bányák száma, amelyeket ma általában bányatavakként, elsősorban horgásztóként hasznosítanak (Melléklet XXV.). Müködő agyagbánya Csornán található. A Rábaközben jelentős reménybeli területek találhatók az építési homokos kavics, az agyag és a homok, mint építési nyersanyagot illetően (Váti: Győr-MosonSopron megy területrendezési tervének módosítása, 2010).

\section{Ipar}

A kistérségben nincsenek jelentős ipari hagyományok (lásd részletesen tájtörténeti elemzés). Ipari parkot Csornán hoztak létre. A jelentős volumenű minőségi mezőgazdasági termelés ellenére a kistérségben nincs kiemelkedő jelentőségű élelmiszeripar. A történelmi hagyományoknak megfelelően kivétel a Csornán a gabona-élelmiszer üzem (Pannon-Gabona Feldolgozó és Kereskedelmi Rt.), a csornai „tejporgyár” (Baranyatej Rt. Csornai Tejüzeme), emiatt a térség jórészt csak nyersanyagot termel más térségek számára.

Nagy volumenü ipari tevékenység nem települt a térségbe. A kistérség cégei közül a Csornán müködő TONDACH Magyarország Cserép- és Téglagyártó Rt., a Szanyban müködő bútorgyár, valamint néhány gépgyártási és öntészeti kisvállalkozást lehet megemlíteni (Agrárstruktúra és vidékfejlesztési Program, 2004). Csornán két gazdasági területet alakítottak ki, amelyek közül a déli iparterület 2004-ben ipari park címet kapott.

A megtelepült helyi feldolgozóipar alapján a kistérség legfontosabb foglalkoztatási központja Csorna, kisebb jelentőségű központok, Szany, Szil, és jelentősebb gazdasági aktivitás jellemző Bősárkány, Kóny, Bágyogszovát, Rábapordány településeken.

A tájhasználati rendszer szerepéről a lakosság jövedelemszintjében, fontos lenne feltárni, hogy mennyire meghatározóak a foglalkoztatásban és a GDP-ben az un. földalapú gazdasági ágak, mint a mezőgazdaság, az erdőgazdaság és az élelmiszeripar. Az elérhető adatok azonban ezt a szétválasztást nem teszik lehetővé, az azonban feltárható, hogy mely települések azok, amelyek gazdasági bázisa alapvetően a mezőgazdaság (alacsony az ingázás, alacsony a gazdasági aktivitás, magas a mezőgazdaságban foglalkoztatottak aránya). A térséget alapvetően kistelepülések jellemzik, ahol számottevő helyi feldolgozóipar nem alakult ki, ezért meghatározó az ingázás, különösen a Csorna körül elhelyezkedő kisfalvak és a tóközi településekre jellemző, hogy a foglalkoztatottak 40-60\%-a más településre jár dolgozni. A tóközi falvakra Csorna, de elsősorban Győr vonzó hatása érvényesül. Alacsonyabb fokú az ingázás a dél-rábaközi falvakban, a tóközi falvak közül Rábcakapi, Tárnokréti településeken. 
A mezőgazdaságban foglalkoztatottak arányát vizsgálva gyakorlatilag minden településen az országos átlag feletti értékékkel találkozunk, de foglalkoztatásban különösen meghatározó jelentőségü a mezőgazdaság Pásztori, Rábacsanak, Páli, Magyarkeresztúr, Egyed, Rábcakapi és Tárnokréti és Maglóca településeken (ahol egyben alacsonyabb az ingázás és nincs jelentősebb ipari tevékenység). Megélhetésüket tekintve tehát ezek a települések utaltak leginkább a mezőgazdasági termesztésre (26. ábra)
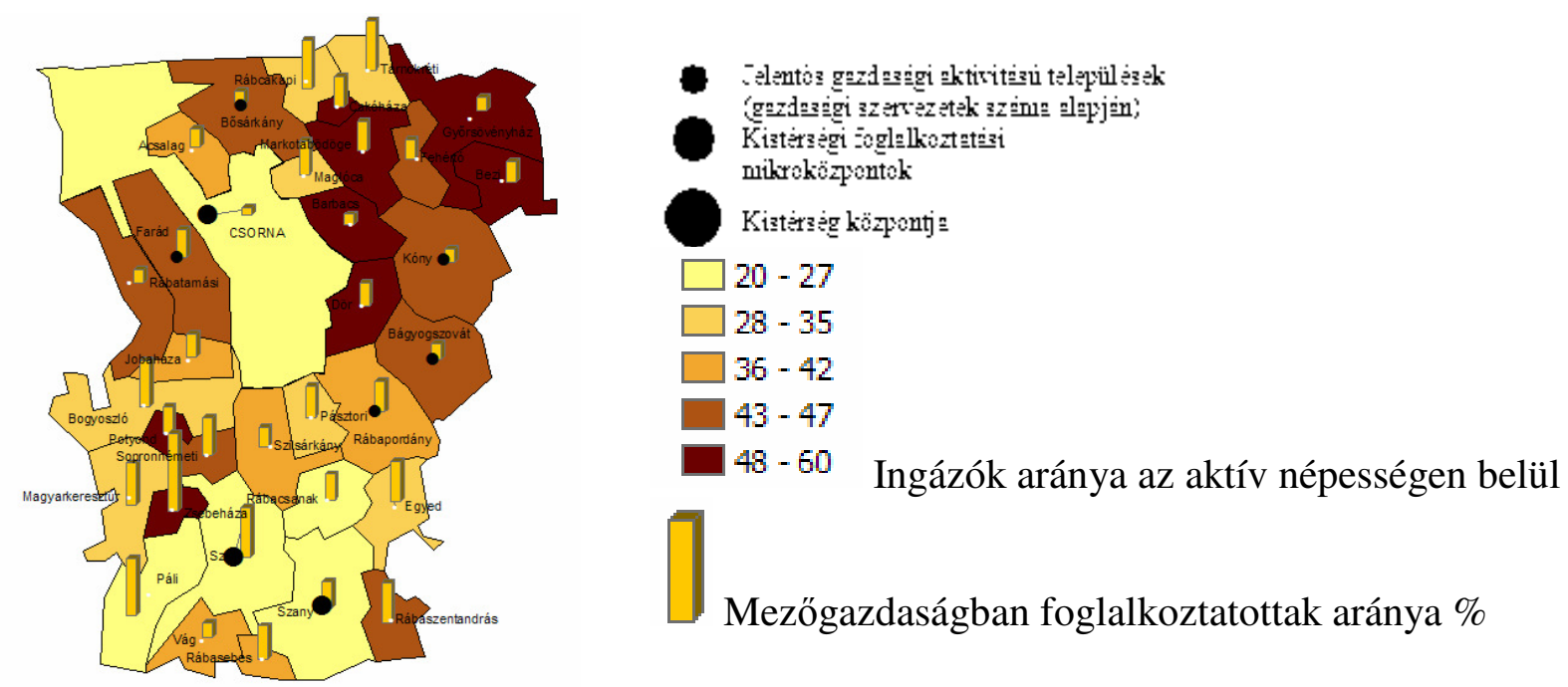

26. ábra: A helyi foglalkoztatás, az ingázás és a mezőgazdaságban foglalkoztatottak aránya (saját szerkesztés, adatok forrása: TEIR)

Összegzés/gazdasági érték

A gazdasági szervezetek száma, iparüzési adó, adófizetők aránya és a lakosság jövedelemszintje alapján összesítve értékeltem (az értékek alapján, a megyei átlaghoz viszonyítva a településeket 10es skálán helyeztem el, pontos adatokat a Melléklet XXVI. szemlélteti). Az egyéb tájhasználati funkciók szintjének összevetéséhez az összesített elemzésben felhasználtam ezt a gazdasági mutatót.

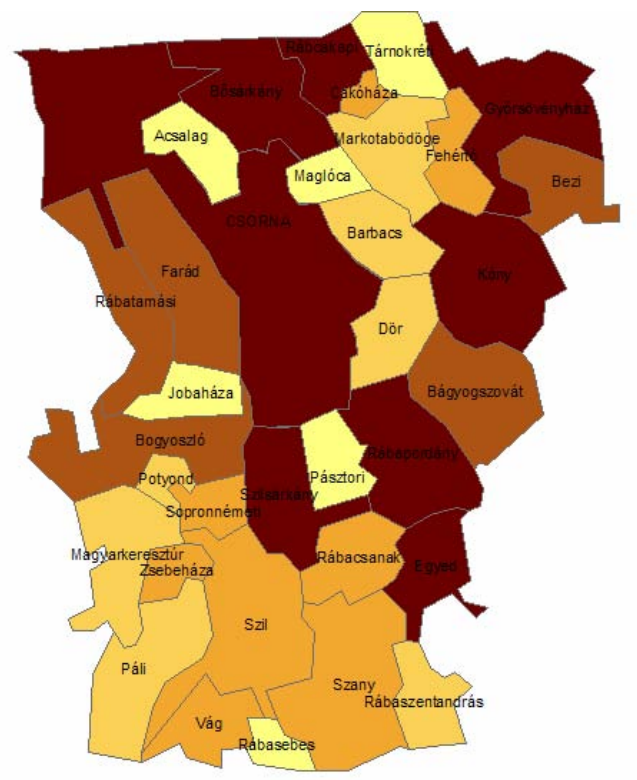

(minél sötétebb, annál magasabb a gazdasági érték a jövedelemszint, az adózók aránya és a gazdasági szervezetek száma, az iparüzési adó alapján)

27. ábra: A települések gazdasági szempontú értékelése (saját szerkesztés) 
A gazdasági érték alapján a kistérség karakteresen elkülönülö egységekre bontható: alacsonyabb gazdasági érték jellemző a dél-rábaközi falvakra és a Csornával határos tóközi falvakra (27. ábra). Magasabb aktivitás, gazdasági értékkel jellemezhető Csorna és a 85-86-os utak mentén elhelyezkedő közeli települések Bősárkány, Farád, Rábatamási továbbá a Győrhöz közelebb elhelyezkedő tóközi falvak és néhány gazdasági szempontból aktívabbnak tekinthető rábaközi település, mint Szilsárkány, Rábapordány.

\subsubsection{Elérhetőségi érték}

A közlekedési kapcsolatokat kiemelt hangsúllyal kell kezelni, hiszen több, a vidéki térségek sikerességével foglalkozó elmélet alapvető szempontként emeli ki az elérhetőség kérdését. A kistérség közlekedés földrajzi helyzete jó. Csornán keresztezi egymást a nagy forgalmú kelet-nyugati kapcsolatot biztosító 85. számú főút és az észak-déli irányú 86. sz. főút.

A transzeurópai áruszállítási törzshálózat részét képező Győr-Sopron-Ebenfurti Vasútvonal a településen halad keresztül. Csorna fontos vasúti csomópont, hiszen itt ágazik ki a Szombathely felé tartó országos jelentőségü vasútvonal emiatt a Budapest-Sopron/Szombathely Intercity járatok is megállnak Csornán. A fővonalakról leágazó három szárnyvonal a kistérségen belül 11 település számára nem biztosít vasúti összeköttetést. A Csorna-Pápa szárnyvonalat 2007-ben lezárták majd újranyitás után ma naponta két járat közlekedik.

A kistérségben egyetlen zsáktelepülés Rábasebes. Viszonylag jók a közúti kapcsolatok, azonban rendkívül rossz állapotban vannak a kistelepüléseket összekötő utak. Az elérhetőség fontos területfejlesztési szempont (elérhető a TEIR-ben elérhetőségi térkép a közúti kapcsolatok alapján), azonban a komplex értékeléshez figyelembe vettem a tömegközlekedési kapcsolatokat, amely árnyaltabb képet fest az elérhetőségi viszonyokról. Legkedvezőbb helyzetben, kiváló közlekedési kapcsolatokkal rendelkeznek a 85-86. számú főutak mentén elhelyezkedő települések, itt a tömegközlekedés helyzete is kedvezőbb. Az egyes települések helyzete a tömegközlekedés lehetőségei alapján rendkívül különbözőek: míg a 85. sz. út mentén Farád, Kóny 25-35 napi járattal van összekötve Csornával, addig Vág, Rábasebes mindössze 2-4 járattal naponta. Leginkább kieső, nehezebben megközelíthető települések a főútvonalaktól és vasutaktól távol eső, dél-rábaközi és tóközi települések a Csornával szomszédos Acsalaggal. A munka-erőpiaci kapcsolatok a tóközi települések jelentős részét Győrhöz kötik, itt annak ellenére, hogy viszonylag kedvezőtlenebb a kapcsolat a kistérségi központtal, a viszonylag jó Győrhöz kötődő autóbusz kapcsolat miatt kedvezőbb helyzetűek a települések (28. ábra). 


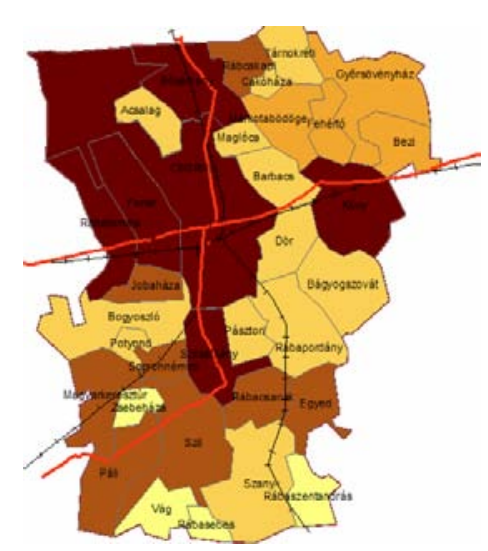

Kedvezőtlen közlekedési kapcsolatok

Alapvető közlekedési kapcsolatok biztosítottak Alapvető közlekedési kapcsolatok biztosítottak a kist. kp-tal, viszonylag jó kapcsolat a megyeközponttal Jó közlekedési kapcsolatok a kist. központtal Kiváló közlekedési kapcsolatok

\section{8. ábra: Elérhetőségi viszonyok a közút-, vasúthálózat és a tömegközlekedési lehetőségek}

\section{alapján (saját szerkesztés, adatok forrása TEIR)}

A 85-ös és a 86-os utakon bonyolódó tranzitforgalom jelentős környezeti terhelést jelent: a rendszerváltás óta rendkívül nagymértékben megnőtt a forgalom a határátkelőhelyek felértékelődése következtében. A 85-ös számú út forgalma Csorna és Győr között 13-14 000 E/nap (Győr-MosonSopron megye területrendezési terve). A kisvárost a két föút forgalma együttesen terheli, mivel az északról érkező 86-os az Eszperantó útnál torkollik a Soproni útba és délre csak több száz méterrel később ágazik el az út, Csorna belvárosán a két út együttes átmenő forgalma dübörög át, szinte már elviselhetetlen terheket róva a városra. A forgalom lassítása és a közlekedés biztonságossá tétele érdekében több körforgalmat alakítottak ki Csorna belvárosában, azonban még így is vannak nagyon balesetveszélyes szakaszok illetve vannak kereszteződések a közlekedési lámpák hibájából, ahol gyakorlatilag csúcsidőszakban lehetetlen a lekanyarodás. Az elkerülő út építése hosszas halasztás után a régészeti feltárás befejeztével megkezdődik.

A kiépített kerékpárút nagyon kevés van a térségben az elmúlt 10 évben gyakorlatilag nem is történt előrelépés ezen a területen (kerékpárutak: Bősárkány-2 km, Farád-2,8 km, Szilsárkány-3 km, Szany-1,7, Páli-1 km). A kisforgalmú utak, különösen a Hanság és a Tóköz területén a kellemes táji környezet ideális feltételeket jelent a kerékpározás számára. A Hanságban és a Rábaközben csaknem 10 éve kitáblázták az ajánlott kerékpárútvonalakat, de különösen a Hanságban a vízviszonyok nem mindig teszik lehetővé az ajánlott útvonal követését és a táblák is eltüntek. Az országos kerékpáros törzshálózat részeként a Dunántúli határmenti kerékpárút áthalad a Hanságon érintve Csorna külterületét. Innen tervezik a Rábaközi kerékpárútvonalat (Győr-Moson-Sopron megye turizmusfejlesztési programja, 2001), amely a Balaton-Rába országos útvonalhoz biztosít kapcsolatot, kiépítése, pihenőhelyek létesítése (Acsalag-Csorna-Dör-Rábapordány-Egyed-Árpás-Sobor) forráshiány következtében tolódik. Térségi jelentőségü kerékpárútként tervezett a Hanság peremi falvain keresztülfutó kijelölt kerékpártúra útvonal Kapuvár-Osli-Acsalag-Bősárkány-Rábcakapi-Tárnokréti szakasz. 


\subsubsection{Környezeti integritás érték}

Jelentős környezetvédelmi problémák nincsenek a térségben, elsősorban a terhelést jelentő tevékenységeket veszem számba. Intenzív ipari tevékenység nem települt a kistérségbe, az ipar kisebb, lokális jellegü szennyezéseket okoz. Jelentős zaj- és levegőszennyezést okoz a kistérségben a 85-86. sz. utak mentén átzúduló tranzitforgalom.

A kistérségben jellemzően a réti talajok, réti öntéstalaj és a lápos réti talaj fordul elö. Kis területen, kiváló termelési feltételeket biztosítva Bágyogszovát és Maglóca térségében található réti csernozjom talaj. A Hanságra lecsapolt és telkesített síkláp talaj jellemző (TAKI, Agrotopo adatbázis).

A talaj a magas talajvízszint (1-2 m) miatt szennyezésre fokozottan érzékeny. Környezetterhelést a lakossági szennyvíz- és hulladék-kezelés okoz. A közmüolló tág a térségben: az ivóvízhálózatba a lakások többsége bekötött, de a közüzemi szennyvízhálózatba a lakásoknak mindössze a 49\%-a van bekapcsolva, ami messze alatta marad a megyei átlagnak (80\%). Nincs kiépült szennyvízhálózat, és meg kell oldani a szennyvíztisztítást a következő településeken: Potyond, Rábcakapi, Cakóháza, Markotabödöge, Szilsárkány, Bogyoszló, Acsalag, Barbacs, Bősárkány, Szilsárkány, Bezi, Fehértó, Jobaháza, Rábatamási, Magyarkeresztúr (Agrárstruktúra és Vidékfejlesztési Program, 2004).

A mezőgazdaságban a rendszerváltás óta a mütrágya-, és peszticid-használat, valamint az intenzív állattartás okozta terhelés visszaesett, kevesebb szennyezés fordul elő.

Defláció, erózió a rábaközi talajokat kevésbé veszélyezteti, a Hanságban a lecsapolt síkláptalajok kiszáradása miatt okoz problémát a defláció.

A felszíni vizek minősége általában a III. és IV. minőségi osztályban tartozik („tűrhető víz, szennyezett víz" kategória) (Győr-Moson-Sopron megye környezetvédelmi programja). A természetvédelmi területeken komoly problémákat okoz a Keszeg-ér rossz vízminősége, amely a Barbacsi-tó és a Fehértó fokozott eutrofizációját, elnádasodását okozza, továbbá a nemzeti park szakértője szerint a Nyírkai-Hany elárasztása után a Rábca rossz vízminősége miatt nem indult be a lápképződési folyamat.

A Rábaköz felszíne alatt elhelyezkedő folyóvízi törmelékes összletben tárolt rétegvizek a jövő fontos ivóvízbázisát képviselik, amelyet a kavicsbányászat veszélyeztethet (Győr-Moson-Sopron megye környezetvédelmi programja).

Nagytérségi hulladéklerakó Jánossomorján épült, több településen is szükség van a felhagyott hulladéklerakó rekultiválására.

A környezeti integritás értéket komplexitása és elsődlegesen környezetvédelmi jellege miatt alapvetően a területhasználat jellemzőire alapozva, Corine térképi adatbázis alapján a Koschke mátrix alkalmazásával értékeltem (29. ábra és Értékelési táblázat melléklet). 


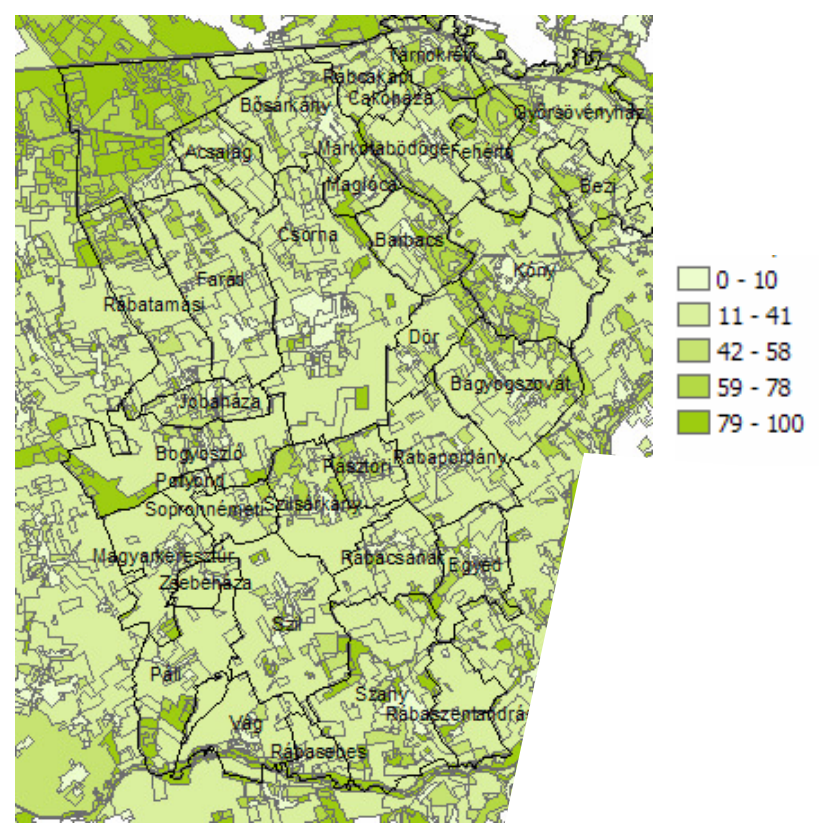

\section{9. ábra: Környezeti integritás érték Koschke mátrix felhasználásával}

\subsection{5. Élőhelyi érték}

A táj- és természetvédelem több évtizedes hagyományainak köszönhetően az élőhelyi érték települési szintü összehasonlítására többféle mutató is könnyen elérhető (11. táblázat). A térség természetvédelmi szempontú értékeléséhez a természetvédelmi területek (nemzeti park és Natura 2000 területek) valamint a Nemzeti Ökológiai Hálózat adatait használtam fel. Az élőhelyvédelem szempontjából fontos, hogy a védett természeti területek és a nem védett természetszerü élőhelyek egységes rendszert, hálózatot alkossanak. Ez az elv vezetett 1993-ban a európai ökológiai hálózat kialakítására vonatkozó igény megjelenéséhez (EECONET), amely nyomán hazánkban is megindult a Nemzeti Ökológiai Hálózat tervezése. A NÖK magába foglalja a természetvédelmi területeket, Natura 2000 területeket és a megmaradt természetszerü, természetközeli élőhelyeket. Élőhelyvédelmi szempontból tehát egy fontos mutatószámnak, mérőszámnak is tekinthetjük, hogy egy-egy településen, térségben mekkora területet foglal el az ökológiai hálózat. A Hanság és a Tóköz településein a védett területek aránya magas, több esetben is meghaladja az országos átlagot, egyaránt találunk itt Nemzeti Parki-, Nemzeti Ökológiai Hálózati-, Natura 2000-, Ramsari- és MAB bioszféra rezervátum területeket. Az 33. ábrán jól látható, hogy a Hanság és Tóköz térségében a nemzeti park védett területei és Natura 2000 területek, míg a Rábaközben a Nemzeti Ökológiai Hálózat részegységei dominálnak. A védelem típusa meghatározó a gazdálkodók számára, a nemzeti park területek többsége állami tulajdon, rajtuk gazdálkodni a természetvédelmi igazgatóság feltételei szerint lehet. Általában nem állami tulajdonban vannak a Natura 2000 területek, de szigorú természetvédelmi szabályok vonatkoznak a gazdálkodókra. A korlátozásokért a gazdálkodókat pénzügyi támogatások kompenzálják, ezzel ellen- 
tétben az ökológiai hálózathoz tartozó területeken gazdálkodók számára hasonló források nem elérhetők. Az ökológiai hálózat területén az építési feltételeket a településrendezési tervek szabályozzák.

11. táblázat: Az élőhely érték meghatározásához alkalmazott indikátorok (saját szerkesztés)

\begin{tabular}{|c|c|l|}
\hline Tájfunkció érték & \multicolumn{1}{|c|}{ Jellemző } & \multicolumn{1}{c|}{ Indikátor (adatok forrása) } \\
\hline $\begin{array}{c}\text { Élőhely } \\
\text { érték }\end{array}$ & $\begin{array}{c}\text { Menedékhely és szaporo- } \\
\text { dó hely biztosítása termé- } \\
\text { szetszerü területeken }\end{array}$ & $\begin{array}{l}\text { Nemzeti park területek aránya (TIR) } \\
\text { Nemzeti Ökológiai hálózat területeinek aránya (OTrT, } \\
\text { TEIR) } \\
\text { Extenzív hasznosítású területek aránya (Corine 2006) }\end{array}$ \\
\hline
\end{tabular}

A Dél-Hanság és Tóköz települései döntően az országos átlag feletti védettségi arányokkal rendelkeznek, hiszen ezek a települések foglalják magukba a Hanság egykori mocsárvilágának megmaradt részeit (Barbacsi-tó and Fehértó), melyek döntően fokozottan védett nemzeti parki területek és Natura 2000 területek, közöttük mocsárréteket, kékperjés lápréteket, láperdőket és keményfás ligeterdőket találunk (Melléklet XXVII.). Mindössze a kistérség területére eső NP területek 4\%-a található a Rábaközben. A már megvalósult élőhely rehabilitációs programoknak köszönhetően újra láthatunk nyílt vízfelületeket a Hanságban, ennek kiváló példája a Nyirkai-Hany, amelynek 400 hektáros területét 2001-ben árasztották el, minek hatására fontos vízimadár élőhellyé vált. A Rábaköz Natura 2000 területei elsősorban a megmaradt természetszerű erdőket (keményfás ligeterdők, pannon cseres tölgyesek, pannon gyertyános tölgyesek) és kisvízfolyásokat tartalmaznak (www.fhnp.nemzetipark.gov.hu).

A Natura 2000 területek esetében hasonló következtetést lehet levonni, itt is a Hanság-Tóköz településein magasabb az arány (Hanság-Tóköz: 65\%). A Nemzeti Ökológia Hálózat védelmi kategória megközelítőleg egyforma a két térségben (Rábaköz: 54\%) (30. ábra).

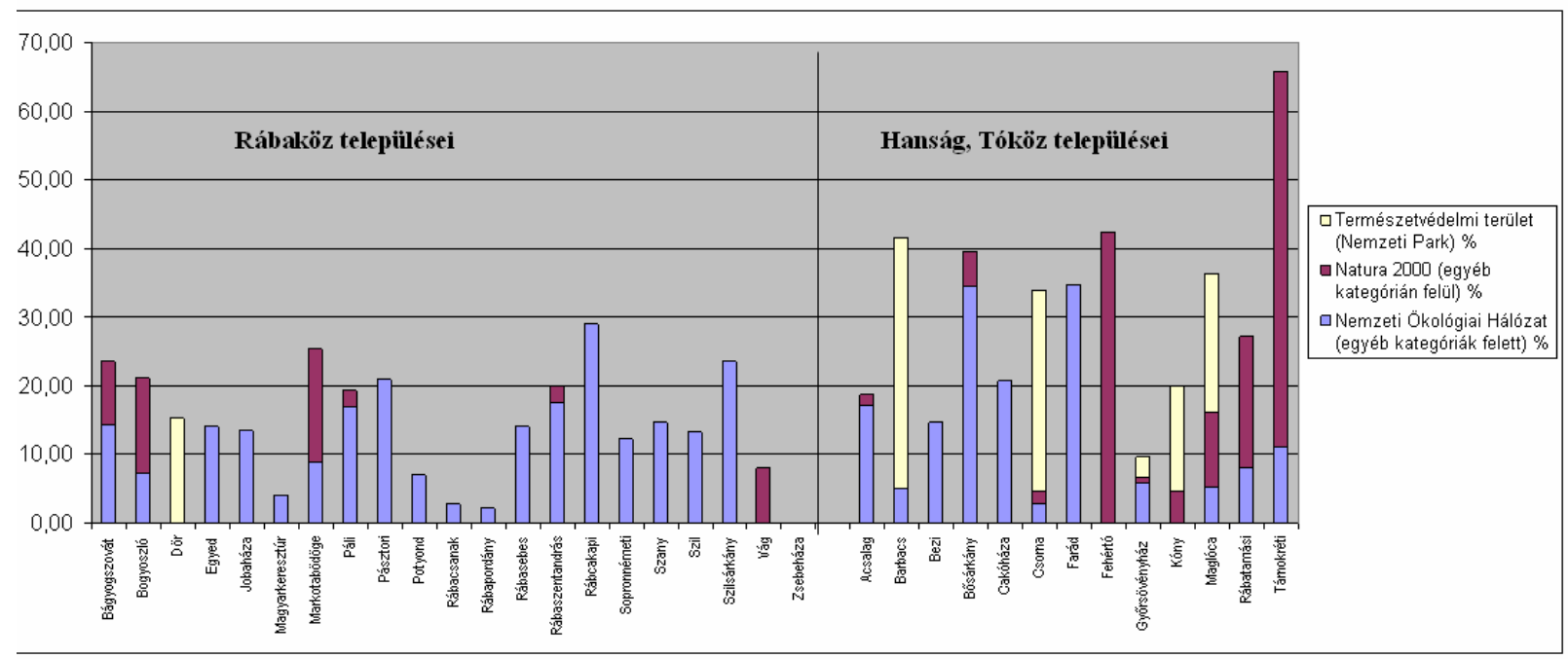

30. ábra: A védett területek aránya a Rábaköz és a Hanság településein

(Forrás: https://teir.vati.hu/) 
Több dél-rábaközi településen nagyon alacsony az ökológiai hálózat területaránya (Zsebeháza:0; Rábapordány:2,28; Rábacsanak: 2,84).

Az élőhely értéket (11. táblázat) a településekre a Nemzeti park területek aránya (TIR), Natura 2000 területek aránya (TIR), Nemzeti Ökológiai hálózat területeinek aránya (OTrT, TEIR), Extenzív hasznosítású területek aránya (Corine 2006) alapján számoltam (részletes adatok a Mellékletben XXVIII., XXIX.).

Összegzés/ élőhely érték

Karakteres különbségek figyelhetők meg a Hanság, Tóköz térsége és az évszázadok óta intenzív agrártájként megjelenő Rábaköz között, ahol egyes települések élöhelyi értéke rendkívül alacsonynak tekinthető. Fontos élőhelyeket jelentenek az erdők, a gyepek, az extenzív gyümölcsösök, a mocsaras területek, az mezővédő erdősávok stb. Kimagaslóan magas az extenzív hasznosítású területek aránya a Hanság peremterületein, egyes tóközi településeken (Fehértó 38\%, Barbacs 41\%).

\subsubsection{Tájesztétikai érték}

A táj magas szintű esztétikai értékek hordozója, az egyes tájtípusok, területhasználatok esztétikai értéke azonban különböző (12. táblázat).

12. táblázat: Alkalmazott indikátorok, tájesztétikai érték (saját szerkesztés)

\begin{tabular}{|c|c|l|}
\hline Tájfunkció érték & Jellemzö & \multicolumn{1}{c|}{ Indikátorok } \\
\hline \multirow{2}{*}{ Tájesztétikai érték } & Változatosság & Shannon-diverzitás index \\
\cline { 2 - 3 } & Természetszerüség & Extenzív hasznosítású területek aránya \\
\hline
\end{tabular}

A térség három alapvetően sík kistáj találkozásánál helyezkedik el: Hanság és a Rábaközhöz tartozó Kapuvári-sík, Csornai-sík (Melléklet XXX.). Kismértékü magasságkülönbségek jellemzőek, amelyek azonban befolyásolhatják a területhasználatot a magas talajvízszint miatt. A belvíz levezetésére sürü csatornahálózat szolgál.

A Hanság pontos lehatárolása a Rábaköztől mindig nehéz volt, ma a kistájhatár meghúzásánál egyértelműen a genetikus talajtípus elterjedése volt meghatározó: a síkláp talajok déli határa. A tájképi változatosságot a vizsgált térségben kevésbé a domborzat sokkal inkább a területhasználatok változatossága, különösen a Rábaközben a mezőgazdasági müvelési szerkezet határozza meg. A tájszerkezet a több évszázados művelés, nagyléptékủ tájalakítás következtében jelentősen megváltozott: a Hanság mocsárvilága visszahúzódott, a hozzá szorosan kapcsolódó Tóköz vizes élőhelyeinek száma/aránya lecsökkent, a Rábaköz intenzív, jórészt fátlan, a Rába árvizeitől védett mezőgazdasági térséggé alakult. 
A települések összehasonlíthatósága érdekében numerikusan értékelem a kistérség tájképi „értékét"/változatosságát. Az értékelés legfontosabb elvei a diverzitás, és a természetszerüség. Magasabb pontszámot kapott tehát az a település, amelynek jelentős részét minél természetszerübb/természetesebb és változatosabb felszínborítás jellemzi. Az esztétikai érték megállapítását a Shannon-diverzitás index ( 0,3 súly) és a természetvédelmi területek aránya ( 0,7 súly) alapján végeztem el (Melléklet XXXI.)

Az értékelés megkönnyítése érdekében nagyobb területű hasonló jegyekkel bíró tájképi szempontból egységesen kezelhető térségeket határoltam le. Nem célom részletes tájkarakter elemzés, a tájképi egységek meghatározása érdekében alkalmaztam a tájkarakter elemzés egyes lépéseit.

A tájkép változatosságát jelentősen növeli a domborzat mozgalmassága, de a vizsgált területen néhány méteres szintkülönbség fordul elő jellemzően (bár belvízveszély szempontjából ez fontos különbség). A kistérség legalacsonyabb és legmagasabb pontja között mindössze 15-20 m a különbség (Melléklet XXXII.), a térszín a Hanság felé lejt, az északi részen homokdűnék emelkednek ki. A relatív relief általában $2 \mathrm{~m} / \mathrm{km}^{2}$, a Hanság peremi részeken $2-8 \mathrm{~m} / \mathrm{km}^{2}$ (Dövényi, 2010).

A Fertő-Hanság medencére készült egy határon átnyúló projekt keretében nagyléptékü tájkarakter értékelés (Konkoly-Gyuró É.-Tirászi Á.-Wrbka T.-Prinz,M.-Renezeder C., 2010), amely tartalmazta a kistérség északi területeit. A 2010-ben kidolgozott tájkarakter elemzés alapvetően három tájkarakter típust határozott meg a kistérség részeként:

1. a lápvidék vízzel átszőtt maradványterületei, alacsony használat intenzitással, erdőgyepmozaik borítással,

2. lecsapolt lápvidék és tómedence, alacsony és közepes használat intenzitással, domináns szántó és gyep felszínborítással, és végül

3. síkvidék magas és közepes használat intenzitással, domináns szántó felszínborítással.

A részletesebb területi elemzés érdekében a tájképi egységek lehatárolásához figyelembe vettem a talajtípust, a felszínborítás jellemzőit és a tájhasználat diverzitását leíró Shannon diverzitás indexet.
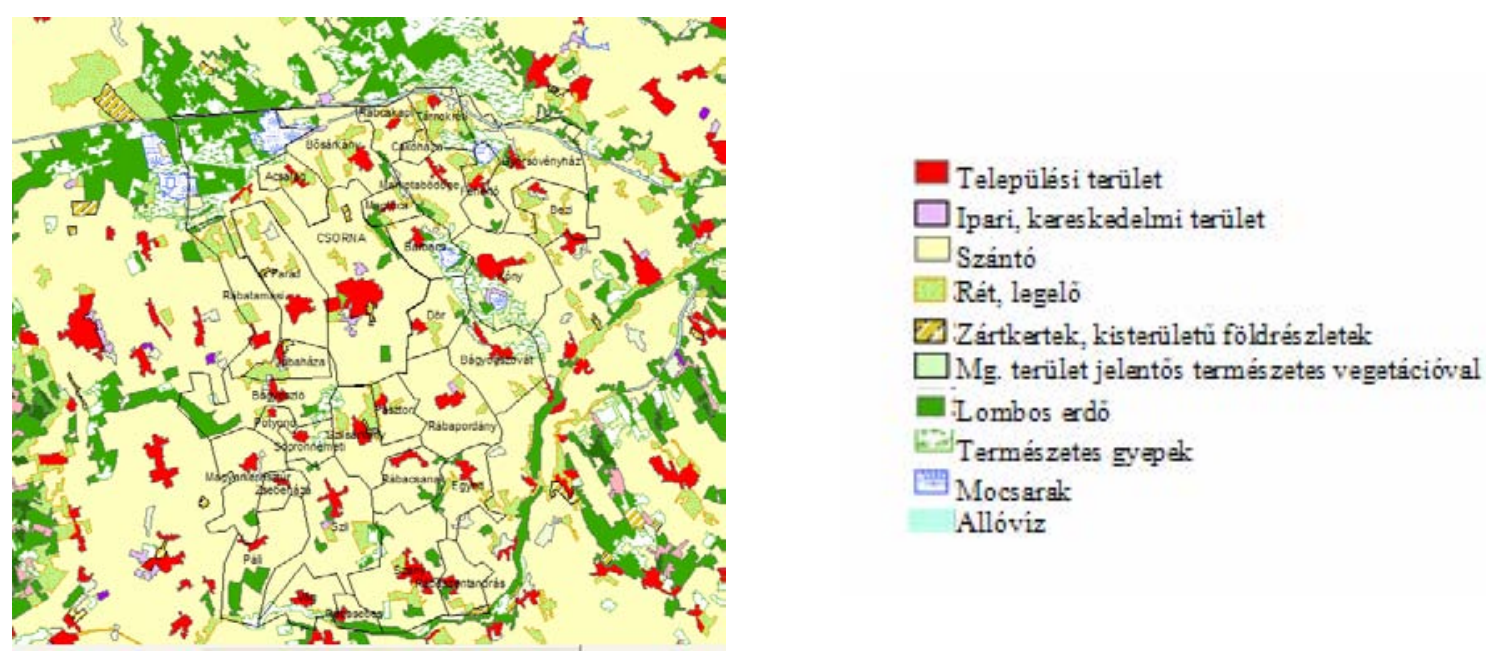

31. ábra: Felszínborítás a Corine 2006 adatbázis alapján 
A felszínborítás (31. ábra) alapján szembetünő a Rábaköz térségének magas szántó aránya, amelyet délről a Rába menti galériaerdők, északról a Hanság peremterületeinek szántó-gyep mozaikja, majd a fennmaradt mocsárvilág, északkeletről pedig a Tóköz teraszszigetei között húzódó gyepesmocsaras, tavak szabdalta sáv (Bősárkány-Bágyogszovát tengely) és keletebbre a GyőrsövényházBezi tengelyben húzódó szántó-gyep mozaikos sáv határolja. A Rábaköz déli részén egyedül Jobaháza, Bogyoszló, Szilsárkány északi része által meghatározott félkaréj alakú térségben maradtak meg nagyobb arányban az egy évszázaddal ezelőtt elterjedt rétek, legelők. A Rábaközben fennmaradt rétek, legelők, erdők a nemzeti Ökológiai Hálózat részeként élveznek bizonyos védelmet.

Térségi elemzéseknél nyújthatnak segítséget különböző térinformatikai módszerekkel előállítható tájindikátorok. A tájhasználatok változatosságát méri a Shannon féle diverzitás mutató, amely egyaránt figyelembe veszi a területen előforduló területhasználat típusok számát és nagyságát (tájhasználatok gazdagsága/richness) és egyenletes eloszlása/evenness) ${ }^{32}$ (Kollányi, 2004).

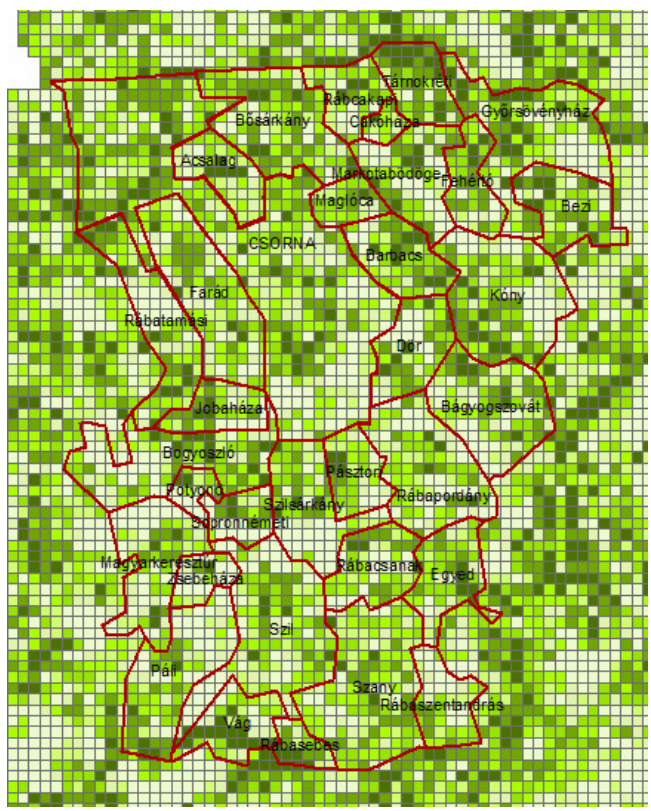

Shannon-diverzitás érték

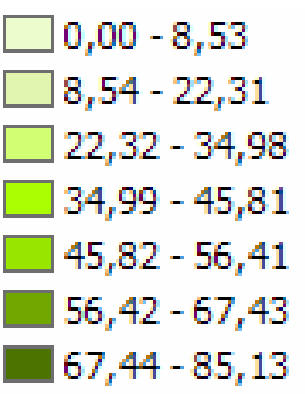

32. ábra: Tájdiverzitás a Shannon-index alapján a Csornai kistérségben (Kollányi, 2004)

A Shannon index alapján készült térkép (500x500 méteres foltokban számítja a területhasználatok változatosságát és egyenletességét), jól szemlélteti a mozaikos területhasználatú térségek megoszlását a kistérség területén: a Hanság és peremterületei, a Tóköz mozaikos sávjai és a Rába-mente (32., 33. ábra).

\footnotetext{
${ }^{32}$ A Shannon féle index számítása:m = területhasználat típusok száma, $\mathrm{Pi}=$ területhasználat típus területaránya $S H D I=-\sum_{i=1}^{m}(E * \ln P i)$
} 


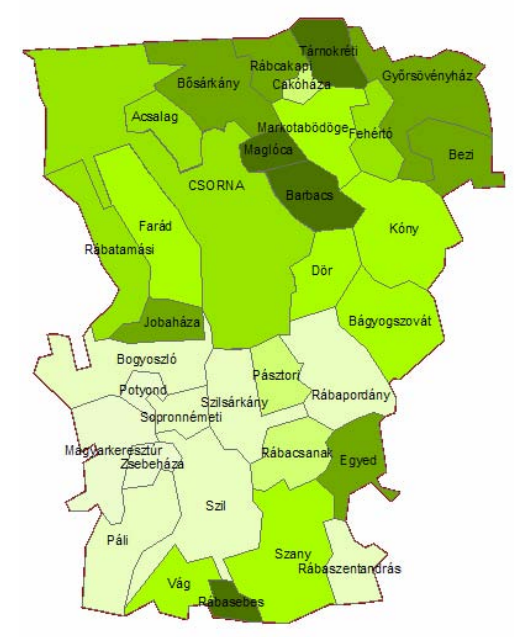

A Shannon-index településenkénti átlaga

\section{3. ábra: Tájdiverzitás települési szintü különbségei Shannon-index alapján a Csornai kistér-} ségben (saját szerkesztés)

A területhasználatok alapján négy tájképi egységet különíthetünk el a kistérségben:

1. Az egykori mocsárvilág maradványterületeit döntően tavak, legelök, erdők, alacsony intenzitású mezőgazdasági területek teszik változatossá, elsősorban a kistérség északi részein (Csorna, Bősárkány közigazgatási területének északi része). A Hanság alacsonyabb térszínein tavakat és mocsarakat fedezhetünk fel, egyébként mesterséges csatornahálózat, ültetett nyárfaerdők, láperdők és keményfás ligeterdők teszik mozaikosabbá a tájegységet. Itt találjuk a nemzeti park élöhely-rehabilitációs projektjeként megvalósult Nyirkai-Hany újraárasztott mocsár- és vízi világát.

2. A lecsapolt mocsárvilág területein közepes müvelési intenzitású müvelt területek (szántók, rétek, legelők) foglalnak helyet, elsősorban a Hanság peremvidékén és a Tóköz területén. Mozaikos tájképet eredményeznek az erdősávok és a csatornák által fragmentált szántók, legelők. Fokozott védettséget élveznek a gazdag természeti értékekkel rendelkező tavak: Barbacsi-tó, Kónyi-tó és Fehér-tó. Területét illetően Bősárkány, Maglóca, Barbacs, Dőr, Kóny, Bágyogszovát egybefüggő sávja, valamint Fehértó, Győrsövényház, Bezi térsége.

3. Síkvidéki táj, meghatározóan szántó művelési ággal, melyet két típusba sorolhatunk:

a. síkvidéki táj nagytáblás szántóföldi müveléssel

b. síkvidéki táj nadrágszíjparcellákkal, erdőfoltokkal, legelőkkel

A Rábaköz térségének jelentős része közepes és magas mủvelési intenzitású tájként írható le. A művelt területek között a vízfolyások mentén elhelyezkedő rétek, legelők rendelkeznek jelentősebb ökológiai értékkel és adnak változatosságot a tájképnek. Nem ritkák a hatalmas összefüggő szántóterületek.

4. Rába-mente galériaerdőkkel, legelőkkel szabdalt viszonylag keskeny sávja. 


\subsubsection{Rekreációs és kulturális érték}

Együtt kezelem a rekreációs, kulturális, müvészeti, nevelési funkciókat (13. táblázat). Hangsúlyozva

— a kulturális feltöltődés lehetőségei, természeti és kulturális értékek (műemlékek, tájértékek)

— a ökoturisztikai hasznosítás alapjául szolgáló lehetőséget: vízfelületek, erdők, Nemzeti Park területek,

— az aktív kikapcsolódás területei, lehetőségei.

13. táblázat: Alkalmazott indikátorok, rekreációs, kulturális érték (saját szerkesztés)

\begin{tabular}{|c|c|c|}
\hline $\begin{array}{l}\text { Tájfunk- } \\
\text { ció érték }\end{array}$ & Jellemző & Indikátorok \\
\hline 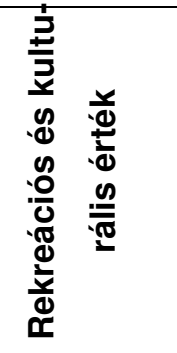 & $\begin{array}{l}\text { Rekreációs, } \\
\text { tudományos és } \\
\text { nevelési, történeti, mű- } \\
\text { vészeti } \\
\text { érték }\end{array}$ & $\begin{array}{l}\text { Jelentősebb vízfelületek } \\
\text { Természetszerü élőhelyek, kiemelten a nemzeti park területe } \\
\text { Egyéb rekreációs lehetőségek: sportközpont, strand, lovaglás lehe- } \\
\text { tőségei } \\
\text { Kulturális kikapcsolódás, feltöltődés lehetőségei (összesített telepü- } \\
\text { lésenkénti értékkataszter, műemlék és tájérték adatbázis alapján) }\end{array}$ \\
\hline
\end{tabular}

Régészeti lelöhelyekben gazdag a térség, hiszen évezredek óta lakott. Az elmúlt években zajló kutatások közül kiemelném a tájtörténeti fejezetben említett tóközi csatornarendszert, amely a térség fejlett középkori vízgazdálkodásáról tanúskodnak. A csatornarendszer sajnos a XVIII. századra jórészt lepusztult. Legjobb állapotban ma a nemzeti park területén a Fehértó közelében maradtak fenn, amely egy szabadtéri tájtörténeti kiállítás keretében bemutatható lenne.

Jelentősek a néprajzi értékek, népi hagyományok. A rábaközi és a hansági falvakban viszonylag sok, a népi építészetet idéző ház maradt fenn különösen szép az utcakép Bogyoszlón, Rábaszentandráson (lásd kép és a mellékletben a Táj-érték leltár).

A települések többségében még az aprófalvakban is találhatók műemlékek, vagy helyi védelem alatt álló értékek, köztük néhány kiemelkedő értékkel. Csornán a késő barokk stílusú premontrei rendház a kulturális örökség szép példája, épülete gazdag tárlattal rendelkező múzeumnak ad otthont. Hasonlóan múzeum és könyvtár működik az egykori püspöki kastély épületében, Szanyban. A kistérség több mủemlék-jellegü kastély és kúria épülettel rendelkezik, amelyek közülük azonban több kihasználatlan, romos állapotban van (Egyed, Farád, Magyarkeresztúr), az egyik legjelentősebb műemléki értéknek számító Rábasebesi Széchenyi kastély sorsa rendezetlen, nevét botrányok övezik.

Jelentősek a természeti értékek mellett a néprajzi értékek, népi hagyományok, fennmaradt kézmüves mesterségek. Többségük müvelésével sajnos mára felhagytak: kékfestést elsősorban Csornán és Kapuváron űzték. Máig él a fazekasság (Dőr, Csorna), gyékényfonással máig foglalkoznak Bősárkányban. 
A kulturális és természeti értékek számbavételéhez használható az egyedi tájérték kataszter, amely azonban nem készült el az ország egészére. A hazai tájvédelem különleges kezdeményezésének tekinthető az egyedi tájértékek kataszterezése. A természet védelméről szóló 1996. évi LIII. törvény (Tvt.) 6. § (3) értelmében egyedi tájértéknek minősül az adott tájra jellemző természeti érték, képződmény és az emberi tevékenységgel létrehozott tájalkotó elem, amelynek természeti, történelmi, kultúrtörténeti, tudományos vagy esztétikai szempontból a társadalom számára jelentősége van. Három nagy csoportja a kultúrtörténeti értékek, a természeti képződmények és a tájképi egyedi tájértékek.

A törvény a nemzeti park igazgatóságok feladatául rendeli az egyedi tájértékek kataszterezését. Hagyományosan az egyedi tájértékeket a védett területeken nem listázzák a kettős védelem elkerülése végett: így a kataszterezést elsősorban a települések belterületén vették számba, ezért a kataszterezett tájértékek 92\%-a kultúrtörténeti tájérték. Ha megnézzük a gémeskutak magyarországi „hálózatát”, jól látható a kistérségben lévő sürüségük, ami egyértelmüen a korábbi hagyományos extenzív legeltető állattartásra vezethető vissza (Melléklet XXXV.).

A rekreációs és tudományos-nevelési funkció elemzéséhez egyrészt értékeltem a táji adottságok nyújtotta lehetőségeket: rekreációs lehetőségeket rejtenek magukban a vízfelületek, a kirándulási lehetőséget biztosító értékes természeti területek (NP területei), az erdők, másrészt a már társadalmi hatásra létrejött attrakciókat: jelentősebb szabadidőközpontok, tanösvények, kiállítóhelyek, kerékpárutak (34. ábra). A lehetőségek alapján turisztikai adatok értékelésével igyekeztem feltárni a kihasználtság mértékét, mindezeknek az adottságoknak a kistérség gazdaságában megjelenő „,hasznát".

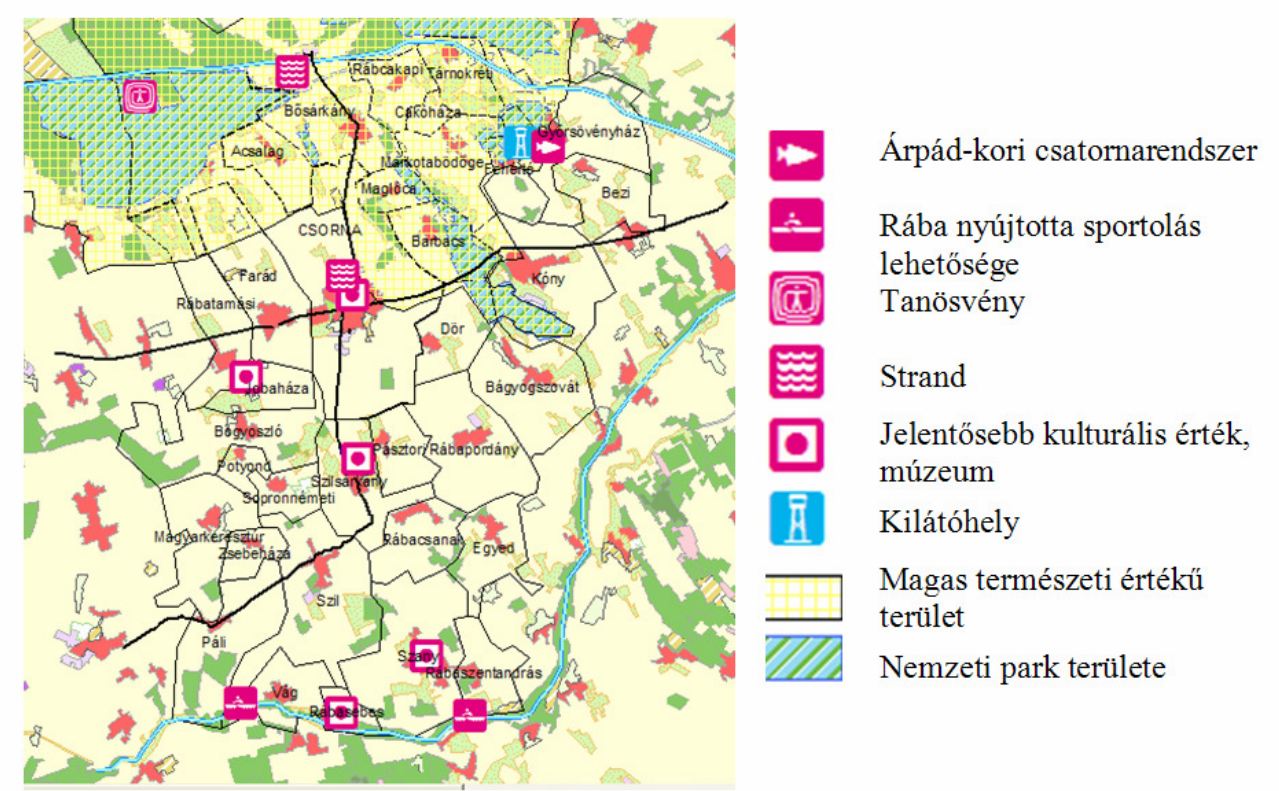

34. ábra: Jelentősebb aktív és kulturális rekreációs lehetőségek a Csornai-kistérségben

(Corine 2006 felhasználásával saját szerkesztés) 
A természeti adottságokhoz köthető rekreációs tevékenységek vizsgálatakor inkább csak megszünő lehetőségek kerültek napvilágra: a csornai termálfürdő a nagyszabású fejlesztési tervek ellenére több évre bezárt, a Rába egykori strandjai elhagyatottak, nincsenek kikötőhelyek, a Hanságban kijelölt kerékpárút jelzőtáblái eltűntek, a fehértói kilátóhely használhatatlan, életveszélyes és a sort még hosszasan lehetne folytatni. A számos bányató közül, csak néhány nyújt rekreációs lehetőséget az elmaradt rekultiváció, nehéz megközelíthetősége miatt.

A Hanságban csak egy tanösvény található, két kilátóhely és két kisebb jelentőségü kiállítás. A Nemzeti Park központja a Fertő-tó közelében fekszik, a programok inkább ide koncentrálódnak, a Hanság inkább periférikus helyzetünek tekinthető ebből a szempontból. A Rábaközben egyáltalán nem találunk tanösvényeket vagy a természeti értékekhez köthető kiállításokat. Az avatatlanok számára semmi sem árulkodik a Tóköz sajátos kora-középkori tógazdálkodásáról, pedig a Nemzeti Park területén az árokrendszerek nyomai megmaradtak.

Egy térség rekreációs/turisztikai kihasználtságának jelzőszáma lehet a szálláshelyek száma, minősége: a Hanságban és a Tóközben csak Csorna, Fehértó, Barbacs, Bősárkány, Farád, Rábatamási településen találhatók vendégházak panziók, a Rábaközben Szilsárkány és Szil valamint a Rába menti települések kivételével egyáltalán nincsenek falusi szálláshelyek. Alapvetően a fő tranzitútvonalak rajzolódnak ki a panziókat, kereskedelmi szálláshelyeket és falusi szálláshelyeket településenként ábrázoló térképen (Melléklet XXXV.).

Együttesen értékeltem településenként a kulturális, rekreációs és tudományos-nevelési funkciót (110-ig terjedő skálán). Az értékelésnél figyelembe vettem a jelentősebb vízfelületeket, természetszerü élőhelyeket, kiemelten a nemzeti park területét és a jelentősebb egyéb rekreációs lehetőségeket, mint sportközpont, strand, lovaglás lehetőségei és egyéb kulturális kikapcsolódás, feltöltődés (összesített településenkénti értékkataszter a mellékletben) lehetőségei. A Rába partjának rendezetlensége csökkenti a rekreációs értéket. Viszonyítási alapként a turisztikai hasznosulás jellemzéséhez a szálláshelyek számát illetve a vendégéjszakák számát is figyelembe vettem (Melléklet XXXVI.).

Kiemelkedik az átlagnál magasabb értékével a kistérségi központ Csorna, néhány tóközi település (Bősárkány, Fehértó), és Rába-menti község (Szany, Rábasebes, Rábaszentandrás). A megyei és a megye vagy a régió más kistérségeihez képest (a csornai kistérségben a harmadik legkevesebb a vendégéjszakák száma a kereskedelmi szálláshelyeken a régióban) nagyon alacsony volumenű a turisztikai hasznosítás még azokon a településeken is ahol jelentősebb rekreációs potenciál jelen van (Rába közelsége, Hanság közelsége, Csornán az országos jelentőségű műemlék a premontrei rendház, termálfürdő.). 
Az „Eredmények” fejezetben összegeztem a gazdasági szemponttal kiegészített tájfunkció elemzés eredményeit térségi és települési szinten és feltártam az összefüggéseket a versenyképességi helyzettel.

\section{4. Élhetőségi szempontrendszer a mintatérségben}

A szakirodalmi kutatásban feltártam, hogy a vidéki térségek sikerességének, versenyképességének nagyon sok összetevője van, alapvető fontosságú az élhetőségi szempontrendszerben kiemelt, a helyi társadalomhoz köthető jellemzők, a társadalom megújuló képessége, a demográfiai folyamatok, továbbá a helyi lakosság aktivitása, együttmüködö- és újításra-, innovációra való képessége stb. Egyes elemek értékelhetők statisztikai adatok alapján, mások nem. A népesség megújuló-képességét több statisztikai adat írja le: népességszám változás (vándorlás, és természetes szaporodás), öregedési mutató; az életkörülmények javulására, a gyarapodásra utal a lakásszám-növekedés. A vidékfejlesztési elméletek kiemelték a megújuló képességet, a helyi szereplők együttmüködési képességét, a helyi értékek, erőforrások hasznosítását oly módon, hogy a lehető legnagyobb hozzáadott értéket hozzák létre. Kutatásaim, vizsgálataim azonban nem a helyi erőforrásokkal tudatosan gazdálkodó, újító, a történeti örökséget bemutató/,,menedzselő” térség képét rajzolták meg a mintatérségben. Az agráriumban szigetszerüen látunk előremutató kezdeményezéseket (biogazdálkodás), nagy volumenü kertészeti termesztést. A természeti, a tájtörténeti értékek, mint a Hanság lápvilága, a tóközi tógazdálkodás fennmaradt emlékei általában „rejtve” pihennek, a helyi termálvíz, termálfürdő fejlesztés helyett pusztul. A helyi mezőgazdaság és az élelmiszeripar a kiváló adottságok ellenére nem állít elő nagyobb volumenben magas hozzáadott értékü, egyedi termékeket, nincsenek tájtermékek és a sort folytathatnám...

\subsubsection{Humángazdasági (demográfiai) jellemzők}

A csaknem $600 \mathrm{~km}^{2}$-es területen 34 település helyezkedik el, jól szemléltetve az aprófalvas településszerkezetet, országos átlagban viszonylag magas 5,68 településsürüség mutatóval.

2002-es adatok szerint még csak egy település rendelkezett 100 fönél kevesebb lakossal, a kistelepülések ingatag társadalmi helyzetét mutatja, hogy ez a szám négyre nőtt 8 év alatt. A települések harmada nem éri el az 500 föt, a következő harmad is az 1000 fő alatti kistelepülések csoportjába tartozik és mindössze három település lakos-száma haladja meg a 2000 föt. A kistérség egyetlen 10000 föt éppen meghaladó kisvárossal rendelkezik, ami betölti a kereskedelmi és szolgáltató-központ szerepet. A kistérség lakosságának közel harmada él a kistérségi központban.

Értékelve az elmúlt évtized népességszám változását, a kistérségben néhány település kivételével általános népességszám csökkenés tapasztalható. Erőteljesen csökkent a népességszám (egyes esetekben a 19\%-os csökkenést is elérve) a dél-rábaközi kistelepüléseken, mint Egyed, Zsebeháza, 
Rábasebes, a 8\%-ot meghaladó mértékben csökkent a népességszám szintén jellemzően dél-rábaközi településeken, de nagyobb lélekszámú településeket is ide sorolva, mint Szil és Szany (35. ábra).

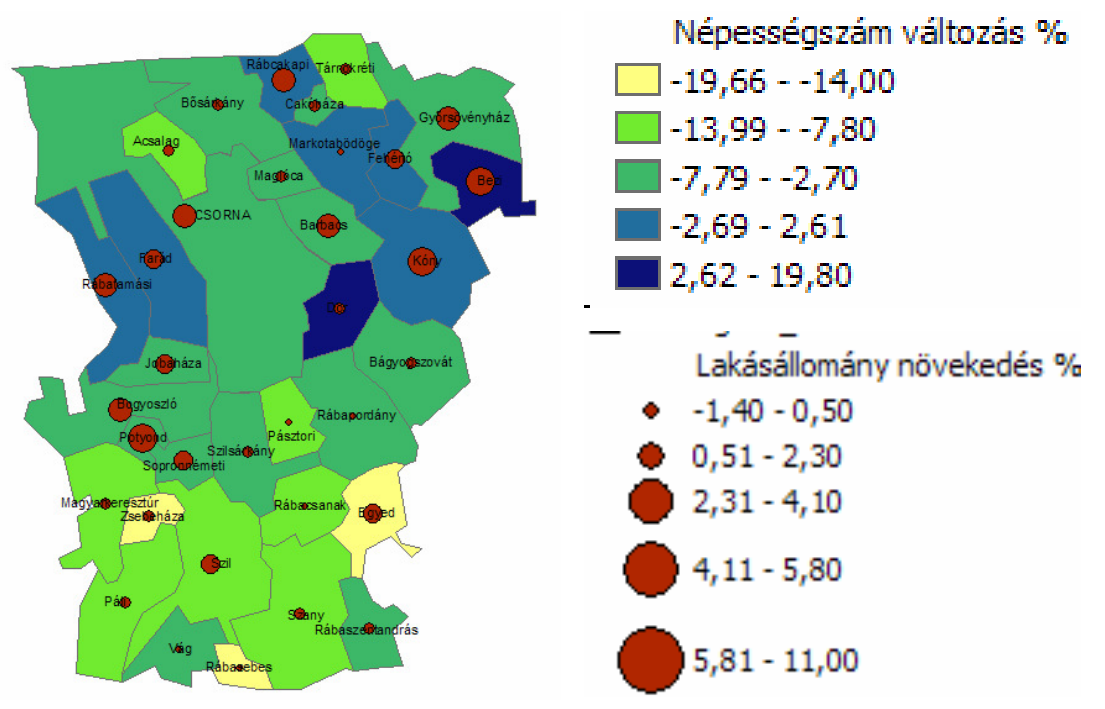

35. ábra: Népességszám változás és a lakásállomány bővülése a kistérségben (2001-2010)

(saját szerkesztés, adatok forrása: TEIR)

Kismértékben csökkenő népességszám tapasztalható Csornán és a kisvárost körülvevő településgyürüben. Stagnáló és növekvő népességszám a Tóközben és Farád, Rábatamási településeken a 85. sz. főut mentén fordul elő. Erőteljesen nőtt a népességszám Bezin (19\%) és Dőrben (10\%). A lakásállomány erőteljesebb bővülése is a kistérség északi részére jellemző (kiugróan sok új lakás épült Kónyban és Bezin). A lakosságszám változást és lakásállomány bővülését illetően egyértelműen kedvezőtlen helyzetűek a dél-rábaközi kistelepülések továbbá Tárnokréti, Acsalag. Különösen veszélyeztetettnek tekinthető az aprófalvak közül Rábasebes és Zsebeháza. A Corine 2000 és 2006-os adatainak összehasonlítása erőteljes települési területnövekedést mutat Csornán (18\%) és Kónyban (24\%) (Forrás: TEIR).

Demográfiai szempontból egyértelmüen veszélyeztetettek a dél-rábaközi aprófalvak. Több településen is gondot okoz ma már az üresen maradt ingatlanok hasznosítása. Kisebb népességfogyás illetve gyarapodás a Győrből, illetve Csornáról jól megközelíthető településeken, a 85. sz. főút mentén jellemző, néhány településre jellemző a szuburbanizáció Kóny, Bezi, mint Győr vonzáskörzete, kevésbé erőteljesen Csorna körüli településeken elsősorban Dörben. A statisztikai adatok egyértelműen jellemzik a lakosság elöregedését, az elvándorlást, az egyszemélyes háztartások arányának növekedését az aprófalvak jelentős részében, elsősorban a dél-rábaközi falvakban és a tóközi települések egy részében (36. ábra). Az 1000 lakosra jutó élve születési adat (8,4; megyei átlag: 9,8), az egyik legalacsonyabb a megyében és a halálozás aránya szintén az egyik legmagasabb (13,1; megyei átlag: 11,9; Forrás: KSH). 


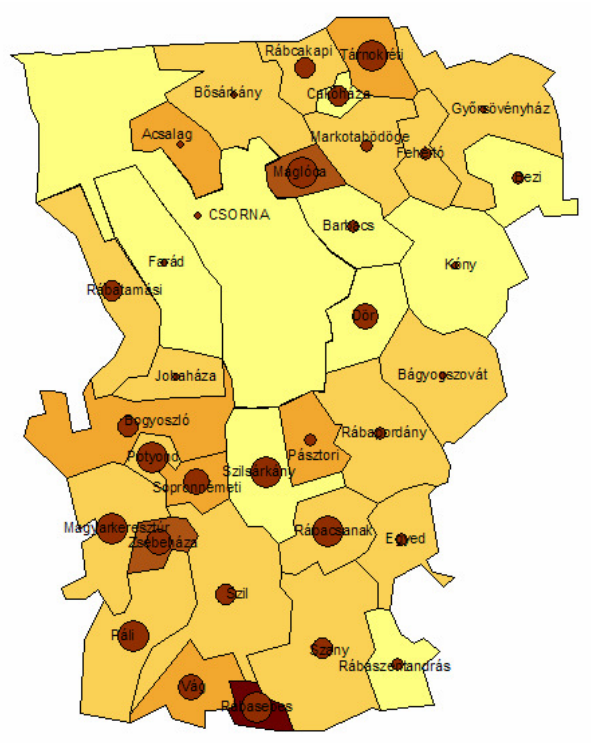

Egyszemélyes háztartások aránya \%

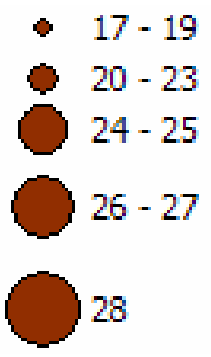

Öregedési mutató (60-X évesek száma/ 0-14 évesek száma)

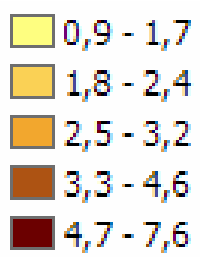

36. ábra: Egyszemélyes háztartások aránya, és az öregedési mutató a kistérségben

(saját szerkesztés, adatok forrása: TEIR és www.nepszamlalas.hu)

A kistérség aprófalvaiban az elöregedés általános tendenciáját mutatja a fenti kép. Jól látható megyei összehasonlításban, hogy a megye dinamikusan fejlődő térségeihez képest (Győr, Mosonmagyaróvár, Sopron) a kistérségben Csorna és a kisváros közvetlen vonzáskörzete (Maglóca, Barbacs, Dőr, Farád) kivételével magasabb az átlagéletkor és az átlagnál magasabb az egyszemélyes háztartások aránya.

Nincs a kistérségben felsőoktatási intézmény, a községek egyre növekvő részében (nyolc település) ma már nincs általános iskolai oktatás, valamint néhányban óvodai ellátás sincs. Az oktatás területén Csorna szerepe meghatározó, amit mutat az is, hogy két középiskolája, egy szakmunkásképzője és három általános iskolája működik. Az utóbbi évek tendenciája, hogy a gyermeklétszám csökkenéséből adódó, az oktatás, nevelés területén jelentkező nehézségeket iskola- illetve óvodatársulásokkal igyekeznek a települések megoldani (Agrárstruktúra és Vidékfejlesztési Program, 2004). A megyében itt a legkedvezőtlenebb az egyetemi, főiskolai oklevéllel rendelkezők aránya valamint a legalacsonyabb a megyében a középiskolások száma (KSH).

A működő összes bölcsődei férőhelyek száma jóval alacsonyabb a megyei és az országos átlagnál. A kistelepüléseken élők életét és gyermekvállalási kedvét jelentősen meghatározza, hogy a kistérség központjában Csornán müködik csak bölcsőde. Az alacsony gyerekszám miatt az egyetlen megoldást a családi napközi intézményének meghonosítása, elterjesztése jelentheti.

Az országos átlaghoz képest jóval kedvezőbb a kistérség foglalkoztatottsága, az alacsony munkanélküliséget azonban jelentős mértékben a kistérségen kívüli ingázás eredményezi (37. ábra). Jelentős vonzásközpontok Csorna mellett Szany, Bősárkány, Szil továbbá a kistérségen kívüli ipari és szolgáltató centrumok (Győr, Beled, Kapuvár, Pápa, Enese, Pér, Jánossomorja). 


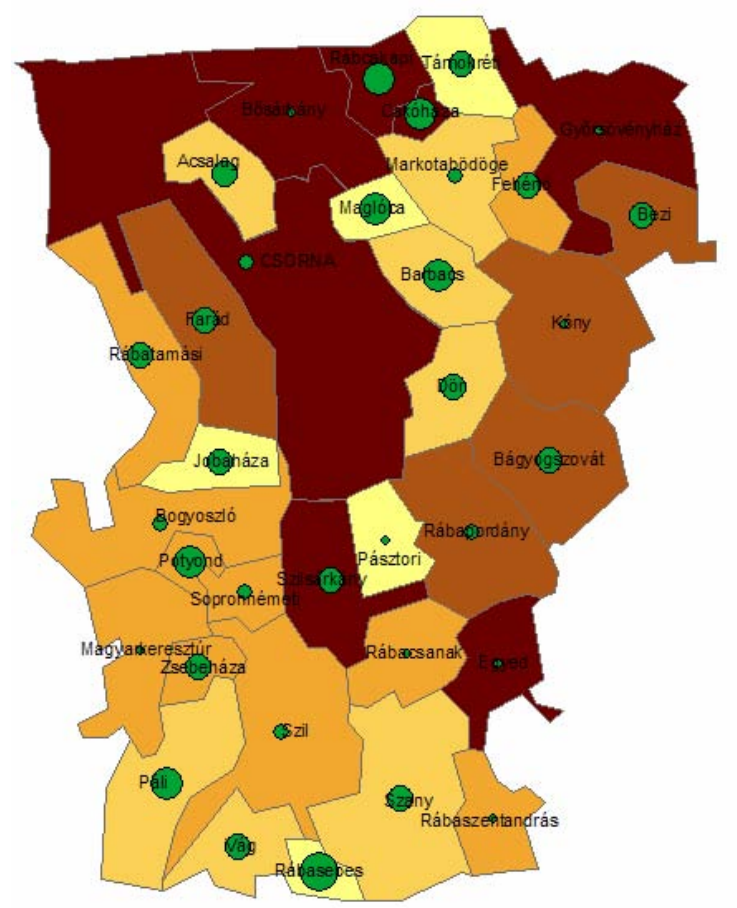

Adófizetők aránya népességben \%

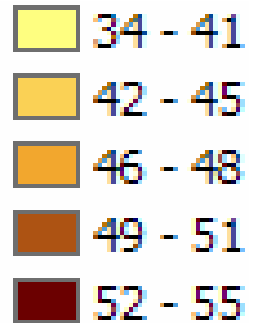

Regisztrált munkanélküliek aránya a népességben

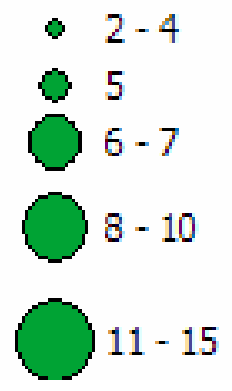

37. ábra: A foglalkoztatottság mutatói a kistérségben

(saját szerkesztés, adatok forrása: TEIR, 2012)

A kistérségben nincsenek jelentősebb nemzetiségi illetve etnikai kisebbségek. Számát tekintve jelentősebbnek mondható a roma népesség Csornán (71 fő), Szilban (28 fö), Szanyban (15 fö) (www.nepszamlalas.hu (2008. november)). Szinte minden településen él néhány külföldi állampolgárságú család, aki az év nagyobb részét itt tölti, viszont nem állandó lakos (osztrák, német, holland állampolgárságú családok.)

\subsubsection{Társadalmi értékrend, civilszféra értékelése}

A térség önszerveződő képessége nagyon jó, országos összehasonlításban magas a civil szervezetek száma, amelyek elsősorban a településekhez kötődnek (Agrárstruktúra és Vidékfejlesztési Program, 2004), több országos és nemzetközi hírü néptánc és hagyományőrző csoport van közöttük. Viszonylag szűk, de évről-évre bővül a kulturális rendezvények száma (Rábaközi perecfesztivál - Páli, Uborkafesztivál - Markotabödöge, Aratófesztivál - Szil és Farád, Rábaközi kiállítás és vásár Csorna, Kistelepülések régiós találkozója - Sopronnémeti, lovasnapok - Farád, Országos Bionap Mihályi), azonban még nem alkalmasak önálló turista-csalogató programmá válásra.

A kistérségben élők tájhoz való viszonyáról valamint a térség fejlődési lehetőségeinek értékelésérő kérdőíves felmérést készítettem, amely során igyekeztem a kistérség több településén élő lakos véleményét regisztrálni. A megkérdezettek az egyes szempontokat 10-es skálán értékelték (kérdőíves eredmények grafikonos feldolgozása a Melléklet XXXVIII.). 
A közvélemény-kutatás során (több mint 40 kitöltött kérdőív alapján) arra kerestem a választ,

- hogy a lakosság hogyan vélekedik a táji adottságok fontosságáról, szerepéről a térség fejlődése szempontjából,

— a lakosság mennyire elégedett a környező táj fenntartásával, a lakókörnyezet minőségével.

Az elégedettséget firtató kérdésekre adott válaszok alapján viszonylag negatív vagy pesszimista kép, elégedetlenség rajzolódik ki a lakosság hozzáállásában, aminek ellentmond, hogy elköltözési szándék csak kivételesen egy-két esetben merült fel. A kérdések egy csoportja azt kutatta, mennyire elégedettek a térség lakosai a természeti környezettel. Leginkább elégedettnek mutatkoztak a térségben lakók a zöldterületek állapotával - a 10-es skálán a válaszok átlaga 6,63 lett. Kevésbé elégedettek a megkérdezettek a kistérségben a táj fenntartásával és legelégedetlenebbek a környezetminőségével (4,75-as átlag). A környezetminőség leértékelésében valószínüleg a nagy átmenőforgalom okozta zaj- és légszennyezés miatti elégedetlenség nyilvánul meg.

Rendkívül nagy elégedetlenség nyilvánult meg az utak állapotát illetően a lakosság részéről, a településeket összekötő úthálózat felújításának szükségességét több szakmai dokumentum is jelzi (10-es skáláról 2,85 lett a válaszok átlaga).

Az átlagosnál alacsonyabb az elégedettség a kulturális lehetőségekkel és az aktív pihenés lehetőségeivel.

A következő kérdéscsoport a térség fejlödéséhez szükséges összetevőket vizsgálta, azaz a lakosság mennyire tartja fontosnak az önkormányzatok, a civil szervezetek és táji adottságok szerepét. Legnagyobb elvárásokkal a lakosság az önkormányzatok felé fordul, és velük szemben nyilvánul meg a legnagyobb elégedetlenség is $(3,7)$, de a civil szféra kezdeményezőképességével sem elégedettek. A megkérdezettek $84 \%$-a tartja hasznosíthatónak a térség fejlődése érdekében a táji adottságokat.

Arra kérdésre, hogy milyen kihasználatlan lehetőségeket rejtenek a térség fejlődése szempontjából a táji adottságok, messze első helyen (az összes válaszadó ezt jelölte meg elsőként) a termálvíz szerepel, majd másodikként a Fertő-Hanság Nemzeti Park és a falusi turizmus lehetőségeit említették. Második csoportban említik a mezőgazdaság, a szélerőmű és a helytörténeti kiállítás lehetőségeit. Érdekes, hogy a Rába, a vízi turizmus lehetőségeivel csak minimális mértékben számolnak.

A megkérdezettek mindössze 35\%-a érzi úgy, hogy a térségre megfogalmazható, leírható jellegzetes tájkép létezik, és még ennél is kisebb arányuk, a válaszadók töredéke tudta jellemezni azt (Kisalföldi síkvidéki erdők, folyópartok, patakok, Hansági füzesek, nádasok).

A térség lakói a legjelentősebb táji adottságoknak a Hanságot (Fertő-Hanság Nemzeti Park) és a termálvizet tartják, több válaszban is megjelent a Rába, a változatos táj és a környék tavai. A térség kitörési lehetőségét a többség a termálfürdő létesítésében, az idegenforgalomban és a falusi turizmusban látja. Kisebb arányban, de hangsúlyosan megjelenik a mezőgazdaság és az ipar nyújtotta lehetőségek kiaknázása. 


\section{Következtetések}

A kérdőív alapján elég karakteresen kettős hozzáállás rajzolódott ki:

— egyrészt a lakosok jelentős része tartja fontosnak a helyi adottságokat, és az ezekre alapuló fejlődés lehetőségeit,

— másrészt elég markánsan megjelenik, hogy sokan nem ismerik a helyi értékeket.

A kérdöív eredményeiből egyértelmü, hogy fel kell hívni a helyiek figyelmét a térség értékeire, szükség lenne a nemzeti park erőteljesebb nyitására a lakosság felé: iskolai programok, lakossági programok számának növelésére, több tájékoztatásra. A tájépítészet eszközeit is igénybe kell venni az aktív pihenés lehetőségeinek bővítésére. Nagy hiányosság a táji identitás hiánya (jellemző tájképet a megkérdezettek többsége nem tudott leírni), erősíteni kell a karakteres tájképi elemeket: erdősávok, patakok, cserjések, fás legelők, legelők, csatornák menti karakteres növényzet, utcafásítás, kavicsbánya-tavak rekultivációja stb.

\subsection{Környezeti fenntarthatóság és versenyképesség}

Az ökológiai értékek védelme össztársadalmi érdek, nagyon fontos azonban, hogy a helyi lakosság, vállalkozások számára a természetvédelmi korlátozások ne jelentsenek az élhetőséget és a versenyképességet veszélyeztető korlátokat. A természetvédelem leginkább a mezőgazdasági tevékenység természetkímélő irányban történő korlátozása és az építési tevékenység szabályozása révén fejti ki hatását. A mintatérségben értékeltem, hogy a természetvédelmi célú szabályozás milyen mértékü korlátokat jelent a helyiek számára és milyen mértékü a kompenzáció illetve az egyéb hasznosítási lehetőségek ,haszna”.

\subsubsection{Környezetgazdálkodási kompenzáció}

A természetvédelmi területek kiemelkedően magas aránya jellemző a hansági és tóközi településeken, aminek nagy jelentősége van a térség ökológiai értékeinek, a hajdani mocsárvilág maradványainak megőrzésében. A természetvédelem azonban korlátozást jelent a gazdálkodás számára. Az agrár-környezetvédelmi program egyik fontos célja, hogy a természetvédelmi korlátozások ne jelentsenek egyben jelentős jövedelemveszteséget a helyi gazdálkodóknak, hiszen ez komoly versenyképességi hátrányt jelenthet. Összevetettem az agrár-környezetvédelmi kifizetések (részletes adatok a Mezőgazdasági és Vidékfejlesztési Hivatal honlapján elérhetők) mértékét a védett területek arányával. Az elemzésben feltártam, hogy alapjában véve nincs szoros korreláció a védett területek aránya és az agrár-környezetvédelmi kifizetések mértéke között egyes településeket leszámítva (pl. Fehértó, Maglóca). Néhány településen hiába nagyon jelentős a Natura 2000 területek aránya, az agrárkörnyezetvédelmi kifizetések szintje alacsony (Tárnokréti). Győrsövényház esetében ellenkező példát láthatunk: bár alacsony a védett területek aránya, a gazdálkodók jelentős agrár-környezetvédelmi forrásokat kapnak, ami elsősorban néhány szervezet által vitt ökológiai gazdálkodásnak köszönhető. 
Magas az agrár-környezetvédelmi kifizetések aránya több rábaközi településen az állattartás nagyobb jelentősége miatt (38. ábra). A 2012-es adatok az agrár-környezetvédelmi kifizetések még erőteljesebb polarizálódását mutatják.

A „Magas Természeti Értékü Terület” programnak kimondottan a mezőgazdasági hasznosítás és a természetvédelem összehangolása (2002-ben indított Érzékeny Természeti Területek) volt a célja, azokon a tájegységeken jelöltek ki MTÉT területeket, ahol a természeti értékek fennmaradásának feltétele a mezőgazdasági hasznosítás (Melléklet XXIX.). A gazdálkodók részvétele a programban lehangolóan alacsony.
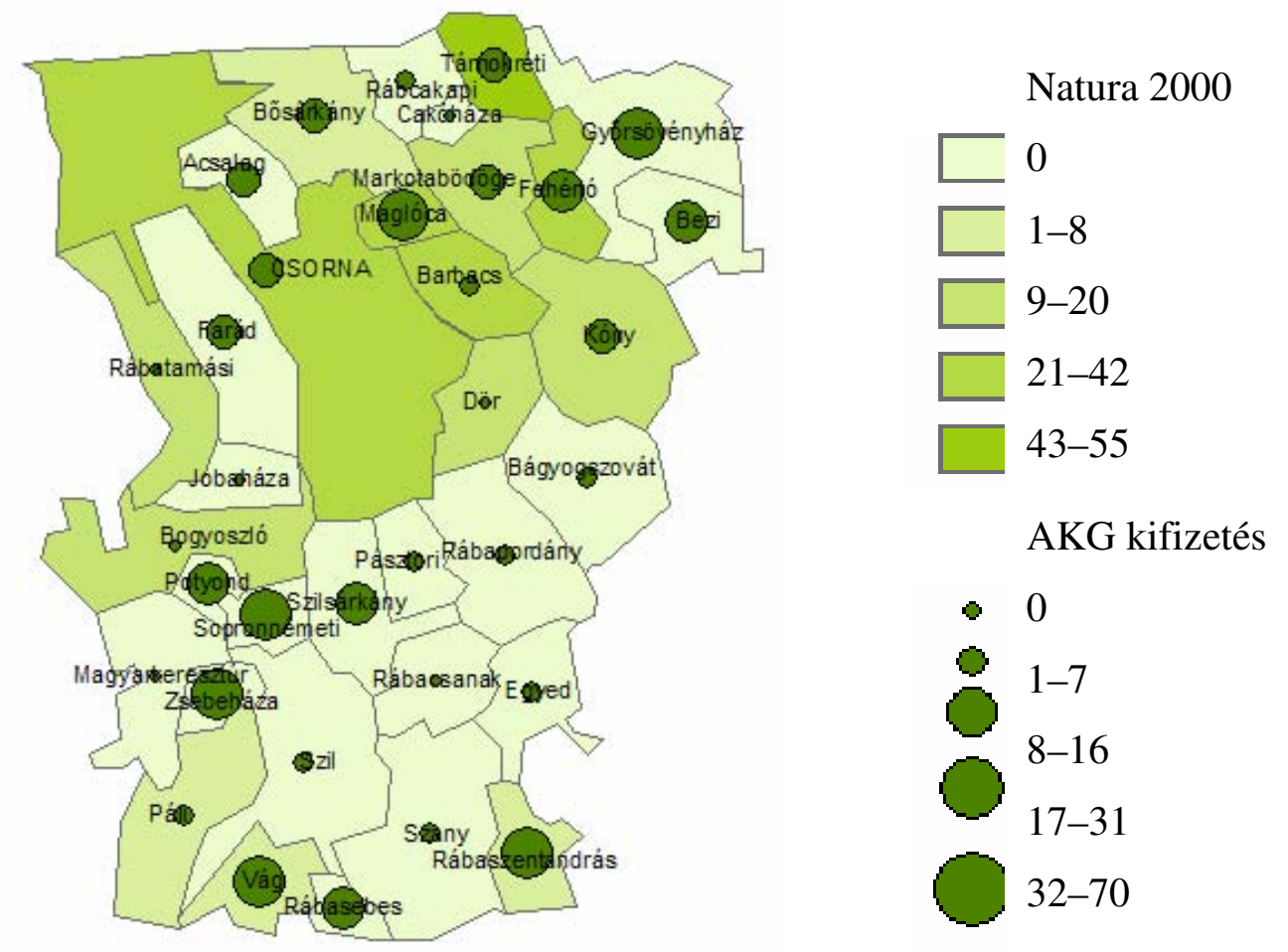

38. ábra: Nemzeti Park és a Natura 2000 területek összesített aránya (színezés), valamint az agrár-környezetvédelmi kifizetések aránya a direkt kifizetések arányában (2011) (kördiagram) (saját szerkesztés)

A magas természeti értékü területek jelentő ökoturisztikai vonzerőt jelenthetnének, a tájfunkció elemzés alapján látható, hogy gyakorlatilag nincs turisztikai hasznosítás.

\subsubsection{Szabályozási keretrendszer müködése a mintatérségben}

A fejlesztési prioritások ismeretében tanulmányoztam a települések szabályozási terveit, a stratégiákban hangsúlyozott szempontok megfelelését kerestem a tervekben:

Milyen mértékben, hogyan jelenik meg

- a táj-, a biodiverzitás védelme,

— a mezőgazdasági tevékenységhez kapcsolódó kiegészítő tevékenységek különös hangsúllyal a falusi turizmus, a kézmüves mesterségek ösztönzése. 
Különösen a tóközi, a Hanság menti településeken szinte kivétel nélkül az általános mezőgazdasági övezeten kívül alkalmaztak korlátozott hasznosítású övezetet (eltérően az OTÉK gyakorlatától), ahol elsődleges prioritás a rét, a legelő müvelési ág megőrzése illetve a természetkímélő gazdálkodás előnyben részesítése. Az előírások részletezettsége igen eltérő volt az egyes szabályozásokban.

Általánosan jellemző, hogy az OTÉK által felsorolt építményeken kívül egyéb a mezőgazdasági tevékenységhez kapcsolódó kiegészítő tevékenységek épületeit/építményeit nem engedélyezték. Kivételes esetekben fordult elő, hogy a mezőgazdasági üzemi területhez kapcsolódóan falusi turizmus épületei elhelyezését engedélyezték. Néhány település szabályozásában egyedi rekreációs, idegenforgalmi célú területet határoltak le. A mezőgazdaság szabályozása nem ösztönzi gazdálkodók körében a kiegészítő jövedelemszerzés lehetőségeinek terjedését, a multifunkcionális agrárgazdálkodás kialakulását.

A táj történetének sajátos lenyomata, a tóközi tógazdálkodás emlékeit idéző csatornarendszer, amelyek egy része a Nemzeti Park területére esnek, sajnos helyreállításuk, akár bemutatásuk sem megoldott. Az egykori fok- és tógazdálkodáshoz hasonló gazdálkodás visszaállításának kevés esélye van, egyedül Bezi terveiben jelenik a hajdani tógazdálkodás felélesztésének lehetősége.

2010-ben fogadták el a megye területrendezési tervét a hosszú távú tájhasználatra vonatkozóan meghatározóak az ökológiai hálózat övezetei, az erdőtelepítésre alkalmas területek lehatárolása, a tájképvédelmi területek, a komplex tájrehabilitációt igénylő övezetek és a belvízjárta területek. A terv az egyes övezetek tájhasználatára vonatkozóan a természeti, táji értékek védelmét szolgáló javaslatokat fogalmaz meg.

Összességében megállapítható, hogy a terület- és településrendezési tervek eszközrendszere alapvetően a korlátozásokat szolgálja, nem elégséges a táji adottságok fenntartható hasznosításának javítására a vidéki térségek versenyképessége érdekében. Olyan tervfajta, amely kimondottan az előbb említett célokat szolgáló komplex beavatkozásokra, mủvelési ágak megválasztására, új funkciók megalapozására, tájrehabilitációra stb. tennének javaslatokat hazánkban gyakorlatilag nem vagy csak kivételes esetben tanulmánytervként készülnek (Schuchmann, 2009). A területfejlesztési törvény elfogadása előtt készült tájrendezési tervek voltak alkalmasak a fenn említett célokra, bár finanszírozásuk, megvalósításuk nem volt biztosított és nem is illeszkedtek a tervezési rendszerbe.

Hasznos lenne, ha mikro-térségi és/vagy kistérségi szintű tájrendezési/tájgazdálkodási tervek készülnének. Mikro-térségi és/vagy kistérségi szintü tájrendezési terv célszerü tartalma:

— a térség területi adottságainak, értékeinek, potenciáljainak bemutatása és értékelése,

— tájfunkciók értékelése,

— a térszerkezet, a területhasználat, a tájhasználati funkciók térségi szintủ értékelése, összehangolása, 
— tájminőségi célkitüzések megfogalmazása,

— tájhasználati konfliktusok feltárása, javaslatok a feloldásra

— javaslatok a táji adottságok fenntartható, a lakosság számára megfelelö jövedelemszintet biztosító hasznosításának meghatározására,

— alulhasznosítás megszűntetése, rehabilitációt igénylő területek feltárása, utóhasznosítás meghatározása, kistérségi szintü összehangolása,

— a települések és a térség egyéb szereplői által preferált fejlesztések összehangolása, területi vonatkozásainak meghatározása, harmonizálása,

— rekreációs, turisztikai fejlesztési területek lehatárolása, térségi szintü összehangolása,

— mezőgazdasági termesztés értékelése,

— javaslatok nagyobb hozzáadott értéket létrehozó termesztési módok elterjesztésére.

\subsection{Versenyképesség értékelése}

A tanulmány alapvető célja a választott térség versenyképességi értékelése, amely magába foglal egy nagytérségi szintü, a kapcsolatrendszer elemzésére kiterjedő értékelést (nem számszerüsített, inkább pozícionálást segíti), továbbá a kistérségen belüli különbségek feltárását (élhetőségi, versenyképességi szempontok alapján).

\subsubsection{Nagytérségi kapcsolatrendszer értékelése}

A versenyképesség jobbára térségi (regionális, nemzeti) és globális szinten értelmezhető. Fontos szempont, hogy ezeken a szinteken a vizsgált térség milyen módon találta meg a helyét, funkcionálisan hogyan illeszkedik a nagytérségi kapcsolatrendszerbe. Településhálózati és vonzáskörzeti szerepkört tekintve a kistérség jelentős része Győr agglomerálódó térségéhez tartozik, a járási központ Csorna munkaerő-piaci vonzáskörzete jóval kisebb, mint a közigazgatási körzet. A járásközpont kiváló közlekedés-földrajzi helyzete ellenére nem tudott valós térségi szerepkört kialakítani (Melléklet XXXIX). Sem jelentősebb ipari tevékenység sem, felsőoktatási központ, vagy egyéb kutatásfejlesztés nem települt a kistérségbe, emiatt nem része a Dunántúl Duna-menti és osztrák-magyar határ menti fejlődéstengelyének (Gazdasági-technológiai magterület OFTK, Melléklet XL.). Magába foglalja a megye legfejletlenebb, leszakadó térségeit.

Határ-menti elhelyezkedése ellenére gyakorlatilag nem rendelkezik határon átnyúló kapcsolatokkal. A mintatérség szükebb értelemben a Bécs-Pozsony-Győr ,,aranyháromszög”-ként is emlegetett dinamikusan fejlődő régió illetve a tágabb térséget felölelő Centrope régió perifériáján helyezkedik el, funkcionális szempontból azonban nem tudott ezekbe a fejlődési zónákba, együttmüködési rendszerekbe bekapcsolódni (Melléklet XLI.).

A Fertő-Hanság Nemzeti Park hansági fokozottan védett területei a kistérségben helyezkednek el, tehát országos szinten is jelentős ökológiai értékekkel rendelkezik, amely azonban még regionális 
jelentőségű vonzerőt sem jelent a térségnek (az OFTK-ban táji értékeken alapuló fejlesztési térségek között a Hanság nem jelenik meg Melléklet XLII).

\subsubsection{Mintatérség településeinek összesített versenyképességi értékelése}

A tájhasználatok értékelésekor már elég sok szó esett a térség településeinek gazdaságáról, aminek egyik legfontosabb meghatározója az itt élők jövedelemszintje. A lakosság jövedelmi helyzetét értékelve karakteresen elkülönülő térségeket lehet lehatárolni, magas jövedelemszint jellemző általában a kistérség északi részére: Csornára és a jó elérhetőségi mutatókkal rendelkező hanságmenti (Farád, Rábatamási) és tóközi falvakra (Kóny, Győrsövényház, amelyek erőteljesebben kötődnek Győrhöz) településekre, kivéve a kistérségi központhoz kötődő települések egy részét. E jelenség arra utal, hogy valószínűleg Csorna nem tud megfelelő számú és jövedelmezőségű munkahelyet biztosítani a környező kistelepülések lakói számára. Alacsonyabb jövedelem-színvonallal jellemezhetők a délrábaközi falvak, egy-két jelentősebb helyi iparral rendelkező település kivételével (Melléklet XLIII).

A gazdasági szervezetek száma, adófizetők aránya és a lakosság jövedelemszintje alapján összesítve értékeltem (az értékek alapján, a megyei átlaghoz viszonyítva a településeket 10-es skálán helyeztem el) a gazdasági helyzetet. Az egyéb tájhasználati funkciók szintjének összevetéséhez az összesített elemezésben felhasználtam ezt a gazdasági mutatót.

A társadalmi, gazdasági indikátorok felhasználásával összesített, versenyképességi elemzést végeztem: a demográfiai folyamatok (népességszám változás, öregedési mutató, közszolgáltatások elérhetősége (Megyei Területfejlesztési Koncepció, Helyzetfeltárás)) és a gazdasági helyzet (gazdasági érték) összevetéséből jól elhatárolható településcsoportok rajzolódtak ki (eredmények fejezet).

\subsubsection{A fejlesztéspolitika hatékonysága}

A hazai forráshiányos környezetben felértékelődött az Európai Unió regionális politikájának a jelentősége, amely az ágazati és az országos érdekeket megtestesítő operatív programokon (Környezet és Energia OP., Gazdasági OP., Közlekedés OP., Társadalmi Infrastruktúra OP., Társadalmi Megújulás OP...) valamint a regionális operatív programokon keresztül finanszírozza a fejlesztéseket.

A vizsgált térségben a Nyugat-Dunántúli Regionális Operatív Program a meghatározó, amely fő célkitűzései:

— Regionális gazdaságfejlesztés

— Turizmusfejlesztés - Pannon örökség megújítása

— Városfejlesztés

— Környezetvédelmi és közlekedési infrastruktúra

— Helyi és térségi közszolgáltatások fejlesztése 
Táji szempontból meghatározók a környezetvédelmi és infrastruktúra-fejlesztések, ahol kiemelt figyelmet szentelnek a kistelepülések szennyvízkezelésének megoldására és az aprófalvas térségek elérhetőségének javítására. A Pannon örökség megújítása prioritáson belül, amely a turisztikai fejlesztéseket fogja össze, a NYDP kiemelten kezeli a tájegységi szintü ökoturisztikai fejlesztéseket, és nevesíti a Hanság és a Rába térségét.

A regionális gazdaságfejlesztés hatásai kisebbek, hiszen beruházási támogatás nem adható azon vállalkozások részére, amelyek nettó árbevételének több mint 50\%-a mezőgazdasági tevékenységből származik, vagy olyan településeken valósul meg, amelyek népsürüsége nem nagyobb, mint 100 fö $/ \mathrm{km}^{2}$, vagy állandó népessége nem haladja meg az 5000 főt, azaz ebben az aprófalvas, döntően agráradottságú térségben a települések többsége ki van zárva ebből a támogatási formából.

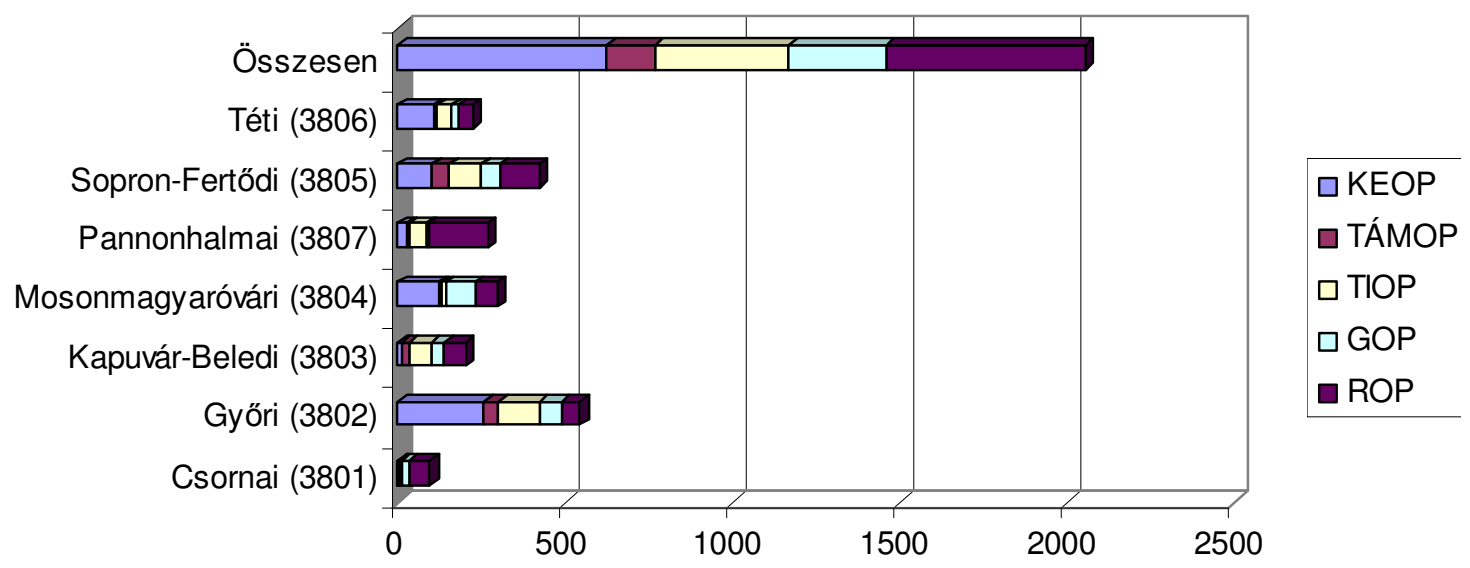

39. ábra: Győr-Moson-Sopron megye kistérségeinek részesedése 2007-2011 időszakban (egy főre jutó támogatás ezer Ft) a Környezet és Energia, a Társadalmi Megújulás, a Társadalmi Infrastruktúra és a Gazdaságfejlesztés valamint a Nyugat-Dunántúl Regionális Operatív Programból (saját szerkesztés, adatok forrása: TEIR)

A 2007-2013-as programozási időszak ágazati és regionális operatív programjai alapján GyőrMoson-Sopron megye kistérségeinek pályázási eredményességét összehasonlítva, a megye legkevésbé sikeres kistérségének tekinthető a vizsgált terület (39., 40. ábra).

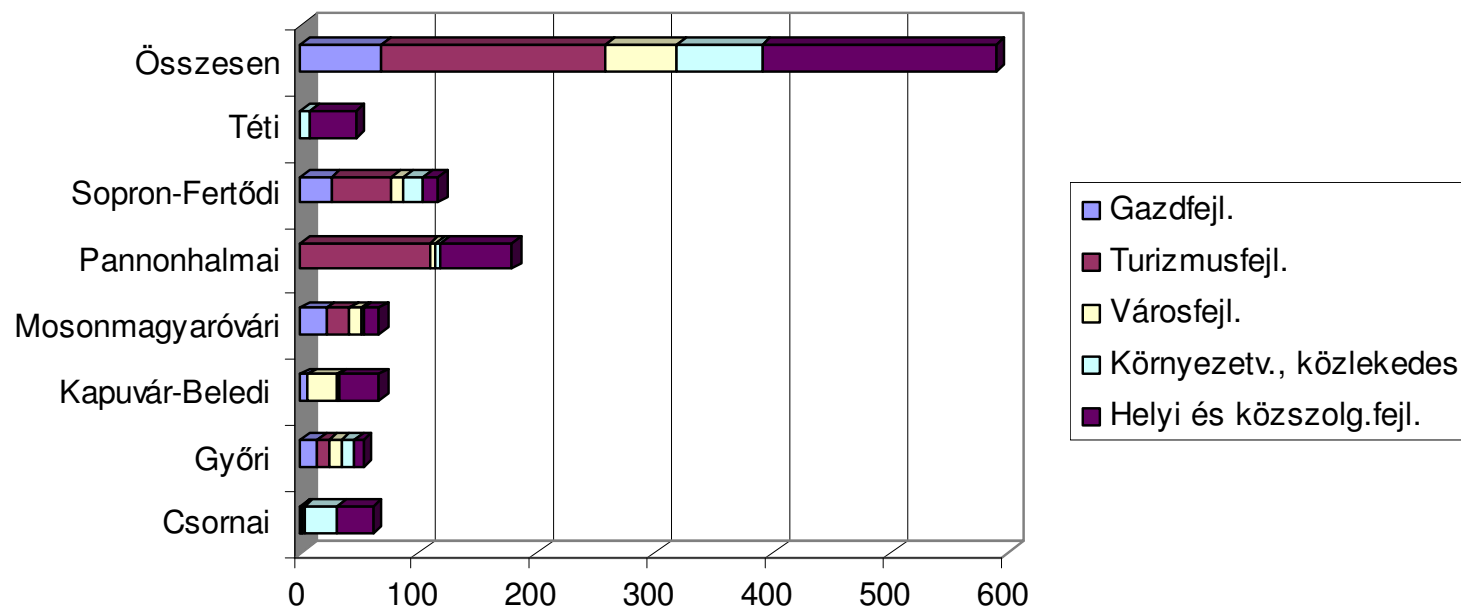

40. ábra: Győr-Moson-Sopron megye kistérségeinek részesedése 2007-2011 időszakban (egy före jutó támogatás ezer Ft) a Nyugat-Dunántúl Regionális Operatív Programból

(saját szerkesztés, adatok forrása: TEIR) 
A Csornai kistérségben leginkább környezetvédelmi (szennyvízkezelés, csatornázás) és közszolgáltatások fejlesztését szolgáló projektek nyertek támogatást az elmúlt években, amely utóbbi a többcélú kistérségi társulás aktivitásának is köszönhető. A gazdaságfejlesztés, a turisztikai fejlesztések és a városfejlesztés prioritásokon keresztül gyakorlatilag nem jutott a kistérség fejlesztési forrásokhoz. Bár a Hanság, mint kiemelt ökoturisztikai célterület nevesítve volt az NYDOP-ben a Nemzeti Park fejlesztései nem a térséget érintve valósultak meg. Azaz elsősorban az élhetőséghez, a fenntarthatósághoz kapcsolódó programok valósultak meg a versenyképesség javítása háttérbe szorult.

\section{Kistérségi szintü fejlesztési stratégiák}

A többcélú kistérség számára több fejlesztési stratégia is készült, a 2005-ben Csornai kistérség, kistérségi integrált projektcsomag 2007-2013 című koncepció egyértelműen fejlett, versenyképes mezőgazdasági termesztés kialakítására és a kiegészítő tevékenységek fejlesztésére, bővítésére helyezi a hangsúlyt. A koncepció alapvető megállapítása hogy a belső munkalehetőségek tekintetében a mezőgazdasági vállalkozások jelentik a fő munkahelyteremtő potenciált a térségben. A mezőgazdasághoz tartozó kiegészítő tevékenységek: a helyi termékekhez és hagyományokhoz kapcsolódó idegenforgalom fejlesztése, a tájjellegü és biotermékek termesztése, a kistérségi öntözőcsatorna-rendszer fejlesztése, a vadgazdálkodás fejlesztés, továbbá a mezőgazdasági és turisztikai oktatás és képzés.

A többcélú kistérségi társulás kidolgoztatott 2006-ban egy, az önkormányzatok projektötletein alapuló gazdaságfejlesztési programot (Melléklet XLIV.). Az önkormányzatok - nem meglepő módon az infrastruktúrafejlesztést (közút, szennyvíz, informatikai fejlesztés) és a turisztikai fejlesztéseket (falusi turizmus szálláshelyek, rendezvények, turistaútvonal) támogatták legnagyobb arányban. Az alternatív energiahasznosítás jórészt a termálvíz hasznosításának igényét foglalta magába. Természetvédelem, környezetfejlesztés területén nagyon alacsony volt a tervezett fejlesztések száma, itt kiemelhető Vágon a Holt-Rába rekonstrukciója. Meglepően kevés a szakképzéssel összefüggő fejlesztési elképzelés, egyetlen említésre méltó terv a Tudáscentrum létesítése Csornán, amely a Norvég Alap támogatásával megvalósult. Az önkormányzatok is felismerték a helyi mezőgazdaság egyik alapvető problémáját, hogy a termékek feldolgozottsága alacsony szintü és több zöldség-, gyümölcs feldolgozóüzem létesítésében/támogatásában gondolkodtak. A stratégiából szinte teljes mértékben hiányzik az együttmüködés és a táji szintü gondolkodás (hol, mire a legkedvezőbbek az adottságok, együttmüködéssel milyen fejlesztés valósítható meg, tervezői javaslatok hiánya). A projektötletekből nagyon kevés valósult meg.

A többcélú kistérségi társulás müködési területének súlypontja az aprófalvas térség egészségügyi, szociális és oktatási ellátásának megszervezése, fejlesztése volt, itt jelentős sikereket ért el. A társulás sorsa jelenleg bizonytalan, bár a nyertes pályázati projektek fenntartáskötelesek. A munkaszervezet megszünt, a társulás sorsáról a következő hónapokban döntenek a települések. 
A Rábaköz Vidékfejlesztési Egyesület a Leader programhoz kapcsolódóan 44 önkormányzat, több mint 80 civil szervezet és mintegy 70 vállalkozás együttmüködésében jött létre. Területi alapon gyakorlatilag a Kapuvári kistérséget és a Csornai kistérség nyugati részét fedi le. Sajnálatosnak tartom, hogy politikai megfontolásból és a nagyobb támogatások reményében a Csornai kistérség több települése a Pannónia Kincse Vidékfejlesztési Egyesülethez csatlakozott (amely a Csornai, Győri, Téti, Pannonhalmi, Pápai kistérség 65 települését foglalja magába), hiszen egy többé-kevésbé táji alapon müködő szervezet alakulhatott volna ki. A Rábaköz, mint földrajzi tájegység 65 települést foglal magába.

A Rábaköz Leader célkitűzései:

— „A társadalmi töke erösítése

- A kulcstelepülések vonzerejének és kisugárzó hatásainak erösítése

- A leszakadó települések aktivizálása a térségi, tájegységi folyamatokba

— A megújuló energiák használatának ösztönzése, erösítése

— Turisztikai fejlesztések támogatása

- Az ökológiai környezet, a biodiverzitás megóvása, védelme

— A népi kismesterségek, a tájtermékek, tájételek fenntarthatóságának, használatának segítése

- A mikro-, kis- és középvállalkozások fejlesztése

- Hálózati együttmüködés serkentése, elösegítése, támogatása

- Vonzó településarculat kialakításának segítése

- A helyi gazdaság kiszolgálása, erösítése a rábaközi tallér bevezetésén és használatának ösztönzésén keresztül."(www.rabakozleader.hu)

Az elnyert támogatások és a futó pályázatok alapján a Kapuvári-kistérség települései, helyi társadalmai jóval aktívabbnak tekinthetők (a most záruló pályázati körben az előbbiből 19, míg a Csornai-kistérségből négy pályázat érkezett, Melléklet XLV.).

A Leader eddigi tapasztalatai azt mutatják, hogy a térségi együttmüködések fontossága lassan tudatosul a helyi társadalmakban. Nagy a jelentősége, hogy a helyi közélet mennyire átpolitizált. A civil, az összefogást igénylő kezdeményezések támogatottsága jóval nagyobb nyugodt helyi közélet esetén. A helyi szereplők aktivitása, együttmüködési készsége meghatározza a térség eredményességét a fejlesztési forrásokért folytatott ,versenyben”.

Lassan formálódik az a készség, képesség, hogy a társadalom aktívan részt vegyen, kezdeményezzen helyi szintü fejlesztéseket:

— figyelje/gyüjtse a tapasztalatokat a hasonló adottságok mellett már megvalósított jó példákról/gyakorlatokról, másolja azokat,

— nyitott legyen az együttműködést igénylő kezdeményezésekre, 
— keresse az együttmüködéseket,

— felismerje a mobilizálható erőforrásokat, értékeket,

— saját projekteket kezdeményezzen, valósítson meg.

A tapasztalatok alapján nem magától értetődő, hogy felismerik a helyi önkormányzatok, civil szervezetek, mik azok a helyi értékek, amelyek védelemre, fejlesztésre érdemesek és aktívan tegyenek ezen értékek védelme érdekében. A Rábaközi Leader-hez alig érkezett be pályázat a „Vidéki örökség megújítása" célterületre, különösen a kulturális örökség, helyi védelem alatt álló épületek felújítása valamint a „Falumegújítás” célterületen belül a védelem alatt nem álló épületek felújítása, helyi piac létesítésére szóló pályázati kiírásokra.

A térség legfontosabb kitörési lehetőségeként a turisztikai fejlesztést jelölte meg a vidékfejlesztési egyesület. Különösen hangsúlyos elemként jelennek meg a táji keretek között zajló aktív turisztikai ágak, mint ökoturizmus, falusi turizmus, vízi turizmus, lovaglás, vadászat, kerékpározás. Több stratégiai dokumentum is készült a turisztikai fejlesztések megalapozására (A Rábaköz Turizmusfejlesztési Stratégiája, Kvalitatív kutatási jelentés, Kvantitatív kutatási jelentés-turizmus). Elsősorban jövedelem kiegészítésként tartom fontosnak a turizmust a térségben, különösen a hátrányos helyzetü Rába-menti falvakban (ahol kisebb az ingázás lehetősége, nagyobb a ráutaltság a mezőgazdaságra) és gazdálkodók számára a természetvédelem által korlátozott jövedelmet biztosító tóközi falvakban. Az intenzív agrártájként jellemezhető Rábaközben kevés valós jelentősége lehet a falusi turizmusnak. Emiatt fontosnak tartom a multifunkcionális mezőgazdasági gyakorlatra törekvést.

Szükség lenne egy táji, tájhasználati potenciálokat és hiányosságokat feltáró, a tájfunkciókat komplex módon értékelő dokumentumra, amelyben a helyi szereplők megfogalmaznák többek között a tájminőségi célkitűzéseket. Tartalmazza a térség tájformálói számára ajánlott szempontokat (pl. a mezővédő erdősávok egyéb természetbarát gazdálkodási módok alkalmazására ajánlott területek). Fontos lenne, hogy Interneten elérhető, térképes felületen megjeleníthető módon tartalmazza a helyi értékeket, konfliktusokat. Jelenítse meg, értékelje a térség tájkarakter típusait, kiemelje a védendő, a fejlesztésre szoruló adottságokat stb.

\section{Következtetések}

Az elsődlegesen vidéki jellegü, döntően agráradottságú kistérség (hasonló, bár jobb eredményt ért el a Téti és a Kapuvár-Beledi kistérség) nem tudta hatékonyan kihasználni a nagytérségi versenyben megszerezhető fejlesztési forrásokat (országos ágazati és regionális operatív program) (39-40. ábra, 14. táblázat). 
14. táblázat: A helyi fejlesztést befolyásoló fejlesztési szervezetek (saját szerkesztés)

\begin{tabular}{|c|c|c|c|c|c|}
\hline $\begin{array}{l}\text { Területi } \\
\text { szint }\end{array}$ & Szervezet & Források & $\begin{array}{l}\text { Szerezhető } \\
\text { források } \\
\text { nagysága }\end{array}$ & Fejlesztési célok & $\begin{array}{l}\text { A vizsgált kistérség } \\
\text { részesedése }\end{array}$ \\
\hline Országos & $\begin{array}{l}\text { Szak-minisztériumok } \\
\text { és közremüködő } \\
\text { szervezetek }\end{array}$ & $\begin{array}{l}\text { Európai Uniós } \\
\text { és hazai }\end{array}$ & Jelentős & $\begin{array}{l}\text { Infrastruktúra fejl., humánerőforrás- } \\
\text { fejl., környezetvédelmi beruházások, } \\
\text { gazdaságfejl stb. }\end{array}$ & $\begin{array}{l}\text { Marginális, csak ha } \\
\text { országos jelentőségű } \\
\text { projekt érinti a térséget }\end{array}$ \\
\hline Térségi & $\begin{array}{l}\text { Regionális fejlesztési } \\
\text { tanács/Megyei Terü- } \\
\text { letfejlesztési Ta- } \\
\text { nács }^{33}\end{array}$ & Hazai & Csekély & $\begin{array}{l}\text { [TTF] Terület- és településfejlesztési } \\
\text { támogatások }\end{array}$ & $\begin{array}{l}\text { Fejletlenebb kistérség- } \\
\text { ként nagyobb arányban } \\
\text { részesült34 }\end{array}$ \\
\hline Térségi & Régió & Európai Uniós & Korlátozott & $\begin{array}{l}\text { Közlekedésfejl. } \\
\text { Környezetvédelem } \\
\text { Turisztikai fejl. } \\
\text { Gazdaságfejlesztés }\end{array}$ & Viszonylag kisebb arány \\
\hline $\begin{array}{l}\text { Térségi/ } \\
\text { kistérségi }\end{array}$ & $\begin{array}{l}\text { Csornai Többcélú } \\
\text { Fejlesztési Társulás }\end{array}$ & $\begin{array}{l}\text { Európai Uniós } \\
\text { és hazai }\end{array}$ & Korlátozott & $\begin{array}{l}\text { Szociális ellátás } \\
\text { Oktatási együttműködések } \\
\text { Képzési programok }\end{array}$ & $\begin{array}{l}\text { Forráshoz jutás függött a } \\
\text { pályázati aktivitástól }\end{array}$ \\
\hline $\begin{array}{l}\text { Térségi/ } \\
\text { kistérségi }\end{array}$ & $\begin{array}{l}\text { Rábaköz Leader } \\
\text { HACS }\end{array}$ & Európai Uniós & Csekély & $\begin{array}{l}\text { Képzés } \\
\text { Közösségi célú fejlesztések } \\
\text { Vállalkozásfejlesztés }\end{array}$ & \\
\hline
\end{tabular}

\subsection{Scenáriók kidolgozása, a fenntarthatóság, az élhetőség, a versenyképesség hosszú távú ér-} tékelése

A tájfunkciók szintjének és a gazdasági helyzet ábrázolása a táj jelenlegi állapotáról ad áttekintést. A sokféle tájfunkció egymás melletti ábrázolása viszonylag nehezen átláthatóvá teszi az egyes térségek helyzetét. A vidékfejlesztés számára azonban az is fontos szempont, hogy képesek vagyunk-e a fenntartható fejlődés hosszú távú biztosítására, azaz az élhetőség, a környezeti fenntarthatóság és a versenyképesség érdekrendszerének egyfajta harmóniáját biztosítani. A népességmegtartó képesség hosszú távú becslésére alapeseteket állítottam fel, amelyek a gazdasági, a termesztési (versenyképesség) és az élőhelyi (ökológiai/ környezeti fenntarthatóság) érték összevetésével szemléltettem. Antonio Gómez-Sal és kutatótársai (a táj jelen állapotának, a táj ökológiai értékének fenntarthatóságát vizsgálták) által alkalmazott modellt kiterjesztettem és a hazai viszonyok között alkalmaztam a táj népességmegtartó képességének hosszú távú értékeléséhez (Gómez-Sal, 2003). A vidéki térségek sikerességének megőrzéséhez alapvető feltételek a táj ökológiai értékének megőrzése és egyben a lakosság számára a megfelelő jövedelem biztosítása, aminek egy lehetséges forrása — annak ellenére, hogy a mezőgazdaság a területi GDP-nek egyre kisebb részét képezi — a mezőgazdasági termesztés és a rá épülő feldolgozóipar. Ideális esetben — ahogy az EU agrárpolitikájának célkitüzései között is alapvető prioritás — a gazdálkodás kedvezőtlen hatásait kompenzálják az agrárkörnyezetvédelmi támogatások, emelve/ megőrizve a táj ökológiai értékét. A megfelelő jövedelemszint biztosítása azonban ma már egyre gyakrabban a közeli város munkahelyei révén lehetséges. A

\footnotetext{
${ }^{33}$ TEKI, CEDE egyéb terület és településfejlesztési források a megyéktől fokozatosan a régiók kezelésébe kerültek ${ }^{34}$ A Csornai, Kapuvár-Beledi, Téti kistérségek nagyobb arányban részesültek a TTF forrásokból mint a Győri és Mosonmagyaróvári kistérség (Forrás: TEIR, Támogatási alrendszer)
} 
gazdasági érték, termesztés volumene, az ökológiai érték összefüggéseit, valamint a táj népességmegtartó képességét foglaltam össze a 15. táblázatban.

A gazdasági, a termesztési és az ökológiai érték alapján hét alapesetet különítettem el, amelyek nem feltétlenül ilyen „tisztán” jelennek meg a valóságban, de adott esetben a jelenlegi tendenciák ismeretében egy térség jövőképe megfogalmazásában, megváltoztatásában támpontul szolgálhatnak. Az eredmények fejezetben a mintatérség településcsoportjaira alkalmaztam ezt a tipizálást. 
15. táblázat: A gazdasági, az ökológiai és a termesztési szempontok kapcsolata a táj népességmegtartó képességének befolyásolásában (saját szerkesztés)

\begin{tabular}{|c|c|c|c|c|c|c|}
\hline $\begin{array}{c}\text { Gazdasági } \\
\text { érték }\end{array}$ & $\begin{array}{l}\text { Termesz- } \\
\text { tési érték }\end{array}$ & $\begin{array}{c}\text { Ökológiai } \\
\text { érték }\end{array}$ & Megnevezés & $\begin{array}{c}\text { Népesség-megtartó képes- } \\
\text { ség }\end{array}$ & Prioritás & Tájkép \\
\hline Alacsony & Alacsony & Magas & $\begin{array}{l}\text { Magas környezeti értékü, hagyo- } \\
\text { mányos, környezet- kímélő gaz- } \\
\text { dálkodás }\end{array}$ & $\begin{array}{l}\text { Alacsony jövedelmezőség } \\
\text { miatt alacsony }\end{array}$ & K. fenntarthatóság & $\begin{array}{c}\text { Magas ökológiai és esztétikai értékü } \\
\text { tájkép }\end{array}$ \\
\hline Közepes & $\begin{array}{l}\text { Magas/ } \\
\text { Közepes }\end{array}$ & Magas & $\begin{array}{c}\text { Magas hozzáadott értéket előállító, } \\
\text { munka-intenzív környezetkímélő } \\
\text { gazdálkodás, változatos vetésszer- } \\
\text { kezet } \\
\text { „Multifunkcionális kultúrtáj” }\end{array}$ & $\begin{array}{c}\text { Népességét hosszútávon meg- } \\
\text { tartó táj }\end{array}$ & $\begin{array}{l}\text { Versenyképesség, } \\
\text { élhetőség }\end{array}$ & $\begin{array}{c}\text { Magas ökológiai és esztétikai értékü } \\
\text { tájkép }\end{array}$ \\
\hline $\begin{array}{c}\text { Ala- } \\
\text { csony/közepe } \\
\text { s }\end{array}$ & Magas & Alacsony & „Ipari” agrártáj & $\begin{array}{l}\text { Alacsony foglalkoztatási } \\
\text { igény miatt alacsony }\end{array}$ & Versenyképesség & $\begin{array}{l}\text { Ökológiai és esztétikai szempontból } \\
\text { egyaránt elszegényedő tájkép }\end{array}$ \\
\hline $\begin{array}{l}\text { Közepes/ } \\
\text { Magas }\end{array}$ & Alacsony & Magas & $\begin{array}{l}\text { Természeti, kulturális értékekben } \\
\text { gazdag táj ahol a fó megélhetési } \\
\text { forrást az agrár-támogatások, a } \\
\text { turizmus biztosítja } \\
\text { „Naturpark” }\end{array}$ & $\begin{array}{c}\text { Népességét megtartó táj, } \\
\text { amennyiben a támogatások, a } \\
\text { turisztikai hasznosítás hosszú- } \\
\text { távon fenntarthatók }\end{array}$ & $\begin{array}{l}\text { Élhetőség, fenntart- } \\
\text { hatóság }\end{array}$ & $\begin{array}{c}\text { Magas ökológiai és esztétikai értékü } \\
\text { tájkép }\end{array}$ \\
\hline $\begin{array}{l}\text { Közepes/ } \\
\text { Magas }\end{array}$ & Alacsony & Magas & $\begin{array}{c}\text { Magas környezeti értékü } \\
\text { szuburbán táj } \\
\text { Fontosabb város vonzáskörzete, } \\
\text { ahol a beépítés terjeszkedését sza- } \\
\text { bályozás korlátozza } \\
\end{array}$ & $\begin{array}{c}\text { Népességét hosszútávon meg- } \\
\text { tartó táj }\end{array}$ & Élhetőség & $\begin{array}{c}\text { Magas ökológiai és esztétikai értékü } \\
\text { tájkép }\end{array}$ \\
\hline $\begin{array}{l}\text { Közepes/ } \\
\text { Magas }\end{array}$ & Alacsony & $\begin{array}{l}\text { Alacsony/ köze- } \\
\text { pes }\end{array}$ & $\begin{array}{c}\text { Természeti értékeit felélő } \\
\text { szuburbán táj } \\
\text { Fontosabb város vonzáskörzete, } \\
\text { ahol a beépítés terjeszkedését sza- } \\
\text { bályozás nem korlátozza } \\
\end{array}$ & $\begin{array}{c}\text { Népességét megtartó táj, ha az } \\
\text { ökológiai értékvesztés megál- } \\
\text { lítható. }\end{array}$ & Versenyképesség & $\begin{array}{c}\text { Az ökológiai és az esztétikai értéket } \\
\text { meghatározza a beépítés. } \\
\text { Ökológiai és esztétikai érték ala- } \\
\text { csony }\end{array}$ \\
\hline Alacsony & Alacsony & Alacsony & Degradált táj & $\begin{array}{c}\text { Alacsony népességmegtartó } \\
\text { képesség }\end{array}$ & $\begin{array}{l}------ \\
\end{array}$ & $\begin{array}{l}\text { Ökológiai és esztétikai érték ala- } \\
\text { csony, tájrehabilitáció szükséges }\end{array}$ \\
\hline
\end{tabular}




\section{EREDMÉNYEK}

\subsection{A tájfunkciók változásának történeti értékelése a versenyképesség változásának tükrében}

Az értékelés eredményeként megállapítottam, hogy a legjelentősebb területhasználati változásoknak a XIX. század adott keretet és gyakorlatilag a XX. század elejéig a tájhasználat átalakulása nagyvonalakban lezajlott. Legszembetünőbb változások a szántók arányának erőteljes növekedése és a rét-legelök arányának drasztikus csökkenése volt.

A versenyképesség általában a középkor végén jelent meg, hiszen alapvető feltétele a külső és a belső adottságokhoz történő maximális alkalmazkodás és a folyamatos újításokra, innovációra való törekvés (a középkori gondolkodás nem kedvezett a haladásnak, a tudatos reformoknak (Huizinga, 1996)). A tóközi tógazdálkodás időszaka sajátos versenyképes korszaknak tekinthető a XI-XIII. században, hiszen a termesztési feltételeknek nem kedvező adottságokhoz kiválóan alkalmazkodtak, amely magas település- és népsűrüség kialakulását tette lehetővé. E sajátos gazdálkodási mód megszűnése a szűken vett tóköz versenyképességi helyzetének, népességeltartó képességének visszaesését hozta, évszázadokon át mocsaras területként fennmaradva. A tájalakítást jelentősen befolyásolta a társadalom értékrendjének megváltozása alkalmazkodás helyett a természet átalakítása kerül előtérbe.

A népességszám-változás értékelése alapján megállapítottam, hogy XIX. század folyamán rendkívül dinamikus, de az országos átlag alatt maradó népességnövekedés volt a kistérségben, a növekedés üteme drasztikusan csökken a század második felére, annak ellenére, hogy ekkorra valósulnak meg a legnagyobb volumenü vízrendezési munkák. Az irtásföldek jelentős része a nagybirtokosok vagyonát gazdagította, akik majorságok keretein belül szervezték a gazdálkodást, általában a kor átlagos technológiai szintjénél fejlettebb színvonalon, azaz kisebb munkaerőigénnyel, mint a kisparaszti gazdaságok. Ez az oka, hogy a nagyarányú tájátalakítás nem hozta magával a táj népességmegtartó képességének hasonló szintü növekedését, hiszen alapvetően versenyképesség javulást nem az életkörülmények javulását illetve a magasabb életszínvonal szétterítését (élhetőség) hozta.

A versenyképességi/gazdasági helyzet sokáig a termesztés és az elérhetőség feltételeinek javulását követte, majd a fejlődés mozgatórugóinak megváltozása a térség jelentős részét hátrányosan érintette. A nagyarányú tájalakítás nem járult hozzá a népességmegtartó képesség hasonló arányú növekedéséhez. A népsürüség területi különbségei fennmaradtak. A táji adottságok a dél-rábaközi, nagybirtok által kevésbé befolyásolt falvakban tették lehetővé magas népsürüség kialakulását, de éppen emiatt a XIX. század végén XX. század folyamán ezek a települések szenvedték el a legerősebb népességvesztést. Bécs ellátó körzetének széléhez tartozott a térség, ami a jó agráradottságok mellett a kistérség településeinek jelentős részén viszonylag magas életszínvonalat biztosított a XIX. század végéig, XX. század elején. A gazdasági és a társadalmi folyamatok nagymértékü átalakulása, 
ami az iparosodott, urbanizált térségek dinamikus fejlödését hozta, a kistérség lemaradását, népességvesztését okozta a XX. század folyamán, egyrészt a szocialista fejlesztéspolitika miatt, amely alapvetően a mezőgazdasági nyersanyag-termesztés térségi szerepkörét kínálja a kistérségnek/járásnak. Jelentősen romlik a kistérség versenyképessége. Megváltoztak a gazdaság és a társadalom mozgatórugói: a mezőgazdasági lehetőségeket alakító természeti adottságok helyett a közlekedés-, és a gazdaságföldrajzi tényezők váltak meghatározóvá. A versenyképesség romlásának elsődleges oka, hogy a térségi kapcsolatrendszerben elveszítette a kistérség korábbi szerepkörét, kapcsolatait (elveszítette piacait). Jelentős népességcsökkenést szenvedtek el a közlekedés- és városárnyékos rábaközi (dél-nyugati aprófalvak és tóközi) aprófalvak, a Tóköz fejlődő településeivé váltak a kistérség közlekedési „ütőerei” mentén elhelyezkedő Bősárkány (86. sz.), Kóny (86. sz.) és a Hanság déli peremét képező Farád (85. sz. út). Kóny fejlődésére Győr vonzása is jelentős hatással van. A negatív tendenciák a rendszerváltás óta sem sokat változtak, míg a megye községei összességében kismértékü növekedést éltek meg, a Rábaköz népességvesztése folytatódik, bár a népességcsökkenés kisebb arányú.

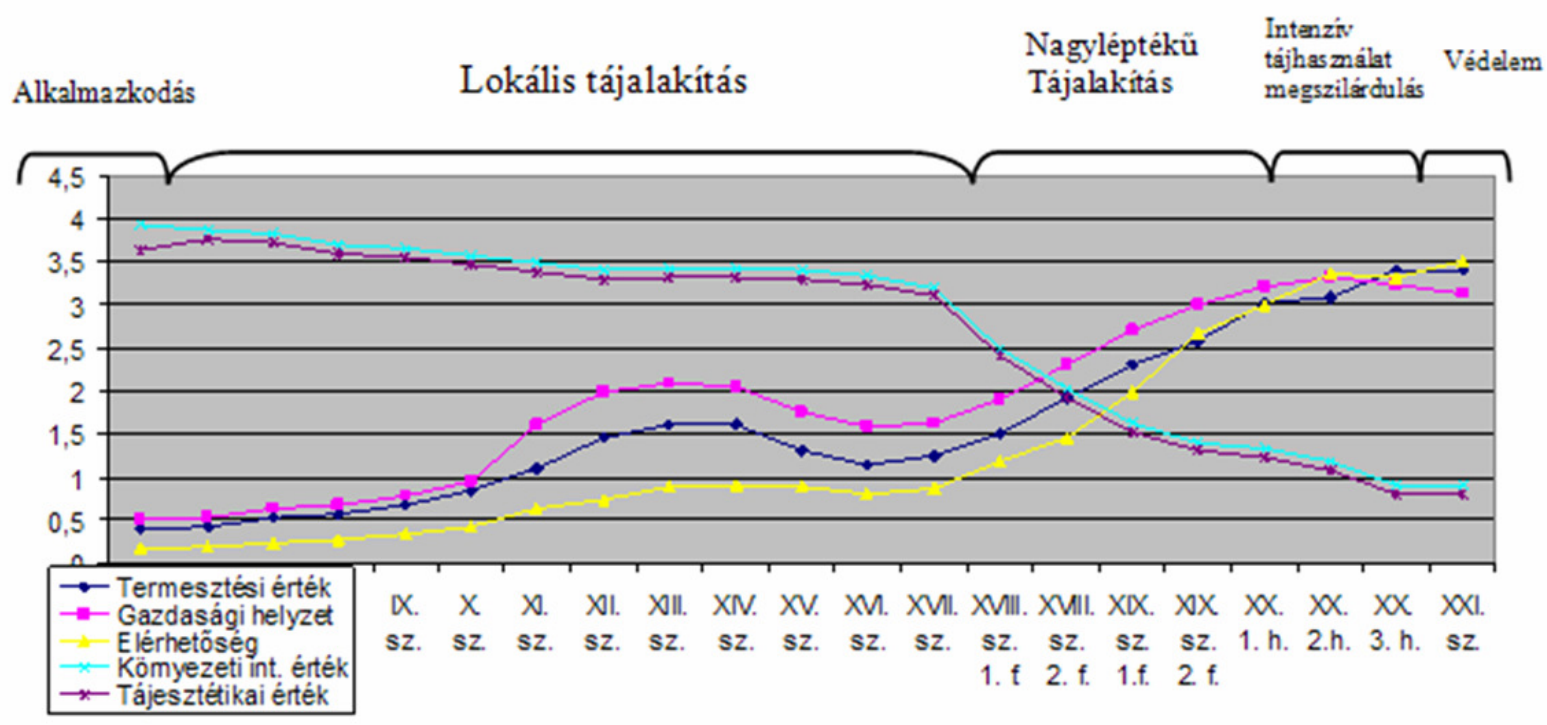

\section{1. ábra: Tájfunkciók, elérhetőség, gazdasági helyzet változása a Hanság mentén és a Tóköz-}

ben (saját szerkesztés)

A táji adottságok és azok hasznosítása még mai is meghatározóak a térség lakói számára, hiszen egyes falvakban a lakosság 20-30\%-a él a mezőgazdaságból, másrészt a kistérség jelentős részén magas a védett területek aránya, amely korlátokat és lehetőségeket is ad a gazdaság számára.

Összegzésként a tájfunkciók működésének szintjét az elérhetőség és a ,versenyképességi helyzet” szintjének változásával együtt grafikonon ábrázoltam (41-42. ábra). A statisztikai adatok (főleg a gyep és szántóterületek arányának változása) alapján, egy négyes skálán vetettem össze (becsültem) a kistérségben jellemző két tájegységben az egyes funkciókat (az ábrák tájékoztató jellegűek, hiszen viszonylag pontos becslés a XIX. század második feléig lehetséges, eddig állnak rendelkezésre statisztikai adatok). 


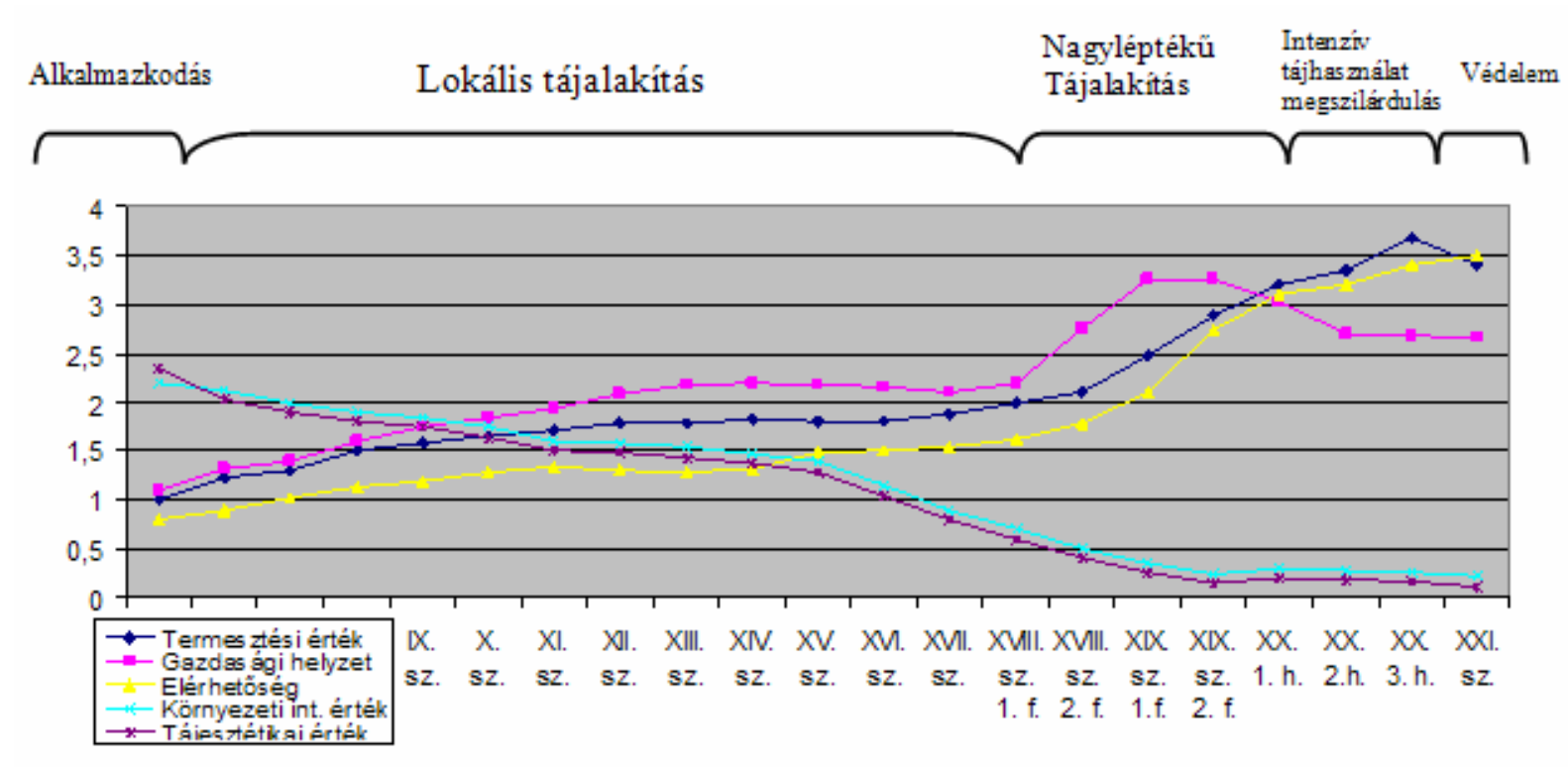

42. ábra: Tájfunkciók, elérhetőség, gazdasági helyzet változása a Rábaközben (saját szerk.)

\subsection{A tájfunkció-elemzés eredményei}

A dolgozat másik hangsúlyos része napjaink tájhasználatának értékelése tájfunkció elemzés segítségével. A vidéki térségek népességmegtartó képességének fenntartásához elengedhetetlen a tájfunkciók, a tájhasználati funkciók harmonikus érvényesülése. Egyes funkciók hiánya, alulreprezentáltsága bizonyos mértékig térségi szinten kompenzálható: amennyiben települési szinten hiányosak ugyan a rekreációs lehetőségek, de a szomszéd településen van kikapcsolódási lehetőség stb. a hiányok térségi együttműködés révén kompenzálhatók, kiküszöbölhetők. A tájfunkciók/tájhasználati funkciók érvényesülésének elégtelensége különösen akkor okoz problémát, ha térségi szinten jelenik meg. Több szempontból is hátrányos helyzetünek tekinthető emiatt a Rábaköz: a gazdasági, az élőhely-védelmi, a kulturális és az esztétikai funkció érvényesülése több településen is elmarad az optimális szinttől (43. ábra).

A fentiekben részletesen elemzett tájhasználati funkciók közül 10-es terjedő skálán értékeltem az összehasonlíthatóság érdekében a mezőgazdasági termesztést, a gazdasági értéket (gazdasági aktivitás, adófizetők aránya, jövedelemszint), az élőhelyi, a rekreációs és az esztétikai funkciót. A kistérségben a mezőgazdaság mind a gazdaságban, a foglalkoztatásban, a tájhasználatban az országos átlagot meghaladó jelentőséggel bír. A mezőgazdaság azonban, ahogy az leginkább az alacsony ingázási, és egyéb gazdasági aktivitással jellemezhető települések esetén egyértelműen kimutatható, nem biztosít versenyképes jövedelmet a lakosság számára. A mezőgazdaság jövedelmezőségét rontja az intenzív kertészeti kultúrák alacsony aránya (pedig a helyi társadalom adottságai ezt régen lehetővé tették) és a kistérségben előállított mezőgazdasági termékek feldolgozottságának alacsony foka, illetve a kiegészítő tevékenységek és jövedelmek szűk köre. 


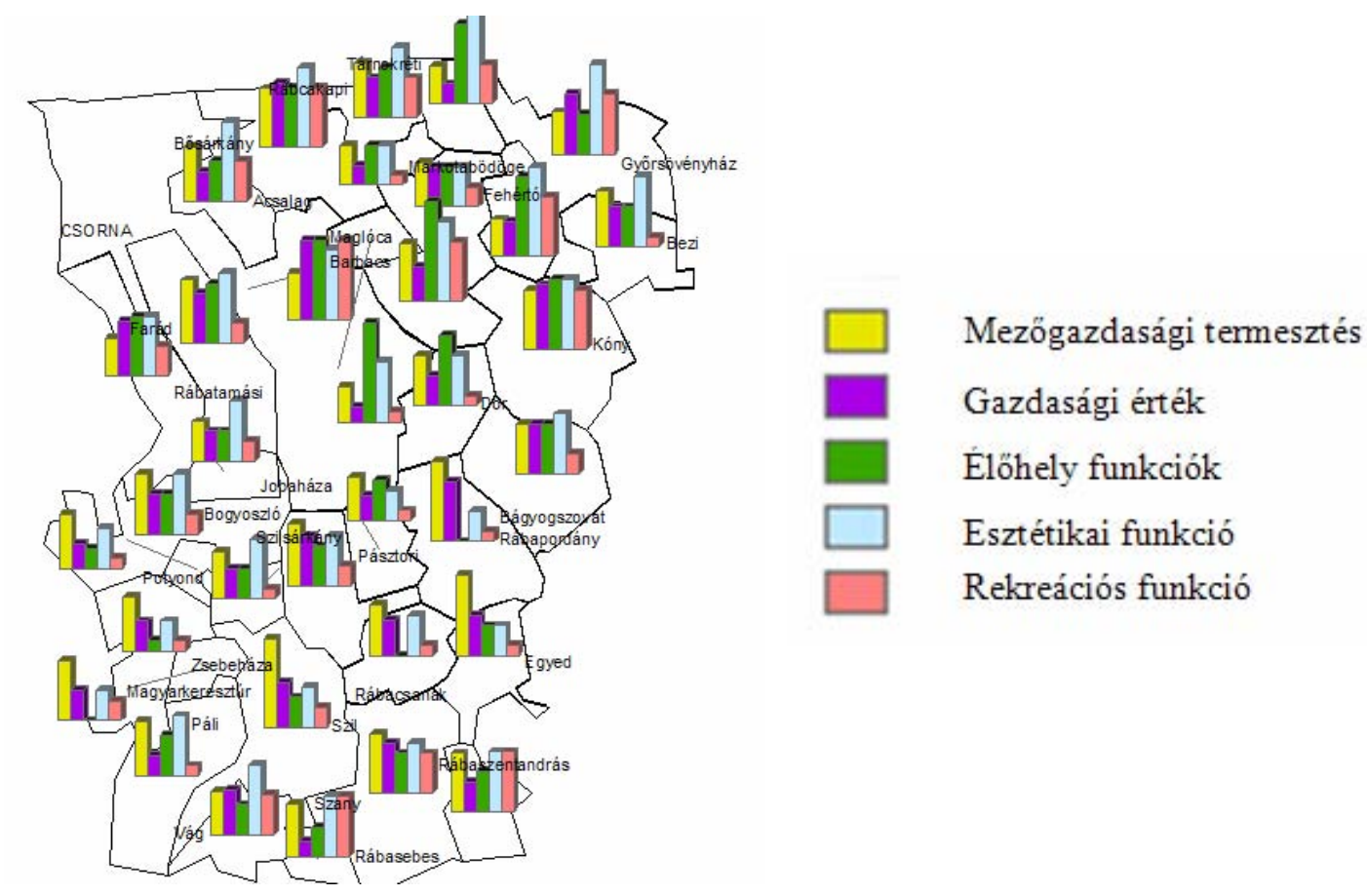

43. ábra: Tájfunkciók, tájhasználati funkciók települési szintű érvényesülése (saját szerkesztés)

A Hanság és a Tóköz térsége nyomokban megőrizte a hajdani ökológiai értékeket, az egykori mocsárvilág értékes területei találhatók meg itt. A térség jelentős része áll védelem alatt (így az élőhely funkció magas értéket képvisel), magas minőségű táji környezetet biztosítva az itt lakók számára. A munkahelyek hiánya ellenére a megyeközpont viszonylag jó elérhetősége révén vonzóak maradtak ezek a települések a társadalom számára. A gazdasági vonatkozásokat vizsgálva azonban az indikátorok alapján megállapítottam, hogy a természeti értékek gyakran korlátokat jelentenek a helyiek részére, az előnyöket kevésbé érzékelik (rekreáció, falusi/ökoturizmus, agrár-környezeti kompenzáció). A védett területek magas aránya ellenére a természeti értékek nem jelennek meg attrakcióként, kevés lehetőség nyílik a kulturált, a természetkímélő megismerésre tanösvények, kilátók, kiállítások keretében. A rekreációs funkciók mellett a tudományos-nevelési funkciót is elégtelennek (átlag alattinak) kellett minősíteni.

A Rábaköz intenzív agrártájnak tekinthető, még a Hanság, a Tóköz térségében is a védett területek dominanciája ellenére a szántók aránya meglepően magas. A rosszabb minőségü szántókon és a belvízveszélyes, mélyen fekvő területeken vissza kellene állítani a réteket és a legelőket. A tájhasználatnak ezt a módját, amely évszázadokon át meghatározta a térség gazdálkodását az állattenyésztés jelenlegi helyzete veti vissza. A kistérség rábaközi részére az intenzív művelés általánosan jellemző, rendkívül alacsony az extenzív hasznosítású területek, az erdők aránya. Itt a hangsúly egyértelműen az ökológiai értékek erősítésén van. A rábaközi falvakban több tájfunkció is elmarad az optimális szinttől. Az élőhely és az információs (esztétikai, rekreációs, nevelési) funkciók elégtelenek és fejlesztésre szorulnak. Amennyiben ezek a tájhasználati adottságok nem változnak térségi szinten, az gátolhatja a helyi fejlesztési stratégiák megvalósulását, lásd a Rábaköz Leader legfontosabb célja a 
turizmus fellendítése. Alapvetően kihasználatlanok a Rába nyújtotta lehetőségek: a vízi túrázók kikötőhelyek híján nem szállnak/állnak meg a településeken. A Hanságban és a Rába mentén az ökoturizmusnak lennének lehetőségei. Az esztétikai funkciók tekintetében a védett területek magas értéket képviselnek, de az intenzív művelés térségeiben monoton tájképet tapasztalhatunk. Erősíteni kell a tájkép mozaikosságát például erdősávok telepítésével, a csatornák, az utak mentén fás vegetáció létrehozásával, a fás legelők területének növelésével a Rábaközben.

\subsection{A versenyképességi értékelés eredményei}

Összesített, (a számszerüsíthető élhetőségi és versenyképességi szempontokat összegezve) versenyképességi értékelést készítettem: a demográfiai folyamatok (népességszám változás, öregedési mutató, közszolgáltatások elérhetősége (Megyei Területfejlesztési Koncepció, Helyzetfeltárás)) és a gazdasági helyzet (gazdasági érték) összevetéséből jól elhatárolható településcsoportok rajzolódtak ki (44. ábra) a térségben.
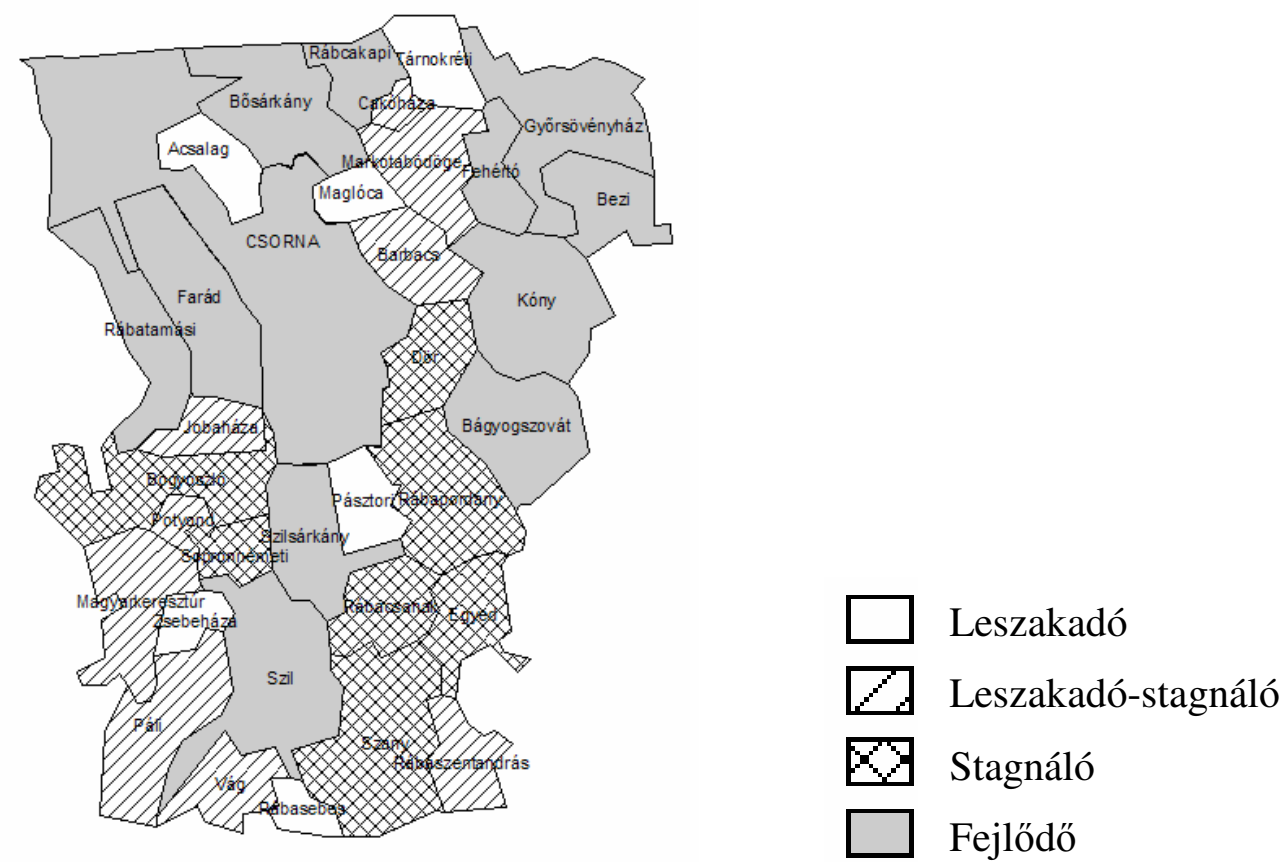

44. ábra: Települések ,,versenyképességi” csoportjai (saját szerkesztés)

Nagyon jó helyzetünek tekinthetők a kistérségi központ és a közeli, a fő közlekedési folyosók mentén elhelyezkedő települések (Bősárkány, Szilsárkány, Farád, Rábatamási), valamint a már inkább Győr vonzáskörzetében tartozó tóközi települések, ahonnan kedvezőek az ingázási feltételek (Győrsövényház, Bezi) és viszonylag jelentősebb a gazdasági aktivitás (Rábapordány, Bágyogszovát, Kóny). A Csornához kötődő tóközi települések, illetve amelyek Győrtől távolabb fekszenek (Dör, Barbacs, Maglóca, Cakóháza) kedvezőtlenebb társadalmi, gazdasági mutatókkal rendelkeznek, amely a kistérségi központ funkciógyengeségét jelzi, és egyben utalhat a természetvédelem korlátozó hatására (ezen településeken magas a védett területek aránya ezen belül is a 
fokozottan védett területek aránya). Markotabödögét, Tárnokrétit kevésbé sújtja a népességfogyás viszont a gazdasági mutatók kedvezőtlenebb képet festenek.

Egyértelműen a legkedvezőtlenebb helyzetünek a dél-rábaközi falvak tekinthetők. A mezőgazdasági termesztés alacsonyabb jövedelemtermelő képessége és az ipari hagyományok hiánya miatt több kistelepülésen - amely a megélhetést illetően erősen a mezőgazdaságtól függ - alacsony a jövedelemszint és a foglalkoztatás, nagy az elvándorlás.

\section{Fejlesztéspolitika hatékonysága}

A fejlesztési koncepciók, pályázati források elnyerésének értékelése alapján egyértelművé vált, hogy a terület- és vidékfejlesztés intézményrendszerének, forráselosztásának valamint az ágazati fejlesztések széttagoltsága, harmonizációjának hiánya nem kedvez a vidéki térségek harmonikus fejlődésének. A magasabb területi szintü, illetve ágazati fejlesztési forrásokért folytatott versenyben a vidéki térségek hátrányos helyzetben vannak.

A támogatástípusok közül leginkább a Leader elvei, támogatásformái segítik a vidéki térségekben a belső erőforrások mobilizálását, a táji értékek hatékonyabb hasznosítását, de térségi szintü, pozitív irányú elmozdulás/fejlődés nagymértékben függ a helyi társadalom aktivitásától, együttműködési formáitól. A Leader program pénzügyi forrásainak szűkössége (kisebb arányú forrásallokáció) és az ágazati kötöttségek (vállalkozásfejlesztés esetén minden, ami nem mezőgazdaság) korlátozzák a hatékonyságát. Szükséges lenne egy olyan fejlesztési szervezet, amely a vidéki térségekben meghatározó valamennyi ágazat fejlesztési igényeit össze tudja fogni (elvileg ilyen formában körvonalazódik az következő programozási időszakra létrehozandó CLLD-k, a Közösségvezérelt Helyi Fejlesztések)). A vidéki foglalkoztatásban ma is meghatározó a mezőgazdaság, ezért a mezőgazdaság korszerüsítése, magas hozzáadott értéket előállító ágazatainak fejlesztése a vidékfejlesztés fontos része. Mind a nagytérségi, mind a helyi fejlesztési források megszerzését segítené a táji erőforrásokat és konfliktusokat feltáró, komplex tájhasználati funkcióelemzést tartalmazó tájrendezési/tájgazdálkodási terv készítése.

\subsection{A tájfunkció értékelés és a versenyképességi értékelés összevetése}

Egy vidéki térség tájhasználati rendszere abban az esetben járul hozzá leginkább a térség népességmegtartó képességének erősítéséhez, illetve megtartásához, ha a gazdasági társadalmi/kulturális és környezeti igényeket egyaránt harmonikusan ki a tudja elégíteni. Összevetettem a tájhasználati funkcióelemzés (45. ábra) és az elsősorban gazdasági/versenyképességi értékelést a vizsgált térségben (Melléklet XLVI.). 


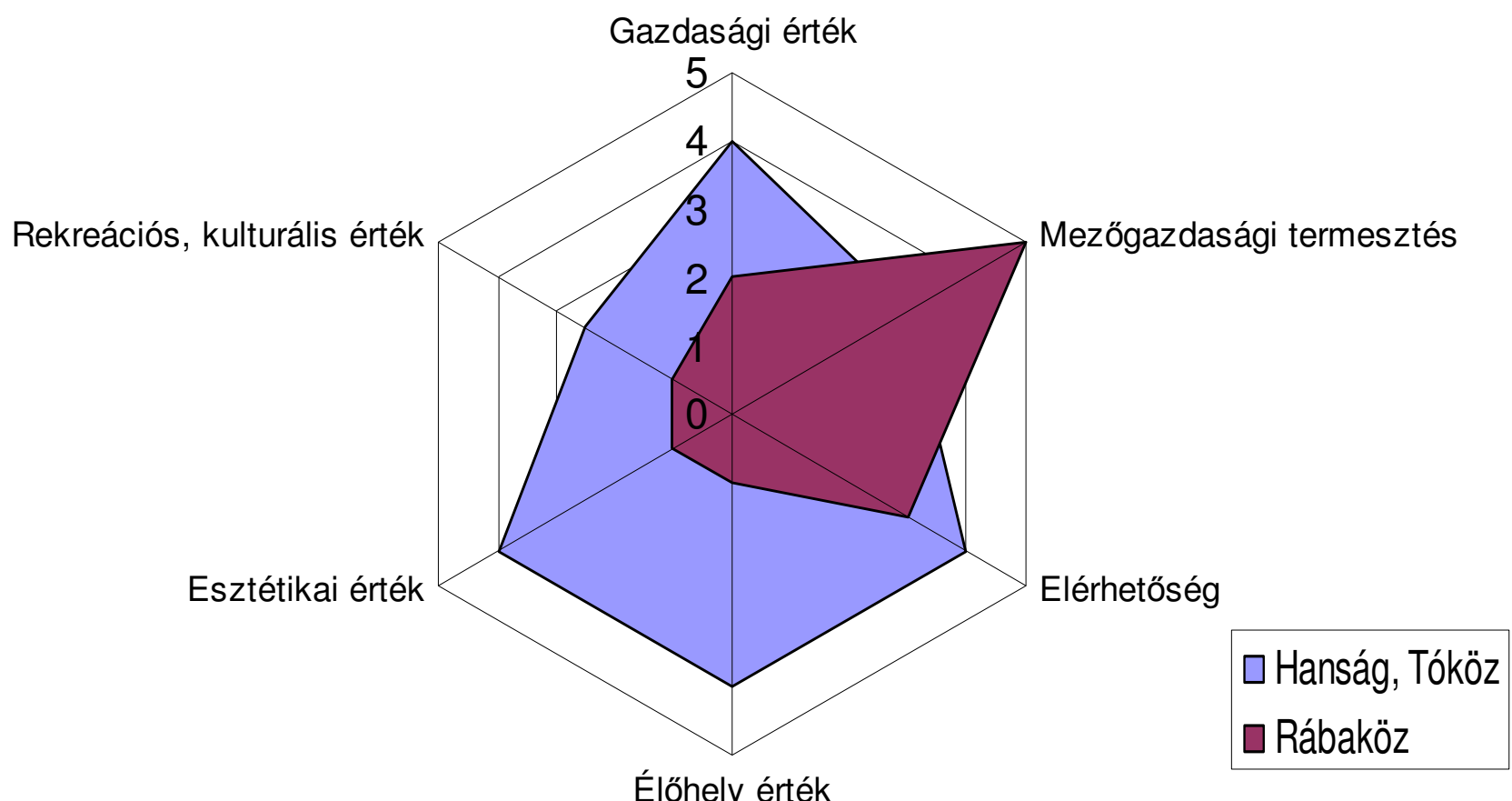

45. ábra: Tájfunkciók, tájhasználati funkciók érvényesülése mikro-térségi szinten (saját szerk.)

Rábaköz térsége:

— a táj élőhely-védelmi, kulturális, rekreációs és esztétikai funkciója, értéke több településen is elmarad az optimális szinttől, a szántóföldi mủvelés általánosan jellemzö, rendkívül alacsony az extenzív hasznosítású területek, az erdők aránya, továbbá az egyéb intenzív kertészeti kultúrák (zöldség, gyümölcs) termesztése, amelyek összességében gátolják a kiegészítő bevételi források növelésének lehetőségeit (pl. falusi turizmus).

— A mezőgazdasági termesztés jövedelmezősége alacsony a lakosság számára.

— Egysíkú szántóföldi termesztés túlsúlya jellemző, alacsony a magas munkaerő igényü kertészeti kultúrák, vagy ökológiai gazdálkodás aránya.

- A Rába nyújtotta rekreációs lehetőségek kihasználását a part rendezetlensége, az infrastruktúra hiánya gátolja.

— A gazdasági, társadalmi mutatók egyértelműen a dél-rábaközi falvak hátrányos helyzetét tárta fel, itt romló demográfiai tendenciák és alacsonyabb jövedelemszint jellemző.

Tóköz:

— Magas természeti értékü területek jelentős arányban megmaradtak, de a védett területek magas aránya ellenére a természeti értékek nem jelennek meg attrakcióként, kevés lehetőség nyílik a kulturált, természetkímélő megismerésre tanösvények, kilátóhelyek, kiállítások keretében.

- A Csornával szomszédos tóközi falvak kedvezőtlen gazdasági, társadalmi mutatókkal rendelkeznek (rosszabb versenyképességi helyzet), ami a kistérségi központ funkciógyengeségének köszönhető, és az adott falvak gyenge gazdasági potenciáljával és a kedvezőtlenebb elérhetőségi viszonyokkal (távol a megyeközponttól, kiesve a fö közlekedési folyosókból alacsonyabb szintü 
a tömegközlekedés) magyarázható. A mezőgazdaságot itt sújtják leginkább a természetvédelmi korlátozások. A természeti értékek a turizmus hiánya miatt nem hasznosulnak „erőforrásként”.

- A gyepterületek legeltetése az állattartás alacsony jövedelmezősége miatt gyakran megoldhatatlan problémát jelent a helyieknek. A környezet- és a természetvédelmi szempontok erőteljes hangsúlya és az agrár-környezetvédelmi program forráshiánya révén a gazdálkodók jelentős része elesik a kompenzáció lehetőségétől így a természetvédelem miatt gyakran korlátozott jövedelmet biztosít a mezőgazdasági tevékenység a tóközi falvakban.

— Rendszeresen belvízjárta területek nagy aránya jellemző, amelyek ennek ellenére gyakran szántóföldi hasznosításban vannak.

— A jó elérhetőségi mutatókkal rendelkező tóközi falvak vonzó lakóterületek maradtak.

Az esettanulmány alapján kapott eredmények is rávilágítanak arra a vidékfejlesztési elméletekben is hangsúlyozott elvre, hogy mennyire fontos az elérhetőség a vidéki térségek népességmegtartó képességét illetően. (Van elmélet, amely az elérhetőség alapján külön foglalkozik a vidéki térségekkel: jól megközelíthető és periférikus helyzetü térségek). Az aprófalvak erősödő, egyoldalú lakófunkciója miatt a kistelepülések helyzetét alapvetően meghatározzák az elérhetőségi viszonyok. A vonzó táji környezetben és kedvező elérhetőségi mutatókkal rendelkező települések lakóhelyi szempontból felértékelődnek, az értékelések alapján kedvező társadalmi és gazdasági mutatókkal rendelkeznek. A legsikeresebb települések a fö közlekedési folyosók mentén helyezkednek el, ahol nemcsak az egyéni közlekedés, hanem a tömegközlekedés lehetőségei is kiválóak és egyben magas életminőséget nyújt a táji, települési környezet.

A táji adottságok által meghatározott legkedvezőbb gazdálkodási forma a Tóköz belvizes, gyengébb termőképességü talajain a rét, legelő- illetve erdőgazdálkodás. Az állattenyésztés alacsony jövedelmezősége, nagy beruházásigénye miatt jelentősen visszaszorult a térségben. Gyakran problémát okoz a Natura 2000 gyepterületek fenntartása.

A táji adottságoknak leginkább kedvező, a foglalkoztatottságot és a jövedelem-viszonyokat is javító tájhasználat kialakulását a mezőgazdasági ágazat szerkezeti hibái (egyes ágazatok preferált helyzete, támogatásrendszer anomáliái), és a társadalmi együttműködési rendszerek hiányosságai gátolják.

A mezőgazdasági hasznosítás jövedelmezősége javítható az intenzív, magas munkaigényű kertészeti- és zöldségkultúrák arányának növelésével. Mind gazdasági mind tájképi szempontból az intenzív és extenzív hasznosítású területek kiegyenlítettebb arányára kell törekedni.

\subsection{Térségi jövőkép}

A jelenlegi tendenciák folytatódása a kistérség területi különbségeinek további mélyülését hozza. Lényeges változást a fejlődési tendenciákban mind a térség érdek-navigációjában, mind az értékgazdálkodásban jelentős elmozdulásra lenne szükség. 


\subsubsection{Jövőkép a jelenlegi tendenciák folytatódásával}

A gazdasági, az ökológiai és a termesztési érték alapján karakteres térségeket határoltam le a kistérségben (46. ábra), illetve besoroltam a 15. táblázatban szereplő alapesetekbe. Az egyes térségtípusok népességmegtartó képessége a jelenlegi tendenciák alapján különböző:

— Tóköz 1. Magas környezeti értékü szuburbán táj

Magas természeti értékü, kevésbé intenzív mezőgazdasági termesztéssel jellemezhető, kedvező gazdasági helyzetü települések, (jó elérhetőségi mutatók) tartoznak ebbe a csoportba.

○ A jelenlegi tendenciák folytatódásával a népességmegtartó képesség hosszútávon fenntartható, népességnövekedés várható.

— Tóköz 2. Hagyományos környezetkímélő, alacsony intenzitású gazdálkodással jellemezhetö táj Magas természeti értékü, kevésbé intenzív mezőgazdasági termesztés, kedvezőtlen gazdaságitársadalmi helyzetü települések tartoznak a csoportba.

○ A jelenlegi tendenciák folytatódásával a mai népességszám hosszútávon nem fenntartható, népességszám csökkenés várható.

○ A tendenciák megfordítása a kistérség központ, Csorna szolgáltató, ellátó, munkahelyteremtő funkcióinak erősítésével (vonzáskörzeti jelleg, szuburbán térség), vagy a korlátok előnnyé alakításával, az ökológiai gazdálkodás, ökoturizmus elterjesztésével, a „,natúrpark jelleg” elérése (ez az opció nagyobb térségi összefogással lehetséges, azonban e települések népességmegtartó képességét javíthatja leginkább).

\section{— Hanságmente Magas környezeti értékü szuburbán táj}

Magas természeti értékü, kiváló elérhetőségü, kedvező gazdasági helyzetü települések.

- A jelenlegi tendenciák folytatódásával a népességmegtartó képesség hosszútávon fenntartható, népességnövekedés várható.

\section{— Rábaköz 1. Intenzív agrártáj (gyenge multifunkcionális jelleg)}

Közepes ökológiai értékü, elsősorban agrárjellegü, de jelentősebb ipari, kereskedelmi aktivitású települések, viszonylag kedvező gazdasági helyzettel rendelkező települések.

- A jelenlegi tendenciák folytatódásával a népességmegtartó képesség fenntartható, a kedvező folyamatok erősíthetők a mezőgazdaság multifunkcionális jellegének erősítésével, a termesztésre épülő feldolgozó ipar fejlesztésével.

\section{— Rábaköz 2. Intenzív agrártáj}

Agrárjellegü, közepes ökológiai értékü, kedvezőtlenebb gazdasági helyzetű települések, mikrotérségi központ Szany.

○ A jelenlegi tendenciák folytatódásával további népességszám csökkenés várható.

○ A kedvezőtlen folyamatok mérsékelhetők a mikrotérségi központ szolgáltató, ellátó, munkahelyteremtő funkcióinak erősítésével, a mezőgazdaság multifunkcionális jellegének, a ter- 
mesztésre épülő feldolgozó ipar fejlesztésével, a mezőgazdasági termesztéshez kapcsolódó kiegészítő tevékenységek elterjedésének ösztönzésével, a táj ökológiai értelmü fejlesztésével (amely például a falusi turizmus elterjedéséhez nélkülözhetetlen).

— Rábaköz 3.Hagyományos környezetkímélö, alacsony intenzitású gazdálkodással jellemezhetö táj Magas természeti értékü, kedvezőtlenebb gazdasági helyzetü települések (Vág, Rábasebes).

○ A jelenlegi tendenciák folytatódásával további népességszám csökkenés várható, a kedvezőtlen folyamatok mérsékelhetők az elérhetőség javításával, a mezőgazdaság multifunkcionális jellegének erősítésével, ökoturizmus fejlesztésével.
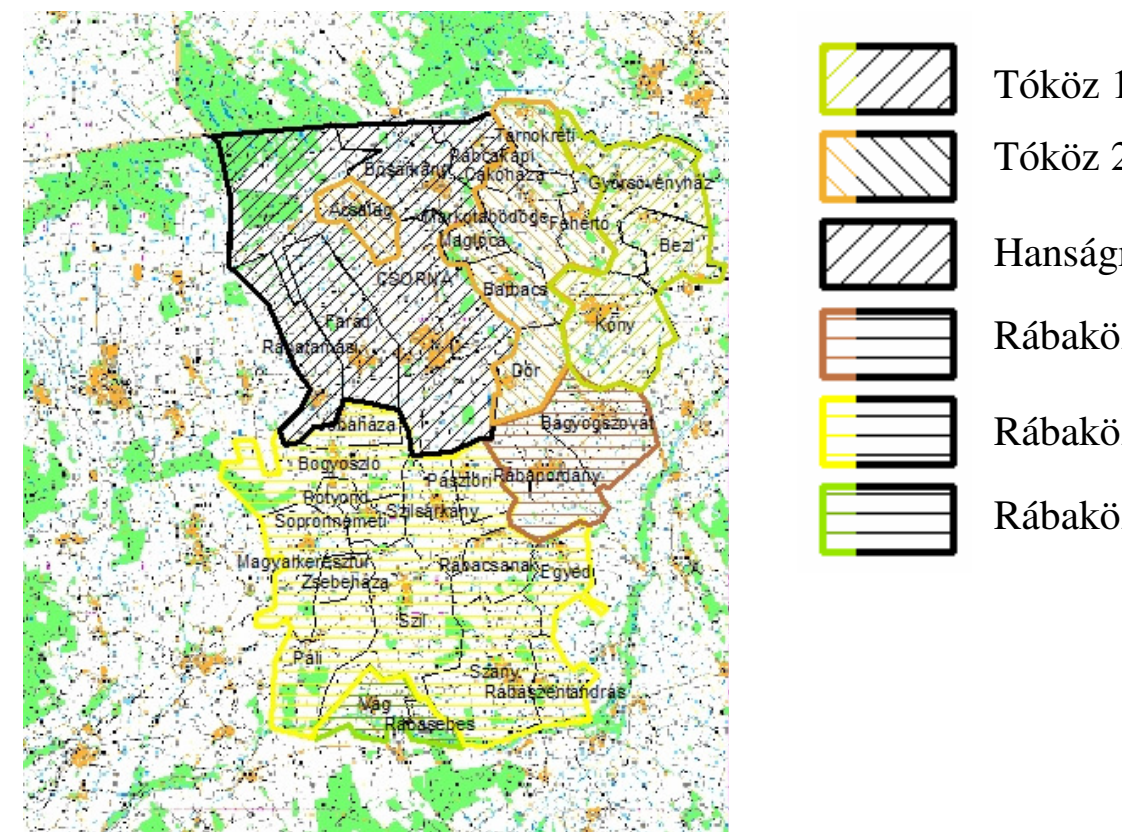

Tóköz 2

Hanságmente

Rábaköz 1

Rábaköz 2

Rábaköz 3

\section{6. ábra: Táji és gazdasági-társadalmi szempontból hasonló helyzetü településcsoportok}

(saját szerkesztés)

Eddigi vizsgálataim alapján egyértelmü, hogy a települések jelentős csoportját tartós népességvesztés sújtja, amennyiben a jelenlegi tendenciák nem változnak meg alapvetően.

\subsubsection{Jövőkép a versenyképességi stratégia alkotás alapelemeivel}

A stratégia legfontosabb elemei a mintatérség által követett, a nagytérségi pozíciót, kapcsolatrendszert meghatározó érdek-navigáció és a belső értékgazdálkodás (47. ábra). Részletes fejlesztési program kidolgozása nem célom a jelenlegi tanulmány keretei között, ahhoz azonban, hogy a térség elmozduljon a jelenlegi részleges sikerű fejlődési tendenciáktól (jó közlekedés földrajzi adottságú települések fejlődnek/stagnálnak, a lehetőségek mértéke alatt, a mintaterület jelentős részét a megállíthatatlan leszakadás fenyegeti), több területen is elmozdulásra, filozófia-váltásra lenne szükség.

Az érdek-navigáció egyes elemei

A versenyképesség egyik legfontosabb eleme - amellyel általában a fejlesztési koncepciók, stratégiák nem foglalkoznak - a nagytérségi szinten megjelenő pozícionálás, kapcsolatrendszer kialakítása. A mintatérség versenyképességi elemzéséből kitünt, hogy a fejlődés egyik legfontosabb gátja, hogy 
nem tudott hatékonyan bekapcsolódni a nagytérségi együttműködési rendszerekbe (lásd határon átnyúló együttműködések (osztrák, szlovák), Centrope régió). A járás vezető városa részéről ezen a területen a jövőben mindenképpen aktívabb szerepvállalásra lenne szükség.

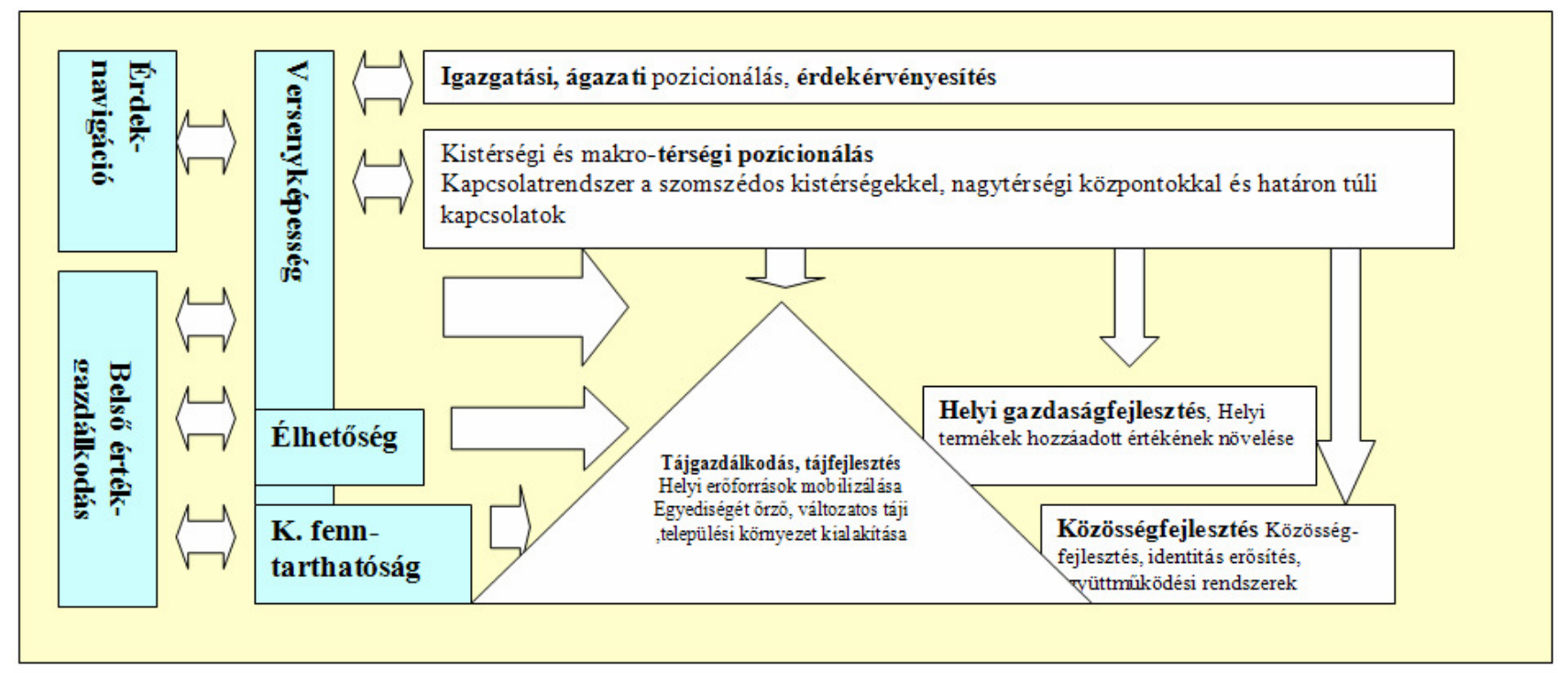

47. ábra: Versenyképességi stratégia-alkotás alapelemei (saját szerkesztés)

Ágazati szinten a mintatérség fejlődését alapvetően meghatározza a mezőgazdaság és a természetvédelem kezelése, szabályozása az országos és térségi politikában. A mezőgazdasági termesztés jövedelmezősége, a felvásárlási, értékesítési láncok kialakításának lehetőségei, egyes ágazatok támogatása stb. alapvetően meghatározza a térség gazdálkodóinak helyzetét és fejlődési lehetőségeit. A természetvédelem „szigora”, a gazdálkodás, és egyéb gazdasági tevékenységek szabályozása, korlátozása meghatározza a tóközi települések ,mozgásterét”. Filozófia-váltásra lenne szükség, hogy a térség ökológiai értékei ne csak a természetvédelemben jelenjenek meg, hanem táji értékre alapozott fejlődési potenciált is jelentsenek (ahogy ma még nem jelent, hiszen a „táji értékekre alapozott növekedés térségei” között a Hanság még részterületként sem szerepel az OTFK-ban). Ehhez sokkal rugalmasabb, a gazdálkodást segítő, a pénzügyi kompenzációt biztosító hozzáállás, természetvédelmi politika szükséges. Országos és térségi szintü egyeztetésre, érdekérvényesítésre lenne szükség, amelyben egyik legfontosabb partner a nemzeti park igazgatóság.

A belső értékgazdálkodás területi vetülete a környezeti (környezeti fenntarthatóság), a gazdasági (versenyképesség) és a társadalmi (élhetőség) igények egyensúlyán alapuló tájgazdálkodás és tájfejlesztés, amelyhez általánosan érvényesíthető irányelveket (tájépítészeti követelmények/tájminőségi célkitüzések Jegyzetek 9.) valamint a mintatérségre vonatkozó javaslatrendszert dolgoztam ki (melléklet). A versenyképesség javítása érdekében nagy hangsúlyt kell fektetni a helyi gazdaságfejlesztrésre (mezőgazdasági termesztésre és ipar, feldolgozóiparra vonatkozó irányelvek a mellékletben). A térségben elsődleges a magas hozzáadott értékű mezőgazdaság és az erre épülő innovatív feldolgozóipar fejlesztése lehet. 


\section{4. ÚJ ÉS ÚJSZERŰ EREDMÉNYEK/TÉZISEK}

\section{Vidéki térségek versenyképességének meghatározása}

Megállapítottam, hogy azok a vidéki térségek tekinthetők versenyképesnek, amelyek képesek népességük hosszú távú megtartására, megfelelő szintü jövedelmet és életminőséget biztosítva a lakosság számára, miközben fenntartható módon gazdálkodnak természeti és kulturális értékeikkel, javaikkal. A versenyképesség elérésének és fenntartásának alapvető eszköze a helyi szereplők együttmüködési képessége, az újításra, az innovációra való készsége. A térségi szintü versenyképesség nélkülözhetetlen feltétele a helyi adottságokhoz és a külső környezet kihívásaihoz történő alkalmazkodás.

Indokolás: A hazai és nemzetközi szakirodalom alapján a hagyományos versenyképességi értelemben a lakosság életminősége és jövedelemszintje határozzák meg egy térség versenyképességét. A vidéki térségek gazdasági teljesítményével foglalkozó szakirodalom sokkal tágabb megközelítést alkalmaz. A városias térségekkel, az agglomerációkkal ellentétben a vidéki térségek esetében a táji értékek, a táji adottságok felértékelődnek, jelentősen növelhetik a versenyképességet, hiszen hozzájárulnak a gazdasági diverzifikációhoz, az életminőség javításához. A térségi szintủ versenyképességet a környezeti fenntarthatóság, az élhetőség egymásra ható, egymást kiegészítő feltételrendszerével együtt értelmeztem. A környezeti, a társadalmi és a gazdasági rendszerek egymástól elválaszthatatlanok, együttesen alkotják a fenntartható fejlődés alapját. A belső erőforrások feltárása, hasznosítása nagymértékben függ a helyi szereplők aktivitásától. Tanulmányomban a versenyképesség erősítését tekintettem prioritásnak, elméleti és gyakorlati alkalmazást a hagyományos értelmezésekkel ellentétben vidéki térségekre dolgoztam ki.

\section{A vidéki térségek versenyképessége és a tájhasználat összefüggéseinek meghatározása}

Megállapítottam, hogy a vidéki térségek versenyképességének gazdasági, környezeti, társadalmi és tájhasználati feltételei vannak. Meghatároztam a vidéki térségek versenyképességét befolyásoló tényezők és a tájhasználati szempontok kapcsolódási pontjait, tájhasználati feltételeit:

— versenyképes jövedelem, magas szintü foglalkoztatottság,

- versenyképes jövedelem a földalapú gazdasági ágazatokban,

- elérhetőség biztosítása más gazdasági ágazatok nyújtotta munkalehetőségekhez,

— tiszta környezet és „,egészséges” tájökológiai rendszer,

- egészséges környezeti szabályozó rendszerek,

- (települési környezet minösége),

- ökológiai diverzitás (biotóphálózat védelme),

— életminőséget meghatározó egyéb kulturális/természeti tényezők megléte,

- rekreáció és pihenés lehetőségét biztosító zöldfelület-rendszer, 
- vonzó, rendezett tájkép,

- gazdag, helyi kulturális, természeti örökség.

Indokolás: A vidéki térségek népességének életminőségét jelentősen meghatározza, hogy az adott térségben milyen tájhasználatok vannak jelen, mennyire egyoldalú a tájhasználat vagy esetleg a lehetséges funkciók széles skálája a megfelelő szinten érvényesül. Egyre több kutatás irányul a mezőgazdasági termesztés egyéb tájfunkciókat gyengítő hatásainak csökkentésére és az agrár-térségek környezeti, ökológiai és kulturális értékének növelésére. Legnagyobb kihívás a tájfunkciók, a területhasználatok optimális összhangjának megteremtése, olyan egyensúly kialakítása, amely az ökológiai rendszert nem rontja és egyben összességében a legnagyobb gazdasági hasznot hozza. Vidéki térségek sikerességének (versenyképességének) egy alapvető feltétele a táji rendszerek által biztosított ökológiai, gazdasági és egyéb oktatási, kulturális és esztétikai javak/szolgáltatások érvényre jutásának sokrétü, harmonikus teljesülése, a tájfunkciók diverzitása. A hazai tájépítészeti terminológiában több szakkifejezés utal a táj fenntartható, erőforrás-megőrző hasznosítására: ilyen a tájgondozás, (de elsősorban) a tájgazdálkodás fogalma, (Csemez, 2009) a tájrehabilitálás, a természetvédelem, a tájvédelem, a környezetvédelem és a fenntartható területfejlesztés összhangjának megteremtése, beágyazása a megtartandó tájelemek rendszerébe. Kiterjesztettem a fogalom értelmezését: tájgazdálkodás a tájhasználatok olyan rendszere egy adott térségben, amely segíti a tájfunkciók és a tájhasználati funkciók sokrétü, kielégítő szintü, hosszútávon fenntartható múködését és egyben törekszik a társadalom mindenkori igényeinek a kielégítésére. Harmonikus fejlődésnek azt tekintem, amikor a társadalmi, a gazdasági és a környezeti feltételek (a fenntartható fejlődés három alappillére) hasonló arányban érvényesülnek.

\title{
3. A versenyképességi feltételek történeti változásának meghatározása
}

\begin{abstract}
Általános megállapítás: A társadalmi-gazdasági fejlődést évszázadokon át a tájalakítás és az egyre intenzívebbé váló tájhasznosítás révén fejlődő mezőgazdasági termesztés és a javuló elérhetőségi viszonyok határozták meg, majd a XIX. század végétől az iparosodás és az urbanizáció váltak a társadalmi fejlődés fô mozgató rugóivá.

Mintatérségre vonatkozó megállapítás: A térség gazdasági, társadalmi helyzete, versenyképessége a kora középkori tógazdálkodás felszámolásához köthető visszaesést követően javult a XX. század első feléig. A XX. században a kedvező illetve a tájalakítás révén kedvezővé vált agráradottságok nyújtotta ,versenyelőnyt” elvesztette. A gazdasági fejlődés mozgatórugóinak megváltozása miatt a térség jelentős népesség-kibocsátóvá vált. A versenyképesség látványos romlásának elsődleges oka, hogy a térség elveszítette a korábbi szerepkörét, kapcsolatait (elveszítette piacait). A mezőgazdasági termékek pedig elveszítették stratégiai jelentőségüiket.
\end{abstract}


Indokolás: A Hanság és a Tóköz térségében a vízviszonyok hátráltatták a gazdálkodást. A kora középkori tógazdálkodás felszámolását követően évszázadokon át korlátozott volt a térség népességeltartó képessége. A Rábaköz kiváló agráradottságú térségeit hamar müvelésbe vonták és jellemzően az ország átlagos színvonalánál magasabb színvonalon müvelték. A térség kevésbé szenvedte meg a török hódításokat, a háborúk a gabonatermesztés fellendülését hozták. Az uradalmak feljegyzései tanúskodnak az állattartás jelentőségéről a térségben a XVIII. században. A háromnyomásos gazdálkodásra ebben a térségben álltak át először a XVIII-XIX. század fordulóján. A XIX. században jelentős fellendülés volt érzékelhető a mezőgazdaságban, duplájára nőtt a gabonatermesztés, általánossá vált a kukorica termesztése, a fellendült sertéstenyésztés, új termékként megjelent a cukorrépa a század végén. A terméseredmények jobbak voltak az országos átlagnál. A Rábaköz térsége a birodalmi főváros Bécs ellátó körzetének peremterületéhez tartozott, az országos átlaghoz képest magasabb vagy átlagos fejlettséget képviselve (Győri, 1999).

A térszerkezet átalakulását hozta a vasúthálózat megépülése: korábban jelentős települések vesztettek térségi szerepkörükből, Csorna fejlődéséhez azonban nagymértékben járult hozzá elsősorban a malomipar megtelepedését segítve.

A vízrendezési munkáknak köszönhetően átalakult a tájszerkezet, a mocsárvilág visszahúzódott, a szántók, a gyepek a térség egyre nagyobb részét foglalták el, ami azonban nem sokáig jelentett versenyképességi előnyt a térségnek, hiszen időközben (XX. század) megváltoztak a társadalom, a gazdaság mozgatóerői: legfontosabb térszervező erővé az iparosodó városok és a nagy forgalmú közlekedéshálózatok (közút, vasút) váltak. A trianoni határok miatt a mintatérség piacainak jelentős részét elvesztette. A szocializmusra jellemző erőltetett iparosítás, amely a korábbi ipari központokat részesítette előnyben és a falvakat háttérbe szorító fejlesztéspolitika hátrányosan érintette a térséget, a kistelepülések jelentős népességvesztést szenvedtek el. Meghatározóvá váltak a mezőgazdasági lehetőségeket alakító természeti adottságok helyett a közlekedés-, és gazdaságföldrajzi tényezők. Jelentős népességcsökkenést szenvedtek el a közlekedés- és városárnyékos rábaközi (dél-nyugati aprófalvak és tóközi) aprófalvak, a Tóköz fejlődő településeivé válnak a kistérség közlekedési „ütőerei” mentén elhelyezkedő Bősárkány (86. sz.), Kóny (86. sz.) és a Hanság déli peremét képező Farád (85. sz. út). Kóny fejlődésére Győr vonzása is jelentős hatással van. A negatív tendenciák a rendszerváltás óta sem sokat változtak, míg a megye községei összességében kismértékű növekedést éltek meg, a Rábaköz népességvesztése folytatódik, bár a népességcsökkenés kisebb arányú.

A napjainkra jellemző munkaerőpiaci vonzáskörzetek alapján látható, hogy a Rábaköz, GyőrMoson-Sopron megye nagycentrumai között, mintegy árnyékhelyzetben helyezkedik el, helyzete belső perifériaként jellemezhető (Rechnitzer, 1999). 


\title{
4. A tájrendezés és a versenyképesség összefüggéseinek meghatározása
}

\author{
Általános megállapítás: A társadalmi rendszer adottságai jelentősen módosíthatják a táj- \\ rendezés hatására javuló népességmegtartó képességet.
}

Mintatérségre vonatkozó megállapítás: A nagyarányú tájalakítás jelentősen növelte a térség népesség eltartó képességét, viszont nem hozta magával a táj népességmegtartó képességének hasonló szintü növekedését. A versenyképesség javulását hozta a nagyarányú tájalakítás (a gazdaságosan, hatékonyan előállított mezőgazdasági termékek könnyen piacra találtak). A népsürüség térségi különbségei fennmaradtak a XX. század elejéig, majd a különbségek kiegyenlítődését az urbanizációs folyamatok indították el.

Indokolás: A birtokrendszer sajátságai miatt a lecsapolt területek a nagybirtokrendszer részeként majorságok keretében magas múszaki technológiával, viszonylag alacsony munkaerőigénnyel korszerü agrárgazdálkodás részeivé váltak, amely országos viszonylatban kedvező jövedelemviszonyok kialakulását, de a népsürüség kisebb mértékü növekedését hozta magával. A mezőgazdaságnak kedvező adottságok a nagybirtokok által kevésbé befolyásolt D-Ny rábaközi falvakban tették lehetővé magas népsürüség kialakulását a XVIII. századra, amely térség a társadalmi változások mozgatórugóinak megváltozása miatt a XX. századra a legjelentősebb népesség-kibocsátó területté váltak. A versenyképesség kiemelt feltétele az adott régió markáns megjelenése a nagytérségi kapcsolatrendszerben. A tájalakítás révén javuló népességeltartó képesség abban az esetben járul tehát hozzá a térség versenyképességének erősödéséhez, amennyiben ez a nagytérségi kapcsolatrendszerben egy kiemelten fontos ,,szerephez/ feladathoz” kötődik, és a térség képes a belső adottságok állította korlátok között, a lehetőségeket maximálisan hasznosítva alkalmazkodni a nagytérségi (globalizációs) folyamatokhoz.

\section{A tájfunkció-elemzés módszertanának kidolgozása és alkalmazása}

Területhasználati és statisztikai adatok felhasználásával a tájhasználat gazdasági, társadalmi, környezeti szempontú értékelése egyértelmúen elvégezhető. A gazdasági értékeléssel kiegészített tájfunkció elemzés vidékfejlesztésben sikeresen alkalmazható eszköz lehet, mert alkalmas egy-egy térség, település táji erőforrásainak, potenciáljának illetve korlátainak feltárására.

A tájfunkciók elemzését többféleképpen végeztem el:

— statisztikai és egyéb gyüjtött adatok, információk alapján, egyedi értékelési szempontrendszer kidolgozásával (kisebb területi egységekre alkalmazható, pontosabb probléma és tényfeltárást lehetővé tevő értékelés),

— alapvetően a területhasználat jellemzőire alapozva, Corine térképi adatbázis alapján (sematikus elemzést lehetővé tevő, de nagyobb területi egységre könnyebben végrehajtható elemzés, alkalmas történeti térképek alapján a tájfunkciók történeti elemzésére). 
A tanulmányban alapvetően az első értékelési módszerre helyeztem a hangsúlyt. Kapcsolódva a vidéki térségek versenyképességének feltételeihez értékeltem a termesztési funkciót, a földalapú ágazatok elkülönített értékelésének nehézsége miatt a gazdasági tevékenységek, iparüzési adó, lakosság jövedelemszintje alapján összesített gazdasági értéket számoltam, továbbá értékeltem az elérhetőség szintjét. A táj- és a természetvédelem több évtizedes hagyományainak köszönhetően az élőhelyi érték települési szintü összehasonlítására többféle mutató is könnyen elérhető: a természetvédelmi területek (Nemzeti Park és Natura 2000 területek) valamint a Nemzeti Ökológiai Hálózat adatait használtam fel. A táj esztétikai értéke nehezen mérhető, az egyes tájtípusok, területhasználatok esztétikai értéke különböző. Értékelési szempontként a diverzitást (Shannon index), és a természetszerüséget (extenzív hasznosítású területek aránya) vettem figyelembe. A tájhasználati rendszer rekreációs, kulturális, művészeti értékeinek feltárásához a kulturális feltöltődés lehetőségeit, (müemlékek, tájértékek), az ökoturisztikai hasznosítás alapjául szolgáló lehetőségeket és az aktív kikapcsolódás területeit, lehetőségeit vettem figyelembe egy általam kidolgozott települési értékkataszter alapján. A tájfunkciók szintjét az indikátorok amplitúdója alapján tízes skálán értékeltem és településenként és mikro-térségi szinten ábrázoltam, összehasonlításukat lehetővé tettem.

Megállapítottam, hogy a tájfunkciók harmonikus működését települési majd mikro-térségi szinten értékelve, fontos következtetések vonhatók le a térség tájhasználati rendszerének hiányosságait/korlátait illetve potenciáljait illetően.

\section{Az összefüggések feltárása a versenyképesség és a tájfunkciók között}

Általános megállapítás: A mintatérségben végzett kutatásaim alapján igazoltam, hogy a vidéki térségek versenyképességének illetve népességmegtartó képességének fenntartásához elengedhetetlen a tájfunkciók harmonikus érvényesülése, diverzitása. A tájfunkciók érvényesülésének elégtelensége különösen térségi szinten okoz versenyképességi hátrányt. Mintatérségre vonatkozó megállapítás: Több tájfunkció harmonikus múködése szenved csorbát a Rábaköz térségében: a gazdasági, az élőhely-védelmi, a kulturális és az esztétikai funkció érvényesülése több településen is elmarad az optimális szinttől, amelyek összességében hozzájárulnak a térség versenyképességi helyzetének romlásához. A tájfunkciók elégtelenségének oka, hogy a táji adottságoknak leginkább kedvező, a foglalkoztatottságot és a jövedelem-viszonyokat is javító tájhasználat kialakulását a mezőgazdasági ágazat szerkezeti hibái (egyes ágazatok preferált helyzete, támogatásrendszer anomáliái), és a társadalmi együttmüködési rendszerek hiányosságai gátolják.

Indokolás: A kistérségben a mezőgazdaság mind a gazdaságban, a foglalkoztatásban, a tájhasználatban az országos átlagot meghaladó jelentőséggel bír. A mezőgazdaság azonban, ahogy az leginkább az alacsony ingázási, és egyéb gazdasági aktivitással jellemezhető települések esetén (amelyek leginkább a mezőgazdaságra utaltak) egyértelmüen kimutatható, nem biztosít versenyképes jöve- 
delmet a lakosság számára. A mezőgazdaság jövedelmezőségét rontja az intenzív kertészeti kultúrák alacsony aránya (pedig a helyi társadalom adottságai ezt régen lehetővé tették) és a kistérségben előállított mezőgazdasági termékek feldolgozottságának alacsony foka, illetve a kiegészítő tevékenységek és jövedelmek szük köre.

A mezőgazdaság versenyképességét rontják a Rábaközben is jellemző országos szintű problémák, mint az elaprózott birtokszerkezet és az egyrészt erre adott válaszként kialakult magas bérleti arány. Az elmúlt évtizedben rendkívül erőteljes koncentráció zajlott le a földhasználatot illetően. A földtulajdonviszonyok miatt kialakuló magas földbérleti arány nem ösztönöz beruházások, fejlesztések végrehajtására. A jelenlegi tendenciák folytatódása előrevetíti a mezőgazdaság jelentőségének további csökkenését a vidék foglalkoztatásában és jövedelemviszonyaiban.

Az állattenyésztés veszteségessége az ökológiailag legkedvezőbb tájhasználat, a legelök és gyepek fenntartását lehetetleníti el. Magas hozzáadott értéket előállító, magasabb foglalkoztatottságot biztosító ágazatok fejlődéséhez a kedvező táji adottságok mellett jelentős pénzügyi forrásokat megmozgató beruházások, felkészült szakemberek, fejlett, összetett horizontális és vertikális együttműködési rendszerek szükségesek. Amennyiben gyengék a társadalom és a gazdaság együttmüködési struktúrái (felvásárlási, értékesítési, feldolgozási szövetkezetek az mezőgazdaságban) elaprózott birtokstruktúrával a mezőgazdasági termesztés nem tud versenyképes lenni, és magas hozzáadott értéket létrehozni hossz távon. Sajnálatos tény az ökológiai gazdálkodás utóbbi években tapasztalható viszszaesése, hiszen mind foglalkoztatáspolitikai (kb. két és félszer több munkaerő igénnyel rendelkezik) mind ökológiai szempontból kedvezőbb mint a konvencionális gazdálkodás. Az ökológiai gazdálkodás jelentősége különösen a birtokkoncentrációs folyamatok tükrében nő meg.

A messze az országos átlag szintje feletti szántó aránnyal jellemezhető agrártájban rendkívül alacsony az extenzív hasznosítású területek, a gyepek és az erdők aránya. Mindezek az élőhely és a kulturális (esztétikai, rekreációs, oktatási) funkciók elégtelenségét okozzák a Rábaközben. Alapvetően kihasználatlanok a Rába nyújtotta lehetőségek. Amennyiben ezek a tájhasználati adottságok nem változnak térségi szinten, az a népesség további drasztikus csökkenéséhez vezethet, és egyben gátolja a helyi fejlesztési stratégiák megvalósulását.

\section{A természeti értékek szerepének meghatározása a versenyképességben}

Általános megállapítás: A védett valamint a magas természeti értékű területek nagy aránya előnyként a jó elérhetőséggel rendelkező falvakban jelenik meg. Gazdag munkahelykínálattal rendelkező központi település hiányában, kedvezőtlenebb elérhetőségi viszonyok mellett, a jelentős gazdálkodási korlátozások következtében, illetve az egyéb hasznosítási lehetőségek (pl. turizmus) hiányában azonban a védett területek magas aránya hátrányként jelenik meg. 
Mintatérségre vonatkozó megállapítás: A Tóköz jelentős része áll természetvédelem alatt magas minőségű környezetet biztosítva az itt lakók számára. A munkahelyek hiánya ellenére a megyeközpont viszonylag jó elérhetősége révén vonzóak maradtak egyes települések. A kedvezőtlenebb elérhetőségi viszonyokkal rendelkező Csorna környéki tóközi falvak a természeti értékek gazdagsága ellenére hátrányos helyzetüek, itt elsősorban a védelem korlátozó jellege érvényesül.

Indokolás: A védett területek magas aránya miatt (amely korlátozásokat jelent a gazdálkodás számára) értékeltem az agrár-környezetvédelmi kifizetések mértékét. Az elemzésben feltártam, hogy alapjában véve a természetvédelmi korlátozások kompenzációját nem szolgálja az agrárkörnyezetvédelmi program: nincs szoros korreláció a védett területek aránya és az agrárkörnyezetvédelmi kifizetések mértéke között egyes településeket leszámítva. Néhány településen hiába nagyon jelentős a Natura 2000 területek aránya, az agrár-környezetvédelmi kifizetések szintje alacsony. Magas az agrár-környezetvédelmi kifizetések aránya több rábaközi településen az állattartás nagyobb jelentősége miatt. Az agrár-környezetvédelmi program prioritásrendszere, forráshiánya miatt a gazdálkodók jelentős része esett el a kompenzáció lehetőségétől.

A védett területek magas aránya ellenére a természeti értékek nem jelennek meg attrakcióként, kevés lehetőség nyílik a kulturált, természetkímélő megismerésre tanösvények, kilátók, kiállítások keretében, ami gátolja az ökoturizmus fejlődését, ezáltal kiegészítő jövedelmek lehetőségének biztosítását a lakosság számára. A „Magas Természeti Értékü Terület” programnak kimondottan a mezőgazdasági hasznosítás és a természetvédelem összehangolása (2002-ben indított Érzékeny Természeti Területek) volt a célja, azokon a tájegységeken jelöltek ki MTÉT területeket, ahol a természeti értékek fennmaradásának feltétele a mezőgazdasági hasznosítás. 2009-ben a Hanságra is kiterjesztették a programot, azonban a gazdálkodók részvétele lehangolóan alacsony.

\section{Térségtípusok meghatározása és lehatárolása}

Általános megállapítás: Sajátos térségtípusokat határoztam meg a gazdasági, a termesztési (versenyképesség) és az élőhelyi (ökológiai-környezeti fenntarthatóság) érték összevetésével, a népességmegtartó képesség hosszú távú becslésére.

Indokolás: A vidékfejlesztés számára fontos szempont, hogy képesek vagyunk-e a fenntartható fejlődés hosszú távú biztosítására, azaz az élhetőség, a környezeti fenntarthatóság és a versenyképesség érdekrendszerének egyfajta harmóniáját biztosítani. A tájfunkció-elemzésben alkalmazott gazdasági, termesztési és ökológiai érték alapján hét alapesetet különítettem el:

— Magas természeti értékü, kevésbé intenzív mezőgazdasági termesztéssel jellemezhető, kedvező gazdasági helyzetü térség: Magas környezeti értékü szuburbán táj: népességmegtartó képesség magas 
— Magas természeti értékü, kevésbé intenzív mezőgazdasági termesztés, kedvezőtlen gazdaságitársadalmi helyzetủ települések: Hagyományos környezetkímélö, alacsony intenzitású gazdálkodással jellemezhetö táj

— Intenzív agrárjellegü, közepes ökológiai értékü, kedvezőtlen gazdasági helyzetü települések: Ipari agrártáj

— Alacsony termesztési intenzitású, magas ökológiai értékü, közepes/magas gazdasági értékü táj: Természeti, kulturális értékekben gazdag táj ahol a fő megélhetési forrást az agrár-támogatások, a turizmus biztosítja: „Naturpark”

— Ökológiai és esztétikai érték alacsony, gazdasági érték magas: Természeti értékeit felélő szuburbán táj, Fontosabb város vonzáskörzete, ahol a beépítés terjeszkedését szabályozás nem korlátozza: Népességét megtartó táj, ha az ökológiai értékvesztés megállítható

— Ökológiai, esztétikai, gazdasági érték alacsony, tájrehabilitáció szükséges: Degradált táj.

A mintatérségben lehatároltam, a karakteresen elkülöníthető térségtípusokat, és becsültem hosszú távú népességmegtartó képességüket. A negatív tendenciák megfordítására fejlesztési célokat fogalmaztam meg.

\section{9. $\quad$ A terület- és a vidékfejlesztés eszközrendszerének értékelése}

\section{Megállapítottam, hogy vidéki térségek táji erőforrásainak mobilizálásához a területi ter-} vezés eszköz- és intézményrendszere hiányos. Kistérségi szinten vagy szervezet-bővítésre vagy új tervtípus alkalmazására lenne szükség:

- Szükséges lenne egy olyan fejlesztési szervezet, amely a vidéki térségekben meghatározó valamennyi ágazat fejlesztési igényeit össze tudja fogni és képes a közösségfejlesztésen alapuló vidékfejlesztési módszereket alkalmazni.

- Mind a nagytérségi, mind a helyi fejlesztési források megszerzését, a települések belső erőforrásainak felismerését segítené a táji erőforrásokat és konfliktusokat feltáró, komplex tájhasználati funkcióelemzést tartalmazó tájrendezési/tájgazdálkodási terv készítése.

Indokolás: A terület- és vidékfejlesztés intézményrendszerének, forráselosztásának valamint az ágazati fejlesztések széttagoltsága, harmonizációjának hiánya nem kedvez a vidéki térségek harmonikus fejlödésének. A magasabb területi szintü, illetve ágazati fejlesztési forrásokért folytatott versenyben a vidéki térségek hátrányos helyzetben vannak. A támogatástípusok közül leginkább a Leader elvei, támogatásformái segítik a vidéki térségekben a belső erőforrások mobilizálását, a táji értékek hatékonyabb hasznosítását, de térségi szintü, pozitív irányú elmozdulás/fejlődés nagymértékben függ a helyi társadalom aktivitásától, együttműködési formáitól. A vidékfejlesztési források hatékony felhasználásának gátja a közösségfejlesztő fejlesztési modellek alkalmazásának hiánya. 
A 2007-2013-as programozási időszak ágazati és regionális operatív programjai alapján GyörMoson-Sopron megye kistérségeinek pályázási eredményességét (egy főre jutó támogatás nagysága) összehasonlítva, a megye legkevésbé sikeres kistérségének tekinthető a vizsgált terület.

A helyi fejlesztési stratégiákból hiányzik a belső erőforrásokat mozgósító a táji adottságokból adódó lehetőségeket és korlátokat feltáró tájszemlélet. A rendezési tervek feladata lenne a tájpotenciál és a tájterhelhetőség feltárása, de a szabályozási jelleg dominanciája miatt alapvetően korlátok felállítására koncentrálnak. A fejlesztési tervek és rendezési/szabályozási tervek szemlélete rendkívül eltér, az egyes ágazatok tervezési, fejlesztési tevékenysége nem kapcsolódik össze, mindezek nagymértékben gátolják a település-, és területfejlesztés sok szempontú, a területhasználati tervezést, a tájfejlesztést is magába foglaló, ennek a tématerületnek a társadalmi oldalát is kezelni tudó megvalósulását. Az Európai Unió szándéka a Leader típusú fejlesztéspolitika általánossá tétele a regionális politikában (CLLD, Közösségvezérelt Helyi Fejlesztések) előremutató kezdeményezésnek tekinthető.

\section{Eredmények gyakorlati alkalmazhatósága}

A dolgozat készítésével bebizonyítottam, hogy a vidéki térségek fenntartható fejlesztésére a gazdasági, a társadalmi és a környezeti szempontokat, feltételeket egyaránt figyelembe kell venni. A megalapozott fejlesztésekhez a táji adottságokat sokkal hangsúlyosabban szükséges elemezni, értékelni. A vidékfejlesztési tervek készítését megelőzően célszerü a tájfunkciók harmonikus müködését értékelő tájfunkció-elemzést készíteni, amely megalapozza a belső, endogén erőforrások mozgósítását lehetővé tevő fejlesztési stratégiák kidolgozását.

A vidékfejlesztési stratégiák készítésekor az adott térség hosszú távú népességmegtartó képességének becslését segíti az adott térség összehasonlítása az általam kidolgozott sajátos térségtípusokkal. A vidéki térségek gazdasági teljesítményével foglalkozó modellek egyértelművé teszik a helyi társadalom szerepének jelentőségét a vidékfejlesztésben. A mintatérség fejlesztési intézményrendszerének és pályázati források elérésének alacsony hatásfoka felhívja a figyelmet a közösségfejlesztést nélkülöző gyakorlat sikertelenségére.

A fenntartható fejlődést megalapozó hármas pillér (környezeti fenntarthatóság, élhetőség, versenyképesség) egymást kiegészítő, együttható érvényesülésére van szükség. Az egyes feltételrendszerek kritériumai nem érvényesülhetnek a másik rovására. A terület- és a településrendezési tervek készítésekor a három feltételrendszer érvényesülésének lehetőségét biztosítani kell, továbbá a természetvédelmi szabályozó rendszerben a gazdálkodók szempontjait, igényeit hangsúlyosabban figyelembe kell venni.

A térség fenntartható fejlődésének biztosítása feltételez egy a jelenleginél tudatosabb belső értékgazdálkodást, amelyhez az általam az egyes tájfunkciókra kidolgozott tájépítészeti irányelvek alkalmazása nyújt segítséget. 


\section{KÖVETKEZTETÉSEK}

A vidéki térségek versenyképességével, sikerességével foglalkozó elméletek felhívták a figyelmet a gazdasági, a társadalmi, a környezeti szempontok/érdekek harmonikus egyensúlyának fontosságára. Ez a sokoldalúság tájhasználati szinten a tájfunkciók, a tájhasználati funkciók harmonikus müködésében nyilvánul meg. Változatos tájhasználat és tájszerkezet a gazdasági tevékenységek diverzifikálódását, a jövedelemszerzési lehetőségek szélesebb körét teszik lehetővé a helyi lakosság számára a vidéki térségekben, ezért össztársadalmi szinten kedvezőbb feltételeket jelentenek. A tájfunkciók diszharmonikus müködése gyengíti a táj népességmegtartó képességét.

Az aprófalvak esetében a közlekedés és a mobilitás fejlesztése a kedvezőtlen környezeti hatások ellenére prioritást kell kapjon, hiszen megmaradásuk fontos záloga a jó elérhetőség. Vidéki térségekben a kistérségi, mikro térségi központok funkciógazdagsága (az élhetőséget, a helyi lakosok életminőségét meghatározza a köz- és egyéb szolgáltatások elérhetősége) a környező kistelepülések harmonikus fejlődésének, népességmegtartó képességének záloga.

Kutatásaim alapján egyértelmủvé vált, hogy népességvesztés magas és alacsony ökológiai értékü településcsoportot egyaránt érint a vizsgált térségben. A környezeti értékek gazdagságát, a környezeti érzékenység által korlátozott gazdálkodást előnnyé kell kovácsolni szisztematikusan felépített „ökotérségi imázs” kialakításával, ehhez kapcsolódó fejlesztésekkel (a tájhasználati szempontok és az agrárérzékenység alapján egyértelmủen a Hanság menti, tóközi települések számára leginkább elérhető). E térség az ökoturisztikai fejlesztések legfontosabb célterülete. A táj vonzerejét, attraktivitását (ezzel a potenciális turisztikai célközönség számát növelné, és egyben a térségi identitást erősítené) javítaná a tájtörténeti sajátságok hangsúlyozása, bemutatása (tóközi tógazdálkodás bemutatása, részleges helyreállítása, a lecsapolások története). Másrészt azonban országos és ágazati szinten sokkal rugalmasabb, a gazdálkodást segítő, a pénzügyi kompenzációt biztosító hozzáállás, természetvédelmi politika szükséges illetve a mezőgazdasági szakirányításban az agrár-környezetvédelem jelentőségének növelése.

Az intenzív agrártájnak tekinthető Rábaközben a gazdagabb jövedelemszerzési lehetőségek feltétele illetve egymást erősítő alapja az ökológiai változatosság, érték növelése és a változatos agrárszerkezet kialakítása. A Rábaközt adottságai a magas versenyképességü, intenzív agrárgazdaság fejlesztésére predesztinálják, azonban kevésbé a monokultúrás szántóföldi termesztés inkább a változatos, magas feldolgozottságú termékszerkezet elérése legyen a cél. A mezőgazdaság versenyképességét rontják a Rábaközben is jellemző országos szintü problémák, mint az elaprózott birtokszerkezet és az egyrészt erre adott válaszként kialakult magas bérleti arány. Az állattenyésztés veszteségessége az ökológiailag legkedvezőbb tájhasználat, a legelők és gyepek fenntartását lehetetleníti el (hiába sújtja a szántóterületeket nagy arányú belvíz, amely akár 50\%-os terméskiesést hoz, a növénytermesztés még ilyen feltételekkel is kifizetődőbb a gazdák számára). Amennyiben gyengék a társadalom és a 
gazdaság együttmüködési struktúrái (felvásárlási, értékesítési, feldolgozási szövetkezetek) elaprózott birtokstruktúrával a mezőgazdasági termesztés nem tud versenyképes lenni, és magas hozzáadott értéket létrehozni hossz távon. Hasonlóan a magas bérleti arány megdrágítja a termesztést, visszaveti a beruházási kedvet. Sajnálatos tény az ökológiai gazdálkodás utóbbi években tapasztalható visszaesése, hiszen mind foglalkoztatáspolitikai (kb. két és félszer több munkaerő igénnyel rendelkezik) mind ökológiai szempontból kedvezőbb mint a konvencionális gazdálkodás. Jelentősége különösen a birtokkoncentrációs folyamatok tükrében nő meg.

A jelenleg is magasabb gazdasági aktivitású települések, mikro-térségi központok a feldolgozóipari kapacitás fejlesztésének potenciális színterei. A Rábaköz elsősorban mezőgazdasági termékei révén csatlakozhat a hansági, tóközi bázisú „ökotérséghez”.

Kutatásaim azt az elvet igazolták, hogy változatás tájhasználat, tájszerkezet, a tájfunkciók harmonikus müködése össztársadalmi szinten kedvezőbbek. Nagyon nehéz azonban a gyakran egymásnak ellentmondó érdekeknek egyformán megfelelni. Ebben kívántam segítséget nyújtani a tájfunkciók, a tájhasználati funkciók esetében alkalmazandó tájépítészeti követelmények, irányelvek összegyüjtésével. A mintatérségre értékeltem a tájépítészeti követelményeknek való megfelelést és ajánlásokat fogalmaztam meg a hiányosságok megszüntetésére, konfliktusok mérséklésére (terjedelmi és tartalmi korlátok miatt ezt a fejezetet a mellékletben helyeztem el). A javaslatok rendkívül komplexek és összetettek megvalósulásuk feltételei (48. ábra).

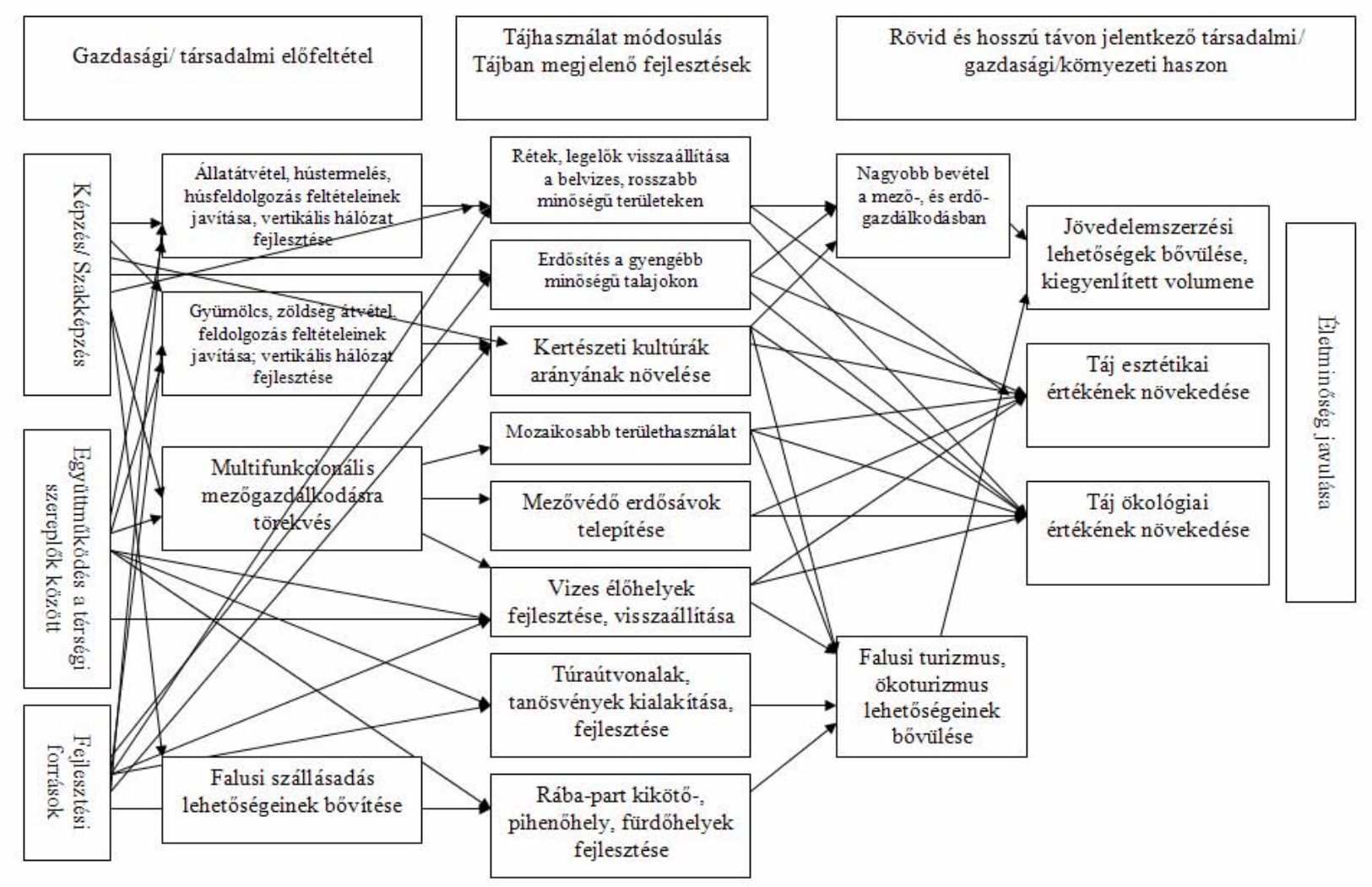

48. ábra: Példa néhány területhasználati, tájfejlesztési beavatkozás hatásaira és előfeltételeire (saját szerkesztés) 
A táji rendszerek összetettsége miatt a tájhasználat változás komplex sokszereplős folyamat részeként valósulhat csak meg, ennek hiányában a tervek csak az asztalfiókok tervei maradnak. Ez a tény felhívja a figyelmet a szakirodalmi kutatás során általam bemutatott vidékfejlesztési modellekre, amelyek a közösségfejlesztésen, a partnerség-építésen alapulnak. Alkalmazásuk hiánya nyilvánul meg a Leader program részleges sikerében.

Itt egy javaslatot emelnék ki, egy olyan, napjainkban egyre népszerübb a tájtervezéshez, tájfejlesztéshez kapcsolódó kezdeményezést, amely társadalmi, gazdasági és környezeti szempontból egyaránt jelentős eredményeket hozhat azokban a térségekben, erősíti az együttműködést, ahol megvalósul. Javasoltam egy (Melléklet XLVII.), a szomszédos kistérségekkel közösen megvalósítható zöldút létrehozását, amely megvalósulása többféle pozitív hozadékkal is járhat:

- a térség eredeti tájképének újjáélesztése,

— az életminőség javítása új rekreációs lehetőségek biztosításával a helyi lakosok és a turisták számára,

— az idegenforgalom fellendítése,

— a helyi identitás növelése (Filepné, Egyed 2012).

A mezőgazdaság még ma is komoly szereppel bír a vidéki kistelepülések foglalkoztatottságában. Fontos kérdés, hogy a jövőben folytatódik-e a mezőgazdaság részesedésének csökkenése a GDPben és foglalkoztatásban. Számos kistelepülés esetében nincs egyéb lehetőség, ami betöltené ezt az ürt, amit az agrárium zsugorodása okoz. A tájhasználat révén elérhető jövedelemszintet alapvetően meghatározzák a helyi társadalom és a gazdaság beágyazottságai, együttmüködési rendszerei. Magas feldolgozottsági fokú, széleskörü, gazdag termékskála létrehozásához a térségben a legkülönfélébb, de alapvetően együttmüködésen alapuló rendszerek létrehozása, megerősödése szüikséges a termesztés, a felvásárlás, a feldolgozás és az értékesítés területén. Alapvető, hogy milyen a helyi társadalom értékrendje, milyen az identitástudata, mennyire nyitott a helyi termékek iránt. Hosszútávon a kistelepülések népességmegtartó képessége csak olyan vidékfejlesztési technikákkal javítható, amelyek a helyi közösség fejlesztésén, identitástudatának erősítésén, közösségépítésen alapulnak. Nyugat-Európában egyre elterjedtebb gyakorlat ilyen módszerek alkalmazása, lásd például Ausztria a Local Agenda 21 program, a hazai vidékfejlesztés hatékonyságát rontja ezen modellek alkalmazásának hiánya.

A térség versenyképességének javítása feltételez egy a jelenleginél tudatosabb értékgazdálkodást (amelyhez segítséget a tájépítészeti elvek alkalmazása nyújt/melléklet), de szükséges egy sokkal tudatosabb érdek-navigáció, amely az adott településcsoport nagytérségi kapcsolatrendszerben betöltött pozícióját befolyásolja, javíthatja. 


\section{ÖSSZEGZÉS}

A hagyományosan gazdasági oldalú megközelítések helyett a környezeti, a társadalmi és a gazdasági feltételrendszereket egyaránt ötvöző megközelítést alkalmaztam a versenyképesség térségi szinten értelmezhető fogalma elemzéséhez, amely nem értelmezhető a fenntarthatóság, az élhetőség egymásra ható, egymást kiegészítő feltételrendszere nélkül. A három különböző szempont összhangja képezi a fenntartható fejlődés komplex feltételrendszerét, kisebb nagyobb súlyponti eltolódással. A tanulmányban a versenyképesség előtérbe helyezésével elemeztem, értékeltem ezt a komplex feltételrendszert és egy hazai, alapvetően rurális jellegű kistérség példáján szemléltettem a különböző kritériumok megvalósulását, az érdekek ütközését. Az élhetőség, a környezeti fenntarthatóság és a versenyképesség érdek és feltételrendszere nyilvánul meg az adott térség belső értékgazdálkodásában. A Csornai-kistérség esetében vizsgáltam, hogy ez az értékgazdálkodás, hogyan hat a tájhasználati rendszerre, az egyes tájhasználati funkciók mennyiben felelnek meg az élhetőség (társadalmi, kulturális), a környezeti fenntarthatóság valamint a versenyképesség (alapvetően gazdasági) feltételrendszerének.

A kistérség napjainkra jellemző helyzetének elemzését részletes tájtörténeti kutatással egészítettem ki, amely során feltártam a vizsgált térségben a fejlődés mozgatórugóit, legfőképpen arra kerestem a választ, hogy a kedvező táji adottságok mennyiben hatottak a táj népességmegtartó képességére valamint mi módon befolyásolta a tájrendezés, tájalakítás a térség versenyképességét.

A táji adottságok évezredeken át rányomták bélyegüket a település-, és a közlekedési-hálózat fejlődésére továbbá a közigazgatási téregységek kialakítását is meghatározták a táji adottságok. A történeti leírások és statisztikai adatok segítségével megállapítottam, hogy a Rábaköz gazdasági, társadalmi helyzete/versenyképessége folyamatosan javult a XX. század első feléig, hiszen a Rábaköz kiváló agráradottságú térségeit hamar művelésbe vonták és jellemzően az ország átlagos színvonalánál magasabb színvonalon müvelték. A térség helyzetét alapvetően befolyásolta, hogy az Osztrák-Magyar Monarchián belül Bécs ellátókörzetéhez tartozott és az itt megtermelt javak könynyen piacra találtak. A tájhasználat, tájalakítás tehát a XIX. században hozzájárult a térség versenyképességének erősödéséhez, az országos átlaghoz képest magasabb (elsősorban Csorna és közvetlen térsége) vagy átlagos fejlettséget képviselve (Györi, 1999), csupán a Tóköz térsége maradt a gazdálkodást nehezítő vízviszonyok miatt fejletlenebb.

A Rábaközzel ellentétben a Hanság peremterületeit fokozatosan vonták művelésbe, az irtásföldek jelentős része azonban a nagybirtokosok vagyonát gazdagította, akik majorságok keretein belül szervezték a gazdálkodást, általában a kor átlagos technológiai szintjénél fejlettebb színvonalon, azaz kisebb munkaerőigénnyel, mint a kisparaszti gazdaságok. A nagyarányú tájalakítás nem hozta magával a táj népességmegtartó képességének hasonló szintű növekedését, a népsürűség területi kü- 
lönbségei fennmaradtak (a versenyképesség erősödött az élhetőség rovására). A Tóköz és a Hanság peremterületein lévő településeken nem alakult ki magas népsürüség, emiatt a XX. század folyamán sokkal kisebb népességvesztés sújtotta ezeket a falvakat.

A XX. században alapvetően megváltoztak a gazdasági fejlődés mozgatórugói, a legfontosabb térszervező erővé a nagy forgalmú közlekedéshálózatok (közút, vasút) és az iparosodó városok váltak és a térség komoly népesség-kibocsátóvá vált. A „hanyatlást” a Trianoni határok miatt kialakult periférikus helyzet, a korábbi felvevőpiacok elvesztése, valamint a szocializmus fejlesztéspolitikája okozta, amely nem ösztönözte, támogatta a határtérségben illetve a kisvárosban az iparfejlesztést (csak késve elsősorban könnyü- és élelmiszeripar).

A tanulmány második felében a mintatérség tájhasználati rendszerét vizsgáltam és értékeltem az élhetőség, a fenntarthatóság és a versenyképesség feltételrendszerének érvényesülését. A vidéki térségek népességének életminőségét jelentősen meghatározza, hogy az adott térségben milyen tájhasználatok vannak jelen, mennyire egyoldalú a tájhasználat vagy esetleg a lehetséges funkciók széles skálája a megfelelő szinten érvényesül. A tájhasználat értékeléséhez gazdasági elemzéssel kiegészített tájfunkció elemzést alkalmaztam. Vidéki térségek sikerességének (versenyképességének) egy alapvető feltétele a táji rendszerek által biztosított ökológiai, gazdasági és egyéb oktatási, kulturális és esztétikai javak/szolgáltatások érvényre jutásának sokrétü, harmonikus teljesülése, a tájfunkciók diverzitása. Vidéki térségek sikerességét illetően alapvető elvnek tartom, hogy a domináns tájhasználat ne torzítsa a tájfunkciók harmonikus érvényesülését. A mintatérségben a tájfunkció elemzés alapján kidolgozott egyedi elemzési rendszert felhasználva értékeltem összehangolva a környezeti, társadalmi/kulturális és gazdasági szempontokat. A tájfunkció elemzést összevetettem az alapvetően társadalmi és gazdasági szempontokat (a versenyképesség és az élhetőség kritériumrendszere) ötvöző versenyképességi elemzéssel.

A hagyományos versenyképességi elemzések értelmében a lakosság életminősége és jövedelemszintje határozzák meg egy térség versenyképességét. A városias térségekkel, az agglomerációkkal ellentétben a vidéki térségek esetében a táji értékek, a táji adottságok felértékelődnek, jelentősen növelhetik a versenyképességet, hiszen hozzájárulnak a gazdasági diverzifikációhoz, az életminőség javításához. Megállapítottam, hogy azok a vidéki térségek tekinthetők versenyképesnek, amelyek képesek népességük hosszú távú megtartására, megfelelő szintü jövedelmet és életminőséget biztosítva a lakosság számára, miközben fenntartható módon gazdálkodnak természeti és kulturális értékeikkel, javaikkal. Meghatároztam a vidéki térségek versenyképességét befolyásoló tényezők és a tájhasználati szempontok kapcsolódási pontjait, tájhasználati feltételeit. A fentiek elérésének alapvető eszköze a helyi szereplők együttműködési képessége, az újításra, az innovációra való készsége. A 
térségi szintü versenyképesség nélkülözhetetlen feltétele a helyi adottságokhoz idomuló alkalmazkodás a külső környezet kihívásaihoz.

Megkerestem a vidéki térségek versenyképességének és a tájhasználati rendszer kapcsolódási pontjait. Kapcsolódva a vidéki térségek versenyképességének feltételeihez értékeltem a termesztési funkciót, a földalapú ágazatok elkülönített értékelésének nehézsége miatt a gazdasági tevékenységek, iparúzési adó, lakosság jövedelemszintje alapján összesített gazdasági értéket számoltam, továbbá értékeltem az elérhetőség szintjét. A táj- és a természetvédelem több évtizedes hagyományainak köszönhetően az élőhelyi érték települési szintű összehasonlítására többféle mutató is könnyen elérhető: a természetvédelmi területek (Nemzeti Park és Natura 2000 területek) valamint a Nemzeti Ökológiai Hálózat adatait használtam fel. A táj esztétikai értéke nehezen mérhető, az egyes tájtípusok, területhasználatok esztétikai értéke különböző. Értékelési szempontként a diverzitást (Shannon index), és a természetszerüséget (extenzív hasznosítású területek aránya) vettem figyelembe. A tájhasználati rendszer rekreációs, kulturális, művészeti értékeinek feltárásához a kulturális feltöltődés lehetőségeit, (műemlékek, tájértékek), az ökoturisztikai hasznosítás alapjául szolgáló lehetőségeket és az aktív kikapcsolódás területeit, lehetőségeit vettem figyelembe egy általam kidolgozott települési értékkataszter alapján. A tájfunkciók szintjét az indikátorok amplitúdója alapján tízes skálán értékeltem és településenként és mikro-térségi szinten ábrázoltam, összehasonlításukat lehetővé tettem.

Megállapítottam, hogy a tájfunkciók harmonikus müködését települési majd mikro-térségi szinten értékelve, fontos következtetések vonhatók le a térség tájhasználati rendszerének hiányosságait/korlátait illetve potenciáljait illetően.

A mintatérségben végzett kutatásaim alapján igazoltam, hogy a vidéki térségek versenyképességének/ népességmegtartó képességének fenntartásához elengedhetetlen a tájfunkciók harmonikus érvényesülése. A tájfunkciók/tájhasználati funkciók érvényesülésének elégtelensége különösen akkor okoz problémát, ha térségi szinten jelenik meg.

Több tájfunkció harmonikus müködése szenved csorbát a Rábaköz térségében: a gazdasági, az élőhely-védelmi, a kulturális és az esztétikai funkció érvényesülése több településen is elmarad az optimális szinttől, amelyek összességében hozzájárulnak a térség versenyképességi helyzetének romlásához.

A kistérségben a mezőgazdaság mind a gazdaságban, a foglalkoztatásban, a tájhasználatban az országos átlagot meghaladó jelentőséggel bír. A mezőgazdaság azonban, ahogy az leginkább az alacsony ingázási, és egyéb gazdasági aktivitással jellemezhető települések esetén (amelyek leginkább a mezőgazdaságra utaltak) egyértelmủen kimutatható, nem biztosít versenyképes jövedelmet a lakosság számára. A mezőgazdaság jövedelmezőségét rontja az intenzív kertészeti kultúrák alacsony aránya (pedig a helyi társadalom adottságai ezt régen lehetővé tették) és a kistérségben előállított mezőgazdasági termékek feldolgozottságának alacsony foka, illetve a kiegészítő tevékenységek és jövedelmek szük köre. 
A messze az országos átlag szintje feletti szántó aránnyal jellemezhető agrártájban rendkívül alacsony az extenzív hasznosítású területek, a gyepek és az erdők aránya. Az élőhely és a kulturális (esztétikai, rekreációs, oktatási) funkciók elégtelenek és fejlesztésre szorulnak a Rábaközben. Alapvetően kihasználatlanok a Rába nyújtotta lehetőségek. Amennyiben ezek a tájhasználati adottságok nem változnak térségi szinten, az a népesség további drasztikus csökkenéséhez vezethet, és egyben gátolja a helyi fejlesztési stratégiák megvalósulását.

Az elérhetőség, a gazdasági viszonyok és a természetvédelmi területek elhelyezkedésének értékelése révén feltártam, hogy a védett területek, és a magas természeti értékü területek nagy aránya előnyként a jó elérhetőséggel rendelkező falvakban jelenik meg. Gazdag munkahely-kínálattal rendelkező központi település hiányában, kedvezőtlenebb elérhetőségi viszonyok mellett, a jelentős gazdálkodási korlátozások következtében, illetve az egyéb hasznosítási lehetőségek (pl. turizmus) hiányában azonban hátrányként jelenik meg (a környezeti fenntarthatósághoz kapcsolódó természetvédelmi és szabályozási rendszer a versenyképesség számára korlátozást jelent).

A Tóköz jelentős része áll természetvédelem alatt magas minőségű környezetet biztosítva az itt lakók számára. A munkahelyek hiánya ellenére a megyeközpont viszonylag jó elérhetősége révén vonzóak maradtak ezek a települések a társadalom számára. A kedvezőtlenebb elérhetőségi viszonyokkal rendelkező Csorna környéki tóközi falvak a természeti értékek gazdagsága ellenére hátrányos helyzetűek. A gazdasági vonatkozásokat vizsgálva azonban az indikátorok alapján megállapítottam, hogy a természeti értékek védelme érdekében hozott korlátozások gyakran hátrányosan érintik a helyieket, az előnyöket kevésbé érzékelik (rekreáció, falusi/ökoturizmus, agrár-környezeti kompenzáció).

A kistérségben élők véleményének feltárására kérdőíves felmérést készítettem, amelynek eredményei alapján nyilvánvalóvá vált számomra, hogy fel kell hívni a helyiek figyelmét a térség értékeire, szükség lenne a nemzeti park erőteljesebb nyitására a lakosság felé: iskolai programok, lakossági programok számának növelésére, több tájékoztatásra. A tájépítészet eszközeit is igénybe kell venni az aktív pihenés lehetőségeinek bővítésére. Nagy hiányosság a táji identitás hiánya (jellemző tájképet a megkérdezettek többsége nem tudott leírni), erősíteni kell a karakteres tájképi elemeket: fás legelők, legelők, patakok, csatornák menti karakteres növényzet, vizes élőhelyek, erdősávok, cserjések, utcafásítás, kavicsbánya-tavak rekultivációja stb.

Értékeltem a jelenlegi fejlesztési gyakorlatot, az országos programokból a térség részesedését, a Leader fejlesztések helyi erőforrásokra alapozottságát. Az esettanulmány tapasztalatai rámutattak arra, hogy a terület- és vidékfejlesztés intézményrendszerének, forráselosztásának valamint az ágazati fejlesztések széttagoltsága, harmonizációjának hiánya nem kedvez a vidéki térségek harmonikus fejlődésének. A magasabb területi szintü, illetve ágazati fejlesztési forrásokért folytatott versenyben 
a vidéki térségek hátrányos helyzetben vannak. A támogatástípusok közül leginkább a Leader elvei, támogatásformái segítik a vidéki térségekben a belső erőforrások mobilizálását, a táji értékek hatékonyabb hasznosítását, de térségi szintü, pozitív irányú elmozdulás/fejlődés nagymértékben függ a helyi társadalom aktivitásától, együttmüködési formáitól. A vidékfejlesztési források hatékony felhasználásának gátja a közösségfejlesztő fejlesztési modellek alkalmazásának hiánya.

A 2007-2013-as programozási időszak ágazati és regionális operatív programjai alapján GyőrMoson-Sopron megye kistérségeinek pályázási eredményességét (egy főre jutó támogatás nagysága) összehasonlítva, a megye legkevésbé sikeres kistérségének tekinthető a vizsgált terület.

A fejlesztési tervek és rendezési/szabályozási tervek szemlélete rendkívül eltér, az egyes ágazatok tervezési, fejlesztési tevékenysége nem kapcsolódik össze, mindezek nagymértékben gátolják a település-, és területfejlesztés sok szempontú, a területhasználati tervezést, a tájfejlesztést is magába foglaló, ennek a tématerületnek a társadalmi oldalát is kezelni tudó megvalósulását. A rendezési tervek feladata lenne a tájpotenciál és a tájterhelhetőség feltárása, de a szabályozási jelleg dominanciája miatt, alapvetően korlátok felállítására koncentrálnak. 


\section{A SZERZŐ TÉMÁHOZ KAPCSOLÓDÓ PUBLIKÁCIÓI}

\section{FOLYÓIRATCIKKEK}

\section{NEM IF-es folyóiratcikk}

- Filepné Kovács Krisztina, Egyed Adrienn (2011): Az élőhelyek rehabilitációja és a zöldúttervezés kapcsolata a Hanságban In: Tájökológiai Lapok 9. évf. 1. szám, pp.: 73-86 ISSN: 1589-4673

- Zsuzsanna Mikházi, Krisztina Filepné Kovács Use of Indicators in Relation of Tourism and Competitiveness Acta Universitatis Sapientiae, Agriculture and Environment, Supplement 2011, 19-27 Acta Universitatis Sapientiae Agriculture and Environment, 3 (Supl.) (2011) ISSN 2068-2964

- http://www.acta.sapientia.ro

- Kollányi László - Baloghné Ormos Ilona- Filepné Kovács Krisztina (2008): Történeti kertek adattára az interneten - 4 D Tájépítészeti és Kertművészeti folyóirat , 11. szám, pp: 44-49, ISSN1787-6613

- Filepné Kovács Krisztina (2002): Tájvédelem, tájtervezés Finnországban. - Tájépítészet, Táj Település Kert Tudományos szakmai folyóirat III. évfolyam 2. szám, pp: 35-38 ISSN1586-5894

\section{IF-es folyóiratcikkek}

- Filepné Kovács Krisztina,. Nagy Gergő Gábor, Kollányi László (2012): Evaluation of rural landscape functions based on domestic case studies. Applied Ecology and Environmental Research 10 (1), p. 1730. (IF: 0,547) ISSN 17850037

\section{KONFERENCIA KIADVÁNYOK ÉS ELEKTRONIKUS PUBLIKÁCIÓK}

\section{Magyar nyelvü (full paper)}

- Filepné Kovács Krisztina, Nagy Gergő Gábor (2012): Tájfunkciók elemzése a Csornai kistérségben p: 19-28 In: SALLAY Á. (Szerk.) (2012): Tájértékelés/Tájmetria, Tudományos Konferencia, Tájakadémia II. Budapest ISBN 978-963-503-503-8, ISSN 2062-7688

- Filepné Kovács Krisztina (2008): A táji versenyképesség fejlesztésének lehetőségei a Rábaköz-TóközHanságmente példáján /A versenyképesség javításának táji szempontjai/, IV. Magyar Földrajzi Konferencia, Debrecen, 2008. november, pp: 588-594, ISBN 978-963-06-6004-4

\section{Magyar nyelvü (abstract)}

- Filepné Kovács Krisztina (2007): Versenyképesebb és/vagy élhetőbb Európa, Tervek és trendek az Európai Unióban. Lippay János - Ormos Imre - Vass Károly Tudományos ülésszak. Budapest 2007 november, pp: 66-67 ISBN 978-963-06-3294-2

- Filepné Kovács Krisztina (2003): Területrendezés az EU-ban. Lippay János - Ormos Imre - Vass Károly Tudományos Ülésszak. Budapest, Budapest 2003 november, pp: 41-42. ISBN 963-7712-68-2 


\section{Nemzetközi konferencia (full paper)}

- Filepné Kovács Kisztina, Sallay Ágnes, Jombach Sándor, Valánszki István (2013): Landscape in the spatial planning system of European countries, Proceedings of Fabos Conference on Landscape and Greenway Planning In: Fábos, J.G., Lindhult, M., Ryan, R.L., \& Jacknin, M. (Eds). 2013. Proceedings of Fábos Conference on Landscape and Greenway Planning: Pathways to Sustainability.University of Massachusetts, Amherst, April 12-13, 2013. Full papers. Amherst, MA: Department of Landscape Architecture and Regional Planning, University of Massachusetts, Amherst. pp: 64-73 ISSN: 23269936

- Filepné Kovács Krisztina, Mikházi Zsuzsanna (2010): Relation of tourism and competitiveness from the point of view of landscape planning, Fábos Conference on Landscape and Greenway Planning Budapest, 2010, July 8-11, pp: 628-635, ISBN 978-963-503-409-3

- Filepné Kovács Krisztina, Egyed Adrienn (2010): Reviving of natural networks in Hungary, Fábos Conference on Landscape and Greenway Planning Budapest, 2010, July 8-11, pp: 607-612, ISBN 978-963-503-409-3

- Sallay Ágnes-Mikházi Zsuzsanna-Csemez Attila-Filepné Kovács Krisztina (2010): Optimal use of landscape conditions of tourist destinations, In: Tamara Rátz, Anna Irimiás (Szerk): Creativity and Innovation in Managing Uncertainity and Risk in Tourism - Theory and Practice Kodolányi János University of Applied Sciences, Székesfehérvár pp: 135-146 ISBN 978-615-5075

- Filepné Kovács Krisztina (2009): Role of churchgardens in the green space system of small villages Erdei Ferenc IV. Tudományos Konferencia, Kecskemét, 2009 augusztus, pp: 1145-1149, ISBN 978963-7294-73-0

- Filepné Kovács Krisztina (2009): Development possibilities of tourism and landscape potential in the area of Rábaköz and Hanság, The Role of tourism in territorial development, II. international conference, 2009, szeptember 18-19, Gheorgeheni, pp: 123-132, 2009 ISBN 978-973-8387-59-1

- Filepné Kovács Krisztina (2008): Landscape values and competitiveness, Landscape values through the competitiveness interpretations of European development strategies. Erdei Ferenc IV. Tudományos Konferencia. 2008, Kecskemét. pp: 285-288 ISBN 978-963-7294 63-1

\section{Nemzetközi konferencia (abstract)}

- Filepné Kovács Krisztina, Mikházi Zsuzsanna (2010): Relation of tourism and competitiveness from the point of view of landscape planning, Fábos Conference on Landscape and Greenway Planning 2010, Budapest, July 8-11, pp: 124-125, ISBN 978-963-503-411-6

- Filepné Kovács Krisztina, Egyed Adrienn (2010): Reviving of natural networks in Hungary, Fábos Conference on Landscape and Greenway Planning 2010, Budapest, July 8-11, pp: 176-177, ISBN 978-963-503-411-6 
- Filepné Kovács Krisztina (2010): Landscape potential and competitiveness, possible indicators on the example of micro-region Csorna, XVI. Nemzetközi Környezetvédelmi és Vidékfejlesztési Diákkonferencia, Mezőtúr, 2010. június 30-július 2. pp: 50 ISBN 978-963-87874-4-6

- Filepné Kovács Krisztina (2009): Social expectations and means of landscape planning in rural development setting example the area of Hanság-Rábaköz, XV. Nemzetközi Környezetvédelmi és Vidékfejlesztési Diákkonferencia, 2009. július 1-3. pp: 25, ISBN 978-963-87874-3-9 


\section{IRODALOMJEGYZÉK}

1. A Fertő-Hanság Nemzeti Park hatéves fejlesztési terve 2009-2014, Sarród, 2008, www.fertohansag.hu

2. Ádám Dénes (2005): 315. számú Dél-hansági Erdőtervezési Körzet erdőterve, 2005-2014. Szombathely, www.mgszh.gov.hu/data/cms/159/14/rabakozi.pdf (2012, április)

3. Ádám Dénes (2005): 324. számú Rábaközi Erdőtervezési Körzet erdőterve, 2005-2014. Szombathely, www.mgszh.gov.hu/data/cms/159/14/rabakozi.pdf (2012, április)

4. Ádám László - Marosi (1975): A Kisalföld és a Nyugat-Magyarországi peremvidék, Akadémiai Kiadó Budapest

5. Agrárstruktúra és Vidékfejlesztési Program, Csornai kistérség, Sapard helyzetfeltárás (2004)

6. Állami Erdészeti Szolgálat: A Dél-hansági körzet erdőterve (2005) www.aesz.hu

7. Ángyán József - Fésüs, István - Podmaniczky László - Tar Ferenc - Vajnáné Madarassy Anikó (1999): Nemzeti Agrárkörnyezetvédelmi Program a környezetkímélö, a természet védelmét és a táj megőrzését szolgáló mezőgazdasági termelési módszerek támogatására. Földművelésügyi és Vidékfejlesztési Minisztérium agrár-környezetgazdálkodási tanulmánykötetek I., 174 pp.

8. Atlas on the Territorial Agenda of the European Union (2007) Bundesministerium für Verkehr,

Bau und Stadtentwicklung (BMVBS) Berlin http://old.mmr.cz/upload/files/uzemni\%20 planovani\%20a\%20stav.rad/07.03.15_Draft_Atlas_TA_EU.pdf

9. Balogh Ákos (2009): A transzintegratív tájépítészet, mint a megújulás egyik modellje - tájépítészeti paradigmaváltás elökészítése In: Fatsar Kristóf (Szerk): MMXC Mőcsényi Mihály Kilencven év, Tanulmányok és esszék a 90 éves Mőcsényi Mihály tiszteletére, Budapesti Corvinus Egyetem, Tájépítészeti Kar, Budapest 2009 ISBN 978-963-503-404-8

10. Balogh Ákos -Kollányi László (1999): A „Tájkonvenciô” átvételének hazai feltételei és az EU-val harmonizáló tájgazdálkodási stratégia megalapozása in: Zöld Belépö, EU-csatlakozásunk környezeti szempontú vizsgálata, BKAE

11. Balogh Ákos: A tájgazdálkodás alapjai, Kandidátusi értekezés, Kertészeti és Élelmiszeripari Egyetem (1993)

12. Barna Tamás: Erdőmüveléstan, Egyetemi jegyzet, Sopron

13. Bedy Vince (1938): A győri székeskáptalan története, Györ, 256-257. p http://mek.oszk.hu/09400/09415/09415.pdf

14. Beluszky Pál: Magyarország településföldrajza. Dialóg Campus Kiadó, Budapest-Pécs (2003)

15. Bryden, John M. (2000): Differential Economic Performance in Rural Areas In: International Conference on Rural Communities and Identities in the Global Millennium - Malpasino University

16. Bryden, John: Rural Development Indicators and Diversity in the European Union (2003) http://srdc.msstate.edu/measuring/bryden.pdf 
17. Bugovics Zoltán (2007): Társadalom, identitás és területfejlesztés, A területi identitás és a regionalitás kapcsolata, L’Harmattan Kiadó, ISBN 9789632360485

18. Buzás Norbert - Lengyel Imre (szerk.) 2002: Ipari parkok fejlődési lehetőségei: regionális gazdaságfejlesztés, innovációs folyamatok és klaszterek. SZTE GTK, JATEPRess

19. Carvalho-Ribeiro S., Pinto-Correia . (2012) : The Index of Function Suitability (IFS): A new tool for assessing the capacity of landscapes to provide amenity functions,, Land Use Policy 29 (2012) 23-34, ELSEVIER

20. Cassatella Claudia, Attilia Peano (2011): Landscape indicators, Assessing and Monitoring Landscape Quality, Springer, ISBN 978-007-0365-0, e-ISBN 978-94-007-0366-7

21. CEMAT (2006) Lisbon Declaration on "Networks for sustainable spatial development of the European continent: Bridges over Europe"

22. Costanza, R., d'Arge, R., de Groot, R., Farber, S., Grasso, M., Hannon, B., Limburg, K., Naeem, S., O’Neill, R. V., Paruelo, J., Raskin, R. G., Sutton, P., van den Belt, M. (1997): The value of the world's ecosystem services and natural capital. Nature 387, p. 253-260.

23. Council of Europe (2000): Guiding Principles for Sustainable Spatial Development of the European Continent

24. Czúcz Bálint - Molnár Zsolt - Horváth Ferenc - Nagy Gergő G. - Botta-Dukát Zoltán - Török Katalin (2012): Using the natural capital index framework as a scalable aggregation methodology for local and regional biodiversity indicators. - Journal for Nature Conservation doi:10.1016/j.jnc.2011.11.002, http://dx.doi.org/10.1016/j.jnc.2011.11.002

25. Csemez Attila: Tájtervezés - tájrendezés, Mezőgazda Kiadó, Budapest (1996)

26. Csima Péter-Kincses Krisztina: Tájrehabilitáció, Egyetemi jegyzet, Budapest (1999)

27. Daily, G. C. (1997): Nature' services: societal dependence on natural ecosystems. Island Press, Washington, $392 \mathrm{pp}$.

28. de Groot R.S., Wilson M., Boumans R., (2002): A typology for the description, classification and valuation of Ecosystem Functions. Goods Services Econ. 41(3), p. 393-408.

29. de Groot, Braat (2012): The ecosystem services agenda: bridging the worlds of natural science and economics, conservation and development, and public and private policy, Volume 1, Issue 1, July 2012, Pages 4-15

30. de Groot, R. (1992): Functions of Nature: Evaluation of Nature in Environmental Planning, Management and Decision Making. Wolters-Noordhoff, Groningen, 315 p.

31. de Groot, R. (2006): Function-analysis and valuation as a tool to assess land use conflicts in planning for sustainable, multi-functional landscapes. Landscape and Urban Planning 75, p. 175186.

32. Derek B. van Berkel, Peter H. Verburg (2011): Sensitising rural policy: Assessing spatial variation in rural development options for Europe In: Land Use Policy 28 (2011) 447-459 
33. Dóka Klára (1977-1978): A Rába felmérése a XIX. század első felében. Arrabona 19-20. Győr,. 344-379.

34. Dr.Tóth Péter: Környezetvédelmi Aktualitások Győr-Moson-Sopron Megyében, „Megújuló enrgiaforrások hasznosításának helyzete és lehetőségei Győr-Moson-Sopron megyében”, Széchenyi István Egyetem, Környezetmérnöki Tanszék (2005) 194.88.46.34/mtt/ meghivok/2005/1007/2.\%20Meguj.energ.\%20a\%20megyeben.doc

35. Enyedi György: A sikeres város, In: Ezredforduló, 1998/3. 3. o

36. ESPON, Policy impact projects 2002-2004 http://www.espon.eu

37. Estók János (Szerk.) (2003): Agrárvilág Magyarországon 1848-2002, Argumentum Kiadó/ Magyar Mezőgazdasági Múzeum, Budapest

38. European Academies Science Advisory Council (2009): Ecosystem services and biodiversity in Europe, The Royal Society, ISBN 9780854037384

39. European competitiveness report 2001, Executive summary http://www1.eeg.uminho.pt/ economia/priscila/intocaveis/LEA_CI/executive_summary.pd

40. Fajkusz Beáta (2005): A Hanság szeszélyei a Szülőföldünk honismereti pályázatra készült 2005ben. In: Győrsövényházi Hírek 2005. december, II. évfolyam 3. szám, 3-6. p

41. Felhő Ibolya (1970): Az úrbéres birtokviszonyok Magyarországon Mária Terézia korában I. Dunántúl, Akadémiai Kiadó, Budapest

42. Filepné Kovács Krisztina - Egyed Adrienn (2011): Az élőhelyek rehabilitációja és a zöldúttervezés kapcsolata a Hanságban In: Tájökológiai Lapok (2011) 1., 73-86.

43. Fleischer Tamás: Fenntartható fejlődés: a fenntarthatóság elve az élet különböző területein www.vki.hu/ tfleisch/PDF/pdf07/fennt-ELVEK-holcim_070615.pps

44. Füle M., Szlávik J., Turchany G. (2002): Útmutató a Fenntartható Fejlődés Helyi Programjai (Local Agenda 21) elkészítéséhez, www.prof-turchany.eu/documents /Helyi_Agenda_21_utmutato.pdf

45. Ghimessy László (1984): A tájpotenciál, Mezőgazdasági Kiadó, Budapest

46. Glatz Ferenc (2010): Sikeres vidéki térségek. MTA Történettudományi Intézet - MTA Társadalomkutató Központ, Budapest, 192 pp.

47. Gómez-Sal A., Belmontes J.-A., Nicolau J.-M. (2003): Assessing landscape values: a proposal for a multidimensional conceptual model In: Ecological modelling 168 (2003) 319-341

48. Győri Róbert (1999): Térszerkezeti változások a polgárosodó Kisalföldön In: Tér és Társadalom 13. évf. 1999/4. 77-106. p.

49. Győr-Moson-Sopron Megye Területrendezési Tervének Módosítása, Vizsgálatok, (egyeztetési anyag) Készült a Győr-Moson-Sopron Megyei Önkormányzat megbízásából, 2010. március hó

50. Győrsziget község árvédelmi biztositásáról http://www.1000ev.hu/index.php?a=3\&param=6180

51. Horváth Gyula (2006): Régiók és települések versenyképessége, MTA RKK, Pécs 
52. Horváth László (2004): „A Kapuvári uradalom az 1580-as évek végén, Soproni Szemle, 58 évf. 4.sz.

53. Horváth Zoltán (1964): Sopron és a megye múltja egykorú iratok tükrében, Sopron, Győr-Sopron megyei nyomda p.123

54. Huizinga Johan (1996): A közékor alkonya, Európa, ISBN: 9630761041

55. Ihrig Dénes (1973): A magyar vízszabályozás története, Országos Vízügyi Hivatal, Budapest

56. Jackson Peter (2005): Local consumption cultures in a globalizing world, Royal Geographical Society (with The Institute of British Geographers) ISSN 0020-2754 New Series, (2204) Vol. 29/2., 165-175

57. Kerényi Attila (2008): Tájvédelem, Pedellus Tankönyvkiadó

58. Keresztesi Béla (1968): Magyar erdők. Akadémiai Kiadó, Budapest, 274 pp.

59. Kogutovicz Károly (1936): Dunántúl és Kisalföld írásban és képben, Magyar Királyi Ferenc József Tudományegyetem Földrajzi Intézete, Szeged

60. Kollányi László (2004): Táji indikátorok alkalmazási lehetőségei a környezetállapot értékeléséhez, BKAE Tájtervezési és Területfejlesztési Tanszék Budapest

61. Koltai Zoltán: A regionális versenyképesség dimenziói http://www.feek.pte.hu/ tudasmenedzsment/index.php?ulink=633

62. Konkoly-Gyuró Éva (2011): Conceptual evolvement of the landscape functions assessment. In: Nagy G. G., Kiss V. (eds.): Borrowing services from nature - Methodologies to evaulate ecosystem services focusin on Hungarian case studies. CEEweb for Biodiversity, Budapest, p. 9-24.

63. Konkoly-Gyuró Éva-Tirászi Ágnes-Wrbka T.-Prinz M.-Renezeder C. (2010): Der Charakter grenzüberschreitener Landschaften. Das Fertö/Neusiedlersee-Hanság-Becken und die Region Sopron/Határon átnyúló tájak karaktere. A Fertő-Hanság medence és Sopron térsége. NyugatMagyarországi Egyetem Kiadó, Sopron 43 p

64. Konkolyné Gyúró Éva (2003): Környezettervezés, Mezőgazda Kiadó, Budapest

65. Koschke Lars - Christine Fürst - Susanne Frank - Franz Makeschin (2012): A multi-criteria approach for an integrated land-cover-based assessment of ecosystem services provision to support landscape planning Ecological Indicators 21 (2012) pp.: 54-66 www.elsevier.com/locate/ecolind

66. Kovách Imre et al, (2005): A civil szervezetek és a területfejlesztési politika, A civil szféra területfejlesztési intézményekkel való együttműködésének tapasztalatai, Magyar Tudományos Akadémia, Politikai Tudományok Intézete, Mühelytanulmányok 2005/4, Digitális archívum ISBN 9637372 202 (PDF) HU ISSN 1787-565X

67. Kovács Mihály (2012): A Hanság medence vízgazdálkodása, Kézirat

68. Krugman Paul (1998): What's new about the new economic geography? In: Oxford Review of Economic Policy, vol. 14, no. 2 http://www.uni-miskolc.hu/ euint/ 20031002zzz20031231/EcoGeo_2008_article2.pdf

69. KSH kiadvány, Győr-Moson-Sopron megye statisztikai évkönyv (2005) 
70. KSH kiadvány, Nyugat-Dunántúl, A kistérségek társadalmi-gazdasági helyzete (2007)

71. KSH, Magyarország Történeti Statisztikai Helységnévtára, 19. kötet Győr- Moson-Sopron megye, Budapest, 2002

72. Lamarque Pénélpe - Quitier Fabien - Lavorel Sandra (2011): The diversity of the ecosystem services concept and its implications for their assessment and management In: Compes rendus Biologies, Volume 334, Issues 5-6, May 2011, pp: 441-449

73. LEADER European Observatory: Global competitiveness for rural areas. "Rural innovation"

74. Leidinger Dániel (2012): Települési vizes stratégiák Pomáz város vizes klímastratégiájának példáján In: Antal Z. László (Szerk): Ökológiai kihívások - klímabarát válaszok 1. Budapest, Klímabarát Települések Szövetsége http://klimabarat.hu/system/files/kologiai_kihivasok-klimabarat _valaszok_1_2.pdf

75. Lengyel Imre (2000): A regionális versenyképességről In: Közgazdasági szemle XLVII. évf. 2000. december (962-987)

76. Lengyel Imre (2003): Verseny és területi fejlődés, JATEPress, Szeged

77. Magyar Regionális Fejlesztési és Urbanisztikai Nonprofit Kft., Térségi Tervezési és Területrendezési Iroda (2010): Győr-Moson-Sopron Megye Területrendezési Tervének Módosítása, Javaslattevő fázis, Budapest

78. Mander Ülo - Wiggering, Hubert - Helming Katharina (Szerk)(2007): Multifunctional Land Use, Meeting Future Demands for Landscape Goods and Services, Springer-Verlag Berlin Heidelberg ISBN 978-3-540-36763-5

79. Marjainé Szerényi Zsuzsanna -, Kerekes Sándor - Flachner Zsuzsanna † - Milton Simon (2011): The possibility of the economic evaluation of ecosystem services described through a domestic case study. In: Nagy G. G., Kiss V. (eds.): Borrowing services from nature - Methodologies to evaulate ecosystem services focusin on Hungarian case studies. CEEweb for Biodiversity, Budapest, p. 9-24.

80. Marosi Sándor- Somogyi Sándor: Magyarország kistájainak katasztere, Budapest, MTA Földrajztudományi Kutató Intézet (1990)

81. MEA (Millennium Ecosystem Assessment) (2005): Ecosystems and human well-being: Biodiversity synthesis. World Resource Institue, Washington D.C., 86 pp.

82. Mészöly Győző (Szerk.) (1981): Parkerdők Magyarországon. Natura, Budapest, 300 pp.

83. Mihály Péter (1971): Régészeti kutatások a Hanságban I. rész, in Soproni Szemle 1971. XXV. évfolyam 1. szám

84. Mőcsényi Mihály (1968): A táj és a zöldterület fogalmi problémái a tájrendezés nézőpontjából Településtudományi Közlemények, 21. sz. pp. 66-76.

85. MSZ-13-195-1990, Általános tájvédelem (Utód: MSZ 2370:2003)

86. Nagy Miklós (1980): Adatok Acsalag történetéhez I-II. Soproni Szemle XXXIV. ÉVFOLYAM 34. SZÁM 
87. Németh Patrícia (2005): A versenyképesség és a környezetvédelem kapcsolata Vezetéstudomány. ISSN 0133-0179. - 2005. XXXVI. évf. IX. szám, 47-57. p.

88. Norgaard Richard (2010): Ecosystem services - From eye-opening metaphor to complexity blinder. - Ecological Economics, 69: 1219-1227.; magyarul Ökoszisztéma szolgáltatások - Hogyan vált egy szemléletes metafora a lényeg elhomályosítójává? Kovász, XV. (1-4): 61-92

89. OECD (2001): Multifunctionality, Towards an Analytical Framework, Agriculture and Food, Head of Publications Service, OECD Publications Service

90. Paládi-Kovács Attila (a szerkesztőbizottság vezetője) (1988-2002): MAGYAR NÉPRAJZ nyolc kötetben, IV. kötet: Életmód. Akadémiai Kiadó, Budapest (http://mek.oszk.hu/ 02100/02152/html/04/7.html)

91. Papp-Váry Árpád - Hrenkó Pál (1989): Magyarország régi térképeken, Gondolat Könyvkiadó/ Officina Nova pp. 140.

92. Péti Márton (2011): A területi tervezés és fejlesztés a fenntarthatóság jegyében, JatePress, Szeged Földrajzi Tanulmányok, Volume 79789633150245

93. Proposal for a COUNCIL DECISION on Community strategic guidelines for Rural Development (Programming period 2007-2013)

94. Radó Dezső (2001): A növényzet szerepe a környezetvédelemben. Zöld Érdek Alapítvány - Levegö Munkacsoport, Budapest, 142 pp.

95. Rakonczay Zoltán (Szerk.)(1996): Szigetköztől az Örségig, A Nyugat-Dunántúl védett értékei, Mezőgazda Kiadó, Szeged

96. Rechnitzer János (2009): A regionális fejlesztések sikertényezői, A vidék fejlesztésének titka, a sikeres vidéki térségek és települések Nyugat-Magyarországon konferencia, Széchenyi István Egyetem, Győr, 2009. április 27-28

97. Rechnitzer János (szerk.)(1994): Fejezetek a regionális gazdaságtan tanulmányozásához. MTA Regionális Kutatások Központja

98. Régiófókusz Nonprofit Kft. (2011): A Rábaköz turizmusfejlesztési stratégiája 2012-2015 a 122/2009 (IX. 17.) FVM rendelet alapján a Helyi Vidékfejlesztési Stratégiák LEADER fejezete keretében megvalósuló 2064293073 azonosító számú pályázati felhívásra benyújtott pályázat

99. Régiófókusz Nonprofit Kft. (2011): Kvantitatív kutatási jelentés a 122/2009 (IX. 17.) FVM rendelet alapján a Helyi Vidékfejlesztési Stratégiák LEADER fejezete keretében megvalósuló 2064293073 azonosító számú pályázati felhívásra benyújtott „Rábaköz turizmusfejlesztési stratégiája” című pályázathoz, Szombathely

100. Rétvári László (1977): Győr-Sopron megye népesedése, Akadémiai Kiadó, Budapest

101. Rockström, J., Steffen, W., Noone, K., Persson, Å., Chapin III, F. S., Lambin, E., Lenton, T. M., Scheffer, M., Folke, C., Schellnhuber, H. J., Nykvist, B., de Wit, C. A., Hughes, T., van der Leeuw, S., Rodhe, H., Sörlin, S., Snyder, P. K., Costanza, R., Svedin, U., Falkenmark, M., Karlberg, L., Corell, R. W., Fabry, J. V. J., Hansen, J., Walker, B., Liverman, D., Richardson, K., Crutzen, P., 
and Foley, J. 2009: Planetary Boundaries: Exploring the Safe Operating Space for Humanity. Ecology and Society 14(2): 32. [online] URL: http://www.ecologyandsociety.org/vol14/iss2/art32/

102. Sárközi Zoltán (1968): Árvizek, ármentesítés és folyószabályozás a Szigetközben és az Alsó-Rába vidékén. Bp. 1968. 13.

103. Schuchmann Péter (2008): A Budapesti Agglomeráció tervezése, a Budapesti Agglomeráció területrendezési terve és a tervről szóló 2005. évi LXIV. Tv, Budapesti Corvinus Egyetem, előadás

104. Scolozzi Rocco Morri Elisa, Riccardo Santolini (2012): Delphi-based change assessment in ecosystem service values to support strategic spatial planning in Italian landscapes, Ecological Indicators 21 (2012) 134-144

105. Sen, Amartya Kumar (2003): A fejlődés, mint szabadság, Európa, Budapest, ISBN: 963-07-73155

106. Slee B.: Endogenous Development; A Concept in Search of a Theory in Options Méditerranéennes, S é , A /no 23, 1993 - Strengthening endogenous development patterns in European agriculture

107. Somlyódy László (2012): Területi vízgazdálkodás Magyarországon: szélsőségek és földhasználat In: A Falu 2012. XXVII. Évf. 1.sz.

108. Soós Imre: Adatok a sopronmegyei középbirtokok 16. századi történetéhez. Soproni Szemle 1937. I. évfolyam 3. szám

109. Stratégiakutató Intézet Kht.: Csorna város komplex városfejlesztési stratégiája és operatív programja (2007-2013) http://csorna.hu/kozadat/letolt/kompl_vfejl_strat.pdf

110. Széchenyi István Egyetem (2002): Győr-Moson-Sorpon Megye Területfejlesztési Koncepció, Helyzetfeltárás, Egyeztetési változat 2.0, Témavezetők: Lados M., Rechnitzer J.; www.gymsmo.hu

111. SZIE Tájtervezési és Területfejlesztési Tanszék és VÁTI KHT: Magyar-Osztrák Fertő-térségi Fenntartható Közlekedési Projekt, Budapest (2001)

112. Szlávik János (2005): Fenntartható környezet- és erőforrás-gazdálkodás, KJK-Kerszöv

113. Szörényiné Kukorelli Irén (2009): A vidéki tér sikertényezői, A vidék fejlesztésének titka, a sikeres vidéki térségek és települések Nyugat-Magyarországon konferencia, Széchenyi István Egyetem, Győr, 2009. április 27-28

114. Takács Gábor -Pellinger Attila (2006): Nyirkai-Hany vizes élőhelyrekonstrukció, www.fertohansag.hu/nyirkai-hany

115. Takács Károly (1999): Egy elfeledett halgazdálkodási mód a Barbacsi-tavon (1999), Soproni Szemle. LIII. évfolyam 4. szám

116. Takács Károly (2000): Árpád-kori csatornarendszerek kutatása a Rábaközben és a Kárpát-medence egyéb területein, Korall Társadalomtörténeti folyóirat 2000, 1. szám pp. 27-61.

117. TEEB (The Economics of Ecosystems and Biodiversity) (2010): Mainstreaming the economics of nature: A synthesis of the approach, conclusions and recommendation of TEEB. $36 \mathrm{pp}$. 
118. Terluin Ida (2003): Differences in economic development in rural regions of advanced countries: an overview and critical analysis of theories, Journal of Rural Studies, Volume 19, Issue 3, pp. $327-344$

119. Terluin Ida (2001): Rural regions in the EU: exploring differences in economic development, Dissertations- University of Groningen, http://dissertations.ub.rug.nl/faculties/rw/2001/i.j.terluin/

120. Territorial State and Perspectives of the European Union towards a stronger European territorial cohesion in the light of the Lisbon and Gothenburg ambitions Informal Ministerial Meeting on Regional Policy and Territorial Cohesion, 20/21 May 2005 in Luxembourg

121. The European Landscape Convention 20.X.2000 - Council of Europe http://www.coe.int/t/dg4/cultureheritage/Conventions/Landscape/default_en.asp

122. Thompson Nicola, Ward Neil (2005): Rural Areas and Regional Competitiveness, Report to Local Government Rural Network, Centre for Rural Economy Research Report

123. Timaffy László (1989): A Rábaköz gazdaságtörténete. A Rábaköz térszerkezete - Rechnitzer János (1989) pp. 27-40.

124. Török Katalin (2009): A Föld ökológiai állapota és perspektívái (a Millennium Ecosystem Assessment alapján). Magyar Tudomány 170(1), p. 48-53.

125. Vass Csaba (2002): Humángazdaság In: Magyar Szemle, Új folyam XI. 3. szám, http://www.magyarszemle.hu/cikk/humangazdasag

126. Vital Pro: Győr-Moson-Sopron megye hosszú távú turizmusfejlesztési koncepciója és programja, (2007)

127. Willemen Louse - Lars Hein - Martinus E. F. van Mensvoorta -, Peter H. Verburg (2010): Space for people, plants, and livestock? Quantifying interactions among multiple landscape functions in a Dutch rural region In: Ecological Indicators 10 (2010) 62-73

128. Willemen Louse - Verburg Peter - Hein Lars - Mensvoort, Martimus (2008): Spatial characterization of landscape functions In: Landscape and urban planning, Volume 88, Issue 1, 28. October, pp: $34-43$

129. World Resources Institute (2005): Ecosystems and human well-being : synthesis / Millennium Ecosystem Assessment, ISBN 1-59726-040-1

130. Zólyomi Bálint (1934): A Hanság növényszövetkezetei In: Vasi Szemle, I. évf. Különlenyomat, Martineum Könyvnyomda Rt., Szombathely, 1934

131. Zólyomi Bálint: A kultúra hatása a vegetációra a Hanság medencéjében, A Debreceni Tisza István Tudományos Társaság II. (Orvos-Természettudományi) Osztályának Munkái I., Tisza István Tudományegyetemi Nyomda, Debrecen, 1931

\section{Európai Uniós jogszabályok, ajánlások}

1. CEC (1999a) Sixth Periodic Report on the Social and Economic Situation and Development of Regions in the EU. European Commission, Luxembourg. 
2. COM(2011) 615 final/2 2011/0276 (COD) Javaslat, AZ EURÓPAI PARLAMENT ÉS A TANÁCS RENDELETE a Közös Stratégiai Kerethez tartozó Európai Regionális Fejlesztési Alapra, Európai Szociális Alapra, Kohéziós Alapra, Európai Mezőgazdasági Vidékfejlesztési Alapra és Európai Tengerügyi és Halászati Alapra vonatkozó közös rendelkezések megállapításáról, az Európai Regionális Fejlesztési Alapra, az Európai Szociális Alapra és a Kohéziós Alapra vonatkozó általános rendelkezések megállapításáról és az 1083/2006/EK tanácsi rendelet hatályon kívül helyezésérôl

3. $\operatorname{COM(2001)} 264$ final: A sustainable Europe for a better world: A European Union strategy for sustainable development - Communication from the Commission

4. $\operatorname{COM}(2005) 0299$ Cohesion Policy in Support of Growth and Jobs: Community Strategic Guidelines, 2007-2013 - Communication from the Commission

5. $\operatorname{COM}(2005) 658$ final: On the review of the Sustainable Development Strategy, A platform for action Brussels - Communication from the Commission to the Council and the European Parliament 13.12.2005

6. $\operatorname{COM(2005)~} 304$ final 2005/0129 Javaslat, A TANÁCS HATÁROZATA a vidékfejlesztésre vonatkozó közösségi stratégiai iránymutatásokról (2007-2013 közötti programozási időszak)

7. COM(2006) 386 végleges 2006/0131 (AVC) Az Európai Tanács határozata a kohézióra vonatkozó közösségi stratégiai iránymutatásokról Brüsszel, 13.7.2006

8. Creating a territorial development strategy in the light of the LEADER experience (2001) http://www.aeidl.be/publications/rural.php

9. EC (1999a): European Spatial Development Perspective/Európai Területfejlesztési Perspektíva, European Commission, Brussels

10. EEC (1992): 2078/92 EU Tanácsi Rendelet a tájfenntartás és a környezetvédelem követelményeinek megfelelő mezőgazdasági termelés támogatásáról.

11. EEC, A Bizottság Közleménye, Európa 2020, Az Intelligens, Fenntartható és Inkluzív Növekedés Stratégiája, Brüsszel, 2010.3.3. Com(2010) 2020 Végleges, Http://Ec.Europa.Eu/ Eu2020/Pdf/1_Hu_Act_Part1_V1.Pdf (2010-12-27)

12. 2006/144/EK TANÁCS HATÁROZATA (2006. február 20.) a vidékfejlesztésre vonatkozó közösségi stratégiai iránymutatásokról (2007-2013 közötti programozási időszak)

13. European Union Strategy For The Danube Region, Action plan, $\{\operatorname{Com}(2010) 715$ Final $\}\{\operatorname{Sec}(2010)$ 1490 Final $\},\{\operatorname{Sec}(2010) 1491$ Final $\}$, Accompanying Document To The, Communication from the Commission to the European Parliament, the Council, the European Economic and Social Committee and the Committee of the Regions (http://ec.europa.eu/regional_policy/sources/ docoffic/official/communic/danube/action_plan_danube.pdf2010-12-27)

14. Territorial Agenda of the European Union (2007) Towards a more Competitive and Sustainable Europe of Diverse Regions, Leipzig Agreed on the occasion of the Informal Ministerial Meeting on Urban Development and Territorial Cohesion in Leipzig on 24 / 25 May 2007 
15. Territorial Agenda of the European Union 2020, Towards an Inclusive, Smart and Sustainable Europe of Diverse Regions, agreed at the Informal Ministerial Meeting of Ministers responsible for Spatial Planning and Territorial Development on 19th May 2011 Gödöllö, Hungary http://www.eu2011.hu/files/bveu/documents/TA2020.pdf

16. Treaty of Amsterdam amending the Treaty on European Union, The Treaties Establishing the European Communities and related acts 2. Article

\section{Hazai jogszabályok}

1. 1840. évi X. törvénycikk vizekről és csatornákról http://www.1000ev.hu/ index.php?a=3\&param $=5206$

2. 1885. évi XV. törvénycikk a Rába és mellékfolyóinak szabályozásáról, valamint Győr város és

3. 1994. évi LV. törvény a termőföldről

4. 1996. évi LIII. törvény a természet védelméröl

5. 1996. évi XXI. törvény a területfejlesztésröl és a területrendezésröl

6. 1997. évi LXXVIII. törvény az épített környezet alakításáról és védelméről

7. 2003. évi XXVI. törvény (módosítva 2008) - az Országos Területrendezési Tervről (http://www.vati.hu/main.php?folderID=2017)

8. 253/1997. (XII.20.) Korm. rendelete az országos településrendezési és építési követelményekröl

9. 314/2012. (XI. 8.) Korm. rendelete a településfejlesztési koncepcióról, az integrált településfejlesztési stratégiáról és a településrendezési eszközökről, valamint egyes településrendezési sajátos jogintézményekről

10. Győr-Moson-Sopron Megyei Önkormányzat Közgyűlése 10/2005. (VI.24.) számú rendelete és 85/2005. (VI.10.) számú határozata a Győr-Moson-Sopron Megyei Területrendezési Tervröl www.gymsmo.hu

11. Győr-Moson-Sopron Megye Önkormányzata Közgyülésének 12/2010. (IX. 17.) számú rendelete a Győr-Moson-Sopron Megyei Területrendezési Tervről szóló 10/2005. (VI. 24.) számú rendelet módosításáról

12. Nemzetgazdasági Tervezési Hivatal (2012): Nemzeti Fejlesztés 2020 — Országos Fejlesztési és Területfejlesztési Koncepció (OFTK) - társadalmi egyeztetési változat, „A Kormány 1254/2012 kormányhatározat a területfejlesztési politika megújításáról, az Országos Fejlesztési és Területfejlesztési Koncepció kidolgozásáról” alapján

13. Országos Területfejlesztési Koncepció (97/2005 (XII.25.) OGY)

14. Új Magyarország Vidékfejlesztési Program, 2007-2013, Budapest 2007. szeptember http://www.umvp.eu/files/umvp_program_teljes.pdf

\section{Településrendezési tervek}


1. Acsalag Község Önkormányzata Képviselő-testületének 19/2011. (II.16.) KT határozata a településszerkezeti terv módosításáról, Regioplan Környezet- és Településtervező Kft.

2. Bágyogszovát, településrendezési szerkezeti és szabályozási terv, HÉSZ módosítás, 1/2007. (I.30) határozat, Regioplan Környezet- és Településtervező Kft

3. Barbacs, településrendezési szerkezeti és szabályozási terv, HÉSZ, 1/2003 (II.18) hat., 1/2003 (II.18) rend., TUTTITERV Kft.

4. Bezi, településrendezési szerkezeti és szabályozási terv, HÉSZ módosítás, Tér-t Rend Terület- és Településtervezési Építészeti Kft. 60/2004, (XI.02) hat. 60/2004, (XI.02) hat.

5. Bősárkány, HÉSZ módosítás 8/2008 (VI.12) rend. Talent-Plan

6. Csorna külterületének övezeti rendszeréről és helyi építésügyi szabályzatáról

7. Dőr, településrendezési szabályozási terv, HÉSZ módosítás, Regioplan Környezet- és Településtervezö Kft. 10/2007. (IX.21) rend.

8. Farád, településrendezési szerkezeti és szabályozási terv, HÉSZ felülvizsgálat, Regioplan Környezet- és Településtervező Kft. 9/2010. (XII. 9.) rend., 207/2010. (XII. 8.) hat.;

9. Fehértó, HÉSZ módosítás, DKT Tervező Szervezet, 5/2005. (III.18.) rend.

10. Kóny, belterületi szabályozási terv, HÉSZ módosítás, 12/2004 (IX.06.) rend.; Regioplan Környezetés Településtervező Kft

11. Maglóca, településrendezési szerkezeti és szabályozási terv, HÉSZ, Menedzser Mérnöki Iroda, 12/2004 (III.31.) hat.; 5/2004 (III.31.) rend.

12. Markotabödöge, településrendezési szerkezeti és szabályozási terv, HÉSZ, Regioplan Környezet- és Településtervező Kft. 53/2004 (X.21.) hat.; 11/2004 (X.22.) rend.módosított 12/2002. ( V. 31.) ÖKR rendelete egységes szerkezetben

13. Rábatamási 11/2003. (XI. 1.). OK. rendelete Helyi Épitési Szabályzata és Szabályozási Terve

14. Szil, településrendezési szerkezeti és szabályozási terv, HÉSZ módosítás

15. Szilsárkány, településrendezési szerkezeti és szabályozási terv, HÉSZ, Sz\&SZ. Tervező és Fővállalkozó Szervezet, 8/2009 (XI.06.) rend., 59/2009 (XI.05.) hat.szóló 22/2004. (IV. 26.) csornai ör.-rel, valamint a 45/2004. (XII. 16.) csornai ör.-rel

16. Tárnokréti helyi építési szabályzat 10/2012.(VII.13.) önkormányzati rendelet

\section{Internetes források:}

maps.google.com - Google Earth

www.index.hu (1958: rólunk a Hanság énekel)

www.csorna.hu

http://csorna.gymsmuzeum.hu

www.gyorsovenyhaz.hu

www.ferto-hansag.hu

www.gymsmo.hu 
www.imd.ch

www.nepszamlalas.hu/hun/egyeb/hnk2006/tablak/load2_2_03.html

www.bezi.hu

www.szany.hu

www.bogyoszlo.hu

www.bosarkany.hu

www.kony.hu

www.gyorsovenyhaz.hu

www.ferto-hansag.hu

http://www.catpaisatge.net)

www.norvegcivilalap.hu

Mezőgazdasági és Vidékfejlesztési Hivatal adatbázisa, www.mvh.gov.hu

TEIR (Országos Területfejlesztési és Területrendezési Információs Rendszer) https://teir.vati.hu/ www.tajertektar.hu

www.takarnet.hu 


\section{ÁBRÁK JEGYZÉKE}

1. ábra: A tanulmány felépítése (saját szerkesztés)

2. ábra: A fenntarthatóság, az élhetőség a versenyképesség fogalomrendszere, értelmezési szintjei (Forrás: Balogh, 2010)

3. ábra: A fenntarthatóság, az élhetőség, a versenyképesség kritériumrendszere (saját szerkesztés)

4. ábra: Régiók versenyképességének piramis-modellje (Forrás: Lengyel Imre, 2000)

5. ábra: Fogalmak közti különbségek (Lamarque, 2011)

6. ábra: Ökoszisztéma szolgáltatások/tájfunkciók hatása az emberi jólétre (Forrás: Millennium Ecosystem Assessment)

7. ábra: A tájfunkciók számának és az átlagos, maximális és összesített teljesítőképességének összefüggései (Willemen et al., 2010) valamint a területhasználat, biodiverzitás, tájfunkciók (Braat, de Groot, 2012)

8. ábra: A környezettervezésben alkalmazható funkció-elemzés és értékelés szerepe (de Groot, 2006 nyomán)

9. ábra: Fennmaradt Árpád-kori csatornarendszer (amelyet a sürü sövénysorok jeleznek), Rábca levágott kanyarulatai, Győrsövényház Forrás: maps.google.com [2010.]

10. ábra: Régészeti kutatások és XIII. századi határleírások alapján feltételezhető csatorna- és halastavak rendszere (Takács, 2000) és a térség az I. katonai felmérésen (XVIII. századra mocsaras területek maradtak vissza a korábbi tórendszer helyén) (www.tajertektar.hu)

11. ábra: A középkori csatornarendszer nyomai Győrsövényház térségében (maps.google.com)

12. ábra: Területhasználat változások a Hanság, Tóköz településein a Csornai kistérségben (saját szerkesztés)

13. ábra: A rét, legelő arányának változása napjainkig (saját szerkesztés, adatok forrása: KSH)

14. ábra: A D-K Rábaköz falvaiban a rét, legelő valamint a szántók arányának változása (Saját szerkesztés, adatok forrása: $\mathrm{KSH}$ )

15. ábra: Tájesztétikai érték az első katonai térkép alapján (saját szerkesztés, Koschke, Fürst, Frank, Makeschin értékelési mátrix átdolgozásával)

16. ábra: Tájesztétikai érték az 1950-es topográfiai térkép alapján (Koscke et.al. nyomán saját szerkesztés)

17. ábra: Népességnövekedés dinamikája, Népességváltozás százalékos értékekkel kifejezve (adatok forrása: Rétvári, 1977, KSH, 2002, TEIR)

18. ábra: Úrbéres földek aránya (\%) az 1865-ben megművelt földekhez (szántó, rét, legelő) képest, és a főbb birtokosok 1770-ben (saját szerkesztés, adatok forrása: Felhő, 1970)

19. ábra: Népsürüség az 1785-ős és az 1860-as években (KSH, 2002; Rétvári, 1977)

20. ábra: Népsürüség változása a XX. század folyamán (KSH 2002; Rétvári, 1977) 
21. ábra: A Hanságmente, Tóközi falvak és a D-Ny Rábaközi falvak népességének növekedése

22. ábra: Tájhasználati szempontok vidéki térségek versenyképességéhez, az esettanulmányban értékelt tájhasználati szempontok (termesztési érték, gazdasági érték, elérhetőség, környezeti integritás, élőhelyi, esztétikai, rekreációs, kulturális, tudományos érték)

23. ábra: Tájhasználatok, tájhasználati funkciók értékelésének folyamata (saját szerkesztés)

24. ábra: A mezőgazdasági termesztés intenzitása (1-10)

25. ábra: Szántót használók számának változása néhány Rábaközi településen 2000-2011 között (saját szerkesztés, Általános Mezőgazdasági Összeírások adatai alapján)

26. ábra: A helyi foglalkoztatás, az ingázás és a mezőgazdaságban foglalkoztatottak aránya (Saját szerkesztés, adatok forrása: TEIR)

27. ábra: A települések gazdasági szempontú értékelése (Saját szerkesztés)

28. ábra: Elérhetőségi viszonyok a közút-, vasúthálózat és a tömegközlekedési lehetőségek alapján (Saját szerkesztés, adatok forrása TEIR)

29. ábra: Környezeti integritás érték Koschke mátrix felhasználásával

30. ábra: A védett területek aránya a Rábaköz és a Hanság településein (Forrás: https://teir.vati.hu/)

31. ábra: Felszínborítás a Corine 2006 adatbázis alapján

32. ábra: Tájdiverzitás a Shannon-index alapján a Csornai kistérségben (Kollányi, 2004)

33. ábra: Tájdiverzitás települési szintủ különbségei Shannon-index alapján a Csornai kistérségben (saját szerkesztés)

34. ábra: Jelentősebb aktív és kulturális rekreációs lehetőségek a Csornai-kistérségben (Corine 2006 felhasználásával saját szerkesztés)

35. ábra: Népességszám változás és a lakásállomány bővülése a kistérségben (2001-2010) (Forrás: TEIR)

36. ábra: Egyszemélyes háztartások aránya, és az öregedési mutató a kistérségben

37. ábra: A foglalkoztatottság mutatói a kistérségben (TEIR, 2012)

38. ábra: Nemzeti Park és a Natura 2000 területek összesített aránya, valamint az agrárkörnyezetvédelmi kifizetések aránya a direkt kifizetések arányában (2011)

39. ábra: Győr-Moson-Sopron megye kistérségeinek részesedése 2007-2011 időszakban a Környezet és Energia, a Társadalmi Megújulás, a Társadalmi Infrastruktúra és a Gazdaságfejlesztés valamint a Nyugat-Dunántúl Regionális Operatív Programból (saját szerkesztés)

40. ábra: Győr-Moson-Sopron megye kistérségeinek részesedése 2007-2011 időszakban a Nyugat-Dunántúl Regionális Operatív Programból (saját szerkesztés)

41. ábra: Tájfunkciók, elérhetőség, gazdasági helyzet változása a Rábaközben (saját szerkesztés)

42. ábra: Tájfunkciók, elérhetőség, gazdasági helyzet változása a Hanság mentén és a Tóközben (saját szerkesztés) 
43. ábra: Tájfunkciók, tájhasználati funkciók települési szintü érvényesülése (saját szerkesztés)

44. ábra: Települések, „versenyképességi” csoportjai (saját szerkesztés)

45. ábra: Tájfunkciók, tájhasználati funkciók érvényesülése mikro-térségi szinten (saját szerkesztés)

46. ábra: Táji és gazdasági- társadalmi szempontból hasonló helyzetü településcsoportok(saját szerkesztés)

47. ábra: Versenyképességi stratégia-alkotás alapelemei (saját szerkesztés)

48. ábra: Példa néhány területhasználati, tájfejlesztési beavatkozás hatásaira és előfeltételeire (saját szerkesztés)

\section{TÁBLÁZATOK JEGYZÉKE}

1. táblázat: Identitás-faktorok városokban és falvakban (Bugovics, 2007)

2. táblázat: A táj „megjelenése” az európai stratégiákban (saját szerk.)

3. táblázat: A Csornai kistérség tájalakulás-történetének, tájhasználat változásainak jellegzetes szakaszai (saját szerkesztés)

4. táblázat: Az I. periódus jellemzői (saját szerkesztés)

5. táblázat: Az II. periódus jellemzői (saját szerkesztés)

6. táblázat: A III. periódus jellemzői (saját szerkesztés)

7. táblázat: A IV. periódus jellemzői (saját szerkesztés)

8. táblázat: Az V. periódus jellemzői (saját szerkesztés)

9. táblázat: Az összesített funkcionális értékelésben alkalmazott indikátorok a termesztési érték jellemzésére (saját szerkesztés)

10. táblázat: A gazdasági értékelésben alkalmazott mutatók (saját szerkesztés)

11. táblázat: Az élőhely érték meghatározásához alkalmazott indikátorok (saját szerkesztés)

12. táblázat: Alkalmazott indikátorok, tájesztétikai érték (saját szerkesztés)

13. táblázat: Alkalmazott indikátorok, rekreációs, kulturális érték (saját szerkesztés)

14. táblázat: A helyi fejlesztést befolyásoló fejlesztési szervezetek (saját szerkesztés)

15. táblázat: A gazdasági, az ökológiai és a termesztési szempontok kapcsolata a táj népességmegtartó képességének befolyásolásában (saját szerkesztés) 


\section{FELHASZNÁLT TÉRKÉPEK JEGYZÉKE}

- A Hanság mocsarainak és a tervezett új vízlevezető csatornáknak a vízrajzi térképe, 1796 Hegedűs, Országos Levéltár S16 373

- A kapuvári uradalom áttekintő térkép vázlata 1800 körül, Országos Levéltár S16 244

- A Kapuvári uradalom Csíkos és Király Éger erdői, Országos Levéltár S16 641

- A Kapuvári uradalomhoz tartozó Kapuvári..., Bogyoszlói és Csornai erdők erdőgazdasági térképe, 1866, Országos Levéltár S16 641

- Corine 2006 adatbázis (Forrás: FÖMI)

- Csorna mezőváros felső mezejének rendezési terve, 1848, Országos Levéltár, S16 115

- Csornához tartozó Föld-Sziget puszta új határainak kijelölése a puszta és Acsalag gazdasági térképe, 19.sz. eleje, Országos Levéltár S16 495

- Hanság és környékének átnézeti térképe, 1756, Zinner F., Országos Levéltár S16 119

- Hanság vízrendezési térkép 1790., Carte ideale du marais ou wasen causé et forme par les eaux de la Raab entree le Neusidl See et la Rabnitza sur les terres du prince Eszterházy, et sur seign. roy. d'Altenbourg / designé par L. Kainrath., Országos Széchenyi Könyvtár (TK 382/ Térképtár, ST 66)

- Hanság vízrendezési térkép 1790., Mappa repraesentans extensionem lacus Ferteö et paludis Hanságh, prouti et fluviorum Ikva Répcze et Arabonis Kapuváriensis influxum in Hanságh ... / L v Kainrath, 1790, Országos Széchenyi Könyvtár, TK 1114

- Hanság vízrendezési térkép 1792. Mappa fluviorum Ikva Répcze et Arabonis Kapuvariensis in paludinosam plagam Hanságh influxum ... repraesentans / praesent. per I. Nep. Hegedüs., Országos Széchenyi Könyvtár

- Katonai felmérés, 1766-1785 Hadtörténeti Térképtár, V/10,11, VI/12,13,14, VII/ 12,13,14

- Katonai felmérés, 1845-1846 Hadtörténeti Térképtár, XXIII/49, 50, XXIV/48,49,50, XXV/48.49,50

- Katonai felmérés 1872-1884, Hadtörténeti Térképtár 4858 3,4; 4958 1,2,3,4; 4959 1,3; 5058 1,2 szelvények

- Katonai felmérés felújított 1920, Hadtörténeti Térképtár 4858 3,4; 4958 1,2,3,4; 4959 1,3; 5058 1,2 szelvények

- Mappa i comitatus Iauriensis et Mossoniensis uniti / Georgiu Király. 1787 Országos Széchenyi Könyvtár (TK 1157/ Térképtár ST, 66)

- Mapppa fluviorum Ikva Répcze et Arabonis Kapuvariensis in Paludinosam Plagam Hansagh..., A Hanság folyóinak és mocsarainak valamint környékének átnézeti térképe, Hegedüss, Országos Levéltár S16 120

- Rábaszabályozás áttekintő térképe (Fertő-tó és Rába közötti terület) 19.sz. vége, Országos Levéltár S16 314

- Sopron vármegye általános térkép 1753. Országos Széchenyi Könyvtár (Térképtár, TK 249/ST 66)

Sopron vármegye térképe, 1844, Országos Levéltár S16 589 


\section{JEGYZETEK}

\section{Jegyzetek 1.}

IMD World Competitiveness Scoreboard versenyképességi rangsorának kritérium-csoportjai

\begin{tabular}{|c|c|}
\hline $\begin{array}{l}\text { Gazdasági teljesít- } \\
\text { mény }\end{array}$ & $\begin{array}{l}\text { Hazai gazdaság (méret, növekedés, gazdagság, elörejelzések) } \\
\text { Nemzetközi kereskedelem } \\
\text { Nemzetközi beruházások } \\
\text { Foglalkoztatottság } \\
\text { Árak }\end{array}$ \\
\hline $\begin{array}{l}\text { Kormányzati haté- } \\
\text { konyság }\end{array}$ & $\begin{array}{l}\text { Közkiadások } \\
\text { Pénzügypolitika } \\
\text { Intézményrendszer (központi bank, állami hatékonyság) } \\
\text { Vállalatokat érintő jogszabályi környezet (nyitottság, verseny és szabályozás, munkaeröre } \\
\text { vonatkozó szabályozás) } \\
\text { Szociális háló }\end{array}$ \\
\hline $\begin{array}{l}\text { Vállalatok hatékony- } \\
\text { sága }\end{array}$ & $\begin{array}{l}\text { Termelékenység } \\
\text { Munkaerő piac } \\
\text { Bank szektor } \\
\text { Vállalatirányítás } \\
\text { Attitűdök és értékek }\end{array}$ \\
\hline Infrastruktúra & $\begin{array}{l}\text { Alap infrastruktúra } \\
\text { Müszaki infrastruktúra } \\
\text { Tudományos infrastruktúra } \\
\text { Egészség és környezet } \\
\text { Oktatás }\end{array}$ \\
\hline
\end{tabular}

Forrás: www.imd.ch

\section{Jegyzetek 2.}

Enyedi György városok esetében a következő tíz pontban összegezte a sikeresség tényezőit:

- A sikeres város képes a gazdasági szerkezet változtatására.

- A sikeres város szolgáltató szektorában magas az értékhozzáadó ágazatok száma.

- A sikeres várost a tudásalapú termelés jellemezi.

- A sikeres városban erős az innovációs képesség.

- A sikeres városban döntések születnek (stratégiai tervezés, innovációk létrehozása, nagyberuházások).

- Erős és gyarapodó a középosztály.

- A sikeres város nagy értékü környezetet nyújt.

- A sikeres város jól kezeli konfliktusait.

- Jelentősek a külső kapcsolatai.

- A sikeres városban növekszik a jövedelem és a foglalkoztatás. 


\section{Jegyzetek 3.}

Koltai Zoltán értelmezésében a régiók versenyképességének kritériumai:

- Gazdasági szerkezet: a sikeres régiókban a foglalkoztatottak túlnyomó része a gazdasági szolgáltatásokban, a feldolgozóiparban rendelkezik munkahellyel, ahol jellemző a magas hozzáadott érték, az erőteljes multiplikátor hatás és nagyfokú rugalmasság.

- Innovációs kultúra: a sikeres régiókra jellemzőek a kiterjedt innovációs tevékenységek, az innovációk hatékony diffúziója, a sok szabadalom. Ez nemcsak kutató- és fejlesztő intézetekben, egyetemekben kell, hogy testet öltsön, legalább ennyire fontosak a megfelelő vállalati kapacitások, a felkészült, innovatív kis- és közepes vállalkozások.

- Regionális elérhetöség: a sikeres régiók jól megközelíthetők, közlekedési kapcsolataik, földrajzi fekvésük előnyös. Mindez a közlekedési és kommunikációs infrastruktúrával kiegészülve alkot egységes egészet.

- Munkaerő felkészültsége: a sikeres régiókban relatív magas a munkaképes korú lakosságon belül a kvalifikált munkaerő aránya, mindez persze nem nélkülözheti a valós munkaerő-piaci igényekre fókuszáló, hatékony oktatási rendszert.

- Társadalmi szerkezet: a sikeres régiókban erős, gyarapodó középosztály jelenik meg, amely igényes keresletével, magasabb jövedelmével segíti a régió fejlődését.

- Döntési központok: a sikeres régiók egyben a vállalatok térségi bázisai, az itt müködő vállalkozások lényegi tevékenységét folytató egységek, önálló döntési kompetenciával rendelkeznek. Jellemzően az új, innovatív stratégiai részlegek fejlesztése a központnak helyet adó városban, régióban történik.

- A környezet minösége: a sikeres régiók színvonalas települési környezettel (közbiztonság, minöségi közszolgáltatások, esztétikus városépítészet, színvonalas lakások, jó helyi közlekedés stb.) és egészséges természeti környezettel rendelkeznek.

- A régió társadalmi kohéziója: a sikeres régiók képesek kezelni a konfliktusokat, származzanak azok gazdasági szerkezetváltásból, erőteljes gazdasági növekedésből, régión belüli területi és települési egyenlőtlenségekböl. A települési önkormányzatok együttmüködésre törekednek, a regionális identitás, a lokálpatriotizmus erősödik.”

\section{Jegyzetek 4.}

Térségi gazdasági fejlődést értékelő közgazdaságtani elméletek

\section{Thünen elmélete}

A közgazdasági elméletek között kivételt képez Thünen (1783-1850) elmélete, amely a mezögazdasági termelés területi elhelyezkedésének törvényszerüségeit taglalja. Thünen leírta egy önellátó gazdaságú állam telephelyrendszerének térbeli elhelyezkedését a XIX. század technikai fejlettségének, illetve a piaci és a munkamegosztási kapcsolatainak tapasztalatai alapján. Kutatásaiban arra kereste a választ, hogy hol érdemes elhelyezni az egyes mezőgazdasági kultúrák termelését. Elméletének legmaradandóbb hozadéka, hogy a különböző gazdálkodási formák értéke csak viszonylagos, mert a keletkezö hasznot egy sor egyéb körülmény dönti el. (Rechnitzer, 1994).

\section{Hagyományos modellek}

A regionális növekedési modellek első csoportja feltételezi, hogy a jövedelem a felhasznált tőke és munka függvénye. A csoport fö képviselöi a neoklasszikus növekedéselmélet és az exportbázis elmélet. A neoklasszikus elmélet szerint a regionális különbségek alakulása a tőke és a munkaerő termelési tényezők elérhetőségén régiók közötti mobilitásától függ. Azonos termelési funkciók esetében a tőke odaáramlik, ahol a munkaerő olcsó és bőségesen rendelkezésre áll, a munkaerő pedig ellentétes irányba áramlik. Ez az áramlás addig folytatódik, míg a tőke és a munkabérek kiegyenlítőd- 
nek mindegyik régióban. Az exportbázis elmélet megkülönbözteti a gazdasági tevékenységeket exportra termelő és belső fogyasztásra termelő tevékenységekre. Az exportra termelő tevékenységek bővülése révén megnövekszik a régióba áramló pénz, amely növeli a javak és szolgáltatások iránti keresletet és magával vonja a belső fogyasztásra termelő tevékenységek bővülését is (Terluin, 2003).

\section{Agglomerációs modellek}

Az agglomerációs modellek közé tartozó elméletek szerint a jövedelem a munkaerő és a tőke egy adott helyen történő koncentrációjától függ. A növekedési pólusok elmélete szerint meghatározó, vezető vállalat jelenléte ösztönzőleg hat más iparágak és gazdasági tevékenységek fejlődésére. A halmozódó hatásokhoz kapcsolódó (cumulative causation) elméletek feltételezik, hogy amint létrejöttek a regionális különbségek, egy önmagát erősítő folyamat kezdődik, ami fenntartja fejlettebb térségek pozícióját. A fejlett térség a növekvő skálahozadék révén tovább fejlődik, újabb befektetők telepednek meg kihasználva a gazdasági tevékenységek koncentrációját. A termelés bővülése magával vonja a hátrányos helyzetü térségekből a munkaerő bevándorlását. A növekvő népességgel fejlödik a szolgáltató szektor. Ez a folyamat számos kedvezőtlen hatást fejt ki a hátrányos helyzetủ régiókra: a hatások eredményeként a fejletlenebb területek mobilizálható erőforrásait (tőke, munkaerő, kereskedelmi áruk) a fejlettebb régiók elvonják, koncentrálják. A fejletlen térségeknek növekvő hátrányokat kell elszenvedni, hiszen nem tudnak a továbbiakban magas színvonalú infrastruktúrát, és egyéb közszolgáltatásokat fenntartani. Az agglomerációs modellek újabb keletű irányzata az 'új gazdaság földrajz' (new economic geography-NEG), amely a népesség és/vagy gazdasági tevékenységek gazdasági koncentrációját tanulmányozza a növekvő skálahozadék révén. Egy már nagy helyi piac további cégeket és munkaeröt vonz (Krugman, 1998). Mindezzel párhuzamosan a nem növekvő régióknak fokozódó hátrányokkal kell szembenézniük, hiszen nem képesek azonos színvonalú infrastruktúrát, közösségi szolgáltatásokat fenntartani

\section{Helyi miliő modellek}

A helyi miliő modellek szerint a régiók jövedelmét számos helyi tényezö befolyásolja mint például a munkaerö képzettsége, technológiai és szervezeti know-how, szociális háló, intézményrendszer. Itt kiemelném az endogén növekedéselméleteket, amelyek általában agglomerációs térségekre - de nem metropoliszokra - vonatkoznak kis és közepes vállalkozásokkal. Ezek a helyi gazdaságok vállalkozó szellemmel, termelési rugalmassággal jellemezhetők. Ezen elméletek közé sorolhatók az iparági körzet modellek. Egy iparági körzet helyi, iparágon belüli kapcsolatok sűrü hálójának is tekinthető (amit a szakirodalom klaszternek is nevez, hiszen annak egy altípusának tekinthető (Buzás-Lengyel, (2002), amely időbeliségét és formáját tekintve tartós hálózata a pozitív és a negatív externáliáknak és történelmi-kulturális örökségnek. Ez a rendszer, amelyben kis és közepes vállalkozások félkész termékeket cserélnek ki egymás között, tulajdonképpen egy kollektív termelési folyamatként írható le. A vállalkozások és a személyek közötti kapcsolatok nem csak a nemzeti előírások által szabályozottak, hanem nagyrészt helyi szabályok által, amelyek a helyi kulturális sajátságokból származnak.

\section{Területi innovációs modellek}

A területi innovációs elméletek elsősorban azért különböznek a helyi miliő modellektől, mert az utóbbitól eltérően úgy vélik, hogy a munkaerőn, a tőkén és a helyi tényezőkön túl - az innovációk terjedése is a fejlődés fontos motorjának tekinthető. Az innováció fogalmát tág értelemben használhatjuk, ugyanúgy magába foglal termék, folyamat és szervezeti innovációt a vállalatok keretein belül, mint társadalmi, intézményi innovációt iparági, regionális és nemzeti szinten. Molle és Cappelin megfogalmazásában (idézte: Terluin, 2003): "a helyi gazdaság fejlödése annak azon képességén múlik, hogy milyen módon képes eröforrásait régi tevékenységek helyett újak számára átadni, hasznosítani” 


\section{Jegyzetek 5.}

Pais indikátorok

\section{Életminőség és társadalmi jólét}

- Környezetminőség

- Közszolgáltatások elérhetősége

- Lakhatás körülményei

- Biztonság

\section{Gazdasági szerkezet és teljesítmény}

- Általában: Gazdasági ágak aránya, vállalkozások, beruházások, munkaerő jellemzői, üzleti infrastruktúra, gazdasági teljesítmény, humán tőke

- Primér szektor: Multifunkcionalitás a mezőgazdaságban, termelékenység és diverzifikáció, pénzügyi erőforrások

- Turizmus: Turisztikai szolgáltatások, kereslet és kínálat paraméterei, foglalkoztatás

\section{Demográfia}

- Népsürüség

- Változás és szerkezet

- Ingázási és migrációs trendek

- Kulturális kérdések

\section{Jegyzetek 6.}

Kiemelten fontosnak tartom témám szempontjából egyezmény meghatározását a tájhoz kapcsolódó tevékenységekről:

„Táj-politika” az illetékes hatóságok olyan általános elveit, stratégiáját és irányelveit jelenti, amelyek lehetővé teszik a tájak védelmét, kezelését és tervezését szolgáló intézkedések megtételét;

c. „Táj minőségére vonatkozó célkitüzés” egy adott táj esetében arra vonatkozik, amikor az illetékes hatóságok megfogalmazzák a lakosságnak a környékbeli táj jellemzőire vonatkozó igényeit.

d. „A táj védelme” a táj jelentős vagy jellemző sajátosságainak megőrzésére és fenntartására vonatkozik. Örökségi értékét a táj természeti adottságai és/vagy az emberi tevékenységek révén kialakult elemeinek jellemző összetétele adja;

e. „A táj kezelése” a fenntartható fejlődés szempontjából olyan tevékenységet jelent, amelynek célja a táj rendszeres fenntartása. Célja, hogy a társadalmi, gazdasági és környezeti folyamatok által elöidézett változásokat irányítsa és összhangba hozza;

f. „A táj tervezése” olyan céltudatos tevékenységet jelent, amelynek célja a táj fejlesztése, helyreállítása vagy új létesítése.

Az egyezmény írói felhívják a figyelmet arra, hogy amikor a táj védelmének, kezelésének és tervezésének legmegfelelőbb egyensúlyát keressük, emlékeznünk kell arra, hogy nem az a cél, hogy a tájat változatlanul megőrizzük, vagy „lefagyasszuk", vagyis rögzítsük hosszú és fokozatos fejlődésének egy bizonyos állapotában. A tájak folyamatosan változtak és a jövőben is változnak majd, mind természeti folyamatok, mind emberi tevékenységek eredményeképpen. Valójában az lenne az ideális cél, hogy a jövendő változásait úgy kezeljük: a múlttól örökölt tájaknál nyerjen elismerést a leggazdagabb sokféleség és legmagasabb minőség.

Az egyezmény aláírói vállalják, hogy

— törvényben rögzítik, hogy a tájak elengedhetetlen összetevői az emberek környezetének, kifejezik közös kulturális és természeti örökségük sokféleségét, és identitásuk alapját képezik;

— olyan táj-politikát alakítanak ki és váltanak valóra, amelynek célja a táj védelme, kezelése és tervezése; 
— kialakítják a részvételhez szükséges eljárásokat a társadalom tagjai, a helyi és a regionális hatóságok, valamint más érdekelt felek számára, amelyek érdekeltek a táj-politika meghatározásában és végrehajtásában;

— a tájat beépítik regionális és várostervezési, továbbá kulturális, környezetvédelmi,

— mezőgazdasági, szociális és gazdasági, valamint minden olyan egyéb politikájukba, amelynek közvetlen vagy közvetett hatása lehet a tájakra.

Mindezek megvalósítása érdekében vállalják továbbá

— a tájak értékeléséhez és működtetéséhez értő szakértők képzését,

— számba veszik az ország területén található tájakat,

— elemezik jellemző vonásaikat, valamint azokat a hatásokat, amelyek alakítják őket

— számon tartják a változásokat

tájminőségi célkitűzéseket fogalmaznak meg a számba vett tájakra.

A fentiekben említett tájminőségi célkitűzések megfogalmazása azonban még nem történt meg. Nemzetközi példaként említem a Katalónia számára megfogalmazott célokat (a katalán tartományi kormány tanácsadó testületeként müködő Tájközpont (Landscape Observatory) által összeállított 10 célkitűzés (válaszul a „Milyen tájakat szeretnénk?” kérdésre):

1. „Jó állapotban megörzött, tervezett és fenntartott tájak, függetlenül tájtípustól (városi, szuburbán, vidéki és természeti) és karaktertöl

2. Élö és dinamikusan fejlödö tájak - a már létezö és az újonnan létrehozott tájak - amelyek képesek az elkerülhetetlen területi változásokat elnyelni anélkül, hogy egyedi jellegüket elveszítenék.

3. Heterogén, változatos tájak, amelyek tükrözik a katalán diverzitást, és elkerülik a homogenizálódást.

4. Rendezett és harmonikus tájak, elkerülve a fragmentációt.

5. Egyedi, nem hétköznapi tájak.

6. Tájak, amelyek megtartják és erösítik egyedi jellemvonásaikat és értékeiket, mind a megfogható és nem megfogható értékeket (ökológiai, történeti, esztétikai, társadalmi, szimbolikus és identitás-alapú)

7. Tájak, ahol tiszteletben tartják a múlt örökségét.

8. Tájak, amelyek nyugalmat közvetítenek, mentesek a disszonáns elemektöl, fényszennyezéstöl, kellemetlen szagoktól.

9. Tájak, amelyek használhatók anélkül, hogy veszélybe kerülne örökségük és egyediségük.

10. Tájak, melyek igazodnak a társadalmi sokszínüséghez és hozzájárulnak az egyéni és a társadalmi jóléthez." (http://www.catpaisatge.net).

\section{Jegyzetek 7.}

— ,A 20-64 évesek legalább 75\%-ának munkahellyel kell rendelkeznie.

- Az EU GDP-jének 3\%-át a K+F-re kell fordítani.

— Teljesíteni kell a „20/20/20” éghajlat-változási/energiaügyi célkitüzéseket (ideértve

— megfelelö körülmények között a kibocsátás 30\%-kal történö csökkentését).

- Az iskolából kimaradók arányát $10 \%$ alá kell csökkenteni, és el kell érni, hogy az ifjabb

— generáció 40\%-a rendelkezzen felsőoktatási oklevéllel.

— 20 millióval csökkenteni kell a szegénység kockázatának kitett lakosok számát." (http://ec.europa.eu/eu2020/pdf/ 1_HU_ACT_part1_v1.pdf, 2010-12-27). 


\section{Jegyzetek 8.}

Az Országos Fejlesztési és Területfejlesztési Koncepció jejlesztési prioritásai

— Innovatív magyar gazdasági növekedés és foglalkoztatás

— Energiahatékonyság, fenntartható erőforrás-gazdálkodás, klíma- és környezetvédelem

— Elérhetőség, megújuló közösségi közlekedés és tranzitgazdaság

— Befogadó, gyarapodó, tudástársadalom

— Budapest és térsége vezető macro-regionális szerepkörben

— Életképes vidék, bővülő agrár- és élelmiszer-gazdaság, halászat

— Kiteljesedő Kárpát-medencei, Duna menti nemzeti és európai területi együttműködésHorizontális fókuszú prioritások

— Hatékony végrehajtás, fejlesztő, közszolgáltató és jó állam

- érdekében

— Direkt uniós források az európai magyar hálózati integráció érdekében

A fejlesztési dokumentum kiemelten foglalkozik a vidék fejlesztési lehetőségeivel

A vidékpolitika átfogó célkitüzéseiként az alábbikat fogalmazza meg:

— Város-vidék kapcsolatok megújítása a kölcsönös előnyökre alapozva

- Vidéki települések, falvak, tanyák fejlesztési, gazdasági létalapjuk megerősítése

— Vidéki gazdaság, kiemelten az agrár és élelmiszergazdaság helyi gazdaságfejlesztésbe illeszkedő fejlesztése, erösítése, foglalkoztatási szerepének növelése, helyi gazdaságfejlesztése

— Vidéki munkaerö, különösen az értelmiség megmaradásának és megtelepedésének támogatás 


\section{Jegyzetek 9.}

3. táblázat: A gazdasági, részben a társadalmi feltételrendszernek megfelelö eltartó funkciókhoz kapcsolható tájépitészeti követelmények (Saját szerkesztés)

\begin{tabular}{|c|c|c|}
\hline $\begin{array}{c}\text { Tájfunkci- } \\
\text { ók }\end{array}$ & $\begin{array}{l}\text { Tájfunkciók } \\
\text { alcsoportjai }\end{array}$ & Tájépítészeti követelmények/Tájminőségi célkitüzések \\
\hline \multirow{5}{*}{ 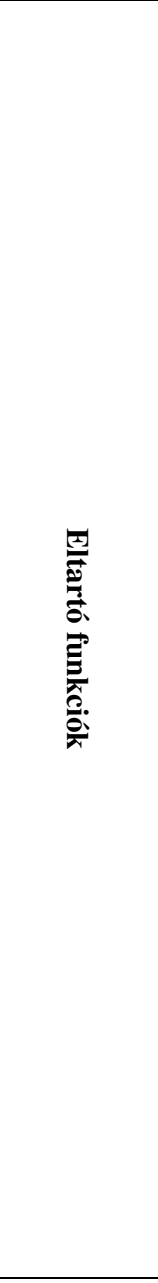 } & $\begin{array}{l}\text { Mezőgazdasági } \\
\text { termelés }\end{array}$ & $\begin{array}{l}\text { - Táji adottságoknak megfelelő mezőgazdasági termelés (domborzat, talajtípusok, vízkészlet } \\
\text { stb.) } \\
\text { - Multifunkcionális gazdálkodásra törekvés, változatos agrár-termékszerkezet (területhasználati } \\
\text { rendszer) kialakítása } \\
\text { - Megfelelő jövedelemszint biztosítása a gazdálkodás révén, az adottságoknak megfelelő magas } \\
\text { hozzáadott értéket biztosító gazdálkodás (bio-, ökológiai gazdálkodás, egyedi, tájtermékek) } \\
\text { - Természetvédelem és gazdálkodás összehangolása, kompenzáció biztosítása a korlátozások } \\
\text { ellenében }\end{array}$ \\
\hline & Erdőgazdálkodás & 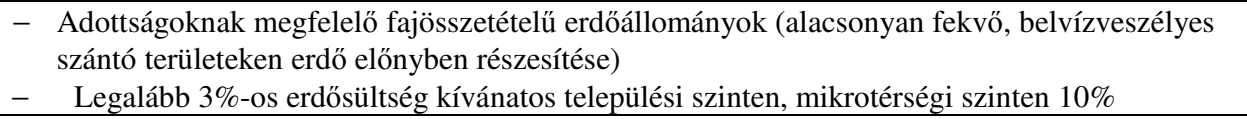 \\
\hline & $\begin{array}{l}\text { Bányászat } \\
\text { Ipar }\end{array}$ & $\begin{array}{l}\text { - Terület-takarékos, szükséges méretű ipari területek kialakítása, zöldmezős beruházásokkal } \\
\text { szemben a barnamezős beruházások előnyben részesítése } \\
\text { - Negatív hatások minimalizálása, ipari parkok zöldfelület-rendszerének fejlesztése, védőfásítás } \\
\text { - Felhagyott ipari területek, majorok, telephelyek felszámolása, rehabilitációja, a funkcióváltás } \\
\text { ösztönzése } \\
\text { - Helyi erőforrásokra épülő ipar fejlesztése } \\
\text { - A térségben elóállított termékek minél később és minél feldolgozottabb formában hagyják el a } \\
\text { térséget „Termelj helyben, fogyassz helyben!”, helyi piacra jutás elősegítése } \\
\text { - Iparterületek védőövezetének kijelölése }\end{array}$ \\
\hline & $\begin{array}{l}\text { Közlekedési } \\
\text { infrastruktúra } \\
\text { Egyéb müszaki } \\
\text { infrastruktúra }\end{array}$ & $\begin{array}{l}\text { - Piacok, munkahelyek, közszolgáltatások elérésének biztosítása } \\
\text { - Gazdasági tevékenységekhez szükséges mértékủ, hatékony infrastruktúra hálózat kialakítása } \\
\text { - Környezetbarát közlekedési módok elönyben részesítése, alternatív közlekedési módok ösztön- } \\
\text { zése a kistelepülések elérhetőségének javítására } \\
\text { - Létesítmények tájba illesztett elhelyezése, negatív hatások minimalizálása }\end{array}$ \\
\hline & Lakóhely & $\begin{array}{l}\text { - Társadalmi igények kielégítése és az építészeti hagyományok védelme szempontjainak harmo- } \\
\text { nizálása } \\
\text { - Kompakt, terület-takarékos településfejlesztés, az újonnan épült településrészek illeszkedjenek } \\
\text { a hagyományos településkarakterhez } \\
\text { - } \\
\text { - Színvonalas települési környezet biztosítása a zöldfelület-rendszer fejlesztésével, } \\
\text { Kistelepüléseknek is legyen közparkja/közkertje, templomkertek színvonalas zöldfelülettel } \\
\text { - Tendelkezö közösségi térré alakítása } \\
\text { településszelógiai hálózat és települési zöldfelület-rendszer kapcsolatának biztosítása, zöld } \\
\text { telása }\end{array}$ \\
\hline
\end{tabular}

A környezeti feltételrendszernek megfelelö szabályozási és élőhely funkciókhoz kapcsolható tájépitészeti követelmények

\begin{tabular}{|c|c|c|}
\hline Tájfunkciók & $\begin{array}{l}\text { Tájfunkciók } \\
\text { alcsoportjai }\end{array}$ & Tájépítészeti követelmények/Tájminőségi célkitűzések \\
\hline $\begin{array}{c}\text { Szabályozási } \\
\text { funkciók/ } \\
\text { Környezeti } \\
\text { integritás }\end{array}$ & $\begin{array}{l}\text { - Biodiverzitás } \\
\text { védelme } \\
\text { - Éghajlat- } \\
\text { szabályozás } \\
\text { - Vízszabályozás } \\
\text { - Vízellátás } \\
\text { - Talajvédelem } \\
\text { - Talajképzés } \\
\text { - Hulladék-kezelés }\end{array}$ & $\begin{array}{l}\text { - A környezeti elemek védelme (víz, levegö, talaj, flóra, fauna) } \\
\text { - } \text { Környezetbarát mezőgazdasági müvelés, erdőgazdálkodás } \\
\text { - } \text { A környezeti szempontból érzékeny területeken az extenzív gazdálkodási módok } \\
\text { előnyben részesítése } \\
\text { - } \\
\text { Biodiverzitás védelmét szolgáló területi tervezés: biotópok védelme, mozaikjellegű } \\
\text { tájak kialakulásának elősegítése, védelme, ökológiai hálózatok védelme } \\
\text { - Terhelések szintjének minimalizálása } \\
\text { - }\end{array}$ \\
\hline \multirow[t]{2}{*}{$\begin{array}{l}\text { Élőhely } \\
\text { funkciók }\end{array}$} & $\begin{array}{l}\text { Menedékhely bizto- } \\
\text { sítása }\end{array}$ & $\begin{array}{l}\text { - } \text { Biotópok védelme } \\
\text { - Vizes élőhelyek védelme, helyreállítása } \\
\text { - } \text { Természetvédelmi terület (természetvédelmi, Natura 2000, Nemzeti Ökológiai } \\
\text { Hálózat elemei) legalább 5\%-os aránya térségi szinten, } \\
\text { - } \text { Extenzív hasznosítású területek legalább } 15-20 \% \text {-os aránya } \\
\text { - } \text { Mozaikjellegủ tájszerkezet fenntartása } \\
\text { - Ökológiai hálózatok védelme és fejlesztése (magas ökológiai értékủ területek vé- } \\
\text { delme és összeköttetésük biztosítása) }\end{array}$ \\
\hline & $\begin{array}{l}\text { Szaporodó hely } \\
\text { biztosítása }\end{array}$ & $\begin{array}{l}\text { - Erdősültség minimális szintjének biztosítása (térségi szinten 10\%) } \\
\text { - } \text { Gyepterületek védelme, arányuk növelése } \\
\text { - Mezőgazdasági területek élőhelyeinek védelme } \\
\quad \text { o Természetszerü lineáris elemek: fasorok, erdősávok fenntartása } \\
\circ \quad \text { Vízfolyások mentén 2-5 m szegély mủvelésmentes fenntartása }\end{array}$ \\
\hline
\end{tabular}




\begin{tabular}{|c|c|c|}
\hline Tájfunkciók & $\begin{array}{l}\text { Tájfunkciók alcso- } \\
\text { portjai }\end{array}$ & Tájépítészeti követelmények/Tájminőségi célkitűzések \\
\hline \multirow{4}{*}{$\begin{array}{l}\text { Kulturális } \\
\text { funkciók }\end{array}$} & $\begin{array}{l}\text { Rekreációs tevékenysé- } \\
\text { gek biztosítása }\end{array}$ & $\begin{array}{l}\text { - Társadalom igényeinek kielégítése: pihenés, kikapcsolódás, sportolási és egyéb } \\
\text { szabadidős tevékenységek lehetőségének biztosítására zöldfelületek fenntartása } \\
\text { térségi szinten } \\
\text { - Vízfelületek, erdők és egyéb természeti területek megközelíthetőségének biztosí- } \\
\text { tása } \\
\text { - Multifunkcionális közösségi terek kialakítása } \\
\text { - Helyi népesség és a turisták igényeinek összehangolása }\end{array}$ \\
\hline & $\begin{array}{l}\text { Tudományos és nevelé- } \\
\text { si tevékenységek bizto- } \\
\text { sítása }\end{array}$ & $\begin{array}{l}\text { - Tanulás és felfedezés helye legyen a táj: látogatóközpontok, tematikus utak, } \\
\text { tanösvények kialakítása, fejlesztése } \\
\text { - Természetvédelmi érdekek és a rekreációs igények összehangolása a természet- } \\
\text { védelmi területek zónarendszerének kialakításával, kevésbé érzékeny területek a } \\
\text { nyilvánosság számára megközelíthetővé, elérhetővé tétele } \\
\text { - A táj történeti jellegének, elemeinek védelme } \\
\text { - Tájértékek számbavétele és védelme }\end{array}$ \\
\hline & $\begin{array}{l}\text { Kulturális és mủvészeti } \\
\text { érték }\end{array}$ & $\begin{array}{l}\text { - Térség identitásának részét képező értékek számbavétele, védelme } \\
\text { - Helyi örökséget bemutató közösségi terek kialakítása }\end{array}$ \\
\hline & Esztétikai információ & $\begin{array}{l}\text { - Táj esztétikai értékének megőrzése és fejlesztése } \\
\text { - Tájkarakter védelme }\end{array}$ \\
\hline
\end{tabular}

Forrás: Leader European Observatory (2001), Ghimessy László (1984), de Groot (2006), (Neugebauer et al. 2011)

\section{Jegyzetek 10.}

A kapuvári uradalom első urbáriuma (1492) alapján következtethetünk legkorábban a tó halászatára, amely szerint a barbacsiak uruknak csónakpénzzel (cholnakpinz) is tartoztak. A csónakpénz valószínűleg a halászat után szedett járandóság lehetett (Takács, 1999). Továbbá Horváth László: „A Kapuvári uradalom az 1580-as évek végén” című munkájából tudhatjuk, hogy ellentétben egyéb falvakkal a halászfalunak számító Barbacson és Bősárkányon az úrbéresek kevesebb helyadót fizettek az uradalom többi településeihez képest, éppen a kevesebb telki állományú szántóterület miatt. „Viszont a „halászvízzel” bíró jobbágyoknak és zselléreknek a helyadó befizetése és az aprójószág és tejtermék beszolgáltatása mellett „,ebédhalat”, valamint rákot is kellett a kijelölt napokon Kapuba beszállítani.” Az egyes halászfalvak a számukra előre megszabott héten szállították a halat, rákot és/vagy csíkhalat a várba (Horváth, 2004). A földesúr úrbéreseinek szántóföldet, rétet „helyföldnek” nevezett jobbágytelket (sessiót) vagy zsellérhelyet adott, amit az ún. beltelek (házhely, kert) és a kültelek (a falu határában kijelölt szántóföld és rét) alkotott, együttesen képezve a telki állományt, aminek használatáért készpénzben fizetendő éves adót (census) és a természetbeni termékszolgáltatást (munera) azaz helyadót kellett fizetni (Horváth, 2004).

Nádasdy Tamás levelei alapján (Idézte Mikó, Mályusz Elemér: Az Országos Levéltár Nádasdy-levéltárának magyar nyelvü levelei, Levéltári Közlemények) valószínüleg kereskedtek is a Barbacsi tóból kifogott halakkal. A levelekben több halfajt is említenek: csukát, harcsát, jászkeszeget, kárászt. A Barbacsi tó halászatáról és a hozzá kapcsolódó árokrendszerről tanúskodik egy 1715-ben kezdődött Barbacs és Kóny közötti határper, amelyhez kapcsolódó iratok (Idézte Mikó, Országos Levéltár (továbbiakban OL) S 16 No.393., 394. (1756)) között az árkokat ábrázoló térképet is találhatunk, azon jobbágyok nevével feltüntetve, akik fenntartották az árkokat („Barbacsi Giczy Márton Ásványa, Barbacsi Nagy Mihály Ásványa”). Az árkok funkciójáról a per írott anyaga tájékoztat. Az ásványokat a barbacsi jobbágyok rendszeresen halászták, rekeszeket és varsákat állítottak rajtuk. Az árkok valószínűleg a víz és ezzel együtt a halak mozgását szabályozták: tavaszi és őszi áradáskor az árkokon keresztül engedték ki a vizet a rétekre nádasokra, amelyek a halak ívó helyei voltak és apadáskor lehalászták őket az árkokban. Az időszakosan elárasztott rétek számítottak a legjobb minőségű réteknek. Az árkoknak komoly hidrológiai szerepük volt, segítettek az áradásokkor a vízszint szabályozásában.

Bedy Vince a győri székeskáptalan történetét feldolgozó munkájában említi a Tóköz másik két jelentősebb taván folyó halászatot, amely jelentős jövedelmet biztosított földesuruknak a győri káptalannak, aki a tavak kezelésére tóbírókat 
jelölt ki. A bírók munkájának ellenőrzésére tómestert küldött ki, aki évente elszámolt a bevételekkel és kiadásokkal. A tóbíró vette a halászathoz szükséges eszközöket például 1676-ban 200 öl kötelet vett 10 forintért (Bedy, 1938).

\section{Jegyzetek 11.}

Legrégebbről ismert a besenyő eredetű Osl nemzetség, belölük sarjadt az Ostffyak, Asszonyfalviak családja, valamint a Kanizsai, Endrédy, Pethő, Viczai, Pókai családoknak volt birtokuk a Rábaközben. A XV. században a Garayak, Ujlakiak, Rozgonyiak, végül a Nádasdy és az Eszterházy családok lettek földesurak

\section{Jegyzet 12.}

A Horváth László által feldolgozott urbáriumi iratok alapján néhány település lakos-számára illetve jobbágy családjainak (lakott jobbágytelkek) számára lehet következtetni: Szil (77) mezővárosként, Bogyoszló (48) voltak a jelentősebb települések, a zsellérhelyek száma a rábaközi településeken alacsonyabb volt (Barbacs, Bogyoszló), jelentősebb arányú pusztatelkek (elhagyott) voltak Szilben, Tamásiban, Barbacson (Horváth, 2004).

\section{Jegyzetek 13.}

Az egyik a Hanság lecsapolásával hosszabb távon is foglalkozó Hegedűs Antal terve, amely a Király-tó térségéből az Ikváig tervezett csatornát illetve L. Kainrath francia mérnök egy 1790-es és 1792-es vízrendezési terve. Az 1792-es terven egy - itt a Répcén és Kisrábán keresztül a Rábába kívánta a Hanság vizeit levezetni -, az 1790-es térképen két hosszabb és egy rövidebb csatorna terve is szerepel. Az északi csatorna a Király-tótól északra a Fertő-tóval biztosította volna az összeköttetést, a délebbi pedig a Hanság déli peremén vezette volna le a vizeket. Érdekesség, hogy a térképen Kainrath megemlített 12-13 vízimalmot, amelyek a középkorban gyakoriak voltak a térségben.

\section{Jegyzetek 14.}

A föág, az Öreg-Rába Kecskéd (Rábakecskéd) határában U alakú kanyart vett. Rábaszentandrásnál a Rába ismét két ágra szakadt, majd Vág és Marcaltő között délkeleti irányba majd ismét északészakkelet felé haladt. Bodonhely előtt ismét nagy szigetet képez. Rábacsécsény után a folyó két ágra szakadt, jobb oldali ága Rábaszentmihály, Mérges, Rábapatona felé folyt. Rábacsécsény és Rábcakapi közötti térségben északnyugat-délkeleti irányban törésvonal húzódott, ahol mély fekvése miatt mocsárvilág helyezkedett el, amelynek legmélyebb részein vannak a Barbacsi-tó, a Kónyitó sőt az utóbbival összeköttetésben egy ún. Rózsás-tó (e tavat csak Sopron megye 1844-es térképén találtam meg, egyéb térképek mocsárvilágként ábrázolták ezt a területet). A folyó alsó szakaszán a lerakott hordalék miatt számtalan ér, patak ágazott ki a Rábából mint például a Keszeg-ér és Linkó-ér, amelyek Malom-érként egyesülnek Csornától délre, vagy Sárdos-ér, Sárdos-Mak ér, Fenyves-ér stb. (Dóka, 1977, S 16 No. 589).

\section{Jegyzetek 15.}

A bizottság megállapította: "Sopron megyében a Rába rendszeresen elönti a közvetlen környékén lévő egész vidéket. A Rábaközben 26 falu szokott víz alá kerülni... Védekezésül kérték annak elrendelését, hogy a vizek útjából a vízi- és hajómalmokat, hidakat, a vízbe esett fákat, gyökereket, farönköket áradások alkalmával távolítsák el, hogy ezek összetorlódva ne akadályozzák az árhullám lefolyását..."(Sárközi, 1968 p.:13).

\section{Jegyzetek 16.}

Keczkés elkészítette a Rába folyó első szabatos vízrajzi leírását, felrajzolta a pontos hossz-szelvényt és megalkotta a Rába-vidék első tudományosan megalapozott rendezési tervét. Megvizsgálta a folyó esését: mérései szerint a Rába esése a határtól a torkolatig 141,5 m, amiből a malmok egy harmad részt elvonnak így csak 105,5 m az összes esés. A Hanság lecsapolására is dolgozott ki tervet (Dóka, 1977). Megállapította, hogy a bővízű mellékfolyók következtében 
kialakuló legnagyobb vízállásnál a vízhozam levezetésére nem alkalmas a meder, ezért törvényszerü, hogy gyakran kiönt. Az általa kidolgozott rendezési terv célja az volt, hogy a meder le tudja vezetni a legnagyobb vizet is. Javasolta a hordalék lerakódása illetve a malomgátak helytelen megépítése miatt kialakult kanyarulatok levágását. A malmokat a folyó bal partján haladó csatornában tervezte elhelyezni és malomcsatornává alakíttatta volna a Kis-Rábát is (Dóka, 1977).

\section{Jegyzetek 17.}

Az 1840. évi V. törvénycikk 7. §-a kimondta, hogy „Az akképpen elrendelt vizi munkálatokra szükséges költségeket, a közbirtokosok közül kiki, birtokához és a nyerendő haszonhoz aránylag, fizetni” köteles (Sárközi, 1968, p.: 19).

\section{Jegyzetek 18.}

$1 . \S$ „Felhatalmaztatik a közmunka- és közlekedési minister, hogy a Rába folyó szabályozását Sárvártól Győrig, a Rábcza folyó szabályozását Beő-Sárkánytól Győrig, a hansági csatorna kiásását Pomogytól a Rábczáig, a Marczal folyó végszakaszának rendezését, valamint az ezen munkálatokkal szoros kapcsolatban álló belvizcsatornázásokat és a kis Duna partján az ártér széleig szükséges védtöltések kiépitését legfölebb hat év alatt a Rába-szabályozó-társulatnak helybenhagyott tervei alapján eszközölhesse, - felhatalmaztatik továbbá arra is, hogy a Győr szab. kir. város és Győrsziget község árviz ellen való biztositására, szükséges munkálatokat a bemutatott tervek alapján az 1885 . év végéig végrehajtassa". (http://www.1000ev.hu/index.php?a=3\&param=6180

\section{Jegyzetek 19.}

A II. katonai térkép alapján leolvasható területhasználat: Földsziget térségében mesterségesen alakított (egyenes vonalakkal határolt) erdőfoltot látunk továbbá több erdőfoltot találunk Csornától északra. Tárnokréti (Réti), Rábcakapi (Kapi), Bősárkány vonalától északra a nedves rétek, mocsaras területek egyeduralkodók. Csornától délre a szántók és gyepek mozaik jellegüen váltakoznak. Dél felé haladva a szántók növekvő aránya figyelhető meg. Bősárkánytól délkeleti irányban egészen a Rábáig széles vizes, mocsaras térség nyúlik el körbeölelve a Kóny-tavat (a mai Barbacsi-tó), Kónytól délre tavat nem jelez a térkép csak nagy kiterjedésű mocsarat. Markáns vonallal, kísérő fasorral jelölt csatorna (Der Canal) köti össze a Rábcát a Rábával. Hasonlóan Bezitől délre Enese vonalában egészen a Rábáig elnyúló nedves területek figyelhetők meg. Egyed település körül hatalmas kiterjedésü ültetvény valamint kastélypark látható. A rábaköz középső részén (Pordány, Csanak térségében) nagy kiterjedésű összefüggő szántóterületek terülnek el. A még szabályozatlan, kanyargós Rába mentén több csatorna vonalát, széles sávban nedves réteket és erdőket találunk. Összességében megállapítható, hogy a Rábaközben továbbra is nagy a gyepek és magas a nedves, vizes területek aránya.

\section{Jegyzetek 20.}

Összehasonlításképpen adatokért Ollram Ferenc munkájához nyúlhatunk: Csornán a Prépost-szeren míg 1778-ban 783 kishold területen 1062 pozsonyi mérő (62,5 liter) búza, 359 rozs, 180 árpa és 176 pozsonyi mérő zab termett, addig 1845-ben 783 hold területen 2825 pozsonyi mérő búza, 1164 mérő rozs, 1463 mérő árpa, 104 mérő zab termett és kukoricából is 569 mérőt jegyeztek fel (Ollram, 1941). 


\section{Jegyzetek 21.}

5. táblázat: Malmok a Rábaközben (Soproni Kereskedelmi és Iparkamarának 1876-ik évi Statisztikai Jelentése alapján idézte Pájer)

\begin{tabular}{|l|c|c|}
\hline & Sopron vármegye & Rábaköz \\
\hline vízimalom & 188 & 11 \\
\hline szárazmalom & 34 & 18 \\
\hline szélmalom & 5 & 2 \\
\hline göz- és mümalom & 6 & 2 \\
\hline
\end{tabular}

\section{Jegyzetek 22.}

A csornai uradalomban 1845-ben 2139 szarvasmarhát, 798 lovat, 2548 sertést és 4470 juhot tartottak (Ollram, 1941). A Hanyban az Eszterházy uradalomnak 3198 szarvasmarhája, 40 bivalya, 348 lova, 1312 sertése legelt a század végén (Kövér Fidél, 1930). Fényes Elek a térségben a szarvasmarha és a lótartást emeli ki, a juhtenyésztés Sövényháza kivételével a Tóközben nem jellemző, a Rábaközben a Veszprém megyével határos területeken jellemző a sertéstenyésztés. A lótenyésztés népszerüségét szemlélteti az alábbi adat Fényes Elek munkájából: a Tóközben nem ritka egy gazdánál 816 ló tartása sem. Fényes Elek a szarvasmarhatartást a tóköziek egyetlen élelemforrásaként említi. Szárnyasok tartása szintén jellemző a Rábaközre. „A tóközi tavak bővelkednek halban, csikban, rákban” (Fényes, 1807-1876).

\section{Jegyzetek 23.}

A gabonát érés idején ,a’ gyakori köd rongállya”. A tóközben többször előfordul, hogy „rétjeik (tüz esvén valahogy bele) magoktól meggyúladnak, 's csak a' rá eső hó olthatja el azt". A tóközi településekre jellemző módon Fényes Elek kiemeli, hogy a rétek, legelők nagyobb arányban foglalják a határt mint a szántóföldek. A gyümölcstermesztés nem kiemelkedő Enese és Sövényháza kivételével a térségben, ez utóbbi községben Fényes Elek szőlőt is ír (Fényes, 18701876).

\section{Jegyzetek 24.}

Nagyobb összefüggő vízjárta terület csak a Hanság föcsatorna és a Rábca szabályozott medre között volt. Rábcakapi térségében a Rábcát még mindig szabályozatlan, nedves rétek kísérték. A korábbi gyepterületek jelentős részét szántották fel például Bősárkány, Acsalag határában. A Rábaközben is jelentősen lecsökkent a korábbi vizes területek aránya, a korábbi térképen még feltűnő, összefüggő északkelet-délnyugat irányú nedves rétek vonulata sokkal kevésbé markánsan jelenik meg: sok helyen teljesen elvékonyodik, felszakadozik a korábbi összefüggő, széles sáv. Kóny térségében jelentős kiterjedésű foltban maradt meg vizenyős terület. Egyed határában nyoma sincs a korábbi hatalmas kiterjedésủ ültetvényeknek, szántók váltották fel azokat. A korábbi kastélypark is csak nyomokban látszik. A Rábaköz középső részeit intenzív agrártérség foglalja el, Rábapordány, Egyed határában 170-200 hektáros egybefüggő szántóterületek is találhatók. Ha a statisztikai adatokhoz fordulunk, a XIX. század során tapasztaljuk a legnagyobb arányú területhasználat változásokat (függetlenül attól, hogy hansági, tóközi vagy egyéb rábaközi településről van szó) egyes településeken akár 1525\%-kal is nőtt a szántók aránya (Kóny (43\% » 58\%), Bezi, Tárnokréti (24\% » 42\%) Csorna (30\% »55\%), Zsebeház (75\% » 90\%), Dőr (53\% » 72\%)). (Magyarország müvelési ágak szerinti terjedelme és földjövedelme, Buda, 1865)

\section{Jegyzetek 25.}

Győrben az 1890-es években a Győri vagongyár, Magyaróváron a Kühne Mezőgazdasági Gépgyár nyílt meg, Sopronban a gyümölcs- és szőlőkultúra és kereskedelem indult fejlődésnek és kisebb üzemek telepedtek meg (Rétvári, 1977). A malomipar és vasútépítés kapcsolata (Pájer, http://www.hontar.hu/hely/pajer04.htm) 


\begin{tabular}{|l|c|c|}
\hline Malom & Malomalapítás & Vasútépítés \\
\hline Bősárkány (Tul.: özv. Némethné és Király Mihály) & 1892 & 1891 \\
\hline Csorna (Tul.: Frankl Sándor) & 1876 előtt & 1876 \\
\hline Csorna (Tul.: Király Mihály) & 1895 & 1876 \\
\hline Egyed & 1876 előtt & 1896 \\
\hline Kapuvár (Tul.: Mohl Gyula) & 1890 & 1876 \\
\hline Kapuvár (Tul.:Berg Gusztáv) & 1891 & 1876 \\
\hline Rábatamási (Tul.: Mesterházy és társai) & 1894 & 1876 \\
\hline Szany (Tul.: Király Mihály) & 1897 & 1896 \\
\hline Szil (Tul.: Szórády és társai) & 1892 & 1891 \\
\hline
\end{tabular}

\section{Jegyzetek 26.}

A földadókataszter döntően az adóztatás érdekében került bevezetésre. A mezö- és erdőgazdasági művelés alatt álló területek a befektetett munka árán tulajdonosuknak a talaj természeti és termelési adottságaitól függő jövedelmet biztosítanak. A tisztajövedelem az, ami a termény árából a termelési költségek levonása után a tulajdonos javára visszamarad. Minél nagyobb az elérhető tisztajövedelem, annál értékesebb, minél kisebb tisztajövedelem származik a termelésből, annál kevésbé értékes a terület. Az országot becslőjárásokra osztották, amelyen belül az eltérő adottságoknak megfelelően több osztályozási vidéket alakíthattak ki. Egy becslöjáráson belül az azonos müvelési ágú földeket a termelési-, a gazdasági- és az értékesítési viszonyok alapján minőségi osztályokba sorolták. A becslöjáráson (osztályozási vidéken) belül az azonos müvelési ágú földeket a termelési-, gazdasági tényezők és az értékesítési viszonyok figyelembevételével minősítették, ill. osztályba sorozták. Minden müvelési ágra vonatkozóan annyi minőségi osztályt vezettek be, amennyire az említett tényezők különbözősége miatt szükség volt. Egy művelési ágra legfeljebb nyolc osztályt lehetett megállapítani. http://www.agt.bme.hu/varga/ingatlan/jegyzet/jegyzet.htm\#katasz_tiszt

A Csornai-kistérség területét a Győri-, és a Kapuvári becslőjárásba osztották. Mindegyik becslőjárást több osztályozási vidékbe sorolták. A győri becslőjárás első osztályozási vidékének adóközségei: Bezi, Czakóháza, Fehértó, Győrsövényház, Kóny, Markotabödöge, Rábapatona, Rápczakapi, Tárnokréti (Észak-Hanság déli pereme és a Tóköz települései). A kapuvári becslőjárás második osztályozási vidékének adóközségei: Farád, Csorna, Jobaháza, Maglócza, Magyarkeresztúr, Potyond, Rábatamási, Sopronnémeti, Szilsárkány. Mindegyik vidék földjeit nyolc minőségi osztályba sorolták.

Győr és Sopron megye adóközségeinek területe és kataszteri tisztajövedelme mívelési áganként és osztályonként, 1914,

Budapest

\begin{tabular}{|c|c|c|c|c|c|c|c|c|c|c|c|c|c|c|c|c|}
\hline \multicolumn{9}{|c|}{ Győri becslő járás, 1. osztályozási v., Kataszteri tisztajövedelmi fokozat } & \multicolumn{8}{|c|}{$\begin{array}{c}\text { Győri becsló járás, 2. o., Kataszteri tisztajövedelmi } \\
\text { fokozat }\end{array}$} \\
\hline \multirow{3}{*}{$\begin{array}{l}\text { Múvelési } \\
\text { ág }\end{array}$} & 1. & 2. & 3. & 4. & 5. & 6. & 7. & 8. & 1. & 2. & 3. & 4. & 5. & 6. & 7. & 8. \\
\hline & \multicolumn{8}{|c|}{ osztály } & \multicolumn{8}{|c|}{ osztály } \\
\hline & \multicolumn{8}{|c|}{ fillér } & \multicolumn{8}{|c|}{ fillér } \\
\hline Szántó & 2500 & 2300 & 1700 & 1500 & 1050 & 700 & 420 & 180 & 1500 & 1050 & 800 & 660 & 480 & 260 & 0 & 0 \\
\hline Kert & 3100 & 2500 & 1300 & 0 & 0 & 0 & 0 & 0 & 1800 & 1500 & 0 & 0 & 0 & 0 & 0 & 0 \\
\hline Rét & 3000 & 2100 & 1700 & 1450 & 950 & 850 & 340 & 150 & 1950 & 1500 & 950 & 620 & 240 & 110 & 0 & 0 \\
\hline Szőlő & 1850 & 0 & 0 & 0 & 0 & 0 & 0 & 0 & 1450 & 0 & 0 & 0 & 0 & 0 & 0 & 0 \\
\hline Legelő & 1500 & 950 & 500 & 500 & 360 & 130 & 0 & 0 & 850 & 560 & 320 & 0 & 0 & 0 & 0 & 0 \\
\hline Nádas & 2300 & 1700 & 1350 & 1000 & 620 & 0 & 0 & 0 & 1700 & 1350 & 0 & 0 & 0 & 0 & 0 & 0 \\
\hline Erdő & 640 & 560 & 500 & 460 & 420 & 320 & 240 & 100 & 520 & 420 & 340 & 240 & 0 & 0 & 0 & 0 \\
\hline
\end{tabular}

\section{Jegyzetek 27.}

A falusi népesség rossz anyagi helyzetét és az agrár-túltelítettséget jelzi, hogy a csornai járásban 9 településen az egy lakosra jutó földterület nem haladta meg az egy hektárt az I. vgh. után (Rétvári, 1977) 


\section{Jegyzetek 28.}

8. táblázat: A hansági belvízcsatorna hálózat bövülése (Ihrig, 1973)

\begin{tabular}{|c|c|c|}
\hline $\mathbf{E} v$ & Kiépült csatornahossz, km & A vízelvezetés intenzitása \\
\hline $\mathbf{1 6 5 8}$ & 8 & - \\
\hline $\mathbf{1 7 9 9}$ & 9 & 0,5 \\
\hline $\mathbf{1 8 1 3}$ & 39,8 & 5 \\
\hline $\mathbf{1 8 3 4}$ & 55,8 & 6 \\
\hline $\mathbf{1 8 4 0}$ & 105,4 & 12 \\
\hline $\mathbf{1 8 9 1}$ & 153,4 & 41 \\
\hline $\mathbf{1 8 9 3}$ & 246 & 52 \\
\hline $\mathbf{1 9 0 0}$ & 346 & 56 \\
\hline $\mathbf{1 9 0 7}$ & 400 & 77,8 \\
\hline $\mathbf{1 9 1 4}$ & 600 & 82 \\
\hline $\mathbf{1 9 2 6}$ & 800 & 87 \\
\hline $\mathbf{1 9 3 2}$ & 1300 & 87 \\
\hline $\mathbf{1 9 4 1}$ & 1300 & 90 \\
\hline $\mathbf{1 9 4 2}$ & 1500 & 100 \\
\hline $\mathbf{1 9 4 7}$ & 1500 & 101 \\
\hline $\mathbf{1 9 5 6}$ & 1714 & 120 \\
\hline
\end{tabular}

\section{Jegyzetek 29.}

Nagy ívü tervek voltak a térség mezőgazdaságának felfuttatására, tervezték a termesztett növények körének kiszélesítését gyógy- és vegyipari növények termesztésével, amelyek ,,annyira kedvelik a láptalajt” (a borsmenta, és a gyűszűvirág), hogy az „országos átlag ötszöröse is elérhető termésátlagként”. 1955-ben Győr-Moson-Sopron megye egész területét városellátó övezetté nyilvánították (Sárközi, 1968). 


\section{TÁJÉPÍTÉSZETI CÉLKITÜZÉSEK TELJESÜLÉSE A CSORNAI KISTÉRSÉGBEN}

\section{MEZŐGAZDASÁGI TERMESZTÉS}

\section{— Táji adottságoknak megfelelö mezögazdasági termelés (domborzat, talajtípusok, vízkészlet stb.)}

Javaslat: átgondolt, racionális módon csökkenteni a szántók arányát, az alacsonyabban fekvö, közepes minöségü szántóterületeken rétek, legelök visszaállítása, erdösítés javasolt

Indoklás: Bár a Rábaközben kiválóak az adottságok a mezőgazdasági termesztésre, a szántóművelésű területek mintegy harmada gyengébb, közepes minőségűnek tekinthető, továbbá a belvizes területek okoznak terméskiesést. A történeti elemzés alapján láthattuk, hogy legelőször a magasabban fekvő jó talajadottságú rábaközi falvakban indult meg a termesztés és a vízrendezések térhódításával terjedt ki az intenzív gazdálkodás a tóközi és a hanságmenti falvakra. Jellemzően az alacsonyabban fekvő, kedvezőtlenebb talajadottságú, vizes területeket rétként, legelőként hasznosították évszázadokon át. A XIX. század végén, a XX. század első felében azonban a réteket, legelőket feltörték és egyre inkább szántóként hasznosították. A szocialista nagyüzemi gazdálkodásra volt jellemző, hogy a müvelésre kevésbé alkalmas szántókat kivonták a mủvelésből és erdősítették. A rendszerváltás után, még az elmúlt évtizedben is folytatódott azonban a gyep-szántó konverzió, ami a belvizes szántó területek arányának növekedéséhez vezetett. A falugazdászok tájékoztatása szerint mintegy 5-10\% a belvíz által sújtott múvelt területek aránya.

— Multifunkcionális gazdálkodásra törekvés, változatos agrár-termékszerkezet (teriülethasználati rendszer) kialakítása/Megfelelö jövedelemszint biztosítása a gazdálkodás révén, az adottságoknak megfelelö magas hozzáadott értéket biztositó gazdálkodás (bio-, ökológiai gazdálkodás, egyedi, tájtermékek)

Javaslat: az intenzív zöldség-, gyümölcstermesztés, ökológiai gazdálkodás arányának növelése, a gazdálkodók több lábon állásának támogatása/ösztönzése.

Indoklás: A térségben a kedvező táji adottságok, a kitűnő munkakultúra ellenére alacsony az intenzív zöldség-, gyümölcstermesztés, az ökológiai gazdálkodás aránya. Gyakorlatilag nincsenek egyedi termékek, tájtermékek. Jelenleg a kistérségben megtermelt élelmiszeripari alapanyagok feldolgozottsága alacsony, a kistérség döntően más kistérségek számára állít elő nyersanyagot. A gazdálkodók közötti együttmüködési rendszerek, kapcsolatok fejlesztésével javítani kell a piacra kerülő termékek feldolgozottságának fokát, minőségét. Jelentősen növekedne az ágazat jövedelemtermelő képessége, ha az itt előállított termékeket itt dolgoznák fel, ehhez azonban növelni kell a feldolgozottság szintjét, bővíteni a tárolókapacitásokat, új feldolgozóüzemeket kell létesíteni.

A mezőgazdasági tevékenységgel foglalkozó egyéni vállalkozások nagyon kis arányban végeznek kiegészítő tevékenységet. A kiegészítő tevékenységek ${ }^{35}$ közül a fuvarozás és a kereskedelem a legelterjedtebb az egyéni vállalkozások között, nagyon kis számban foglalkoznak vendégfogadással, kézművességgel valamint hús- és

\footnotetext{
${ }^{35}$ (Egyéb élelmiszerip.(település),Egyéb tevékenység(település), Fafeldolgozás(település), Fuvarozás(település), Gyümölcs, zöldség(település), Halászat(település), Húsfeldolgozás(település), Kereskedelem(település), Kézmüvesség(település), Megújuló energiaf.(település), Takarmánykeverés(település), Tejfeldolgozás(település), Vendégfogadás(település) Forrás: ÁMÖ 2000
} 
tejfeldolgozással. A kiegészítő tevékenységet folytató vállalkozások száma alapján az átlagnál magasabb értékkel rendelkezik Kóny, Bogyoszló, Bősárkány, Szany és a magas lakosságszám miatt nem meglepő módon Csorna. A települések csaknem felében (15) az egyéni vállalkozók nem folytatnak egyéb tevékenységet.

- A természetvédelem és a gazdálkodás összehangolása, kompenzáció biztositása a korlátozások ellenében

Javaslat: az agrár-környezetvédelmi pályázatok feltételrendszerének a gazdálkodók igényei szerinti átalakítása.

Elsősorban a Nemzeti Park területeinek közelében valamint a Rábaközi Natura 2000 területeken és térségében a gazdálkodók és a gazdálkodó szervezetek minél nagyobb arányban vegyenek részt a Nemzeti AgrárKörnyezetvédelmi Programban. A részvétel egyrészt a támogatások miatt növeli a gazdálkodók bevételeit, másrészt a környezetvédelmi szempontok elötérbe kerülése javítja a környezetállapotokat. Az ösztönzésben nagy a jelentösége a falugazdász hálózatnak.

Indoklás: A Hanság és a Rábaköz térségében a Natura 2000 területeket elsősorban rétek, legelők alkotják, így az állattenyésztés alacsony jövedelmezősége megnehezíti a gazdálkodók helyzetét, éppen ezért szükségük van az agrár-környezetvédelmi támogatási formák nyújtotta kifizetésekre. Annak ellenére, hogy a Hanság és a Tóköz MTÉT terület (kiemelt környezetvédelmi érték, kiemelt szempont a gazdák kompenzációja), a gazdálkodók töredéke vesz részt a programban.

\section{ERDŐGAZDÁLKODÁS}

— Öshonos erdöállományok telepítése, fenntartása

— Adottságoknak megfelelö helyü, fajösszetételü erdöállományok létrehozása (alacsonyan fekvö, belvízveszélyes terïleteken erdö vagy esetleg gyep elönyben részesítése)

— Legalább 3\%-os erdősültség kívánatos települési szinten, mikrotérségi szinten 10\%

Javaslat: A környezeti szempontból érzékeny területeken, elsősorban a védett területek közelében, továbbá a belvízzel fenyegetett területeken erdösités vagy rétek, legelök létesitése (nem a Natura 2000 területek).

A kedvezö talajadottságok ellenére ökológiai, élőhely-, és talajvédelmi szempontból is célszerü a nagykiterjedésü szántóföldek erdösávokkal történő megszakitása. Ezeken a síkvidéki, intenzív müvelésü térségeken egyetlen tájképi változatosságot a területhasználatok változatossága (erdö-szántó-gyep mozaikosság) jelent. Fontosnak tartom az erdöterületek növelését különösen azokon a településeken, ahol az erdöterületek aránya nem éri el a 3\%-ot (Dél-Rábaköz). A Rábaközben el kellene érni a 10\% erdösültséget (Csorna nélkül a rábaközi falvakban $7,7 \%$ )

Indoklás: Védett területeken a természetvédelmi hatóság előírásait alapján csak honos fajok telepíthetők. Újabb telepítés általában magántulajdonú területeken történik, a tulajdonosok kedvező tendenciaként a szántóföldi termesztésre kevésbé alkalmas gyenge termőhelyü területeken, esetleg alacsonyfekvésủ, gyakran vizes területeken választják az erdősítést. Elsősorban a gyors növekedés miatt akácot és nemes nyárt telepítenek, de az említett fajok ezeken a termőhelyeken gyenge növekedésủek (a tájökológiai problémák mellett), tehát gazdasági szempontból is honos fajokat kell alkalmazni. 
A Hanság védett területein az alacsony termőrétegü láptalajokon a szocializmus alatt telepített nemes nyaras állományok nem tudnak megfelelően fejlődni, ennek ellenére az erdőtörvény előírásai alapján az erdőt fenn kell tartani.

\section{BÁNYÁSZAT}

\section{— Degradált területek térségi szinten összehangolt rehabilitációja}

Javaslat: Javaslom a bányatavak elsősorban rekreációs célú utóhasznosítását a kistérségi adottságok figyelembevételével

Indoklás: A kistérségben számos felhagyott bányató található. Kavicsbánya-tavak fürdőzésre csak abban az esetben használhatók, ha még a kitermelés során kialakítanak lankás partszakaszokat, valamint egyenletesen lejtő sekélyvizű zóna (vízmélység $\leq 1,8$ m) kialakítása (a ma még működő bányáknál célszerü lenne). Hasonlóan kell eljárni, ha egyéb vízisportolási lehetőségeket is terveznek a tavon (Kincses, Csima, 1998). A már felhagyott bányatavak esetében sajnos általában nem gondoskodtak a balesetmentes fürdőzés feltételeiről így ezek elsősorban horgászat, és egyéb rekreációs lehetőségek céljaira hasznosíthatók. Több felhagyott kavicsbányató jelenleg is horgásztóként hasznosul, ezek minőségi fejlesztése (környezetrendezés, növénytelepítés, sétautak kialakítása, csónakkikötők, stégek építése) indokolt. Érdemes kistérségi szinten összehangolni a kavicsbánya-tavak rekultivációját (felhagyott kavicsbánya-tavak: Szilsárkány, Szil, Sopronnémeti, Rábatamási, Rábapordány, Páli, Magyarkeresztúr, Jobaháza, Farád, Magyarkeresztúr).

— Új bányák nyitása az ökológiai és a felszín alatti vízkészletek védelme szempontjából kevésbé érzékeny/értékes területeken indokolt

Új bányák nyitásakor több szempontot is át kell gondolni:

— a tájökológiai szempontokat mérlegelni kell: az ökológiai szempontból kevésbé érzékeny/értékes területeken indokolt (Dél-Rábaköz), az utóhasznosítás ésszerủ megtervezésével (célszerü pl. fürdőzésre alkalmas, vagy egyéb rekreációs lehetőséget biztosító utóhasznosítási formának alkalmas bányatavat kialakítani).

— részletes vizsgálatok szükségesek annak feltárásához, hogy a felszín alatti vízkészleteket mennyiben veszélyeztethetik a bányanyitások.

A Rábaköz és a Rába völgyének felszín alatti vízkészletei a megye távlati ivóvízbázisát jelenthetik, ezért új bányák nyitása nem javasolható. A bányászattal kialakuló bányatavak a talaj és rétegvizek szennyező forrásaivá válhatnak.

\section{IPAR}

\section{— Terület-takarékos, szüikséges méretü ipari terïletek kialakítása}

Csornán két ipari/gazdasági övezetet alakítottak ki, amelyeken korábban is koncentrálódtak a gazdasági tevékenységek. A déli iparterület 2004-ben ipari park címet kapott, a területnek nem egészen felén telepedtek meg vállalkozások. A gazdasági övezetetekben mára elkeltek az önkormányzati tulajdonú telkek, így a városvezetésnek jelentősen csökkent a befolyása a vállalkozások letelepedésének ösztönzésére. Az ipari park és a keleti gazdasági övezet alulhasznosítottnak tekinthető.

— Negatív hatások minimalizálása, ipari parkok zöldfelület-rendszerének fejlesztése, védöfásítás, Iparterületek védöövezetének kijelölése 
Az iparterületek zöldfelület-rendszerének fejlesztésével, védőfásítással, jelentős környezetterheléssel járó üzemek letelepedésének adminisztratív eszközökkel történő szabályozásával, korlátozásával csökkenteni kell a lakóterületek terhelését (a kistérségben elsősorban Csorna és a jelentősebb ipari/gazdasági területtel rendelkező községek Szany, Szil, Kóny, Bősárkány).

\section{- Helyi eröforrásokra épüiő feldolgozó ipar fejlesztése}

Javaslat: A helyi eröforrások alapján legkedvezöbbnek az élelmiszeripari-, a mezögazdasági termék feldolgozás fejlesztését tartom, amelyek legkedvezöbb helyszíne a kistérségi és mikro-térségi központok.

— Felhagyott ipari területek, telephelyek felszámolása, rehabilitációja, a funkcióváltás ösztönzése

Javaslat: ösztönözni kell a barnamezös területek (volt gyárépületek, mezögazdasági majorok) funkcióváltását, a zöldmezös beruházások engedélyezése elött.

Az ipari hagyományok hiánya miatt csak kisebb barnamezős területek találhatók a kistérségben, elsősorban Csornán. Megszűnt a Richards Finomposztógyár, a Mofém, amelynek üzemcsarnokai még mindig üresen állnak az ipari park területén. Az ipari park zöldmezős területeinek beépítése előtt fontos lenne a barnamezős területek hasznosítása.

A kistelepüléseken problémát a volt TSZ majorokhoz kapcsolódó telephelyek kihasználatlansága okoz. E korábbi telephelyek funkcióváltása részben zajlott le, ma ezek a területek, épületállomány gyakran túl nagynak bizonyul.

\section{KÖZLEKEDÉS}

\section{— Piacok, munkahelyek, közszolgáltatások elérésének biztositása}

\section{— Gazdasági tevékenységekhez szükséges mértékü, hatékony infrastruktúra hálózat kialakítása}

Javaslat: a kedvezötlenebb elérhetöségi viszonyokkal rendelkezö településeken alternatív közlekedési módok támogatása, hiányzó közúti kapcsolatok kiépítése.

Indoklás: A kistérség településeinek elérhetőségi viszonyai nagy szórást mutatnak: kiváló elérhetőségi mutatókkal rendelkeznek a föutak (85-86. sz.) menti települések, viszonylag kedvező helyzetben vannak a kistérségi központ és egyben a megyeközpont jó megközelíthetősége révén a tóközi települések. Kedvezőtlen helyzetben vannak ugyanakkor a dél-rábaközi falvak, különösen Rábasebes, Vág, amelyek elérhetőségének javítása népességmegtartó képességüknek egy fontos eleme: a kistérségi központ mellett javítani kell kapcsolataikat a szomszédos kistérséggel (hiszen peremhelyzetűek a Csornai-kistérségben), foglalkoztatási központokkal.

\section{— Környezetbarát közlekedési módok előnyben részesítése}

Javaslat: a vasúti szolgáltatások színvonalának fejlesztése szükséges a vasúti kapacitások növelésére. Különösen a teherforgalom vasútra terelése lenne fontos környezeti szempontból, kedvezö hatású lenne a Csornán kijelölt keleti iparterülethez tervezett ipari vágány kiépítése.

Indoklás: Az elmúlt évtizedekben jelentős forgalom terelődött a vasútról a közutakra, komoly terhelést okozva a településeknek. Jelentős teher- és személyforgalmat bonyolít a Győr-Sopron-Ebenfurti Vasútvonal, tervezik második vágány építését. Két vágány kialakítása és a villamosítás is megoldandó feladat a kisebb forgalmat bonyolító Rajka-Porpác vonalon. A Pápa-Csorna vasútvonalat 2007-2010 között szüneteltették, jelenleg napi két járat közlekedik, sajnos a munkába járás szempontjából nem kedvező időpontokban. 
A kerékpárutak kiépítettségének színvonala megyei viszonylatban alacsony, a kerékpáros közlekedés fejlesztése nemcsak ökoturisztikai célból lenne kedvező, hanem mert több településen halad keresztül nagy forgalmú fơút.

Javaslat: mind turisztikai, mind a napi forgalom megkönnyítése érdekében (Pl. Csornán a kelet-nyugati irányú kerékpáros közlekedés) kerékpárutak fejlesztése, kijelölése a települések belterületén és a települések között, továbbá a természeti értékek felkeresésének megkönnyitése érdekében (nincs közvetlen kerékpárút Csorna belterülete és a közigazgatásilag a városhoz tartozó Hany Istók tanösvény között).

\section{- Negatív hatások minimalizálása}

A 85. és 86. sz. főutak jelenlegi kiépítettségüket meghaladó mértékủ forgalmat bonyolítanak. A nagy forgalmú főutak fejlesztése, a településeket elkerülő szakaszainak megépítése sürgető feladat. Az OTrT és a megyei terv a 85. sz. főút gyorsforgalmúvá fejlesztését Csorna-Győr között a meglévő nyomvonalon, települések elkerülésével, Csorna-Sopron szakaszon, új nyomvonalon, a 86. sz. foút fejlesztését új nyomvonalon irányozza elő. Az úthálózat döntően elkerüli a természetvédelmi területeket. Kivétel a Barbacsi-tó fokozottan védett terület, amely a 85. sz. főút közelében és a tervezett gyorsforgalmú út közelében (a nyomvonal azonos) helyezkedik el, az élőhelyvédelmet biztosítani kell. A Nyirkai-Hany élőhelyrehabilitációs területtől a kiépítendő gyorsforgalmi 86. sz. út a jelenlegi nyomvonaltól keletre, tehát a védett területtől távolabb épül majd meg.

\section{KÖRNYEZETI INTEGRITÁS}

\section{- A környezeti szempontból érzékeny területeken az extenzív gazdálkodási módok elönyben részesítése}

Az ökológiai szempontból értékes területek a nemzeti park területek, a Magas Természeti Értékủ Területek, amelyek lefedik a kistérség északi, észak-keleti részét, mintegy harmaduk Natura 2000 terület (Rábcakapi, Cakóháza, Markotabödöge, Rábatamási, Csorna, Bősárkány, Maglóca, Barbacs, Dőr, Kóny, Bágyogszovát, Tárnokréti, Fehértó).

Javaslat: Az emlitett területeken extenzív vagy környezeti szempontból kevésbé terhelö gazdálkodási módokat kell elönyben részesíteni. Az MTÉT területeken gazdálkodók a védelmi korlátozások betartásához támogatást igényelhetnek. Ösztönözni kell a gazdálkodók részvételét az MTÉT, AKP programokban.

\section{— Terhelések szintjének minimalizálása}

A szennyvízkezelés környezetbarát megoldása a kistérségben még nem megoldott.

Javaslat: A szennyvíztisztítás helyzetének rendezése, a nem csatornázott települések szennyvízhálózatának kiépítése, az összegyüjtött szennyvíz tisztítása (akár alternatív módszerekkel költségtakarékosabb lehet, hiszen aprófalvakról van szó).

\section{- Környezetbarát mezögazdasági gyakorlat}

A mütrágyahasználat jelentősen visszaesett a rendszerváltás óta. Jelentős szennyezések nem fordulnak elő. Konfliktusok forrása lehet a hígtrágya elhelyezési módja.

Javaslat: Javaslom a rendszerváltás óta felére visszaesett állatlétszám növelését a környezetbarát mezögazdasági gyakorlat érdekében is (szervestrágyázás). 
- Fenntartható térségi vízgazdálkodás alapvetö irányelvei: vízminöség védelme, víztöbblet elleni védekezés, vízhiány elkeriulése érdekében víztárolás, vízvisszatartás

Az ökológiai rendszerek hosszú távú fenntartható müködése érdekében (és Európai Uniós kötelezettségeink lásd Víz Keretirányelv) több vízgazdálkodási problémát kell kezelni országosan és a Rábaközben egyaránt. A felszíni vizek (Rábca, Keszeg-ér stb.) vízminősége nem kielégítő a Kisalföldön.

Javaslat: Fontos feladat a befolyó vizek minőségének javítása (szürőrendszer kialakítása), a kistelepülések szennyvízkezelésének megoldása, a vízfolyások kotrása (FHNP fejlesztési terv 2009-2014). A vízminöségi problémákon túl a klímaváltozáshoz kapcsolódóan elengedhetetlen, hogy nagyobb figyelmet szenteljünk a vízvisszatartásnak (Somlyódy, 2012, Leidinger 2012), amely a Nemzeti Park területén az élőhely-rekonstrukciós programok folytatásával, a Rábaközben a vízfolyások mentén a gyakran belvizes területek, vizes élöhelyek visszaalakításával lehetséges (Keszeg-ér, Linkó-ér, Kölesmajor-Kepési csatorna és egyéb kisvízfolyások, csatornák menti belvizes területeken vizes élőhelyek, nedves rétek visszaállítása).

\section{LAKÓTERÜLETEK}

— Társadalmi igények kielégítése és az építészeti hagyományok védelme szempontjainak harmonizálása

Javaslat: A települések hagyományos építészeti karakterét örzö épületek felújításának, megörzésének ösztönzésére javasolt a helyi önkormányzatok támogatása (egyedi ösztönzö-rendszerek kidolgozása pályázatok vagy egyéb adminisztratív intézkedések útján).

Indoklás: A Rábaközben egy jellegzetes homlokzat alakult ki, s az épület udvar felőli oldalán pedig megjelent a tornác, amely évszázadokon keresztül a paraszti épületek jellemzője lett. A rábaközi és a hansági falvakban viszonylag sok, a népi építészetet idéző ház maradt fenn, amelyeket azonban veszélyeztet a demográfiai fogyás. Különösen szép az utcakép Bogyoszlón (lásd kép és a mellékletben a Táj-érték leltár),

— Kompakt, terület-takarékos településfejlesztés, az újonnan épült településrészek illeszkedjenek a hagyományos településkarakterhez

Javaslat: Az újonnan létesülö településrészek szabályozásában jelenjenek meg a hagyományos településkép fenntartásához nélkülözhetetlen elemek (épületmagasság, alkalmazott anyagok, színek stb.)

Indoklás: A szuburbanizációs folyamatok által érintett falvakban (különösen a tóközi falvak, és a fő forgalmi utak mentén elhelyezkedő települések) jelentős építkezési hullám volt megfigyelhető a rendszerváltás óta, karakterükben az új lakóépületek gyakran sajnos nem illeszkednek a hagyományos településképhez.

— Színvonalas települési környezet biztosítása a zöldfelület-rendszer fejlesztésével, aprófalvaknak is legyen közparkja/közkertje, templomkertek közösségi térré alakítása

— Ökológiai hálózat és települési zöldfelület-rendszer kapcsolata, zöld településszegély kialakítása

Javaslat: Községekben és városokban egyaránt komoly figyelmet kellene szentelni a zöldfelület-rendszer fejlesztésének, hiszen a közkertek, parkok a helyi társadalom találkozásának fontos színterei. Ki- 
emelten kell kezelni különösen aprófalvak esetén a templom körüli zöldfelületeket és a temetöt. Alapvetö elvárásnak tarto, hogy aprófalvakban is legyenek közösségi célú zöldfelületek.

Indoklás: Az életminőséget meghatározza a települési zöldfelület-rendszer minősége. Kisebb településeken gyakran nem fordítanak kellő figyelmet közösségi zöldterületek kialakítására, fenntartására, pedig a közösségformálásában nagy szerepük van. A vizsgált térség kistelepüléseinek jelentős részében nincs zöldterület.

Az aprófalvak nem bővelkednek közcélú zöldfelületekben, többségükben a templomok környezetében elhelyezkedő zöldfelületeknek meghatározó szerepe van a településképben. A fennmaradt paraszti porták mellett gyakran az aprófalvak egyetlen kiemelkedő építészeti értéke a templom, amelynek környezete (van-e templomkert, az mekkora vagy mennyire nyitott) a település zöldfelületrendszerében meghatározó lehet. A falvak többségében változó színvonallal jellemző, hogy zöldfelület veszi körül a templomot. A településkép javításához jelentősen hozzájárulna, ha a templomok körül színvonalas közkerteket alakítanának ki.

A másik lényeges, különleges szerepü közösségi zöldterület a falvak életében a temető, amely általában a település egyik kiemelkedő helyét foglalja el. A temető rendezettsége sokat elárul a község lakóiról. A temetők rendezésénél alapvető elvárás a temető körülkerítése és fasor telepítése.

\section{ÉLÖHELY ÉRTÉK}

- Biotópok védelme, Természetvédelmi területek (természetvédelmi, Natura 2000, Nemzeti Ökológiai Hálózat elemei) legalább 5\%-os aránya

A Dél-Hanság és Tóköz települései döntően az országos átlag feletti védettségi arányokkal rendelkeznek a megmaradt vizes élőhelyeknek köszönhetően, azonban a Rábaköz intenzív agrártérségének több településén túlzottan alacsony az élőhelyvédelmi szempontból értékesnek tekinthető területek aránya (Zsebeháza; Rábapordány, Rábacsanak, Magyarkeresztúr).

Javaslat: $\quad$ Ezeken a településeken törekedni kell mezővédö erdösávok, gyepes területek kialakítására, területarányuk növelésére.

\section{— Extenzív hasznositású terïletek legalább 10-15\%-os arányának elérése}

Javaslat: a dél-Rábaközben növelni kell az extenzív területhasználatok arányát.

Hasonló eredményt ad a térségben az extenzív hasznosítású területek arányának vizsgálata. Fontos élőhelyeket jelentenek az erdők, gyepek, extenzív gyümölcsösök, mocsaras területek, mezővédő erdősávok stb. A Corine 2006-os adatbázisa ad lehetőséget a területhasználatok értékelésére. Kimagaslóan magas az extenzív hasznosítású területek aránya a Hanság peremterületein, egyes tóközi településeken (Fehértó 38\%, Barbacs $41 \%$ ), azonban kritikusan alacsony a dél-rábaközi térségben.

\section{— Mozaikjellegü tájszerkezet fenntartása}

Ahogy az eddigi értékelések feltárták tájképi, és tájökológiai szempontból is kedvezőtlenebb helyzetủek a rábaközi települések, sajnos különösen ebben a térségben folytatódott a rendszerváltás óta a gyepek feltörése. Jelentős gyepterületek tüntek el Csorna belterületétől délre, Vág, Rábasebes, Szilsárkány, Rábacsanak, Rábaszentandrás, Rábapordány településeken. Ezek a folyamatok egyértelműen az agrártáj további szegénye- 
déséhez járulnak hozzá. Ezek a müvelésbe vont területek általában rosszabb minőségü (ezért maradtak mindezidáig is gyepek), illetve belvízveszélyes területek. Ellenkező irányú folyamatra alig akad példa (Acsalag).

\section{— Ökológiai hálózatok védelme és fejlesztése,}

\section{— Gyepterületek védelme, arányuk növelése}

A Nemzeti Park és a Natura 2000 területek védelme a szigorú szabályozás miatt biztosított, az egyéb döntően a dél-rábaközi térségben a gyepfeltörés és ez által az ökológiai hálózat leromlása ma is folytatódik.

Javaslat: Belvízveszélyes területek visszagyepesitése.

— Erdösültség minimális szintjének biztositása települési szinten 3\%, mikro-térségi szinten legalább (10\%)

— Mezögazdasági területek élóhelyeinek védelme, természetszerü lineáris elemek: fasorok, erdösávok fenntartása

A jó minőségủ szántó területeknek köszönhetően nem várható jelentősebb erdősítés a Rábaközben, azonban a nagyon alacsony erdősültségi mutatókkal rendelkező térségben elsősorban a mezővédő erdősávok, cserjesávok, fasorok arányát kellene növelni, amely viszonylag kisebb területkivonást jelent a müvelésből továbbá a kedvező tájökológiai hatásai miatt a terméskiesést minimálisra csökkenti.

Javaslat: A rendszeresen belvízjárta területek müvelésből kivonása erdösitése vagy rétté, legelövé alakitása ajánlott.

\section{— Vizfolyások mentén 5-10 m fás szárú növényzettel is rendelkezö szegély müvelésmentes fenntartása}

Elsősorban az intenzív hasznosítású agrártérségben a vízfolyások mentén maradtak meg kisebb nagyobb élőhelyek, tájökológiai szempontból nagy jelentőségű maradványterületek. A Rábaköz jelentősebb vízfolyásai a Keszeg-ér és Linkó-ér mentén jellemzően 1-2 m természetes lágyszárú vegetációval kísért szegély található, cserjés fás, vegetáció rövid szakaszokon fordul elő.

Javaslat: A patakok, a sürü belvízlevezetö csatornahálózat mentén is ajánlott szélesebb „zöld védösáv"kialakítása, fenntartása.

\section{— Vizes élöhelyek védelme, helyreállitása}

Az intenzív tájhasználat révén visszaszorul a térség gazdag vízvilága. A nemzeti park területén nagyszabású élőhely-rehabilitációs, visszaárasztásos tevékenységek indultak (Nyirkai-Hany, előkészítés alatt Osli-Hany).

Javaslat: A kistérség más területein is, különösen a gyakran belvizes, vízfolyások menti területeken szükséges lenne a vizes élöhelyek legalább részleges helyreállitása, gazdagítva a térség ökológiai értékét, különösen a rábaközi agrártájban jelentösebb zöldfolyosó kialakításával a Keszeg-ér, a Linkó-ér mentén.

— Táj esztétikai értékének megőrzése és fejlesztése, Tájkarakter védelme, Agrártájak monotonitásának csökkentése (erdősávok, kisebb táblaméretek, patakok, csatornák kísérőnövényzete stb.)

Az egykori mocsárvilág maradványai, a mozaikos művelésủ peremterületek és tóközi települések jelentős esztétikai értékkel rendelkeznek. A Rábaköz egyéb területein, különösen a nagytáblás müvelésủ monoton agrártérségekben viszont oldani kellene a hatalmas szántók monotonitását. 
Javaslat: A tájképet gazdagító megmaradt természetes, természetszerü élőhelyek védelme a természetvédelmi területek keretein belül a pénzügyi lehetöségekhez mérten biztositott. Sokkal komolyabb figyelmet kell fordítani a nem védett területeken található gyepterületekre, ahol tudatformálással, ösztönzö programokkal (agrár-környezetvédelem) lehet elérni, hogy a gazdálkodás mellett is fennmaradjanak az ökológiai értékek illetve a gazdálkodók növeljék a gyepterületek, erdösávok, természetszerü élöhelyek arányát. Az ökológiai értéket növelö intézkedések szorosan kötödnek a tájképi érték-növelö intézkedésekhez.

\section{— Térség identitásának részét képezõ értékek számbavétele, védelme, bemutatása}

Javaslat: a táj történeti értékeinek védelme, bemutatása a lakosság számára

Kiállitások, tanösvények formájában javaslom felhívni a figyelmet a Hanság és a Tóköz lecsapolás elötti történetére, a tájalakítás módjára, a történeti tájhasznosítás emlékeire.

A tóközi tógazdálkodás csatornarendszere nagyon jó állapotban örződött meg a védett területeken (Fehértó, Györsövényháza), ezek szabályozott bemutatása, információk megosztása a lakossággal jelentösen hozzájárulna a táji identitás fejlödéséhez és turisztikai vonzeröt is jelentene.

Kistérségi szinten (mind a többcélú területfejlesztési társulás, mind a Leader közösség részéről) az elmúlt évben kezdődött a helyi értékek feltérképezése, számbavétele, elkészülttek a települési kataszterek.

A kulturális örökség veszélyeztetett, máig pusztuló részét képezik a felhagyott kastélyépületek, kúriák.

Javaslat: Kistérségi szintü összefogással keresni kell az elhagyott, értékes kastélyépületek hasznositásának lehetőségeit. Funkcióként sokféle hasznosítási forma számba jöhet: szálló, vadász-szálló, kulturális központ, szociális otthon stb. Létre kellene hozni egy kúria-katasztert, amely on-line elérhetö, napra kész információkkal szolgál az érdeklödőknek. Egy-egy település nem tudja felvállalni a kastélyépületek önálló hasznositását, fenntartását kistérségi összefogásra van szükség.

Népi építészeti emlékek fennmaradása is veszélyeztetett. Helyi védelem alá kell helyezni a hagyományos népi építészet emlékeit idéző parasztházakat, helyreállításukat támogatni kell. A helyi identitást erősítenék a térség különleges tájtörténeti hagyományai, emlékei.

Javaslat: Sokkal nagyobb hangsúlyt kell fektetni a tájtörténet felelevenitésére, a megmaradt emlékek, mondák bemutatására, népszerüsitésére. A kora-középkori tógazdálkodás bemutatása egyedi szabadtéri kiállitás témája lehetne a Fehér-tó természetvédelmi területen.

\section{— Helyi örökséget bemutató közösségi terek kialakítása}

Javaslat: Minden településen legyen elérhető információ, tájékoztató a település értékeiröl, rendezzenek be egy szobát, kiállitó helyiséget a közösségi házban, vagy önkormányzatnál. A természeti értékek bemutatására hozzanak létre tanösvényeket stb.

— Társadalom igényeinek kielégítése: pihenés, kikapcsolódás, sportolási és egyéb szabadidős tevékenységek lehetöségének biztositása térségi szinten

A helyi hagyományok, lehetőségek fejlesztésére kell elsősorban a hangsúlyt fektetni. 
Javaslat: fejleszteni kell a vízi sportolás lehetöségeit: Rába kikötőhelyek, fürdözés lehetöségeinek, megteremtése; Szávizi Vizi centrum fejlesztése, Csornai termálfürdö fejlesztése, bányatavak környezetének rendezése stb.

A térség, különösen a Hanság, Hanságmente és Tóköz térségének kevésbé forgalmas útjai kiválóan alkalmasak rekreációs célú kerékpározásra. Kerékpárutak fejlesztése, kijelölése, pihenöhelyek létesítése jelentösen javítaná a térségben az ökoturizmus és falusi turizmus vonzerejét. Több településen erösek maradtak a lótartás hagyományai. Lovas-turisztikai szolgáltatások fejlesztése: lovas udvar kialakítása és eszközök beszerzése pl. kocsi, szán, fedett lovardák kialakításának támogatása, lovas túra útvonalak kialakítása a Rábaközben.

\section{— Vizfelületek, erdök és egyéb természeti területek megközelíthetőségének biztosítása}

- Tanulás és felfedezés helye legyen a táj: látogatóközpontok, tanösvények, tematikus utak, zöld utak kialakítása, fejlesztése javasolt.

A helyi identitást erősítenék a térség különleges tájtörténeti hagyományai, emlékei.

Javaslat: Sokkal nagyobb hangsúlyt kellene fektetni a tájtörténet felelevenítésére, a megmaradt emlékek, mondák bemutatására, népszerüsitésére. A kora-középkori tógazdálkodás bemutatása egyedi szabadtéri kiállítás témája lehetne a Fehér-tó természetvédelmi területen.

Javaslat: Hanság-Rábaköz zöldút létrehozása

Indoklás: Az elmúlt évtizedekben népszerüvé vált zöldút-program megvalósítását javaslom a térségben, mert a természeti, kulturális értékek megőrzésén, védelmén, közösségi összefogáson alapulva egyaránt szolgálja a térség turisztikai vonzerejének növelését, és a helyi lakosság rekreációs lehetőségeinek bővülésé és, erősíti a helyi identitást. A természeti értékek önmagukban nem szolgálhatnak a zöldút alapjául, hiszen a térségben bár magas a védett területek aránya, nagyon nagy arányban találhatók fokozottan védett területek, így csak a kulturális vonzerők tudják érdemben differenciálni a településeket, amelyek azonban jelenlegi formájukban még nem rendelkeznek regionális mértékü vonzerővel. Ahhoz, hogy egy zöldút rendszer kialakulhasson, jelentős összefogásra van szükség a térségben, a több helyen elindult kezdeményezések (lovas turizmus, kerékpáros turizmus, tematikus fesztiválok) összehangolására, illetve a térségben még élő, de lassan eltűnő hagyományok, mesterségek, népszokások megőrzésére „,attrakcióvá” fejlesztésére.

- Természetvédelmi érdekek és a rekreációs igények összehangolása a természetvédelmi területek zónarendszerének kialakitásával, kevésbé érzékeny területek a nyilvánosság számára megközelíthetővé, elérhetővé tétele

A térség természeti értékekben gazdag ugyan, de a fokozottan védett területek magas aránya miatt, a védett területek jelentős része nem látogatható. A térségi identitás, a fejleszteni kívánt turisztikai hasznosítás miatt szükséges lenne a természetvédelmi területek ,megnyitása”, programok keretében történő bemutatása a helyi lakosság és az odalátogatók számára. Az utóbbi években megfigyelhető a Nemzeti Park nyitottabb hozzáállása, de a hansági térség periférikusabb helyzetben van a Nemzeti Parkon belül. Az egykori vizes élőhelyek újjáélesztése nagyon fontos lépés a térség jövőképének formálásában. Ennek a célnak a megvalósítása során mérföldkövet jelentett a Bősárkány közelében lévő Nyirkai-Hany 2001-ben történt rehabilitációja, melynek 
során 400 ha került elárasztásra. Az elárasztott terület szabadon látogatható, bár egyszerre csak korlátozott számban fogadhatja látogatókat, amit a gyakorlatban a viszonylag nehéz megközelíthetőséggel valósítanak meg a gyakorlatban. Tervezik, illetve folyamatban van Osli térségében egy még nagyobb léptékü visszaárasztás. Nagyon fontosnak tartom, hogy az új élőhelyeknek legalább egy része látogatható legyen, az információkat pedig táblák és tanösvények segítségével osszák meg a turistákkal és a helyi lakosokkal. 


\section{MELLÉKLETEK}




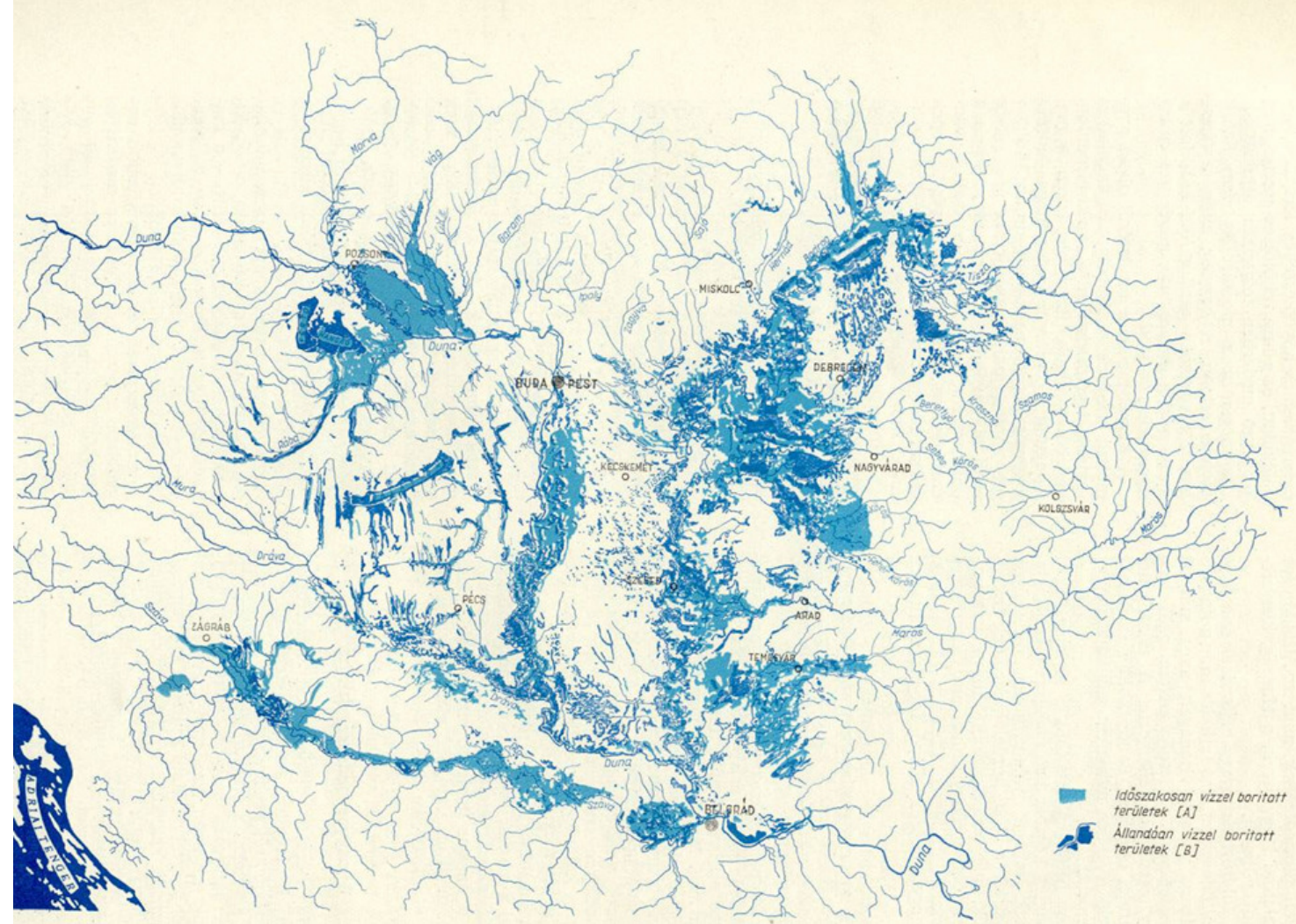

A Kárpát-medence vízborította területei a XVIII. század végén, a magyar vízszabályozási munkák megindítása és tervszerü végrehajtása előtt. Készült korabeli térképek alapján (Ihrig,)

II. melléklet

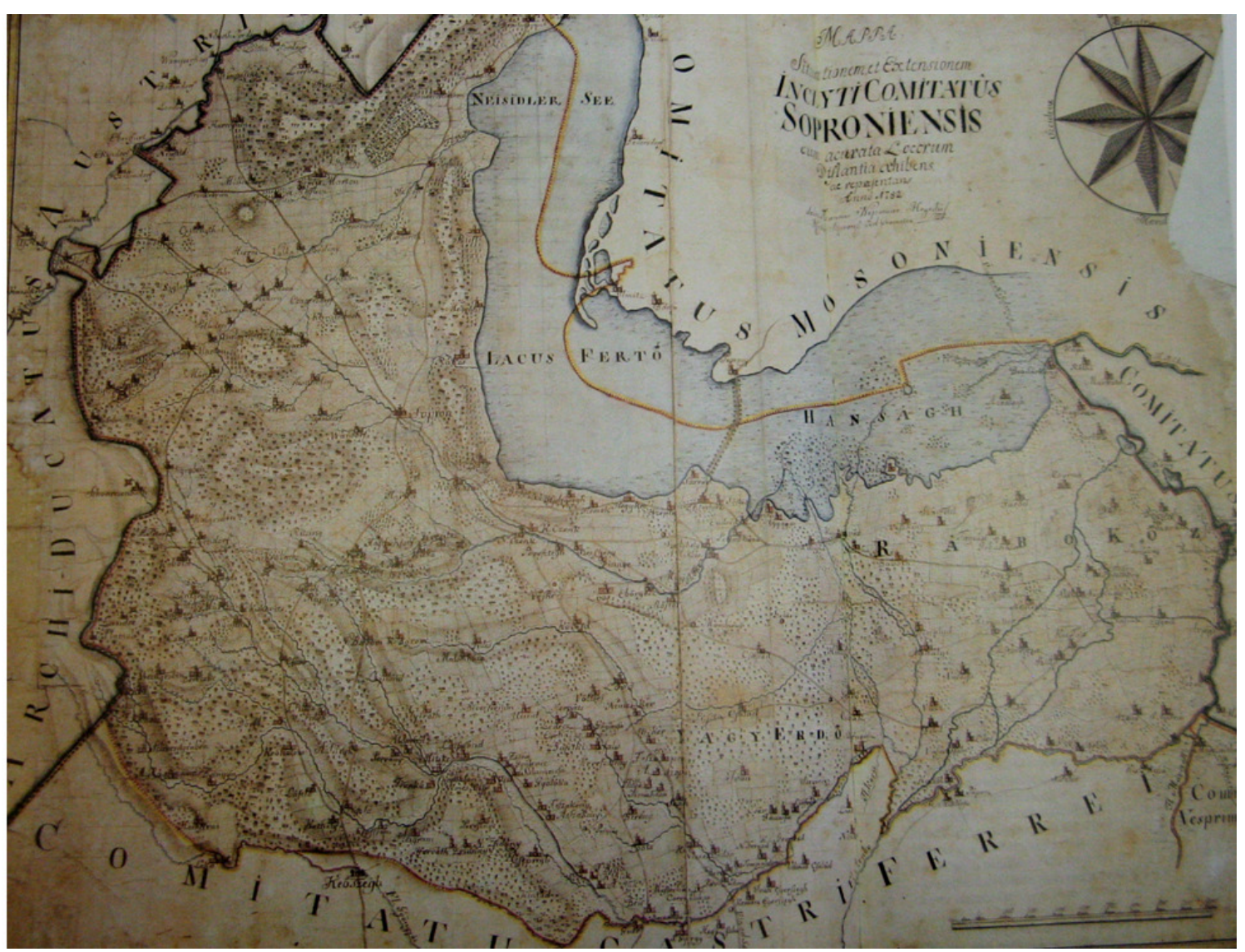

1782-es térkép Forrás: Papp-Váry (1989) 
III. melléklet

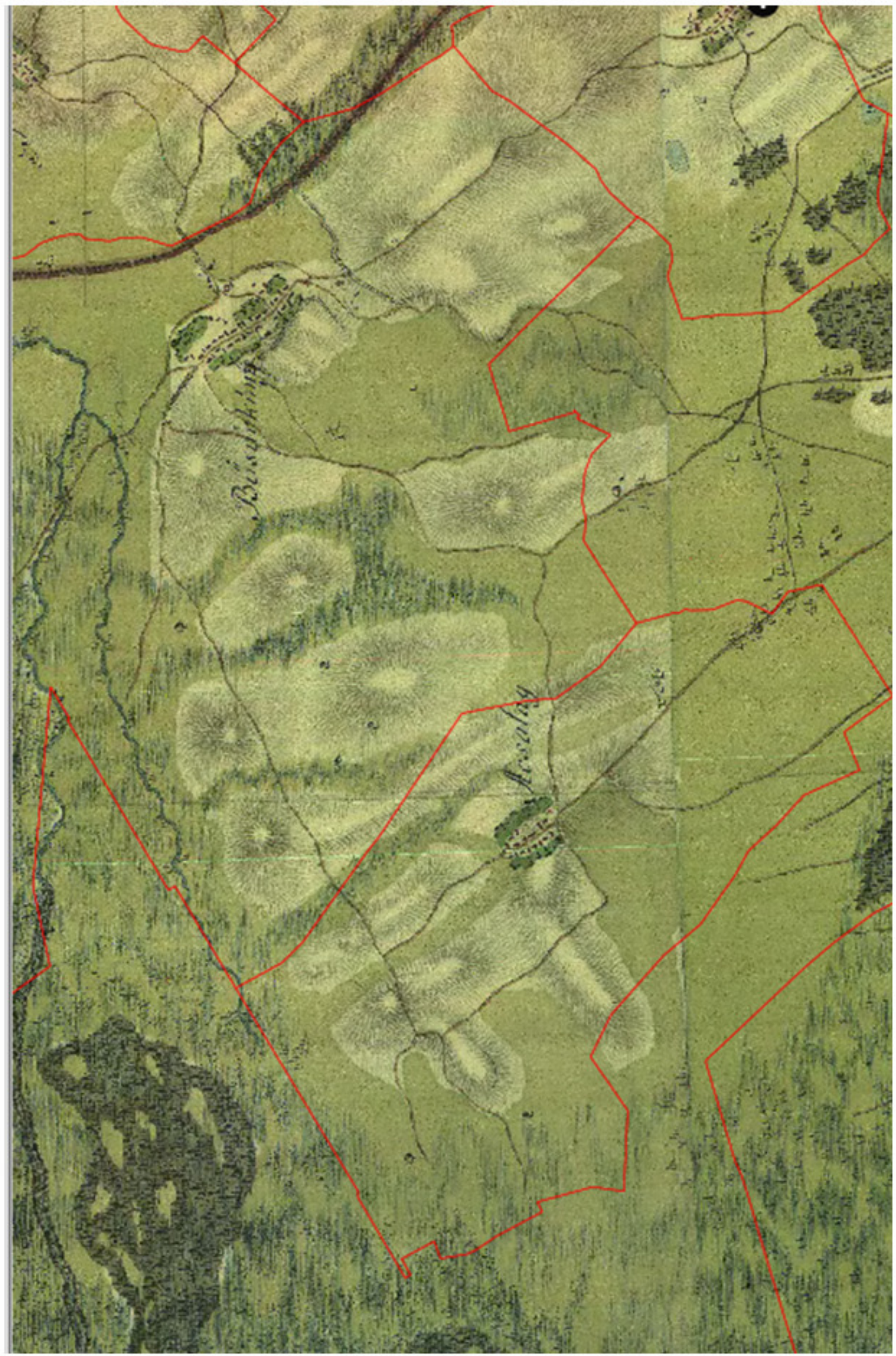

I. katonai felmérés, (részlet) www.tajertektar.hu 
Tájhasználat az I. katonai felmérés

Település

Szántó

Komplex müv.

Gyep, legelő

Szőlő, gyümölcs

Erdö

Láp, mocsár

Vízfelület

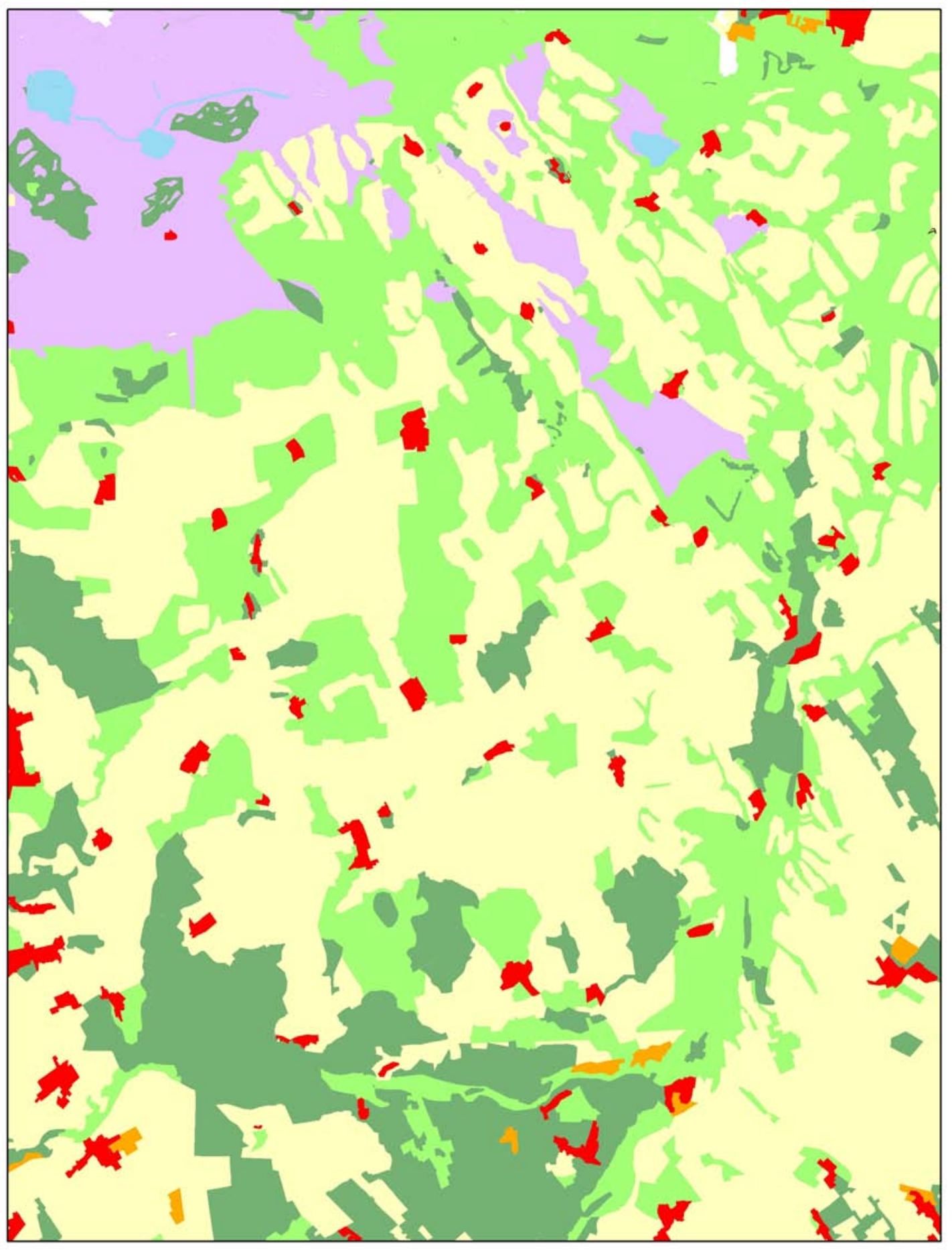




\section{Hanság vízrendezési térképek}

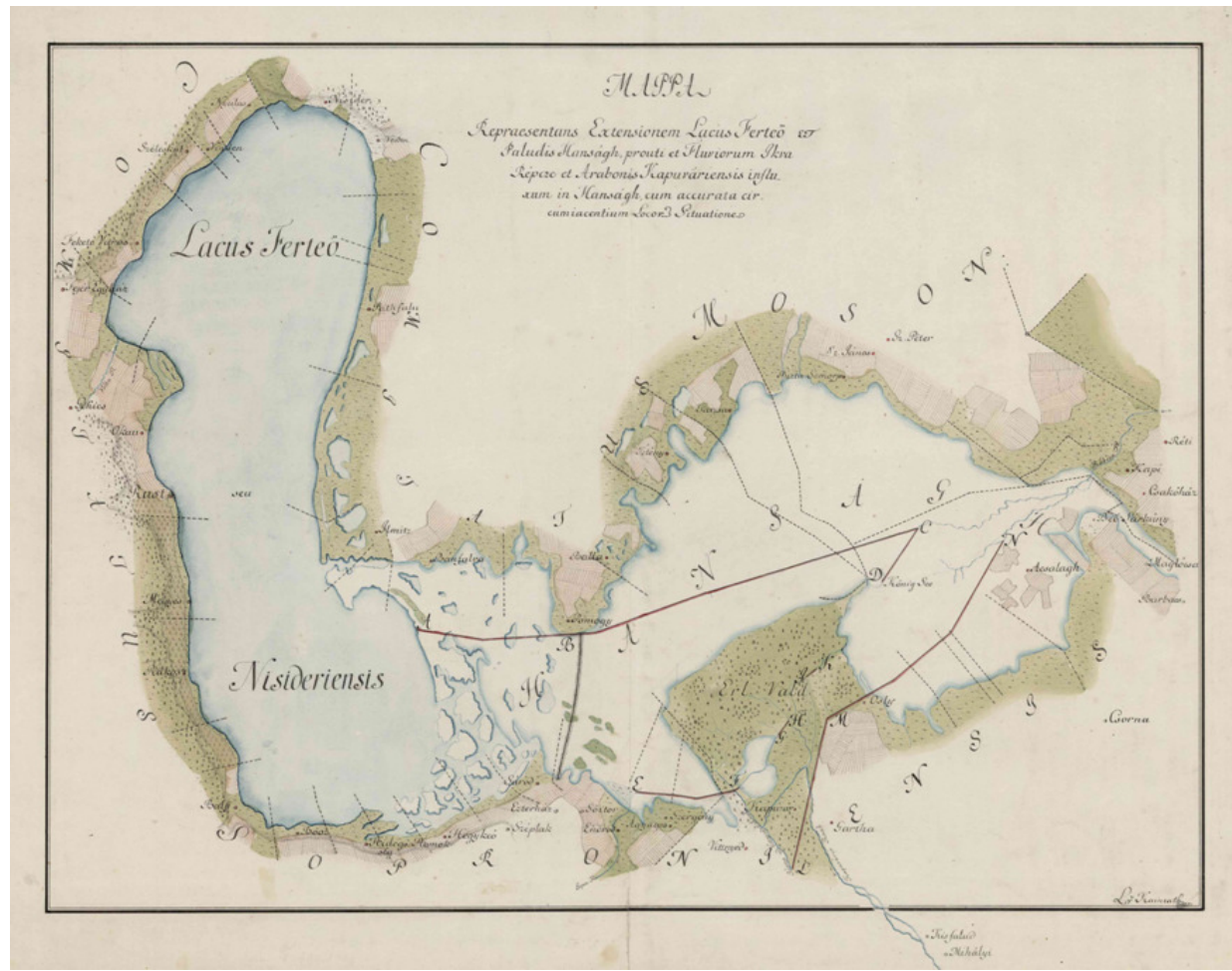

Hanság vízrendezési térkép 1790.

Mappa repraesentans extensionem lacus Ferteö et paludis Hanságh, prouti et fluviorum Ikva Répcze et Arabonis Kapuváriensis influxum in Hanságh ... / L v Kainrath. , 1790, TK 1114

Forrás: Országos Széchenyi Könyvtár

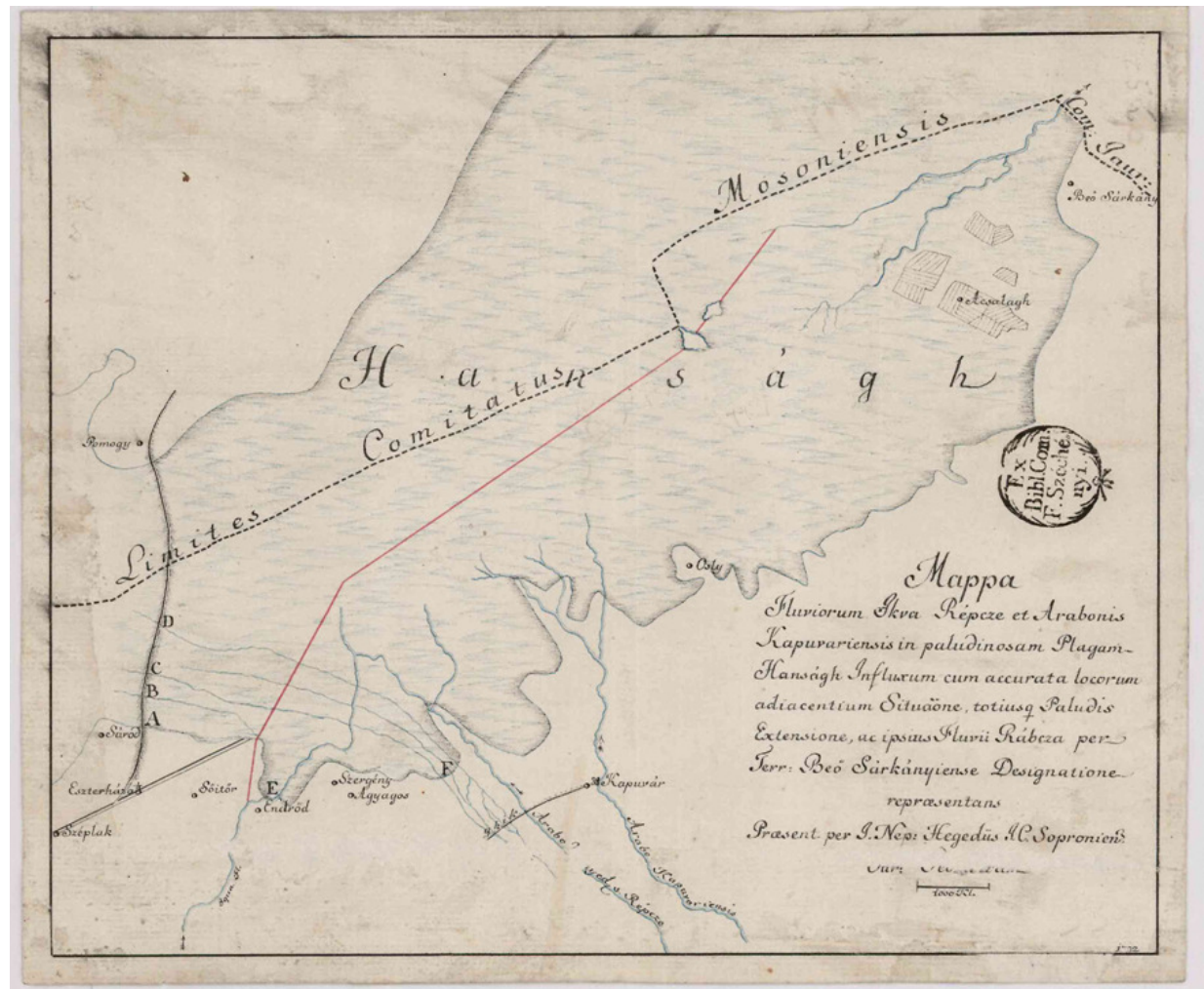

Hanság vízrendezési térkép 1792

Mappa fluviorum Ikva Répcze et Arabonis Kapuvariensis in paludinosam plagam Hanságh influxum ... repraesentans / praesent. per I. Nep. Hegedüs., Országos Széchenyi Könyvtár

Forrás: Országos Széchenyi Könyvtár 
Herceg Esterházy Miklós birtokai Sopron megyében és az 5000 holdon felüli birtokok Győr megyében (Felhő, 1970).

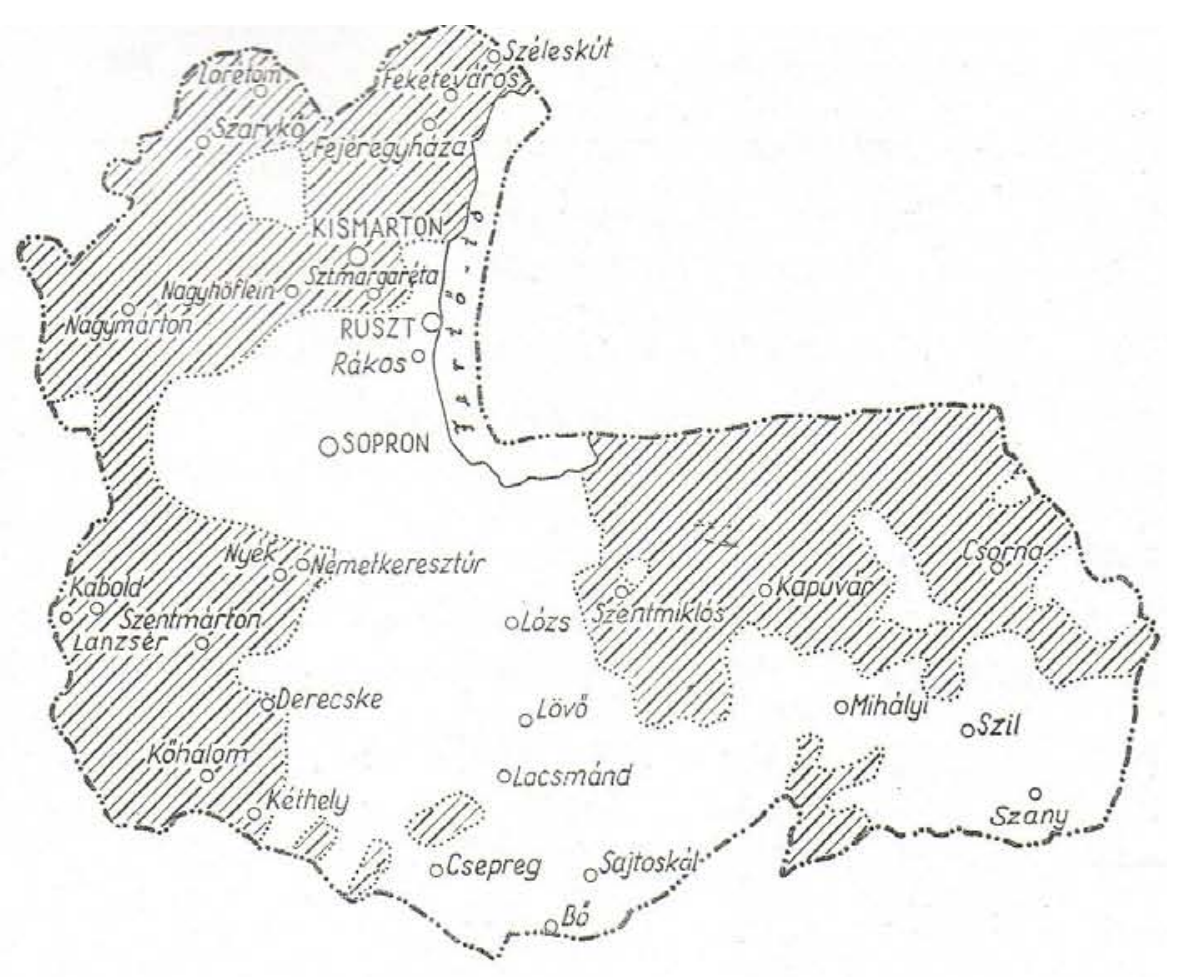

QIIA Hg. Esterházy Miklós birtokai

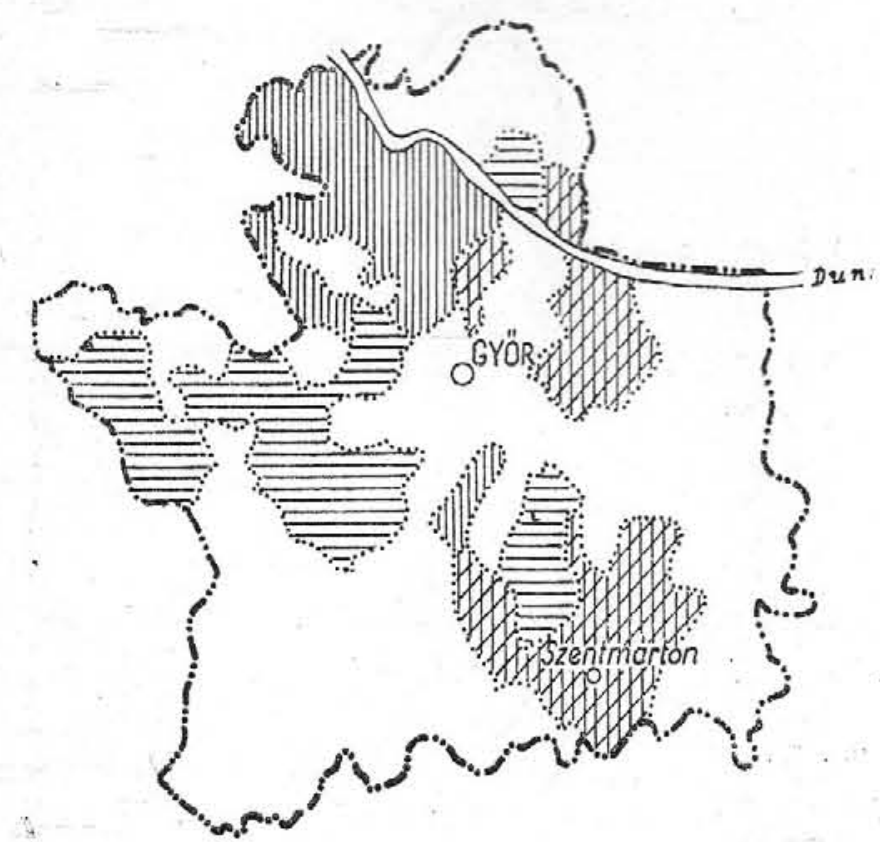

A györi káptalan birtokai

QXX) A pannonhalmi bencések birtokat

In⿴囗十⿵冂卄 a viczay család birtokai 
Tájhasználat a III. felújított katonai térkép alapján (saját szerkesztés)

1920, Hadtörténeti Térképtár 4858 3,4; 4958 1,2,3,4; 4959 1,3; 5058 1,2 szelvények alapján

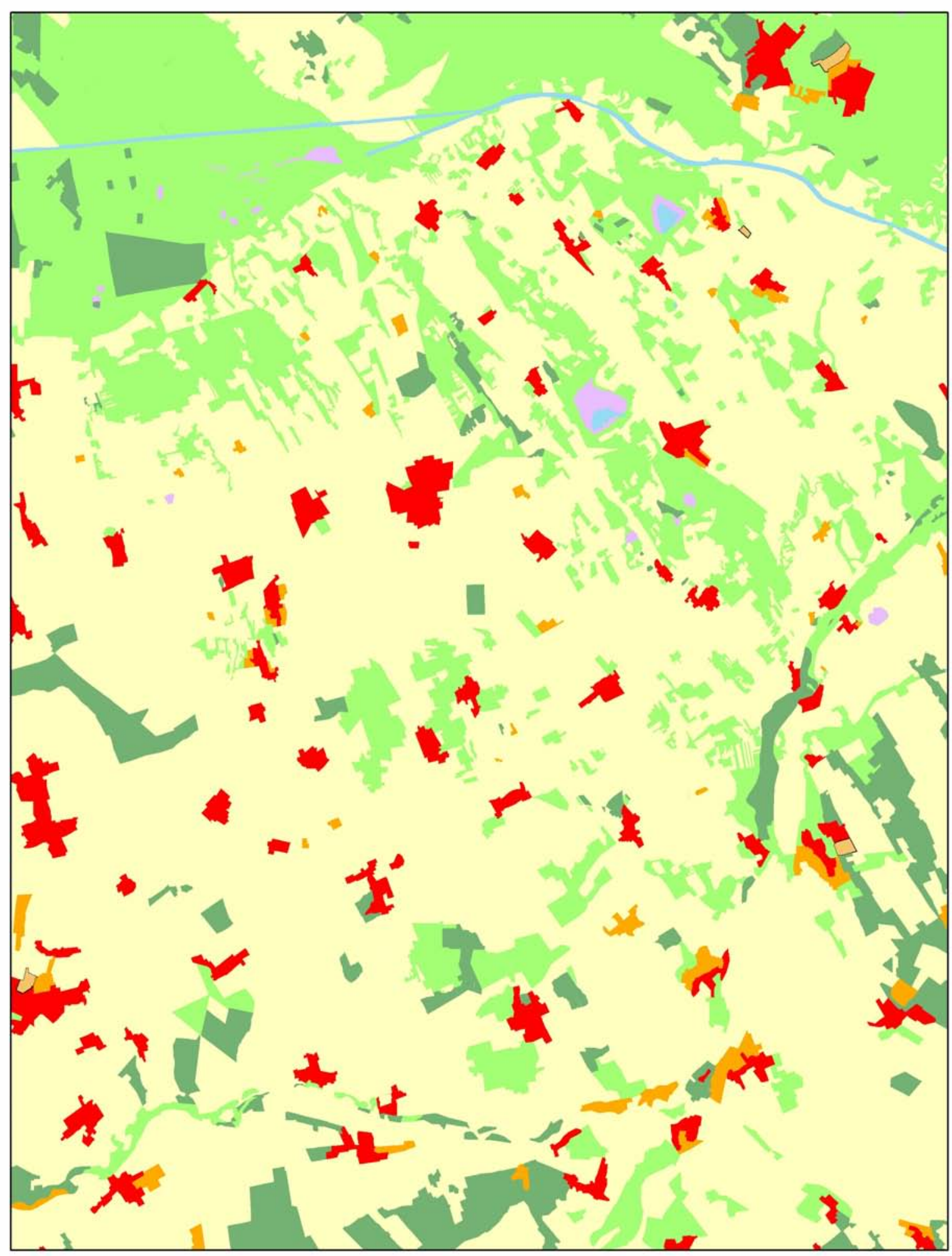


Tájhasználat az 1951-es topográfiai térkép alapján (saját szerkesztés)

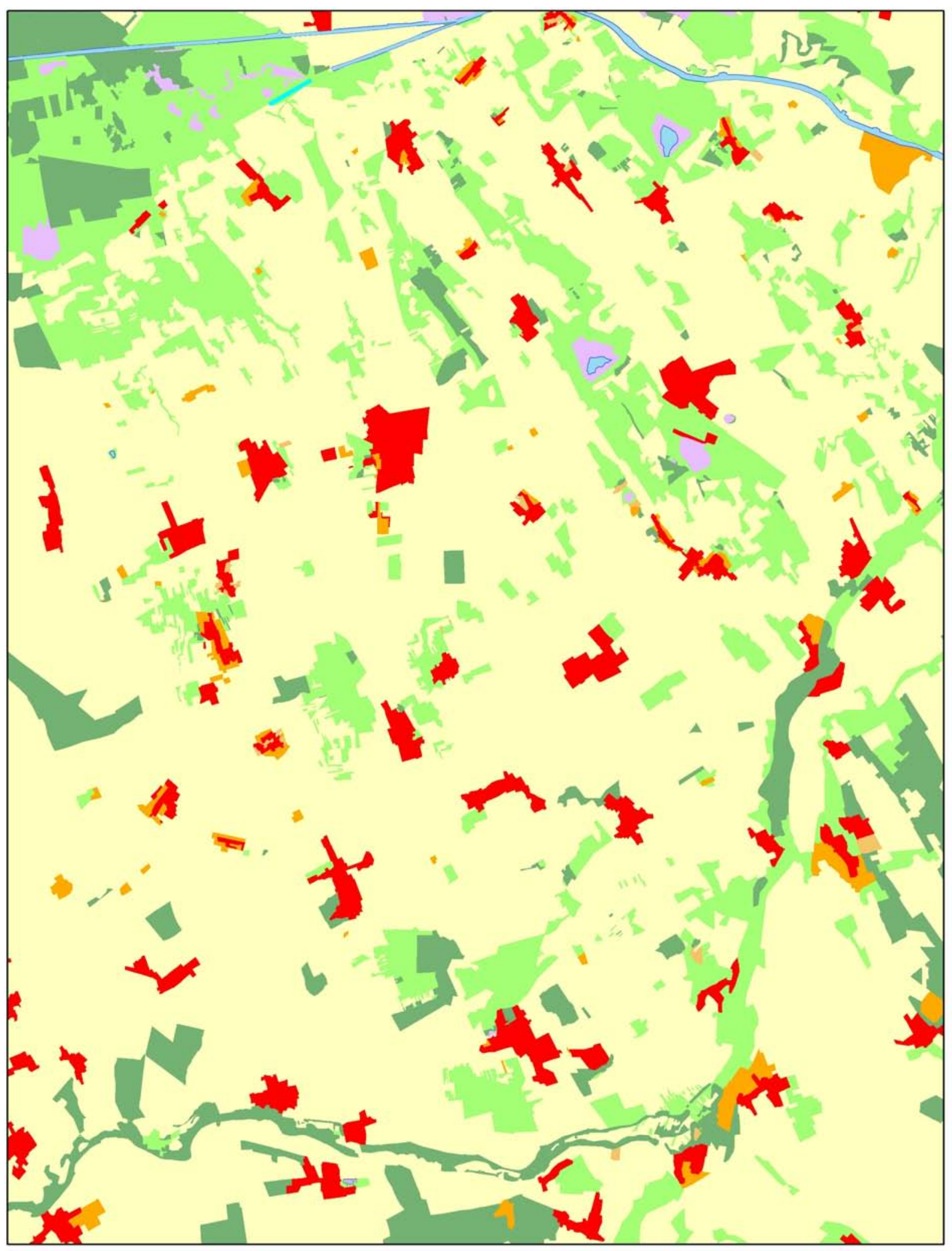


Területhasználati változások Hanság, Tóköz településein (saját szerkesztés, adatok forrása: KSH)
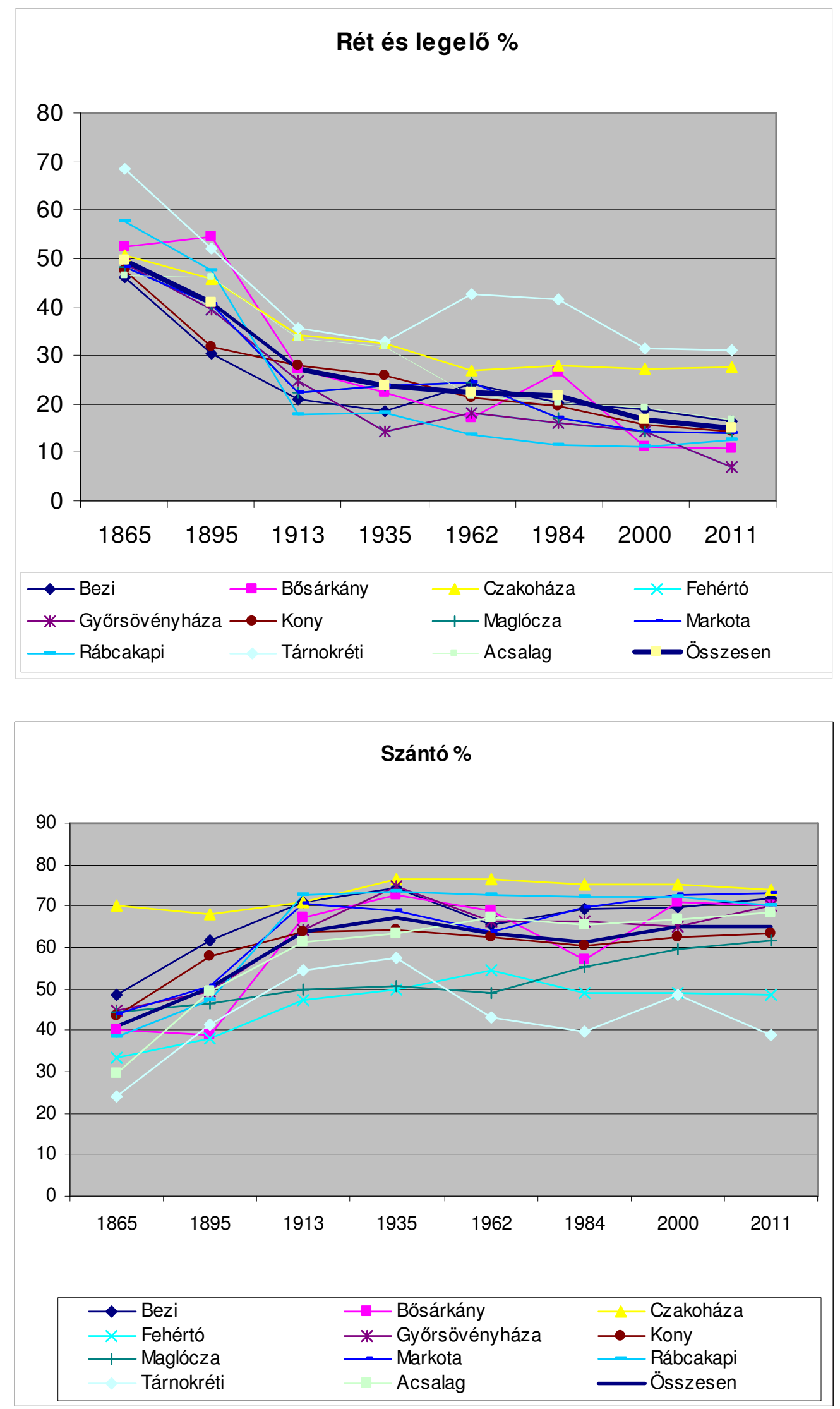
Tájfunkció értékelési mátrix (Koschke et al. Alapján)

\begin{tabular}{|c|c|c|c|c|c|c|c|}
\hline CLC & Főkategória & Név & Kód & 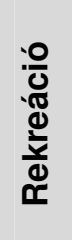 & 旁 & 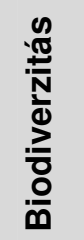 & 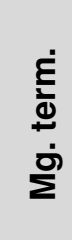 \\
\hline 111 & $\begin{array}{l}\text { Összefüggő telepü- } \\
\text { lésszerkezet }\end{array}$ & Lakott területek & 0 & 5 & 37 & 22 & 5 \\
\hline 112 & $\begin{array}{c}\text { Nem összefüggő tele- } \\
\text { pülésszerkezet }\end{array}$ & Lakott területek & 0 & 5 & 37 & 22 & 5 \\
\hline 121 & $\begin{array}{l}\text { Ipari vagy kereske- } \\
\text { delmi területek }\end{array}$ & $\begin{array}{c}\text { Ipari, kereskedelmi területek, } \\
\text { közlekedési hálózat }\end{array}$ & 0 & 5 & 37 & 22 & 5 \\
\hline 122 & $\begin{array}{l}\text { Út- és vasúthálózat és } \\
\text { csatlakozó területek }\end{array}$ & $\begin{array}{l}\text { Ipari, kereskedelmi területek, } \\
\text { közlekedési hálózat }\end{array}$ & 0 & 5 & 37 & 22 & 5 \\
\hline 131 & $\begin{array}{l}\text { Nyersanyag- } \\
\text { kitermelés }\end{array}$ & $\begin{array}{l}\text { Bányák, lerakóhelyek és } \\
\text { építési munkahelyek }\end{array}$ & 0 & 5 & 37 & 22 & 5 \\
\hline 132 & $\begin{array}{l}\text { Lerakóhelyek (med- } \\
\text { dőhányók) }\end{array}$ & $\begin{array}{c}\text { Bányák, lerakóhelyek és } \\
\text { építési munkahelyek }\end{array}$ & 0 & 5 & 37 & 22 & 5 \\
\hline 133 & Építési munkahelyek & $\begin{array}{l}\text { Bányák, lerakóhelyek és } \\
\text { építési munkahelyek }\end{array}$ & 0 & 5 & 37 & 22 & 5 \\
\hline 141 & Városi zöldterületek & $\begin{array}{c}\text { Mesterséges, nem mezőgaz- } \\
\text { dasági zöldterületek }\end{array}$ & 0 & 5 & 37 & 22 & 5 \\
\hline 142 & $\begin{array}{l}\text { Sport- és szabadidő- } \\
\text { létesítmények }\end{array}$ & $\begin{array}{l}\text { Mesterséges, nem mezőgaz- } \\
\text { dasági zöldterületek }\end{array}$ & 0 & 5 & 37 & 22 & 5 \\
\hline 211 & $\begin{array}{c}\text { Nem öntözött szántó- } \\
\text { földek }\end{array}$ & Szántóföldek & 1 & 30 & 30 & 30 & 100 \\
\hline 213 & Rizsföldek & Szántóföldek & 1 & & & & \\
\hline 221 & Szőlők & Állandó növényi kultúrák & 2 & 58 & 58 & 50 & 90 \\
\hline 222 & $\begin{array}{l}\text { Gyümölcsösök, bo- } \\
\text { gyósok }\end{array}$ & Állandó növényi kultúrák & 2 & & & & \\
\hline 231 & Rét / legelő & Legelők & 3 & 63 & 68 & 61 & 60 \\
\hline 242 & $\begin{array}{l}\text { Komplex müvelési } \\
\text { szerkezet }\end{array}$ & $\begin{array}{l}\text { Vegyes mezőgazdasági terü- } \\
\text { letek }\end{array}$ & 4 & 74 & 89 & 72 & 70 \\
\hline 243 & $\begin{array}{l}\text { Mezőgazdasági terü- } \\
\text { letek, jelentős termé- } \\
\text { szetes növényzettel }\end{array}$ & $\begin{array}{c}\text { Vegyes mezőgazdasági terü- } \\
\text { letek }\end{array}$ & 4 & 74 & 89 & 72 & 70 \\
\hline 311 & Lomblevelü erdők & Erdők & 5 & 95 & 95 & 89 & 65 \\
\hline 312 & Tülevelü erdők & Erdők & 5 & 95 & 95 & 89 & 65 \\
\hline 313 & Vegyes erdők & Erdők & 5 & 95 & 95 & 89 & 65 \\
\hline 321 & $\begin{array}{l}\text { Természetes gyepek, } \\
\text { természetközeli rétek }\end{array}$ & $\begin{array}{c}\text { Cserjés és/vagy lágyszárú } \\
\text { növényzet }\end{array}$ & 5 & 95 & 95 & 89 & 65 \\
\hline 324 & $\begin{array}{l}\text { Átmeneti erdős- } \\
\text { cserjés területek }\end{array}$ & $\begin{array}{c}\text { Cserjés és/vagy lágyszárú } \\
\text { növényzet }\end{array}$ & 5 & 95 & 95 & 89 & 65 \\
\hline 333 & Ritkás növényzet & $\begin{array}{c}\text { Növényzet nélküli vagy kevés } \\
\text { növényzettel fedett nyílt terü- } \\
\text { letek }\end{array}$ & 5 & 95 & 95 & 89 & 65 \\
\hline 411 & Szárazföldi mocsarak & $\begin{array}{c}\text { Belső (szárazföldi) vizenyős } \\
\text { területek }\end{array}$ & 6 & 95 & 95 & 100 & 0 \\
\hline 412 & Tőzeglápok & $\begin{array}{l}\text { Belső (szárazföldi) vizenyős } \\
\text { területek }\end{array}$ & 6 & 95 & 95 & 100 & 0 \\
\hline 511 & Folyóvizek, vízi utak & Kontinentális vizek & 7 & 95 & 95 & 44 & 35 \\
\hline
\end{tabular}


A kisalföldi városok helyzete a Beluszky Pál által készített városhierarchiában (idézte Győri Róbert, 1999)

\begin{tabular}{|c|c|}
\hline Település & Rangszám \\
\hline Sopron & 15. \\
\hline Györ & 16. \\
\hline Szombathely & 18. \\
\hline Pápa & 85. \\
\hline Magyaróvár & 113. \\
\hline Szentgotthárd & 117. \\
\hline Köszeg & 137. \\
\hline Csorna & 182. \\
\hline Kapuvár & 188. \\
\hline Körmend & 192. \\
\hline Sárvár & 205. \\
\hline Devecser & 222. \\
\hline Nagymarton & 226. \\
\hline Kiscell & 235. \\
\hline Muraszombat & 238. \\
\hline Kismarton & 239. \\
\hline
\end{tabular}

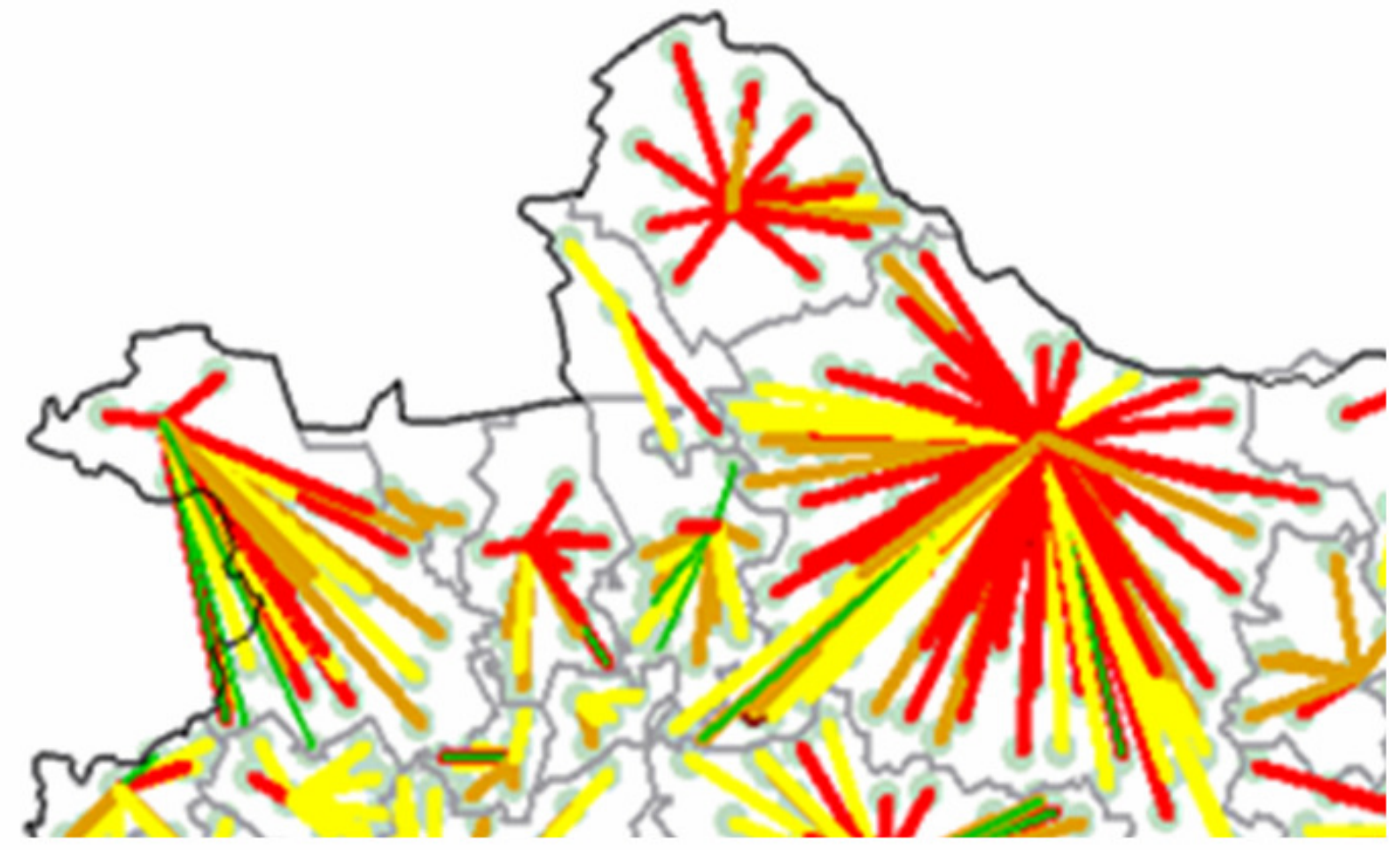

Munkaerőpiaci kapcsolatrendszer (Forrás: OTfK) 


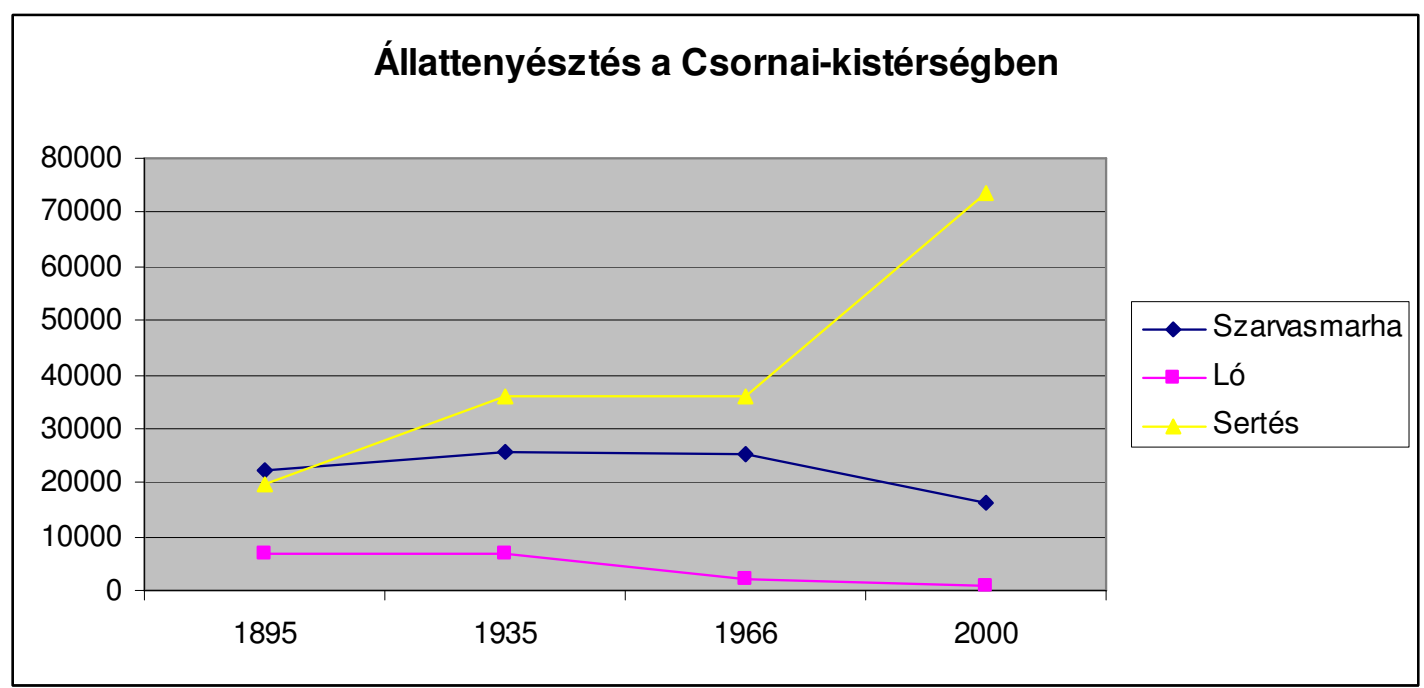

Az állattenyésztés arányainak változása a Csornai-kistérségben (adatok forrása: KSH)

XIV. melléklet
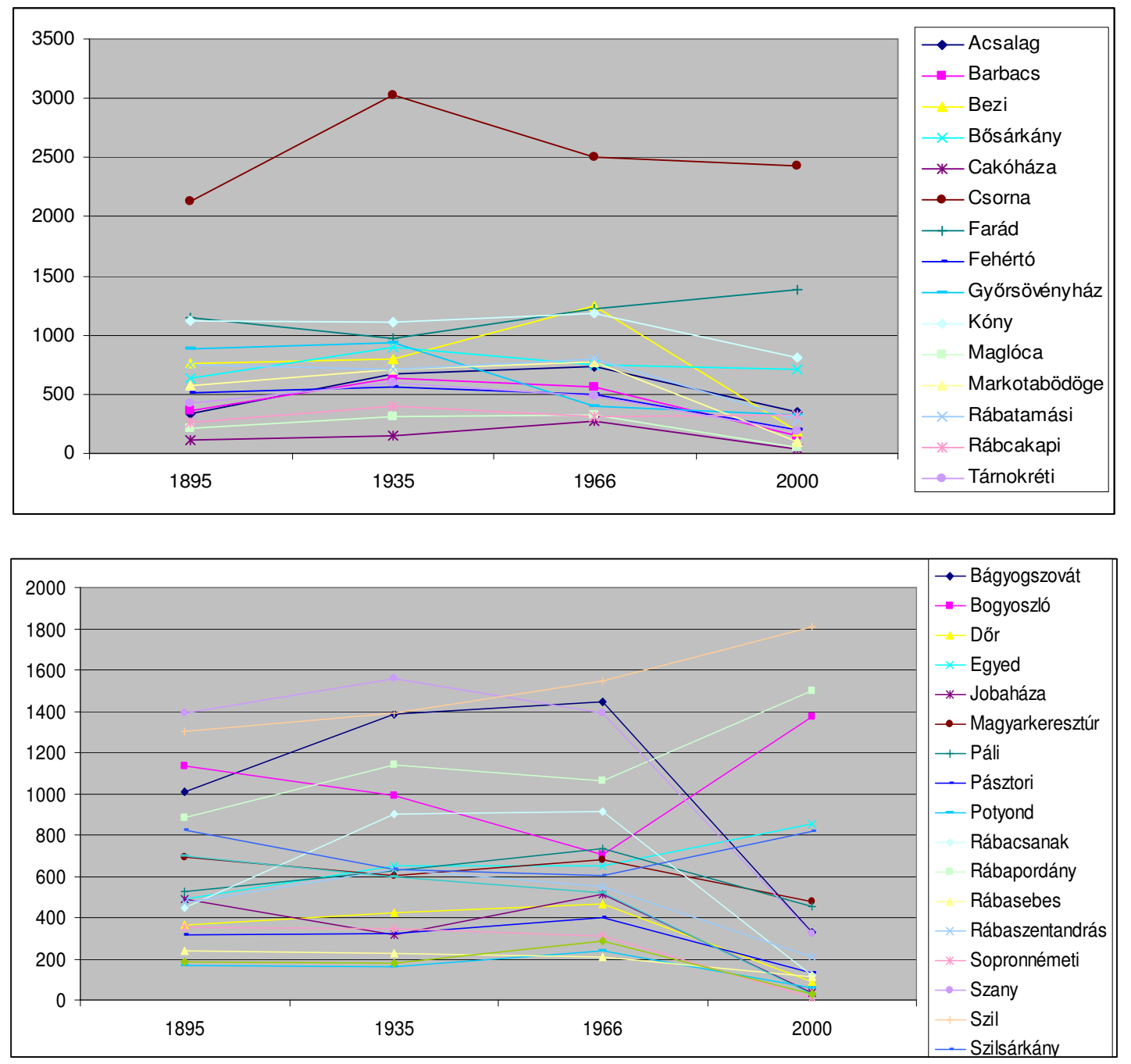

Szarvasmarha tenyésztés volumenének változása a Hanság, Tóköz valamint a Dél-Rábaköz településein a Csornaikistérségben (saját szerkesztés, adatok forrása: KSH) 
Foglalkoztatottak aránya a mezőgazdaságban, szolgáltatásokban és az ipar, építőiparban (saját szerkesztés, adatok forrása: TEIR, 2001)
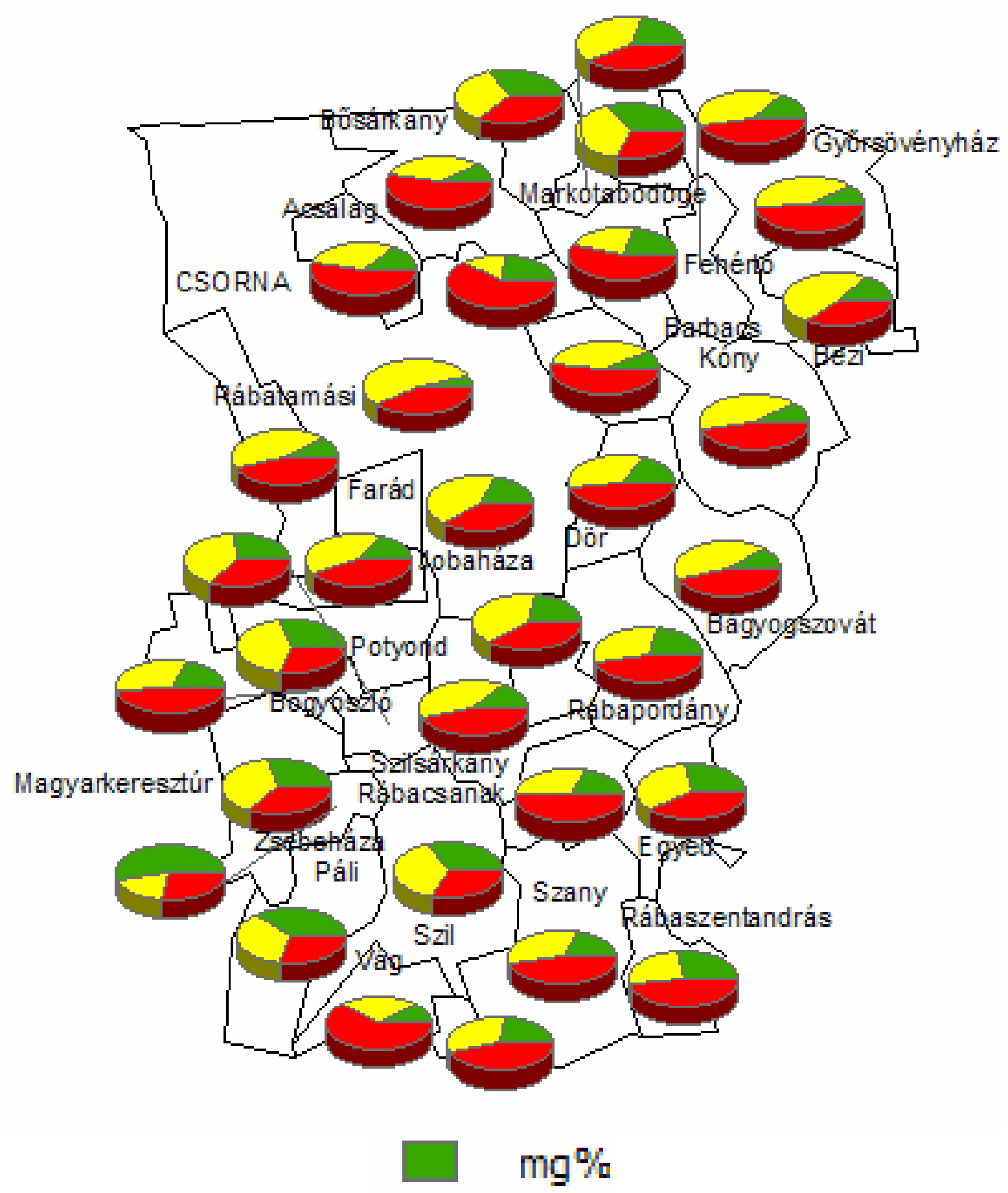

$\square \quad s z \%$

ip $\%$ 
Tájfunkció értékek területhasználatonként Koschke et. al. 2012 nyomán

\begin{tabular}{|c|c|c|c|c|c|c|}
\hline $\begin{array}{l}\text { CLC } 50 \\
\text { Kódok }\end{array}$ & Területhasználat típusa & Egyszerüsített területh. & Rekreáció & Esztétika & Biodiverzitás & Termesztés \\
\hline 1111 & Városközpontok & Összefüggő települési & 0 & 26 & 6 & 0 \\
\hline 1112 & Történelmi belvárosi területek & Nem összefüggő tel. & 5 & 37 & 22 & 5 \\
\hline 1121 & $\begin{array}{l}\text { Nem összefüggő település szerkezet, kertek nélküli többemeletes } \\
\text { lakóházakkal beépitve }\end{array}$ & Nem összefüggő tel. & 5 & 37 & 22 & 5 \\
\hline 1122 & Nem összefüggö, családi házas és kertes beépítés & Nem összefüggő tel. & 5 & 37 & 22 & 5 \\
\hline 1123 & Erdei környezetben lévő, nem-összefüggö beépítés & Nem összefüggő tel. & 5 & 37 & 22 & 5 \\
\hline 12111 & Ipari és kereskedelmi létesítmények & Ipari, ker., kikötő & 0 & 0 & 0 & 0 \\
\hline 12112 & Agrár létesítmények & Ipari, ker., kikötő & 0 & 0 & 0 & 0 \\
\hline 12113 & Oktatási és egészségügyi létesítmények & Ipari, ker., kikötő & 0 & 0 & 0 & 0 \\
\hline 1212 & Speciális műszaki létesítmények & Ipari, ker., kikötő & 0 & 0 & 0 & 0 \\
\hline 1221 & Úthálózat és csatlakozó területek & Út, vasút, építési t. & 0 & 0 & 0 & 0 \\
\hline 1222 & Vasúthálózat és csatlakozó területek & Út, vasút, építési t. & 0 & 0 & 0 & 0 \\
\hline 1232 & Folyami és tavi kikötők & Út, vasút, építési t. & 0 & 0 & 0 & 0 \\
\hline 1233 & Hajógyárak, hajójavitó üzemek & Ipari, ker., kikötő & 0 & 0 & 0 & 0 \\
\hline 1234 & Sport és szabadidő kikötők & Városi zöldfel., sport & & & & 0 \\
\hline 1241 & Repülőterek szilárd burkolatú kifutópályával & Ipari, ker., kikötő & 0 & 0 & 0 & 0 \\
\hline 1242 & Füves kifutópályájú repülőterek & Városi zöldfel., sport & & & & 0 \\
\hline 1311 & Külszíni bányák & Bánya & 0 & 0 & 6 & 45 \\
\hline 1312 & Kőbányák & Bánya & 0 & 0 & 6 & 45 \\
\hline 1321 & Szilárd-hulladék lerakó helyek & Hulladéklerakó & 0 & 0 & 6 & 0 \\
\hline 1322 & Folyékony-hulladék tároló telepek & Hulladéklerakó & 0 & 0 & 6 & 0 \\
\hline 1331 & Épitési munkahelyek & Út, vasút, építési t. & 0 & 0 & 6 & 0 \\
\hline 1411 & Parkok & Városi zöldfel., sport & 53 & 53 & 53 & 10 \\
\hline 1412 & Temetők & Városi zöldfel., sport & 53 & 53 & 53 & 10 \\
\hline 1421 & Sport létesitmények & Városi zöldfel., sport & 53 & 53 & 53 & 10 \\
\hline 1422 & Szabadidő területek & Városi zöldfel., sport & 53 & 53 & 53 & 10 \\
\hline 1423 & Üdülő települések & Nem összefüggő tel. & 5 & 37 & 22 & 5 \\
\hline 2111 & Nagytáblás szántóföldek & Nagytáblás szántóföld & 26 & 26 & 28 & 90 \\
\hline 2112 & Kistáblás szántóföldek & Kistáblás szántóföld & 30 & 30 & 30 & 85 \\
\hline 2113 & Melegházak & Komplex múv. szerk. & 74 & 89 & 72 & 100 \\
\hline 2121 & Állandóan öntözött szántó területek & Öntözött szántó & 26 & 26 & 28 & 100 \\
\hline 2131 & Rizsföldek & Öntözött szántó & 26 & 26 & 28 & 90 \\
\hline 22111 & Nagytáblás szölök & Szölö, gyümölcs & 58 & 58 & 50 & 90 \\
\hline 22112 & Kistáblás szőlők & Szölő, gyümölcs & 58 & 58 & 50 & 90 \\
\hline 2221 & Gyümölcsfa ültetvények & Szölő, gyümölcs & 58 & 58 & 50 & 100 \\
\hline 2222 & Bogyós ültetvények & Szőlő, gyümölcs & 58 & 58 & 50 & 90 \\
\hline 2223 & Komló ültetvények & Szölö, gyümölcs & 58 & 58 & 50 & 90 \\
\hline 2226 & Füzfa ültetvények & Lombhullató erdő & 95 & 95 & 89 & 65 \\
\hline 2311 & Intenzív legelök és erősen degradált gyepek bokrok és fák nélkül & Legelő & 63 & 68 & 61 & 60 \\
\hline 2312 & Intenzív legelök és erősen degradált gyepek fákkal és bokrokkal & Legelö & 63 & 68 & 61 & 60 \\
\hline 2421 & Komplex müvelési szerkezet épületek nélkül & Komplex műv. szerk. & 74 & 89 & 72 & 70 \\
\hline 24221 & Komplex müvelési szerkezet szórt elhelyezkedésű épületekkel & Komplex müv. szerk. & 74 & 89 & 72 & 70 \\
\hline 24222 & Tanyák & Komplex műv. szerk. & 74 & 89 & 72 & 70 \\
\hline 2431 & $\begin{array}{c}\text { Mezőgazdasági területek túlsúlyban szántókkal és jelentős } \\
\text { természetes vegetációval }\end{array}$ & Mezőgazdasági terület & 74 & 68 & 61 & 60 \\
\hline
\end{tabular}




\begin{tabular}{|c|c|c|c|c|c|c|}
\hline $\begin{array}{l}\text { CLC } 50 \\
\text { Kódok }\end{array}$ & Területhasználat típusa & Egyszerüsített területh. & Rekreáció & Esztétika & Biodiverzitás & Termesztés \\
\hline 2432 & $\begin{array}{c}\text { Mezőgazdasági területek túlsúlyban intenzív legelökkel és jelen- } \\
\text { tös természetes vegetációval }\end{array}$ & Mezőgazdasági terület & 74 & 68 & 61 & 60 \\
\hline 2433 & $\begin{array}{c}\text { Mezőgazdasági területek túlsúlyban szórt megjelenésủ természe- } \\
\text { tes vegetációval }\end{array}$ & Mezögazdasági terület & 74 & 68 & 61 & 60 \\
\hline 2434 & $\begin{array}{c}\text { Mezőgazdasági területek kis tavak jelentős részarányával és } \\
\text { szórt természetes vegetáció elöfordulásával }\end{array}$ & Mezőgazdasági terület & 74 & 68 & 61 & 60 \\
\hline 2435 & $\begin{array}{c}\text { Mezőgazdasági területek állandó kultúrák jelentős előfordulásá- } \\
\text { val, és szórt megjelenésű természetes vegetációval }\end{array}$ & Mezögazdasági terület & 74 & 68 & 61 & 60 \\
\hline 3111 & $\begin{array}{c}\text { Zárt lombkoronájú természetes lombhullató erdők nem vizenyős } \\
\text { területen }\end{array}$ & Lombhullató erdő & 95 & 95 & 89 & 65 \\
\hline 3112 & $\begin{array}{l}\text { Zárt lombkoronájú természetes lombhullató erdők, vizenyős } \\
\text { területen }\end{array}$ & Lombhullató erdő & 95 & 95 & 89 & 65 \\
\hline 3113 & $\begin{array}{l}\text { Nyilt lombkoronájú természetes lombhullató erdők nem vizenyős } \\
\text { területen }\end{array}$ & Lombhullató erdő & 95 & 95 & 89 & 65 \\
\hline 3114 & Nyilt lombkoronájú természetes lombhullató & Lombhullató erdő & 95 & 95 & 89 & 65 \\
\hline 3115 & Lombos erdő ültetvények & Lombhullató ültetvény & 70 & 95 & 70 & 65 \\
\hline 3121 & Zárt lombkoronájú természetes fenyőerdők & Örökzöld erdő & 84 & 79 & 60 & 75 \\
\hline 3125 & Tülevelü ültetvények & Örökzöld ültetvény & 84 & 79 & 72 & 75 \\
\hline 3131 & $\begin{array}{c}\text { Szálanként elegyes természetes (lombos és fenyő) erdők zárt } \\
\text { lombkoronával }\end{array}$ & Vegyes erdő & 100 & 100 & 100 & 70 \\
\hline 3135 & $\begin{array}{c}\text { Csoportosan elegyes természetes (lombos és fenyő) erdők zárt } \\
\text { lombkoronával }\end{array}$ & Vegyes erdő & 100 & 100 & 100 & 70 \\
\hline 3139 & Elegyes ültetvények & Vegyes ültetvény & 100 & 80 & 80 & 70 \\
\hline 3211 & Természetes gyep fák és cserjék nélkül & Természetes gyep & 84 & 89 & 94 & 20 \\
\hline 3212 & Természetes gyep fákkal és cserjékkel & Természetes gyep & 84 & 89 & 94 & 20 \\
\hline 3241 & Fiatalos erdők és vágásterületek & $\begin{array}{l}\text { Átmeneti cserjés-erdős } \\
\text { ter. }\end{array}$ & 95 & 95 & 94 & 25 \\
\hline 3243 & Spontán cserjésedő-erdősödő területek & $\begin{array}{l}\text { Átmeneti cserjés-erdős } \\
\text { ter. }\end{array}$ & 95 & 95 & 94 & 25 \\
\hline 3244 & Csemetekertek, erdei faiskolák & $\begin{array}{l}\text { Átmeneti cserjés-erdős } \\
\text { ter. }\end{array}$ & 95 & 95 & 94 & 25 \\
\hline 3245 & Károsodott erdők & $\begin{array}{l}\text { Átmeneti cserjés-erdős } \\
\text { ter. }\end{array}$ & 95 & 95 & 94 & 25 \\
\hline 3313 & Folyópartok & Vizfolyás, állóviz & 95 & 95 & 44 & 35 \\
\hline 3321 & Csupasz sziklák & Csupasz szikla & 40 & 60 & 0 & 0 \\
\hline 3331 & Ritkás növényzet homokon vagy löszön & Ritkás, term. növényzet & 85 & 85 & 100 & 0 \\
\hline 3332 & Ritkás növényzet kőzetkibúvásokon & Ritkás, term. növényzet & 85 & 85 & 100 & 0 \\
\hline 3333 & Ritkás növényzet szikes területeken & Ritkás, term. növényzet & 85 & 85 & 100 & 0 \\
\hline 3341 & Leégett területek & Leégett terület & 0 & 0 & 0 & 0 \\
\hline 4111 & Édesvizü mocsarak & Láp, mocsár & 95 & 95 & 100 & 0 \\
\hline 4113 & Szikes mocsarak & Láp, mocsár & 95 & 95 & 100 & 0 \\
\hline 4121 & Tőzeglápok kitermelés alatt & Láp, mocsár & 95 & 95 & 100 & 0 \\
\hline 4122 & $\begin{array}{c}\text { Természetes tőzeglápok bokrok és fák szórványos előfordulásá- } \\
\text { val }\end{array}$ & Láp, mocsár & 95 & 95 & 100 & 0 \\
\hline 5111 & Folyóvizek & Vizfolyás, állóvíz & 95 & 95 & 44 & 35 \\
\hline 5112 & Csatornák & Vízfolyás, állóvíz & 95 & 95 & 44 & 35 \\
\hline 51211 & Állandó vizű természetes tavak & Vízfolyás, állóvíz & 95 & 95 & 44 & 35 \\
\hline 51212 & Természetes, időszakos, szikes tavak & Vízfolyás, állóvíz & 95 & 95 & 44 & 35 \\
\hline 51221 & Mesterséges tavak, víztározók & Vizfolyás, állóvíz & 95 & 95 & 44 & 35 \\
\hline 51222 & Halastavak & Vízfolyás, állóvíz & 95 & 95 & 44 & 35 \\
\hline
\end{tabular}


Környezeti integritás értéke Koschke értékelési mátrix módosításával (Koschke et. al., 2012)

\begin{tabular}{|c|c|c|c|c|c|c|c|c|}
\hline $\begin{array}{l}\text { CLC } 50 \\
\text { Kódok }\end{array}$ & Területhasználat típusa & Egyszerüsitett területh. & $\begin{array}{l}\text { Tiszta } \\
\text { levegö }\end{array}$ & Klímaszab. & $\begin{array}{l}\text { Víz } \\
\text { szab. }\end{array}$ & $\begin{array}{l}\text { Tiszta } \\
\text { víz }\end{array}$ & Talajerózió & $\begin{array}{l}\text { Környezeti } \\
\text { integritás* }\end{array}$ \\
\hline 1111 & Városközpontok & Összefüggő települési & 0 & 0 & 0 & 0 & 0 & 0 \\
\hline 1112 & Történelmi belvárosi területek & Nem összefüggö tel. & 10 & 11 & 10 & 5 & 15 & 10 \\
\hline 1121 & $\begin{array}{c}\text { Nem összefüggő település szerkezet, kertek nélküli } \\
\text { többemeletes lakóházakkal beépitve }\end{array}$ & Nem összefüggő tel. & 10 & 11 & 10 & 5 & 15 & 10 \\
\hline 1122 & Nem összefüggő, családi házas és kertes beépítés & Nem összefüggő tel. & 10 & 11 & 10 & 5 & 15 & 10 \\
\hline 1123 & Erdei környezetben lévő, nem-összefüggő beépités & Nem összefüggő tel. & 10 & 11 & 10 & 5 & 15 & 10 \\
\hline 12111 & Ipari és kereskedelmi létesítmények & Ipari, ker., kikötő & 0 & 0 & 0 & 0 & 0 & 0 \\
\hline 12112 & Agrár létesítmények & Ipari, ker., kikötő & 0 & 0 & 0 & 0 & 0 & 0 \\
\hline 12113 & Oktatási és egészségügyi létesítmények & Ipari, ker., kikötő & 0 & 0 & 0 & 0 & 0 & 0 \\
\hline 1212 & Speciális müszaki létesítmények & Ipari, ker., kikötö & 0 & 0 & 0 & 0 & 0 & 0 \\
\hline 1221 & Úthálózat és csatlakozó területek & Út, vasút, építési t. & 0 & 0 & 0 & 0 & 0 & 0 \\
\hline 1222 & Vasúthálózat és csatlakozó területek & Út, vasút, építési t. & 0 & 0 & 0 & 0 & 0 & 0 \\
\hline 1232 & Folyami és tavi kikötök & Út, vasút, épitési t. & 0 & 0 & 0 & 0 & 0 & 0 \\
\hline 1233 & Hajógyárak, hajójavitó üzemek & Ipari, ker., kikötő & 0 & 0 & 0 & 0 & 0 & 0 \\
\hline 1234 & Sport és szabadidő kikötők & Városi zöldfel., sport & 45 & 53 & 30 & 30 & 35 & 39 \\
\hline 1241 & Repülöterek szilárd burkolatú kifutópályával & Ipari, ker., kikötő & 0 & 0 & 0 & 0 & 0 & 0 \\
\hline 1242 & Füves kifutópályájú repülöterek & Városi zöldfel., sport & 45 & 53 & 30 & 30 & 35 & 39 \\
\hline 1311 & Külszíni bányák & Bánya & 0 & 0 & 0 & 0 & 0 & 0 \\
\hline 1312 & Kőbányák & Bánya & 0 & 0 & 0 & 0 & 0 & 0 \\
\hline 1321 & Szilárd-hulladék lerakó helyek & Hulladéklerakó & 0 & 0 & 0 & 0 & 0 & 0 \\
\hline 1322 & Folyékony-hulladék tároló telepek & Hulladéklerakó & 0 & 0 & 0 & 0 & 0 & 0 \\
\hline 1331 & Épitési munkahelyek & Út, vasút, építési t. & 0 & 0 & 0 & 0 & 0 & 0 \\
\hline 1411 & Parkok & Városi zöldfel., sport & 45 & 53 & 30 & 30 & 35 & 39 \\
\hline 1412 & Temetök & Városi zöldfel., sport & 45 & 53 & 30 & 30 & 35 & 39 \\
\hline 1421 & Sport létesítmények & Városi zöldfel., sport & 45 & 53 & 30 & 30 & 35 & 39 \\
\hline 1422 & Szabadidő területek & Városi zöldfel., sport & 45 & 53 & 30 & 30 & 35 & 39 \\
\hline 1423 & Üdülő települések & Nem összefüggő tel. & 10 & 11 & 10 & 5 & 15 & 10 \\
\hline 2111 & Nagytáblás szántóföldek & Nagytáblás szántóföld & 35 & 42 & 35 & 20 & 30 & 32 \\
\hline 2112 & Kistáblás szántóföldek & Kistáblás szántóföld & 35 & 42 & 40 & 20 & 35 & 34 \\
\hline 2113 & Melegházak & Komplex műv. szerk. & 60 & 63 & 55 & 50 & 60 & 58 \\
\hline 2121 & Állandóan öntözött szántó területek & Öntözött szántó & 35 & 42 & 35 & 20 & 30 & 32 \\
\hline 2131 & Rizsföldek & Öntözött szántó & 35 & 42 & 35 & 20 & 30 & 32 \\
\hline 22111 & Nagytáblás szőlők & Szölö, gyümölcs & 50 & 63 & 50 & 50 & 60 & 55 \\
\hline 22112 & Kistáblás szőlők & Szölö, gyümölcs & 50 & 63 & 50 & 50 & 60 & 55 \\
\hline 2221 & Gyümölcsfa ültetvények & Szölö, gyümölcs & 50 & 63 & 50 & 50 & 60 & 55 \\
\hline 2222 & Bogyós ültetvények & Szölö, gyümölcs & 50 & 63 & 50 & 50 & 60 & 55 \\
\hline 2223 & Komló ültetvények & Szölö, gyümölcs & 50 & 63 & 50 & 50 & 60 & 55 \\
\hline 2226 & Füzfa ültetvények & Lombhullató erdő & 90 & 100 & 100 & 100 & 100 & 98 \\
\hline 2311 & $\begin{array}{c}\text { Intenzív legelők és erősen degradált gyepek bokrok } \\
\text { és fák nélkül }\end{array}$ & Legelő & 50 & 58 & 60 & 50 & 60 & 56 \\
\hline 2312 & $\begin{array}{c}\text { Intenzív legelők és erősen degradált gyepek fákkal } \\
\text { és bokrokkal }\end{array}$ & Legelö & 50 & 58 & 60 & 50 & 60 & 56 \\
\hline 2421 & Komplex müvelési szerkezet épületek nélkül & Komplex müv. szerk. & 60 & 63 & 55 & 50 & 60 & 58 \\
\hline 24221 & $\begin{array}{c}\text { Komplex müvelési szerkezet szórt elhelyezkedésü } \\
\text { épületekkel }\end{array}$ & Komplex müv. szerk. & 60 & 63 & 55 & 50 & 60 & 58 \\
\hline 24222 & Tanyák & Komplex müv. szerk. & 60 & 63 & 55 & 50 & 60 & 58 \\
\hline 2431 & $\begin{array}{c}\text { Mezőgazdasági területek túlsúlyban szántókkal és } \\
\text { jelentös természetes vegetációval }\end{array}$ & Mezőgazdasági terület & 50 & 63 & 55 & 50 & 65 & 57 \\
\hline
\end{tabular}




\begin{tabular}{|c|c|c|c|c|c|c|c|c|}
\hline $\begin{array}{l}\text { CLC } 50 \\
\text { Kódok }\end{array}$ & Területhasználat típusa & Egyszerüsített területh. & $\begin{array}{l}\text { Tiszta } \\
\text { levegő }\end{array}$ & Klímaszab. & $\begin{array}{l}\text { Víz } \\
\text { szab. }\end{array}$ & $\begin{array}{l}\text { Tiszta } \\
\text { víz }\end{array}$ & Talajerózió & $\begin{array}{l}\text { Környezeti } \\
\text { integritás* }\end{array}$ \\
\hline 2432 & $\begin{array}{l}\text { Mezőgazdasági területek túlsúlyban intenzív } \\
\text { legelökkel és jelentős természetes vegetációval }\end{array}$ & Mezőgazdasági terület & 50 & 63 & 55 & 50 & 65 & 57 \\
\hline 2433 & $\begin{array}{c}\text { Mezőgazdasági területek túlsúlyban szórt megjele- } \\
\text { nésü természetes vegetációval }\end{array}$ & Mezögazdasági terület & 50 & 63 & 55 & 50 & 65 & 57 \\
\hline 2434 & $\begin{array}{l}\text { Mezőgazdasági területek kis tavak jelentős rész- } \\
\text { arányával és szórt természetes vegetáció előfordu- } \\
\text { lásával }\end{array}$ & Mezőgazdasági terület & 50 & 63 & 55 & 50 & 65 & 57 \\
\hline 2435 & $\begin{array}{c}\text { Mezőgazdasági területek állandó kultúrák jelentős } \\
\text { előfordulásával, és szórt megjelenésü természetes } \\
\text { vegetációval }\end{array}$ & Mezőgazdasági terület & 50 & 63 & 55 & 50 & 65 & 57 \\
\hline 3111 & $\begin{array}{c}\text { Zárt lombkoronájú természetes lombhullató erdők } \\
\text { nem vizenyős területen }\end{array}$ & Lombhullató erdő & 90 & 100 & 100 & 100 & 100 & 98 \\
\hline 3112 & $\begin{array}{c}\text { Zárt lombkoronájú természetes lombhullató erdők, } \\
\text { vizenyős területen }\end{array}$ & Lombhullató erdő & 90 & 100 & 100 & 100 & 100 & 98 \\
\hline 3113 & $\begin{array}{c}\text { Nyilt lombkoronájú természetes lombhullató erdők } \\
\text { nem vizenyős területen }\end{array}$ & Lombhullató erdő & 90 & 100 & 100 & 100 & 100 & 98 \\
\hline 3114 & Nyilt lombkoronájú természetes lombhullató & Lombhullató erdő & 90 & 100 & 100 & 100 & 100 & 98 \\
\hline 3115 & Lombos erdő ültetvények & Lombhullató ültetvény & 90 & 100 & 100 & 100 & 100 & 98 \\
\hline 3121 & Zárt lombkoronájú természetes fenyőerdők & Örökzöld erdő & 100 & 95 & 100 & 90 & 100 & 97 \\
\hline 3125 & Tűlevelü ültetvények & Örökzöld ültetvény & 100 & 95 & 100 & 90 & 100 & 97 \\
\hline 3131 & $\begin{array}{c}\text { Szálanként elegyes természetes (lombos és fenyö) } \\
\text { erdök zárt lombkoronával }\end{array}$ & Vegyes erdő & 100 & 100 & 100 & 100 & 100 & 100 \\
\hline 3135 & $\begin{array}{c}\text { Csoportosan elegyes természetes (lombos és } \\
\text { fenyö) erdök zárt lombkoronával }\end{array}$ & Vegyes erdő & 100 & 100 & 100 & 100 & 100 & 100 \\
\hline 3139 & Elegyes ültetvények & Vegyes ültetvény & 100 & 100 & 100 & 100 & 100 & 100 \\
\hline 3211 & Természetes gyep fák és cserjék nélkül & Természetes gyep & 50 & 63 & 80 & 80 & 90 & 73 \\
\hline 3212 & Természetes gyep fákkal és cserjékkel & Természetes gyep & 50 & 63 & 80 & 80 & 90 & 73 \\
\hline 3241 & Fiatalos erdők és vágásterületek & $\begin{array}{l}\text { Átmeneti cserjés-erdős } \\
\text { ter. }\end{array}$ & 70 & 68 & 75 & 80 & 95 & 78 \\
\hline 3243 & Spontán cserjésedő-erdősödő területek & $\begin{array}{l}\text { Átmeneti cserjés-erdős } \\
\text { ter. }\end{array}$ & 70 & 68 & 75 & 80 & 95 & 78 \\
\hline 3244 & Csemetekertek, erdei faiskolák & $\begin{array}{l}\text { Átmeneti cserjés-erdős } \\
\text { ter. }\end{array}$ & 70 & 68 & 75 & 80 & 95 & 78 \\
\hline 3245 & Károsodott erdők & $\begin{array}{l}\text { Átmeneti cserjés-erdős } \\
\text { ter. }\end{array}$ & 70 & 68 & 75 & 80 & 95 & 78 \\
\hline 3313 & Folyópartok & Vízfolyás, állóvíz & 20 & 68 & 70 & 45 & 0 & 41 \\
\hline 3321 & Csupasz sziklák & Csupasz szikla & 0 & 0 & 0 & 0 & 0 & 0 \\
\hline 3331 & Ritkás növényzet homokon vagy löszön & Ritkás, term. növényzet & 50 & 63 & 80 & 85 & 80 & 72 \\
\hline 3332 & Ritkás növényzet közetkibúvásokon & Ritkás, term. növényzet & 50 & 63 & 80 & 85 & 80 & 72 \\
\hline 3333 & Ritkás növényzet szikes területeken & Ritkás, term. növényzet & 50 & 63 & 80 & 85 & 80 & 72 \\
\hline 3341 & Leégett területek & Leégett terület & 0 & 0 & 0 & 0 & 0 & 0 \\
\hline 4111 & Édesvizű mocsarak & Láp, mocsár & 50 & 63 & 90 & 85 & 90 & 76 \\
\hline 4113 & Szikes mocsarak & Láp, mocsár & 50 & 63 & 90 & 85 & 90 & 76 \\
\hline 4121 & Tőzeglápok kitermelés alatt & Láp, mocsár & 50 & 63 & 90 & 85 & 90 & 76 \\
\hline 4122 & $\begin{array}{c}\text { Természetes tőzeglápok bokrok és fák szórványos } \\
\text { előfordulásával }\end{array}$ & Láp, mocsár & 50 & 63 & 90 & 85 & 90 & 76 \\
\hline 5111 & Folyóvizek & Vizfolyás, állóvíz & 20 & 68 & 70 & 45 & 0 & 41 \\
\hline 5112 & Csatornák & Vízfolyás, állóvíz & 20 & 68 & 70 & 45 & 0 & 41 \\
\hline 51211 & Állandó vizű természetes tavak & Vizfolyás, állóvíz & 20 & 68 & 70 & 45 & 0 & 41 \\
\hline 51212 & Természetes, időszakos, szikes tavak & Vizfolyás, állóvíz & 20 & 68 & 70 & 45 & 0 & 41 \\
\hline 51221 & Mesterséges tavak, víztározók & Vizfolyás, állóvíz & 20 & 68 & 70 & 45 & 0 & 41 \\
\hline 51222 & Halastavak & Vízfolyás, állóvíz & 20 & 68 & 70 & 45 & 0 & 41 \\
\hline
\end{tabular}

* alapértékek (Tiszta levegő, Klímaszab...) átlaga 
Tájfunkciók területhasználatok alapján (saját szerkesztés, alaptérkép Corine 100)

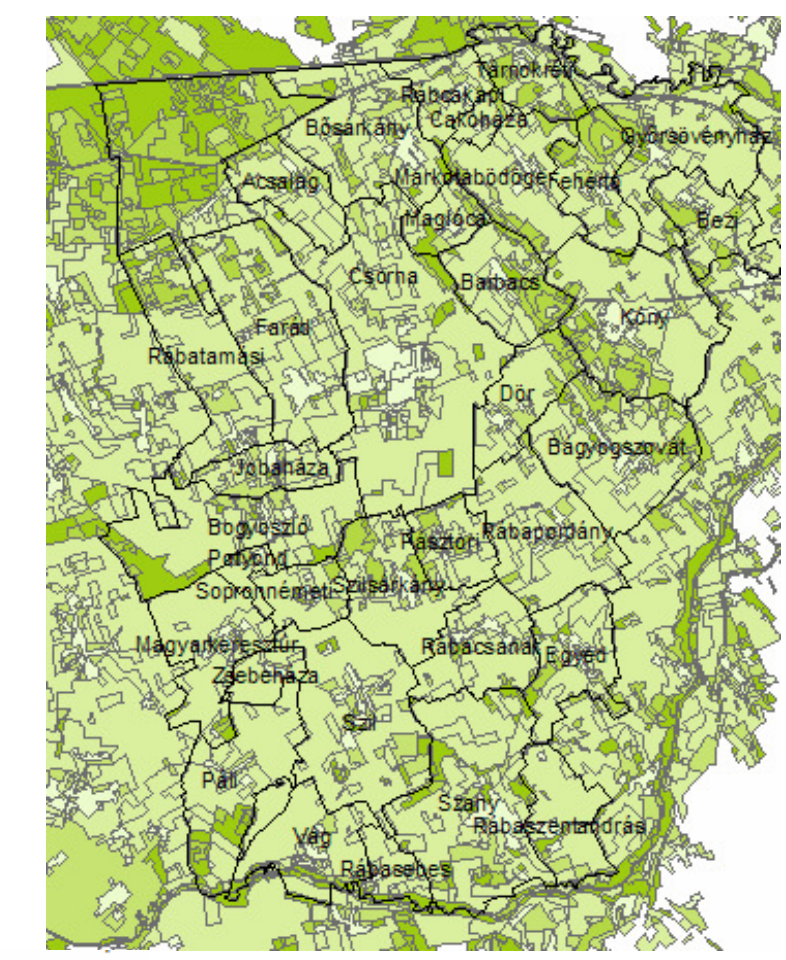

$\square 0-10$

$\square$ 11- 41

$\square 42-58$

$\square 59-78$

$\square 79-100$

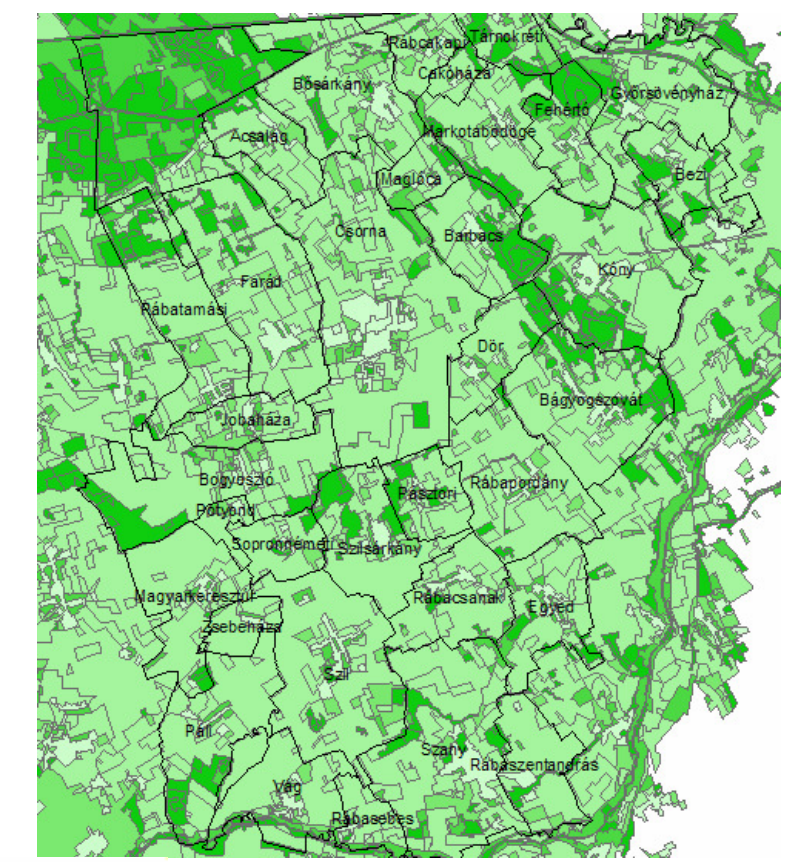

$\square 0-5$

$\square-30$

$\square 31-63$

Rekreációs érték

$64-74$

$75-100$

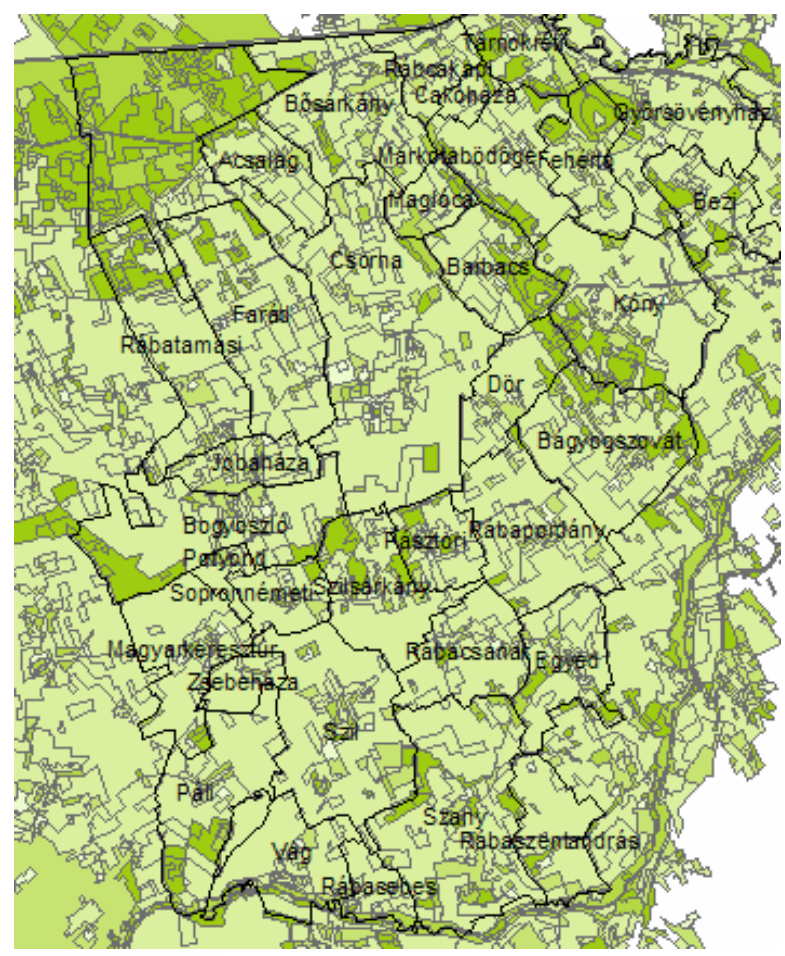

$\square 0,00-6,00$

$\square 6,01-44,00$
$\square 44,01-61,00$
$\square 61,01-80,00$
$\square 80,01-100,00$$\quad$ Élöhely érték

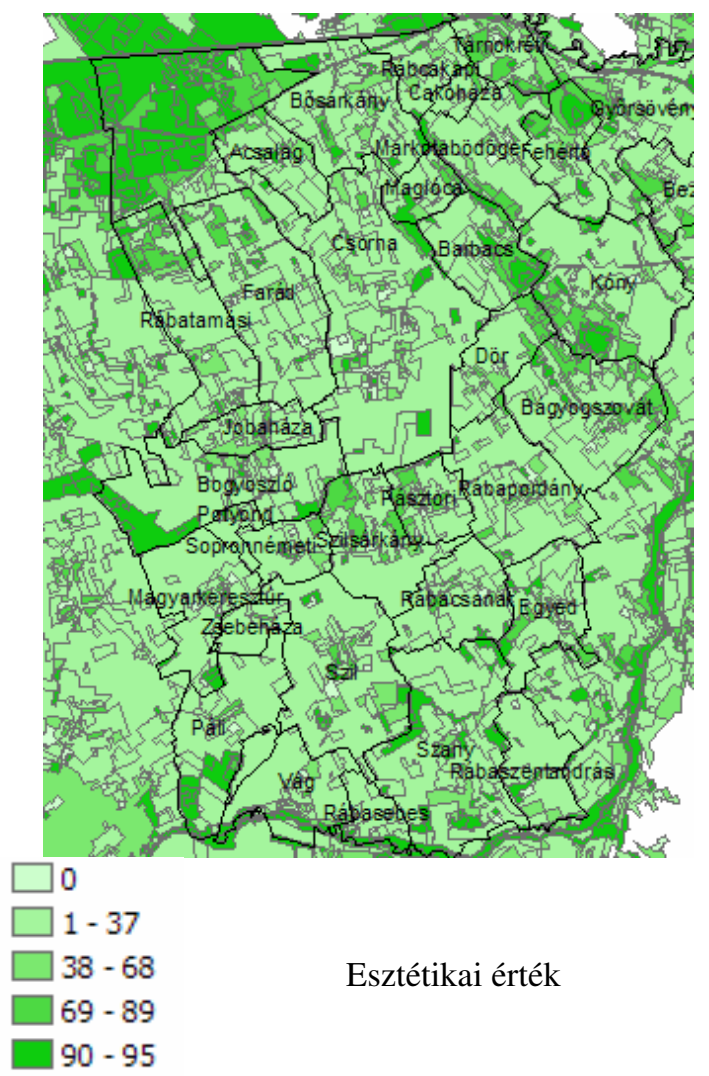


Mezőgazdasági termesztési érték (saját szerkesztés)

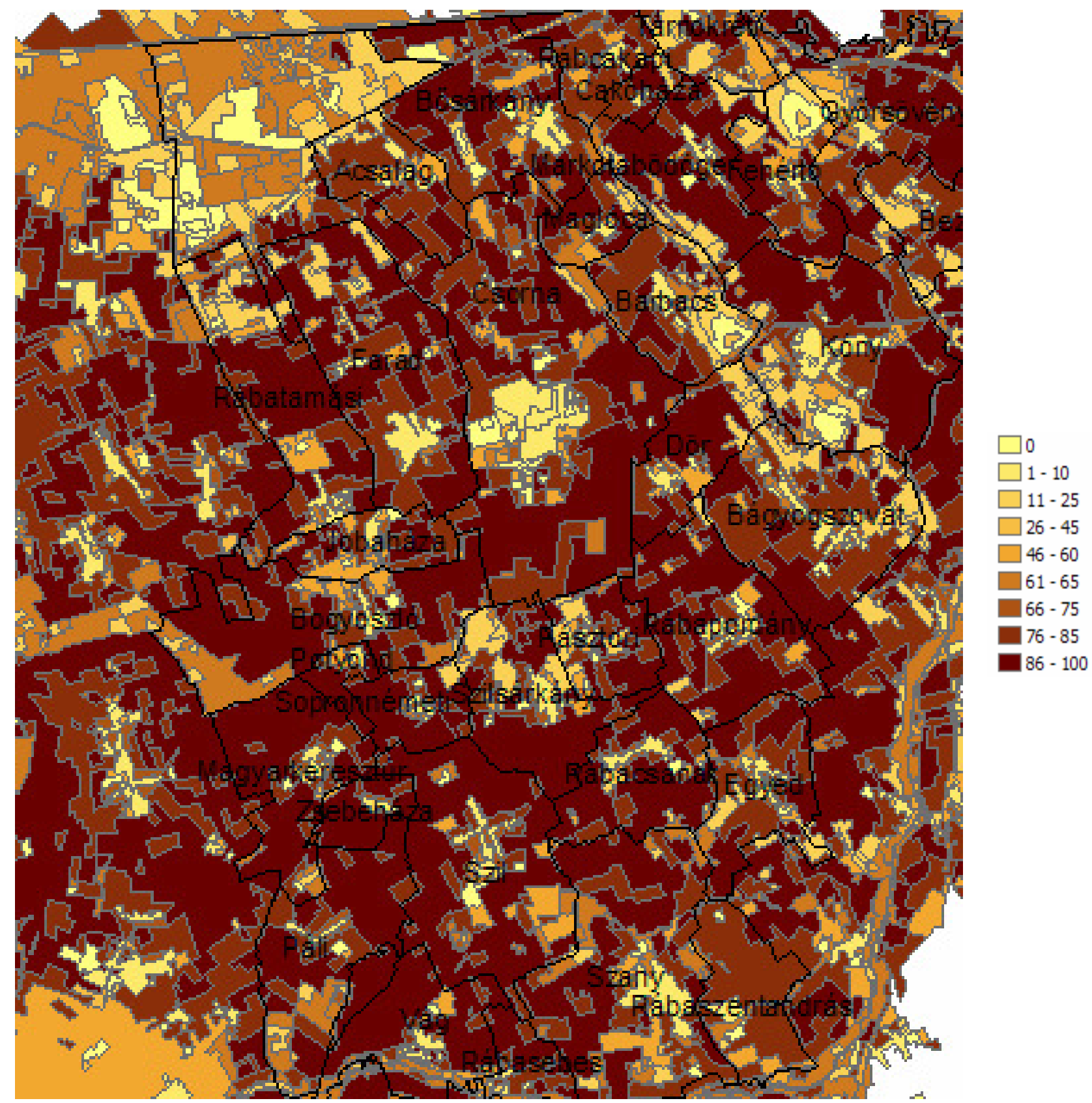




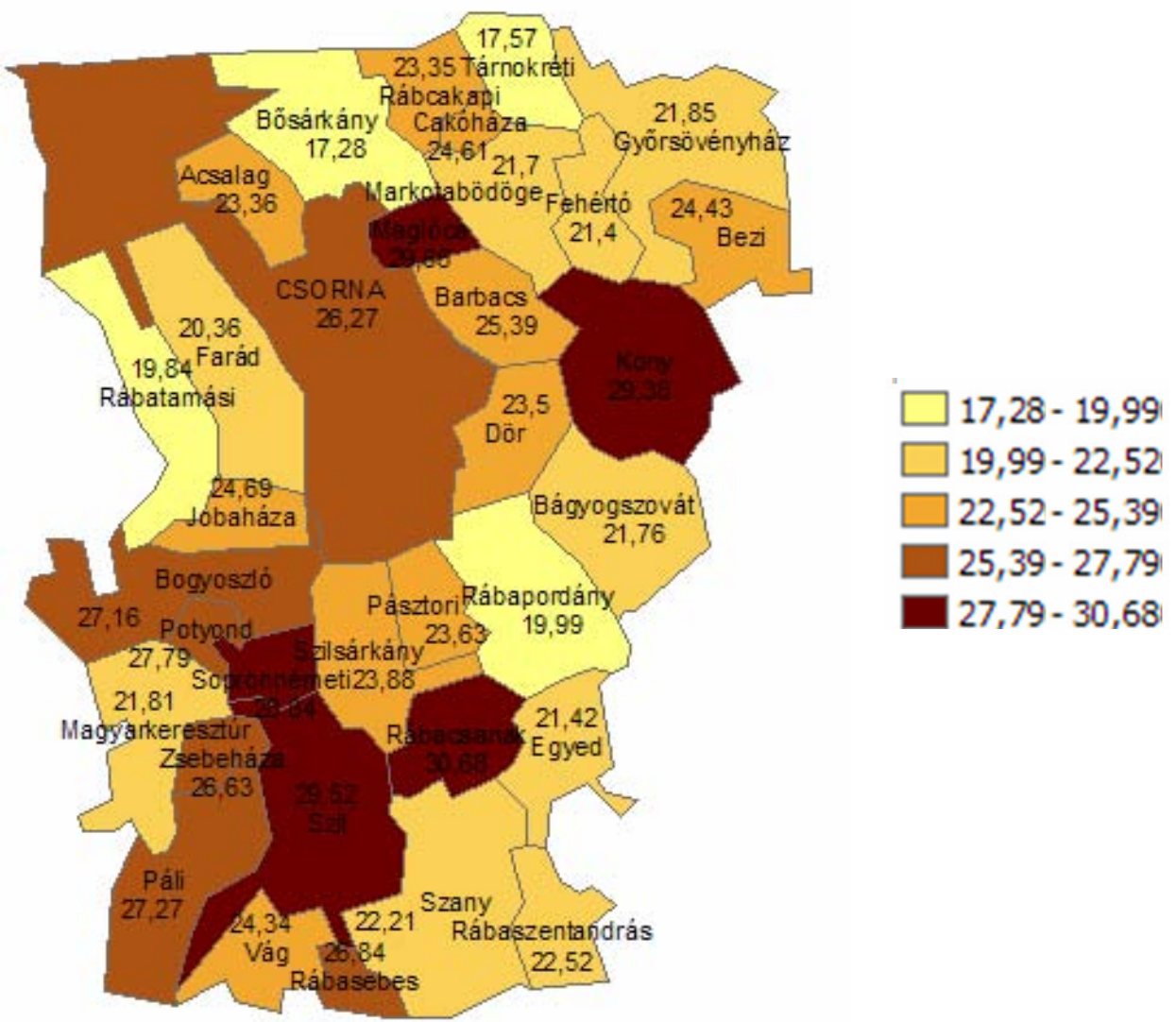

Szántók aranykorona értéke (saját szerkesztés, adatok forrása: TEIR)

XIX. melléklet

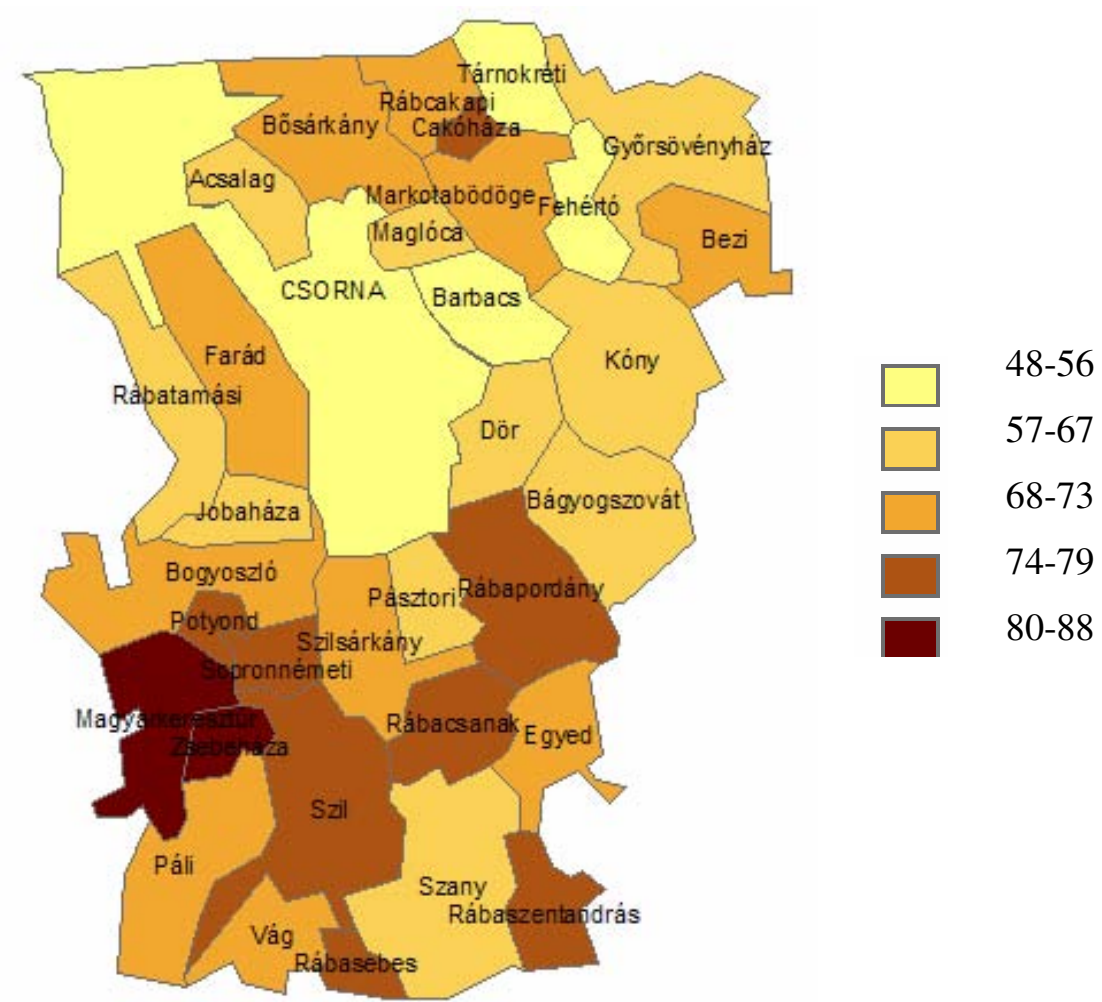

Szántók aránya (\%) a településeken (saját szerkesztés, adatok forrása: TEIR) 


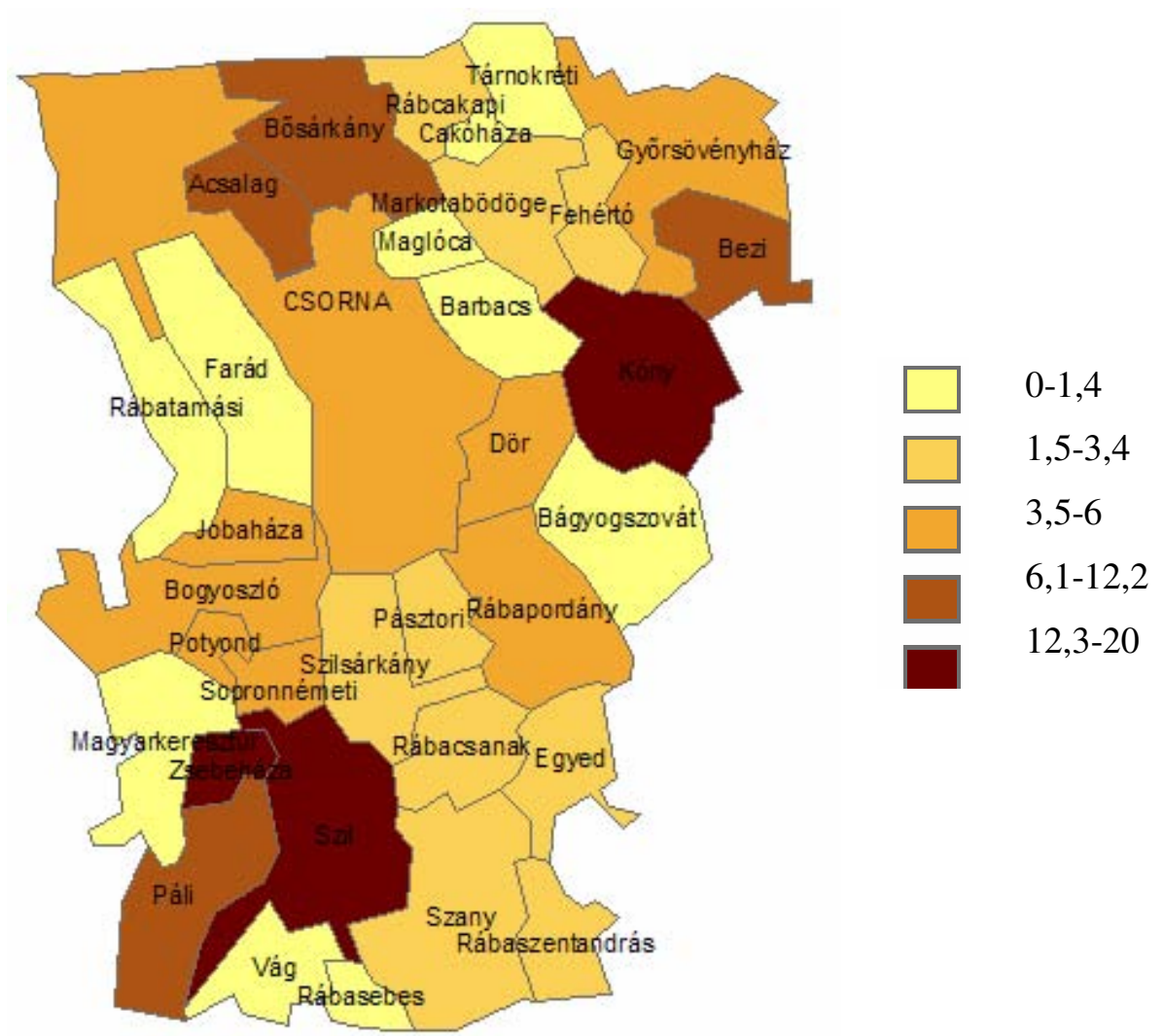

Öntözhető területek aránya a mezőgazdasági terület százalékában (saját szerkesztés, adatok forrása: TEIR)

XXI. melléklet

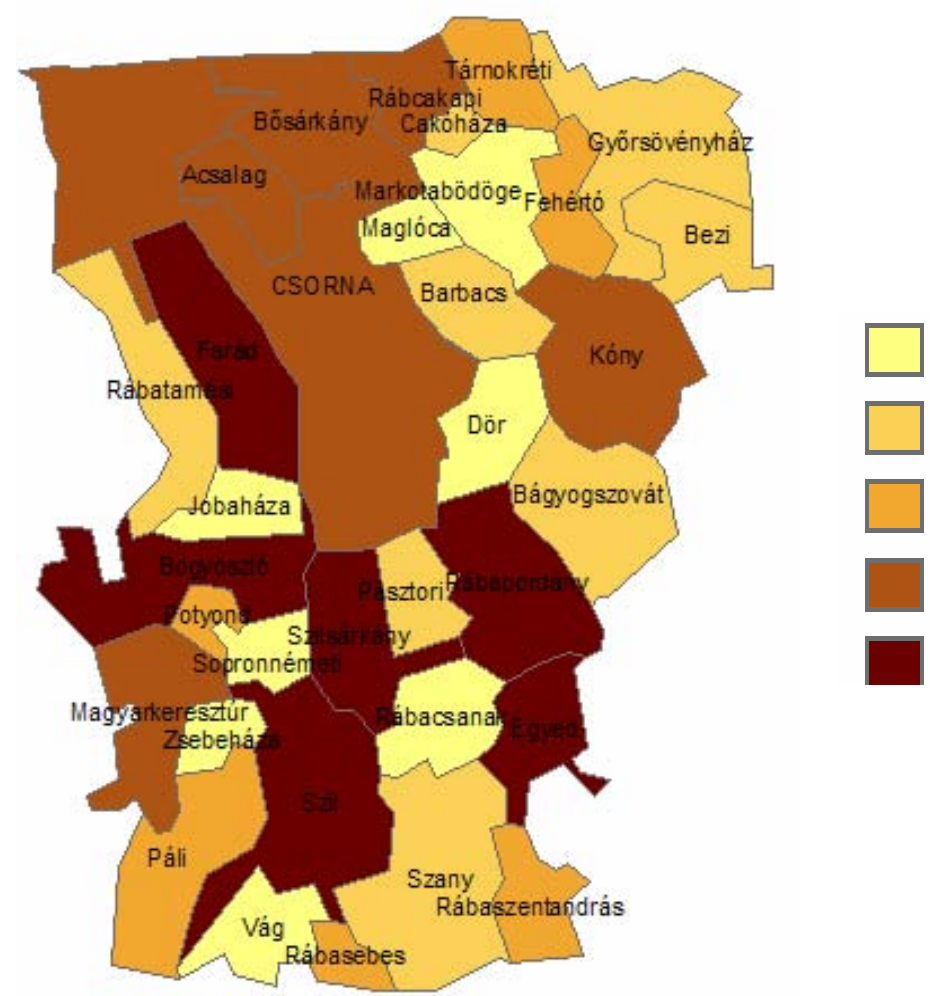

$2-10$

11-19

20-30

31-50

51-79

Szarvasmarha sürüség db/100 ha (saját szerkesztés, adatok forrása: TEIR) 


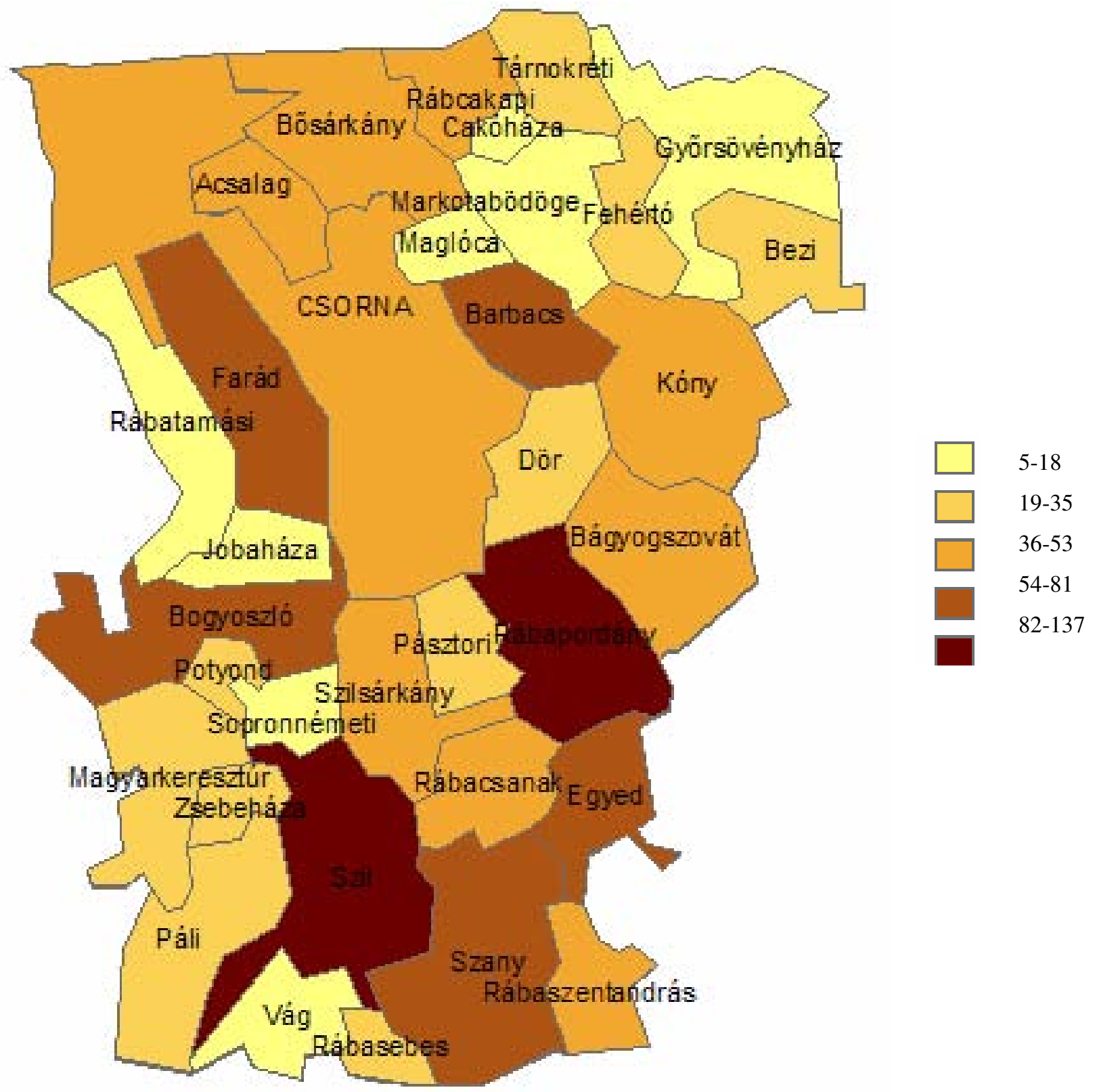

Számosállat sűrüség db/100 ha (saját szerkesztés, adatok forrása: TEIR) 
Termesztési érték (saját szerkesztés)

\begin{tabular}{|c|c|c|c|c|c|c|c|c|c|c|c|c|}
\hline Megnevezés & 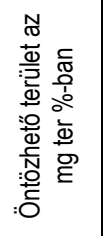 & 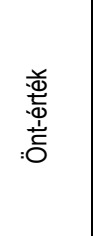 & 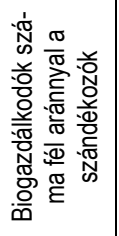 & 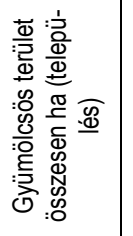 & 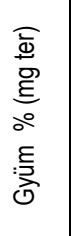 & $\begin{array}{l}\text { 岀 } \\
\text { 志 }\end{array}$ & 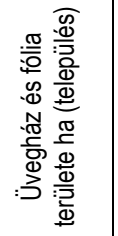 & 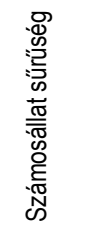 & 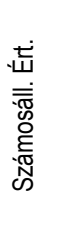 & 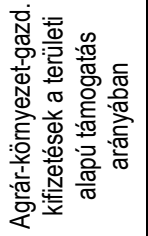 & 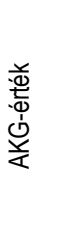 & 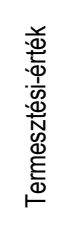 \\
\hline Acsalag & 7,6 & 4,0 & 0,5 & ,02 & , &, &, 14 & 49, & 4 & 12,00 & 5 & 5,45 \\
\hline Bágyogszovát & 0,1 & 1,0 & 0,0 & ,86 & ,04 & , & ,08 & 47, & 4 & 4,30 & 2 & 5,00 \\
\hline Barbacs & 0,1 & 1,0 & 0,5 & ,39 & ,04 & , & ,06 & 76 & 7 & 4,00 & 2 & 5,80 \\
\hline Bezi & 12,2 & 8,0 & 2,5 & ,55 & ,05 & 1, & ,08 & 23 & 2 & 20,00 & 6 & 5,55 \\
\hline Bogyoszló & 4,6 & 3,0 & 0,5 & 24, & 1,2 & 4, &, 11 & 62 & 6 & 0,60 & 0 & 6,10 \\
\hline Bősárkány & 8,1 & 5,0 & 0,0 & 1,61 & ,08 & 1, &, 01 & 45, & 4 & 9,00 & 3 & 5,90 \\
\hline Cakóháza & 0,0 & 0,0 & 0,0 & & , & , & , & 18 & 1 & 1,00 & 1 & 4,05 \\
\hline Csorna & 4,4 & 3,0 & 11,0 & 19,29 & ,3 & 3 & ,54 & 42 , & 4 & 11,00 & 4 & 4,65 \\
\hline Dör & 6,0 & 4,0 & 0,0 & 6,91 &, 7 & 4, & ,0024 & 31 , & 3 & 0,00 & 0 & 5,00 \\
\hline Egyed & 2,3 & 2,0 & 0,5 & 3,53 & ,3 & 3 & ,04 & 81 , & 10 & 5,00 & 2 & 8,05 \\
\hline Farád & 1,2 & 1,0 & 0,0 & 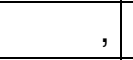 & , & , & ,0093 & 64, & 6 & 12,00 & 5 & 6,35 \\
\hline Fehértó & 3,1 & 2,0 & 0,5 &, 41 & ,05 & 1, &, 11 & 29 , & 2 & 28,00 & 6 & 3,75 \\
\hline Győrsövényház & 3,9 & 2,0 & 0,0 & 2,53 &, 13 & 2 & ,04 & 18, & 1 & 49,00 & 7 & 4,25 \\
\hline Jobaháza & 5,4 & 3,0 & 0,0 & ,37 & ,05 & 1, &, 0062 & 13, & 1 & 0,00 & 0 & 3,95 \\
\hline Kóny & 14,1 & 8,0 & 6,5 & 31,11 & ,4 & 3 & ,6 & 44, & 4 & 9,00 & 3 & 5,90 \\
\hline Maglóca & 0,0 & 0,0 & 0,0 & & , & , & , & 12 , & 1 & 47,00 & 7 & 3,55 \\
\hline Magyarkeresztúr & 1,0 & 1,0 & 0,0 & 2,86 & ,2 & 2, & , & 34, & 3 & 0,30 & 0 & 5,40 \\
\hline Markotabödöge & 3,3 & 2,0 & 0,0 & , 16 & 01 & , & ,02 & 17, & 1 & 12,00 & 5 & 4,45 \\
\hline Páli & 9,3 & 6,0 & 0,0 & ,36 & ,02 & 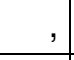 &, 0015 & 35, & 3 & 2,90 & 1 & 5,45 \\
\hline Pásztori & 2,1 & 2,0 & 0,5 &, & , & , & & 25 , & 2 & 7,00 & 3 & 4,35 \\
\hline Potyond & 3,8 & 2,0 & 0,0 &, 5 & ,2 & 2 &, 01 & 30 , & 3 & 25,00 & 6 & 5,40 \\
\hline Rábacsanak & 1,9 & 1,0 & 0,0 & 4,01 & ,3 & 3 & ,02 & 38, & 3 & 1,00 & 1 & 5,10 \\
\hline Rábapordány & 4,8 & 3,0 & 0,0 & 3,91 & ,2 & 2 & ,04 & 137 & 10 & 4,00 & 2 & 8,10 \\
\hline Rábasebes & 0,0 & 0,0 & 0,0 & 1,85 & ,4 & 3 &, 0015 & 32 , & 3 & 31,00 & 6 & 5,25 \\
\hline Rábaszentandrás & 3,0 & 2,0 & 0,0 & 1,17 &, 12 & 2 &, 0082 & 45 , & 4 & 53,00 & 7 & 5,85 \\
\hline Rábatamási & 0,6 & 1,0 & 0,0 & ,87 &, 05 & 1, &, 0093 & 18, & 1 & 0,00 & 0 & 3,75 \\
\hline Rábcakapi & 1,8 & 1,0 & 0,0 & 31 &, 05 & 1, & & 45 , & 4 & 6,00 & 3 & 5,50 \\
\hline Sopronnémeti & 5,2 & 3,0 & 0,0 & 60 & 10 & 10 & ,01 & 5 , & 0 & 45,00 & 7 & 4,75 \\
\hline Szany & 3,4 & 2,0 & 0,5 & ,81 & ,03 & , & ,05 & 68, & 6 & 6,60 & 3 & 5,95 \\
\hline Szil & 20,0 & 10,0 & 0,0 & 3,48 &, 13 & 2 & ,05 & 116 & 10 & 5,80 & 3 & 8,85 \\
\hline Szilsárkány & 2,0 & 2,0 & 1,0 & 17,85 & ,23 & 3 &, 0026 & 53 & 5 & 25,00 & 6 & 6,25 \\
\hline Tárnokréti & 0,4 & 1,0 & 0,5 & 7,11 & ,9 & 4 & & 25 , & 2 & 16,60 & 5 & 3,75 \\
\hline Vág & 1,4 & 1,0 & 1,0 & 2,35 & ,2 & 2 &, 0046 & 8, & 0 & 70,00 & 10 & 4,30 \\
\hline Zsebeháza & 17,7 & 9,0 & & ,06 &, 01 & , & & 22 , & 2 & 46,00 & 7 & 6,05 \\
\hline
\end{tabular}




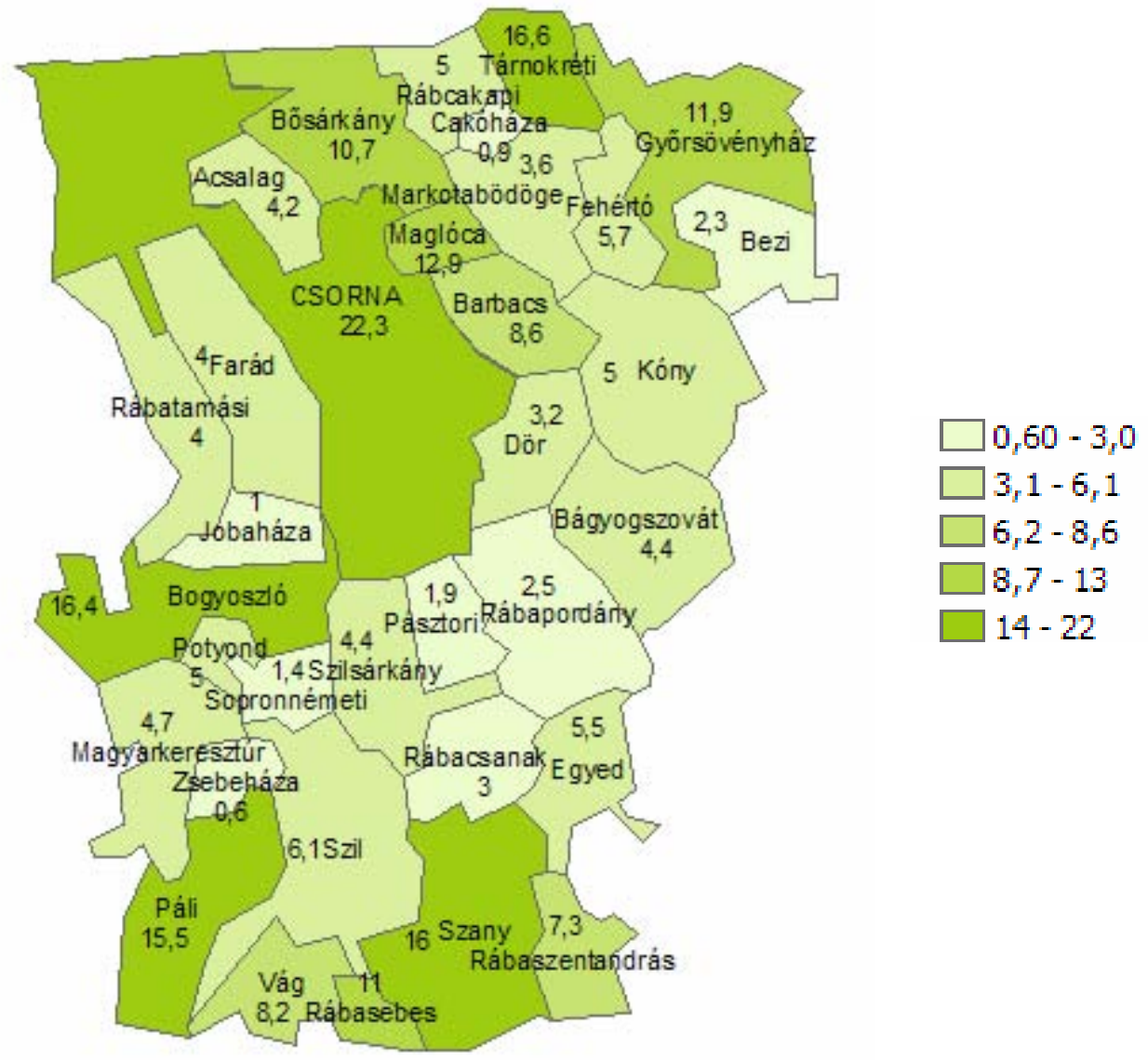

Az erdősültség aránya a kistérség településein (saját szerkesztés, adatok forrása: TEIR)

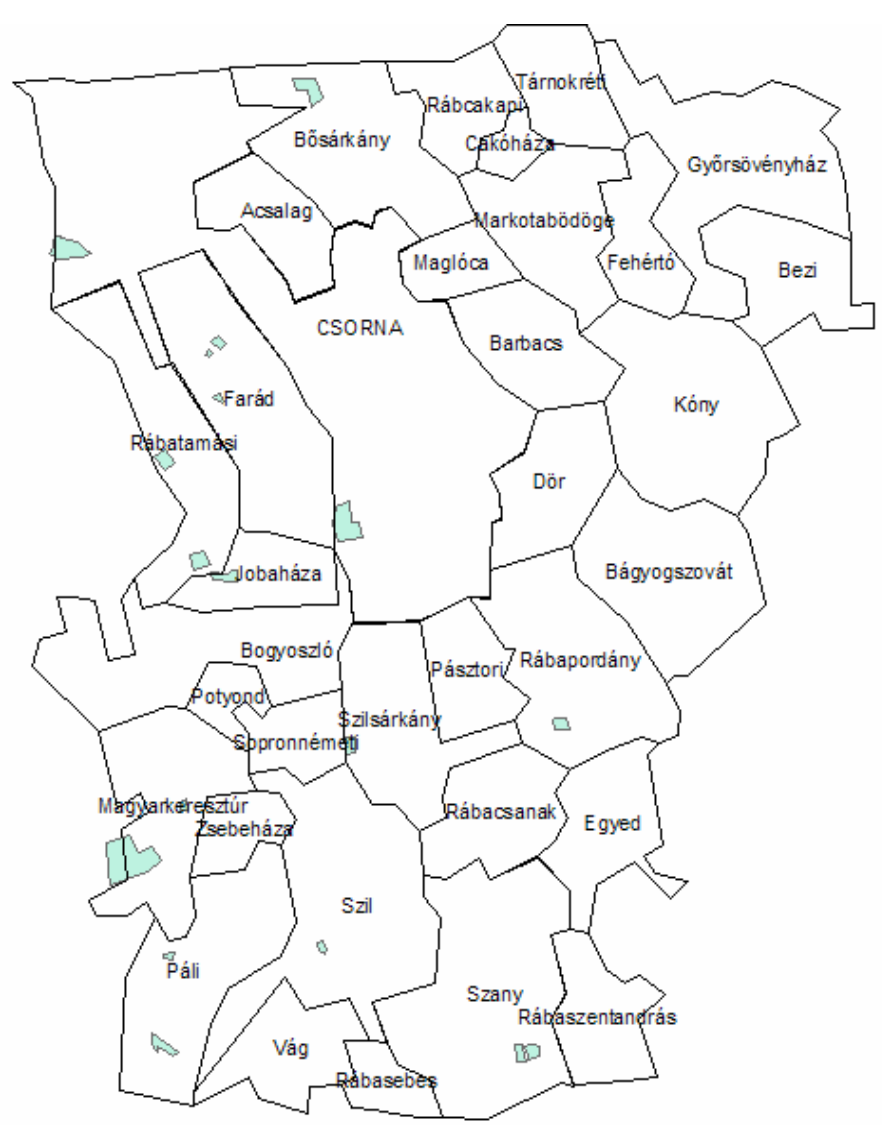

XXV. melléklet

Müködő és felhagyott bányák a Csornai kistérségben (saját szerkesztés, adatok forrása: TEIR) 
Gazdasági érték (saját szerkesztés)

\begin{tabular}{|c|c|c|c|c|c|c|c|c|c|c|c|c|}
\hline Megnevezés & 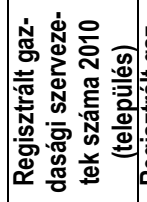 & 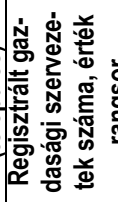 & & 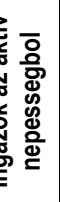 & 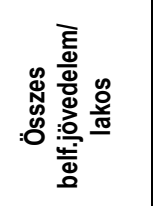 & 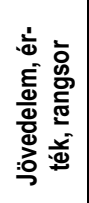 & 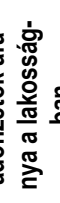 & 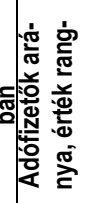 & & 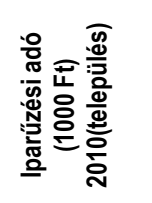 & 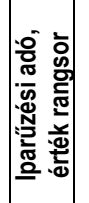 & 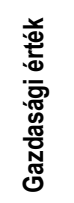 \\
\hline Acsalag & 91, & 2 & 2 & 41 & 542318 & 3 & 42 & 2 & 2 & & 0 & 2,15 \\
\hline Bágyogszovát & 304 & 5 & 5 & 43 & 711763 & 5 & 48 & 5 & 5, & 10189 , & 3 & 4,8 \\
\hline Barbacs & 82, & & 2 & 50 & 623632 & 3 & 44 & 3 & 3, & 3249 & 2 & 2,7 \\
\hline Bezi & 91, & & 2 & 51, & 701595 & 5 & 49 & 6 & 6, & 7419, & 2 & 4,45 \\
\hline Bogyoszló & 178 & & 4 & 35 & 709457 & 5 & 47 & 5 & 5, & 6163 & 2 & 4,5 \\
\hline Bösárkány & 296 & & 5 & 44 & 826455 & 7 & 52 & 7 & 7 & 11418 & 3 & 6,2 \\
\hline Cakónáza & 12, & & 1 & 50 & 623504 & 3 & 55 & 8 & 8, & & 0 & 4,05 \\
\hline Csorna & 1866 & & 9 & 23 & 873190 & 8 & 52 & 7 & 7 , & 280142 & 8 & 7,85 \\
\hline Dör & 130 & & 3 & 49 & 580530 & 3 & 44 & 3 & 3 & 1724 & 2 & 2,9 \\
\hline Egyed & 170 & & 4 & 35 & 704617 & 5 & 54 & 8 & 8, & 1488 & 2 & 5,55 \\
\hline Farád & 334 & & 5 & 43 & 692997 & 4 & 49 & 6 & 6, & 9971, & 2 & 4,7 \\
\hline Fehértó & 110 & & 3 & 47, & 672325 & 4 & 47 & 5 & 5 & & 0 & 3,75 \\
\hline Györsövényház & 110 & & 3 & 51 & 836171 & 7 & 51 & 7 & 7 & 1506 & 2 & 5,7 \\
\hline Jobaháza & 94 & & 2 & 40 & 624688 & 3 & 40 & 2 & 2 & 3535 & 2 & 2,35 \\
\hline Kóny & 386 & & 6 & 46 & 812336 & 7 & 51 & 7 & 7 , & 29 421, & 3 & 6,4 \\
\hline Maglóca & 21 & & 1 & 31 & 317011 & 2 & 34 & 1 & 1, & & 0 & 1,25 \\
\hline Magyarkeresztúr & 85 & & 2 & 34 & 634610 & 3 & 47 & 5 & 5, & 1892 & 2 & 3,4 \\
\hline Markotabödöge & 67 & 1 & 1 & 49 & 665164 & 4 & 44 & 3 & 3 & & 0 & 2,65 \\
\hline Páli & 125 & 3 & 3 & 20 & 487364 & 2 & 43 & 3 & 3 & 1514 & 2 & 2,55 \\
\hline Pásztori & 41 & & 1 & 31 & 565700 & 3 & 39 & 1 & 1, & 379 & 1 & 1,7 \\
\hline Potyond & 28 & & 1 & 60 & 658561 & 4 & 46 & 4 & 4 & 329 & 1 & 3,1 \\
\hline Rábacsanak & 154 & & 4 & 27 & 636789 & 3 & 48 & 5 & 5, & 3167 & 2 & 3,8 \\
\hline Rábapordány & 258 & 5 & 5 & 38 & 838459 & 7 & 49 & 6 & 6, & 8745 & 2 & 5,75 \\
\hline Rábasebes & 30 & 1 & 1 & 39 & 420328 & 2 & 40 & 2 & 2 & 359 & 1 & 1,7 \\
\hline Rábaszentandrás & 136 & & 3 & 45 & 566052 & 3 & 46 & 4 & 4 & 2010 & 2 & 3,25 \\
\hline Rábatamási & 157 & 4 & 4 & 47 & 739431 & 6 & 47 & 5 & 5, & 3767 & 2 & 4,85 \\
\hline Rábcakapi & 51 & 1 & 1 & 33 & 773466 & 6 & 54 & 8 & 8 & & 0 & 5,1 \\
\hline Sopronnémeti & 90 & 2 & 2 & 43 & 641214 & 4 & 47 & 5 & 5, & 1343, & 2 & 3,75 \\
\hline Szany & 500 & 7 & 7 & 20 & 667188 & 4 & 45 & 4 & 4 & 86592 & 5 & 4,7 \\
\hline Szil & 456 & 7 & 7 & 24 & 646291 & 4 & 46 & 4 & 4, & 17327 & 3 & 4,5 \\
\hline Szilsárkány & 141 & 4 & 4 & 40 & 797729 & 6 & 51 & 7 & 7 & 5522, & 2 & 5,55 \\
\hline Tárnokréti & 36 & 1 & 1 & 29 & 605003 & 3 & 41 & 2 & 2 & 222 & 1 & 2,05 \\
\hline Vág & 101, & & 3 & 42 & 711556 & 5 & 45 & 4 & 4 & 1903 & 2 & 3,95 \\
\hline Zsebeháza & 50 & 1 & 1 & 56 , & 701314 & 5 & 47 & 5 & 5, & 694 & 1 & 3,8 \\
\hline
\end{tabular}


Védett területek rendszere a Csornai-kistérségben

(Forrás: TEIR, http://arcgis.vati.hu:81/teirgis_termeszetvedelem/)

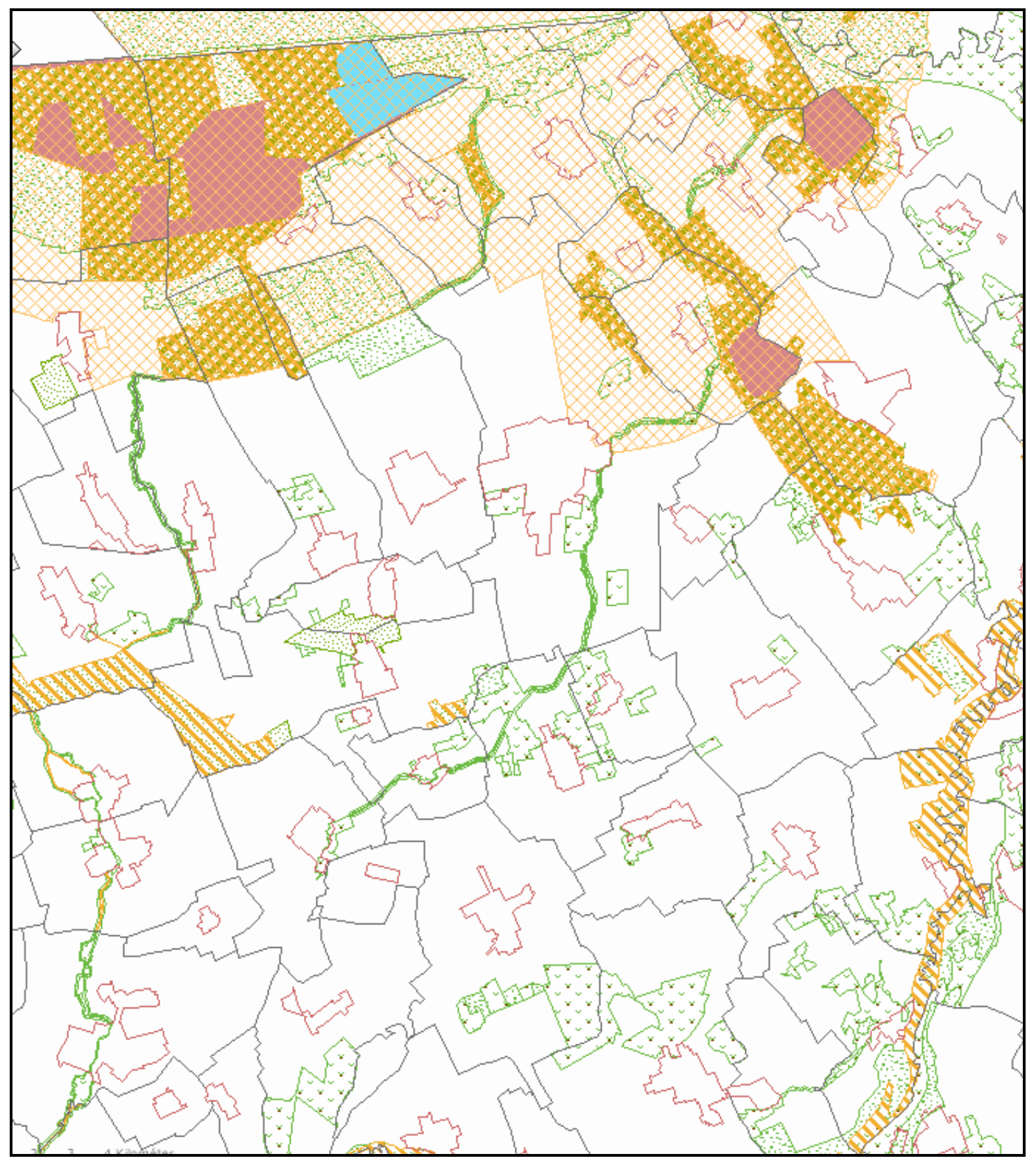

Természetvédelmi terület

MAB bioszféra rezervátum

Natura 2000 SCI

Natura 2000 SPA

Ramsar terület

Nemzeti Ökológiai Hálózat 
Élőhely érték (saját szerkesztés)

\begin{tabular}{|c|c|c|c|c|c|c|c|c|c|}
\hline Megn & 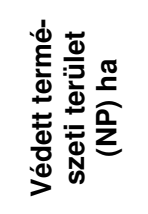 & 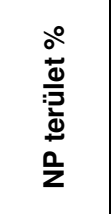 & 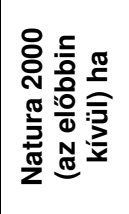 & 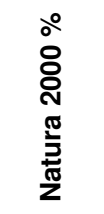 & 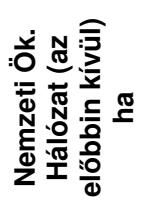 & $\begin{array}{l}\stackrel{\circ}{\grave{2}} \\
\text { ò }\end{array}$ & 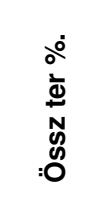 & 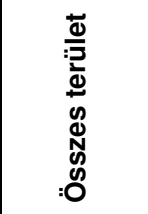 & 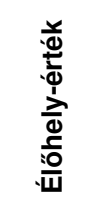 \\
\hline Acsalag & 0,00 & 0,00 & 16,55 & 1,59 & 177,96 & 17,10 & 18,68 & 1041,00 & 4,00 \\
\hline Bágyogs & 0,00 & 0,00 & 224,00 & 9,31 & 344,30 & 14,31 & 23,62 & 2406,00 & 5,00 \\
\hline Barbacs & 500,30 & 36,65 & 0,00 & 0,00 & 68,20 & 5,00 & 41,65 & 1365,00 & 10,00 \\
\hline Bezi & 0,00 & 0,00 & 0,00 & 0,00 & 163,66 & 14,59 & 14,59 & 1122,00 & 4,00 \\
\hline Bogyoszló & 0,00 & 0,00 & 362,00 & 13,81 & 189,30 & 7,22 & 21,03 & 2621,00 & 4,00 \\
\hline Bösá & 0,00 & 0,00 & 118,32 & 5,07 & 805,33 & 34,52 & 39,59 & 2333,00 & 6,00 \\
\hline Cakóház & 0,00 & 0,00 & 0,00 & 0,00 & 59,56 & 20,68 & 20,68 & 288,00 & 4,00 \\
\hline Csorr & 2700,00 & 29,43 & 154,00 & 1,68 & 266,00 & 2,90 & 34,01 & 9173,00 & 10,00 \\
\hline Dör & 69,41 & 15,39 & 0,00 & 0,00 & & 0,00 & 15,39 & 1101,00 & 7 \\
\hline Egye & 0,00 & 0,00 & 0,00 & 0,00 & 190,00 & 14,15 & 14,15 & 1343,00 & 3,00 \\
\hline Fará & 0,00 & 0 & 0,00 & 0,00 & 1007,00 & 34,70 & 34,70 & 00 & 6,00 \\
\hline Fehértó & 0,00 & 0,00 & 483,75 & 42,51 & & 0,00 & 42,51 & 1138,00 & 8 \\
\hline Győrsövé & 71,20 & 2,94 & 21,00 & 0,87 & 141,56 & 5,85 & 9,66 & 2421,00 & 2,00 \\
\hline Jobaháza & 0,00 & 0,00 & 0,00 & 0,00 & 108,00 & 13,40 & 13,40 & 806,00 & 3,00 \\
\hline Kóny & 442,37 & 15,32 & 135,49 & 4,69 & & 0,00 & 20,01 & 2888,00 & 7 \\
\hline Maglóca & 116,95 & 20,27 & 63,00 & 10,92 & 30,00 & 5,20 & 36,39 & 577,00 & 10,00 \\
\hline Magyarke & 0,00 & 0,00 & 0,00 & 0,00 & 66,00 & 3,94 & 3,94 & 1674,00 & 1,00 \\
\hline Markc & 0,00 & 0,00 & 267,42 & 16,42 & 144,66 & 8,88 & 25,30 & 1629,00 & 6,00 \\
\hline Páli & 0,00 & 0 & 51,00 & 2,60 & 329,00 & 16,80 & 19,41 & 1958,00 & 4,00 \\
\hline Pásztori & 0,00 & 0 & 0,00 & 0,00 & 80 & 20,87 & 20,87 & 00 & 4,00 \\
\hline Potyond & 00 & 0 & 0,00 & 0 & 94 & 2 & 02 & 00 & 2,00 \\
\hline Rábacsc & 0,00 & 0 & 0,00 & 0 & 39,36 & 2,84 & 2,84 & 00 & 0,00 \\
\hline Rábapordán & 0,00 & 0 & 0,00 & 0,00 & 49,92 & 2,28 & 2,28 & 2189,00 & 0,00 \\
\hline Rábasebes & 0,00 & 0,00 & 0,00 & 0,00 & 76,30 & 14,16 & 14,16 & 539,00 & 3,00 \\
\hline Rábaszentan & 0,00 & 0,00 & 28,38 & 2,45 & 202,50 & 17,46 & 19,90 & 1160,00 & 4,00 \\
\hline Rábatamási & 0,00 & 0,00 & 415,00 & 19,07 & 176,80 & 8,13 & 27,20 & 2176,00 & 6,00 \\
\hline Rábcakapi & 0,00 & 0,00 & 0,00 & 0,00 & 228,20 & 29,00 & 29,00 & 787,00 & 5,00 \\
\hline Sopronn & 0,00 & 0,00 & 0,00 & 0,00 & 87,62 & 12,36 & 12,36 & 709,00 & 3,00 \\
\hline Szany & 0,00 & 0,00 & 0,00 & 0,00 & 501,60 & 14,70 & 14,70 & 3413,00 & 4,00 \\
\hline Szil & 0,00 & 0,00 & 0,00 & 0,00 & 411,00 & 13,25 & 13,25 & 3103,00 & 3,00 \\
\hline Szilsárkány & 0,00 & 0,00 & 0,00 & 0,00 & 393,65 & 23,60 & 23,60 & 1668,00 & 4,00 \\
\hline Tárnokréti & 0,00 & 0,00 & 522,97 & 54,82 & 105,40 & 11,05 & 65,87 & 954,00 & 8,00 \\
\hline Vág & 0,00 & 0,00 & 111,75 & 7,97 & 0,00 & 0,00 & 7,97 & 1403,00 & 3,00 \\
\hline Zsebeháza & 0,00 & 0,00 & 0,00 & 0,00 & 0,00 & 0,00 & 0,00 & 465,00 & 0,00 \\
\hline
\end{tabular}


Extenzív területek aránya (saját szerkesztés, adatok forrása: TEIR)

\begin{tabular}{|c|c|c|c|c|c|c|c|c|c|c|c|c|}
\hline 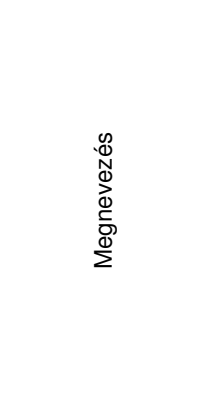 & 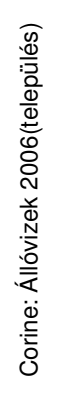 & 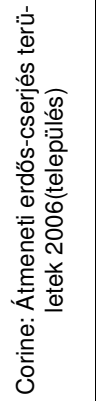 & 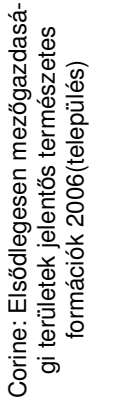 & 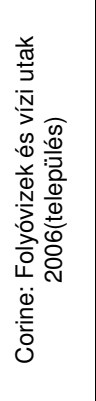 & 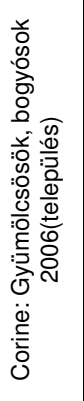 & 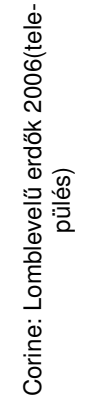 & 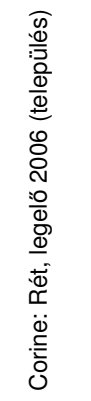 & 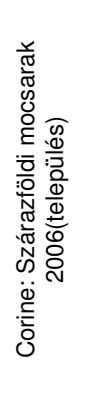 & 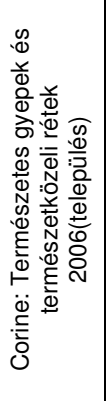 & 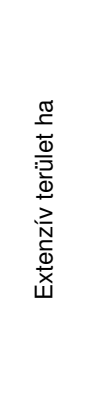 & 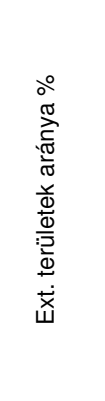 & 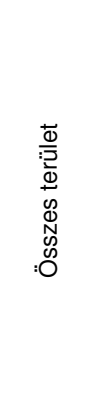 \\
\hline Acsalag & , & , & , & , & , & , & 107,11 & , & 90,08 & 197,19 & 18,9424 & 1041,00 \\
\hline Bágyogszovát & , & , & 35,08 & , & , & 53,5 & 8,66 & ,06 & 434,84 & 532,14 & 22,1172 & 2406,00 \\
\hline Barbacs & , & , & 47,91 & , & , & 113,17 & 68,98 & 92,72 & 201,57 & 524,35 & 38,4139 & 1365,00 \\
\hline Bezi & , & , & 32,49 & , & , & , & 178,67 & , & , & 211,16 & 18,82 & 1122,00 \\
\hline Bogyoszló & , & 5,06 & 44,62 & , & 24,77 & 386,61 & 145,4 & , & 39,1 & 645,56 & 24,6303 & 2621,00 \\
\hline Bősárkány & 27,45 & , & 3,35 & 24,61 & , & 78,62 & 251,11 & 3,66 & 41,47 & 430,27 & 18,4428 & 2333,00 \\
\hline Cakóháza & , & , & , & , & , & , & 41,85 & , & , & 41,85 & 14,5313 & 288,00 \\
\hline Csorna & ,08 & 308,84 & 28,28 & 9,92 & , & 1425,68 & 311,51 & 540,73 & 739,24 & 3364,28 & 36,6759 & 9173,00 \\
\hline Dör & , &, & , & , & , & 1,76 & 94,26 & , & 171,25 & 267,27 & 24,2752 & 1101,00 \\
\hline Egyed & , & , & 2,97 & , & , & 52,29 & 113,36 & , & , & 168,62 & 12,5555 & 1343,00 \\
\hline Farád & , & , & 50,41 & , & , & , & 257,43 & , & , & 307,84 & 10,6079 & 2902,00 \\
\hline Fehértó & , & , & 7,23 & , & , & 34,41 & 169,99 & 126,05 & 136,27 & 473,95 & 41,6476 & 1138,00 \\
\hline Győrsövényház & , & , & 128,16 & 140,44 & , & 144,95 & 170,16 & , & 59,82 & 643,53 & 26,5812 & 2421,00 \\
\hline Jobaháza & , & , & 30,53 & , & , & , & 97,38 & , & , & 127,91 & 15,8697 & 806,00 \\
\hline Kóny & 50,9 & , & , & , & , & 80,55 & 85,69 & 76,95 & 315,81 & 609,9 & 21,1184 & 2888,00 \\
\hline Maglóca & , & , & 41,37 & , & , & 60,89 & 87,98 & , & , & 190,24 & 32,9705 & 577,00 \\
\hline Magyarkeresztúr & , & , & 55,78 & , & , & 64,77 & , & , & , & 120,55 & 7,2013 & 1674,00 \\
\hline Markotabödöge & , & , & 21,1 & , & , & 12,3 & 122,95 & , & 91,47 & 247,82 & 15,213 & 1629,00 \\
\hline Páli & , & 22,99 & , & , & , & 271,96 & 5,5 & , & , & 300,45 & 15,3447 & 1958,00 \\
\hline Pásztori & , & , & , & , & , & , & 146,59 & , & , & 146,59 & 17,2054 & 852,00 \\
\hline Potyond & , & , & , & , & , & , & 37,23 & , & , & 37,23 & 13,1092 & 284,00 \\
\hline Rábacsanak & , & , & , & , & , & 44,53 & 4,43 & , & , & 48,96 & 3,535 & 1385,00 \\
\hline Rábapordány & , & , & , & , & , & , & 91,02 & , & , & 91,02 & 4,1581 & 2189,00 \\
\hline Rábasebes & , & 2,37 & , & , & , & 51,9 & , & , & , & 54,27 & 10,0686 & 539,00 \\
\hline Rábaszentandrás & , & , & 4,42 & , & , & 41,48 & 55,45 & , & , & 101,35 & 8,7371 & 1160,00 \\
\hline Rábatamási & , & , & 14,11 & , & , & 37,05 & 418,36 & , & 51,9 & 521,42 & 23,9623 & 2176,00 \\
\hline Rábcakapi & , & , & , & 54,47 & , & 5,52 & 87,08 & , & , & 147,07 & 18,6874 & 787,00 \\
\hline Sopronnémeti & , & , & , & , & 59,76 & 2,58 & , & , & 41,98 & 104,32 & 14,7137 & 709,00 \\
\hline Szany & , & 106,89 & 3,03 & , & , & 299,74 & 192,09 & , & , & 601,75 & 17,6311 & 3413,00 \\
\hline Szil & , & 67,08 & , & , & ,06 & 125,39 & 192,44 & , & , & 384,97 & 12,4064 & 3103,00 \\
\hline Szilsárkány & , & 24,14 & , & , & ,08 & 5,28 & 183,82 & , & 109,5 & 322,82 & 19,3537 & 1668,00 \\
\hline Tárnokréti & , & 2,09 & 51,01 & 42,49 & , & 33,24 & 265,06 & , & 94,37 & 488,26 & 51,1803 & 954,00 \\
\hline Vág & , & 131,76 & , & , &, & 3,07 & 25,52 & , & , & 160,35 & 11,4291 & 1403,00 \\
\hline Zsebeháza & , & , & 5,58 & , &, & , & , & , & , & 5,58 & 1,2 & 465,00 \\
\hline
\end{tabular}




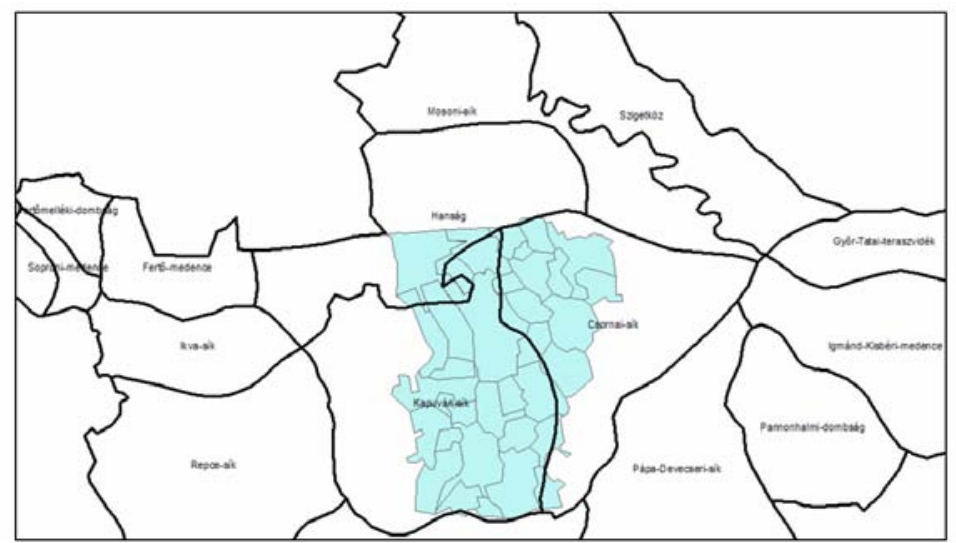

A földrajzi kistájak és a kistérség elhelyezkedése

Tájesztétikai érték (saját szerkesztés Kollányi, 2004 nyomán)

\begin{tabular}{|c|c|c|c|c|c|}
\hline Megnevezés & $\begin{array}{c}\text { Shannon } \\
\text { átlag }\end{array}$ & $\begin{array}{l}\text { Shannon } \\
\text { pontérték }\end{array}$ & $\begin{array}{c}\text { Ext. Terület } \\
\text { aránya \% }\end{array}$ & Ext. Pont & Tájesztétika-érték \\
\hline Acsalag & 37,00 & 3,70 & 19 & 6 & 5,31 \\
\hline Bágyogszovát & 36,00 & 3,60 & 22, & 7 & 5,98 \\
\hline Barbacs & 47,00 & 4,70 & 38 & 8 & 7,01 \\
\hline Bezi & 40,00 & 4,00 & 18 & 6 & 5,4 \\
\hline Bogyoszló & 31,00 & 3,10 & 24 & 7 & 5,83 \\
\hline Bősárkány & 42,00 & 4,20 & 18 & 6 & 5,46 \\
\hline Cakóháza & 34,00 & 3,40 & 14, & 4 & 3,82 \\
\hline Csorna & 38,00 & 3,80 & 36 & 8, & 6,74 \\
\hline Dör & 35 & 3,50 & 24 & 7 & 5,95 \\
\hline Egyed & 41,00 & 4,10 & 12 & 4 & 4,03 \\
\hline Farád & 35,00 & 3,50 & 10 & 3 & 3,15 \\
\hline Fehértó & 39 & 3,90 & 42 & 9 & 7,47 \\
\hline Győrsövényház & 40,00 & 4,00 & 26 & 7 & 6,1 \\
\hline Jobaháza & 41,00 & 4,10 & 16 & 5 & 4,73 \\
\hline Kóny & 37 & 3,70 & 21 & 7 & 6,01 \\
\hline Maglóca & 46,00 & 4,60 & 33 & 8, & 6,98 \\
\hline Magyarkeresztúr & 24,00 & 2,40 & 7 & 2 & 2,12 \\
\hline Markotabödöge & 36,00 & 3,60 & 15 & 5 & 4,58 \\
\hline Páli & 30,00 & 3,00 & 15 & 5 & 4,4 \\
\hline Pásztori & 34,00 & 3,40 & 17 & 6, & 5,22 \\
\hline Potyond & 25,00 & 2,50 & 13 & 4 & 3,55 \\
\hline Rábacsanak & 33,00 & 3,30 & 3 & 2 & 2,39 \\
\hline Rábapordány & 28,00 & 2,80 & 4 & 2 & 2,24 \\
\hline Rábasebes & 48,00 & 4,80 & 10 & 3 & 3,54 \\
\hline Rábaszentandrás & 29,00 & 2,90 & 9 & 3 & 2,97 \\
\hline Rábatamási & 39,00 & 3,90 & 23 & 7 & 6,07 \\
\hline Rábcakapi & 40,00 & 4,00 & 19 & 6 & 5,4 \\
\hline Sopronnémeti & 30,00 & 3,00 & 15 & 5 & 4,4 \\
\hline Szany & 36,00 & 3,60 & 18 & 6 & 5,28 \\
\hline Szil & 28,00 & 2,80 & 12 & 4, & 3,64 \\
\hline Szilsárkány & 29,00 & 2,90 & 19 & 6 & 5,07 \\
\hline Tárnokréti & 54,00 & 5,40 & 51, & 9 & 7,92 \\
\hline Vág & 36,00 & 3,60 & 11, & 4, & 3,88 \\
\hline Zsebeháza & 19,00 & 2,00 & 1, & 2 & 2 , \\
\hline
\end{tabular}


Melléklet XXXII.

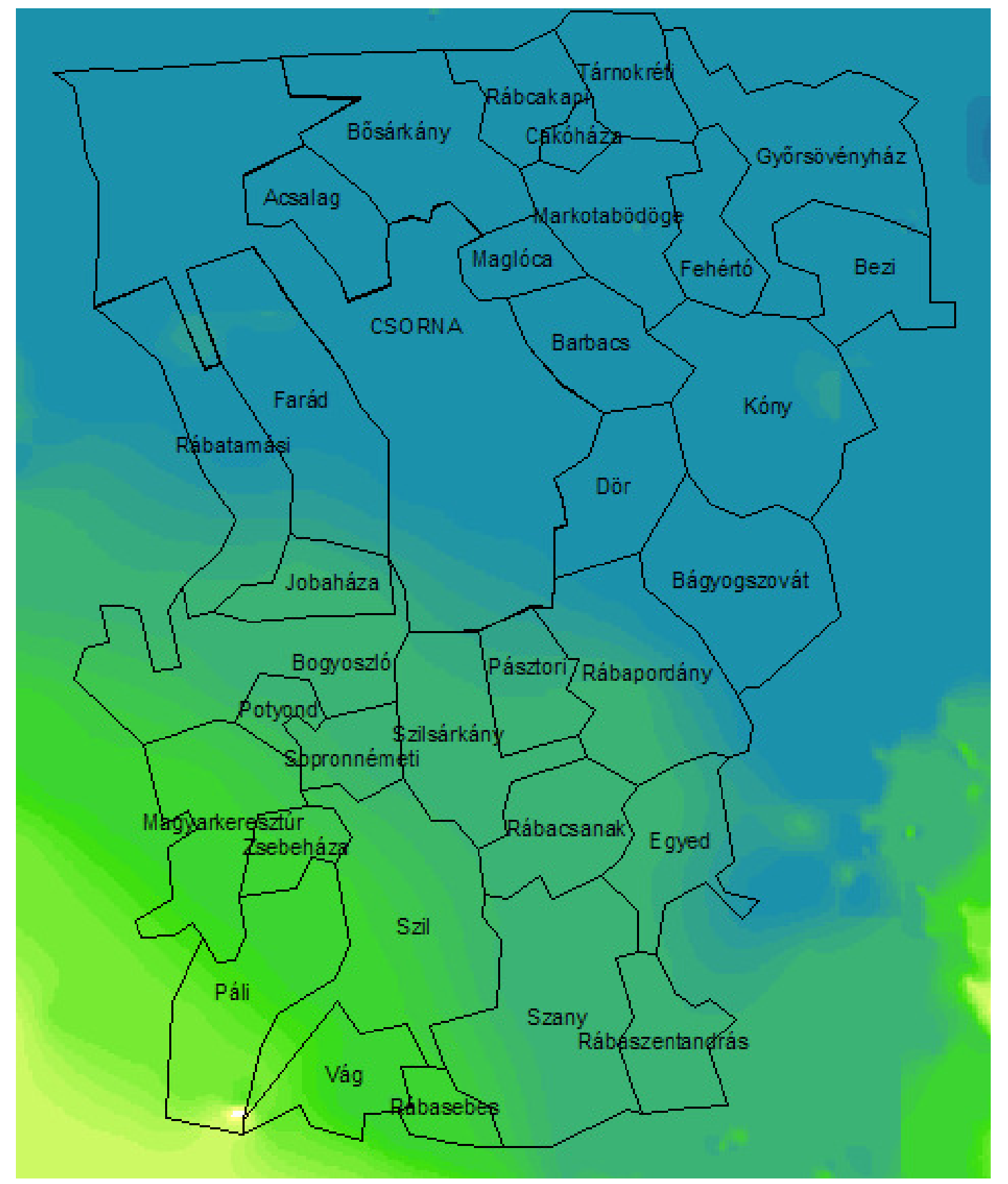

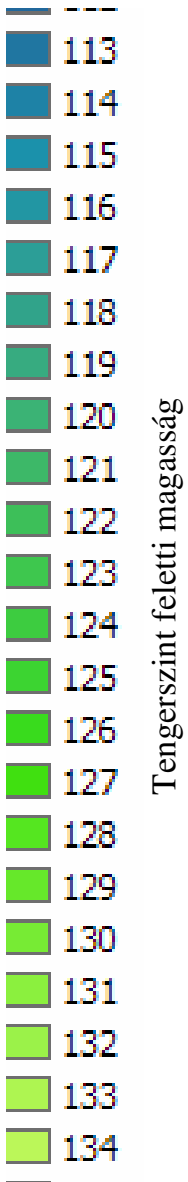

A Hanság felé lejtő terepfelszín (tengerszint feletti magasság, www.fomi.hu) 
Elérhetőség (saját szerkesztés, alapadatok: TEIR)

\begin{tabular}{|c|c|c|c|c|c|c|}
\hline Megnevezés & 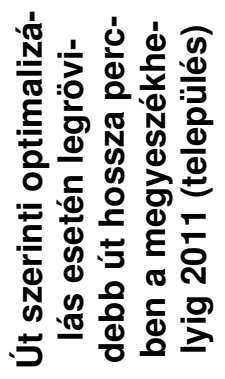 & 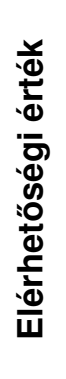 & 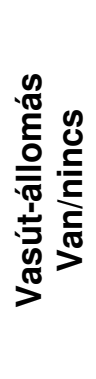 & 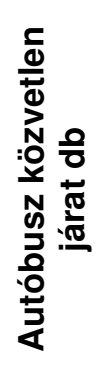 & 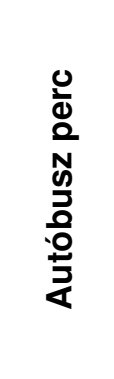 & 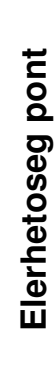 \\
\hline Acsalag & 42,33 & 1 & , & 4, & 25 & 2 \\
\hline Bágyogszovát & 35,42 & 1, & , & 7 & 20 & 4 \\
\hline Barbacs & 32,37 & 1 & , & 7 & 15 & 4 \\
\hline Bezi & 25,45 & 2 & , & 5 & 45 & 6 \\
\hline Bogyoszló & 47,02 & 1 & , & 11 & 20 & 4 \\
\hline Bősárkány & 38,83 & 4 & 1, & 22 & 15 & 8 \\
\hline Cakóháza & 36,43 & 1, & , & 6 & 35 & 2 \\
\hline Csorna & 36,77 & & 2 & & & 10 \\
\hline Dör & 35,65 & 1 & 1, & 10 & 7 & 4 \\
\hline Egyed & 45,27 & 3 & , & 13 & $25-40$ & 6 \\
\hline Farád & 40,27 & 4 & 1, & 34 & $7-10$ & 8 \\
\hline Fehértó & 29,88 & 2 & , & 5 & 45 & 6 \\
\hline Győrsövényház & 28,23 & 2 & , & 5 & 50 & 6 \\
\hline Jobaháza & 44,2 & 3 & , & 12 & 16 & 6 \\
\hline Kóny & 27,98 & 4 & 1, & 44 & 13 & 8 \\
\hline Maglóca & 35,12 & 1 & 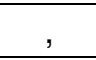 & 7 & 25 & 3 \\
\hline Magyarkeresztúr & 53,39 & 1 & , & 11 & 30 & 3 \\
\hline Markotabödöge & 32,9 & 2 & , & 6 & 35 & 4 \\
\hline Páli & 56,56 & 3 & , & 13 & $35-40$ & 6 \\
\hline Pásztori & 45,71 & 1 & , & 10 & $15-30$ & 3 \\
\hline Potyond & 49,72 & 1 & , & 11 & 25 & 3 \\
\hline Rábacsanak & 48,63 & 3 & 1, & 15 & $20-30$ & 6 \\
\hline Rábapordány & 40,58 & 1, & 1, & 10 & 15 & 4 \\
\hline Rábasebes & 57,12 & , & , & 2 & 50 & 2 \\
\hline Rábaszentandrás & 51,98 & , & , & 5 & 45 & 2 \\
\hline Rábatamási & 44,97 & 4 & 1 & 34 & 16 & 8 \\
\hline Rábcakapi & 37,32 & 3 & , & 11 & 25 & 6 \\
\hline Sopronnémeti & 49,27 & 3 & , & 11 & 25 & 6 \\
\hline Szany & 50,78 & 1 & 1, & 9 & 35 & 4 \\
\hline Szil & 50,76 & 3 & , & 17 & 30 & 6 \\
\hline Szilsárkány & 45,18 & 4 & , & 24 & 20 & 8 \\
\hline Tárnokréti & 36,18 & 1 & , & 9 & 25 & 3 \\
\hline Vág & 58,4 & , & , & 7 & 45 & 2 \\
\hline Zsebeháza & 55,84 & , & 1, & 5 & 35 & 2 \\
\hline
\end{tabular}


Egyedi tájértékek a Csornai-kistérségben (www.tajertektar.hu)
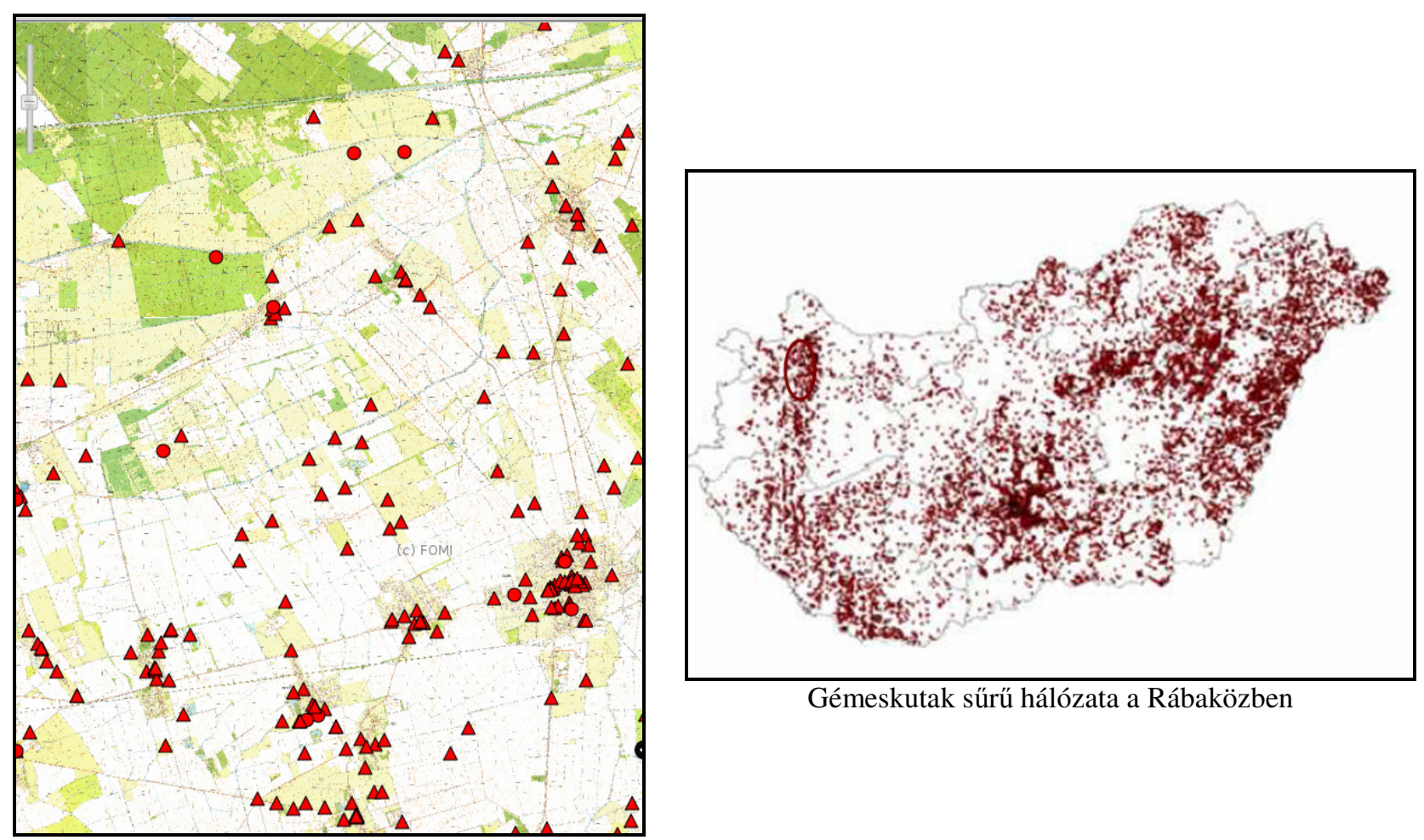

Gémeskutak sürü hálózata a Rábaközben

Egyedi tájértékek a Csornai-kistérségben

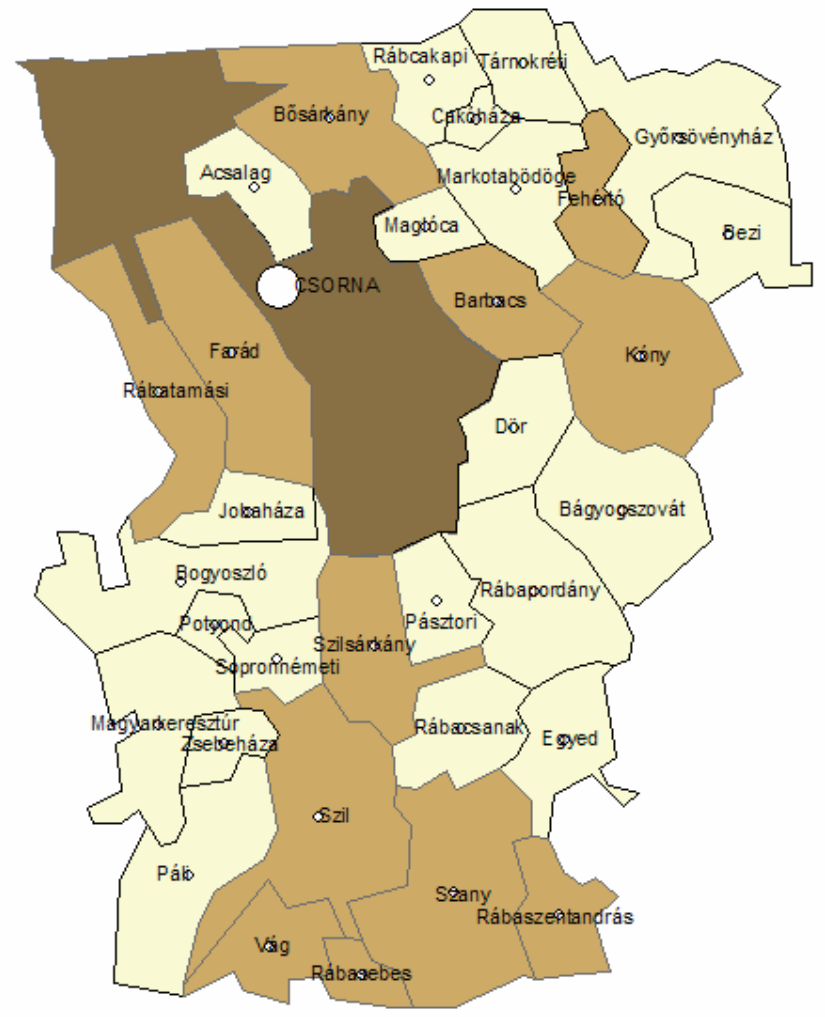

XXXV. melléklet

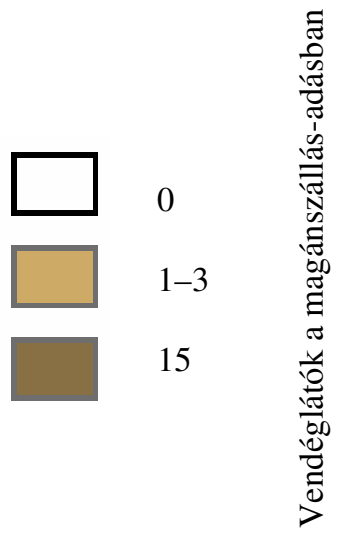

Panziók és vendéglátók a magán szállásadásban Csornai-kistérségben (saját szerkesztés, adatok forrása: TEIR 
Rekreációs és kulturális érték (saját szerkesztés, adatok forrása: TEIR

\begin{tabular}{|c|c|c|c|}
\hline Megnevezés & $\begin{array}{l}\text { Múemlékek száma (M) } \\
2009 \text { (település) }\end{array}$ & $\begin{array}{l}\text { Régészeti lelöhelyek száma } \\
2009 \text { (település) }\end{array}$ & Rekreáció \\
\hline Acsalag & 1, & , & 4 \\
\hline Bágyogszovát & 3, & 12 & 2 \\
\hline Barbacs & 5, & 6 , & 6 \\
\hline Bezi & 1, & 26 , & 1 \\
\hline Bogyoszló & 2 & 17 & 2 \\
\hline Bősárkány & 5 , & 21, & 6 \\
\hline Cakóháza & & 8 & 1 \\
\hline Csorna & 7 & 53 & 8 \\
\hline Dör & 1, & 11 & 1 \\
\hline Egyed & 1, & 24, & 1 \\
\hline Farád & 2 & 10 , & 2 \\
\hline Fehértó & 2 , & 27 & 6 \\
\hline Győrsövényház & 1, & 31, & 6 \\
\hline Jobaháza & & 12 & 2 \\
\hline Kóny & 1, & 33 & 6 \\
\hline Maglóca & 2 , & 5 & 1 \\
\hline Magyarkeresztúr & 3 & 8 & 1 \\
\hline Markotabödöge & 1, & 20, & 2 \\
\hline Páli & 5 , & 18, & 1 \\
\hline Pásztori & 1, & 2 & 1 \\
\hline Potyond & & 4 & 1 \\
\hline Rábacsanak & 1, & 10 & 1 \\
\hline Rábapordány & 1, & 26 , & 1 \\
\hline Rábasebes & 1, & 3 & 6 \\
\hline Rábaszentandrás & 2 , & 5 & 6 \\
\hline Rábatamási & 1, & 8 & 3 \\
\hline Rábcakapi & 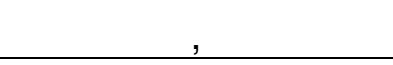 & 14 & 4 \\
\hline Sopronnémeti & 2 , & 6 & 1 \\
\hline Szany & 3, & 18, & 4 \\
\hline Szil & 1, & 23, & 2 \\
\hline Szilsárkány & 10 , & 10 , & 2 \\
\hline Tárnokréti & 2 & 18, & 4 \\
\hline Vág & 2 , & 13 & 4 \\
\hline Zsebeháza & , & 1, & 4 \\
\hline
\end{tabular}




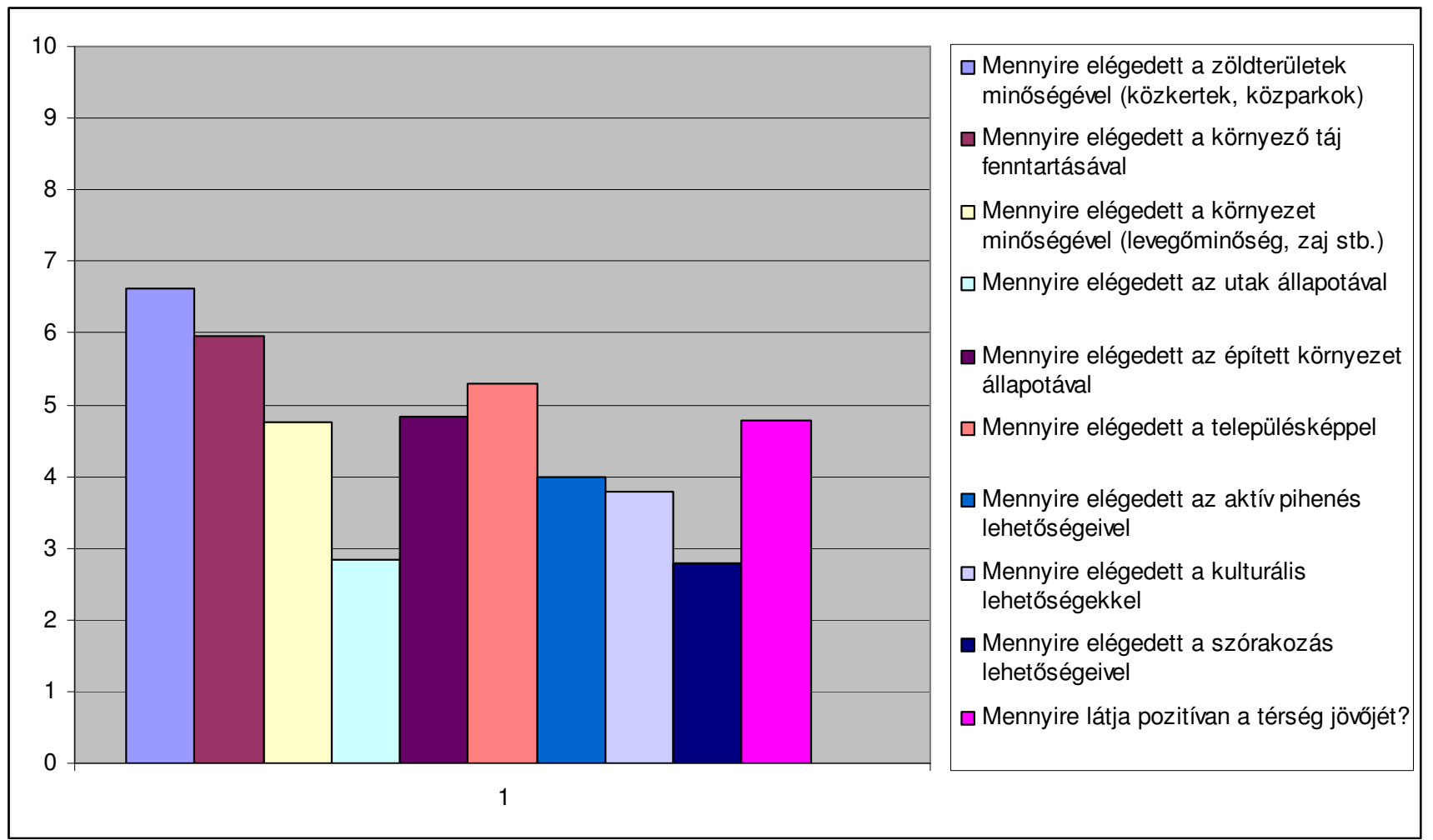

Lakossági elégedettség értékelése (saját szerkesztés)

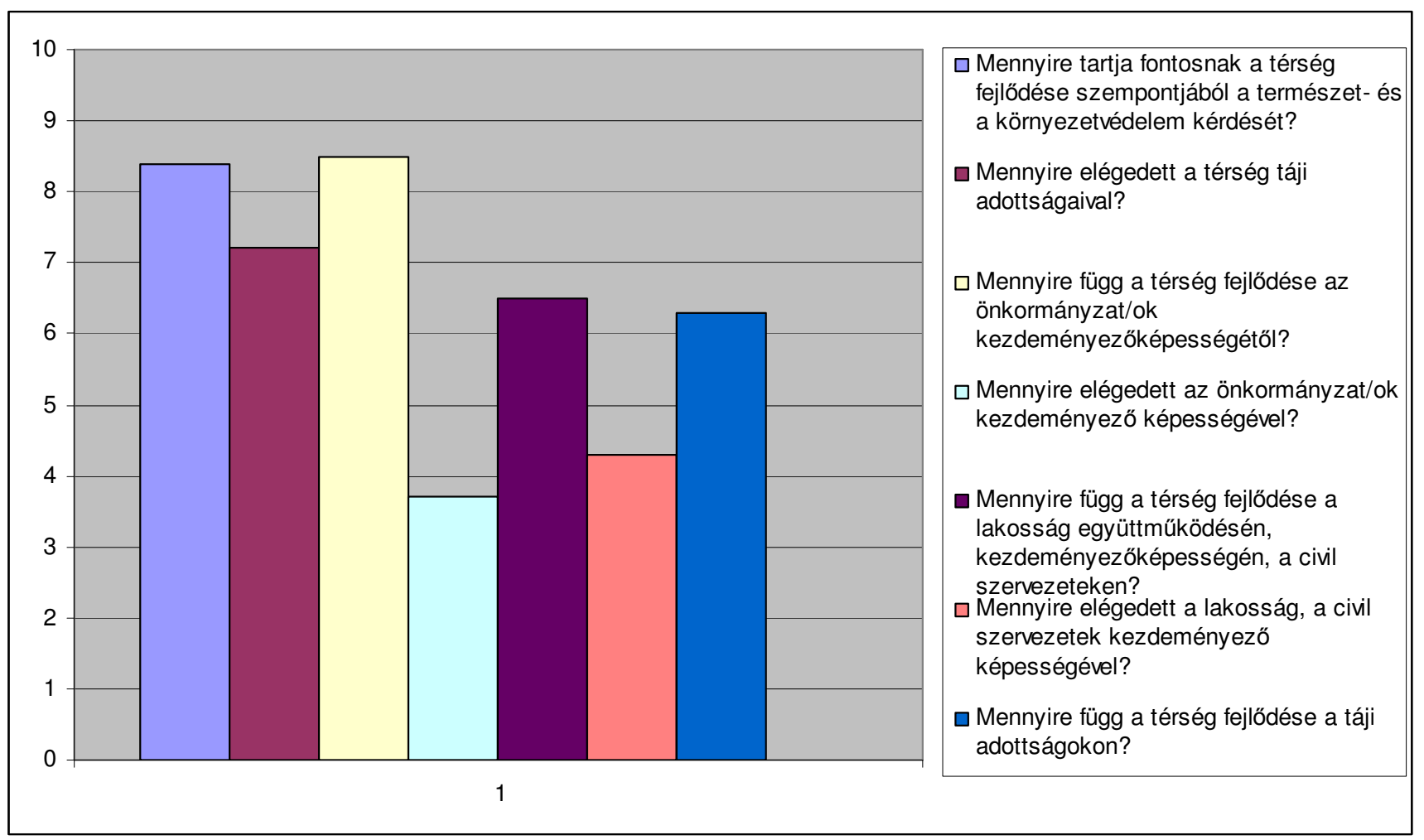

A területi fejlödést befolyásoló tényezők lakossági értékelése (saját szerkesztés) 
Lehetőségek és táji értékek a Csornai kistérségben, lakossági értékelés (saját szerkesztés)

\begin{tabular}{|c|c|c|c|}
\hline $\begin{array}{c}\text { Milyen kihasználatlan } \\
\text { lehetöségeket rejtenek } \\
\text { a táji adottságok a } \\
\text { kistérségben? }\end{array}$ & $\begin{array}{l}\text { Fontosság/ } \\
\text { Súlyozott } \\
\text { érték }\end{array}$ & $\begin{array}{l}\text { Mit tart a térség } \\
\text { legjelentősebb } \\
\text { táji értékének? }\end{array}$ & $\begin{array}{c}\text { Fontosság/Súlyozott } \\
\text { érték }\end{array}$ \\
\hline termálvíz & 63 & FHNP & 52 \\
\hline falusi turizmus & 28 & termálvíz & 29 \\
\hline FHNP & 13 & Rába & 12 \\
\hline mezőgazdaság & 10 & változatos táj & 8 \\
\hline szélerőmű & 8 & erdőség & 5 \\
\hline helytörténeti kiállítás & 7 & Szávíz, Barbacsi tó, tavak, patakok & 5 \\
\hline ipar, ipari park & 5 & településszerkezet & 4 \\
\hline Keszeg-ér & 5 & Györ, Pozsony, Bécs & 3 \\
\hline kerékpárút & 3 & munkaerő & 3 \\
\hline Premontrei park & 3 & falusi turizmus & 2 \\
\hline vízi turizmus & 3 & 86-os főút & 2 \\
\hline Lovas turizmus & 3 & biohús termelésre legalkalmasabb terület & 1 \\
\hline munkahelyteremtés & 3 & "érintetlen" terület & 1 \\
\hline infrastruktúra & 3 & termőföld & 1 \\
\hline földrajzi fekvés & 2 & & \\
\hline logisztika & 2 & & \\
\hline Rába & 1 & & \\
\hline
\end{tabular}

Fejlődési lehetőségek lakossági értékelése (saját szerkesztés)

\begin{tabular}{|l|c|l|c|}
\hline \multicolumn{1}{|c|}{$\begin{array}{c}\text { Miben látja a térség } \\
\text { kitörési lehetőségeit? }\end{array}$} & $\begin{array}{c}\text { Érték az } \\
\text { említés } \\
\text { gyakorisága } \\
\text { alapján }\end{array}$ & $\begin{array}{c}\text { Miben látja a térség } \\
\text { kitörési lehetöségeit? }\end{array}$ & $\begin{array}{c}\text { Érték az } \\
\text { említés } \\
\text { gyakorisága } \\
\text { alapján }\end{array}$ \\
\hline termálfürdő & 12 & elkerülöút & 2 \\
\hline idegenforgalom & 4 & környezeti adottságok & 1 \\
\hline $\begin{array}{l}\text { mezőgazdaság, biogazdálkodás, } \\
\text { magyar fajták tenyésztése }\end{array}$ & 4 & kistérségi összefogás & 1 \\
\hline falusi turizmus & 3 & több szórakozóhely & 1 \\
\hline ipar & 3 & semmiben & 1 \\
\hline ökoturizmus & 3 & munkahelyteremtés & 1 \\
\hline több vidékfejlesztési forrás & 2 & bioenergia & 1 \\
\hline forgalmi központ, logisztikai központ & 2 & szabadidőpark & 1 \\
\hline politikamentesség & 2 & népi hagyományok bemutatása & 1 \\
\hline
\end{tabular}


XXXVIII. melléklet

MTÉT Hanság (http://www.termeszetvedelem.hu/_user/downloads/agrar/Hansag.pdf
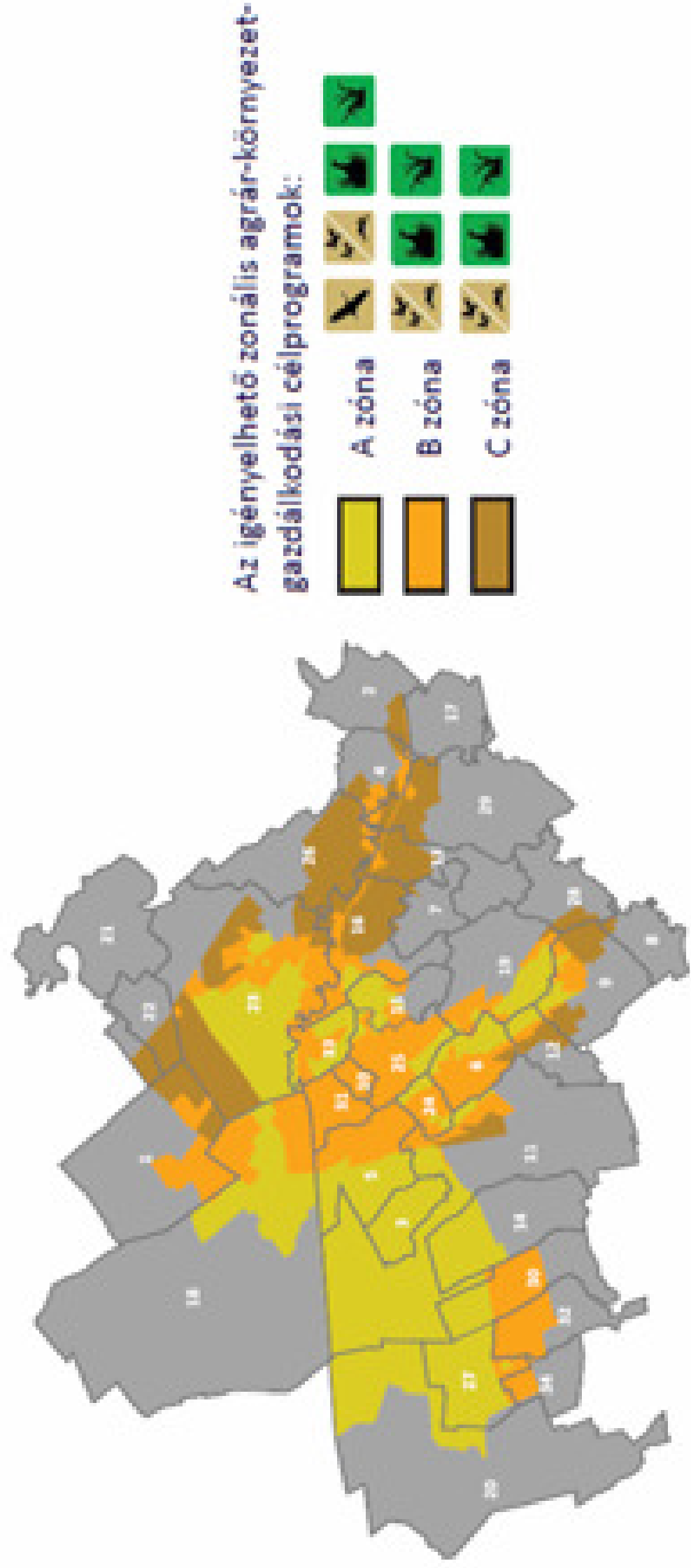
XXXIX.. melléklet

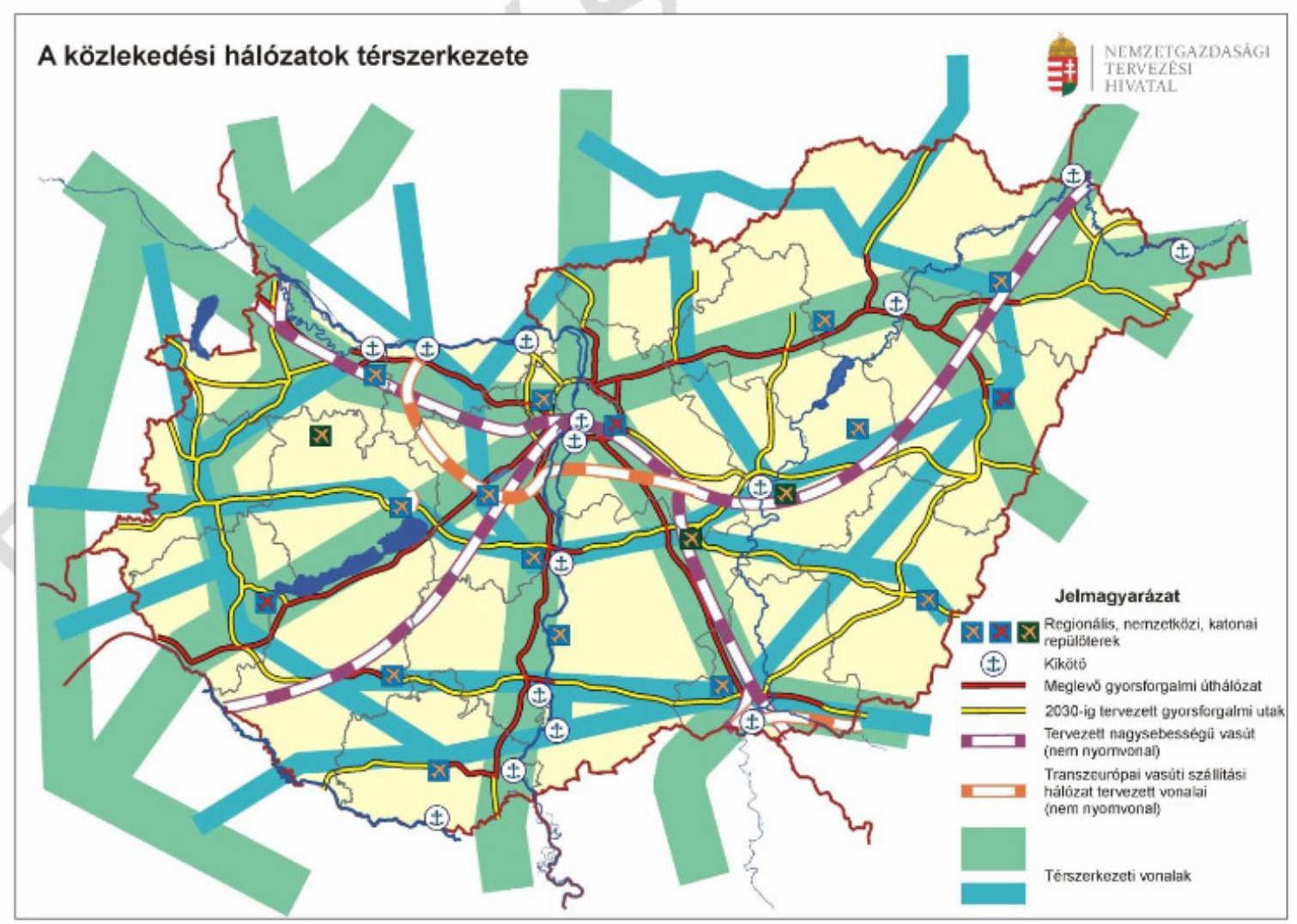

Meghatározó térszekzetei vonalak a meglévő és tervezett közelekedési folyosók alapján (Forrás: Országos Fejlesztési és Területfejlesztési Koncepció)

XL. melléklet

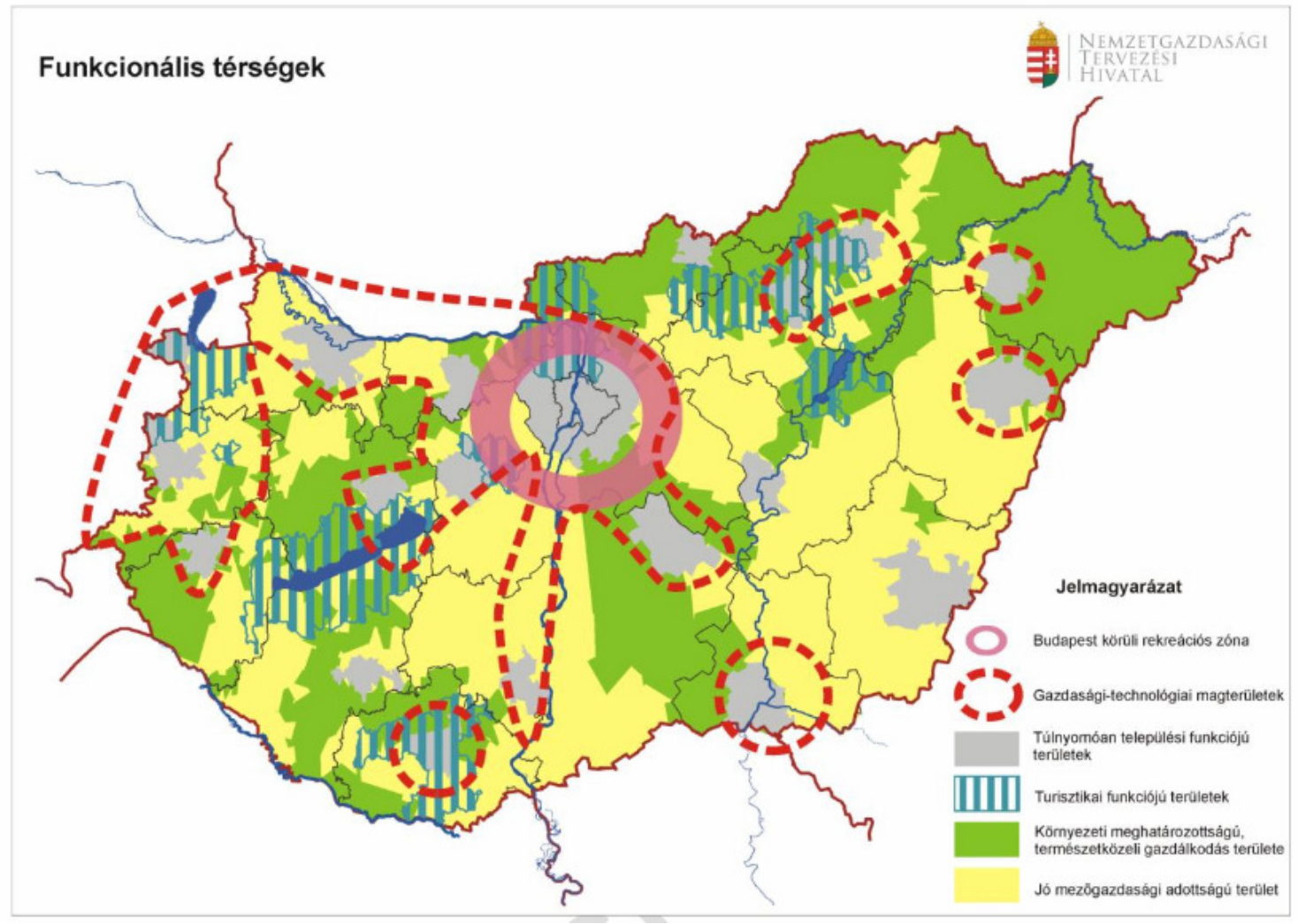

Az ország térszerkezete

(Forrás: Országos Fejlesztési és Területfejlesztési Koncepció) 
XLI. melleklet

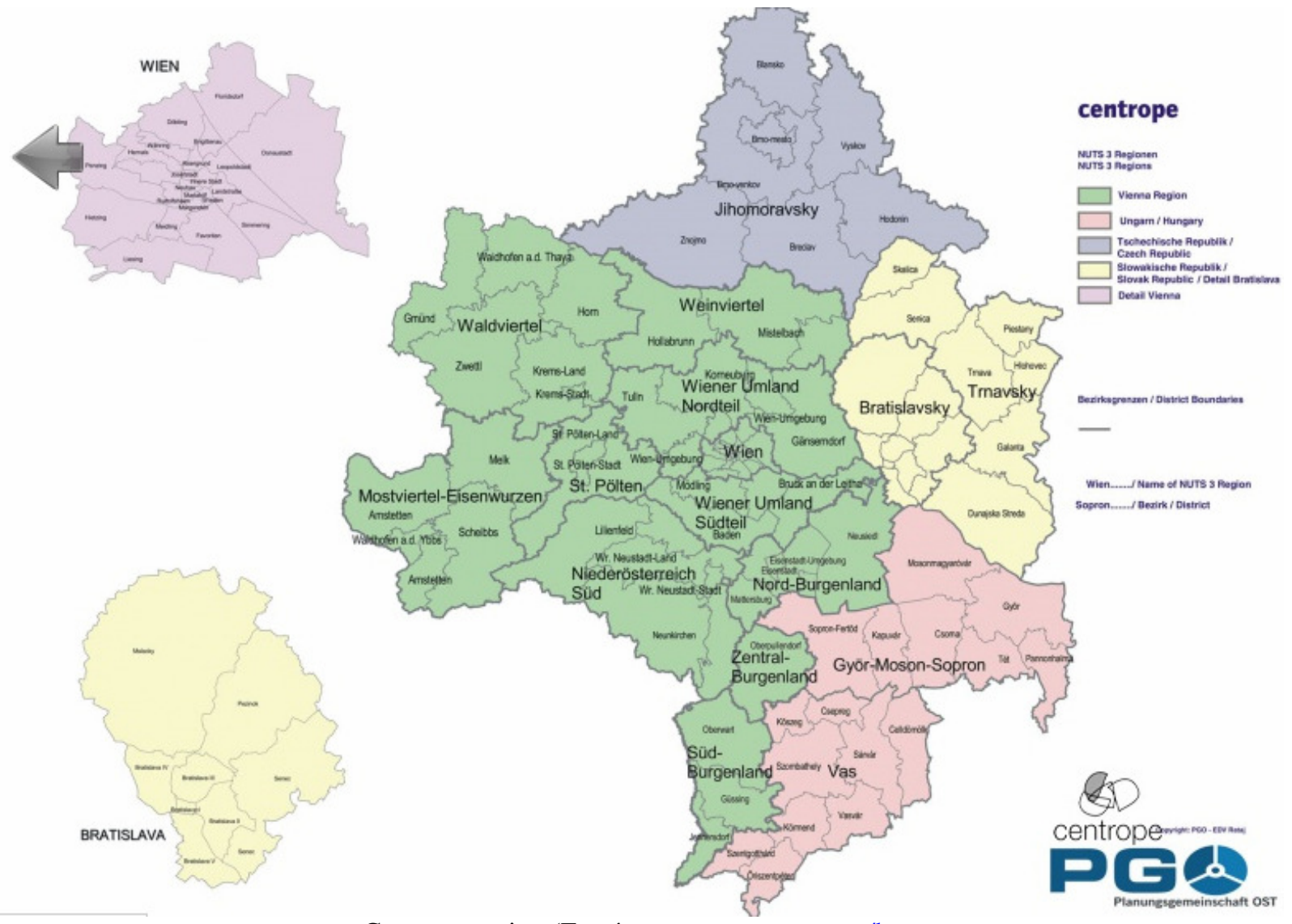

Centrope region (Forrás: www.centrope.com/hu

XLII. melléklet

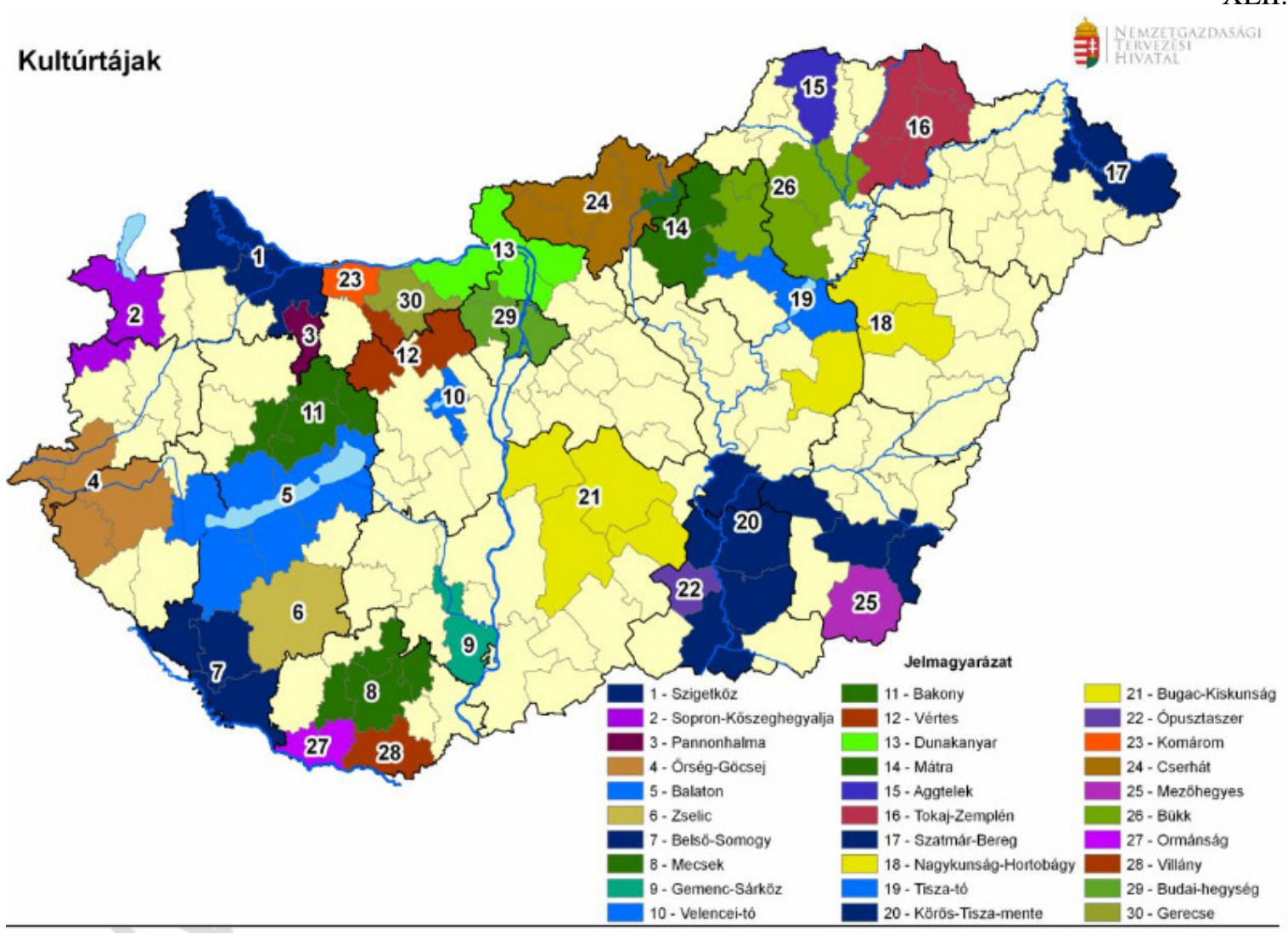

Táji értékekre alapozott növekedés térségei

(Forrás: Országos Fejlesztési és Területfejlesztési Koncepció) 


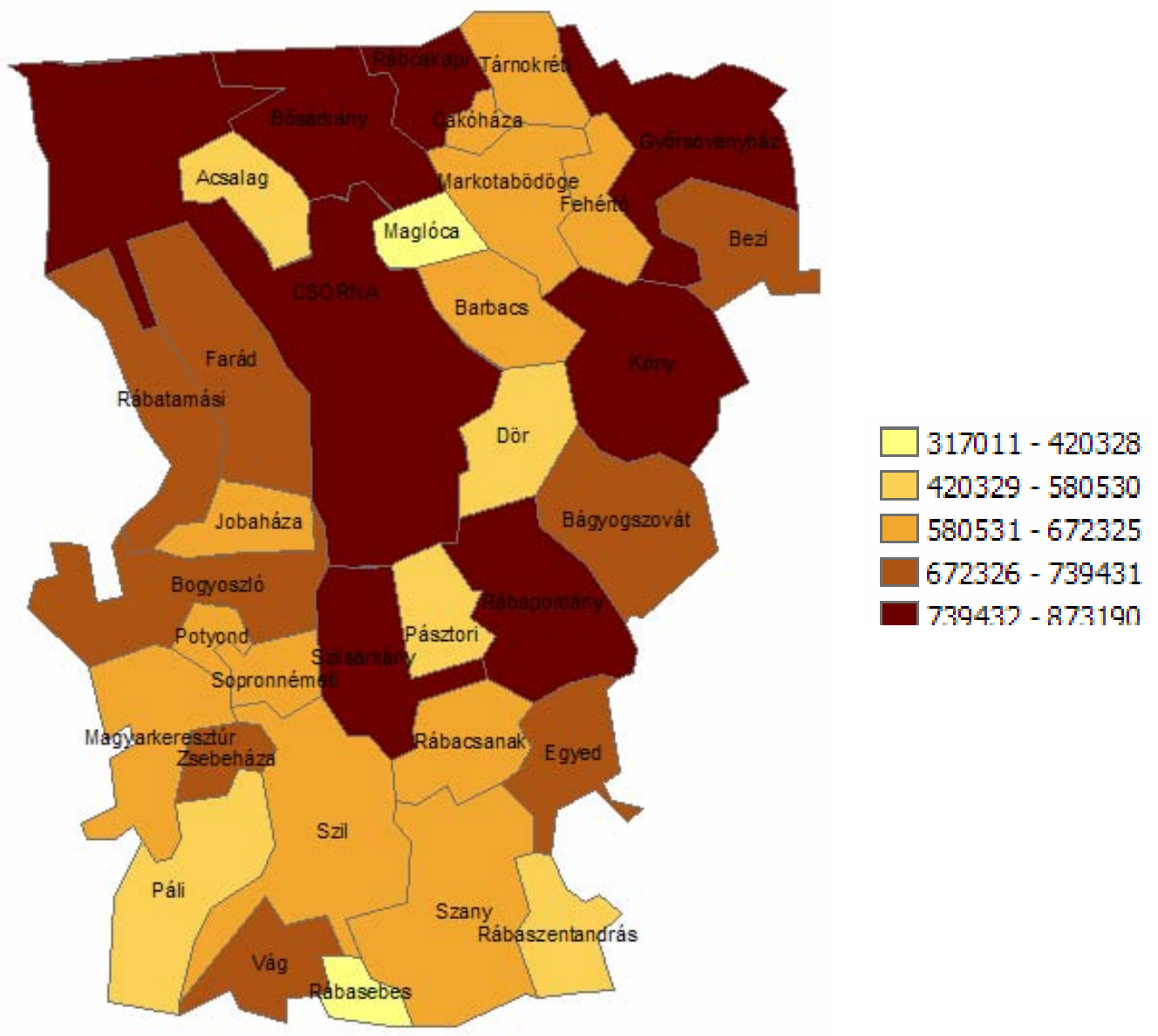

Egy lakosra jutó összes belföldi jövedelem (Ft) (saját szerkesztés. Forrás: TEIR, 2009)

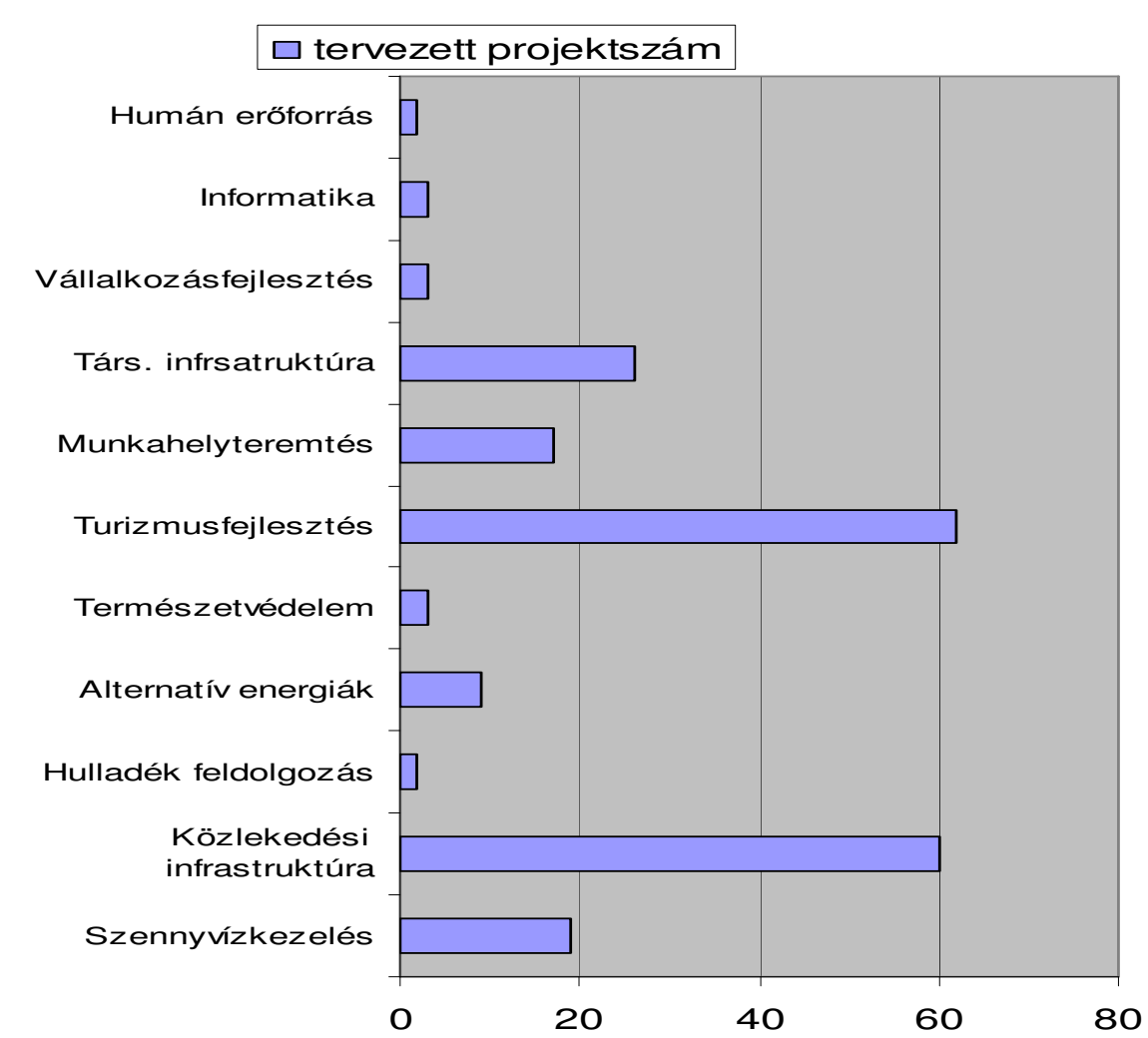

XLIV. melléklet

Az önkormányzatok által preferált fejlesztési projektek (Csornai többcélú kistérségi társulás, Gazdaságfejl. p., 2006) 
Nyertes Leader pályázatok a Rábaköz Vidékfejlesztési Egyesület területén

(Forrás: www.rabakoz.hu, www.terport.hu)

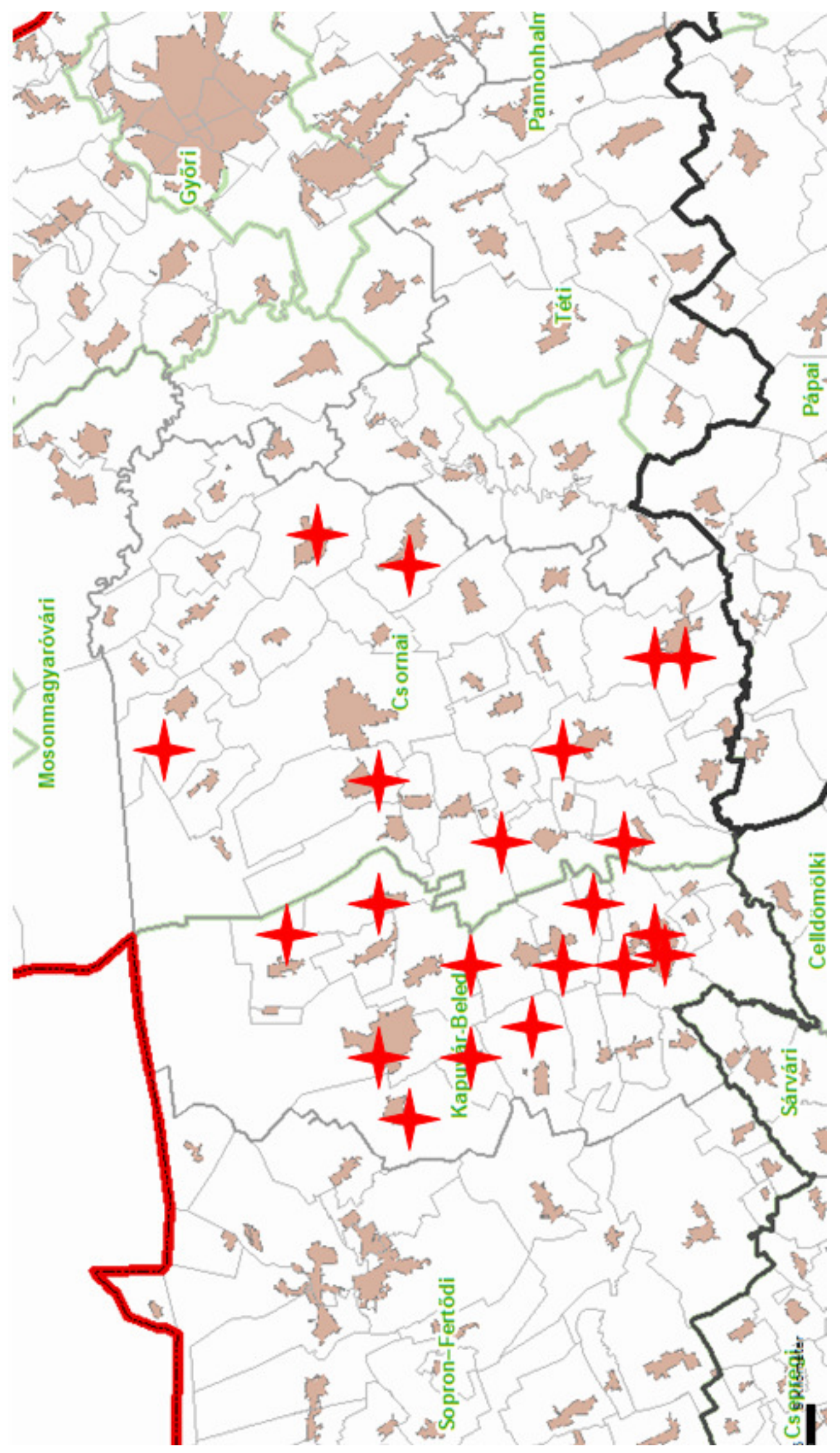


Versenyképességi helyzet és tájfunkció-elemzés összefüggései (saját szerkesztés)

Leszakadó települések tájifunkció értékei

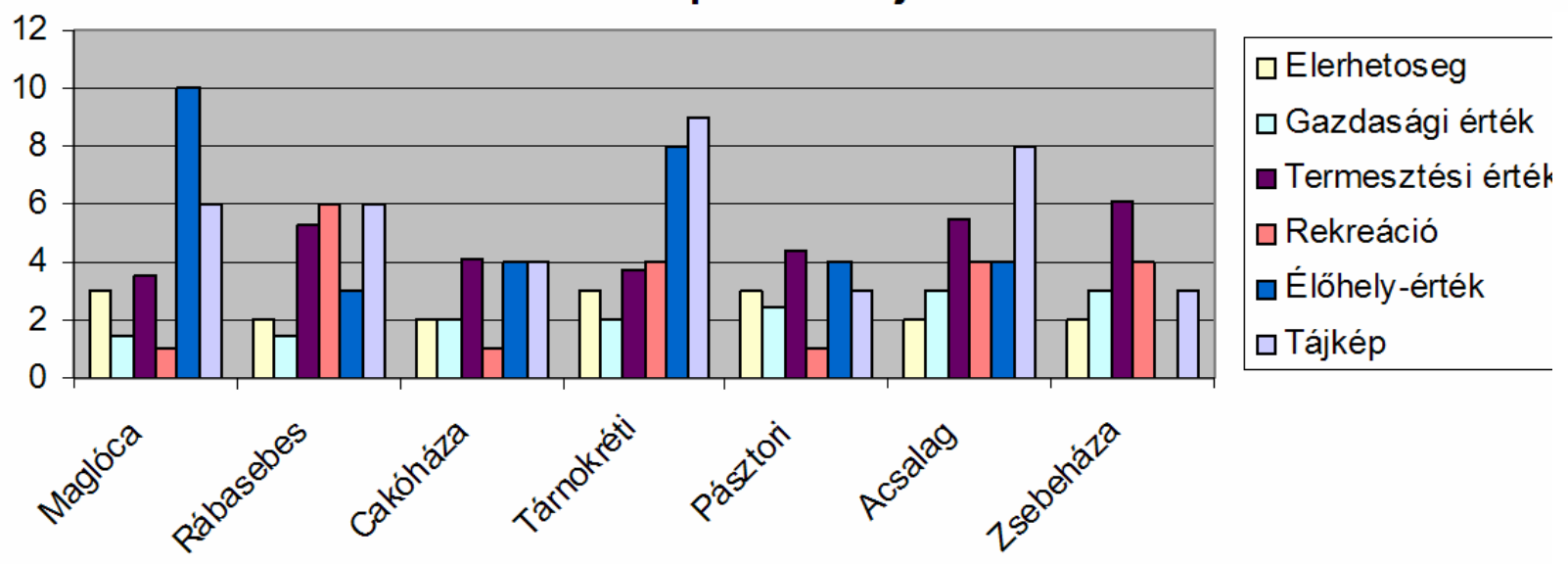

Leszakadó-stagnáló települések

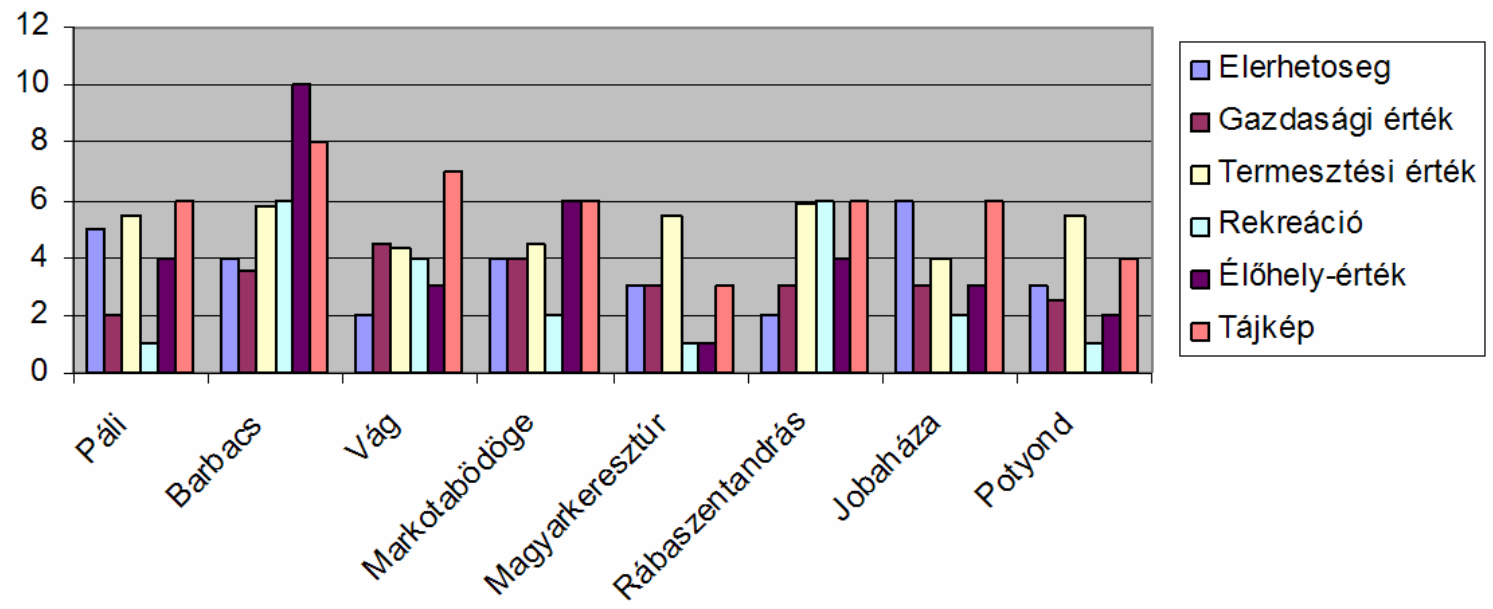

Stagnáló település ek tájfunkció értékei

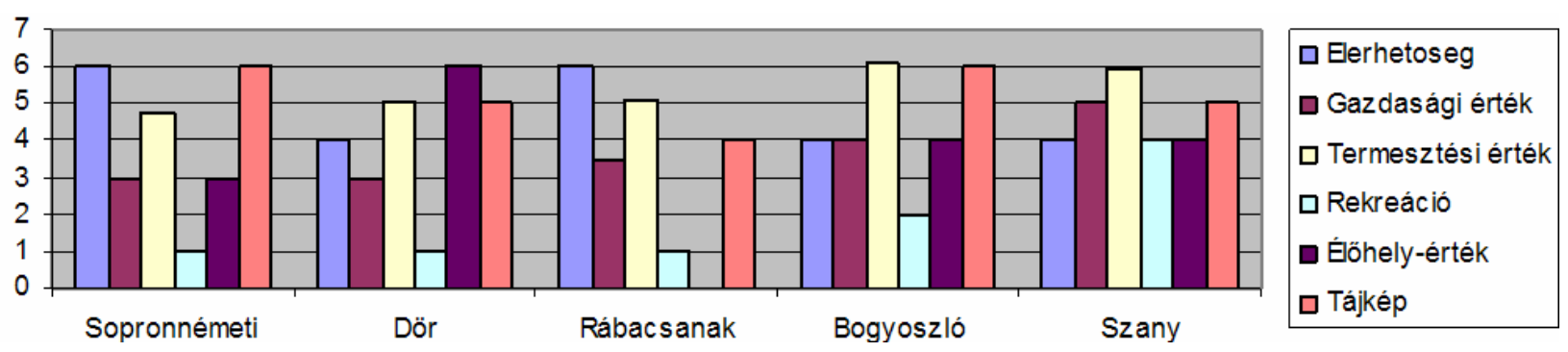

Fejllődő települések tájfunkció értékei

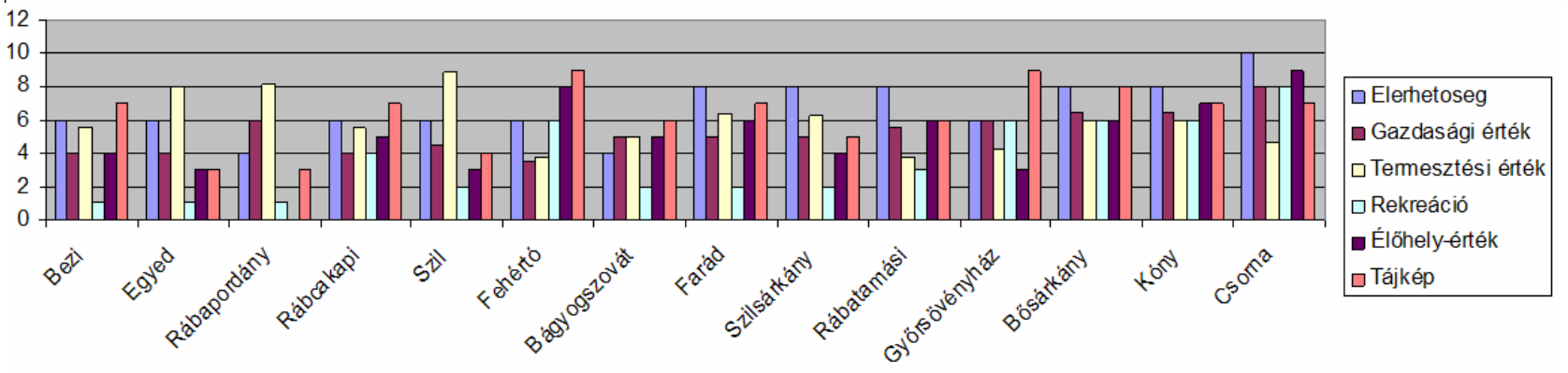


A Hanság zöldút lehetséges nyomvonalai (Filepné, Egyed, 2010)

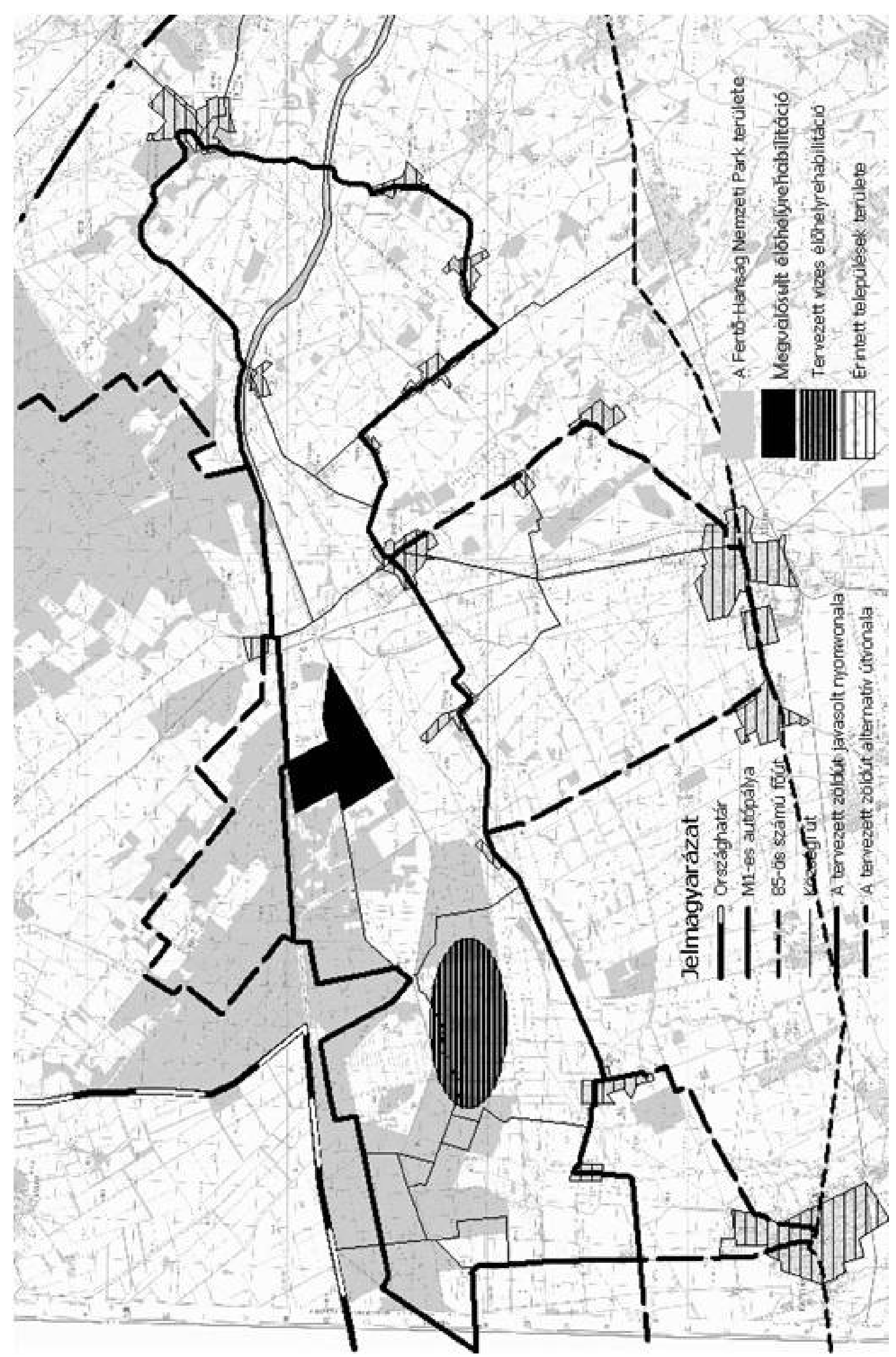


Tabló I.

A Hanság természeti ,kincsei” (saját fényképek)

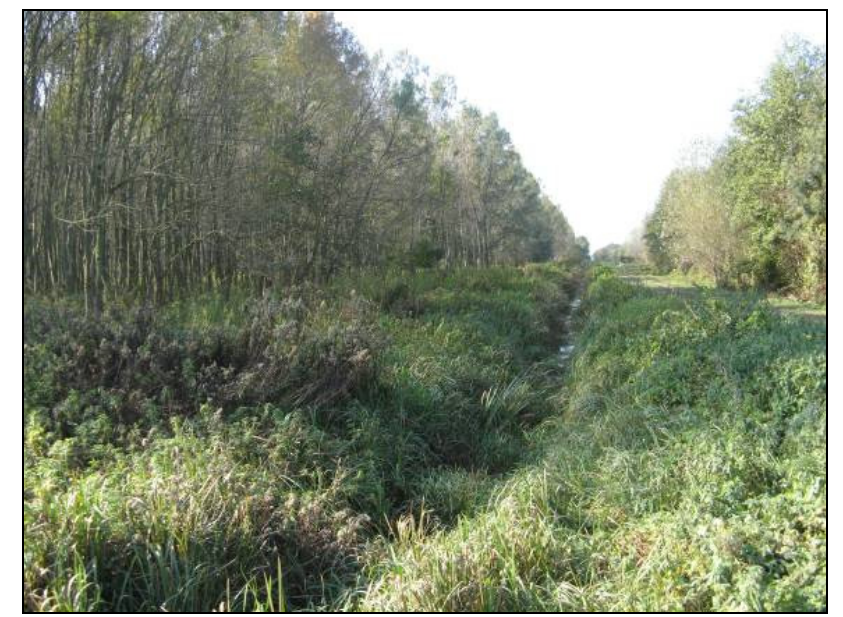

1. kép: Csatorna a Hanságban

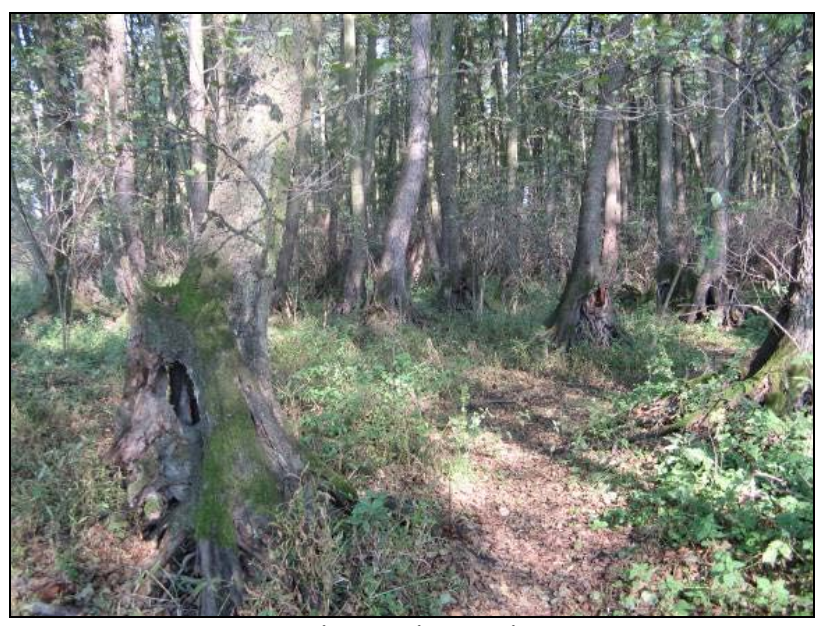

3. kép: ,Lábas” éger

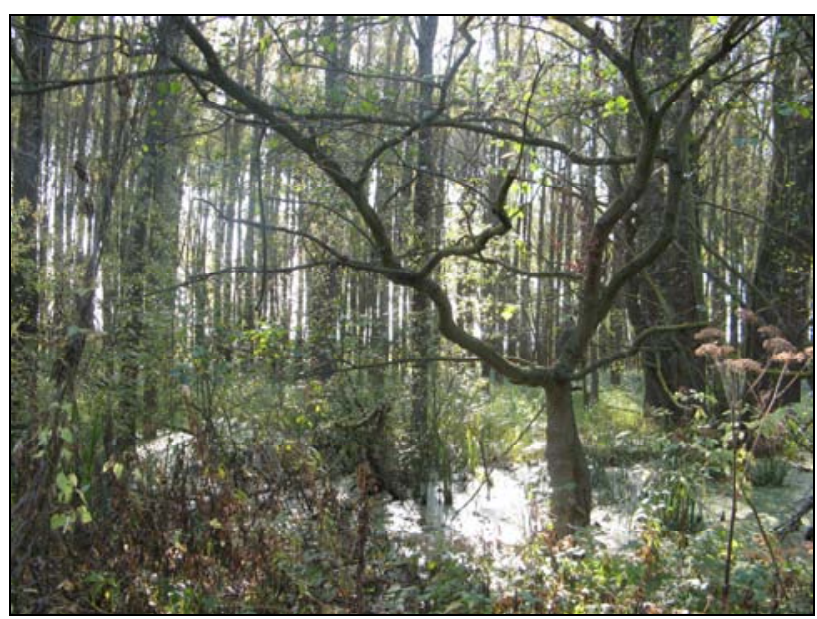

5. kép: Láperdő

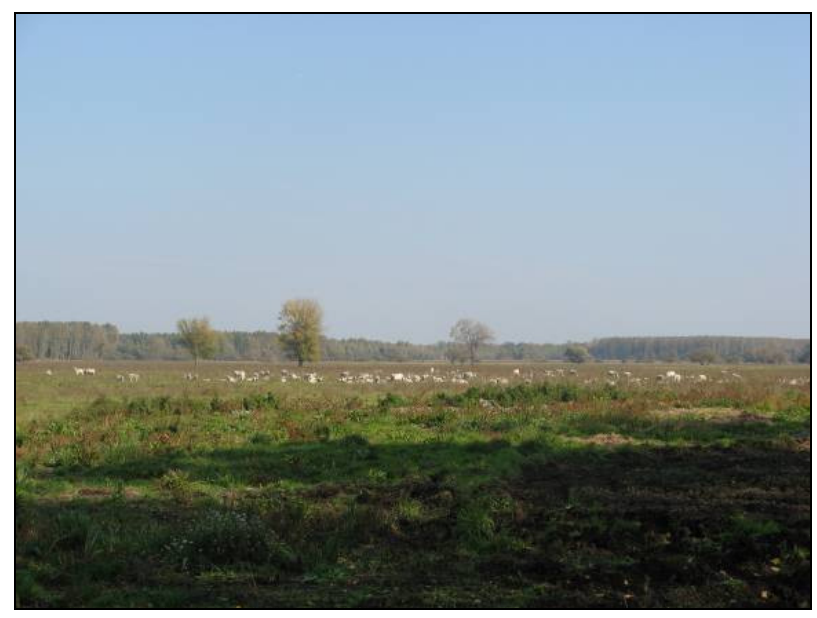

2. kép: Magyar gulya

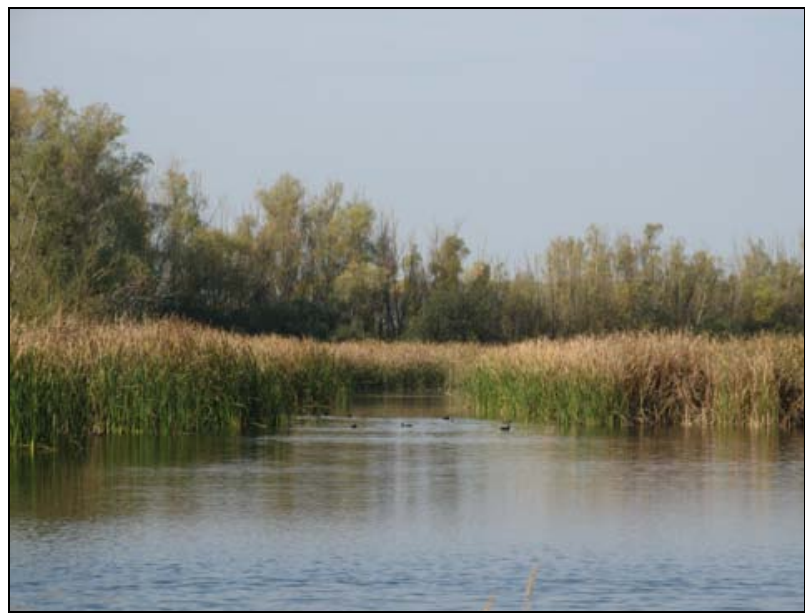

4. kép: Király-tó

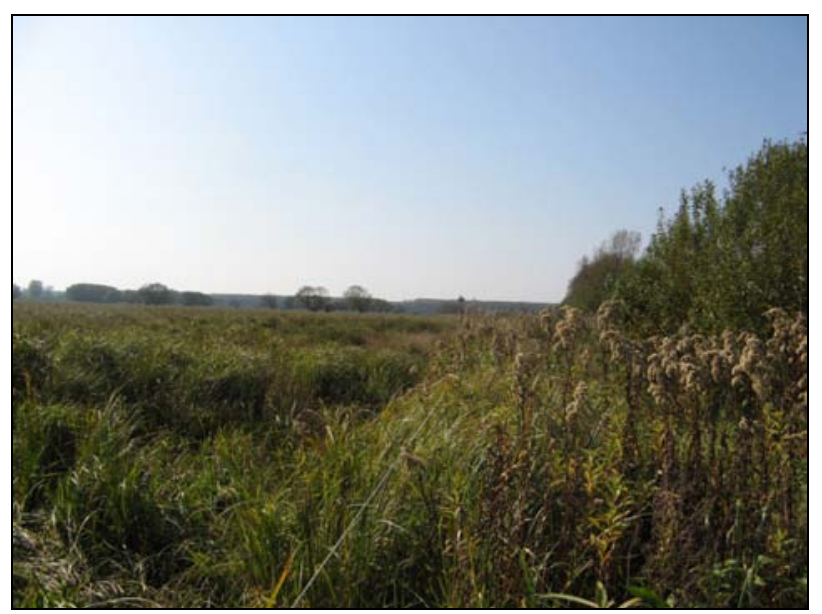

6. kép: Tőzeg-láp 
Tabló II.

A Rábaköz elhagyott kastélyai (saját fényképek)

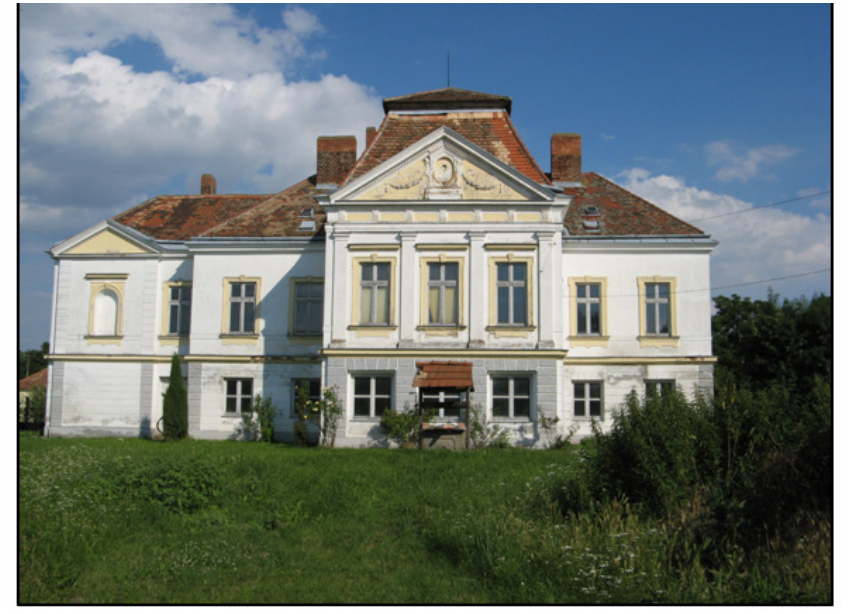

1. kép: Az elhagyatott Baditz-kastély, Magyarkeresztúr

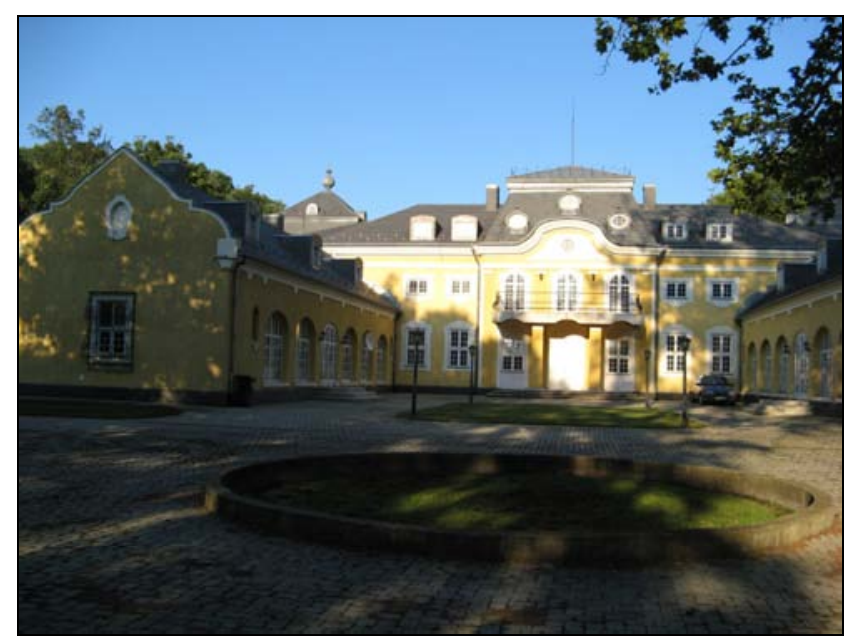

3. kép: Rábasebesi Széchenyi kastély

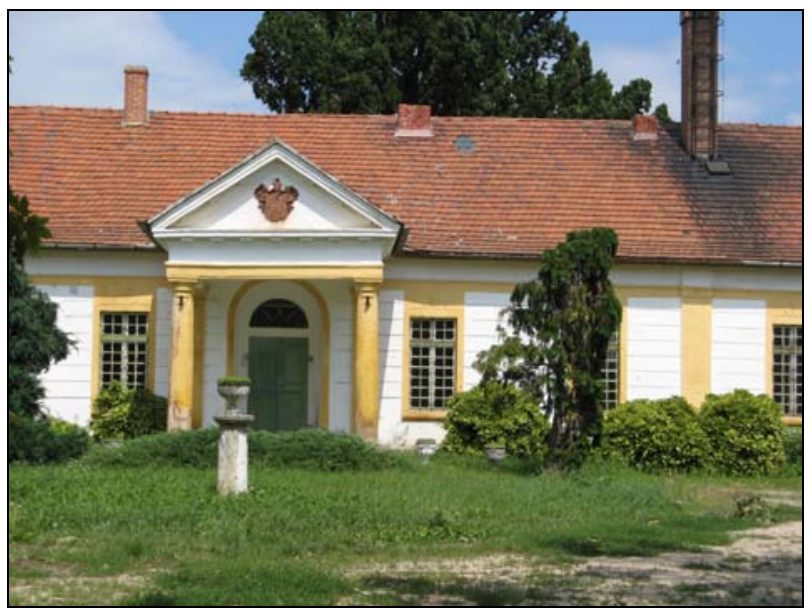

2. kép: Elhagyott kúria, Farád

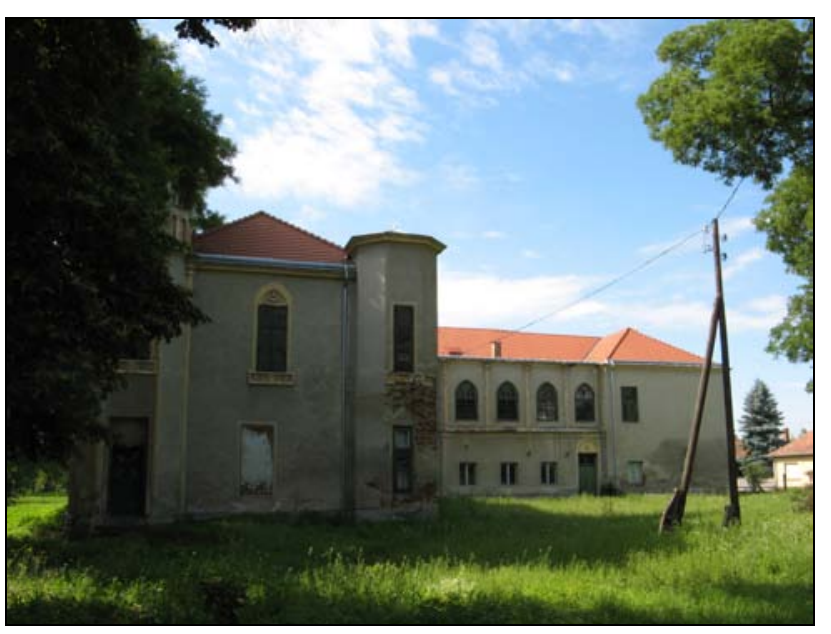

4. kép: Elhagyott kastélyépület, Egyed 
Tabló III.

Rekreáció (saját fényképek)

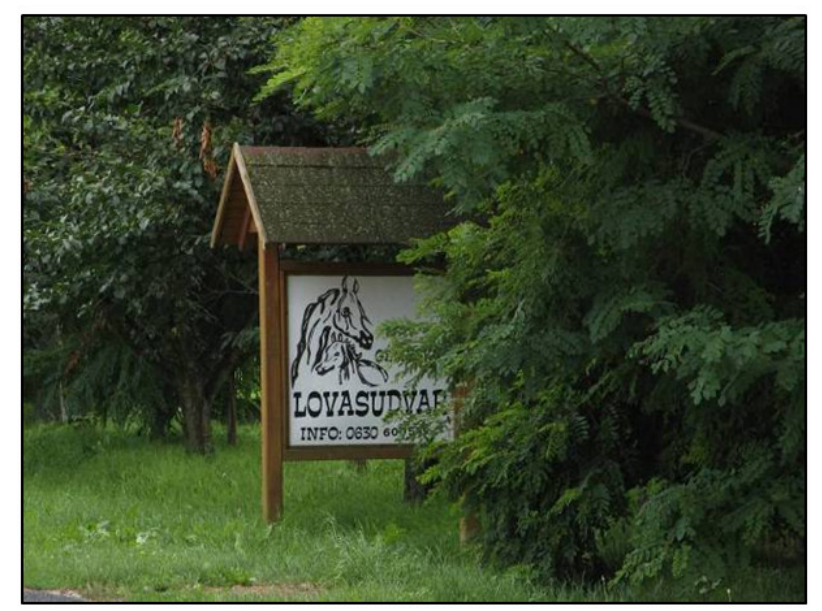

1. kép: Lovagoltatás Vágon

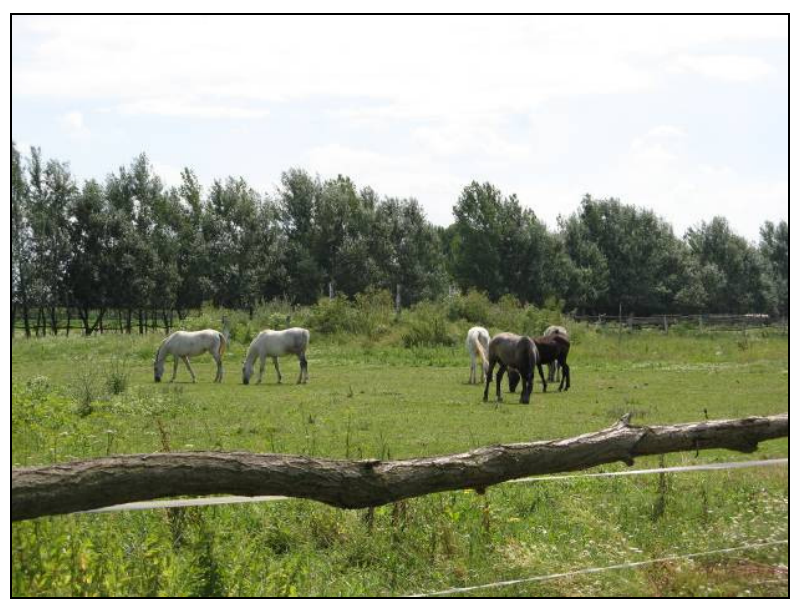

3. kép: Lovagoltatás Farádon

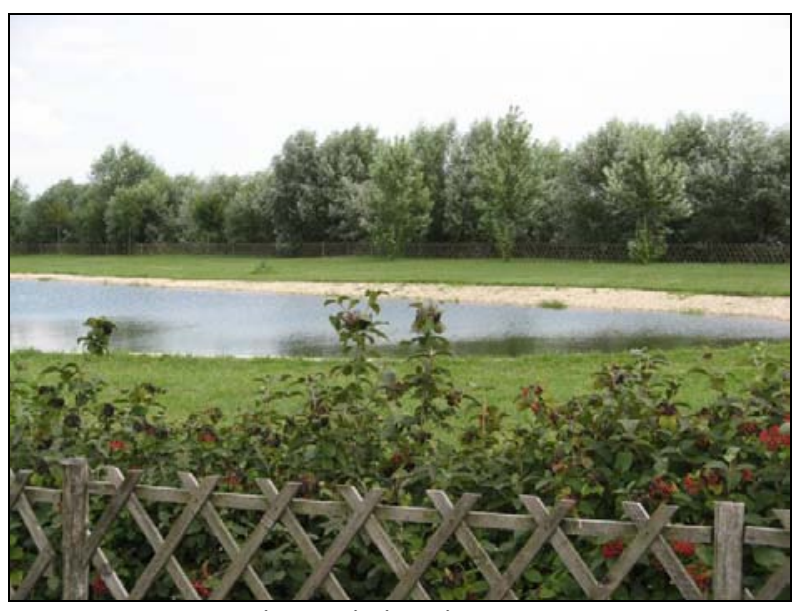

5. kép: Szávízi vízicentrum

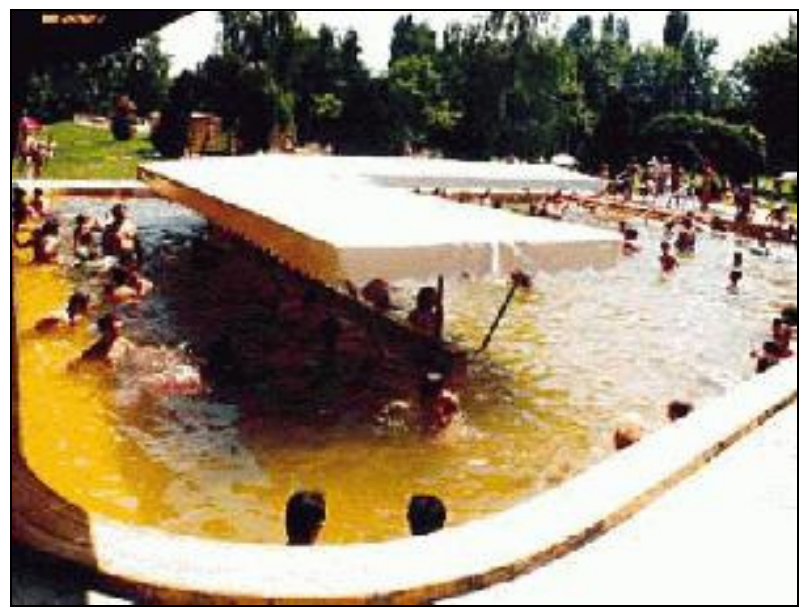

2. kép: Csornai termálfürdő (www.termalfurdo.net)

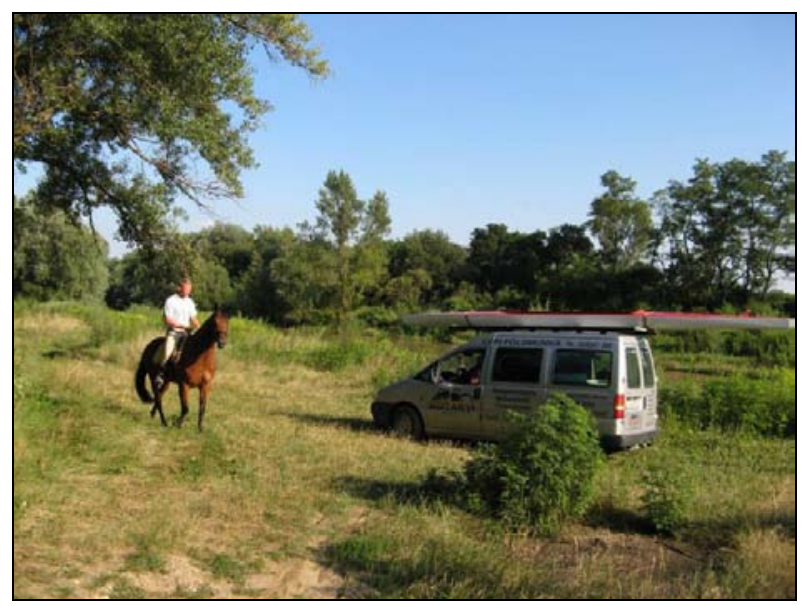

4. kép: A Rába nyújtotta lehetőségek

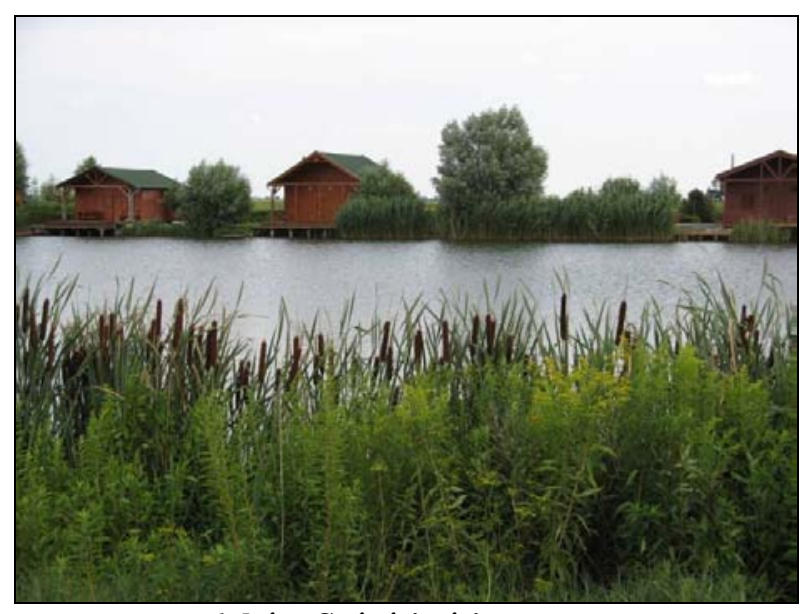

6. kép: Szávízi vízicentrum 
A népi építészet emlékei (saját fényképek)

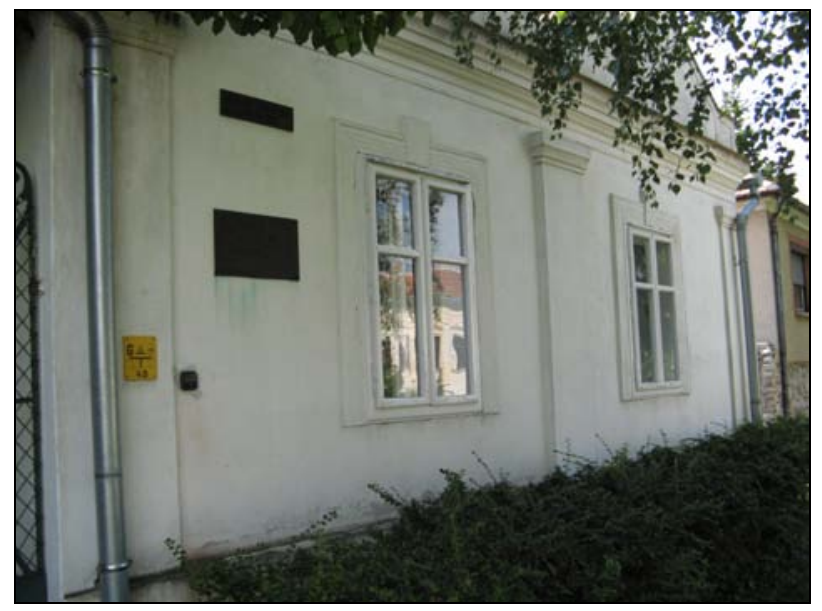

3. kép: Jászai Mari emlékszoba

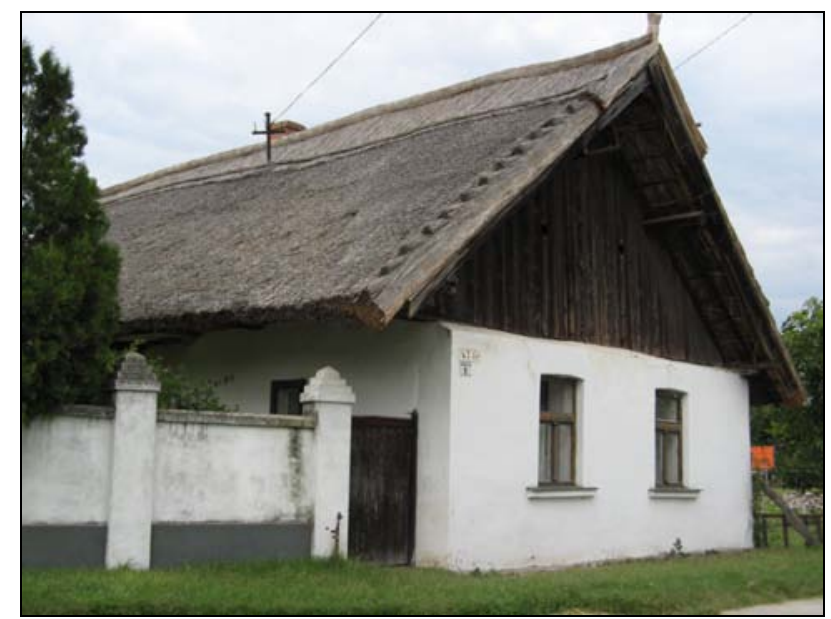

1. kép: Fehértó, parasztház

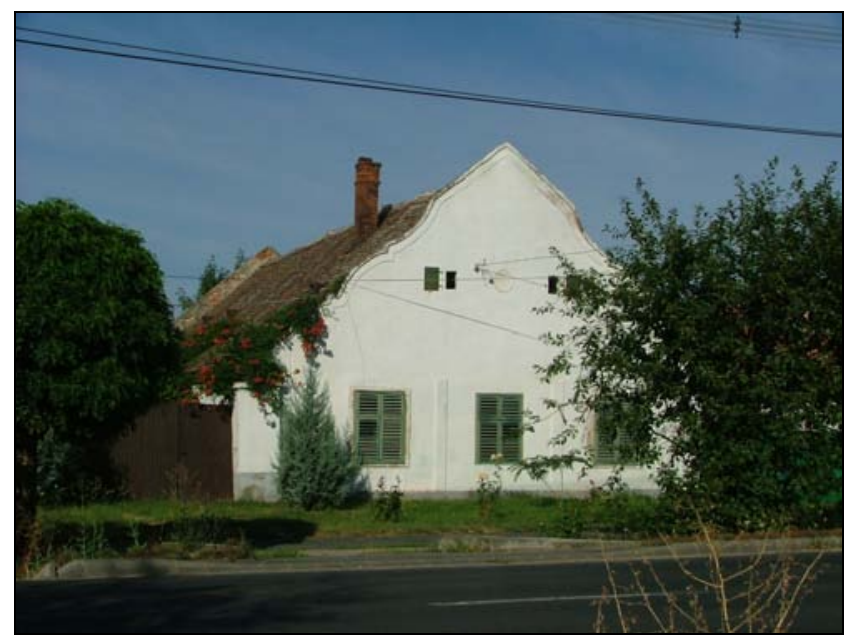

2. kép: Szilsárkány, paraszt barokk

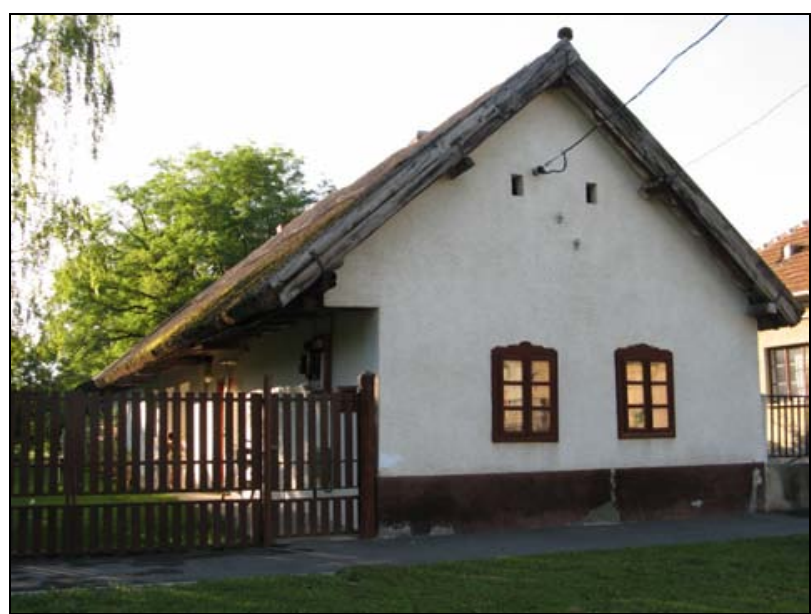

4. kép: Barbacs, Csornai utca 1.

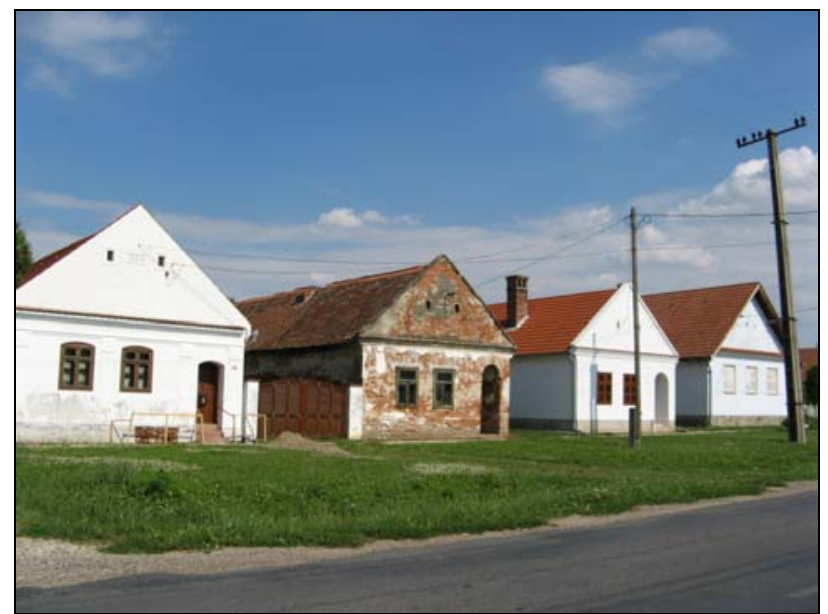

5. kép: Bogyoszló, parasztházsor

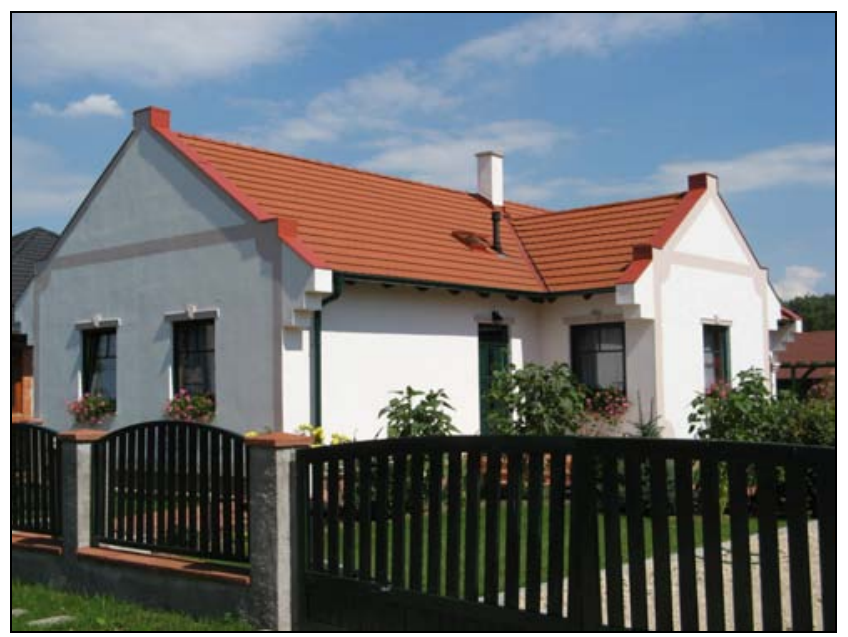

6. kép: Felújított, átalakított parasztház, Rábatamási 
Tabló V.

Hanság és Rábaköz természeti értékei (saját fényképek)

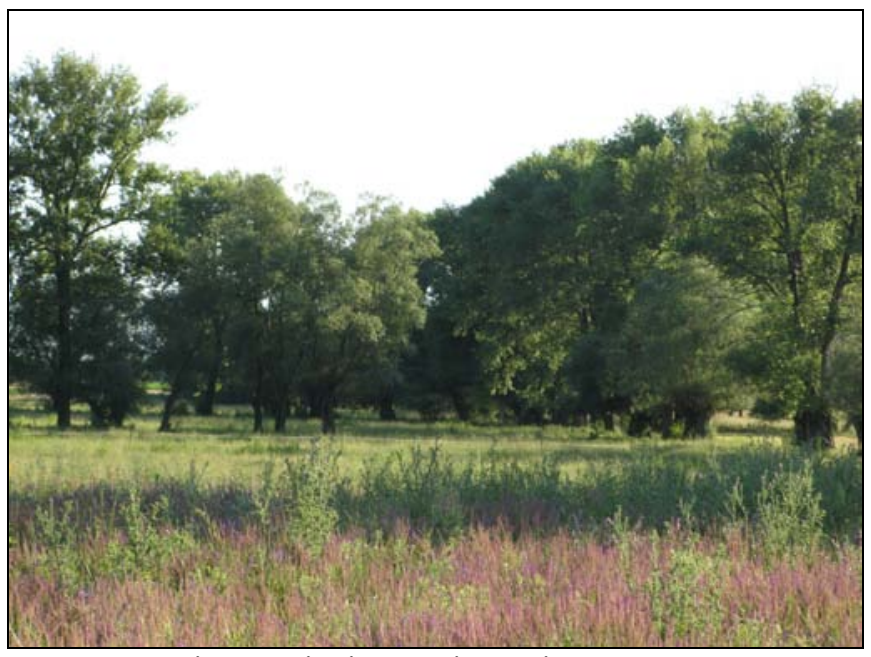

1. kép: Fehértó, természetvédelmi terület

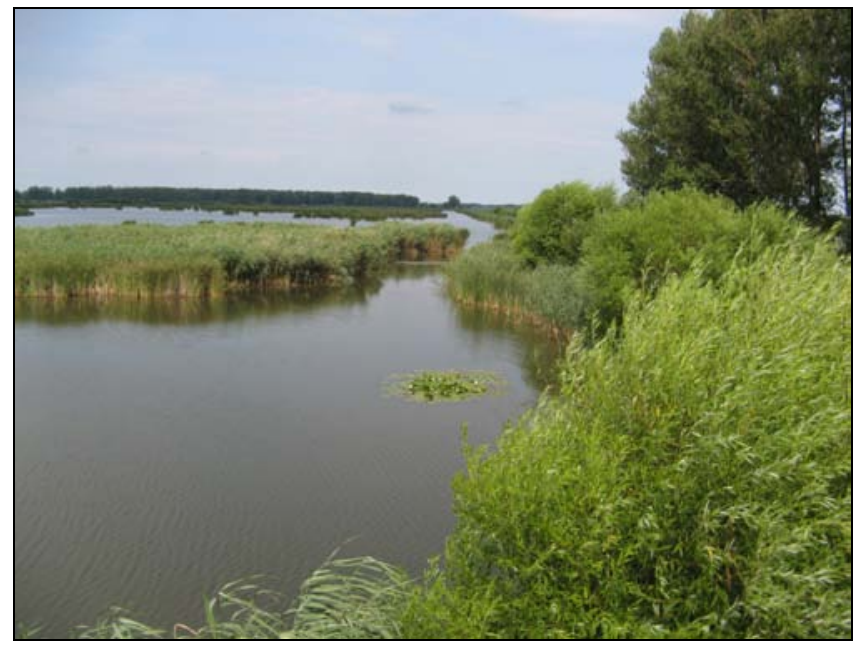

3. kép: A Nyirkai-Hany nyáron

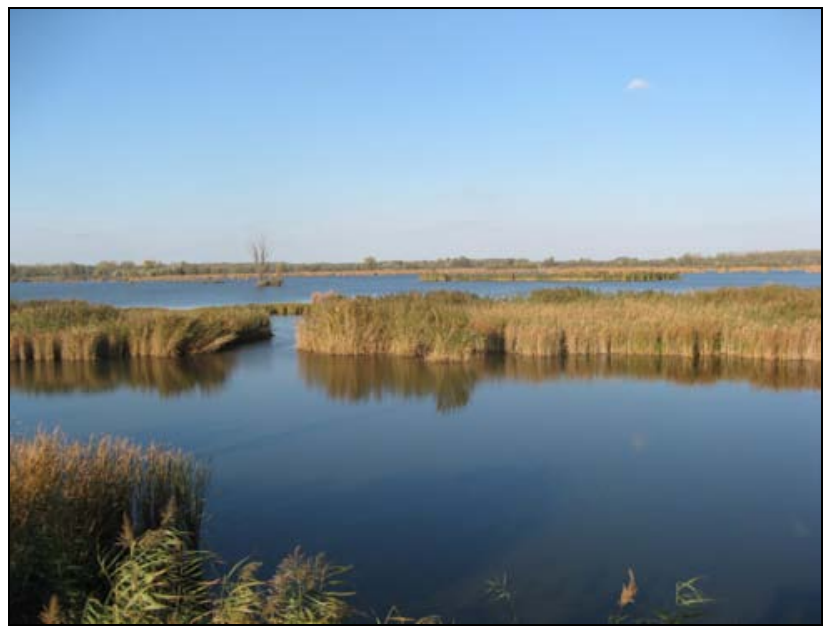

5. kép: A Nyirkai-Hany

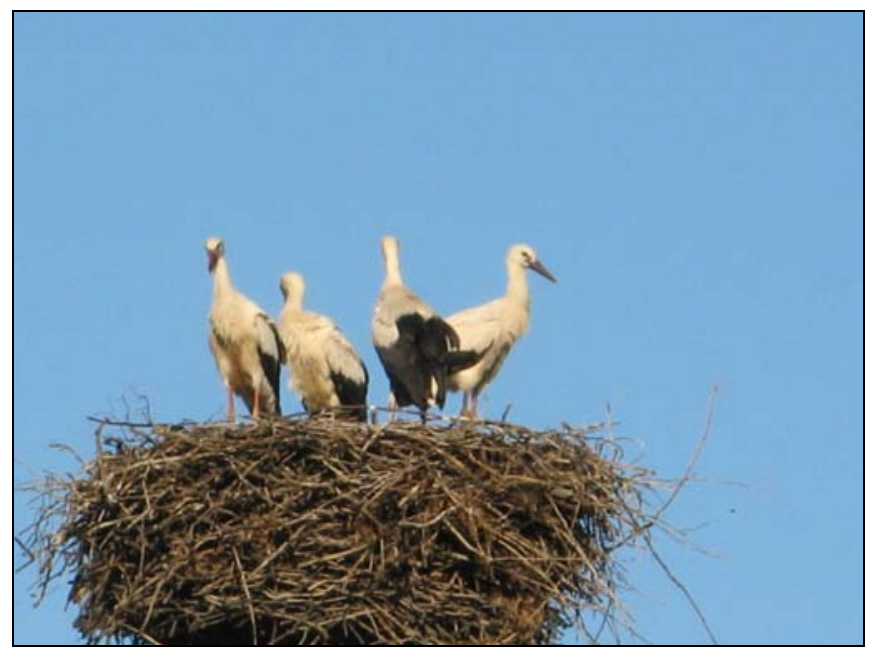

2. kép: Számtalan gólya él a térségben

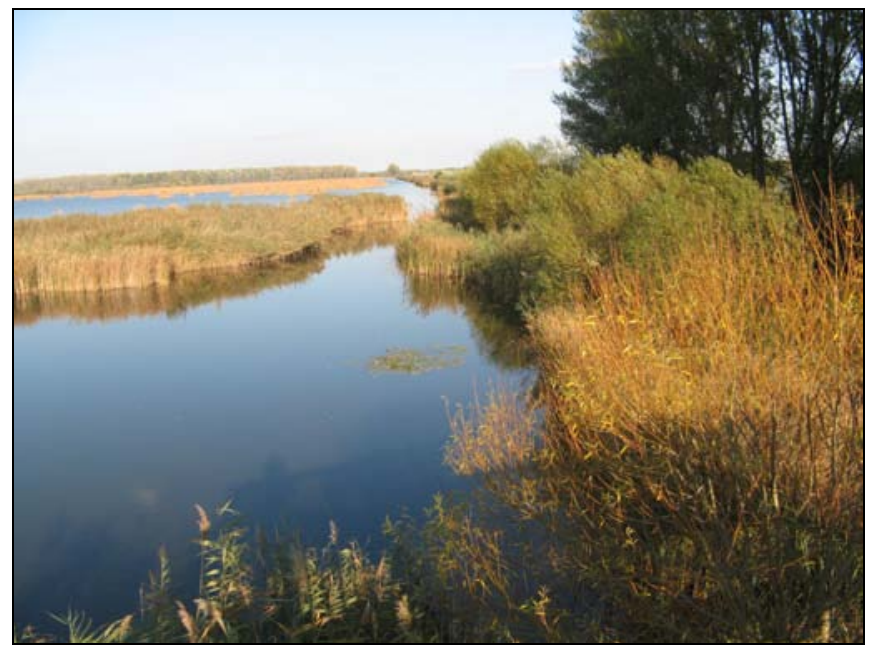

4. kép: A Nyirkai-Hany ősszel

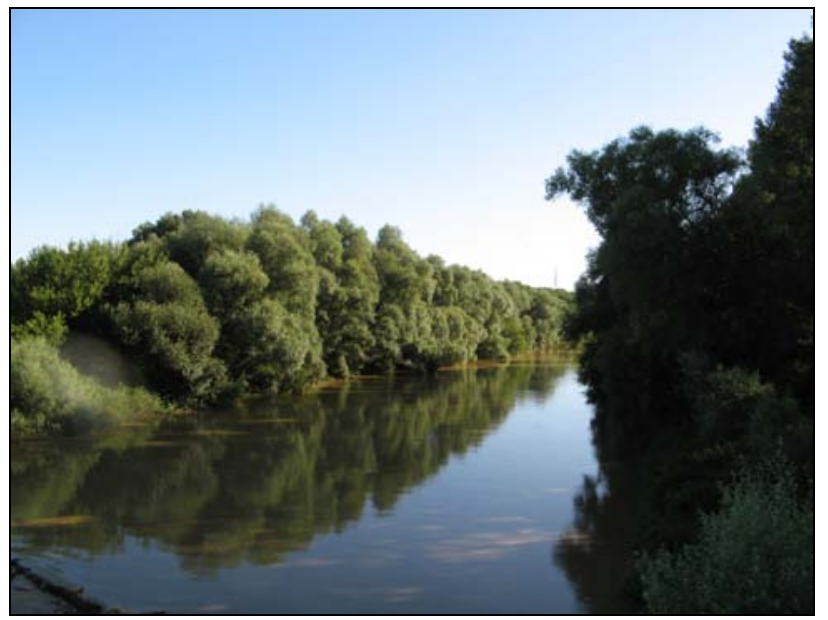

6. kép: A Rába 
Tabló VI.

Tájhasználat (saját fényképek)

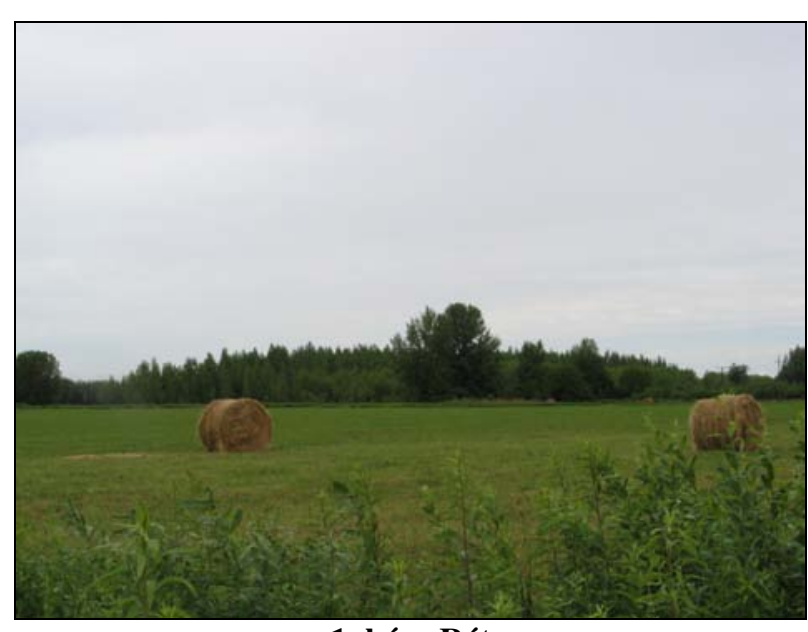

1. kép: Rét

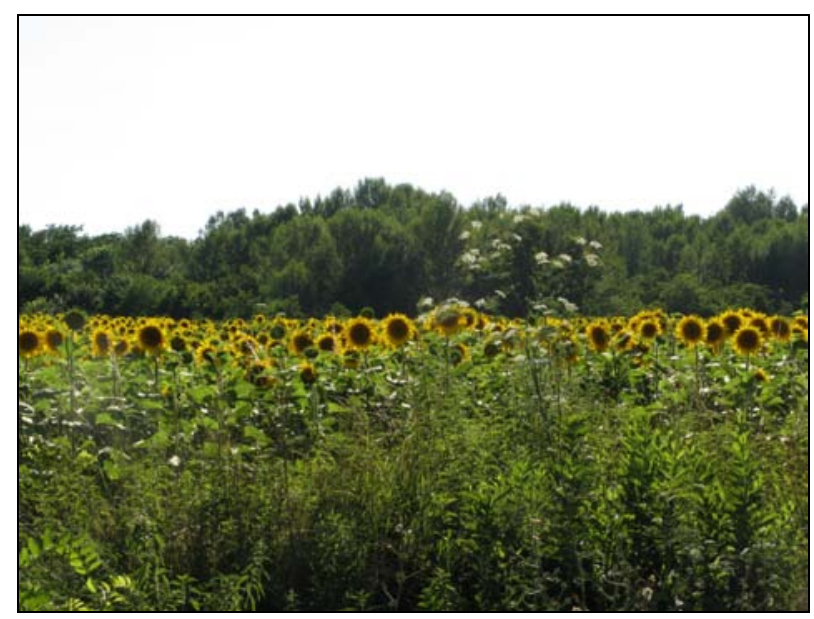

3. kép: Napraforgó ültetvény

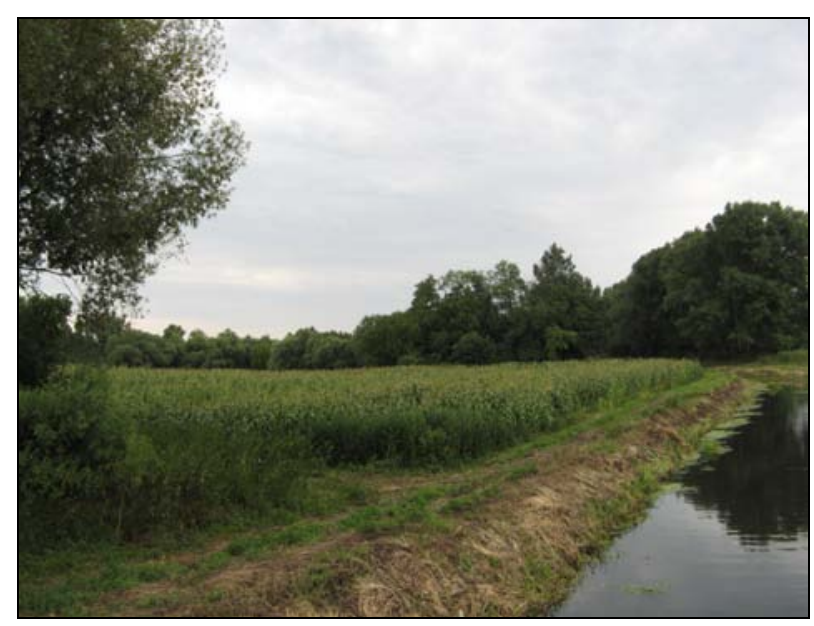

5. kép: Barbacs, Keszeg-ér partja

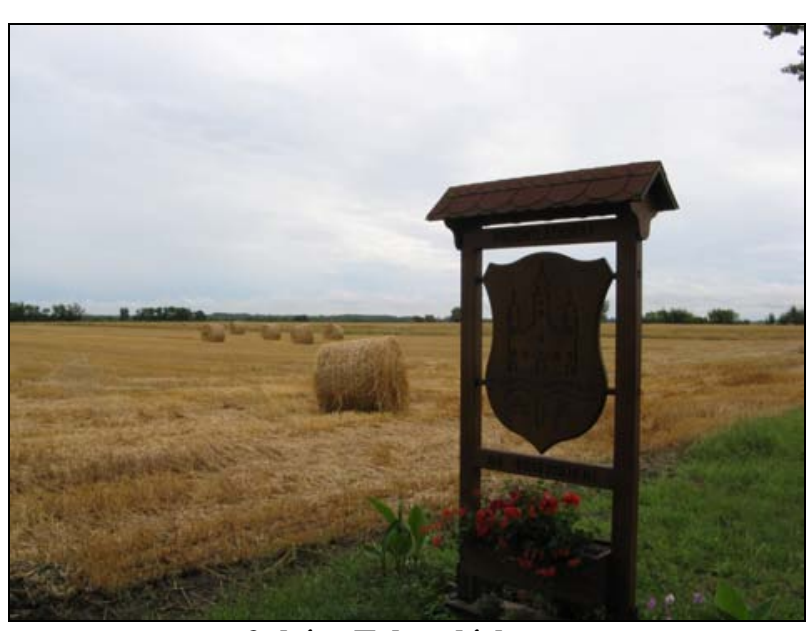

2. kép: Településkapu

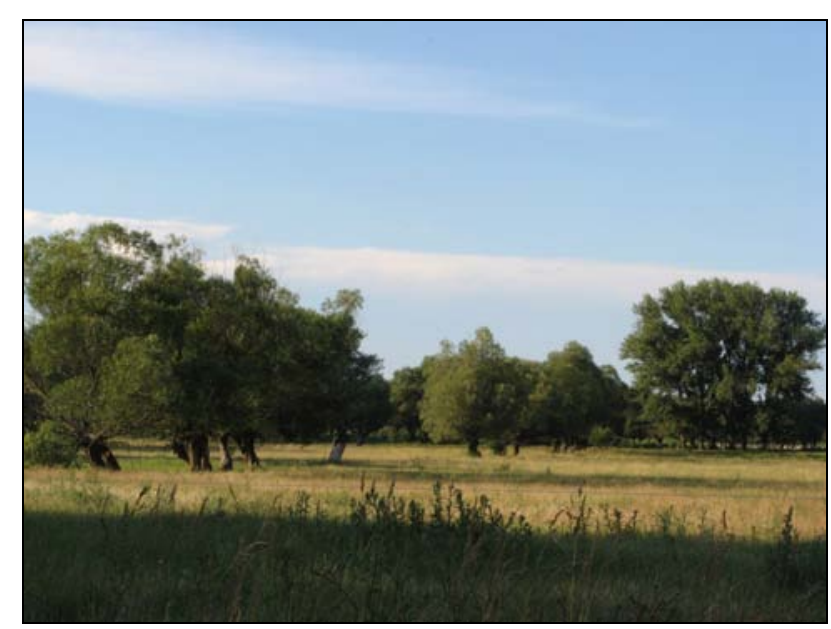

4. kép: Fehértó, hagyásfás legelő

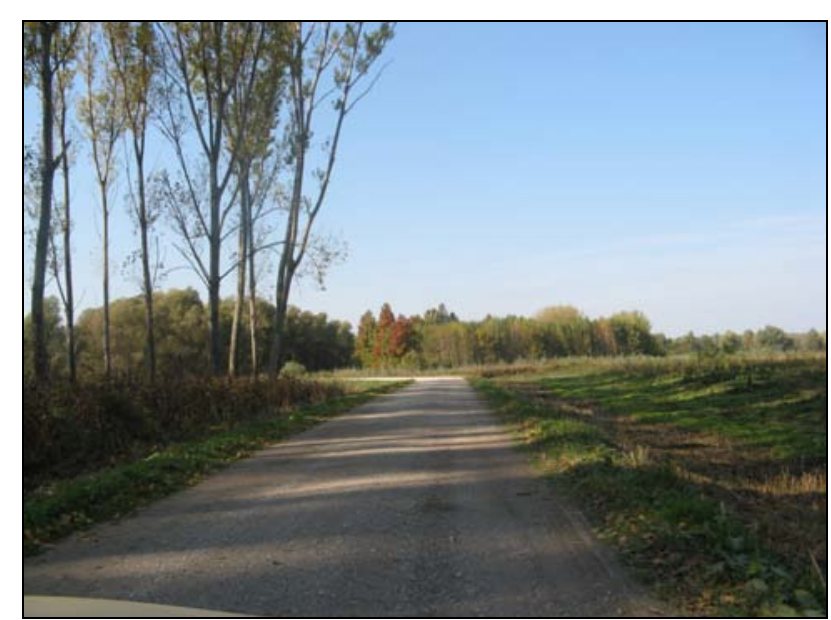

6. kép: Földsziget 
Tájérték leltár

\begin{tabular}{|c|c|c|c|c|}
\hline Település & Természeti értékek & Épített értékek & $\begin{array}{l}\text { Belterületi zöldfelü- } \\
\text { let-rendszer értékei }\end{array}$ & Programok \\
\hline Acsalag & $\begin{array}{l}\text { Fertő-Hanság Nem- } \\
\text { zeti Park közelsége } \\
\text { (Nyirkai-Hany, Nany- } \\
\text { istók tanösvény) }\end{array}$ & $\begin{array}{l}\text { R.k. téglatemplom (1795, főoltár és szó- } \\
\text { szék: XVII. Század) } \\
\text { Szentháromság-szobor }\end{array}$ & $\begin{array}{l}\text { Millenniumi emlékpark, } \\
\text { millenniumi emlékkővel }\end{array}$ & $\begin{array}{l}\text { Lőrinc naphoz kötődik a } \\
\text { helyi búcsú, melyet a } \\
\text { templom védőszentjé- } \\
\text { nek napjához legköze- } \\
\text { lebb eső vasárnapon } \\
\text { tartanak. } \\
\\
\text { Július 15-én, „kisbúcsú- } \\
\text { kor” rendezik meg a } \\
\text { falunap }\end{array}$ \\
\hline $\begin{array}{l}\text { Bágyog- } \\
\text { szovát }\end{array}$ & & $\begin{array}{l}\text { R.k. templom, XVIII. sz. } \\
\text { R.k. templom, copf, } 1804 . \\
\text { TemetöKereszt, késő barokk, } 1781 .\end{array}$ & & $\begin{array}{l}\text { Élő népszokások: } \\
\text { betlehemezés, lucázás, } \\
\text { locsolás } \\
\text { Mária-Magdolna napi } \\
\text { búcsú, Márton napi búcsú }\end{array}$ \\
\hline Barbacs & $\begin{array}{l}\text { Fertö-Hanság Nem- } \\
\text { zeti Park közelsége } \\
\text { (Fokozottan védett } \\
\text { Barbacsi-tó) } \\
\text { Keszeg-ér }\end{array}$ & $\begin{array}{l}\text { Vitéz-kastély jelenleg hasznosításra vár. } \\
\text { Népi épitészet emlékei (Csornai utca 1.) } \\
\text { Lakóház, népi, XIX. sz. második fele } \\
\text { (Csornai út 1.) } \\
\text { TemetöKereszt, késő barokk, } 1800 \text { körül } \\
\text { (József A. u.) } \\
\text { Kút, barokk, 1792. (József A. u. 73.) } \\
\text { R.k. templom, barokk, XVIII. sz. (József } \\
\text { A. u.) } \\
\text { Szent Család-szobor, barokk, } 1800 \\
\text { körül. (Maglócai dülö) }\end{array}$ & $\begin{array}{l}\text { Temetőkert panorámá- } \\
\text { val }\end{array}$ & $\begin{array}{l}\text { Élő népszokások: gyé- } \\
\text { kényfonás, kosárfonás }\end{array}$ \\
\hline Bezi & $\begin{array}{l}\text { Külterület: rétek, } \\
\text { erdők, ligetek }\end{array}$ & $\begin{array}{l}\text { Népi építészeti emlékek } \\
\text { R.k. templom }\end{array}$ & $\begin{array}{l}\text { Temető kriptával és } \\
\text { zsidó sírokkal }\end{array}$ & \\
\hline $\begin{array}{l}\text { Bogyosz- } \\
\text { ló }\end{array}$ & Kavicsbányató & $\begin{array}{l}\text { R.k. templom, klasszicista, } 1836 . \\
\text { Kálvária-szoborcsoport, késő barokk, } \\
1808 . \\
\text { Ornitológus Király Iván szülőháza } \\
\text { Parasztporták 1864-1866 között épültek, } \\
\text { Főutca }\end{array}$ & $\begin{array}{l}\text { Erzsébet kerti kereszt } \\
\text { (Paptagi kereszt) I.vgh } \\
\text { után }\end{array}$ & $\begin{array}{l}\text { Élő népszokások: fafara- } \\
\text { gás } \\
\text { Nemzetközi hírủ néptánc- } \\
\text { csoport }\end{array}$ \\
\hline $\begin{array}{l}\text { Bősár- } \\
\text { kány }\end{array}$ & $\begin{array}{l}\text { Szávízi vizicentrum } \\
\text { Elárasztott Nyirkai- } \\
\text { Hany FHNP } \\
\text { Rábca, Hansági- } \\
\text { föcsatorna }\end{array}$ & $\begin{array}{l}\text { R.k. templom, barokk, } 1750 \text { körül. (Fö } \\
\text { u.) } \\
\text { Szent Család-szobor, barokk, } 1750 \\
\text { körül. } \\
\text { Szt. Sebestyén-szobor, barokk, } 1750 \\
\text { körül. } \\
\text { Pieta-szobor, késő barokk, } 1802 . \\
\text { KöKereszt, klasszicista, } 1802 .\end{array}$ & & $\begin{array}{l}\text { Gyékényezés (értékesités } \\
\text { szinte teljesen megszünt) }\end{array}$ \\
\hline Cakóháza & $\begin{array}{l}\text { Cakóháza / } 100 \text { éves } \\
\text { tölgyfa (helyi véde- } \\
\text { lem) }\end{array}$ & & & Búcsú (helyiek ünnepe) \\
\hline Csorna & $\begin{array}{l}\text { Termálvíz (szezoná- } \\
\text { lis fürdő) }\end{array}$ & $\begin{array}{l}\text { Mária-oszlop, rokokó, 1757. (Bartók B. } \\
\text { u.) } \\
\text { Szent Donát-szobor, rokokó, } 1818 . \\
\text { (Kossuth L. u.) } \\
\text { Nepomuki Szt. János-kápolna és szo- } \\
\text { bor (Laky Döme u.) } \\
\text { KőKereszt, copf, 1799. (Szent István tér) } \\
\text { R.k. templom, barokk (Szabadság tér 5.) } \\
\text { premontrei prépostság, késő barokk, } \\
\text { 1802-08. (Szabadság tér 16.) } \\
\text { KőKereszt, copf, 1799. Tersánszky E. } \\
\text { sírköve, 1831. }\end{array}$ & $\begin{array}{l}\text { Vilmos-park } \\
\text { Premontrei park }\end{array}$ & $\begin{array}{l}\text { Szent István nap } \\
\text { Rábaközi napok és vásár } \\
\text { Pántlika néptánc együttes } \\
\text { Rábaközi perec } \\
\text { Lovaglás }\end{array}$ \\
\hline
\end{tabular}




\begin{tabular}{|c|c|c|c|c|}
\hline Település & Természeti értékek & Épített értékek & $\begin{array}{c}\text { Belterületi zöldfe- } \\
\text { lület-rendszer } \\
\text { értékei }\end{array}$ & Programok \\
\hline Dör & & $\begin{array}{l}\text { TemetőKereszt, klasszicista, 1808. (Rákóczi } \\
\text { u.) } \\
\text { Faluházban helytörténeti kiállitás }\end{array}$ & & $\begin{array}{l}\text { Fazekasság } \\
\text { Völcsey fazekasmühely }\end{array}$ \\
\hline Egyed & & $\begin{array}{l}\text { Festetics-kastély, barokk, XVIII. sz. (Árpási út } \\
\text { 1.)romos állapotban, hasznositásra vár }\end{array}$ & & $\begin{array}{l}\text { Élő népszokások, citera- } \\
\text { zenekar, tánccsoport }\end{array}$ \\
\hline Farád & Horgásztó & $\begin{array}{l}\text { Ev. templom, késő barokk, } 1785 . \\
\text { Mária oszlop, copf, XVIII. sz. vége (Győri út) } \\
\text { Sarlay-kastély homlokzatán Felsőbüki Nagy } \\
\text { Sándor címere (ma elhagyatott) } \\
\text { Ostffy kastély (ma iskola) }\end{array}$ & & $\begin{array}{l}\text { Premontrei Cserkészta- } \\
\text { nya } \\
\text { Lovaglás/ Rábaköz lovas- } \\
\text { életének központja } \\
\text { Pávakör énekkar } \\
\text { Hanyi-csárda }\end{array}$ \\
\hline Fehértó & FHNP: Fehér-tó & $\begin{array}{l}\text { R.k. templom, barokk, } 1734 . \\
\text { Mária-oszlop, barokk, } 1747 . \\
\text { Népi építészet emlékei }\end{array}$ & & Ornitológiai tábor \\
\hline $\begin{array}{l}\text { Györsö- } \\
\text { vényház }\end{array}$ & $\begin{array}{l}\text { FHNP: Fehér-tó } \\
\text { tanösvény, Rábca } \\
\text { Fennmaradt Árpád- } \\
\text { kori csatornarendszer }\end{array}$ & $\begin{array}{l}\text { TemetöKereszt, klasszicista, } 1830 \text { körül } \\
\text { (Gárdonyi u.) } \\
\text { Harangláb }\end{array}$ & $\begin{array}{l}\text { Értékes vadgesz- } \\
\text { tenye-fasor } \\
\text { Tó }\end{array}$ & $\begin{array}{l}\text { Majális, Kihívások napja, } \\
\text { Búcsú, Falunap }\end{array}$ \\
\hline Jobaháza & & $\begin{array}{l}\text { Dőry-kastély (ma szociális otthon) } \\
\text { Népi épitészet emlékei }\end{array}$ & Korszerū játszótér & \\
\hline Kóny & $\begin{array}{l}\text { FHNP: tőzegtavak } \\
\text { rendszere }\end{array}$ & Nepomuki Szt. János-szobor, barokk, 1794. & $\begin{array}{l}\text { Kerék-tó } \\
\text { Korszerű játszótér }\end{array}$ & $\begin{array}{l}\text { Erkel Ferenc Énekkar } \\
\text { Faluház }\end{array}$ \\
\hline Maglóca & FHNP & $\begin{array}{l}\text { Szentháromság-szobor, késő barokk, } 1804 . \\
\text { R.k. templom, barokk, 1754. (Petöfi u.) } \\
\text { Népi épitészet emlékei }\end{array}$ & & \\
\hline $\begin{array}{l}\text { Magyar- } \\
\text { keresztúr }\end{array}$ & Keszeg-ér, Kanális & Baditz-kastély (elhanyagolt, eladó) & & Helytörténeti kiállitás \\
\hline $\begin{array}{l}\text { Marko- } \\
\text { tabödöge }\end{array}$ & $\begin{array}{l}\text { FHNP Markotai-hany, } \\
\text { Bödögei-hany, Tözeg } \\
\text { és mocsári rétek, } \\
\text { nyárfa ligetek, Ke- } \\
\text { szeg-ér }\end{array}$ & $\begin{array}{l}\text { R.k. templom, 1752. (Fő u.) } \\
\text { Kálvária, kőkereszt (1791) } \\
\text { Honfoglalási kopjafa } \\
\text { Népi építészet szép emléke a Fő u. 78.sz. } \\
\text { alatti Tóközi lakóház } \\
\text { A barokk stillusú Római } \\
\text { - A markotai temetőben a temetőkereszt } \\
\text { (1681) Szentháromság-szobor (1896) } \\
\text { - A bödögei temetőben Mária-szobor "Pieta" } \\
\text { (1746) } \\
\text { Millenniumi emlékkereszt. } \\
\text { Népi építészet szép emlékei (Fő u. 78.sz. } \\
\text { alatti Tóközi lakóház). }\end{array}$ & „Markotai liget” & $\begin{array}{l}\text { Apák napja- "A Tókőz- } \\
\text { Rábaköz İzei "szabadtéri } \\
\text { sütö-főzző verseny } \\
\text { Uborkaparti } \\
\text { Búcsú }\end{array}$ \\
\hline Páli & $\begin{array}{l}\text { Tölgyfa (helyi véde- } \\
\text { lem) } \\
\text { Keszeg-ér } \\
\text { Rába közelsége }\end{array}$ & $\begin{array}{l}\text { R.k. templom, barokk, } 1642 . \\
\text { Kálvária, barokk, XVIII. sz. } \\
\text { Krisztus-szobor, barokk, } 1690 . \\
\text { Pieta-szobor, barokk, } 1690 . \\
\text { Csigaházi J. sírköve, } 1839 .\end{array}$ & Horgásztó & Rábaközi Perecfesztivál \\
\hline Pásztori & & $\begin{array}{l}\text { R.k. templom, gótikus eredetü, barokk, XVIII. } \\
\text { sz. második fele (Alsó utca) }\end{array}$ & Játszótér & \\
\hline Potyond & & Szent László kápolna és kőkereszt & & \\
\hline $\begin{array}{l}\text { Rába- } \\
\text { csanak }\end{array}$ & & $\begin{array}{l}\text { 1926-ban készültt r.k. templom } \\
\text { Mária-szobor, barokk, XVIII. sz. első fele. }\end{array}$ & $\begin{array}{l}\text { Milleniumi emlék- } \\
\text { park (fejlesztendő) }\end{array}$ & \\
\hline $\begin{array}{l}\text { Rába- } \\
\text { pordány }\end{array}$ & & Kökereszt, késő barokk, 1804. Megújitva. & & $\begin{array}{l}\text { Falunap, Szent Rókus } \\
\text { búcsú }\end{array}$ \\
\hline $\begin{array}{l}\text { Rába- } \\
\text { sebes }\end{array}$ & Rába, holtágak & $\begin{array}{l}\text { R.k. templom, késő barokk, } 1780 \text { körül (Szé- } \\
\text { chenyi u.) } \\
\text { Szechenyi Jenő építette kastély } 1902 \text { (kas- } \\
\text { télyszálló, nem üzemel) }\end{array}$ & & \\
\hline $\begin{array}{l}\text { Rábaszt.- } \\
\text { andrás }\end{array}$ & $\begin{array}{l}\text { Sebes-Sobori csator- } \\
\text { na }\end{array}$ & $\begin{array}{l}\text { R.k. templom, barokk, } 1750 \text { körül (Kossuth } \\
\text { utca) } \\
\text { Kis János szülöháza (költő, író, MTA tag) }\end{array}$ & & \\
\hline
\end{tabular}




\begin{tabular}{|c|c|c|c|c|}
\hline Település & Természeti értékek & Épített értékek & $\begin{array}{l}\text { Belterületi zöldfe- } \\
\text { lület-rendszer } \\
\text { értékei }\end{array}$ & Programok \\
\hline $\begin{array}{l}\text { Rába- } \\
\text { tamási }\end{array}$ & & $\begin{array}{l}\text { TemetöKereszt, klasszicista, } 1845 \\
\text { Jászai Mari emlékszoba }\end{array}$ & $\begin{array}{l}\text { Kálvária domb } \\
\text { (1811 pestisjár- } \\
\text { vány emlékére) }\end{array}$ & \\
\hline $\begin{array}{l}\text { Rábca- } \\
\text { kapi }\end{array}$ & $\begin{array}{l}\text { Rábca, Bősárkány- } \\
\text { Réti csatorna, FHNP } \\
\text { közelsége } \\
\text { Árpád-kori csatorna- } \\
\text { rendszer maradvá- } \\
\text { nyai }\end{array}$ & & & \\
\hline $\begin{array}{l}\text { Sopron- } \\
\text { németi }\end{array}$ & & & $\begin{array}{l}\text { Játszótér, pihenő- } \\
\text { hely a Keszegér } \\
\text { mellett }\end{array}$ & $\begin{array}{l}\text { keramikus és diszmü } \\
\text { kovácsolás }\end{array}$ \\
\hline Szany & Linkó-ér & $\begin{array}{l}\text { Nepomuki Szt. János-szobor, barokk, XVIII. } \\
\text { sz. (Kossuth L. u.) } \\
\text { Volt püspöki kastély, barokk, XVIII. sz. (Kos- } \\
\text { suth L. u. 5.) ma könyvtár és helytörténeti } \\
\text { kiállitás } \\
\text { MIKLÓSPUSZTA } \\
\text { Szt. Vendel-kápolna, barokk, } 1747 . \\
\text { Szent Anna kápolna-búcsújáróhely }\end{array}$ & & $\begin{array}{l}\text { Téglamúzeum } \\
\text { Bokréta néptáncegyüttes } \\
\text { Falunap } \\
\text { Vadásznap } \\
\text { Rába-fesztivál }\end{array}$ \\
\hline Szil & Linkó-ér & $\begin{array}{l}\text { R.k. templom, késő barokk, XVIII. sz. vége } \\
\text { (Dózsa Gy. utca) }\end{array}$ & Játszótér & \\
\hline $\begin{array}{l}\text { Szilsár- } \\
\text { kány }\end{array}$ & Termálvíz & $\begin{array}{l}\text { Lakóház, volt Baditz katély, klasszicista, XIX. } \\
\text { sz. első fele (Dózsa Gy. u. 2.) } \\
\text { R.k. templom, barokk, XVIII. sz. első fele (Fő } \\
\text { u.)Mária-szobor, késő barokk, XVIII. sz. vége } \\
\text { (Fő u.) } \\
\text { Ált. iskola, volt Hőgyész-kúria, klasszicista, } \\
\text { XIX. sz. első fele (Fö u. 16.) } \\
\text { Lakóházak, népi (Fő u., Rákóczi u.) } \\
\text { Volt pálos kolostor, késő barokk, 1793. (Fő u. } \\
\text { 117.) } \\
\text { Kovácsmühely, népi, XVIII. sz. (Falumúze- } \\
\text { umba helyezve, Fő u. 120.) } \\
\text { Ev. templom, klasszicista, } 1810 \text { körül. (Kiss } \\
\text { F. u.) } \\
\text { Kiss Ferenc erdész szülõháza }\end{array}$ & $\begin{array}{l}\text { Kiss Ferenc erdész } \\
\text { szülōháza körül } \\
\text { növénygyûjtemény } \\
\text { - közel } 150 \text { fa-és } \\
\text { cserjefajjal - } \\
\text { jelentõs természeti } \\
\text { és kultúrtörténeti } \\
\text { értéket képvisel }\end{array}$ & $\begin{array}{l}\text { A község híres szülöttei: } \\
\text { Kiss Ferenc erdész, } \\
\text { ahogy nevezték-A Sze- } \\
\text { gedi erdõk atyja. } \\
\text { Hegedüs András minisz- } \\
\text { terelnök, szociológus } \\
\text { Híres lakója volt a köz- } \\
\text { ségnek: Závory Zoltán } \\
\\
\text { Ismeretterjesztő szabad- } \\
\text { téri állatbemutató prog- } \\
\text { ramok óvodás és iskolás } \\
\text { csoportoknak }\end{array}$ \\
\hline $\begin{array}{l}\text { Tárnokré- } \\
\text { ti }\end{array}$ & $\begin{array}{l}\text { FHNP közelsége } \\
\text { Rábca } \\
\text { Termálvíz (nincs } \\
\text { hasznositva) } \\
\text { Árpád-kori csatorna- } \\
\text { rendszer maradvány }\end{array}$ & $\begin{array}{l}\text { Evangélikus templom, késő barokk épültet } \\
\text { 1785-böl. }\end{array}$ & & $\begin{array}{l}\text { Tüzoltóverseny-május } \\
\text { Falunap-június } \\
\text { Tóparti Parti-augusztus } \\
\text { Nyugdijas találkozó- } \\
\text { november } \\
\text { Búcsú-október } \\
\text { Jótékonysági-bálok: } \\
\text { Mikulás-bál, Locsoló-bál }\end{array}$ \\
\hline Vág & Rába & & Halastó & Lovaglás \\
\hline $\begin{array}{l}\text { Zsebe- } \\
\text { háza }\end{array}$ & & $\begin{array}{l}\text { Harangláb } \\
\text { Evangélikus templom }\end{array}$ & & \\
\hline
\end{tabular}

Forrás: maps.google.com, települési honlapok, A Csornai kistérség telepuilései c. kiadvány, saját bejárás 